2. To: (Rocoiving Organization)

TWRS

\section{Proj./Prog./Dopt./Div.: \\ 8. Originator Romerks: \\ ER4945 \\ For original release.}

3. Fram: (Originating Organization)

$$
\text { ICF-KH }
$$

8. Cog. Engr.:
11. Recoiver Romarks:

DATA TRANSMITTED

15.

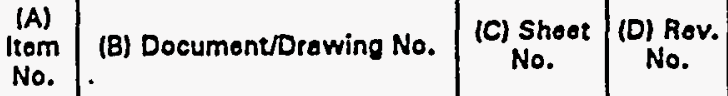

$0^{-}$Historical Tank Content

(E) Title or Description of Dote Transmitted

Estimate for the Northeast

Quadrant of the Hanford 200 East Areas
1. EDT 136989

4. Related EDT No.:

7. Purchaso Ordor No.:

9. Equip./Component No.:

N/A

10. System/Bldo./Facility:

Tank Farms

12. Major Assm. Dwg. No.:

$$
N / A
$$

13. Pormit/Pormit Application No.: - N/A

14. Roquirod Responso Dato: $N / A$

(F)

(C)

(G)

\begin{tabular}{|c|c|c|} 
& (H) & (II \\
\hline $\begin{array}{c}\text { Origi- } \\
\text { nator } \\
\text { Dispo- } \\
\text { stion }\end{array}$ & $\begin{array}{c}\text { Rocoiv } \\
\text { or } \\
\text { Dispo- } \\
\text { sition }\end{array}$ \\
\hline 1 & 1 \\
\hline
\end{tabular}

\begin{tabular}{ll|l}
\hline & & \\
\hline & & \\
& & \\
& & \\
& & \\
& & \\
& & \\
\hline
\end{tabular}

16.

\begin{tabular}{l|l}
\hline Impact Lovol (F) & \\
\hline $\begin{array}{l}\text { 1. 2, 3, or } 4 \text { (s00 } \\
\text { MRP 5.43) }\end{array}$ & $\begin{array}{l}\text { 1. Approval } \\
\text { 2. Relosso } \\
\text { 3. Information }\end{array}$
\end{tabular}

Reason for Tranamittal (G)

\section{Roviow}

5. Post-Roviow

6. Dist. (Rocoipt Acknow. Roquirod)
KEY

\begin{tabular}{l|l|ll} 
(G) & (H) & 17. & SIGNATURE/OISTRIBUTION
\end{tabular}

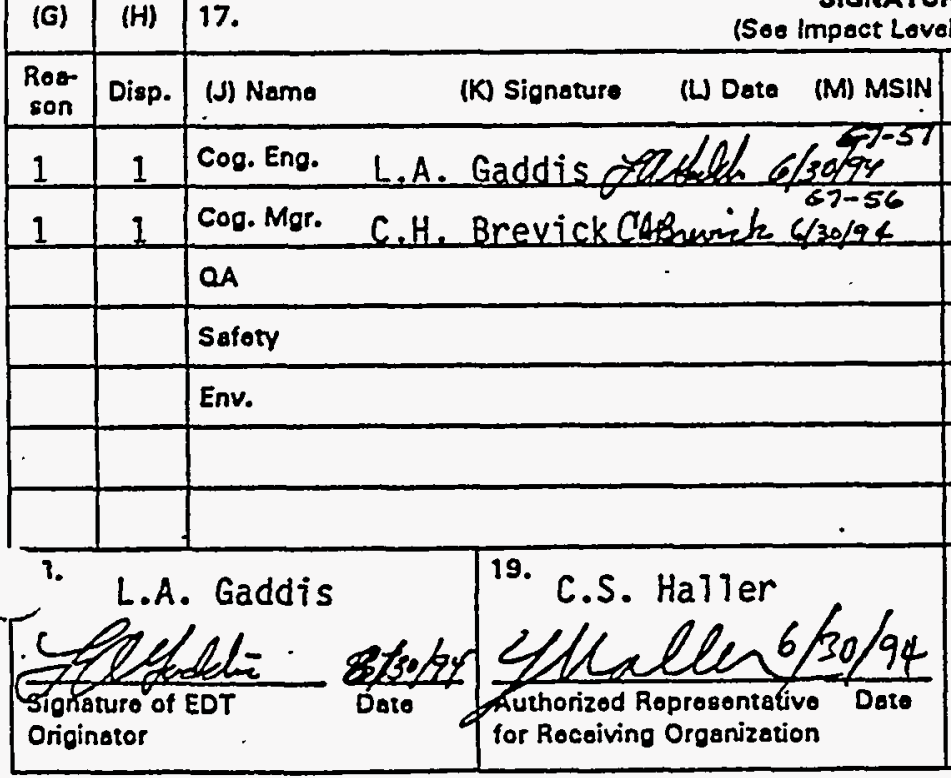

20. C.H. Brevick

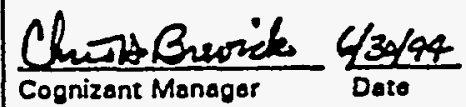

Disposition (H) \& (I)
1. Approved

2. Approved w/comment

3. Disepproved w/comment
4. Roviowod no/comment

5. Reviowed w/comment

6. Rocoipt acknowlodgod

\section{vel for roquirod signatures)}




\section{DISCLAIMER}

Portions of this document may be illegible in electronic image products. Images are produced from the best available original document. 


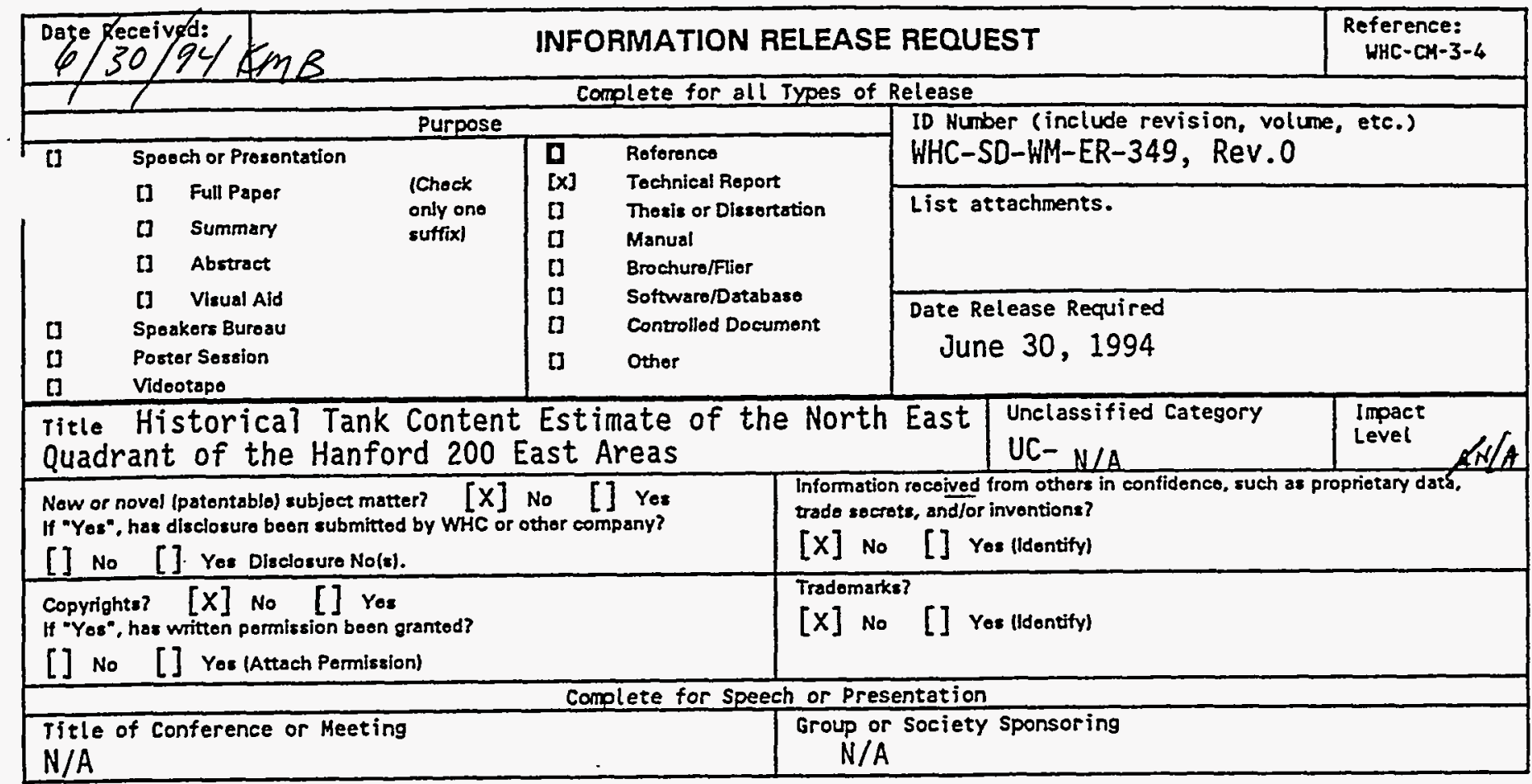

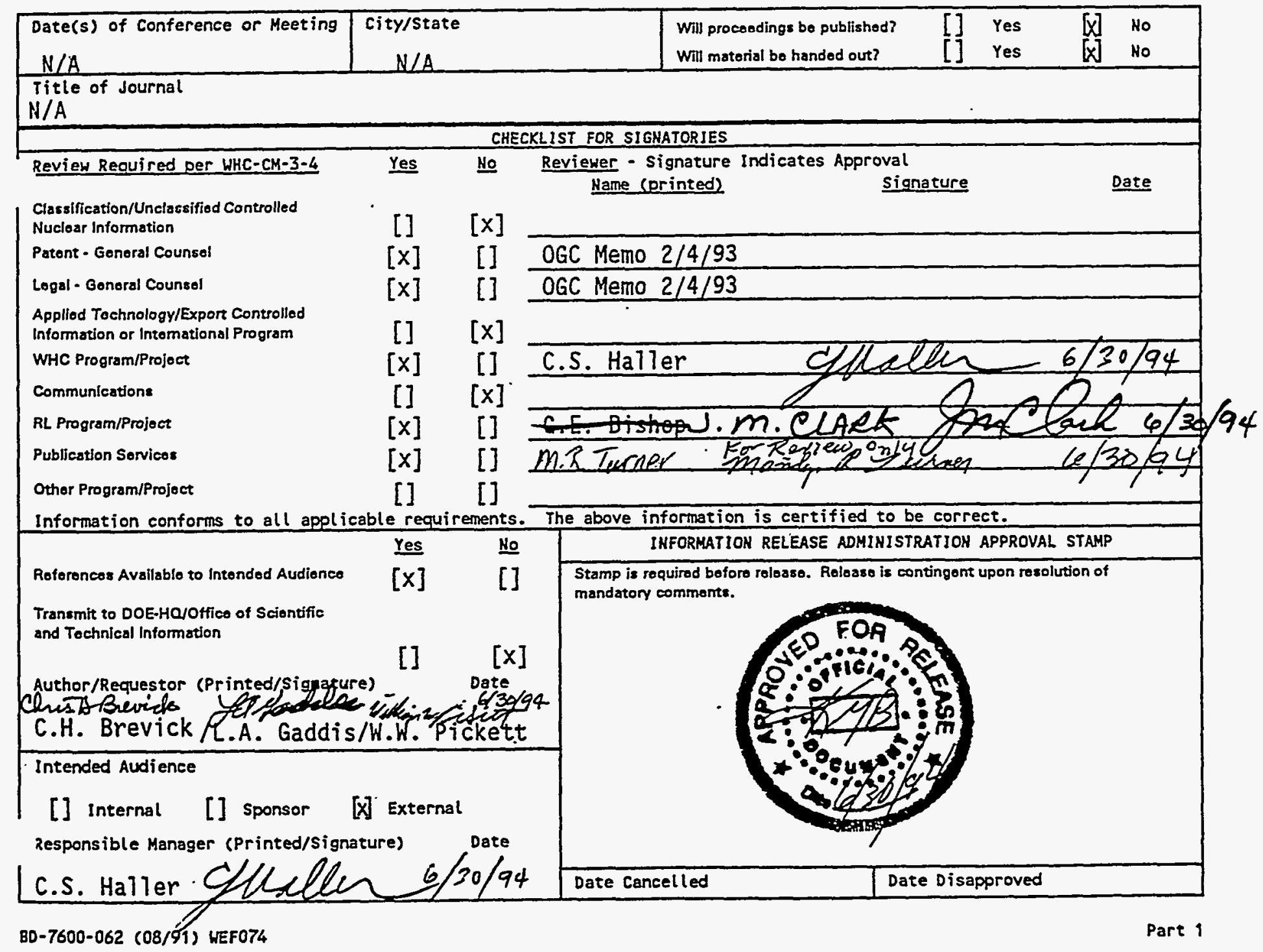




\title{
HISTORICAL TANK CONTENT ESTIMATE FOR THE NORTHEAST QUADRANT OF THE HANFORD 200 EAST AREA
}

\author{
WORK ORDER ER4945
}

Prepared for

Westinghouse Hanford Company

June 1994

\author{
Prepared by \\ ICF Kaiser Hanford Company \\ Richland, Washington
}


2. Title

Historical Tank Content Estimate for the Northeast Quadrant of the Hanford 200 East Area

\section{Key Words}

Northeast Quadrant, Historical Tank Content Estimate, Historical Characterization, Tank Farms, Tank Waste Level, Tank Farm Aerial Photos, In-Tank Photo, Tank Layer Model, Estimated Composite Inventories, Riser Locations.

\section{APPROVED FOR} Temb $\% 30 / 94$ PUBLIC RELEASE

3. Number

WHC-SD-WM-ER-349 4. Rev No. 0
6. Author

Name: C.H. Brevick, L.A. Gaddis, H.W. Pickett

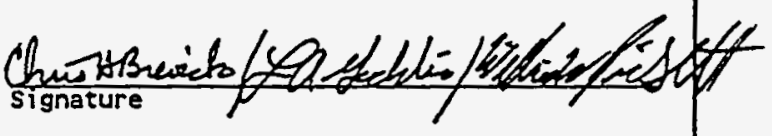

\section{Abstract}

Historical Tank Content Estimate of the Northeast Quadrant provides historical evaluations on a tank by tank basis of the radioactive mixed wastes stored in the underground single-shell tanks of the Hanford 200 East area. This report summaries historical information such as waste history, temperature, tank integrity, inventory estimates and tank level history on a tank by tank basis. Tank Farm aerial photos and in-tank photos of each tank are provided. A brief description of instrumentation methods used for waste tank surveillance, along with the components of the data management effort, such as waste status and Transaction Record Summary, Tank Layering Model, Defined Haste Types, and Inventory Estimates to generate these tank content estimates are also given in this report.

8. PORROSE AIID USE OF DOCUMENT - This document was prepared for use Within U.S. Department of Energy and its contractors It is to be used onty to perform, direct, or integrate work under U.S. Department of Energy contracts. This docyment is not approved for public release until reviewed.

PATEHT STATUS - This document copy since it is transmitted in advance of patent clearance, is mada available in confidence solely for use in performance of work oder contracts with the U.S. Department of Energy. This document is not to be publ ished nor its contents otberwise disseminated or used for pucposes other than specified above before patent approval for such release or use has been secured, upon request, from the Patent counsel, U.S. Department of Energy Field office, Richland, HA.

10.

RELEASE STAMP

DISCLAIMER - This report was prepared as an account of work sponsored by an agency of the United States Government. Neither the United States Government nor any agency thereof, nor any of their employees, nor any of their contractors, subcontractors or their employees, makes any warranty, express or implied, or assumes any legal liability or responsibility for the accuracy, completeness, or any third party's use or the results of such use of any information, apparatus, product, or process disclosed, or represents that its use would not infringe privately onned rights. Reference herein to any specific comercial product, process, or service by trade name, trademark, manufacturer, or otherwise, does not necessarily constitute or imply its endorsement, recommendation, or favoring by the United states Goverment or any agency thereof or its contractors or subcontractors. The vieks and opinions of authors expressed herein do not necessarily state or reflect those of the United states Government or any agency thereof.

9. Impact Level $\mathscr{N} N / \mathrm{A}$ CH\&

${ }^{\wedge}$ GMACPATH ${ }^{\sim}$ GEF $1000^{\wedge} \mathrm{G}$

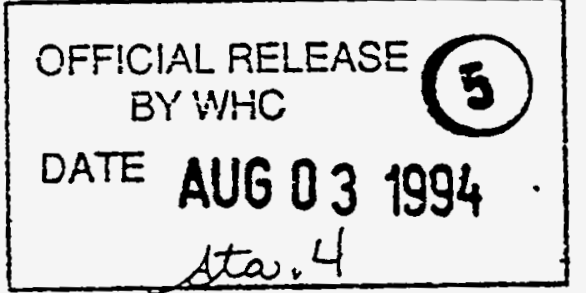




\section{HISTORICAL TANK CONTENT ESTIMATE FOR THE NORTHEAST QUADRANT OF THE HANFORD 200-EAST AREA $:$ \\ WORK ORDER ER4945}

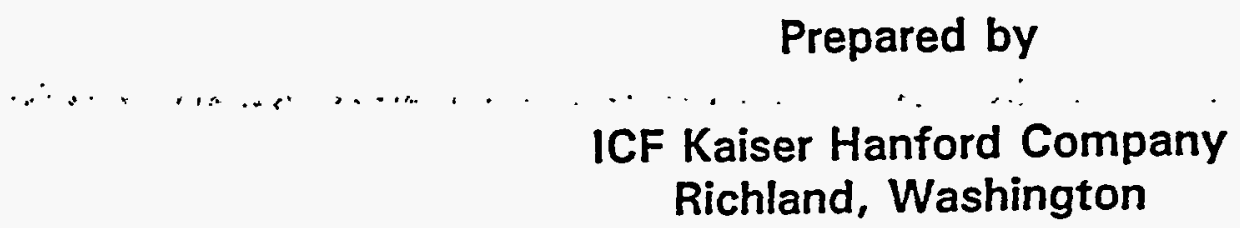

for

Westinghouse Hanford Company

Teveree

Principal Lead Engineer

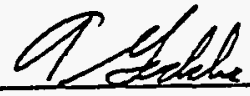

$\frac{6-29-94}{\text { Date }}$

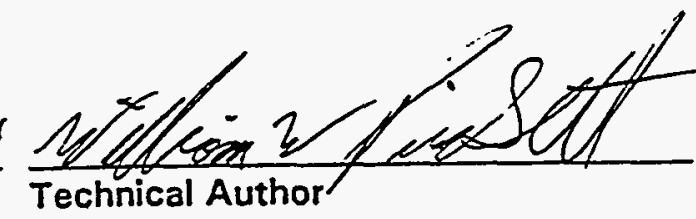

$\frac{6-29-94}{\text { Date }}$

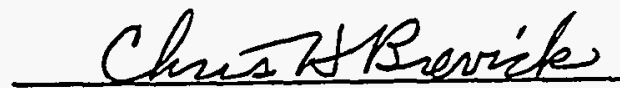

Project Manager
6-29-94 Hunomsians

Date Technical Documents

$\frac{6-29-94}{\text { Date }}$

\section{Westinghouse Hanford Company}

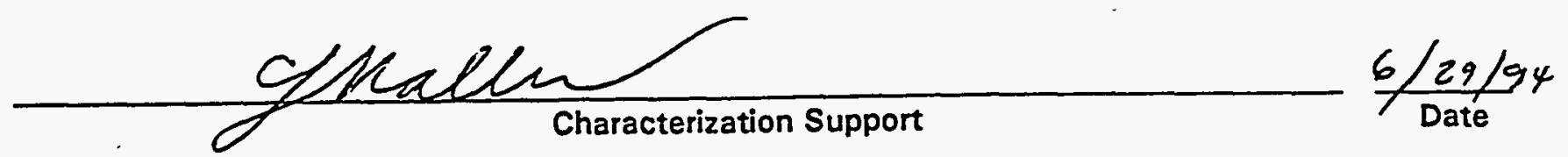

\section{DISCLAIMER}

This report was prepared as an account of work sponsored by an agency of the United States Government. Neither the United States Government nor any agency thereof, nor any of their employees, makes any warranty, express or implied, or assumes any legal liability or responsibility for the accuracy, completeness, or usefulness of any information, apparatus, product, or process disclosed, or represents that its use would not infringe privately owned rights. Reference herein to any specific commercial product, process, or service by trade name, trademark, manufacturer, or otherwise does not necessarily constitute or imply its endorsement, recommendation, or favoring by the United States Government or any agency thereof. The views and opinions of authors expressed herein do not necessarily state or reflect those of the United States Government or any agency thereof. 
1.0 Introduction .................... 1

1.1 Purpose .................. . . . 1

1.2 Scope . . . . . . . . . . . . . 1

1.3 Approach...... .91

1.3.1 Surveillance Techniques for the Hanford

1.3.2 . Radioactive Mixed Waste Storage Tanks . . 3

Approach and Development of Supporting

Information Contained in the Historical

1.3 .3

Tank Content Estimate . . . . . . . . 4

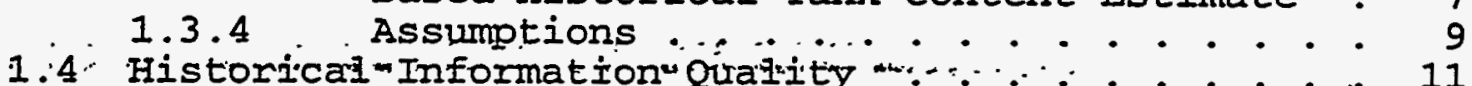

Approach and Development of the Process-

Based Historical Tank Content Estimate . 7

1.5 Background NE Quadrant . . . . . . . . 15

1.5.1 Waste Generating Plants and Processes: 15

1.5.2 Waste Management Operations ...... 18

1.5.3 Miscellaneous Waste Sources and

1.5 .4 Timpment . . . . . . . . 20

1.6 Safety Issues . . . . : . : : 25

1.6.1 Watch List Safety Issues : . : . : 25

1.6.2 Non-Watch List Safety Issues : :.: 26

2.0 A Tank Farm . . . . . . . . . . . . 29

2.0 .1

A Tank Farm History . . . . . . . . 29

2.0.1.1 A Tank Farm Waste History . . . . 31

2.0.1.2 A Tank Farm Temperature History : 31

A Tank Farm Integrity

2.1 Tank 241-A-101ent Status of A Tank Farm .... 32

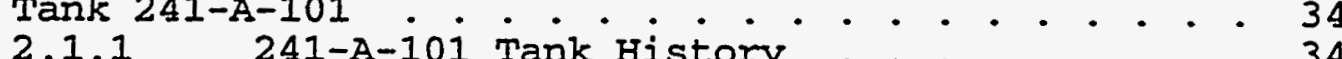

2.1.1.1 Waste History Tank $241-\dot{A}-i 0 i \cdot \cdot \cdot 34$

2.1.1.2 Temperature History $241-\mathrm{A}-101^{\circ}: \therefore 34$

2.1.1.3 Integrity of Tank 241-A-101 ... 34

2.1 .2 Current Status of Tank 241-A-101:.: 34

2.1.2.1 Inventory estimate 241-A-101... 35

2.1.2.2 In-Tank Photograph 241-A-101: : 35

2.1.3 Synopsis Tank 241-A-101 ........ 35

$2.2 \operatorname{Tank} 241-\mathrm{A}-102 \quad . \quad . \quad . \quad 39$

2.2.1 241-A-102 Tank History : : : : 39

2.2.1.1 Waste History Tank 241-A-102.: 39

2.2.1.2 Temperature History $241-\mathrm{A}-102$ : . 39

2.2.1.3 Integrity of Tank 241-A-102 . . . 39

2.2.2 Current Status of Tank 241-A-102: : : 39

2.2.2.1 Inventory estimate 241-A-102... 40

2.2.2.2 In-Tank Photograph 241-A-I02... 40

2.3 Tank 241-A-103 Synops is Tank 241-A-102 . . . . . 40

2.3.1 24I-A-103 Tank History $\therefore 44$

2.3.1.1 Waste History Tank 241-A-103... 44

2.3.1.2 Temperature History $241-\mathrm{A}-103 \div .: 44$

$$
\begin{array}{ll}
-i i- & 6 / 94
\end{array}
$$


2.3.1.3 Integrity of Tank 241-A-103 . . . . 44

2.3.2 Current Status of Tank 241-A-103 . . . . 44

2.3.2.1 Inventory estimate $241-A-103 . . .45$

2.3.2.2 In-Tank Photograph 24I-A-103... . 45

2.3 .3 Synopsis Tank 241-A-103 . . . . . . . . 45

2.4 Tank 241-A-104 . . . . . . . . . . . . . . . . . . 49

2.4.1 241-A-104 Tank History . . . . . . . . 49

2.4.1.1 Waste History Tank 241-A-104... . 49

2.4.1.2 Temperature History 241-A-104. . . 49

2.4.1.3 Integrity of Tank 241-A-104 . . . 49

2.4 .2 Current Status of Tank 241-A-104 . . . . 49

2.4.2.1 Inventory estimate 241-A-104. . . 50

2.4.2.2 In-Tank Photograph 241-A-104. . . 50

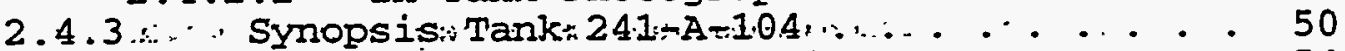

2.5 Tank 241-A-105 . . . . . . . . . . . . . . . 54

2.5.1 241-A-105 Tank History . . . . . . 54

2.5.1.1 Waste History Tank 241-A-105. . . 54

2.5.1.2 Temperature History 241-A-105 . . . 54

2.5.1.3 Integrity of Tank 241-A-105 . . . . 54

2.5 .2 Current Status of Tank 241-A-105 . . . . 55

2.5.2.1 Inventory estimate $241-\mathrm{A}-105 . . .55$

2.5.2.2 In-Tank Photograph 241-A-105. . . . 55

2.5 .3 Synopsis Tank 241-A-105... . . . . . . 55

2.6 Tank 241-A-106 . . . . . . . . . . . . . . . . . 59

2.6 .1 241-A-106 Tank History . . . . . . . 59

2.6.1.1 Waste History Tank 241-A-106. . . . 59

2.6.1.2 Temperature History 241-A-106 . . . 59

2.6.1.3 Integrity of Tank 241-A-106 . . . . 59

2.6 .2 Current Status of Tank 241-A-106 . . . . 59

2.6 .2 .1 Inventory estimate $241-\mathrm{A}-106 . . .60$

2.6.2.2 In-Tank Photograph 241-A-106... . 60

2.6.3 Synopsis Tank 241-A-106... . . . . . 60

3.0 AX Tank Farm . . . . . . . . . . . . . . . 64

3.0.1 AX Tank Farm History. . ....... 64

3.0.1.1 AX Tank Farm Waste History. . . . 66

3.0.1.2 AX Tank Farm Temperature History . . 66

Current Status of AX Tank Farm

3.1 Tank 241-AX-101 . . . . . . . . . . . . . . . . 68

3.1.1 241-AX-101 Tank History . . . . . . 68

3.1.1.1 Waste History Tank 241-AX-101 . . . 68

3.1.1.2 Temperature History 241-AX-101. . . 68

3.1 .1 .3 . Integrity of Tank $241-\mathrm{AX}-101 . . . \cdot 68$

3.1 .2 Current Status of Tank 241-AX-101. . . . 68

3.1.2.1 Inventory estimate 241-AX-101 . . . 69

3.1.2.2 In-Tank Photograph 241-AX-101 . . . 69

3.1 .3 Synopsis Tank 241-AX-101 . . . . . . . 69

3.2 Tank 241-AX-102 . . . . . . . . . . . . . . . . 73

3.2.1 241-AX-102 Tank History . . . . . . . 73

3.2.1.1 Waste History Tank 241-AX-102 . . . 73

3.2.1.2 Temperature History 241-AX-102 •. . 73

3.2.1.3 Integrity of Tank 241-AX-102... . 73 
3.2.2 Current Status of Tank 241-AX-102 . . . 74

3.2.2.1 Inventory estimate 241-AX-102 . . . 74

3.2.2.2 In-Tank Photograph 241-AX-102 . . . 74

3.2 .3 Synopsis Tank 241-AX-102 . . . . . . . . 74

3.3 Tank 241-AX-103 . . . . . . . . . . . . . . . 78

3.3.1 241-AX-103 Tank History . . . . . . . . 78

3.3.1.1 Waste History Tank 241-AX-103 ... 78

$\because 3.3 .1 .2$ Temperature History 241-AX-103. . . 78

$\therefore 3.3 .1 .3$ Integrity: of Tank 241-AX-103... . 78

3.3.2 Current status of Tank 241-AX-103 . . . . 79

3.3.2.1 Inventory estimate 241-AX-103 . . . 79

.2 In-Tank Photograph 241-AX-103 • • 79

241-AX-104_.............................. 83

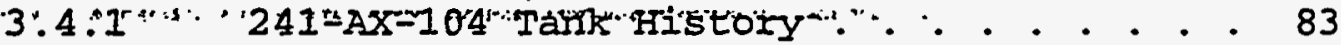

3.4.1.1 Waste History Tank 241-AX-104 . . . 83

3.4.1.2 Temperature History 241-AX-104 . . 83

3.4.1.3 Integrity of Tank 241-AX-104... . 83

3.4 .2 Current Status of Tank 241-AX-104. . . . 83

3.4.2.1 Inventory estimate 241-AX-104 . . . 84

3.4.2.2 In-Tank Photograph 241-AX-104 . . . 84

3.4 .3 Synopsis Tank 241-AX-104 . . . . . . . . 84

4.0 B Tank Farm . . . . . . . . . . . . . . . . . 88

4.0.1 B Tank Farm History.......... . 88

4.0.1.1 B Tank Farm Waste History . . . . . 88

4.0.1.2 B Tank Farm Temperature History . . 90

4.0.1.3 B Tank Farm Integrity ........ 90

4.0.2 Current Status of B Tank Farm. . . . . . 90

4.1 Tank 241-B-101 . . . . . . . . . . . . . . . . . . 92

4.1.1 241-B-101 Tank History . . . . . . . . 92

4.1.1.1 Waste History Tank 241-B-101... . 92

4.1.1.2 Temperature Fistory 241-B-101 . . . 92

4.1.1.3 Integrity of Tank 241-B-101. . . . 92

4.1.2 Current Status of Tank 241-B-101 . . . . 92

4.1.2.1 Inventory estimate 241-B-101 . . . 93

4.1.2.2 In-Tank Photograph 241-B-101... . 93

4.1.3 Synopsis Tank 241-B-101... . . . . . 93

4.2 Tank 241-B-102

4.2.1 241-B-102 Tank History . . . . . . . 97

4.2.1.1 Waste History Tank 241-B-102... . 97

4.2.1.2 Temperature History 241-B-102 . . . 97

4.2.1.3 Integrity of Tank 241-B-102 . . . . 97

4.2.2 Current Status of Tank 241-B-102 . . . . 97

4.2.2.1 Inventory estimate 241-B-102:... . 98

4.2.2.2 In-Tank Photograph 24I-B-102... . 98

4.2.3 Synopsis Tank 241-B-102 . . . . . . . . . 98

4.3 Tank 241-B-103 ................. . . 102

4.3.1 241-B-103 Tank History . . . . . . . 102

4.3.1.1 Waste History Tank 241-B-103... . 102

4.3.1.2 Temperature History $241-B-103$. . 102

4.3.1.3 Integrity of Tank 241-B-103 . . . . 102

4.3 .2 Current Status of Tank 241-B-103 . . . . 102

- iv -

$6 / 94$ 
4.3.2.1 Inventory estimate 241-B-103 . . . 103

4.3.2.2 In-Tank Photograph 241-B-103... . 103

4.3.3 Synopsis Tank 241-B-103 . . . . . . . . 103

4.4 Tank 241-B-104 . . . . . . . . . . . . . . . . . 107

4.4.1 241-B-104 Tank History . . . . . . . . 107

4.4.1.1 Waste History Tank 241-B-104... . 107

4.4.1.2 Temperature History 241-B-104 . . . 107

4.4.1.3 Integrity of Tank 241-B-104 . . . . 107

4.4.2 Current Status of Tank 241-B-104 . . . . 107

4.4.2.1 Inventory estimate 241-B-104... . 108

4.4.2.2 In-Tank Photograph 241-B-104... . 108

4.4.3 Synopsis Tank 241-B-104... . . . . . . 108

4.5 Tank 241-B-105 .. . . . . . . . . . . . . . . 112

4.5.1 . .. 241.-B-1.0.5 Tankr.Histony......... . . 112

4.5.1. $I^{\cdots}$ Waste History Tank 24I=B-105\%: . . . 112

4.5.1.2 Temperature History 241-B-105 . . . 112

4.5.1.3 Integrity of Tank 241-B-105 . . . . 112

4.5.2 Current Status of Tank 241-B-105 . . . . 112

4.5.2.1 Inventory estimate 241-B-105... . 113

4.5.2.2 In-Tank Photograph 241-B-105 . . . . 113

4.5.3 Synopsis Tank 241-B-105 . . . . . . . . . 113

4.6 Tank 241-B-106 . . . . . . . . . . . . . . . . . . 117

4.6.1 241-B-106 Tank History . . . . . . . . 117

4.6.1.1 Waste History Tank 241-B-106. . . 117

4.6.1.2 Temperature History 241-B-106 . . . 117

4.6.1.3 Integrity of Tank 241-B-106 . . . . 117

4.6.2 Current Status of Tank 241-B-106 . . . . 117

4.6.2.1 Inventory estimate 241-B-106. . . . 118

4.6.2.2 In-Tank Photograph 241-B-106. . . . 118

4.6.3 Synopsis Tank 241-B-106... . . . . . 118

4.7 Tank 241-B-107 . . . . . . . . . . . . . . . 122

4.7.1 241-B-107 Tank History . . . . . . . . . 122

4.7.1.1 Waste History Tank 241-B-107. . . . 122

4.7.1.2 Temperature History 241-B-107 . . . 122

4.7.1.3 Integrity of Tank 241-B-107 . . . . 122

4.7 .2 Current Status of Tank 241-B-107 . . . . 123

4.7.2.1 Inventory estimate 241-B-107... . 123

4.7.2.2 In-Tank Photograph 241-B-107... . 123

4.7.3 Synopsis Tank 241-B-107 . . . . . . . . 123

4.8 Tank 241-B-108 . . . . . . . . . . . . . . . . . . 127

4.8.1 241-B-108 Tank History . . . . . . . . . 127

4.8.1.1 Waste History Tank 241-B-108 . . . . 127

4.8.1.2 Temperature History 241-B-108 . . . 127

4.8.1.3 Integrity of Tank $241-\mathrm{B}-108$. . . . 127

4.8.2 Current Status of Tank 241-B-108 . . . . 127

4.8.2.1 Inventory estimate 241-B-108. . . . 128

4.8.2.2 - In-Tank Photograph 241-B-108... . 128

4.8 .3 Synopsis Tank 241-B-108... . . . . . 128

4.9 Tank 241-B-109 . . . . . . . . . . . . . . . 132

4.9.1 241-B-109 Tank History . . . . . . . . 132

4.9.1.1 Waste History Tank 241-B-109. . . . 132

4.9.1.2 Temperature History 241-B-109 . . . 132

4.9.1.3 Integrity of Tank 241-B-109 . . . . 132 
4.9.2 Current Status of Tank 241-B-109 . . . . 132 4.9.2.1 Inventory estimate 241-B-109... . 133

4.9.2.2 In-Tank Photograph 241-B-109... . 133

4.9.3 Synopsis Tank 241-B-109 . . . . . . . . . 133

4.10 Tank 241-B-110 . . . . . . . . . . . . . . . . 137

4.10.1 241-B-110 Tank History . . . . . . . 137

4.10.1.1 Waste History Tank 241-B-110... . 137

4.10:1.2 Temperature History 241-B-110 . . . 137

4.10.1.3 Integrity. of. Tank 241-B-110 ... . 137

4.10.2 Current Status of Tank 241-B-110 ․ . . 137

4.10.2.1 Inventory estimate 241-B-110. . . . 138

4.10 .10 .2 .2 In-Tank Photograph 241-B-110.*. 138

4.11 Tank $241-B-111$. . . . . . . . . . . . . . . . . 142

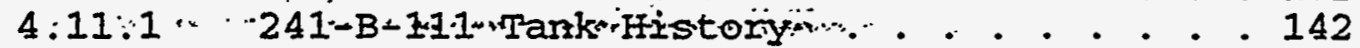

4.11.1.1 Waste History Tank 241-B-111. . . . 142

4.11.1.2 Temperature History 241-B-111 . . . 142

4.11.1.3 Integrity of Tank 241-B-111 . . . . 142

4.11.2 Current Status of Tank 241-B-111 . . . . 142

4.11.2.1 Inventory estimate 241-B-111 . . . . 143

4.11.2.2 In-Tank Photograph 241-B-111 . . . . 143

4.11.3 Synopsis Tank 241-B-111... . . . . . 143

4.12 Tank 241-B-112 . . . . . . . . . . . . . . . . . 147

4.12.1 241-B-112 Tank History . . . . . . . . 147

4.12.1.1 Waste History Tank 241-B-112 . . . . 147

4.12.1.2 Temperature History 241-B-112 . . . 147

4.12.1.3 Integrity of Tank $241-B-112$. . . . 147

4.12.2 Current Status of Tank 241-B-112 .. . . 147

4.12.2.1 Inventory estimate 241-B-112 . . . 148

4.12.2.2 In-Tank Photograph 241-B-112 . . . . 148

4.12 .3 Synopsis Tank 241-B-112... . . . . . . 148

4.13 Tank 241-B-201 . . . . . . . . . . . . . . . . 152

4.13.1 241-B-201 Tank History . . . . . . . . 152

4.13.1.1 Waste History Tank 241-B-201. . . . 152

4.13.1.2 Temperature History 241-B-201 . . . 152

4.13.1.3 Integrity of Tank $241-\mathrm{B}-201 \%$. . . . 152

4.13.2 Current Status of Tank 241-B-201 . . . . 152

4.13.2.1 Inventory estimate 241-B-201 . . . . 153

4.13.2.2 In-Tank Photograph 241-B-201. . . . 153

4.13 .3 Synopsis Tank 241-B-201. . . . . . . . . 153

4.14 Tank $241-\mathrm{B}-202$. . . . . . . . . . . . . . . . 157

4.14.1 241-B-202 Tank History . . . . . . . . 157

4.14.1.1 Waste History Tank 241-B-202 . . . . 157

4.14.1.2 Temperature History 241-B-202... . 157

4.14.1.3 Integrity of Tank 241-B-202 ... . 157

4.14.2 Current Status of Tank 241-B-202 . . . . 157

4.14.2.1 Inventory estimate 241-B-202 . . . . 158

4.14.2.2 In-Tank Photograph 241-B-202:... 158

4.14.3 Synopsis Tank 241-B-202 . . . . . . . . 158

4.15 Tank 241-B-203 . . . . . . . . . . . . . . 162

4.15.1 241-B-203 Tank History . . . . . . . 162

4.15.1.1 Waste History Tank 241-B-203. . . . 162

4.15.1.2 Temperature History 241-B-203 . . . 162 
4.15.1.3 Integrity of Tank 241-B-203 . . . . 162

4.15.2 Current Status of Tank 241-B-203 . . . . 162

4.15.2.1 Inventory estimate 241-B-203. . . . 163

4.15.2.2 In-Tank Photograph 241-B-203... . 163

4.15.3 Synopsis Tank 241-B-203... . . . . . 163

4.16 Tank 241-B-204 . . . . . . . . . . . . . . . . . . 167

4.16.1 241-B-204 Tank History . . . . . . . . . 167

4.16.1.1 Waste History Tank 241-B-204. . . . 167

4.16.1.2 Temperature History 241-B-204 . . . 167

4.16.1.3 Integrity of Tank 241-B-204 . . . . 167

4.16.2 Current Status of Tank 241-B-204 . . . . 167

4.16.2.1 Inventory estimate 241-B-204. . . . 168

4.16.2.2 In-Tank Photograph 241-B-204... . 168

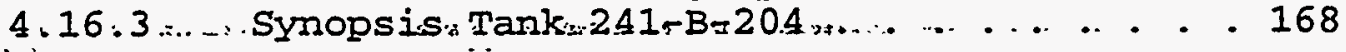

5.0 BX Tank Farm . . . . . . . . . . . . . . . . . 172

5.0.1 BX Tank Farm History . . . . . . . . 172

5.0.1.1 BX Tank Farm Waste History. . . . . 174

5.0.1.2 BX Tank Farm Temperature History . . 174

5.0.1.3 BX Tank Farm Integrity . . . . . . 174

5.0.2 Current Status of BX Tank Farm . . . . . 174

5.1 Tank 241-BX-101... . . . . . . . . . . . . 176

5.1.1 241-BX-101 Tank History . . . . . . . 176

5.1.1.1 Waste History Tank 241-BX-101 . . . 176

5.1.1.2 Temperature History 241-BX-101. . . 176

5.1.1.3 Integrity of Tank 241-BX-101. . . . 176

5.1 .2 Current Status of Tank 241-BX-101. . . . 176

5.1.2.1 Inventory estimate 241-BX-101 ... . 177

5.1.2.2 In-Tank Photograph 241-BX-101 . . . 177

5.1 .3 Synopsis Tank 241-BX-101 . . . . . . . . 177

5.2 Tank 241-BX-102 . . . . . . . . . . . . . . . . . . 181

5.2.1 241-BX-102 Tank History . . . . . . . . 181

5.2.1.1 Waste History Tank 241-BX-102 . . . 181

5.2.1.2 Temperature History 241-BX-102... 181

5.2.1.3 Integrity of Tank 241-BX-102 . . . . 181

5.2.2 Current Status of Tank 241-BX-102 . . . . 181

5.2.2.1 Inventory estimate 241-BX-102 . . . 182

5.2.2.2 In-Tank Photograph 241-BX-102 . . . 182

5.2 .3 Synopsis Tank 241-BX-102 . . . . . . . 182

5.3 Tank 241-BX-103 . . . . . . . . . . . . . . 186

5.3.1 241-BX-103 Tank History . . . . . . . 186

5.3.1.1 Waste History Tank 241-BX-103 . . . 186

5.3.1.2 Temperature History 241-BX-103 . . . 186

5.3.1.3 Integrity of Tank 241-BX-103. . . . 186

5.3 .2 Current Status of Tank 241-BX-103. . . . 186

5.3.2.1 Inventory estimate 241-BX-103 . . . 187

5.3.2.2 In-Tank Photograph 241-BX-103 . . . 187

5.3 .3 Synopsis Tank 241-BX-103 . . . . . . . . 187

5.4 Tank 241-BX-104 . . . . . . . . . . . . . . . . . . 191

5.4.1 241-BX-104 Tank History . . . . . . . . . 191

5.4.1.1 Waste History Tank 241-BX-104 . . . 191

5.4.1.2 Temperature History 241-BX-104. . . 191

5.4.1.3 Integrity of Tank 241-BX-104... . 191 
5.4.2 Current Status of Tank 241-BX-104. . . . 191 5.4.2.1 Inventory estimate 241-BX-104: . . 192

5.4.2 In-Tank Photograph 241-BX-104 . . . 192

5.4.3 Synopsis Tank 241-BX-104 . . . . . . . . 192

5.5 Tank 241-BX-105 . . . . . . . . . . . . . . 196

5.5.1 241-BX-105 Tank History . . . . . . . 196

5.5.1.1 Waste History Tank 241-BX-105 . . 196

5.5.1.2 Temperature History 241-BX-105. . . 196

5.5.1.3 Integrity of Tank 241-BX-105 . . . . 196

5.5.2 Current Status of Tank 241-BX-105. : . 196.

5.5.2.1 Inventory estimate 241-BX-105 . . . 197

5.5.2.2 In-Tank Photograph 241-BX-105 . . . 197

5.5 .3 Synopsis Tank 241-BX-105 . . . . . . . . 197

5.6 Tank 241-BX-106 ................. . . 201

5.6.1:. : 241-BX-106. Tank

5.6.1.1 Waste History Tank 241-BX-106 . . . 201

5.6.1.2 Temperature Fistory $241-\mathrm{BX}-106: .201$

5.6.1.3 Integrity of Tank 241-BX-106... . 201

5.6 .2 Current Status of Tank 241-BX-106... . 201

5.6.2.1 Inventory estimate 241-BX-106 . . . 202

5.6.2.2 In-Tank Photograph 241-BX-106 . . . 202

5.6 .3 Synopsis Tank 241-BX-106 . . . . . . 202

5.7 Tank 241-BX-107.................. . . . . . . . . . . . . . . .

5.7.1 241-BX-107 Tank History . . . . . . . . 206

5.7.1.1 Waste History Tank 241-BX-107... 206

5.7.1.2 Temperature History 241-BX-107.. . 206

5.7.1.3 Integrity of Tank 241-BX-107. . . . 206

5.7 .2 Current Status of Tank 241-BX-107:. . . 206

5.7.2.1 Inventory estimate 241-BX-107 . . . 207

5.7.2.2 In-Tank Photograph 241-BX-107 . . 207

5.7 .3 Synopsis Tank 241-BX-107 . . . . . . . 207

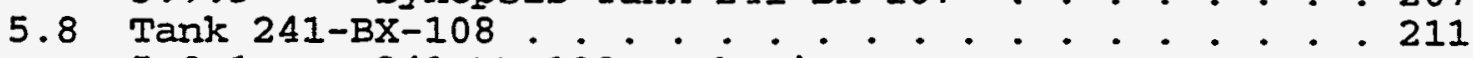

5.8.1 241-BX-108 Tank History. . . . . . . . 211

5.8.1.1 Waste History Tank 241-BX-108:. . 211

5.8.1.2 Temperature History 241-BX-108... 211

5.8.2 5.8.1.3 Integrity of Tank 241-BX-108. : . . . 211

5.8.2.1 Inventory estimate 241-BX-108: $: .212$

5.8.2.2 In-Tank Photograph 241-BX-108 ... . 212

5.8 .3 Synopsis Tank 241-BX-108 . . . . . . . . 212

5.9 Tank 241-BX-109. . . . . . . . . . . . . . . . . 216

5.9.1 241-BX-109 Tank History........ . 216

5.9.1.1 Waste History Tank 241-BX-109.. . 216

5.9.1.2 Temperature History 241-BX-109... 216

5.9.1.3 Integrity of Tank 241-BX-109... . 216

5.9 .2 Current Status of Tank 241-BX-109:. . . 216

5.9.2.1 Inventory estimate 241-BX-109 . . . 217

5.9.2.2 In-Tank Photograph 241-BX-109:. . 217

5.9.3 Synopsis Tank 241-BX-109 . . . . . . . . 217

5.10 Tank 241-BX-110 . . . . . . . . . . . . . . 221

5.10.1 241-BX-110 Tank History . . . . . . . 221

5.10.1.1 Waste History Tank 241-BX-110 . . 221

5.10.1.2 Temperature History 241-BX-110.. . 221

$$
\text { - viii - } \quad 6 / 94
$$


5.10.1.3 Integrity of Tank 241-BX-110... . 221

5.10 .2 Current Status of Tank 241-BX-110. . . . 222

5.10 .2 .1 Inventory estimate 241-BX-110 . . . 222

5.10.2.2 In-Tank Photograph 241-BX-110 . . . 222

5.10 .3 Synopsis Tank 241-BX-110 . . . . . . . . 222

5.11 Tank 241-BX-111 . . . . . . . . . . . . . . . 226

5.11.1 241-BX-111 Tank History . . . . . . . . 226

5.11.1.1 Waste History Tank 241-BX-111 . . . 226

5.11 .1 .2 Temperature History 241-BX-111... . 226

5.11.1.3 Integrity of Tank 241-BX-111 . . . . 226

5.11 .2 Current Status of Tank 241-BX-111 . . . . 227

5.11.2.1 Inventory estimate 241-BX-111 . . . 227

5.11.2.2 In-Tank Photograph 241-BX-111 . . . 227

$5.11 .3 \ldots$ Synopsis :Tank 241-BX-111,........ . 227

5.12 Tank 241-BX-112\%. . . . . . . . . . . . . . . 231

5.12.1 241-BX-112 Tank History . . . . . . . . 231

5.12.1.1 Waste History Tank 241-BX-112 . . . 231

5.12 .1 .2 Temperature History 241-BX-112 . . 231

5.12.1.3 Integrity of Tank 241-BX-112 . . . . 231

5.12 .2 Current Status of Tank 241-BX-112... . 231

5.12 .2 .1 Inventory estimate 241-BX-112 . . . 232

5.12 .2 .2 In-Tank Photograph 241-BX-112 . . . 232

5.12 .3 Synopsis Tank 241-BX-112 . . . . . . . . 232

6.0 BY Tank Farm . . . . . . . . . . . . ... . 236

6.0.1 BY Tank Farm History . . . . . . . 236

6.0.1.1 BY Tank Farm Waste History . . . . . 238

6.0.1.2 BY Tank Farm Temperature History . . 238

6.0.1.3 BY Tank Farm Integrity . . . . . . 238

6.0 .2 Current status of BY Tank Farm . . . . . 239

6.1 Tank 241-BY-101............ . . 241

6.1.1 241-BY-101 Tank History . . . . . . . 241

6.1.1.1 Waste History Tank 241-BY-101 . . . 241

6.1.1.2 Temperature History 241-BY-101 . . . 241

6.1.1.3 Integrity of Tank 241-BY-101... . 241

6.1 .2 Current Status of Tank 241-BY-101... . 242

6.1.2.1 Inventory estimate 241-BY-101 . . . 242

6.1.2.2 In-Tank Photograph 241-BY-101 . . 242

6.1 .3 Synopsis Tank 241-BY-101 ....... 242

6.2 Tank 241-BY-102 . . . . . . . . . . . . 246

6.2.1 241-BY-102 Tank History . . . . . 246

6.2.1.1 Waste History Tank 241-BY-102 ․ . 246

6.2.1.2 Temperature History 241-BY-102 . . 246

6.2.1.3 Integrity of Tank 241-BY-102 . . . 246

6.2 .2 Current Status of Tank 241-BY-102 . . . 247

6.2.2.1 Inventory estimate 241-BY-102 . . . 247

6.2.2.2 In-Tank Photograph 241-BY-102 . . . 247

6.2 .3 Synopsis Tank 241-BY-102 ...... . 247

6.3 Tank 241-BY-103 . . . . . . . . 251

6.3.1 241-BY-103 Tank History . . . . . . 251

6.3.1.1 Waste History Tank 241-BY-103 . . . 251

6.3.1.2 Temperature History 241-BY-103:. 251

6.3.1.3 Integrity of Tank 241-BY-103... 251 
6.3.2 Current Status of Tank 241-BY-103. . . . 252

6.3.2.1 Inventory estimate 241-BY-103 . . . 252

6.3.2.2 In-Tank Photograph 241-BY-103 . . . 252

6.3 .3 Synopsis Tank 241-BY-103 . . . . . . . . 252

6.4 Tank 241-BY-104. . . . . . . . . . . . . . . 256

6.4.1 241-BY-104 Tank History . . . . . . . . 256

6.4.1.1 Waste History Tank 241-BY-104 . . . 256

6.4.1.2 Temperature History 241-BY-104... 256

16.4.1.3 Integrity- of Tank 241-BY-104. . . . 256

6.4 .2 Current status of Tank 241-BY-104. . . . 257

6.4.2.1 Inventory estimate 241-BY-104 . . . 257

In-Tank Photograph 241

6.5 . Tank 241-BY=10.5 ....................... . . . 261

$6: 5: 1$ 241-BY-105 Tâk-Hitstorym $\because \because . . . .261$

6.5.1.1 Waste History Tank 241-BY-105 . . . 261

6.5.1.2 Temperature History 241-BY-105.. . 261

6.5.1.3 Integrity of Tank 241-BY-105... . 261

6.5.2 Current Status of Tank 241-BY-105. . . . 262

6.5.2.1 Inventory estimate 241-BY-105 . . . 262

6.5.2.2 In-Tank Photograph 241-BY-105 $\quad \cdot{ }^{\circ} \cdot .262$

6.5 .3 Synopsis Tank 241-BY-105 ........ 262

6.6 Tank 241-BY-106 . . . . . . . . . . . . . . . 266

6.6.1 241-BY-106 Tank History....... . . 266

6.6.1.1 Waste History Tank 241-BY-106 . . . 266

6.6 .1 .2 Temperature History 241-BY-106.. . 266

6.6.1.3 Integrity of Tank 241-BY-106... . 266

6.6 .2 Current Status of Tank 241-BY-106... . . 267

6.6.2.1 Inventory estimate 241-BY-106 . . . 267

6.6.2.2 In-Tank Photograph 241-BY-106 . . . 267

6.6 .3 Synopsis Tank 241-BY-106 . . . . . . . 267

6.7 Tank 241-BY-107................ . . . . . . . . . . . .

6.7.1 241-BY-107 Tank History . . . . . . . 271

6.7.1.1 Waste Fistory Tank 241-BY-107 ... 271

6.7.1.2 Temperature History 241-BY-107. . . 271

6.7 6.7.1.3 Integrity of Tank 241-BY-107. . . . 271

Current status of Tank 241-BY-107... . 272

6.7.2.1 Inventory estimate 241-BY-107 . . . 272

6.7.2.2 In-Tank Photograph 241-BY-107 . . 272

6.7 .3 Synopsis Tank 241-BY-107 . . . . . . . 272

6.8 Tank 241-BY-108 . . . . . . . . . . . . . . . 276

6.8.1 241-BY-108 Tank History . . . . . . . . 276

6.8 .1 .1 Waste History Tank 241-BY-108 . . . 276

6.8.1.2 Temperature History 241-BY-108. . . 276

6.8.1.3 Integrity of Tank 241-BY-108... . 276

6.8 .2 Current Status of Tank 241-BY-108... . 276

6.8.2.1 Inventory estimate 241-BY-108 . . . 277

6.8.2.2 In-Tank Photograph 241-BY-108 . . . 277

6.8 .3 Synopsis Tank 241-BY-108 . . . . . . . 277

6.9 Tank 241-BY-109 . . . . . . . . . . . . . . . . 281

6.9.1 241-BY-109 Tank History . . . . . . . . 281

6.9.1.1 Waste History Tank 241-BY-109 . . . 281

6.9.1.2 Temperature History 241-BY-109. . . 281

$-x-\quad 6 / 94$ 
6.9.1.3 Integrity of Tank 241-BY-109... . 281

6.9 .2 Current status of Tank 241-BY-109.. . . 282

6.9.2.1 Inventory estimate 241-BY-109 . . . 282

6.9.2.2 In-Tank Photograph 241-BY-109 . . . 282

6.9 .3 Synopsis Tank 241-BY-109 . . . . . . . . 282

6.10 Tank 241-BY-110 . . . . . . . . . . . . . . . 286

$6.10 .1241-B Y-110$ Tank History . . . . . . . 286

6.10.1.1 Waste History-Tank 241-BY-110 . . . 286

6.10 .1 .2 . Temperature History 241-BY-110 . . . 286

6.10 .1 .3 Integrity of Tank 241-BY-110... . 286

6.10.2 Current status of Tank $241-B Y-110$. . . . 286

6.10.2.1 Inventory estimate 241-BY-110 . . . 287

6.10.2.2 In-Tank Photograph 241-BY-110 • . . 287

$6: 11$ Tank-241-BY-1.11-

6.11.1 241-BY-111 Tank History . . . . . . . . . 291

6.11 .1 .1 Waste History Tank 24I-BY-111 . . . 291

6.11.1.2 Temperature History 241-BY-111 . . . 291

6.11 .1 .3 Integrity of Tank 241-BY-111... . 291

6.11 .2 Current Status of Tank 241-BY-111. . . . 292

6.11 .2 .1 Inventory estimate 241-BY-111 . . . 292

6.11.2.2 In-Tank Photograph 241-BY-111 . . . 292

6.11 .3 Synopsis Tank 241-BY-111 . . . . . . . . 292

6.12 Tank 241-BY-112 . . . . . . . . . . . . . . . . . . 296

6.12.1 241-BY-112 Tank History . . . . . . . . 296

6.12.1.1 Waste History Tank 241-BY-112 . . . 296

6.12 .1 .2 Temperature History 241-BY-112 . . 296

6.12 .1 .3 Integrity of Tank 241-BY-112 . . . 296

6.12 .2 Current Status of Tank 241-BY-112 . . . . 296

6.12 .2 .1 Inventory estimate $241-B Y-112 \div . \cdot 297$

6.12 .2 .2 In-Tank Photograph 241-BY-112 . . . 297

6.12 .3 Synopsis Tank 241-BY-112 . . . . . . . 297

7.0 C Tank Farm . . . . . . . . . . . . . . . . . . . 301

7.0.1 C Tank Farm History . . . . . . . . . 301

7.0.1.1 C Tank Farm Waste History . .. . . 303

7.0.1.2 C Tank Farm Temperature History . . 303

7.0.1.3 C Tank Farm Integrity . . . . . . 303

7.0.2 Current Status of C Tank Farm . . . . . 304

7.1 Tank 241-C-101 . . . . . . . . . . . . . . . 306

7.1.1 241-C-101 Tank History . . . . . . . . 306

7.1 .1 .1 Waste History Tank 241-C-101... 306

7.1.1.2 Temperature History 241-C-101 . . . 306

7.1.1.3 Integrity of Tank 241-C-101 . . . . 306

7.1.2 Current Status of Tank 241-C-101 . . . . 306

7.1.2.1 Inventory estimate 241-C-101... . 307

7.1.2.2 In-Tank Photograph 241-C-101... . 307

7.1 .3 Synopsis Tank 241-C-101........ . 307

7.2 Tank 241-C-102 . . . . . . . . . . . . . . . . . 311

7.2.1 241-C-102 Tank History . . . . . . . 311

7.2.1.1 Waste History Tank 241-C-102 . . . 311

7.2 .1 .2 Temperature History 241-C-102 . . . 311

7.2.1.3 Integrity of Tank 241-C-102 . . . . 311 
7.2.2 Current Status of Tank 241-C-102 . . . . 311

7.2.2.1 Inventory estimate 241-C-102 . . . . 311

2.3 Synopsis Tank 241-C-102

7.3 Tank 241-C-103 . . . . . . . . . . . . 316

7.3.1 241-C-103 Tank History . . . . . . . 316

7.3.1.1 Waste History Tank 241-C-103... . 316

7.3.1.2 Temperature History $241-C-103$. . . 316

i7.3.1.3 Integrity of Tank 241-C-103 .... 316

7.3.2 Current" Status of Tank 241-C-103 ... . . 316

7.3.2.1 Inventory estimate 241-C-103... . 317

7.3.2.2 In-Tank Photograph 241-C-103 . . . 317

7.3.3 Synopsis Tank 241-C-103 . . . . . . . . 317

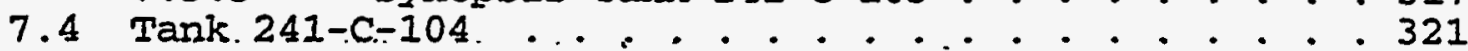

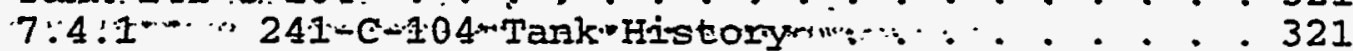

7.4.1.1 Waste History Tank 241-C-104... . 321

7.4.1.2 Temperature History 241-C-104 . . . 321

7.4.1.3 Integrity of Tank 241-C-104 . . . . 321

7.4 .2 Current Status of Tank 241-C-104 .. . . 321

7.4.2.1 Inventory estimate $241-\mathrm{C}-104 . \mathrm{C}^{\circ} .322$

7.4.2.2 In-Tank Photograph 241-C-104... . 322

7.4 .3 Synopsis Tank 241-C-104... . . . . . . 322

7.5 Tank 241-C-105 ................ . . . . . . . . . . . . .

7.5.1 241-C-105 Tank History . . . . . . . . 326

7.5.1.1 Waste History Tank 24I-C-105... . 326

7.5.1.2 Temperature History 241-C-105 . . . 326

7.5.1.3 Integrity of Tank $241-C-105$. . . . 326

7.5 .2 Current Status of Tank 241-C-105:.. . 326

7.5.2.1 Inventory estimate 241-C-105... . 327

7.5.2.2 In-Tank Photograph 241-C-105. . . . 327

7.5.3 Synopsis Tank 241-C-105 . . . . . . . . . 327

7.6 Tank 241-C-106 . . . . . . . . . . . . . . . 331

7.6.1 241-C-106 Tank History . . . . . . . . 331

7.6.1.1 Waste History Tank 241-C-106... . 331

7.6.1.2 Temperature History 241-c-106. . . 331

7.6.1.3 Integrity of Tank 241-C-106 . . . . 331

7.6 .2 Current Status of Tank 241-C-106 . . . . 331

7.6.2.1 Inventory estimate 241-C-106... 332

7.6.2.2 In-Tank Photograph 241-C-106. . . 332

7.6.3 Synopsis Tank 241-C-106. . . . . . . . . 332

7.7 Tank 241-C-107 . . . . . . . . . . . . . . . 336

7.7.1 241-C-107 Tank History . . . . . . 336

7.7.1.1 Waste History Tank 241-C-i07... . 336

7.7 .1 .2 Temperature History $241-\mathrm{C}-107$. . 336

7.7.1.3 Integrity of Tank 241-C-107 . . . . 336

7.7 .2 Current Status of Tank 241-C-107 ... . 336

7.7 .2 .1 Inventory estimate 241-C-107. . . 337

7.7.2.2 In-Tank Photograph 241-C-107... 337

7.7.3 Synopsis Tank 241-C-107. . . . . . . . . 337

7.8 Tank 241-C-108 . . . . . . . . . . . . . . . . 341

7.8.1 241-C-108 Tank Fistory . . . . . . 341

7.8.1.1 Waste History Tank 241-C-108... . 341

7.8.1.2 Temperature History 241-C-108 . . . 341

- xii- $6 / 94$ 
WHC-SD-WM-ER-349, Rev. 0

7.8.1.3 Integrity of Tank 241-C-108 . . . . 341

7.8 .2 Current Status of Tank 241-C-108 . . . . 341

7.8.2.1 Inventory estimate 241-C-108... . 342

7.8.2.2 In-Tank Photograph 241-C-108... . 342

7.8 .3 Synopsis Tank 241-C-108... . . . . 342

7.9 Tank 241-C-109 . . . . . . . . . . . . . . . 346

7.9.1 241-C-109 Tank History . . . . . . . 346

7.9.1.1 Waste History Tank 241-C-109... . 346

7.9.1.2 Temperature History 241-C-109 . . . 346

7.9.1.3 Integrity of Tank 241-C-109 . . . . 346

7.9 .2 Current Status of Tank 241-C-109 . . . . 346

7.9.2.1 Inventory estimate 241-C-109... . 347

7.9.2.2 In-Tank Photograph 241-C-109. . . 347

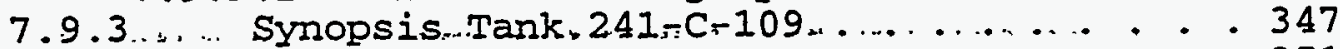

7.10 Tänk $241=\mathrm{C}-110 \cdots .$. . . . . . . . . . . . . . . . 351

7.10.1 241-C-110 Tank History . . . . . . . 351

7.10.1.1 Waste History Tank 241-C-110... . 351

7.10.1.2 Temperature History 241-C-110 . . . 351

7.10.1.3 Integrity of Tank 241-C-110 . . . . 351

7.10 .2 Current Status of Tank 241-C-110 . . . . 351

7.10.2.1 Inventory estimate $241-C-110 . . .352$

7.10.2.2 In-Tank Photograph 241-C-110... . 352

7.10 .3 Synopsis Tank 241-C-110....... . . 352

7.11 Tank 241-C-111 . . . . . . . . . . . . . . . . . 356

7.11.1 241-C-111 Tank History . . . . ... . 356

7.11.1.1 Waste History Tank 241-C-111. . . . 356

7.11.1.2 Temperature History 241-C-111 . . 356

7.11.1.3 Integrity of Tank 241-C-111 . . . 356

7.11 .2 Current Status of Tank 241-C-111... . 356

7.11.2.1 Inventory estimate $241-C-111$. . . . 357

7.11.2.2 In-Tank Photograph 241-C-111... . 357

7.11 .3 Synopsis Tank 241-C-111. . . . . . . . 357

7.12 Tank 241-C-112 . . . . . . . . . . . . . . . . 361

7.12.1 241-C-112 Tank History . . . . . . 361

7.12.1.1 Waste History Tank 241-C-112... . 361

7.12 .1 .2 Temperature History $241-\mathrm{C}-112$. . 361

7.12.1.3 Integrity of Tank 241-C-112 . . . 361

7.12 .2 Current status of Tank 241-C-112 . . . . 361

7.12.2.1 Inventory estimate 241-C-112. . . . 362

7.12.2.2 In-Tank Photograph 241-C-112... . 362

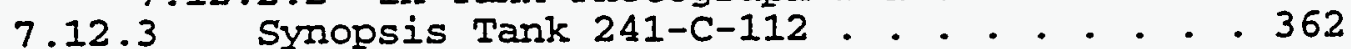

7.13 Tank 241-C-201 . . . . . . . . . . . . . . . 366

7.13.1 241-C-201 Tank History . . . . . . . 366

7.13.1.1 Waste History Tank 241-C-201... . 366

7.13 .1 .2 Temperature History 241-C-201 . . 366

7.13 .1 .3 Integrity of Tank 241-C-201 . . . 366

7.13 .2 Current Status of Tank 241-C-201 . . . 366

7.13.2.1 Inventory estimate 241-C-201 . . . 367

7.13 .2 .2 In-Tank Photograph 241-C-201 . . . 367

7.13 .3 Synopsis Tank 241-C-201... . . . . . 367

7.14 Tank 241-C-202 . . . . . . . . . . . . . . . . . 371

7.14.1 241-C-202 Tank History . . . . . . 371

$7: 14.1 .1$ Waste History Tank 241-C-202... 371

$\begin{array}{ll}-x i i \text { - } & 6 / 94\end{array}$ 


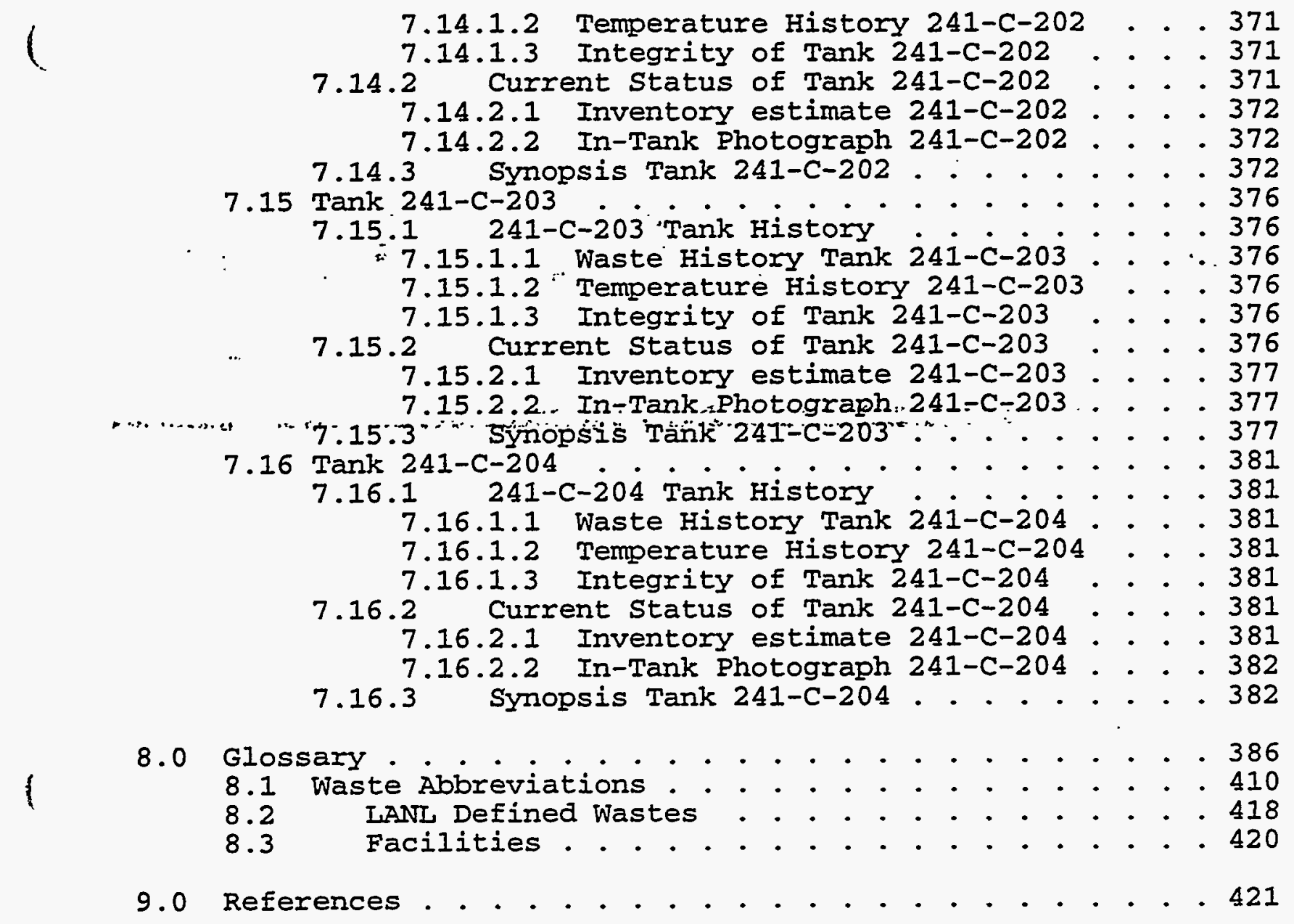


WHC-SD-WM-ER-349, Rev. 0

\author{
INFORMATION FEEDBACK CARD
}

\title{
HISTORICAL TANK CONTENT ESTIMATE FOR THE NORTHEAST QUADRANT OF THE HANFORD 200 EAST AREAS ER4945
}

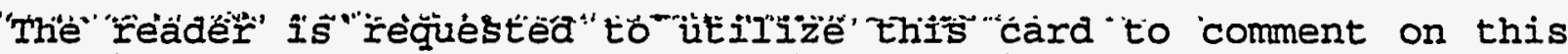
working document, report any discrepancies, or contribute new information to improve the accuracy and content of the report. Please use the space provided below, add additional pages if necessary, and return to the addressee on the reverse side. 
WHC-SD-WM-ER-349, Rev. 0

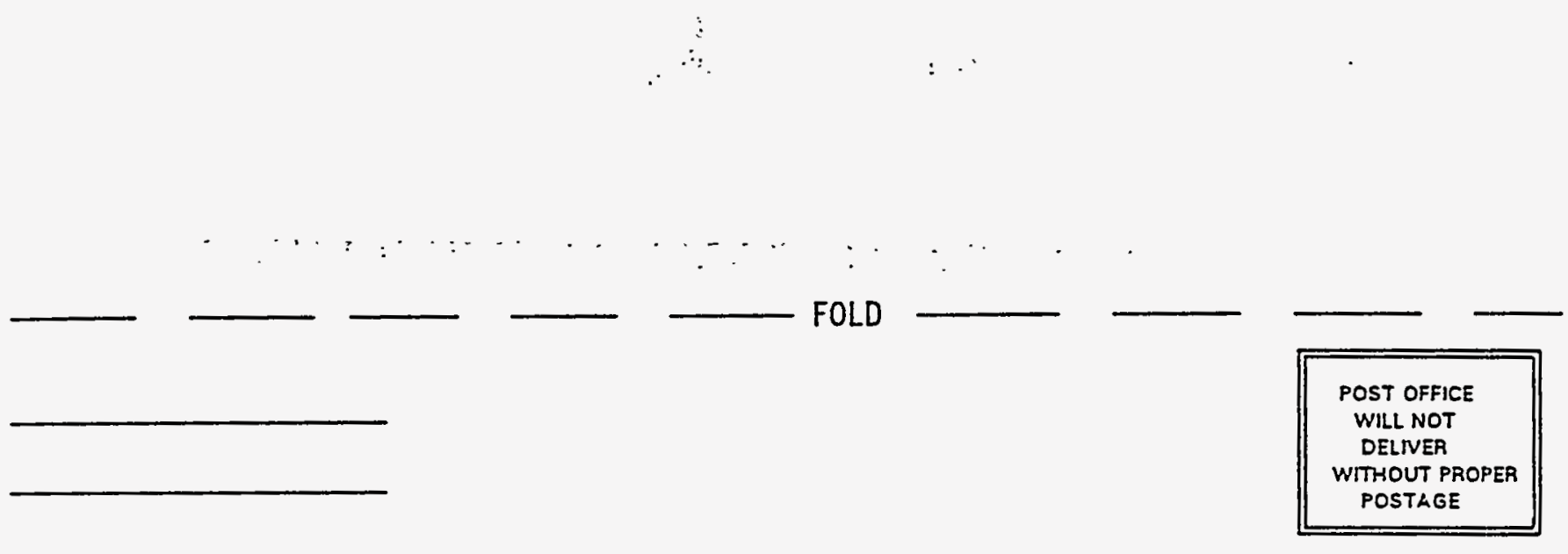

Mr. Carl S. Haller

Manager, Characterization Support

Westinghouse Hanford Company

P.0. Box 1970

Richland, WA 99352

FOLD 
컴
을
일

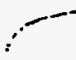

S 


\subsection{Introduction}

\subsection{Purpose}

This document provides historical evaluations of the radioactive mixed wastes stored in the Hanford Site 200-East Area underground single-shell tanks (SSTs). A Historical Tank Content Estimate has been developed by reviewing the process histories, waste transfer data, and available.. physical and chemical characterization data from"various Department: of Energy (DOE) "and Department of Defense (DOD) contractors.

The historical data will supplement information gathered from in-tank core sampling.activities that are presently. underway.

" "Review" of" $a$ "tank" history"accompanied by" "current"characterization data will create an inventory estimate that is more complete and reliable then core sampling alone. Additionally, historical review of the tanks may reveal anomalies or unusual contents that are critical to characterization and post characterization activities.

Complete and accurate tank waste characterizations are critical first steps for the DOE and Westinghouse Hanford Company safety programs, waste pretreatment, and waste retrieval activities.

\subsection{Scope}

The scope of this document is Iimited to the SSTs in the northeast quadrant of the 200 Areas. The northeast and southeast quadrants represent an approximate geographical division of the 200-East Area tank farms. The division was made as follows:

- NE Quadrant: $A, A X, B, B X, B Y, C$

- SE Quadrant: $A N, A Z, A P, A W, A Y, S Y$

The map on the following page details the 200-East Area

\subsection{Approach}

This report is a compilation of work performed by ICF Kaiser Hanford Company, Los Alamos National Laboratories, and Westinghouse Hanford Company.

Westinghouse Hanford Company requested that ICF Kaiser Hanford Company review the history of the tanks in each of the four quadrants and incorporate the tank layering models and inventory estimates being developed by Los Alamos National Laboratories into the report. Historical waste transfer and level data, tank physical information, temperature data, sampling data, and drywell and liquid observation well data have been compiled for this report and the supporting documents for the northeast quadrant historical tank content estimates (Brevick 1994). 

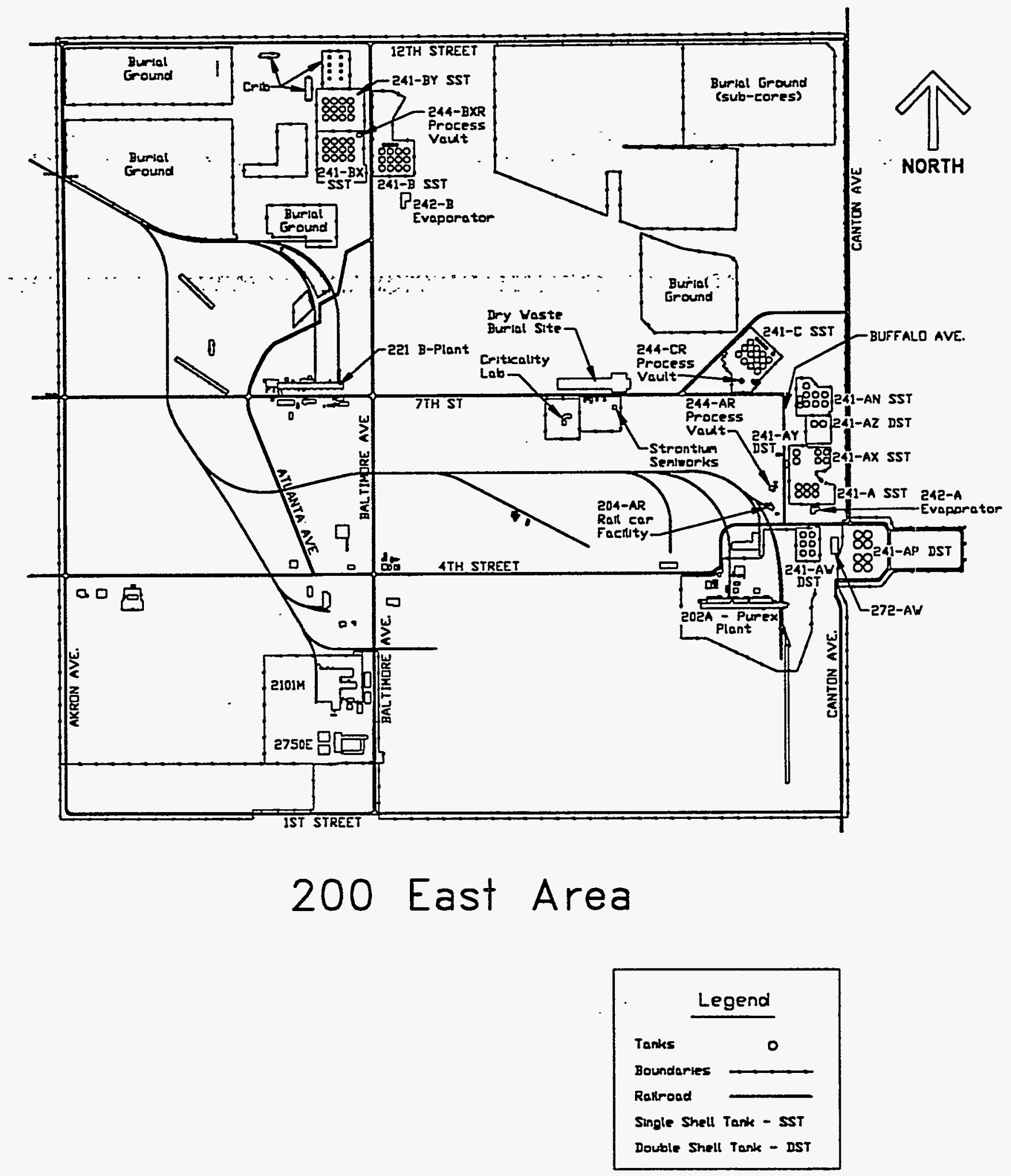

Waste Storage Tanks

Surveillance information is used for tank characterization. Tank integrity (i.e., sound, assumed leaker, assumed re-leaker) is investigated by comparing the changing liquid levels to liquid observation well data and drywell activity. Waste temperatures can be used to correlate the inventories of heat-generating radionuclides $\left({ }^{137} \mathrm{Cs}\right.$ and $\left.{ }^{91} \mathrm{Sr}\right)$ in the tanks. The instrumentation and methods used for tank surveillance are described in the following sections.

\section{In-Tank Surface Levels}

Surface levels within the SSTs are monitored by instruments consisting "of calibrated"steel" tapes "with "an" electrode plummet on the end that will complete a circuit when it contacts a conducting surface (i.e., liquid). The surface level measurements are usually taken with Food Industry Corporation gauges and manual tapes. The measurements are recorded on a computer automated surveillance system (CASS).

\section{Interstitial Iiquid Ievel (Iiquid observation Wells)}

Food Industry Corporation gauges and manual tapes are limited to surface level measurement; therefore, liquid observation wells in many tanks have been installed specifically to monitor the interstitial liquid level within the SSTs. The interstitial liquid is the Iiquid trapped within and underneath the solid waste. Gamma, neutron, and acoustic probes may be lowered into the liquid observation wells to determine the interstitial liquid levels within the tank. Each probe scan is fully automatic and successful scans are input to the computer automated surveillance system.

Internal Tank Temperatures (Thermocouples)

Temperature data are usually recorded automatically in the computer automated surveillance system (CASS). Some tanks are monitored manually and the data is recorded on data sheets. Temperatures are monitored with thermocouple trees that are comprised of stainless steel pipe with 4 to 18 thermocouples. Usually, the lowest sensor is located approximately 4 in. from the tank bottom and the other sensors progress up the tree at 2 -ft intervals. More frequent temperature readings are available for a few select tanks due to an upgrade in the surveillance data acquisition system to the tank monitor and control system (TMACS) in 1991.

In general, a single thermocouple sensor is sent down the Iiquid observation well to take semiannual readings in tanks that do not contain a thermocouple tree. The temperatures are recorded manually in degrees Fahrenheit and are entered into the surveillance analysis computer system (SACS) that currently uses the ORACLE database. 
External Leak Detection (Drywells)

Drywelis are located around the circumference of each SST and throughout the tank farms to determine if tank wastes have leaked. The drywells are generally 6-in. diameter carbon steel pipe and are between 75 and 250 ft deep. The wells are termed dry because they are not deep enough to reach ground water.

Laterals (i.e., horizontal drywelis) are positioned under some SSTs to detect radionuclides in the soil which could be indicative of tank leakage. The drywells are monitored by radiation detection probes and occasionally by a temperature probe. Laterals have 4in. inside diameter steel pipes located 8 to 10 ft below the concrete base of the tank, and each tank has three laterals. Laterals are. Iocated only, in, the 241-A :Tank, Earm-and a portion of the 24I-SX" Tẩik Fârm:"

\section{- In-Tank Photography}

In-tank photography is another waste volume determination method used to resolve in-tank measurement anomalies and determine tank integrity. photographs can determine sludge and liquid levels, provide a degree of corroboration with other waste management processes, and be a source of information for foreign objects contained in the tanks. The photos can be compared to see if wastes in tanks with similar histories have similar characteristics.

1.3.2 Approach and Development of Supporting Information Contained in the Historical Tank Content Estimate and Supporting Documents

Extensive historical information was gathered for each tank. The data is summarized in the Historical Tank Characterization Estimate including the tank level history, the tank layering model, and the inventory estimate. For a more comprehensive data set on each tank, refer to the supporting documents for the northeast quadrant historical tank content estimates (Brevick 1994).

\section{- Tank Level Eistories}

The tank level histories are graphical representations of waste levels over the lifetime of a tank. They include information such as pH, in-tank photo dates, waste types, transfer data, and physical data. Information was gathered from various documents and resulting comments were added directly to each drawing.

The liquid, solid, and interstitial liquid levels (liquid observation wells data) are shown on the tank level history graphs as volumes and tank elevations. The following conversions were used to relate the volumes to the respective elevation for each tank farm design: 


\section{FORMULAS}

$\frac{\text { Total Gallons }}{2750 \frac{\text { Gallons }}{\text { Inch }}}=$ Total Inches

Total Gallons $-12,500+12$. Inches $=$ Total Inches $2750 \frac{\text { Gallons }}{\text { Inch }}$

$\frac{\text { Total Gallons }-12,500}{2750 \frac{\text { Gallons }}{\text { Inch }}}=$ Total Inches

(3)

$\frac{\text { Total Gallons }-18,500}{2750 \frac{\text { Gallons }}{\text { Inch }}}+12$ Inches $=$ Total Inches

(4)

$\frac{\text { Total Gallons }-590}{196 \frac{\text { Gallons }}{\text { Inch }}}+6$ Inches $=$ Total Inches

\begin{tabular}{|c|l|c|}
\hline Equation No. & Applicable Tank Farms: & Tank Diameter \\
\hline 1 & A, AN, AP, AW, AX, AY, AZ, SY & $75 \mathrm{ft}$ \\
\hline 2 & BY, S, TX, TY & $75 \mathrm{ft}$ \\
\hline 3 & B, BX, C, T, U & $75 \mathrm{ft}$ \\
\hline 4 & SX & $75 \mathrm{ft}$ \\
\hline 5 & B, C, T, U (200 Series) & $20 \mathrm{ft}$ \\
\hline
\end{tabular}


- Temperature plots

The historical temperature data were obtained from the Westinghouse Hanford Company ORACLE database commonly known as the Surveillance Analysis Computer system (SACS). The thermocouple temperature information was parsed in an EXCEL spreadsheet and graphed to show each individual thermocouple probe. Temperature versus time plots were developed for all the thermocouples. If documentation was available, thermocouple elevations were included in the plots for tanks currently containing thermocouple trees. Thermocouples are ordered from the bottom to the top of the tank. Therefore, a plot of thermocouple 1 over time would indicate the temperature near the bottom of the tank. In-tank temperature information is available in the supporting documents (Brevick $1994)$

\section{Surface Level Plots}

The surface level data from 1991 to 1993 were obtained from the Westinghouse Hanford Company ORACLE database. The information was parsed in an EXCEL spreadsheet and graphed to show waste level versus time. Current in-tank surface level information is available in the supporting documents (Brevick 1994).

\section{Drywell Plots}

The drywell information was obtained from the manual records of the Westinghouse Hanford Company Tank Farm Surveillance Group. Data from 1990 to the present were input into an EXCEL spreadsheet and graphed to show the peaks in counts/second (c/s) and the depth at which the peak occurred in feet (ft) versus the date on the same chart. Tank arywell information is available in the supporting documents (Brevick 1994).

\section{- Tank Profiles and Other Drawings}

The drawings in this report were compiled from several sources including as-built drawings, the Waste storage Tank Status and Leak Detection Criteria (Welty 1988), and the Riser Configuration Document for Single-Shell Waste Tanks (Alstad 1991).

The risers and penetrations throughout the tank dome have several purposes. Some risers were installed during the original tank construction and others were added later.

Through the years, sleeves or smaller risers were installed in many of the larger $(42-i n$.$) risers. For the riser configurations$ in this report, a tank may have a. riser number followed by a letter which means that a larger riser was fitted with smaller sleeves. Depending on the intended use, the riser sleeves can be as large as 12-in. or as small as 4-in. For example, a saltwell pump and screen requires a $12 \mathrm{in.} \mathrm{riser} \mathrm{but} \mathrm{a} \mathrm{thermocouple} \mathrm{tree} \mathrm{requires}$ only a 4-in. riser.

\section{- Photographs}

The tank farm photos were labeled to indicate the relative position of each tank in the farm and arrows were added to show the 
cascade series of each tank farm.

The latest in-tank and tank farm photos were obtained from Pacific Northwest Laboratory. In-tank photos have been arranged to show the contents of each tank. The auxiliary equipment within each photo collage was identified if possible and labeled appropriately.

Bistorical Sample Analysis Data:

The sampling data were obtained from the WHC Tank Waste and Retrieval Group. Tables of analytical data were made for samples taken prior to september 1989. The information was compiled in EXCEI to present the data in as similar a manner as possible. The tables include physical data, chemical and radiological analysis

- "data by analyte: " other data"included with the "sample references are summarized as text. Historical tank sample analysis data is available in the supporting documents (Brevick 1994).

1.3.3 Approach and Development of the Process-Based Historical Tank Content Estimate

The process-based historical tank content estimates presented in this report were developed by Los Alamos National Laboratories. The tank content estimates are the primary source of tank characterization data until the tank characterization reports are completed. The tank characterization reports will incorporate current core sampling and analysis results with historical-based tank content estimates to present the most current evaluation of the tank waste constituents.

Generating historical tank content estimates involves management and evaluation of large quantities of data. Several smaller components of the data management effort make up the system of generating historical tank estimates. The components are described in the following sections.

Waste Status and Transaction Record Summary Database

The waste status and transaction record sumary database is a database of all known waste transfer records. Historically, when waste was pumped from plant (process) to tank or tank to tank, a record was kept of the volume and type of waste that was pumped. The transaction summary is the recorded waste level of the solids and supernate.

The waste status and transaction record summary database is partitioned into four separate sections (i.e., quadrants). The database for the northeast quadrant is available in Document No. WHC-SD-WM-TI-615 Rev. O (Agnew 1994).

Tank Layering Model

The tank layering model is derived from the waste status and transaction record summary database. The purpose of the tank layering model is to predict the waste types and volumes in each 
tank. The transaction summary database records the types of waste that enter each tank and the corresponding increase in the solids volume from each waste entry. Each waste type that increases the solids volume in the tank is recorded in. the tank layering model. Therefore, the completeness and accuracy of the information in the tank layering model is directly related to the completeness and accuracy of the transaction summary database.

: The tank layering model was created to develop historical tank content estimates. The results of the tank layering model are reported in this document. The tank layering model is presented graphically with the inventory estimate described below.

.. Defined. Waste .Types....

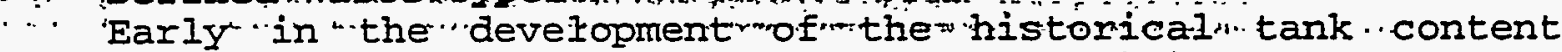
estimates, a need to compile the chemical compositions of all known waste types into one reference document was recognized. The information was compiled by Los Alamos National Laboratories. The Hanford Defined Waste Document was developed independently of the waste status and transaction record summaries database and the tank layering model. However, the Hanford defined waste list will be used with the tank layering model to obtain the actual tank waste inventory estimates described below.

The Hanford defined waste document gives the compositions and physical properties for all known Hanford waste types that went into the double-shell and single-shell tanks. For more details on the methods used to develop these waste types, refer to the Hanford Defined Wastes Document (Agnew 1994).

\section{- Inventory Estimates}

The end result of combining the tank layering model and the Hanford defined waste types is the tank inventory estimate. When the volumes and compositions of each waste type in a particular tank are known from the tank layering model and the Hanford Defined Wastes Document, a calculation of the total chemical inventory in the tank is performed. The Tank Layering Model (Agnew 1994) predicts unknown layers for some tanks. When possible, these unknown layers are assigned to a best estimate defined waste type for the composite inventory estimates. Layers that haven't been assigned a best estimate waste type are not included in the composite tank estimates. Supernatants, diatomaceous earth, and cement are also not included in the composite inventory estimates. The tank inventories use data through the June, 1993 Tank Farm Surveillance and Waste Status Summary Reports (Hanlon 1993). The individual tank results are presented in tabular form with tanks with unassigned waste layers indicated.

The inventory estimates developed by Los Alamos National Laboratory are quality checked against existing data from current sample analyses, thermal and physical models, and historical records. The checking constitutes a large portion of the time required to develop the estimates. When estimates are checked 
against existing data, the models used may be reevaluated. Thus, the process of generating estimates will iterate and the associated errors will be reduced over time as the historical knowledge of the tank waste operations increases.

\subsubsection{Assumptions}

The quality of the historical information available for the tanks often requires that assumptions.and judgement calls be made on the applicability and validity of the data: Some assumptions were used to interpret the data.

\section{Temperature Data.}

The... Iines. joining. the data points. on the temperature plots

"were "detached"to' 'show"gaps" in data"of more-than"three "years.

The single thermocouple tree in some tanks was removed and replaced with two trees. The original single thermocouple tree and tree 1 data were plotted on the same graph. Tree 2 data were graphed separately.

No conclusion has been made on the status of thermocouples with less than five data points. Some possible explanations are that the thermocouple failed, it was inoperable when readings were taken, or the operator misrepresented the number of thermocouples and the temperature data in the tank.

The thermocouples used in the trees were installed as purchased. There were no field calibrations before 1991. In 1991, a survey of thermocouple trees in ferrocyanide watch list tanks was conducted. The thermocouple tree probe temperatures were tested against probes inserted in liquid observation wells or by other methods specified in Engineering Evaluation of Thermocouples in FeCN Watch list Tanks, (Bussell 1992). Failed thermocouples that could be repaired outside of the tank were made operable at this time.

It is assumed that the sinusoidal variances in the data can be attributed to seasonal and diurnal trends which are clear after 1991 due to an upgrade in thermocouple surveillance to a computerized data acquisition system, i.e., Tank Monitor and Control System (TMACS). Also, in general, the temperatures decrease from the bottom to the top of the tanks.

Occasionally the operator would read the temperature in degrees celsius instead of degrees fahrenheit and would not indicate this on the data sheets. If there were data points that unexpectantly dropped well below the others it was assumed that it was reading in degrees celsius.

Dryoli Data

The drywell data did not appear to have quality review which resulted in the following assumptions about the data: 
A data point is considered suspect if an apparent rerun has been performed.

- A data point is considered to be a rerun if the preceding data are erratic, and if the rerun is performed on the same day when monitored daily, within one or two days when monitoring weekly, or within several days when monitoring monthly or yearly.

$\therefore \quad$ - If suspect data was relevant, the appropriate surveillance organizations would have followed procedures.., to identify any problems to their satisfaction.

\section{Sampling Data}

.. The data, obtained from, the historical analy,tical, information are understood to be widely ${ }^{\prime}$ variable-in type; quality $;$ and scope. The data ranges from process control analysis obtained from a grab sample on a few selected analytes to a total characterization suite performed on a core sample. There are no specific quantitative data quality criteria for the information incorporated into the historical tank content estimate. A qualitative assessment of the information sources is done during construction of the historical tank content estimate. The available data will be assessed for suitability and consistency in the study and each data source is weighted appropriately for its. contribution to the overall estimates.

When the sampling data were compiled, a sample was considered a solids sample if it contained greater than $30 \%$ solids. sludge/slurry samples were included.

\section{- Inventory Estimates}

Solids formation of the wastes vary by type and are determined individually by examination of the historical fill records. Further refinement and bounding of the solids formation are provided by conformation to physically attainable systems (e.g., waste volumes contained in the tanks do not exceed the tank capacity, and negative void eractions are not possible, etc.).

Waste stream compositions were based on process flowsheet information and previous analytical data.

Solids were evenly distributed throughout tank. The solids were assumed to be evenly distributed throughout the slurry during their transfer and their settling rate was assumed to be uniform throughout the tank.

Complete settling. of the sludge occurred and the solids settled in a pseudo-pancake formation (i.e., flat layers conforming to the boundaries of the tank) which was a simplifying assumption. Localized mounding and pocketing in various areas of the tank may -have occurred due to inlet/outlet phenomena (e.g., cascades and transfers through floating suction pumps removing or depositing sludge, etc.). This phenomenon would have affected only a small 
fraction of the tank area and does not impact the overall results of this study. However, spatial variability within the physical configuration and process history is acknowledged. No method currently exists that would adequately model this discrepancy.. An effort is underway to develop this concept further and incorporate it into the tank characterization process, but it is incomplete at this time.

$\therefore$ Solids . from a specificaliy. designated waste type are homogeneous which is a simplifying assumption. Variation and layering of the sludge due to component concentration differences between batches, precipitate particle size, and particle density were quite likely. The effect of these factors on the distribution of analytes within the solids. is unknown; however, the effect

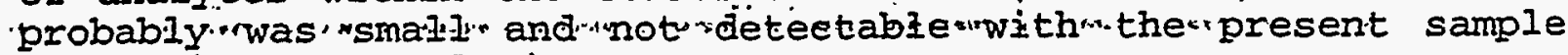
collection and analysis process.

Solids compaction did not occur and was not accounted for in the study which is a simplifying assumption. Although compaction probably occurred in the history of the tanks because of the formation of additional solids layers on top of each other, the degree of compression was unknown and, therefore, was not incorporated.

Density and other physical characteristics of the solids were determined by individual waste type using available information or were based on approximate physical analogues.

The capacity of the tanks was never exceeded during transfers. Tank capacity is dependent on fill status, fill order, tank location in a cascade, and tank type.

Leaking of the tanks was not incorporated during the study but was accounted for at the end.

Cascades, tank transfers, and crib line effluents were normally iree of particulate; therefore, the majority of solids were confined to their initial receiver tanks and were not cribbed or transferred extensively between tanks. This assumption was based on cases of plugged cascade lines when appreciable amounts of solids tried to cascade, and the pumping equipment typically was not designed to transfer a substantial quantity of solids (except when sluicing-or specifically transferring solids).. Monitors on the crib discharge lines should have indicated significant solids contamination, and the tank farm operating procedures would have prevented solids discharges to the ground.

\subsection{Historical Information Quality}

The quality of historical data compiled for this report varied greatiy. Some data came from referenceable published documentation. Other data were retrieved electronically from various Westinghouse Hanford Company databases. The quality of 
WHC-SD-WM-ER-349, Rev. 0

data used in the estimates is described in the following section.

\section{Ievel Bistories}

The level history narrative is designed to give a general description of the waste types contained in a specific tank from startup to the present. The history presents physical characteristics, such as waste $\mathrm{pH}$ values and the latest maximum temperature of the waste. It also presents information on when the

* tank was removed from service, stabilization status, the method of stabilization, leaks, and the current status. The history is not designed to be a detailed summary of every waste type and transaction for a tank. The waste types are general and are usualiy given only for large transactions (i.e., if a waste is not

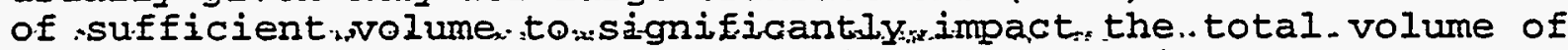
the tank then it was not reported in the narrative) $\because$ For a more complete record of transactions and types of wastes involved, refer to the waste status and transaction record summary (Agnew 1994).

The accuracy of the tank level histories relies on the completeness of the Westinghouse Hanford Company document "A History of the 200 Area Tank Farms" (Anderson 1990); the monthly Westinghouse Hanford Company, Atlantic Richfield Hanford Company, and Rockwell Hanford Operations waste summary reports; and the waste status and transaction record summary (Agnew 1994).

Surface level readings may be affected by plummet error, flushing water accumulation, and waste surface irregularities. Crystalline wastes (i.e., saltcake) can build up on the end of the plummet gradually and contact the waste which indicates a false surface level increase. Significant level discrepancies occur when the buildup breaks off or when the measuring instrument plummet is flushed to remove the saltcake buildups. Flushing the Food Industry Corporation Gauge, manual tapes, or any other equipment may cause accumulated wash water to collect under the plummet which indicates a false increase in the overall volume of waste within the tank. Surface level readings are often difficult to obtain from tanks with a relatively dry saltcake surface. Some tanks have crystalline buildup on in-tank equipment (i.e., pumps, thermocouples, liquid observation wells, and other protruding equipment). As the supernatant is pumped from the tanks, the crystalline structure may remain attached to the equipment and be suspended above the liquid. Therefore, an accurate surface level measurement would be difficult if the breakup of the crystalline structure was inconsistent and a nonuniform waste surface was created. Steel tapes that are bent or warped from operation or those discarded on the waste surface are other sources of altered surface level readings.

Routine measurements of solids and sludges in most SSTs were not reported in the Anderson document until 1965. The solids measurements are taken with a steel donut on a string and operators interpret the sludge level. This interpretation could introduce a wide range of variability in the recorded solids level. Sometimes 
WHC-SD-WM-ER-349, Rev. 0

estimates taken from photographic data and saltwell pumping activities are the only indications of the solids levels.

\section{Iiquid Observation Well Data}

The liquid observation well data were obtained electronically from the Westinghouse Hanford Company Surveillance Group. Some discrepancies exist in the liquid observation well readings for tanks with liquid waste surfaces.. The discrepancies were supposed to be addressed in a December 1993 rebaselining of the liquid observation well data. Agreement between the liquid observation well plots and the data obtained from the surveillance group has been verified; however, errors in the data prior to the exchange of information could still exist. The liquid observation well data were understood to be unverified prior to the exchange. Therefore,

"..the "data" should"be" "reviewed mbeforembeing ".mused. for any design purposes or safety evaluations.

Temperature Readings

The single-shell tank temperature profiles are provided by electronic data from Westinghouse Hanford Company. Agreement between the thermocouple plots and the data obtained from the surveillance group has been verified; however, errors in the data prior to the exchange of information could still exist. Thermocouples used in the thermocouple trees were purchased and installed according to the American Society of Testing and Materials (ASTM) standard. There were no field calibrations before 1991 when a survey of the thermocouple trees in ferrocyanide watch list tanks was conducted and a few of the thermocouple trees were compared against a thermocouple probe inserted in a liquid observation well.

During a review of the plots, some thermocouples were found to have outlying data points and many of them have only one or two readings. The unusual readings may have resulted from the thermocouples functioning on only one occasion, the operator misrepresenting the number of thermocouples in the tank, unnecessary thermocouples readings, or possible thermocouple failure.

occasionally the operator would read the temperature in degrees celsius instead of degrees fahrenheit and would not indicate this on the data sheets. The thermocouple data were understood.to be unverified prior to the exchange. Therefore, the data should be checked before being used for any design purposes or safety evaluations. .

\section{- Surface Level Data}

The surveillance automated computer system data were obtained electronically from the Westinghouse Hanford Company Surveillance Group and were plotted. The data are actual surface levels recorded from the surveillance equipment. If the surveillance equipment in a particular tank riser was removed from service, the readings may show a level change when a new instrument and/or riser 
WHC-SD-WM-ER-349, Rev. 0

is used, especially if the waste surface shows severe heterogeneity.

Agreement between the plots and the data obtained from the surveillance group has been verified; however, errors in the data prior to the exchange of information could still exist. The surveillance automated computer system data were understood to be unverified prior to the exchange.- Therefore, the data should be reviewed before being used for any design purposes or safety evaluations.

- Drywell Data

Drywell information is received on data sheets for each

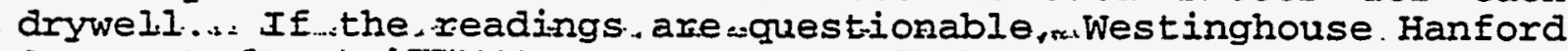
Company often wiII request a rerun of the drywel' scan. Because the reruns are not always indicated on the data sheets, determining if the data sheet has been superseded can be difficult. In some wells, several scans occurred on the same day with no explanation; therefore, the scan with the accepted results is not identifiable.

- Riser Configuration

The riser configuration was determined from the WHC Riser Configuration Document for Single-Shell Waste Tanks (Alstad 1991). The information was current as of June 1991; therefore, any changes made after that date would not be included.

- Photographs

The photo collages were made from the latest available in-tank photographs. In some tanks, photos have not been taken since the early 1970s. Some tanks had fogging problems in the vapor space which prevented use of the latest photos. Sometimes a review of the older photos was useful to determine the waste changes. Collages made from older photos may not be indicative of current tank contents, especially if the tank has been pumped since the last photo date.

Eistorical Sample Analysis Data

The historical sample results only refer to sample and analysis information obtained before August 1989. The historical sample and analysis results have not been validated by the characterization program. When validation occurs, they will be reissued in a later revision of the Historical Tank Content Estimate report and supporting documentation. The sample data often were retrieved from memos indicating the results of the sample analysis. The analytical methods, holding times, and quality control information are unavailable. The location at which the sample was taken was not provided which leads to integration of some uncertainty into the sampling results. The analytical scope performed in many cases was quite narrow which limited the available data set. However, the data set is the only available historical chemical characterization information. 


\subsection{Background NE Quadrant}

The SSTs located on the Hanford Site near Richland, Washington were built between 1943 and 1964 to provide interim storage for high-level nuclear wastes. Processes such as plutonium separation from spent nuclear fuel and uranium metal recovery generated the millions of gallons of mixed radioactive hazardous waste solutions stored within these tanks.:

Several waste tanks are on watch lists. A watch list tank is defined in a succeeding section of this report.

The northeast quadrant is located in the 200-East exclusion area and consists of 66 tanks grouped into six tank farms: the A

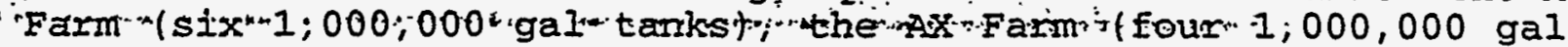
tanks), the B Farm (twelve 530,000 gal tanks and four 55,000 gal tanks), the BX Farm (twelve 530,000 gal tanks), the BY Farm (twelve 758,000 gal tanks), and the C Farm (twelve 530,000 gal tanks and four 55,000 gal tanks). Single-shell tank construction consists of mild steel cylinders and bases inside reinforced concrete that are covered by a reinforced concrete dome. Depending on the farm, the top of the tanks are buried between six and nine feet underground.

Wastes stored in the NE quadrant were generated mostly from Plutonium Uranium Extraction (PUREX) and a Bismuth Phosphate Plant (B Plant); however, some tanks in the quadrant received wastes from the other onsite separation processes. The separation processes went through many changes as new technologies became available. Liquid waste volumes were reduced by evaporators, in-tank solidification units, or through chemical precipitation of radionuclides. The resulting supernatant was disposed of in the ground. Vaults were used for temporary storage or treatment of waste and they were the intermediate storage point for tank waste or waste awaiting further processing. A special rail car facility in the NE quadrant was used to unload onsite waste that was distributed to an evaporator, tanks, or processing facilities.

\subsubsection{Waste Generating Plants and Processes}

Although not all of the processes listed below contributed waste directly to tanks in the NE quadrant, the waste they generated could have indirectly been transferred to the quadrant through tank-to-tank transfers. The plants and processes that generated waste now contained in the SSTS and DSTs are presented in chronological order in this section. Typically the name of the plant and the process are synonymous.

T Plant

T plant was the first full scale separations plant at Hanford. It was constructed in 1944 and was used as a separation facility for irradiated production reactor fuel until 1956. The bismuth phosphate separation process used at $T$ Plant was identical to the one used at B Plant. The 224 Building was part the bismuth 
phosphate process that was adjacent to $T$ Plant. Since 1957, $T$ Plant has been used as a decontamination and repair facility. The facility was modified in 1978 for storage of pressurized water reactor (PWR) core II fuel assemblies. T Plant provided facilities for decontamination, decommissioning, repairing, testing, shipping, and burial of contaminated tools and equipment from onsite and offsite locations.

The following wastes were sent to SSTs: waste solution from equipment decontamination efforts at $\mathrm{T}$ Plant, decontamination waste (DW), metal waste (MW) from the bismuth phosphate process, firstcycle (1C) decontamination waste from the bismuth phosphate process, second-cycle (2C) decontamination waste from the bismuth

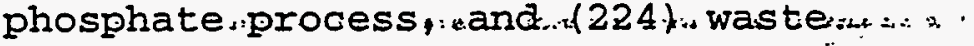

\section{B Plant}

B Plant was constructed between August 1943 and February 1945 and ran the bismuth phosphate process until 1952. As one of the first plants built along with $\mathrm{T}$ Plant, $\mathrm{B}$ Plant was designed to separate plutonium from uranium and the bulk of fission products in irradiated fuel through the bismuth phosphate separation process. The 224 Building was part the bismuth phosphate process that was adjacent to B Plant. In 1968, B Plant became a waste fractionation plant and was retrofitted to remove cesium 137 and strontium 90 from PUREX acid waste, high-level supernatant liquids, and sludge from self-boiling liquid wastes.

The following B Plant waste streams were sent to SSTs: B Plant high-level waste (B), B Plant flush (BFSH), low-level waste from the waste fractionation plant (BI), complex concentrate (CC) or (CCPL), complexed waste (CPIX), fission products waste (FP), metal waste (MW), REDOX ion exchange waste processed at B Plant (RIX), ion exchange (IX), strontium sludge (SRS), cell 5 tank 6 waste (56), first-cycle waste (1C), second-cycle waste (2C), and (224) waste.

\section{- Bismuth Phosphate Process}

The $B$ and $T$ Plants used the bismuth phosphate extraction to remove plutonium from uranium fuel elements. The 224 Buildings were also part the bismuth phosphate process. The extraction waste that resulted was a metal waste that still contained $90 \%$ of the fission products and 998 of the original uranium. The metal waste (MW) was sent to specific tank cascades in the 200-East and 200West Areas. First-cycle decontamination waste (1C), which contained approximately $10 \%$ of the fission products, second-cycle waste (2C), and (224) waste were also stored in other underground waste tanks in the 200 Areas.

\section{- Plutonium Finishing Plant}

The Plutonium Finishing Plant (PFP) or $\mathbf{z}$ Plant, previously called Plutonium Recovery and Finishing Operations, began operating in late 1949 to process plutonium and prepare plutonium products. The PFP operations included plutonium handling, plutonium 
WHC-SD-WM-ER-349, Rev. 0

reclamation, plutonium conversion, and decontamination and decommissioning.

Waste from the Plutonium Reclamation Facility and the remote mechanical $C$ line $(Z)$ was sent to tanks.

- Dranium Oxide Plant

The 224-U Building was .completed in 1944 as part of the U Plant complex.. The building was converted to an $\mathrm{UO}_{3}$ plant in 1951 . The 224-UA Building was constructed in 1957 with six installed calciners. The $\mathrm{UO}_{3}$ plant capability was sufficient to handle the Uranyl Nitrate Hexahydrate (UNH) stream from REDOX, U Plant, and PUREX. The $\mathrm{UO}_{3}$ plant shut down in 1972 and restarted in 1984 with the feed lines. from REDOX and the U Plant canyon disconnected. 'Since 1984;" there"have"been"17" campaigns"at" the plant that averaged 8 days each. The plant can calcine UNH much faster than the PUREX plant can produce it. Final deactivation was ordered for the plants in 1992. In April 1993, the $\mathrm{UO}_{3}$ plant resumed operations to convert 200,000 gal of remaining $\mathrm{UNH}$ to uranium oxide powder. A final deactivation plan for the facility was prepared in the summer of 1993 and will be carried out in the next few years.

\section{REDOX}

The Reduction and Oxidation extraction (REDOX) plant was built between May 1950 and August 1951, and operated until July 1967. Uranium and plutonium were extracted from solid uranium metal slugs that were irradiated in the Hanford reactors or piles into methyl isobutyl ketone (hexone) solvent through a continuous solvent extraction process. The REDOX process was the first at Hanford to recover both plutonium and uranium.

The following wastes were sent to SSTs: REDOX process waste resulting from the dissolution of aluminum and zircaloy fuel element cladding, REDOX coating waste (CWR), REDOX high-level waste $(R)$, the supernatant liquid portion of waste generated by the REDOX process, and REDOX supernatant (RSN). RSN is found above the sludge in the underground storage tanks.

D Plant

$U$ Plant (221-U) was built as one of three original bismuth phosphate process facilities, although it was not used for that purpose. U Plant was modified extensively and used for the uranium recovery process. U Plant operated from 1952 to 1958. The main canyon at U Plant currently stores failed equipment.

Uranium in waste from the $\mathrm{BiPO}_{4}$ process initially was stored in the SSTs. Later it was mined by sluicing, dissolved in nitric acid, and processed through a solvent extraction process. For every gallon of metal waste originally stored, the uranium extraction process yielded approximately 1.4 gal of UR waste. The increase in waste volume made development of a technology to reduce the volume of stored waste a priority. This need resulted in the development/implementation of the ferrocyanide scavenging process. 
WHC-SD-WM-ER-349, Rev. 0

The waste sent to the SSTS from U Plant was called tributyl phosphate (TBP). In reality, it contained very little TBP. Therefore, to eliminate confusion, it will be referred to as uranium recovery (UR) waste in this report.

\section{strontium Semiworks}

The strontium or hot semiworks processing facility (i.e., C Plant) was built in 1949 as a hot pilot plant for the REDOX process, but was converted to a pilot plant for the PUREX process. In 1960, the plant was reactivated and used as a process demonstration for the conversion of $B$ Plant to $a$ waste fractionation facility and was used to recover strontium 90,

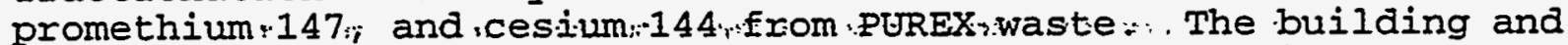
the building site have been decontaminated and decommissioned.

The strontium semiworks waste sent to SSTs was known as hot semiworks (HS), strontium semiworks (SSW), and fission products waste (FP).

\section{PUREX}

The Plutonium Uranium Extraction (PUREX) plant (i.e., A Plant) was an advanced solvent extraction process that used tributyl phosphate in a paraffin hydrocarbon solvent to recover uranium and plutonium from nitric acid solutions of irradiated uranium. PUREX was built between April 1953 and April 1955, and it operated until 1972 when it was closed for 11 years. Two thorium campaigns were conducted in the PUREX plant between 1966 and 1971. The irradiated waste was similar to the PUREX waste but it contained thorium and uranium 233 rather than uranium and plutonium which was extracted from typical PUREX waste. It restarted in November 1983 and was shut down in 1988 after a safety violation. The PUREX Plant was shut down several times between 1988 and 1990 for various reasons. In October 1990, the PUREX Plant was put in standby mode and was eventually identified for closure in December 1992 .by Secretary of Energy James Watkins.

The following PUREX waste streams were sent to SSTs: cladding waste (CW) or (CWP), organic solvent wash waste (OWW), neutralized PUREX plant acid waste (P), low-level waste from PUREX (PL), PUREX sludge supernatant liquid (PSS), organic wash waste using sodium carbonate (CARB), cesium feed (CF), and concentrated neutralized high-level waste (IWW).

\subsubsection{Waste Management Operations}

This section describes the different waste concentrating methods used in the 200 Areas. Evaporating, concentrating, and scavenging are all methods used to reduce liquid volumes or precipitate solids out of the supernatant solutions. The operations are presented in chronological order.

This section describes the different waste concentrating methods used in the 200 Areas. Evaporating, concentrating, and 
WHC-SD-WM-ER-349, Rev. 0

scavenging are all methods used to reduce liquid volumes or precipitate solids out of the supernatant solutions. The operations are presented in chronological order.

\section{T Evaporator}

The $242 \mathrm{~T}$ Evaporator was built in the early 1950 s to reclaim nonboiling waste storage capacity in existing tanks. The evaporator was shut down in the sumer of 1.955. and modified for tributyl phosphate scavenging, :although scavenging 'was never performed in this evaporator. The $242 \mathrm{~T}$ Evaporator restarted in 1965 and operated until 1976. Tank 241-TX-118 was the feed tank for this evaporator.

The. following. wastes. were... sent.. to .tanks. from the $242 \mathrm{~T}$

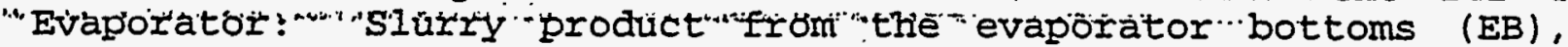
evaporator feed (EF), and terminal liquor (TI).

\section{- 242 B Evaporator}

The 242 B Evaporator was built south of the B Tank Farm and started operating in December 1951. It received feed waste until November 1954 and was shutdown in september 1955. The evaporator was never reactivated. Tanks $241-B-106$ and -105 were used as the feed tank and bottoms tank respectively. The evaporator operated at atmospheric pressure.

\section{Ferrocyanide scavenging}

Ferrocyanide scavenging was developed to reduce waste volumes. The ferrocyanide flowsheet was first tested in U Plant in October 1953, and in-farm scavenging was completed in March 1956 and December 1957 for the 200-West and 200-East Areas respectively. The ferrocyanide scavenging program was designed to remove fission products such as ${ }^{137} \mathrm{Cs}$ (half life: $28.6 \mathrm{Yr}$ ) and ${ }^{90} \mathrm{Sr}$ (half life: $30.2 \mathrm{yr}$ ) from the uranium recovery and $1 \mathrm{C}$ wastes as a precipitate. After the ${ }^{137} \mathrm{Cs}$ and ${ }^{90} \mathrm{Sr}$ precipitates settled, the clarified supernatant was sampled and disposed of in cribs.

In-Tank Solidification

The primary function of the in-tank solidification systems was to concentrate the nomboiling waste directly inside of specially designed tanks. The in-tank solidification tanks produced a saltcake slurry. Each of the in-tank solidification systems included a heat exchanger for water evaporation and a series of bottoms tanks. The first in-tank solidification unit (ITS \#1) operated with an airlift circulator through Tank 241-BY-102 and the second in-tank solidification unit (ITS \#2) operated with a similar circulator through Tank 241-BY-112. Tank 241-BY-112 also contained a $4,000 \mathrm{~kW}$ electric immersion heater. Tank 241-BY-101 contained an in-tank solidification prototype that was used only for demonstration purposes. In-tank solidification unit 1 and unit 2 began operating in 1965 and 1968, respectively. In 1971, in-tank solidification unit 1 became the cooler for in-tank solidification unit 2. Both units were shutdown in 1974. 
WHC-SD-WM-ER-349, Rev. 0

- REDOX Concentrator

The REDOX concentrator was used for volume reduction of dilute 200-West Area tank farm wastes by removing water. The concentrator received tank farm wastes from July 28, 1967 until June 30, 1972 . Cell $D$ in the REDOX process was the concentration and neutralization section of the plant.

\section{S Evaporator/Crystallizer}

The 242 S Evaporator/Crystallizer began operating in November 1973 and was shut down in 1981. It was designed as a reduced pressure (i.e., partial vacuum) evaporator/crystallizer. Aqueous salt wastes were converted in the evaporator to salt crystals for storage in underground tanks in the 241-S and 241-SX Tank Farms.

The following waste types were sent to SSTs from the $242 \mathrm{~S}$ Evaporator: noncomplexed waste concentrated until the solution was nearly saturated with sodium aluminate known as double-shell slurry feed (DSSF), slurry product from the evaporator bottoms (EB), evaporator feed (EF), Hanford defense residual liquor (HDRI), partial neutralized feed waste (PNF), and terminal liquor (TL).

\section{A Evaporator/Crystalizer}

Construction of the 242 A Evaporator/Crystallizer was completed in 1976. The evaporator began operation in March 1977 with a design life of 10 years. In 1987, design changes were developed to extend the facilities operating life by 10 years. The evaporator was shut down in April 1989 because of regulatory issues. The evaporator was restarted in May 1994 after extensive modifications.

The following evaporated waste was sent to SSTs: evaporator bottoms from B Plant low-level waste feed (BLEB), noncomplexed waste concentrated in evaporators known as double-shell slurry feed (DSSF), evaporator feed (EF) or (EVAP), evaporator bottoms (EB), and terminal liquor (TL).

\subsubsection{Miscellaneous Waste Sources and Equipment}

There are various other sources of waste on the Hanford site and other material has been added to the tanks. Some wastes are from the 300 Area, 100 Area production reactors, various laboratories, and catch tanks. Unique contents added to SSTs included laboratory wastes, diatomaceous earth, Portland cement, shroud tubes, ceramic balls, experimental fuel elements, and relatively small amounts of enriched uranium, plutonium, cobalt, and natural uranium.

The following wastes contribute to SST waste: diatomaceous earth (DE), Hanford defense residual liquor (HDRL), Hanford laboratory operations ( $\mathrm{HLO}$ ), filtered Hanford water $\left(\mathrm{H}_{2} \mathrm{O}\right)$, phosphate decontamination waste from $N$ reactor (N), and noncomplexed waste (NCPL). 


\section{- Critical Mass Iab}

The critical mass lab was used to develop data on the factors necessary to make a criticality or self-sustained nuclear reaction occur. Because plutonium is the key radioactive element on the Hanford site, the research was based on plutonium criticality safety in various fuel cycles. The facility was located next to the strontium semiworks and ran from the early 1950 s to the early 1980s. The plutonium used in the lab was reprocessed in PUREX.

\section{$244 A R, B X R$, and $C R$ PIocess vaults}

There are three process vaults in the NE quadrant: the AR Vault, the BXR Vault, and the CR Vault. These vaults were composed of several process vessels or tanks used to prepare the waste for treatment or storage. Specific. wastes from tanks can be pumped "temporarily"to"the vauzts "and"the"wastes" carr"be" sert- directly to desired tanks or processing facilities later.

The AR Vault was designed and constructed between 1964 and 1968 and is located next to the $A$ and AX Tank Farms. The AR Vault has been in standby mode since 1978 .

The 244-BXR vault is located south of the 241-BX Tank Farm and was constructed between 1950 and 1951. The BXR Vault began operating in 1952 and became inactive in 1956. The waste in the vault was difficult to handle, so the vault was high-pressure steam jetted in 1976. The vault was interim isolated after 1976 and interim stabilized in March 1985. Tank-BXR-004 was removed in 1963 .

The CR Vault was constructed in 1952 and is located next to the C Tank Farm. Saltwell waste from the C Tank Farm is interim stored in the $C R$ Vault. The 244-BXR and $-C R$ vaults were originally constructed to aid in the recovery of uranium from bismuth phosphate metal waste. The CR Vault received waste from the Strontium Semiworks Plant in route to the 241-C Tank Farm.

204-AR and 204-S Railroad Car Facilities

The 204-AR rail car unloading facility was built in 1981 and replaced the 204-S rail car unloading facility. The facilities were built for the unloading of radioactive liquid waste tank cars.

Iiquids or slurries from the 1314-N Building in the 100 Area and the 340 Building in the 300 Area are unloaded at the 204-AR unloading facility. 


$$
\text { - WHC-SD-WM-ER-349, Rev. } 0
$$

\subsubsection{Timeline}

A timeline is presented on the following pages that represent the times and spans of different events that occurred during the lifetime of major Hanford plants in the 200-East and 200-West areas. The plants were the main contributors to the waste currently contained in SSTs. The following list of abbreviations and corresponding meanings are used on the timeline:

PUREX: Plutonium uranium extraction process

$\mathrm{UO}_{3}: \quad \ldots \quad$ Uranium trioxide

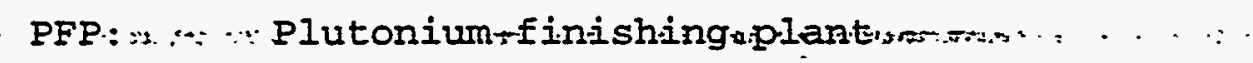

RG-RB: Rubber glove - remote button line

RMA: Remote mechanical "A" line

RSE: Recuplex solvent extraction

RMC: $\quad$ Remote mechanical "C" line

PRF : $\quad$ Plutonium reclamation facility

PCB : Polychlorinated biphynels

WESF: Waste encapsulation and storage facility

ITS: In-tank solidification (units \#1 and \#2)

PWR: $\quad$ Pressurized water reactor

REDOX: Reduction oxidation process 
$i^{-}$

\section{PROCESSES PRODUCING WASTE CONTAINED IN 200 AREA TANK FARMS}

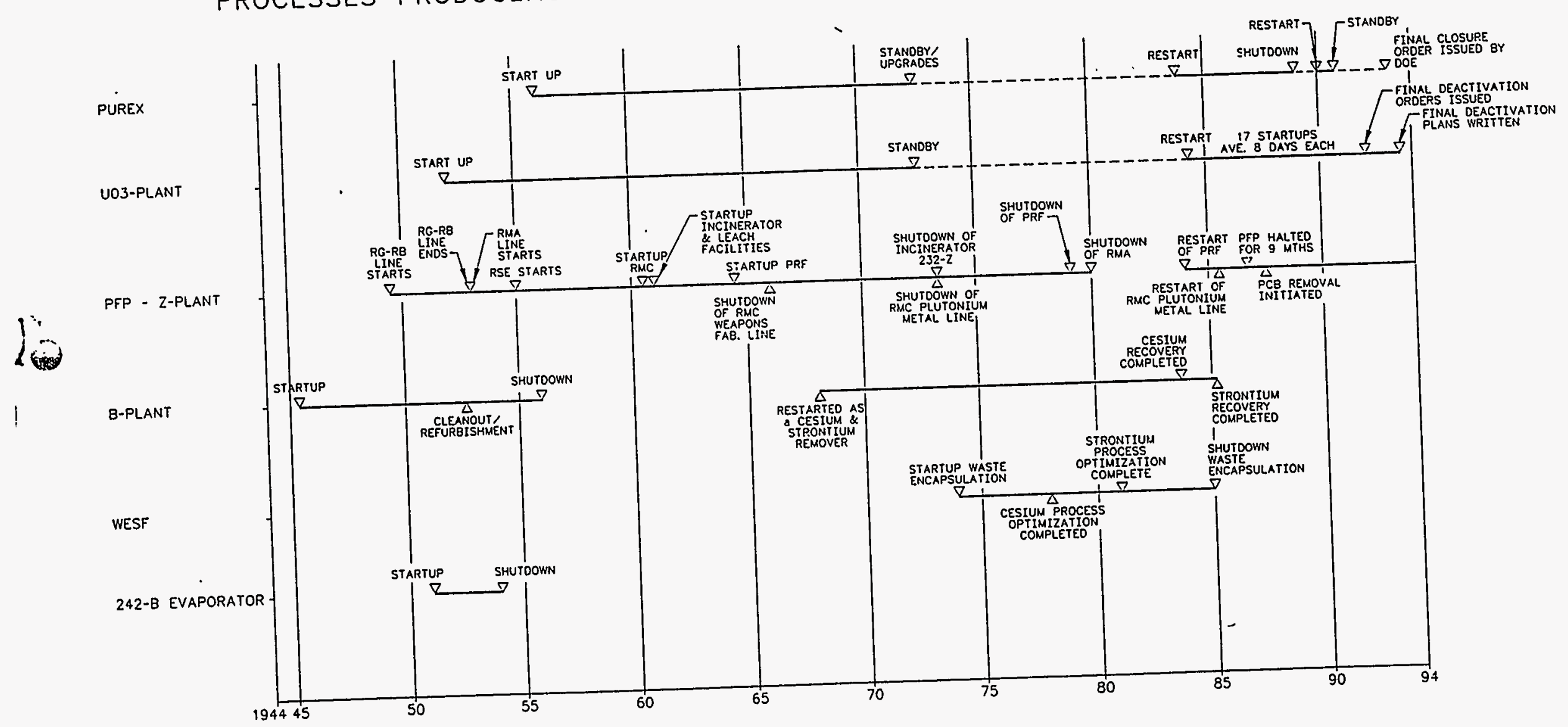


WHC-SD-WM-ER-349 Rev. 0

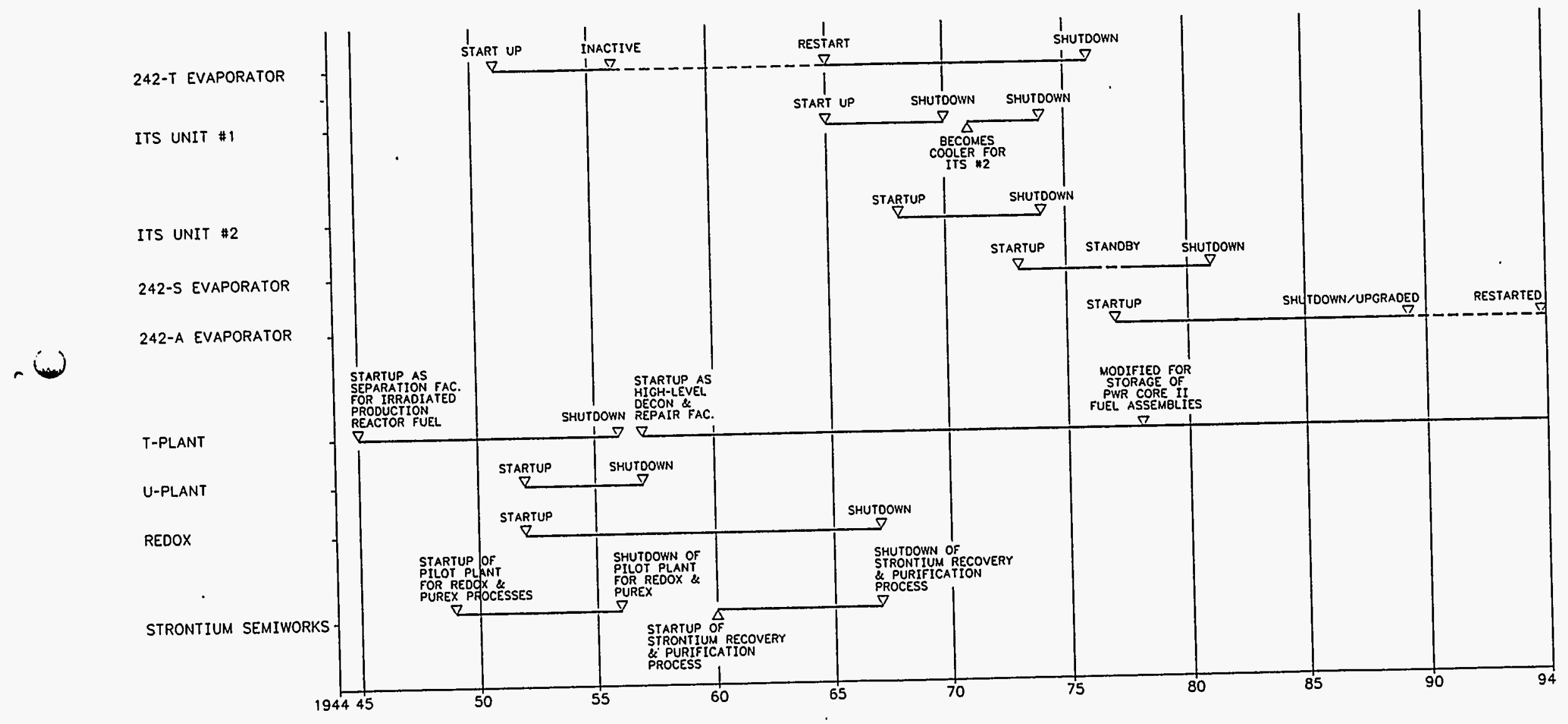

$-24-$ 


\subsection{Safety Issues}

The safety issues that effect the tanks can be divided into two groups: watch list and non-watch list. The watch lists are a listing of all tanks that are believed to pose potential safety hazards to the environment and the public. Non-watch list issues are of concern because they may impact the environment.

\subsubsection{Watch List Safety Issues}

Issues in these tanks were identified as "issues/situations that contain most necessary conditions that could lead to worker (onsite) or offsite radiation exposure through an uncontrolled release of fission products" under Public Law 101-510, Section - 3137; of the National Defense Authorization:Act"of Fiscal.Year 1991 (i.e., the Wyden Amendment). As of November 1993, 45 SSTs and 6 DSTs are on a watch list. In the NE quadrant, 21 of the 66 SSTs are on a watch list. The four watch list designations described in this report are: ferrocyanide, hydrogen/flammable gas, organic salts, and high-heat load. The following sections provide a general description and criteria of the different watch lists. For a more complete explanation, refer to the Hanford Site Tank Farm Facilities Interim Safety Basis (WHC 1993).

\section{- Ferrocyanide}

A tank containing or believed to contain greater than 1,000 gram moles of ferrocyanide (dry basis) is on the ferrocyanide watch list. Tanks containing ferrocyanide have a potential for explosion if ferrocyanide and nitrates combine.

\section{Eydrogen and Flammable Gas}

Tanks were placed on this watch list mostly because of the potential to contain flammable gases rather than the verified presence of hazardous concentrations. Hydrogen/flammable gas watch list tanks have been identified as an unreviewed safety question due to the concern of a flammable gas burn resulting in a radiological release.

- Organic salts

Tanks containing or believed to contain more than the equivalent of $10 \%$ by weight of sodium acetate or 3 wto total organic carbon (TOC) on a dry basis received a watch list designation as in the Tank Farm Surveillance and Waste status Sumnary Report (Hanlon 1993). Tanks containing organic salts have a potential to release waste resulting from an uncontrolled increase in temperature or pressure resulting from oxidation by nitrates and nitrites.

\section{Bigh-Eeat Loads}

Tanks with a heat load greater than 40,000 Btu/hr are designated as high-heat load tanks. Tank 241-C-106 is the only high-heat load tank on the high-heat load watch list. 
WHC-SD-WM-ER-349, Rev. 0

Any tank not appearing on the high-heat load tank list or the high-heat load watch list, but with a heat load less than 40,000 $\mathrm{Btu} / \mathrm{hr}$ is considered, by default, a low-heat load tank.

The following table lists the tanks in the NE quadrant that appeared on a watch list as of November 1993. A current listing is published monthly in the Tank Farm Surveillance and waste status Summary Report (Hanlon 1993).

NE Quadrant SST Watch List Tanks

\begin{tabular}{|c|c|c|c|}
\hline 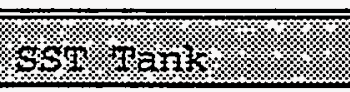 & 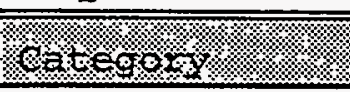 & 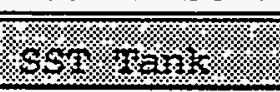 & 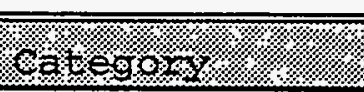 \\
\hline $241-A-101$ & Hydrogen & $241-B Y-108$ & Ferrocyanide \\
\hline$-A X-101$ & Hyarogen & $-B Y-110$ & Ferrocyanide \\
\hline$-A X-103$ & Hydrogen & $-B Y-111$ & Ferrocyanide \\
\hline$-B-103$ & Organic Salts & $-B Y-112$ & Ferrocyanide \\
\hline$-B X-102$ & Ferrocyanide & $-C-103$ & Organic Salts \\
\hline$-B X-106$ & Ferrocyanide & $-C-106$ & High-Heat Load \\
\hline$-B Y-103$ & Ferrocyanide & $-C-108$ & Ferrocyanide \\
\hline$-B Y-104$ & Ferrocyanide & $-C-109$ & Ferrocyanide \\
\hline$-B Y-105$ & Ferrocyanide & $-C-111$ & Ferrocyanide \\
\hline$-B Y-106$ & Ferrocyanide & $-C-112$ & Ferrocyanide \\
\hline$-B Y-107$ & Ferrocyanide & & \\
\hline
\end{tabular}

1.6.2 Non-Watch Iist Safety Issues

Tank leaks are a safety hazard because of the potential chemical and radioactive liquid releases to the ground. Corrosion is the main cause of tank leaks; therefore, stabilization, integrity, and intrusion prevention are discussed in the corrosion section of this report. Three other safety issues that do not require a watch list and continual monitoring under the Wyden Amendment include criticality, tank bumps, and toxic vapor releases.

\section{Corrosion}

Corrosion is believed to be caused by localized or general reduction in SST mild carbon liner thickness. Localized liner thickness reduction is caused by three types of corrosion: pitting corrosion, stress corrosion cracking, and crevice cracking. General liner thickness reduction may be caused by uniform corrosion.

The SSTs were removed from service on or before November 21 , 1980 and no longer accept wastes. When the SSTs are deactivated, 
an effort is made to minimize potential leaks into the earth by reducing the liquid waste contained in the SSTs. Primary stabilization is the first deactivation process of removing the supernatant or free liquid above the solid wastes within the SSTs. Supernatant is removed by turbine or jet pumps in a saltwell system, low-volume submersible pumps, or in situ drying. In saltwell systems, the liquid is pumped from the waste through a pipe screen in a manner similar to ground water pumping. . Tanks with less then $50,000 \mathrm{gal}$ of drainable interstitial liquid and less then 5,000 gal of supernatant liquid are known as interim stabilized tanks. Iiquid waste is sent to the evaporator/crystallizer concentrating facilities and the concentrated waste is deposited into double-shell tanks (DSTS).

Eventually;-SSTs will.be interimstabilizedand prepared for intrusion prevention (formerly known as interim isolation). Stabilization efforts will be completed prior to final closure of the SSTs. Partial isolation of the tanks includes sealing the piping and risers that are not required for puriping or other stabilization methods. Intrusion prevention is the total physical and administrative effort involved in sealing inactive storage tank accesses against liquid additions while still allowing for longterm surveillance.

In the 200-East and 200-West Areas, 67 SSTS are assumed/confirmed leaking. The NE quadrant contains 32 of these tanks. The remaining 34 tanks in the NE quadrant are sound. There are 51 interim stabilized tanks in the NE quadrant and 15 non-interim stabilized tanks. Intrusion prevention is in place for 46 SSTs in the NE quadrant and 20 tanks are at the partial interim isolation stage.

Criticality

Criticality is an inadvertent self-sustained nuclear chain reaction. Studies have concluded that a nuclear criticality accident in the tank farms is probably not an imminent risk. However, there is a lack of definitive knowledge on the fissile material inventory and distribution within the tanks. Therefore, criticality remains a safety issue. The key criticality radionuclide on the Hanford Site is plutonium. A fissile material criticality prevention specification of $125 \mathrm{~kg}$ has been placed on the tanks. An unusual occurrence report involving nuclear criticality was filed in June 1991 for Tank 241-C-104. An inventory of $56 \mathrm{~kg}$ was calculated later which indicated a low probability for criticality. Criticality is considered an unreviewed safety question but is not affected by the Wyden Amendment according to the Hanford Site Tank Farm Facilities Interim Safety Basis (WHC 1993).

Tank Bumps

Tank bumps have been an issue at Hanford since 1953 with the last bump occurring in 1968. Tank bumps occur when heat from the hotter solid waste in the lower portion of the tank is suddenly 
transferred to a near boiling supernatant. Mixing can be achieved by "roll over" or sudden restart of airlift circulators which results in rapid fluid vaporization and a sudden internal tank pressurization that causes a bump. The three documented bumps that have occurred were due to airlift circulator failure followed by rapid startup of the airlift circulators which causes rapid mixing. Two key factors have been identified to control bumping: liquid and solid temperatures must be maintained as far away from the local boiling point as possible, and airlift circulators and ventilation systems must be operated as designed. A tank bump is extremely unlikely if airlift circulators and vent flowrates are maintained at 500 to $1,000 \mathrm{ft}^{3} / \mathrm{min}$ per tank and $50 \mathrm{ft}^{3} / \mathrm{min}$ to the airlift circulators, according to the Hanford site Tank Farm

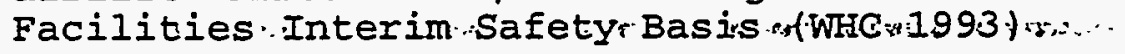

\section{Toxic Vapor Releases}

Toxic vapor releases are a recently analyzed safety concern at Hanford. Odors have been released from the $C$ Tank Farm in. the NE quadrant and from Tank 241-SY-101 in the SE quadrant. If toxic vapors are determined to exist in a tank, three safety recommendations should be followed: determine a release rate, determine offsite and onsite exposure concentrations, and determine if the release is a spray effect. The entire issue of toxic gas releases at the tank farms has just begun to be understood, according to the Hanford Site Tank Farm Facilities Interim Safety Basis (WHC 1993). 


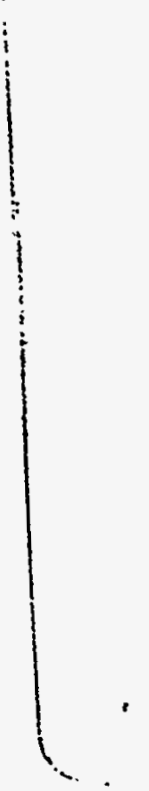

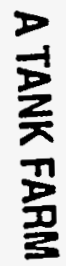

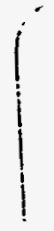

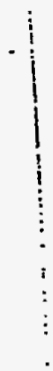




\subsection{A Tank Farm}

\subsubsection{A Tank Farm History}

The A Tank Farm is located east of Buffalo Avenue and west of Canton Avenue in the 200-East Area. The A Tank Farm contains six 100 series; $1,000,000 \mathrm{gal} ; 75$-ft diameter single-shell tanks. The A Tank Farm was considered a fourth generation design for holding boiling or self-concentrating waste.: Each tank was allowed to boil or self-concentrate over a 5 to 10 year period with a $250^{\circ} \mathrm{F}$ fluid temperature. Cascade overflows are connected from Tank 241-A-10I to -102 to -103 to -106 , and from Tank 241-A-104 to -105 to -106 . The cascade overflow height is approximately 371 in. from the tank "bottom... It has been reported but not verified that the cascade lines "were" ever used: ".."

A 1993 color aerial photograph of the A Tank Farm shows the 100 series tank orientation, leak detection caissons, a thermocouple probe caisson, a transfer box, valve pits, and a north arrow. The arrows between the tanks represent the cascade overflow lines and the flow directions. 


\section{A Tank Farm}

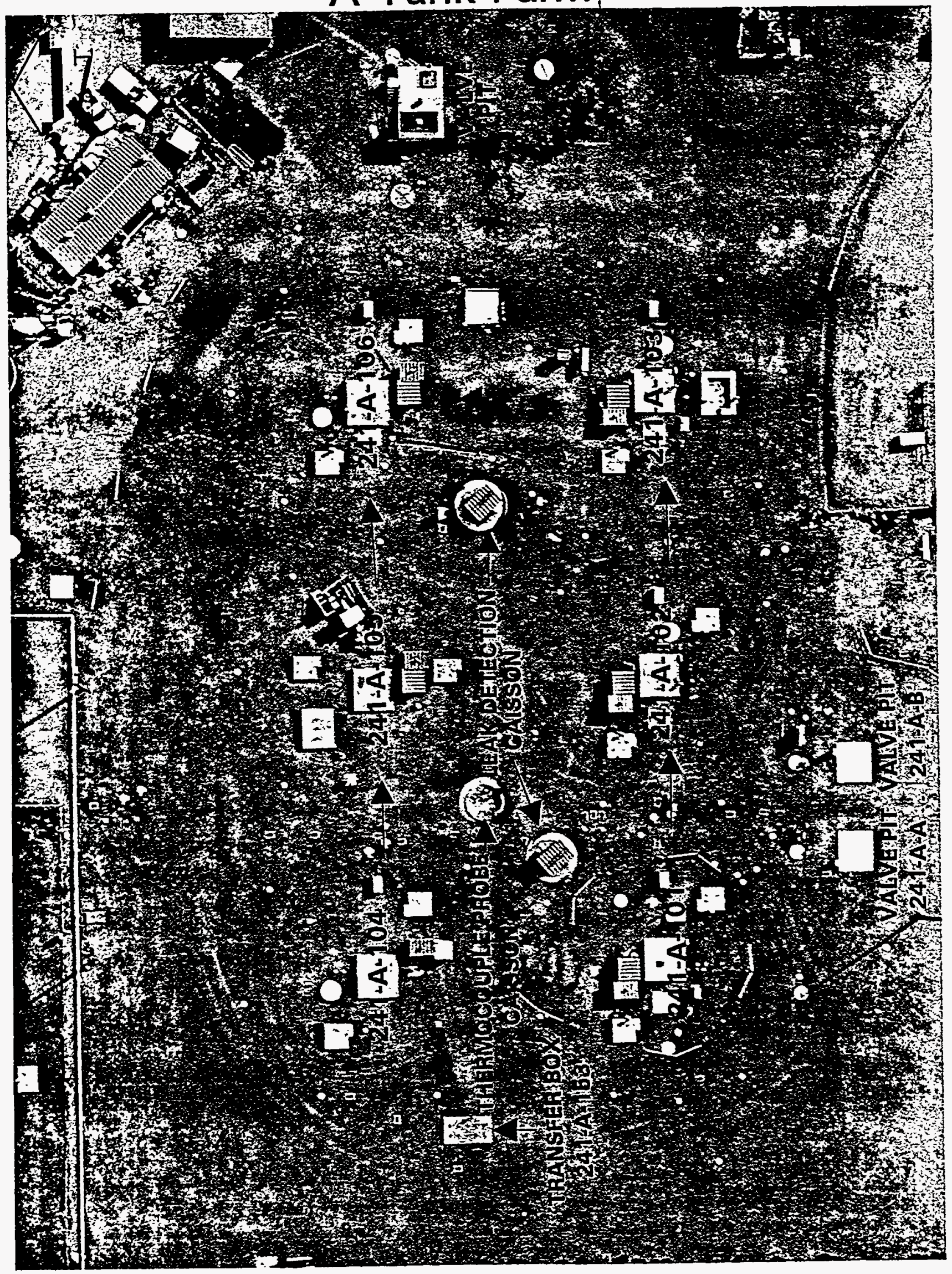




\subsubsection{A Tank Farm Waste History}

Aging PUREX high-level waste was stored in Tanks 241-A-101, 102, -103, -104, and -106. Tank 241-A-105 stored PUREX Plant acid concentrator waste for approximately three years, but the steel liner bulged on the tank bottom in January 1965 due to a buildup of steam between the tank bottom and concrete foundation. Organic wash waste from the PUREX PIant was stored in Tank. 241-A-104 and was sluiced in 1975 when the tank began to leak. Tanks 241-A-104. and -105 were no longer used after they were determined to be leakers.

Tank sluicing was used to reduce the amount of strontium in the sludge.portion and the .amount of...cesium.in..the liquid portion of the tank: Thiese two radioactive isotopes were found to be the main heat generating sources in the A and AX Tank Farms. Early sluicing operations in the A Tank Farm began in the mid 1960s and continued into the 1970s. Sluicing from Tanks 241-A-102 and -103 began in 1964. The waste was sent to the CR Vault until the AR Vault was complete in 1968. Often, the sluiced sludge waste was returned-to the tank after the strontium was recovered.

Initially, the sluicing goal was to sluice the tanks to a 4to 6-in. heel prior to the 242-A Evaporator startup in 1976. The thought was that the 241-A tanks could be used to store saltcake. This goal was reduced and the tanks were sluiced to a smaller 1- to $2-$ in. heel in the late 1970 s because it was determined that the tank temperatures would be maintained better with the smaller heel. Tanks 241-A-101, -102 , and -103 were sluiced and released for saltcake storage in 1978. Tank 241-A-102 was used as the 242-A evaporator feed tank prior to receiving saltcake.

\subsubsection{A Tank Farm Temperature History}

Tanks 241-A-101, $-102,-103$, and -106 contain a single thermocouple tree. Tanks with one thermocouple tree contain 18 thermocouple probes. Tanks 241-A-104 and - 105 have two and eight thermocouple trees respectively. Of the two trees in Tanks 241-A104, one has two thermocouple probes to record temperature data and the other has only one thermocouple probe. All eight of the trees in Tank 241-A-105 are single sensor temperature probes that have been staggered at varying depths in the tank. Tank 241-A-101, a Hydrogen watch list tank, and Tanks $241-A-104$ and -105 , which are high-heat load tanks, have weekly temperature reading requirements. The remaining tanks in the $A$ Tank Farm have semiannual reading requirements.

\subsubsection{A Tank Farm Integrity}

All six 1 Mgal tanks in the A Tank Farm are out of service. As of July 1993, Tanks 241-A-101, -102 , and -106 are categorized as sound and Tanks 241-A-103,-104, and -105 are categorized as 
assumed leakers.

The A Tank Farm has 51 leak detection wells that were drilled from 1955 to 1981. Drywells associated with assumed leaking tanks are monitored for contamination migration.

Each tank in the A Tank Farm has three laterals positioned approximately 8 ft below the bottom of the tank. The laterals extend from two leak detection caissons and are monitored with Geiger-Mueller probes. For the past three years, the laterals beneath Tank 241-A-105 have had readings greater than the $50 \mathrm{c} / \mathrm{s}$ background radiation.

The A.Tank Farm layout on the following page, includes the peak drywell'information, lateral layout, tank integrity, status, and isolation information. The drywell information is based on summarized data prior to 1987 and data collected from January 1990 to the present.

\subsubsection{Current Status of A Tank Farm}

Tank 241-A-101 was added to the Hydrogen Watch List officially in January 1991. It has been declared an unreviewed safety question because of the potential consequences of a radiological. release resulting from a flammable gas burn.

Tanks 241-A-104 and -105 are non-watch list high-heat load tanks $(>40,000 \mathrm{Btu} / \mathrm{hr})$. The tanks are actively ventilated and the temperatures are monitored weekly.

The total volume of waste in the A Tank Farm is 1,536,000 gal: 8,000 gal of supernatant; 449,000 gal saltslurry; 937,000 gal of saltcake; and $106,000 \mathrm{gal}$ of sludge. 


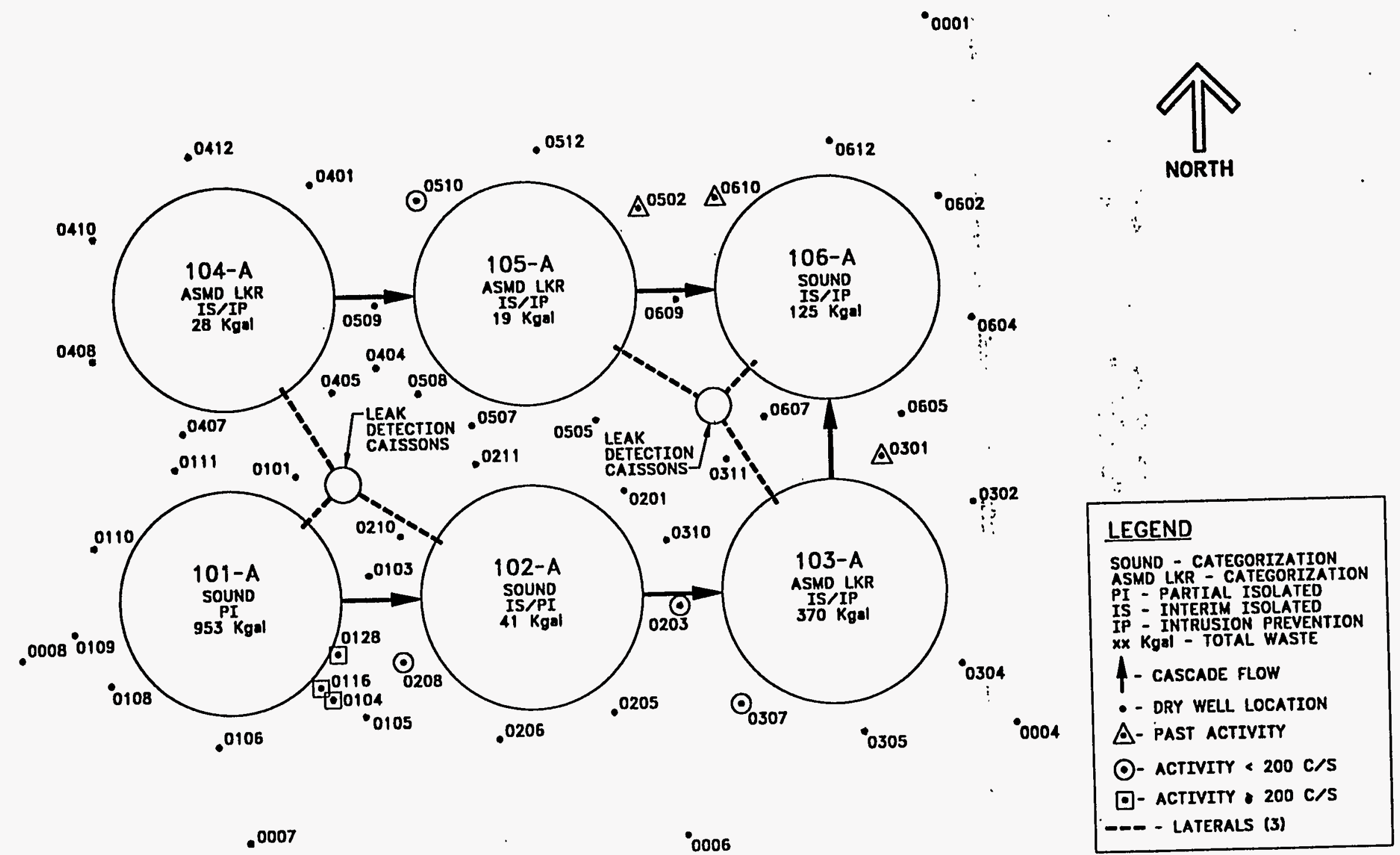

241-A FARM 
2.1 Tank 241-A-101

2.1.1 241-A-101 Tank History

\subsubsection{Waste History Tank 241-A-101}

Activity in Tank 241-A-101 began when it was filled with PUREX high-level waste and organic wash, waste during the first quarter of 1956. Activity ceased when the tank was deactivated in November 1980. Partial isolation was completed in 1982 and the tank remains to be stabilized. The tank was placed on the hydrogen watch list during January 1991. (See sketch ES-TKS-E1 for a graphical representation of Tank 241-A-101 level history.)

2.1 .1 .2 Temperatare History $241-A=101 \cdots$

The single thermocouple tree in Tank $241-A-101$ has 18 thermocouple probes to record temperature data in riser 12 . A sum of the squares regression line fit for all the thermocouples starting in 1976 shows an overall zero slope $\pm 9.8^{\circ} \mathrm{F}$ with an average $x$ square value of 0.27 . An annual temperature undulation is evident in some of the thermocouples. From October 1976 to the present, the median temperature has been $147^{\circ} \mathrm{F}$ with a minimum of $75^{\circ} \mathrm{F}$ and a maximum of $180^{\circ} \mathrm{F}$. Current analysis of the tank shows the waste has a nominal bulk temperature in the range of $155^{\circ} \mathrm{F}$. Refer to the supporting document for a more thorough review of the temperature data (Brevick 1994).

\subsubsection{Integrity of Tank 241-A-101}

Tank 241-A-101 is categorized as sound and is partially isolated. The surface level in Tank 241-A-101 is monitored quarterly with a manual tape through riser 6 . Liquid waste volume is determined by a photographic evaluation and the solid waste volume is determined with a food instrument gauge. A figure that graphically represents the surface level measurements from January 1991 to the present can be found in the supporting documents (Brevick 1994). The surface level for the past 3 years has been steady with the readings ranging between 341 and $345.5-$ in.

An occurrence report was issued in July of 1980 due to increased activity in drywell 10-01-04. The source of activity for drywell 10-01-04 and 10-01-16 was attributed to spilled contamination leaching in the soil around the 241-A-01B pit area.

Eleven drywells are identified for 241-A-101. Data and graphical representations of the active drywell from January 1990 to the present can be found in the supporting document (Brevick 1994).

\subsubsection{Current Status of Tank 241-A-101}

Tank 241-A-101 entered service in January 1956 and currently stores $953,000 \mathrm{gal}$ of waste. The waste is comprised of 403,000 gal 
of saltslurry, $547,000 \mathrm{gal}$ of saltcake, and $3,000 \mathrm{gal}$ of sludge, with 390,000 gal of pumpable interstitial liquid remaining. The tank is identified on the Hydrogen watch List, is passively ventilated, and is categorized as sound with partial interim isolation completed. The following plan view and tank cross section depict the approximate waste level, riser configuration, and tank layer volumes. Tank 241-A-101 has 22 tank dome risers and three are available for use: one 6-in. riser (no. 10), one 42-in. riser (no. 13), and one 12-in. riser (no. 16).

\subsubsection{Inventory estimate 241-A-101}

The following tank layer volume approximation was derived from the Ios: Alamos - National 2 -Laboratories. Waste sstatus. and... Transaction Record Summary (Ağnew 1994):" The estimated inventory of Tank 241A-101 is also presented.

\subsubsection{In-Tank Photograph 241-A-101}

The Tank 241-A-101 photograph shows a white to grayish-yellow saltcake surface with no visible liquid. The waste is about $29 \mathrm{ft}$ deep. The heating coil in the top right corner kept the waste from cooling too quickly which prevented thermal gradient limitations on the steel and concrete surrounding the tank from being exceeded. The debris near the center of the photograph is an old flange gasket.

2.1.3 Synopsis Tank 241-A-101

(To be completed.) 


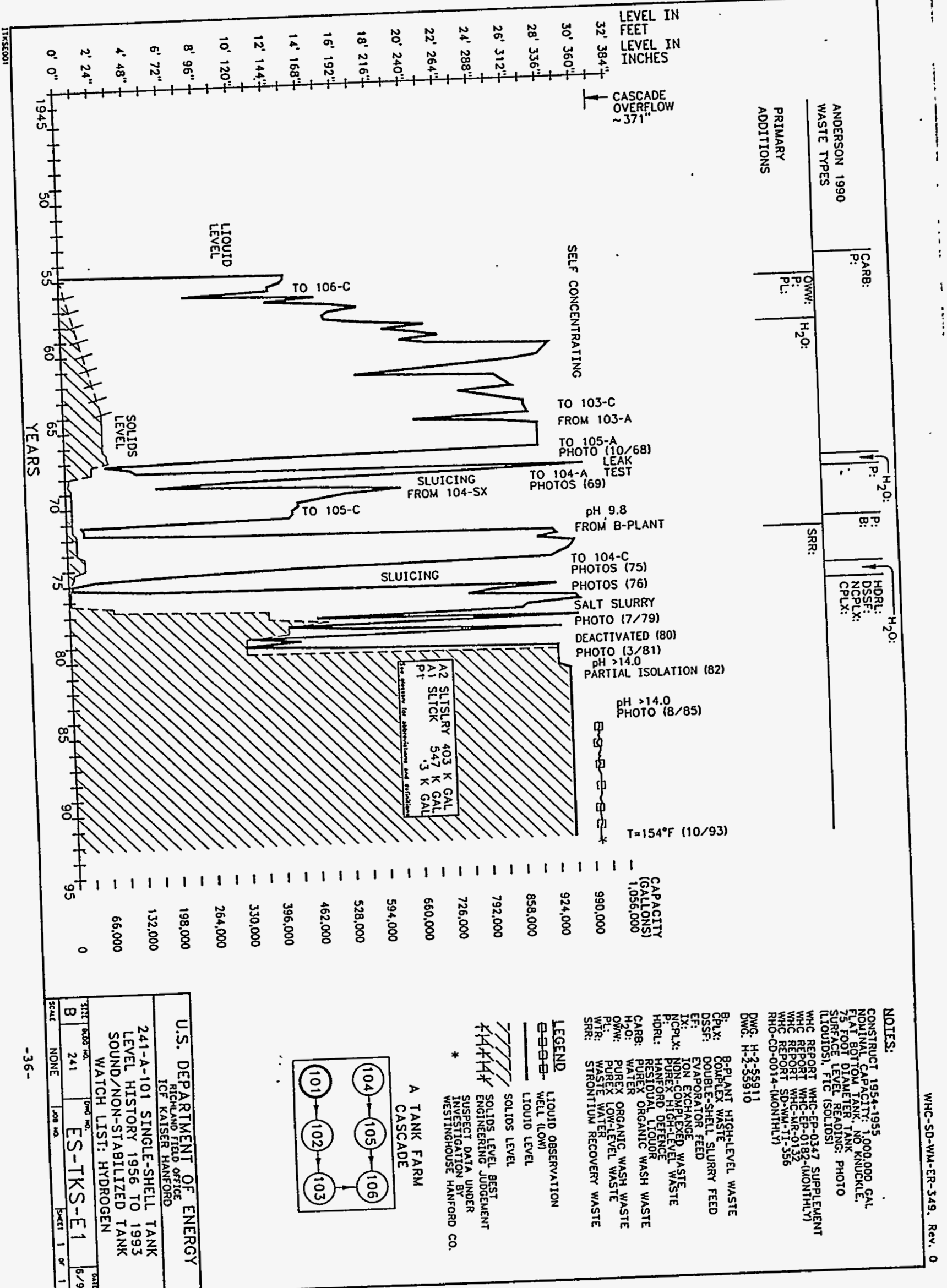


WHC-SD-WM-ER-349, Rev. 0

\begin{tabular}{|c|c|c|c|}
\hline \multicolumn{4}{|c|}{ Single-Shell Tank 241-A-101 } \\
\hline \multicolumn{4}{|c|}{ Solids Composite Inventory Estimate } \\
\hline \multicolumn{4}{|c|}{ 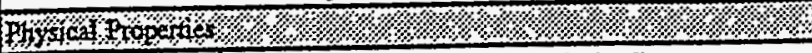 } \\
\hline Toxal Solid Waste & \multicolumn{3}{|c|}{$5.74 \mathrm{E}+06 \mathrm{~kg}(953 \mathrm{kgal})$} \\
\hline Heat load & \multicolumn{3}{|c|}{$6.09 \mathrm{~kW}(2.08 \mathrm{E}+04 \mathrm{BTU} / \mathrm{hr})$} \\
\hline Bulk Density & \multicolumn{3}{|c|}{$1.59(\mathrm{~g} / \mathrm{c})$} \\
\hline Void Fraction & \multicolumn{3}{|c|}{0.31} \\
\hline Water wt\% & \multicolumn{3}{|c|}{8.63} \\
\hline TOC wt\% C (wet) & \multicolumn{3}{|c|}{0.22} \\
\hline \multicolumn{4}{|c|}{ 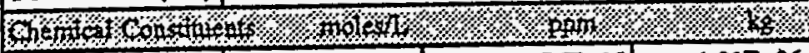 } \\
\hline $\mathrm{Na}^{+1}$ & 12.17 & $1.76 \mathrm{E}+05$ & $1.01 \mathrm{E}+06$ \\
\hline $\mathrm{Al}^{6^{3}}$ & 0.82 & $1.39 \mathrm{E}+04$ & $7.97 E+04$ \\
\hline $\mathrm{Fe}^{43}$ (total Fe) & $8.56 \mathrm{E}-03$ & $3.00 \mathrm{E}+02$ & $1.72 \mathrm{E}+03$ \\
\hline$C^{43} \therefore \quad \therefore$ & 6:27E-03 & $\therefore \therefore 2.05 \mathrm{E}+02$ & $\because 1.18 E+03$ \\
\hline $\mathrm{Bi}^{+3}$ & 0 & o & 0 \\
\hline $\mathrm{La}^{43}$ & 0 & of & 0 \\
\hline $\mathrm{Ce}^{+3}$ & 0 & 0 & 0 \\
\hline $\mathrm{Zx}\left(\mathrm{as} \mathrm{ZrO}(\mathrm{OH})_{2}\right)$ & 0 & 이 & 0 \\
\hline $\mathrm{Pb}^{+2}$ & 0 & 0 & 0 \\
\hline $\mathrm{Ni}^{+2}$ & $1.60 \mathrm{E}-02$ & $5.89 \mathrm{E}+02$ & $3.39 \mathrm{E}+03$ \\
\hline$S r^{+2}$ & 0 & 0 & 0 \\
\hline $\mathrm{Mn}^{4+}$ & 0 & 0 & 0 \\
\hline $\mathrm{Ca}^{42}$ & 0 & 0 & 0 \\
\hline $\mathrm{K}^{42}$ & $1.05 \mathrm{E}-02$ & $2.59 \mathrm{E}+02$ & $1.49 \mathrm{E}+03$ \\
\hline $\mathrm{OH}^{13}$ & 2.97 & $3.17 \mathrm{E}+04$ & $1.82 \mathrm{E}+05$ \\
\hline $\mathrm{NO}^{-1}$ & 4.18 & $1.63 \mathrm{E}+05$ & $9.36 \mathrm{E}+05$ \\
\hline $\mathrm{NO}^{-1}$ & 0.34 & $9.83 E+03$ & $5.65 \mathrm{E}+04$ \\
\hline $\mathrm{CO}^{2-2}$ & 0.48 & $1.81 \mathrm{E}+04$ & $1.04 \mathrm{E}+05$ \\
\hline $\mathrm{PO}^{-3}$ & 0.39 & $233 E+04$ & $1.34 \mathrm{E}+05$ \\
\hline $\mathrm{SO}^{.2}$ & 2.33 & $1.41 E+05$ & $8.09 \mathrm{E}+05$ \\
\hline Si (as $\mathrm{S}_{\mathrm{i}} \mathrm{O3}^{\prime \cdot 3}$ & $6.72 \mathrm{E}-03$ & $1.18 \mathrm{E}+02$ & $6.80 \mathrm{E}+02$ \\
\hline $\mathrm{F}^{-1}$ & 0.53 & $6.37 \mathrm{E}+03$ & $3.66 \mathrm{E}+04$ \\
\hline $\mathrm{Cl}^{-3}$ & $2.05 \mathrm{E}-02$ & $4.57 \mathrm{E}+02$ & $2.62 \mathrm{E}+03$ \\
\hline $\mathrm{C}_{6} \mathrm{H}_{3} \mathrm{O}_{7}{ }^{3}$ & $2.77 E-02$ & $3.28 \mathrm{E}+03$ & $1.89 \mathrm{E}+04$ \\
\hline EDTA $^{4}$ & 0 & 0 & 0 \\
\hline HEDTA $^{-3}$ & $3.28 \mathrm{E}-05$ & 5.65 & 32.43 \\
\hline $\mathrm{NTA}^{-3}$ & 0 & 0 & 0 \\
\hline glycolate & $4.60 \mathrm{E}-02$ & $2.17 E+03$ & $1.24 \mathrm{E}+04$ \\
\hline acetate & $3.21 \mathrm{E}-02$ & $1.19 \mathrm{E}+03$ & $6.84 \mathrm{E}+03$ \\
\hline oxalase-2. & 0 & 0 & 0 \\
\hline DBP & 0 & 0 & 0 \\
\hline $\mathrm{NPH}$ & 0 & 0 & 0 \\
\hline $\mathrm{CCl}_{4}$ & 0 & 0 & 0 \\
\hline hexone & 0 & 0 & 0 \\
\hline $\mathrm{Fe}(\mathrm{CN})_{6}^{-1}$ & 0 & $0(\mathrm{~g}-\mathrm{mol})$ & \\
\hline Cofolog 100 & bons $\% / \%$ & \% & \% $/ \%$ / \\
\hline Pu & & $3.45 \mathrm{E}-03(\mu \mathrm{Ci} / \mathrm{g})$ & $0.33(\mathrm{~kg})$ \\
\hline $\mathrm{U}$ & $3.74 \mathrm{E}-02(\mathrm{M})$ & $5.59 \mathrm{E}+03(1 \mathrm{~g} / \mathrm{g})$ & $3.21 \mathrm{E}+04(\mathrm{~kg})$ \\
\hline Cs & $0.32(\mathrm{Ci} / \mathrm{L})$ & $2.00 \mathrm{E}+02(\mu \mathrm{Ci} / \mathrm{g})$ & $1.15 \mathrm{E}+06(\mathrm{Ci})$ \\
\hline$\underline{S r}$ & $2.88 \mathrm{E}-02(\mathrm{Ci} / \mathrm{L})$ & $18.08(\mu \mathrm{Ci} / \mathrm{g})$ & $1.04 \mathrm{E}+05(\mathrm{Ci})$ \\
\hline
\end{tabular}

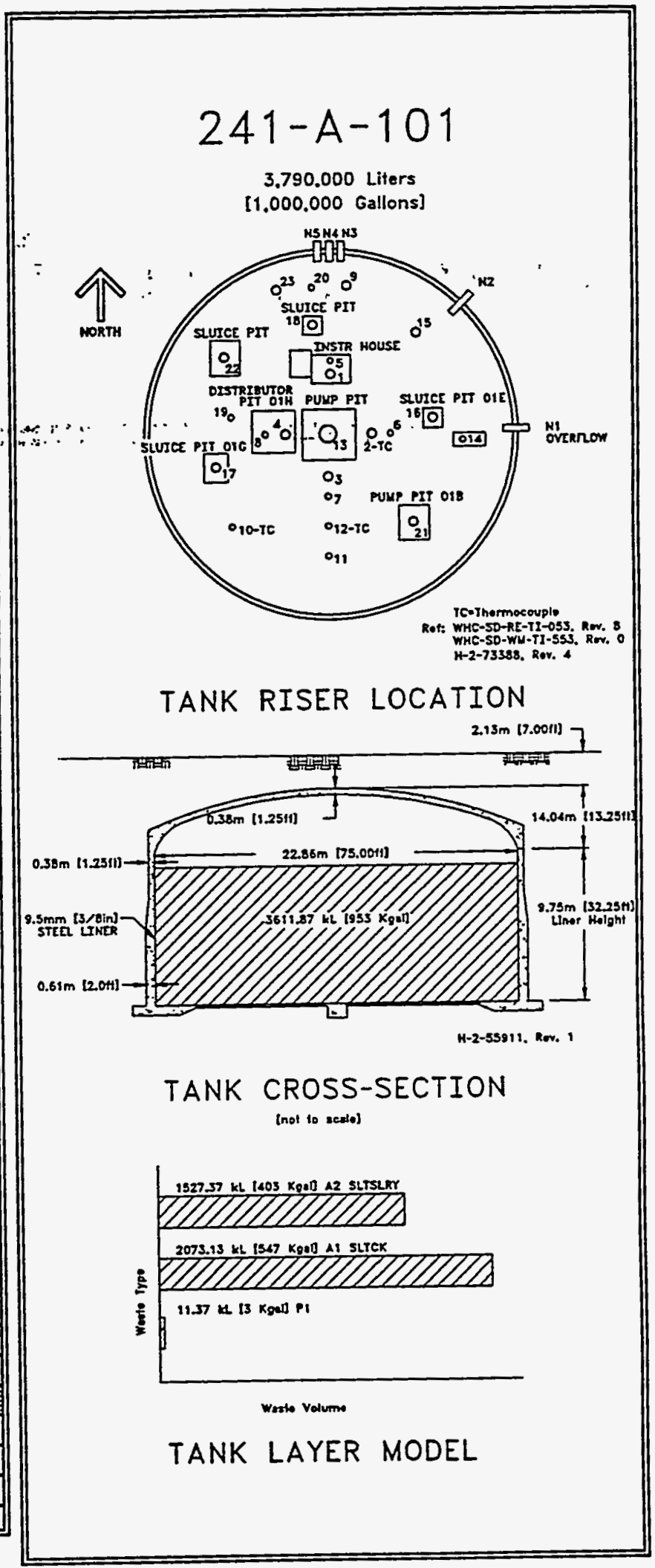

Untenowns in tank inventory art assigned by Tank Layering Model (TLM). 


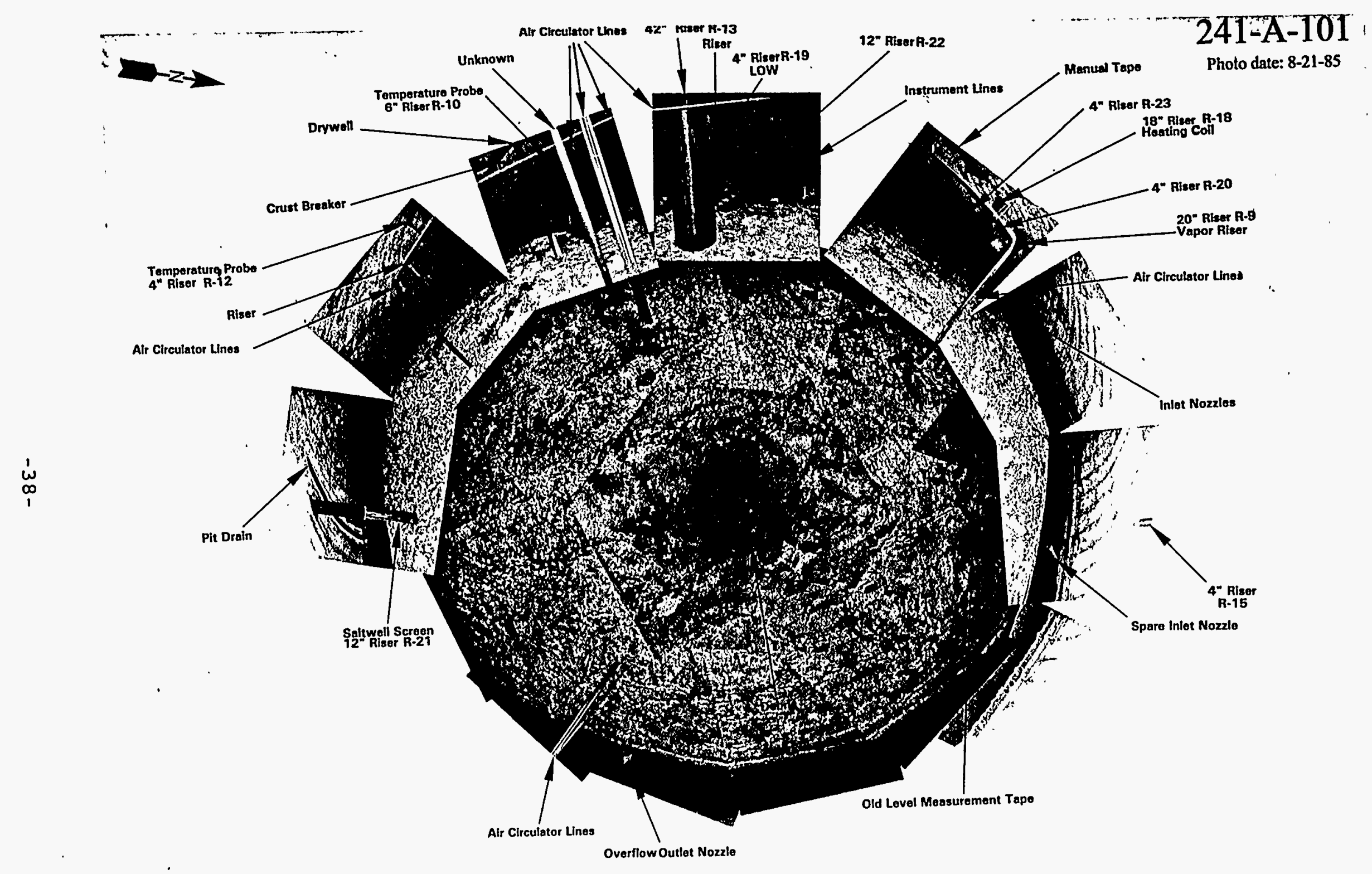




\subsection{Tank 241-A-102}

\subsubsection{1-A-102 Tank History}

\subsubsection{Waste History Tank 241-A-102}

Tank 241-A-102 was filled with PUREX waste in the first quarter of 1956 and, presently; the tank waste is.classified as double-shell slurry feed. The tank was declared deactivated in November 1980 and intrusion prevention was completed during '1982. The tank was interim stabilized in August 1989 after most of the supernatant was pumped. (See sketch ES-TKS-E2 for a graphical representation of the Tank 241-A-102 level history.)

\section{$2: 2.1 .2$ Temperature.History $241-A-102 \cdots$}

The single thermocouple tree in Tank 241-A-102 has 18 thermocouple probes to measure temperatures in riser 7 . The first available in-tank sludge temperature reading in March 1958 was $210^{\circ} \mathrm{F}$. A sum of the squares regression line fit for all the thermocouples starting in 1977 shows an overall zero slope $\pm 8.5^{\circ} \mathrm{F}$ with an average $r$ square value of 0.02 . From March 1977 to present, the median temperature is $89^{\circ} \mathrm{F}$ with a minimum of $63^{\circ} \mathrm{F}$ and a maximum of $137^{\circ} \mathrm{F}$. Refer to the supporting document for a more thorough review of the temperature data (Brevick 1994).

\subsubsection{Integrity of Tank 241-A-102}

Tank 241-A-102 is categorized as sound, interim stabilized, and partially isolated. The surface level in Tank 241-A-102 is monitored with a Food Instrument Corporation gauge through riser 6 . Iiquid waste volume is determined by a photographic evaluation and the solid waste volume is determined with a food instrument gauge and a photographic evaluation. In February 1989, the Tank 241-A-102 decrease criteria Iimit of 1-in. was exceeded and an unusual occurrence report was issued. In-tank photographs showed no evidence of increase or decrease in the liquid level. For more information on surface levels see supporting documents (Brevick 1994).

Seven drywells are identified for 241-A-102. Data and graphical representations of the active drywell from January 1990 to the present can be found in the supporting document (Brevick 1994).

\subsubsection{Current Status of Tank 241-A-102}

Tank 241-A-102 currently stores 41,000 gal of waste. The waste is comprised of 4,000 gal of supernatant; $15,000 \mathrm{gal}$ of saltslurry; 19,000 gal of saltcake; and 3,000 gal of sludge with no pumpable liquid remaining. It is identified as a low-heat load tank with passive ventilation. The tank is categorized as sound, with interim stabilization and partial interim isolation completed. The following plan view and tank cross section depict the approximate waste level and riser configuration. Tank 241-A-102 has 20 tank dome risers and two are 
available for use: one 8-in. riser (no. 2) and one 12-in. riser (no. 19).

\subsubsection{Inventory estimate 241-A-102}

The following tank layer volume approximation was derived from the Los Alamos National Iaboratories Waste Status and Transaction Record Summary (Agnew 1994). The estimated inventory of Tank-241-A-102 is also presented.

2.2.2.2 In-Tank Photograph 241-A-102

The following photograph of Tank 241-A-102 shows a thin grey saltcake surface.layer broken -up :with supernatant, showing : through. The

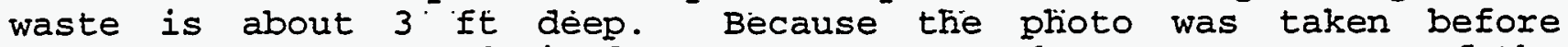
supernatant was pumped, it does not represent the current status of the tank.

2.2.3 Synopsis Tank 241-A-102

(To be completed.) 


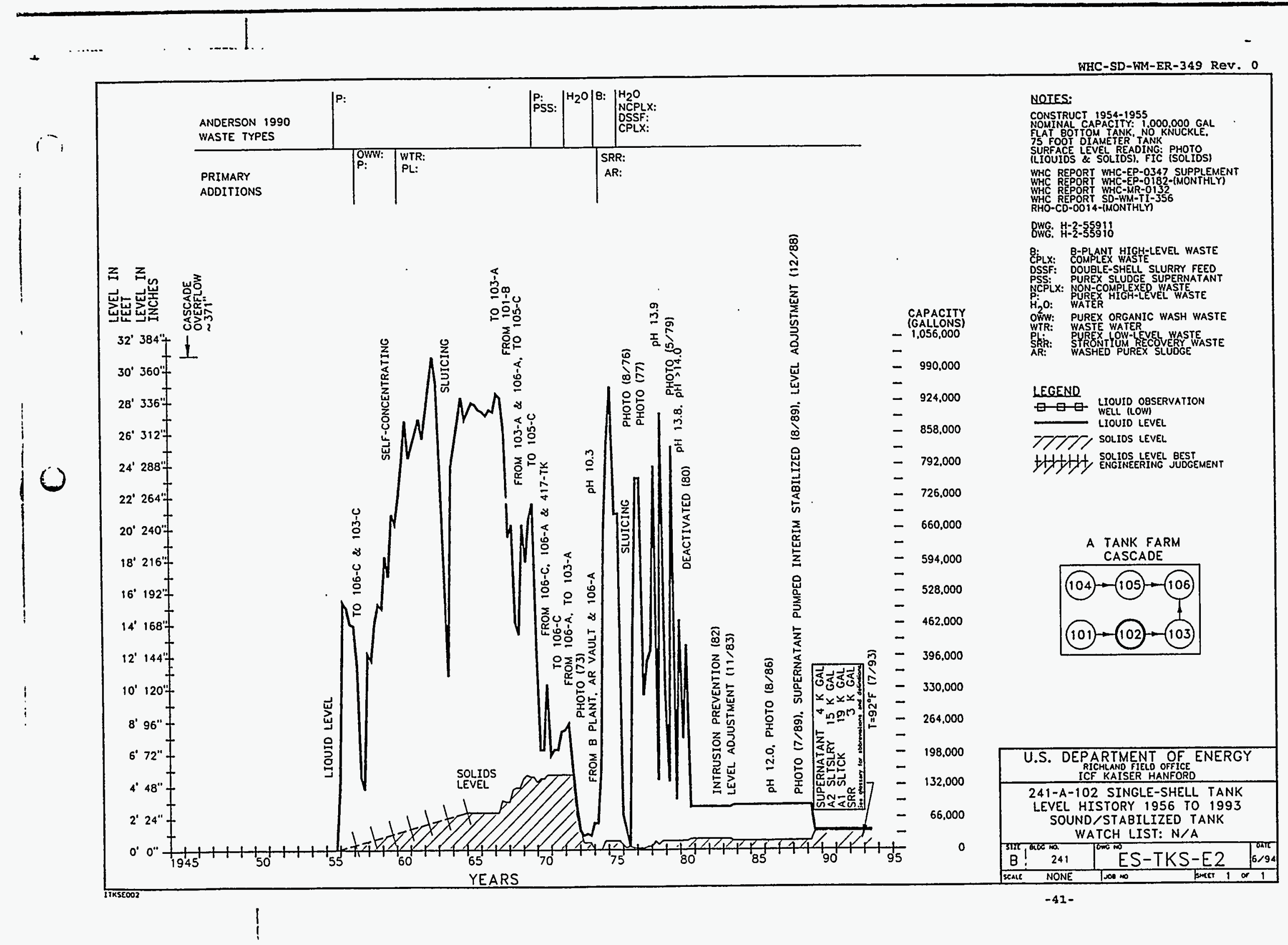




\begin{tabular}{|c|c|c|c|}
\hline \multicolumn{4}{|c|}{ Single-Shell Tank 241-A-102 } \\
\hline \multicolumn{4}{|c|}{ Solids Composite Inventory Estimate } \\
\hline Phishof Properties & & স/\% & $\% \% / \%$ \\
\hline Total Solid Waste & \multicolumn{3}{|c|}{$2.20 \mathrm{E}+05 \mathrm{~kg}(37 \mathrm{kgal})$} \\
\hline Hesa load & \multicolumn{3}{|c|}{$0.77 \mathrm{~kW}(2.63 \mathrm{E}+03 \mathrm{BTU} / \mathrm{hr})$} \\
\hline Bulk Density & \multicolumn{3}{|c|}{$1.57(g / \infty)$} \\
\hline Void Fraction & \multicolumn{3}{|c|}{0.36} \\
\hline \begin{tabular}{|l|} 
Water wt\% \\
\end{tabular} & \multicolumn{3}{|c|}{13.43} \\
\hline TOC wt\% C (wet) & \multicolumn{3}{|c|}{0.57} \\
\hline \multicolumn{4}{|c|}{ Whothes } \\
\hline $\mathrm{Na}^{4+2}$ & 11.80 & $1.73 E+05$ & $3.80 \mathrm{E}+04$ \\
\hline $\mathrm{Al}^{+3}$ & 0.78 & $1.34 \mathrm{E}+04$ & $2.96 \mathrm{E}+03$ \\
\hline $\mathrm{Fe}^{43}$ (Iotal Fe) & $6.65 \mathrm{E}-02$ & $2.36 \mathrm{E}+03$ & $5.20 \mathrm{E}+02$ \\
\hline$c^{43} \ldots$ & 5.61E-03 & $\because: 1.86 \mathrm{E}+02$ & $\because-40.85^{\circ}$ \\
\hline $\mathrm{Bi}^{+3}$ & 0 & 0 & 0 \\
\hline $\mathrm{La}^{\mathrm{63}}$ & 0 & 0 & 0 \\
\hline $\mathrm{Ce}^{+3}$ & 요 & 0 & 0 \\
\hline $\mathrm{Zr}\left(\right.$ as $\left.\mathrm{ZrO}(\mathrm{OH})_{2}\right)$ & 의 & 0 & 0 \\
\hline $\mathrm{Pb}^{+2}$ & o & 0 & 0 \\
\hline $\mathrm{Ni}^{+2}$ & $1.43 \mathrm{E}-02$ & $5.35 \mathrm{E}+02$ & $1.18 \mathrm{E}+02$ \\
\hline $\mathrm{Sr}^{+2}$ & 0 & 0 & 0 \\
\hline $\mathrm{Mn}^{+\infty}$ & of & of & 0 \\
\hline $\mathrm{Ca}^{+2}$ & 0 & 0 & 0 \\
\hline $\mathrm{K}^{+1}$ & 1.01E-02 & $2.51 \mathrm{E}+02$ & 55.19 \\
\hline $\mathrm{OH}^{-1}$ & 3.01 & $3.26 \mathrm{E}+04$ & $7.17 \mathrm{E}+03$ \\
\hline $\mathrm{NO}^{-1}$ & 4.04 & $1.60 \mathrm{E}+05$ & $3.51 \mathrm{E}+04$ \\
\hline $\mathrm{NO}^{-1}$ & 0.33 & $9.52 E+03$ & $2.09 \mathrm{E}+03$ \\
\hline $\mathrm{CO}^{22}$ & 0.48 & $1.82 \mathrm{E}+04$ & $3.99 \mathrm{E}+03$ \\
\hline $\mathrm{PO}^{-3}$ & 0.36 & $2.16 E+04$ & $4.76 \mathrm{E}+03$ \\
\hline $\mathrm{SO}^{-2}$ & 2.11 & $1.29 \mathrm{E}+05$ & $2.84 \mathrm{E}+04$ \\
\hline $\mathrm{Si}\left(\right.$ as $\left.\mathrm{SiO}_{3}^{-2}\right)$ & 0.13 & $2.32 E+03$ & $5.10 \mathrm{E}+02$ \\
\hline $\mathrm{F}^{-1}$ & 0.51 & $6.17 \mathrm{E}+03$ & $1.36 \mathrm{E}+03$ \\
\hline $\mathrm{C}^{\cdot \mathrm{I}}$ & 1.96E-02 & $4.42 E+02$ & 97.32 \\
\hline $\mathrm{C}_{6} \mathrm{H}_{3} \mathrm{O}_{7}^{-3}$ & $2.64 \mathrm{E}-02$ & $3.18 \mathrm{E}+03$ & $7.00 \mathrm{E}+02$ \\
\hline EDTA $^{4}$ & $1.09 \mathrm{E}-02$ & $2.01 E+03$ & $4.41 E+02$ \\
\hline HEDTA ${ }^{-3}$ & $2.19 \mathrm{E}-02$ & $3.82 E+03$ & $8.41 \mathrm{E}+02$ \\
\hline $\mathrm{NTA}^{-3}$ & 요 & 0 & 0 \\
\hline glycolate $e^{-1}$ & 6.58E-02 & $3.14 \mathrm{E}+03$ & $6.92 \mathrm{E}+02$ \\
\hline acetate & 3.07E-02 & $1.15 \mathrm{E}+03$ & $2.54 \mathrm{E}+02$ \\
\hline oxalate ${ }^{-2}$ & 0 & 0 & 0 \\
\hline DBP & 요 & 0 & 0 \\
\hline NPH & 0 & of & 0 \\
\hline $\mathrm{CCl}_{x}$ & 0 & of & 0 \\
\hline hexone & 0 & o & 0 \\
\hline $\mathrm{Fe}(\mathrm{CN})_{6}{ }^{-}$ & 01 & 0 (g-mol) & \\
\hline \multicolumn{4}{|c|}{$\mathrm{Fe}(\mathrm{CN})_{6}$} \\
\hline $\mathrm{Pu}$ & & $0.17(\mu \mathrm{Ci} / \mathrm{g})$ & $0.62(\mathrm{~kg})$ \\
\hline $\bar{U}$ & $3.56 \mathrm{E}-02(\mathrm{M})$ & $5.39 \mathrm{E}+03(\mathrm{\mu g} / \mathrm{g})$ & $1.19 \mathrm{E}+03(\mathrm{~kg})$ \\
\hline Cs & $0.33(\mathrm{Ci} / \mathrm{L})$ & $2.09 \mathrm{E}+02(\mu \mathrm{Ci} / \mathrm{g})$ & $4.59 \mathrm{E}+04(\mathrm{Ci})$ \\
\hline St & $0.59(\mathrm{Ci} / \mathrm{L})$ & $3.75 \mathrm{E}+02(\mu \mathrm{Ci} / \mathrm{g})$ & $8.25 \mathrm{E}+04(\mathrm{Ci})$ \\
\hline
\end{tabular}

- Composite inveatory excludes supernatant, fiatomscoous carth, and cement Unknowns in tank inventory are assigned by Tank Layering Model (TLM).

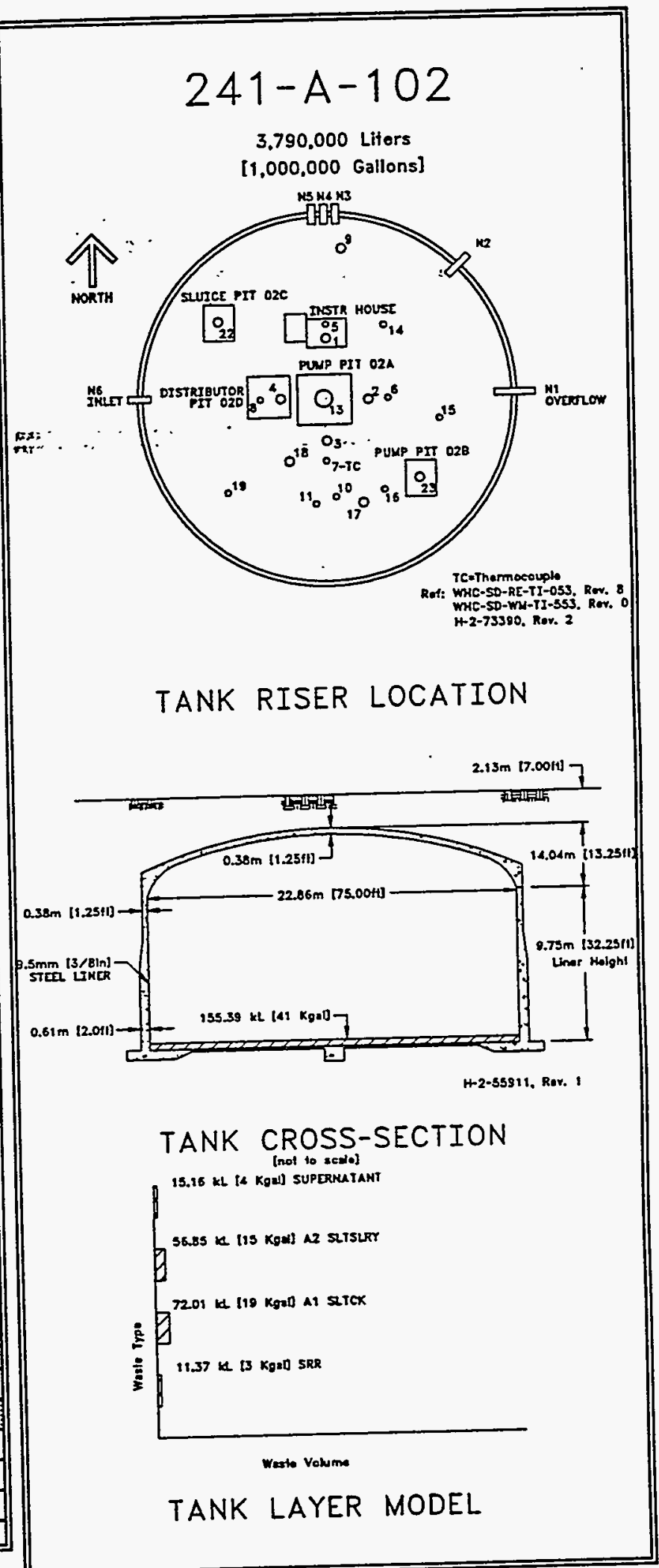




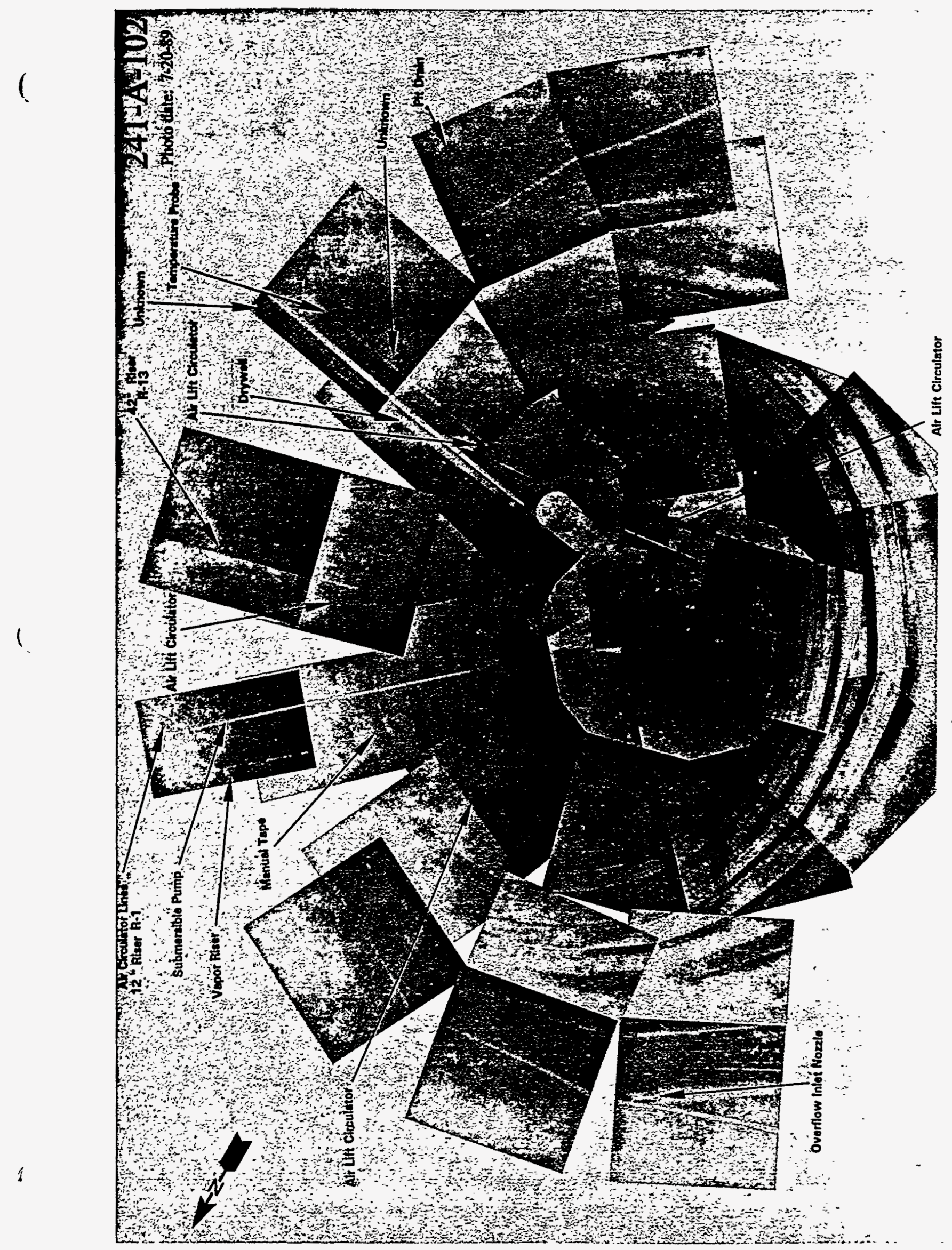




\subsection{Tank 241-A-103}

\section{3 .1 \\ 241-A-103 Tank History}

\subsubsection{Waste History Tank 241-A-103}

Tank 241-A-103 was filled with self-concentrating PUREX waste from the second quarter. of 1956 unti.I. the fourth quarter of 1969 . Tank 241A-103 was declared inactive in August 1980. The tank was declared an assumed leaker in 1987 with a leak volume of 5,550 gal. Interim stabilization was administratively completed in August 1988. (See sketch ES-TKS-E3 for a graphical representation of the Tank 241-A-103 level history.)

\subsubsection{Temperature-ustory-241-103}

The single thermocouple tree in Tank 241-A-103 has 18 thermocouple probes to record temperature data in riser 15 . Risers 2 and 19 were also used to record temperature data. A sum of the squares regression line fit starting in October 1976 for all the thermocouples shows a slightly negative, near zero slope $\pm 16.7^{\circ} \mathrm{F}$ with an average $r$ square value of 0.07 . From October 1976 to present, the median temperature is $90^{\circ} \mathrm{F}$ with a minimum of $50^{\circ} \mathrm{F}$ and a maximum of $143^{\circ} \mathrm{F}$. Refer to the supporting document for a more thorough review of the temperature data. (Brevick 1994)

\subsubsection{Integrity of Tank 241-A-103}

Tank 241-A-103 is categorized as an assumed leaker and is interim stabilized with intrusion prevention completed. Because there is no supernatant, the liquid waste volume is determined by a liquid observation well and the solid waste volume (or surface level) is determined by a Food Industry Corporation gauge through riser 6 and a photographic evaluation. An occurrence report was issued in september 1980 due to a liquid level decrease. The decrease was attributed to the mixing of dissimilar solids within the tank. An occurrence report was also issued in December 1979 due to a liquid level decrease. The decrease was attributed to slumping of the crust. For more information on surface levels see supporting documents (Brevick 1994).

An occurrence report was issued in May 1978 due to a small peak in aryweli 10-03-01. The activity was associated with contamination leaching in the soil caused by a 60,000 -gal raw water leak.

Seven arywells are identified for 241-A-103. Data and graphical representations for the active arywell from January 1990 to the present can be found in the supporting document (Brevick 1994).

\subsubsection{Current Status of Tank 241-A-103}

Tank 241-A-103 entered service in May 1956 and currently stores $370,000 \mathrm{gal}$ of waste. The waste is comprised of $4,000 \mathrm{gal}$ of supernatant, 363,000 gal of saltcake, and 3,000 gal of sludge, with no

$$
\text { - } 44-
$$


pumpable liquid remaining. The tank is identified as a low heat-load tank with passive ventilation and is categorized as an assumed leaker with interim stabilization and intrusion prevention completed. Tank 241-A-103 is equipped to cascade to Tank 241-A-106 and is third in a four-tank cascade flow series. The following plan view and tank cross section depict the approximate waste level and riser configuration. Tank 241-A-103 has 19 tank dome risers and three are available for use: one 4-in. riser (no. 5), one 8-in. riser (no. 11), and one 12-in. riser (no. 12).

\subsubsection{Inventory estimate 241-A-103}

The following tank layer volume approximation was derived from the Los Alamos: National Iaboratories waste status and. Transaction Record Summary (Agnew 1994):- The estimated in̈̈rentory of Tank 241-A-103 is also presented.

\subsubsection{In-Tank Photograph 241-A-103}

The following photograph of Tank 241-A-103 shows a grey sludge surface with pockets of supernatant to the right and bottom. The waste is about $11.5 \mathrm{ft}$ deep. Only two airlift circulators show through the waste because one pair is shorter than other two. The photo does not quite represent the current status of the tank because the level was adjusted by about 6 in. after the photograph was taken. This change in level was due a liquid/solids method of evaluation update in April 1990.

2.3.3 Synopsis Tank 241-A-103

(To be completed.) 
WHC-SD-WM-ER-349 Rev. 0

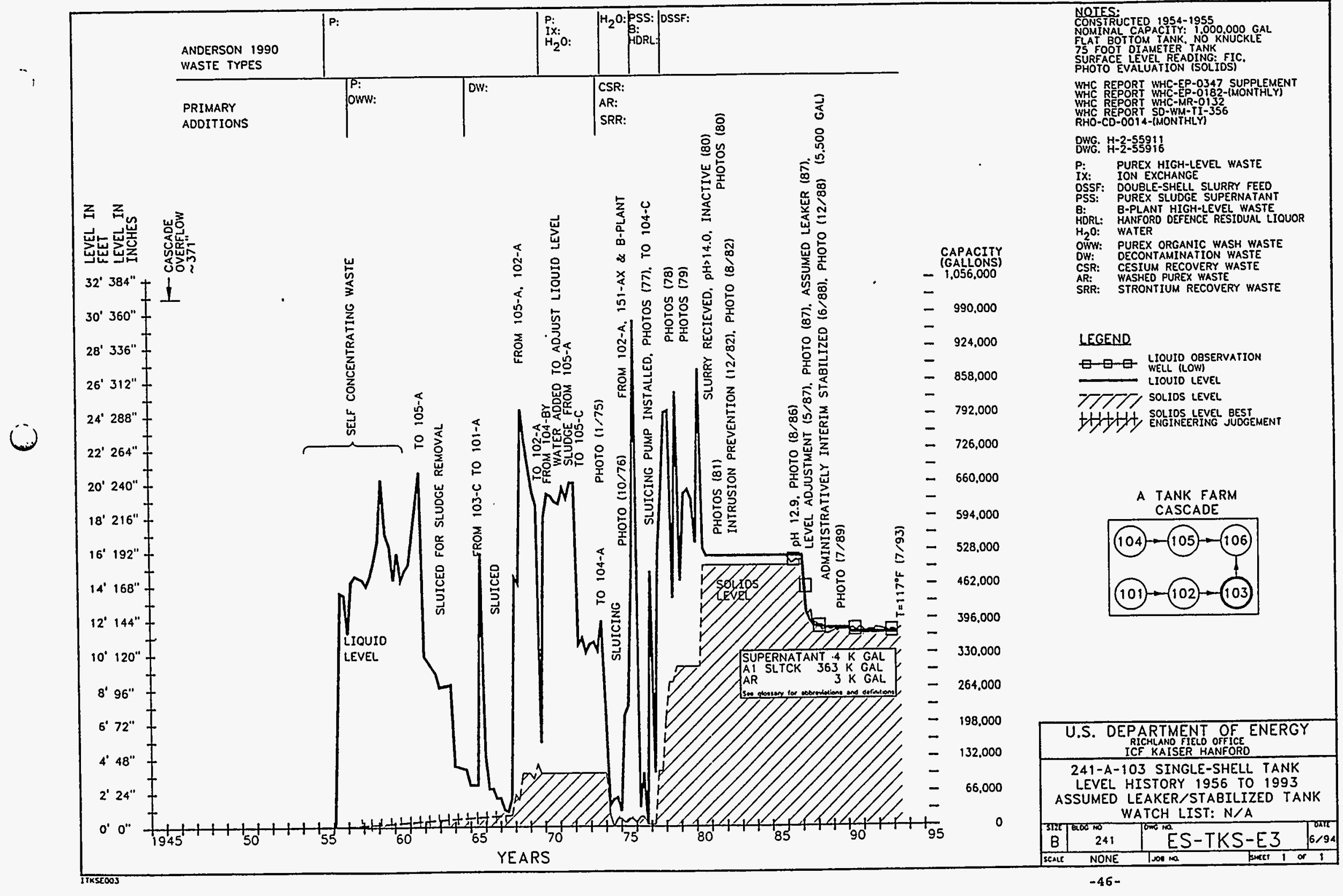




\begin{tabular}{|c|c|c|c|}
\hline \multicolumn{4}{|c|}{ Single-Shell Tank 241-A-103 } \\
\hline \multicolumn{4}{|c|}{ Solids Composite Inventory Estimate } \\
\hline \multicolumn{4}{|c|}{ 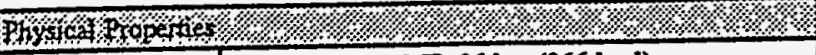 } \\
\hline Total Solid Warte & \multicolumn{3}{|c|}{$2.06 \mathrm{E}+06 \mathrm{~kg}(366 \mathrm{kgal})$} \\
\hline Heal load & \multicolumn{3}{|c|}{$0.77 \mathrm{~kW}(2.62 \mathrm{E}+03 \mathrm{BTU} / \mathrm{hr})$} \\
\hline Bulk Density & \multicolumn{3}{|c|}{$1.48(g / \infty)$} \\
\hline Void Fraction & \multicolumn{3}{|c|}{0.15} \\
\hline Water wt\% & \multicolumn{3}{|c|}{8.39} \\
\hline TOC wt\% C (wet) & \multicolumn{3}{|c|}{0.02} \\
\hline \multicolumn{4}{|c|}{ 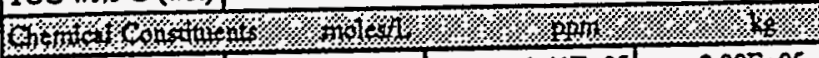 } \\
\hline \begin{tabular}{|l|l}
$\mathrm{Na}^{+1}$ \\
\end{tabular} & $\begin{array}{r}9.10 \\
\end{array}$ & $1.41 \mathrm{E}+05$ & $2.90 \mathrm{E}+05$ \\
\hline $\mathrm{Al}^{+3}$ & $6.86 \mathrm{E}-02$ & $1.25 \mathrm{E}+03$ & $2.56 \mathrm{E}+03$ \\
\hline $\mathrm{Fe}^{.3}$ (total Fe) & $8.40 \mathrm{E}-03$ & $3.16 \mathrm{E}+02$ & $6.50 \mathrm{E}+02$ \\
\hline $\mathrm{Cr}^{+3}$ & $1.08 \mathrm{E} \times 02$ & $P=3.79 \mathrm{E}+02$ & $7-7.80 \mathrm{E}+02^{2}$ \\
\hline $\mathrm{Bi}^{+3}$ & of & 0| & $\begin{array}{r}0 \\
\end{array}$ \\
\hline $\mathrm{La}^{43}$ & of & of & 0 \\
\hline $\mathrm{Ce}^{43}$ & of & 0) & 0 \\
\hline $\mathrm{Zx}$ (as $\left.\mathrm{ZrO}(\mathrm{OH})_{2}\right)$ & of & of & 0 \\
\hline $\mathrm{Pb}^{+2}$ & 0 & - 0 & 0 \\
\hline $\mathrm{Ni}^{+2}$ & $2.76 \mathrm{E}-02$ & $1.09 \mathrm{E}+03$ & $2.25 \mathrm{E}+03$ \\
\hline $\mathrm{Sr}^{42}$ & o & 0 & 0 \\
\hline $\mathrm{Mn}^{+4}$ & of & of & 0 \\
\hline $\mathrm{Ca}^{+2}$ & 0 & 0 & 0 \\
\hline $\mathrm{B}^{+1}$ & 9.58E-04 & 25.23 & 51.89 \\
\hline $\mathrm{OH}^{2}$ & 0.37 & $4.27 \mathrm{E}+03$ & $8.79 \mathrm{E}+03$ \\
\hline $\mathrm{NO}^{-1}$ & 0.33 & $1.40 \mathrm{E}+04$ & $2.87 \mathrm{E}+04$ \\
\hline $\mathrm{NO}^{-1}$ & $2.83 \mathrm{E}-02$ & $8.76 \mathrm{E}+02$ & $1.80 \mathrm{E}+03$ \\
\hline $\mathrm{CO}^{-2}$ & $5.36 \mathrm{E}-02$ & $2.17 \mathrm{E}+03$ & $4.46 \mathrm{E}+03$ \\
\hline $\mathrm{PO}^{-2}$ & 0.45 & $2.89 \mathrm{E}+04$ & $5.94 \mathrm{E}+04$ \\
\hline $\mathrm{SO}^{-2}$ & 3.59 & $2.32 \mathrm{E}+05$ & $4.78 \mathrm{E}+05$ \\
\hline $\mathrm{Si}\left(\right.$ as $\mathrm{SiO}_{3}^{-2}$ ) & $1.64 \mathrm{E}-02$ & $3.10 E+02$ & $6.38 \mathrm{E}+02$ \\
\hline$F^{-1}$ & $4.51 \mathrm{E}-02$ & $5.77 \mathrm{E}+02$ & $1.19 \mathrm{E}+03$ \\
\hline $\mathrm{Cl}^{-1}$ & $1.74 \mathrm{E}-03$ & 41.62 & 85.62 \\
\hline $\mathrm{C}_{6} \mathrm{H}_{5} \mathrm{O}_{3}{ }^{-3}$ & 2.57E-03 & $3.27 \mathrm{E}+02$ & $6.72 E+02$ \\
\hline EDTA $^{-4}$ & 0 & 0 & 0 \\
\hline HEDTA ${ }^{-3}$ & 3.04E-06 & 0.56 & 1.16 \\
\hline $\mathrm{NTA}^{3}$ & 0 & 0 & 0 \\
\hline glycolate ${ }^{-1}$ & $4.27 \mathrm{E}-03$ & $2.16 \mathrm{E}+02$ & $4.44 \mathrm{E}+02$ \\
\hline acetate $^{-1}$ & $2.71 \mathrm{E}-03$ & $1.08 \mathrm{E}+02$ & $2.21 E+02$ \\
\hline oxalate & o & 0 & 0 \\
\hline $\mathrm{DBP}$ & 0 & o) & 0 \\
\hline NPE & 0 & 0 & 0 \\
\hline $\mathrm{CCl}_{4}$ & of & 0 & 0 \\
\hline bexone & 0 & - 0 & 0 \\
\hline $\mathrm{Fe}(\mathrm{CN})_{6}^{+}$ & of & $0(\mathrm{~g}-\mathrm{mol})$ & \\
\hline \multicolumn{4}{|c|}{ 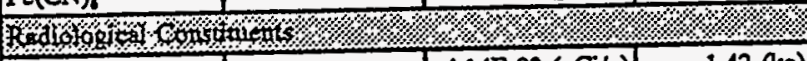 } \\
\hline $\mathrm{Pu}$ & & $4.14 \mathrm{E}-02(\mu \mathrm{Ci} / \mathrm{g})$ & $1.42(\mathrm{~kg})$ \\
\hline$U$ & 8.04E-03 $(M)$ & $1.29 \mathrm{E}+03(\mu \mathrm{g} / \mathrm{g})$ & $2.65 \mathrm{E}+03(\mathrm{~kg})$ \\
\hline Cs & $2.83 \mathrm{E}-02(\mathrm{Ci} / \mathrm{L})$ & $19.09(\mu \mathrm{Ci} / \mathrm{g})$ & $3.93 \mathrm{E}+04(\mathrm{Ci})$ \\
\hline Sr & $6.24 \mathrm{E}-02(\mathrm{Ci} / \mathrm{L})$ & $42.00(\mu \mathrm{Ci} / g)$ & $8.64 \mathrm{E}+04(\mathrm{Ci})$ \\
\hline
\end{tabular}

- Composite inventory exchudes supernatast, diatomacoous earth, and cement. Unkowns in tank inveatory are assigned by Tank Layering Model (TLM).

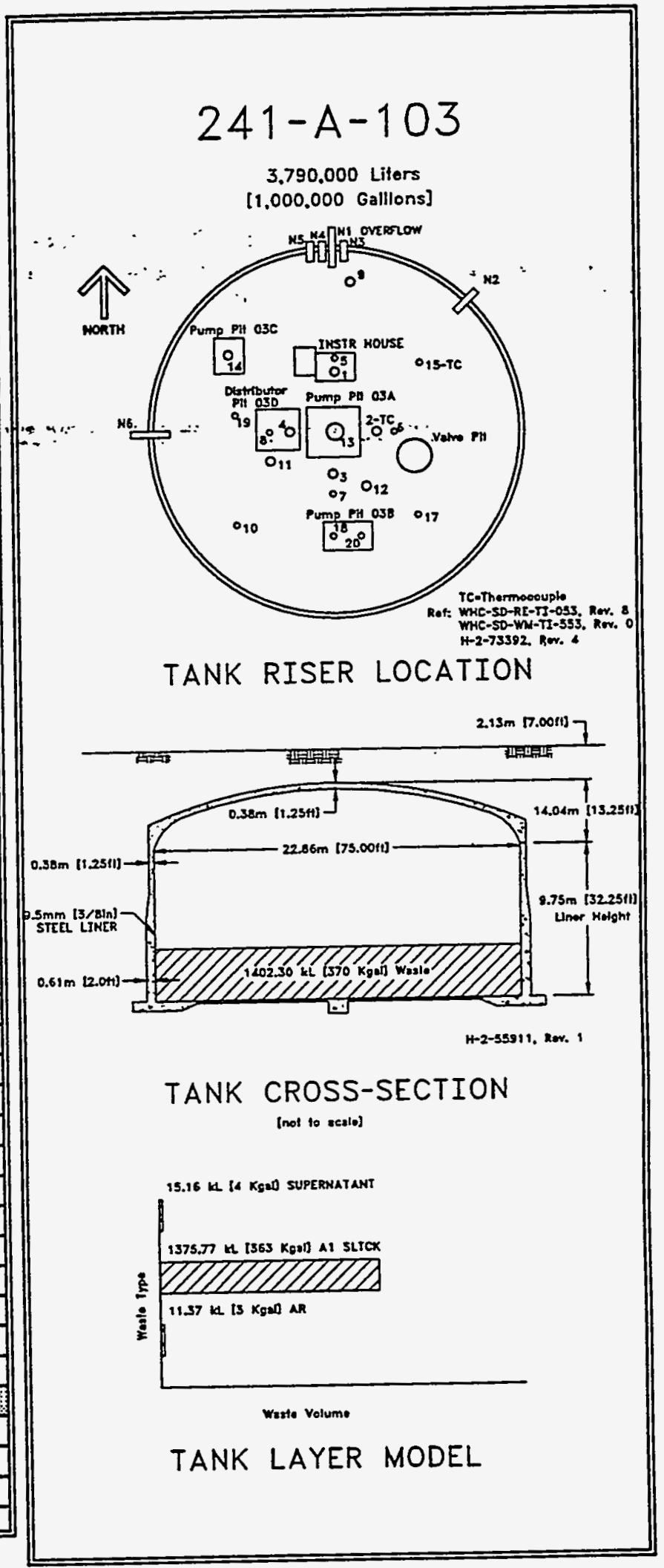

$6 / 94$ 
WHC-SD-WM-ER-349 ReV. 0

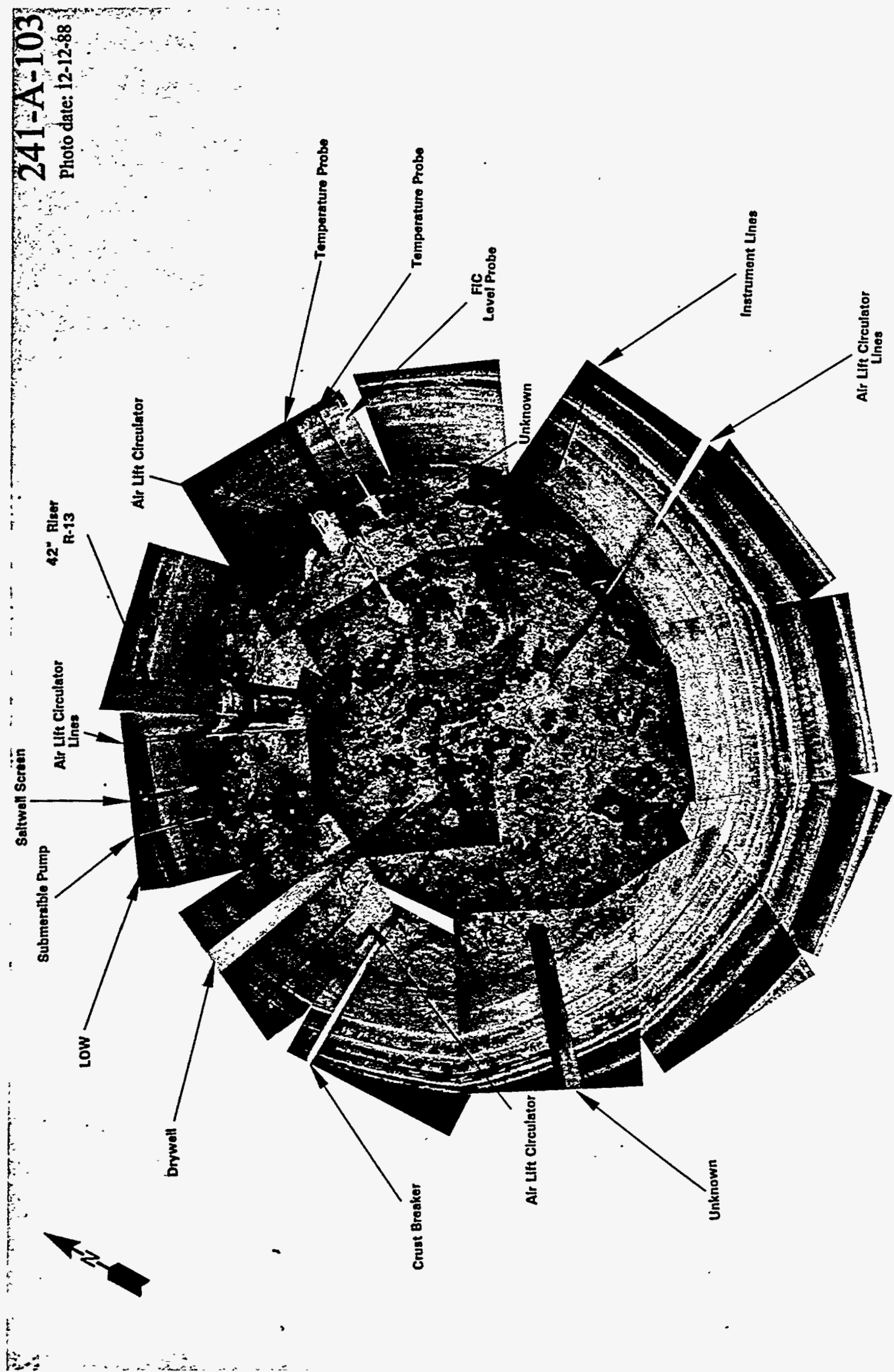


2.4 Tank 241-A-104

$2: 4.1 \quad 241-\mathrm{A}-104$ Tank History

2.4.1.1 Waste History Tank 241-A-104

Tank 241-A-104 was filled with test water from the second quarter of 1957.until the second quarter of 1958.. Presently, the tank contains non-complexed waste. . Intrusion prevention was completed in 19.83.. The tank was declared an assumed leaker in 1975 and was interim stabilized administratively in september 1978. (See sketch ES-TKS-E4 for a graphical representation of the Tank 241-A-104 level history.)

2.4.1.2. Temperature History.247-A-104

Tank 241-A-104 has two thermocouple trees. Trees 12 and 18 are single sensor probes in risers 12 and 18 . A sum of the squares regression line fit for both thermocouple trees shows an overall zero slope $\pm 12.7^{\circ} \mathrm{F}$ with an average $r$ square value of 0.08 . From August 1974 to present, the median temperature is $188^{\circ} \mathrm{F}$ with a minimum of $100^{\circ} \mathrm{F}$ and maximum of $236^{\circ} \mathrm{F}$. Current isotopic analysis results indicate the heat generation rate of the sludge to be $14.3 \mathrm{Btu} / \mathrm{hr}$; therefore, cooling is required for the tank. Refer to the supporting document for a more thorough review of the temperature data (Brevick 1994).

\subsubsection{Integrity of Tank 241-A-104}

Tank 241-A-104 is categorized as an assumed leaker and is interim stabilized with intrusion prevention completed. The surface level in Tank 241-A-104 is monitored quarterly with a manual tape through riser 6 . A figure that graphically represents the surface level measurements from January 1991 to the present can be found in the supporting documents (Brevick 1994). The plot shows an inaccurate data point in the second quarter of 1993, which is attributed to input error of the field data sheets into the Computer automated Surveillance system. The surface level has not exceeded the increase criteria and the readings range from 11.5 to 3 -in.

An occurrence report was issued in July 1976 due to increasing radiation levels in the laterals. An evaluation indicated a minor leak migration.

Seven drywells are identified for 241-A-104, none of which are considered active.

\subsubsection{Current Status of Tank 241-A-104}

Tank 241-A-104 entered service in June 1959 and stores 28,000 gal of waste. The waste is comprised entirely of sludge with no pumpable liquid remaining. It is identified as a non-watch list high-heat load tank with active ventilation. Tank 241-A-104 cascades to Tank 241-A-105 and is first in a three-tank cascade flow series. The following plan view and tank cross section depict the approximate waste level and riser 
WHC-SD-WM-ER-349, Rev. 0

configuration. Tank 241-A-104 has 21 tank dome risers and three 12-in. risers (nos. 4, 7, and 17) are available for use.

2.4.2.1 Inventory estimate 241-A-104

The following tank layer volume approximation was derived from the Ios Alamos National Laboratories Waste Status and Transaction Record Summary (Agnew 1994). The estimated inventory of Tank 241-A-104 is also presented.

2.4.2.2 In-Tank Photograph 241-A-104

The following photograph of Tank 241-A-104 shows a dry cracked sludge surface that is grey to.dark.brown in color... The waste is about 1 ft dèep: The Iighnt blüe to white discolöration is damage to the negative which may be due to overexposure from radiation. The lines shown hanging in the top right of the photo are air lines to the airlift circulator that have loosened from their brackets in the dome.

2.4.3 Synopsis Tank 241-A-104

(To be completed.) 


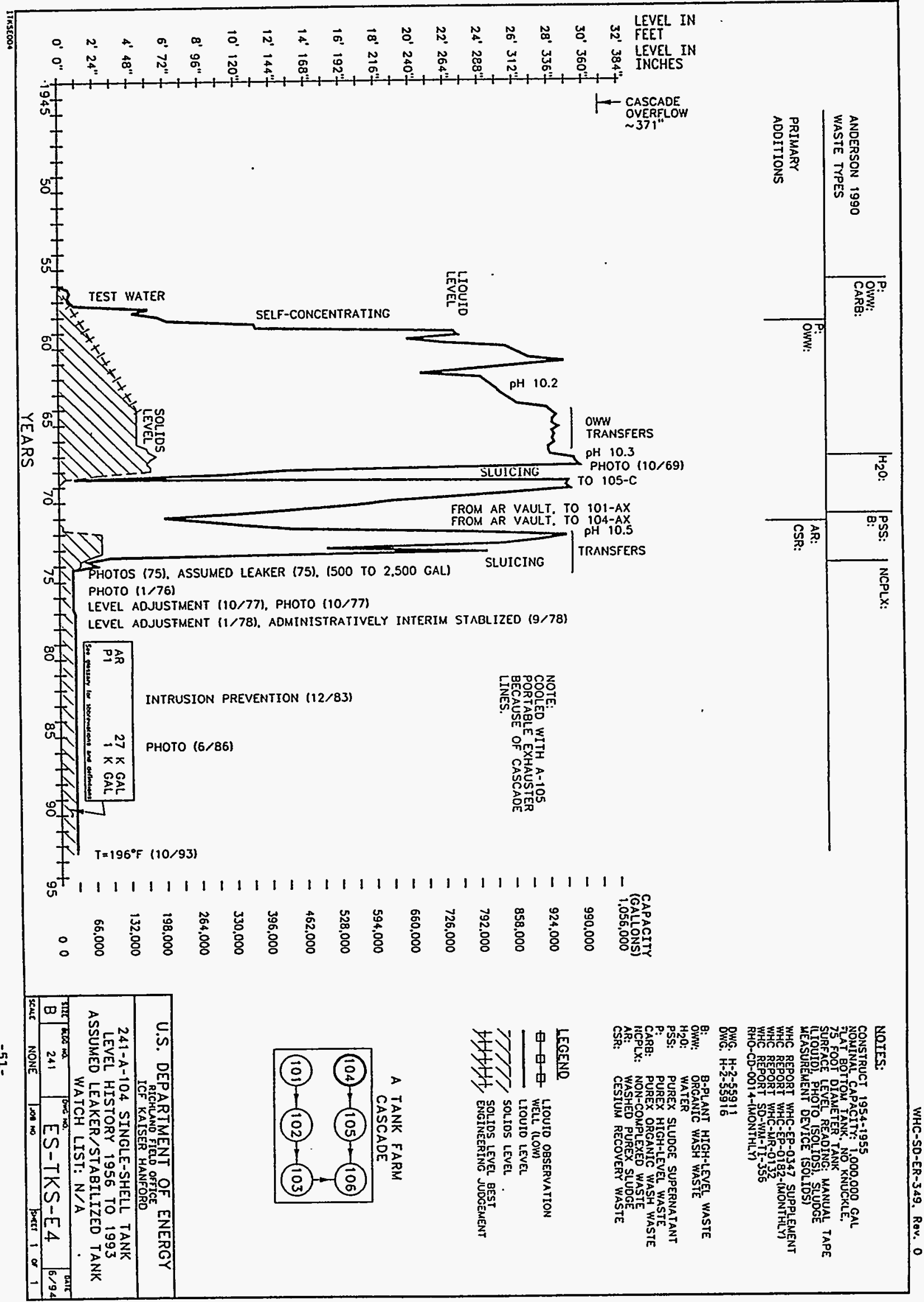


WHC-SD-WM-ER-349, ReV . 0

\begin{tabular}{|c|c|c|c|}
\hline \multicolumn{4}{|c|}{ Single-Shell Tank 241-A-104 } \\
\hline \multicolumn{4}{|c|}{ Solids Composite Inventory Estimate } \\
\hline 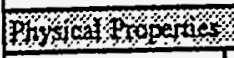 & \%/\% & \%. & 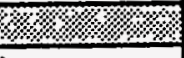 \\
\hline Total Solid Waste & \multicolumn{3}{|c|}{$1.31 \mathrm{E}+05 \mathrm{~kg}(28 \mathrm{kgal})$} \\
\hline Eeal load & \multicolumn{3}{|c|}{$5.61 \mathrm{~kW}(1.91 \mathrm{E}+04 \mathrm{BTU} / \mathrm{hr})$} \\
\hline Bulk Density & \multicolumn{3}{|c|}{$1.24(g / \infty)$} \\
\hline Void Fraction & \multicolumn{3}{|c|}{0.87} \\
\hline Water wr\% & \multicolumn{3}{|c|}{67.43} \\
\hline TOC wt\% C (wet) & \multicolumn{3}{|c|}{0.00} \\
\hline \multicolumn{4}{|c|}{ Q } \\
\hline $\mathrm{Na}^{\mathrm{at}}$ & 4.88 & 9.05E+04 & $1.19 \mathrm{E}+04$ \\
\hline $\mathrm{Al}^{+3}$ & 0 & .0 & 0 \\
\hline $\mathrm{Fe}^{+3}$ (total $\left.\mathrm{Fe}\right)$ & 1.09 & $4.89 E+04$ & $6.42 \bar{E}+03$ \\
\hline$C^{+3 \ldots}, \cdots$ & $\therefore$ 요 & 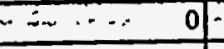 &.$\quad 0$ \\
\hline $\mathrm{Bi}^{43}$ & 0 & of & 0 \\
\hline $\mathrm{Lat3}^{+3}$ & 0] & 0 & 0 \\
\hline $\mathrm{Ce}^{43}$ & O & 0 & 0 \\
\hline $\mathrm{Zx}\left(\right.$ as $\left.\mathrm{ZrO}(\mathrm{OH})_{2}\right)$ & of & of & 0 \\
\hline $\mathrm{Pb}^{42}$ & 0 & 이 & 0 \\
\hline $\mathrm{Ni}^{+22}$ & 0 & 0 & 0 \\
\hline $\mathrm{Sr}^{42}$ & of & 요 & 0 \\
\hline $\mathrm{Mn}^{+4}$ & 0 & of & 0 \\
\hline $\mathrm{Ca}^{* 2}$ & 0 & 0) & 0 \\
\hline $\mathrm{K}^{+1}$ & 0 & 0 & 0 \\
\hline $\mathrm{OH}^{-1}$ & 3.29 & $4.51 \mathrm{E}+04$ & $5.92 \mathrm{E}+03$ \\
\hline $\mathrm{NO}^{-1}$ & 0.43 & $2.14 \mathrm{E}+04$ & $2.82 \mathrm{E}+03$ \\
\hline $\mathrm{NO}^{-1}$ & 0 & 0 & 0 \\
\hline $\mathrm{CO}^{-2}$ & $8.70 \mathrm{E}-02$ & $4.21 \mathrm{E}+03$ & $5.54 \mathrm{E}+02$ \\
\hline $\mathrm{PO}^{.3}$ & $1.68 \mathrm{E}-02$ & $1.29 \mathrm{E}+03$ & $1.69 \mathrm{E}+02$ \\
\hline $\mathrm{SO}^{\cdot 2}$ & $9.50 \mathrm{E}-02$ & $7.36 \mathrm{E}+03$ & $9.67 \mathrm{E}+02$ \\
\hline $\mathrm{Si}$ (as $\left.\mathrm{SiO}^{-2}\right)$ & 2.00 & $4.54 \mathrm{E}+04$ & $5.97 \mathrm{E}+03$ \\
\hline $\mathrm{F}^{1}$ & 0 & of & 0 \\
\hline $\mathrm{Cl}^{-3}$ & 0 & 이 & 0 \\
\hline $\mathrm{C}_{6} \mathrm{H}_{3} \mathrm{O}_{7}^{-3}$ & of & 0 & 0 \\
\hline EDTA $^{-1}$ & 0 & 0 & 0 \\
\hline HEDTA $^{.3}$ & of & of & 0 \\
\hline NTA $^{-3}$ & 0 & 0 & 0 \\
\hline Slycolate $e^{-1}$ & 요 & 0 & 0 \\
\hline acetate $^{-1}$ & 0 & 0 & 0 \\
\hline oxalare & of & 0 & 0 \\
\hline DBP & 0 & 0 & 0 \\
\hline NPH & 요 & 0 & 0 \\
\hline$\overline{\mathrm{CCl}_{4}}$ & of & 0 & 0 \\
\hline hexone & 0 & 0 & 0 \\
\hline $\mathrm{Fe}(\mathrm{CN})_{6}{ }^{4}$ & 0 & $0(\mathrm{~g}-\mathrm{mol})$ & \\
\hline \multicolumn{4}{|c|}{ 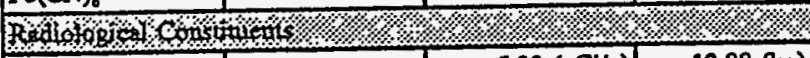 } \\
\hline $\mathrm{Pu}$ & & $5.88(\mu \mathrm{Ci} / \mathrm{g})$ & $12.88(\mathrm{~kg})$ \\
\hline $\mathrm{U}$ & $3.44 \mathrm{E}-04(\mathrm{M})$ & $66.09(\mu \mathrm{g} / \mathrm{g})$ & $8.68(\mathrm{~kg})$ \\
\hline$\overline{C s}$ & $0.28(\mathrm{Ci} / \mathrm{L})$ & $2.22 \mathrm{E}+02(\mu \mathrm{Ci} / \mathrm{g})$ & $2.92 \mathrm{E}+04(\mathrm{Ci})$ \\
\hline$S_{\mathbf{r}}$ & $7.66(\mathrm{Ci} / \mathrm{L})$ & $6.18 \mathrm{E}+03(\mu \mathrm{C} / \mathrm{g})$ & $8.12 \mathrm{E}+05(\mathrm{C})$ \\
\hline
\end{tabular}

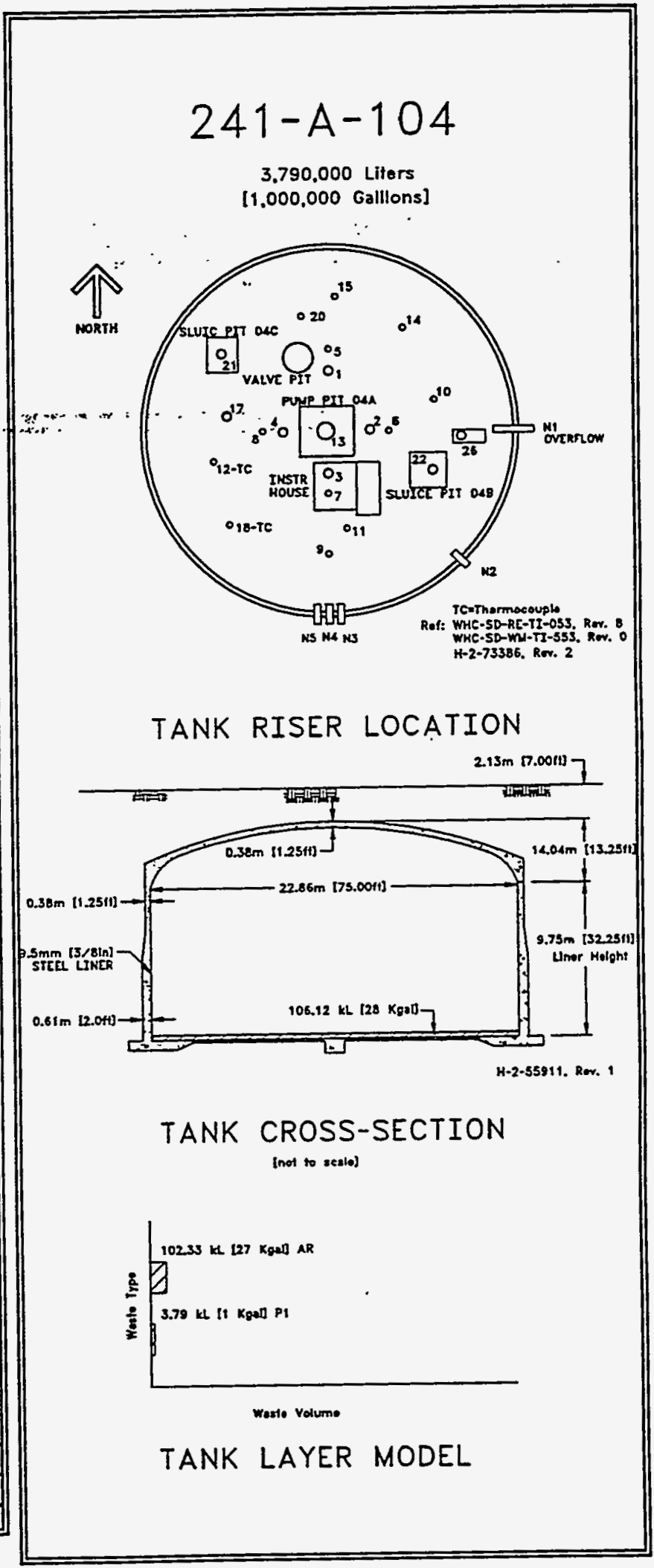




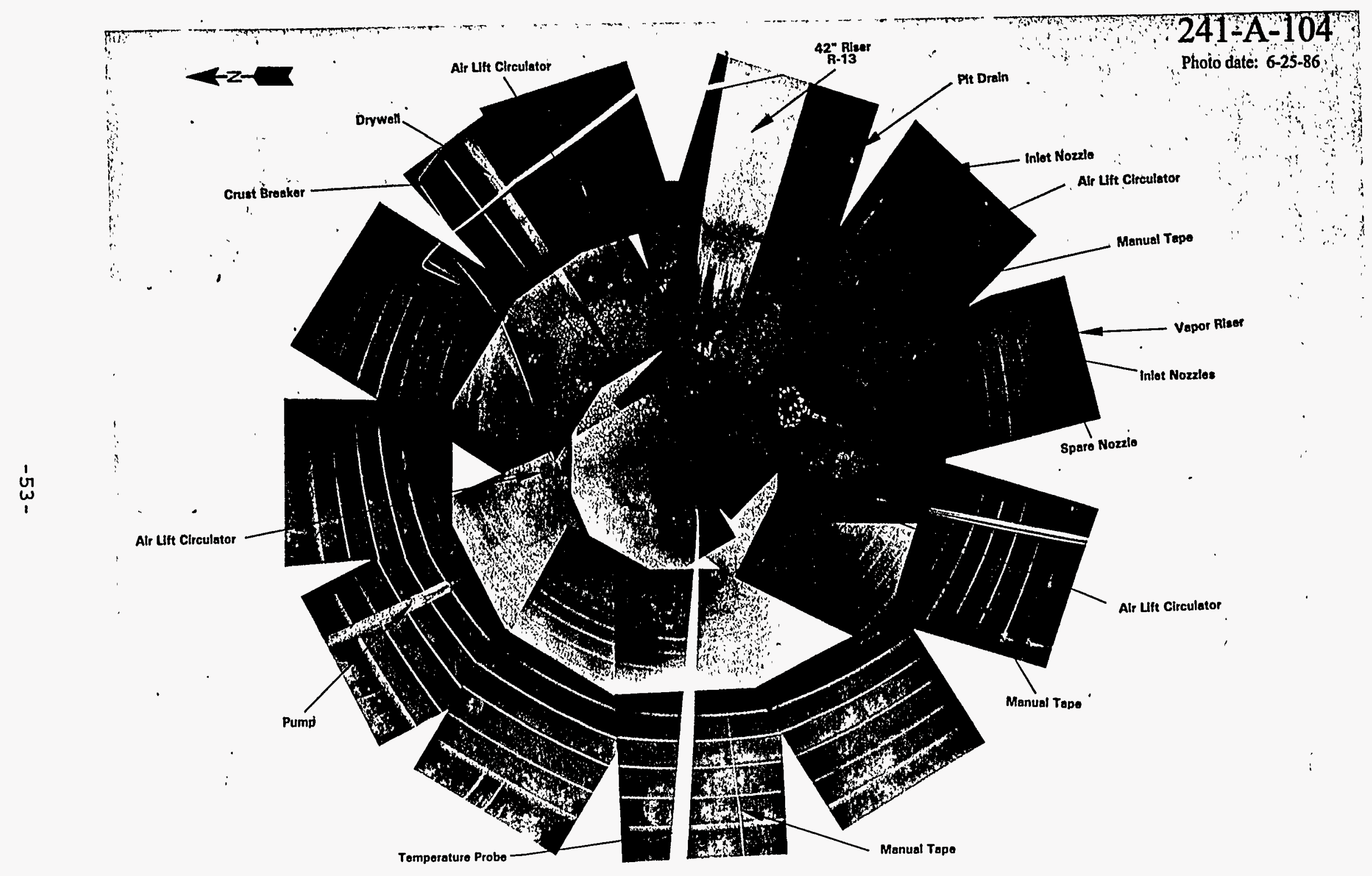

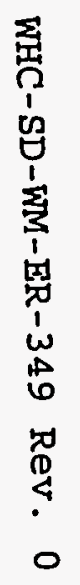


WHC-SD-WM-ER-349, Rev. 0

\subsection{Tank 241-A-105}

\subsubsection{1-A-105 Tank History \\ 2.5.1.1 Waste History Tank 241-A-105}

Tank 241-A-105 was filled with test water in the second quarter of 1957. The tank was suspected of-leaking in 1963 and was declared an assumed leaking tank at that time: Leaking occurred in the fourth quarter of 1967 and the first quarter of 1968, and a steam explosion between the carbon steel liner and the concrete base occurred in January 1965. Presently, the tank waste is classified as non-complexed.

The tank ...was interim..stabilized. in.127. . and intrusion prevention was completed in $1985 \%$ "Water additions to cool the"tank were stopped in January 1979 and then a portable exhauster was used to control sludge temperatures. The portable exhauster failed in 1988 and was restarted. The exhauster ran for approximately two years and is slated to be removed from the A Tank Farm. The removal has been approved due to lowheat generation of the tank waste. (See sketch ES-TKS-E5 for a graphical representation of the Tank 241-A-105 level history.)

\subsubsection{Temperature History 241-A-105}

Tank 241-A-105 has 8 single-sensor probes (i.e.; 9, 12, 15, 16, 17, 18, 19, and 22) that each contain one thermocouple in risers $9,15,16$, 17, 19, and 22. A sum of the squares regression line fit starting in December 1985 for trees $9,15,16,17,19$, and 22 shows a 0.03 overall slope $\pm 10.70 \mathrm{~F}$ with an average $r$ square value of 0.2 . There are not enough points for an accurate regression or variability assessment on thermocouple trees 12 and 18. The tank has an annual temperature undulation that is more evident after October 1989. From December 1985 to present, the median temperature is $128^{\circ} \mathrm{F}$ with a minimum of $47.9^{\circ} \mathrm{F}$ and a maximum of $189^{\circ} \mathrm{F}$. Refer to the supporting document for a more thorough review of the temperature data (Brevick 1994).

An unusual occurrence report was issued in December 1990 due to an increasing temperature trend in the thermocouple lateral under Tank 241A-105. The cause of the trend was determined to be faulty wiring.

\subsubsection{Integrity of Tank 241-A-105}

Tank 241-A-105 is categorized as an assumed leaker and is interim stabilized with intrusion prevention completed. The Tank 241-A-105 surface level is monitored quarterly with a manual tape through riser 5 . A figure that graphically represents the surface level measurements from January 1991 to the present can be found in the supporting documents (Brevick 1994). The surface level plot has an increasing trend for the past 3 years as the surface level during the third quarter of 1991 was 13-in. and steadily increased to 15-in. during the fourth quarter of 1993. An inaccurate data point with an apparent "rerun" is included on the plot. 
Seven drywells are identified for 241-A-105. Data and graphical representations of the active drywell from January 1990 to the present can be found in the supporting document (Brevick 1994).

\subsubsection{Current Status of Tank 241-A-105}

Tank 241-A-105 entered service in 1962 and currently stores 19,000 gal of waste. The waste is comprised entirely of sludge with no pumpable liquid remaining. The tank is identified as a high heat-load tank with active ventilation and is categorized as an assumed leaker with interim stabilization and intrusion prevention completed. Tank 241-A-105 is equipped to cascade to Tank 241-A-106 and is second in the three-tank cascade flow series. The following plan view and tank cross section depict the approximate waste level:and.r-iser.configuration. Tank 241-A-105 häs $25^{\circ}$ tank döme rïsers sixirisers are availäble for use; one 12-in. riser (no. 4), and five 4-in. risers (nos. 7, 8, 14, 18, and 20).

\subsubsection{Inventory estimate 241-A-105}

The following tank layer volume approximation was derived from the Los Alamos National Laboratories Waste Status and Transaction Record Summary (Agnew 1994). The estimated inventory of Tank 241-A-105 is also presented.

\subsubsection{In-Tank Photograph 241-A-105}

The following photograph of Tank 241-A-105 shows a grey sludge surface that is just under 1 ft deep. The acid milling machine to the right of the photo was used to drill through the 5-ft high bulge in the steel bottom. Operators were able to take a sample from the air space under the tank to determine if a combustible gas was present. A large amount of debris is visible on the bottom the tank. Many of the instrument lines and other equipment are loose from their anchors.

2.5.3 Synopsis Tank 241-A-105

(To be completed.) 


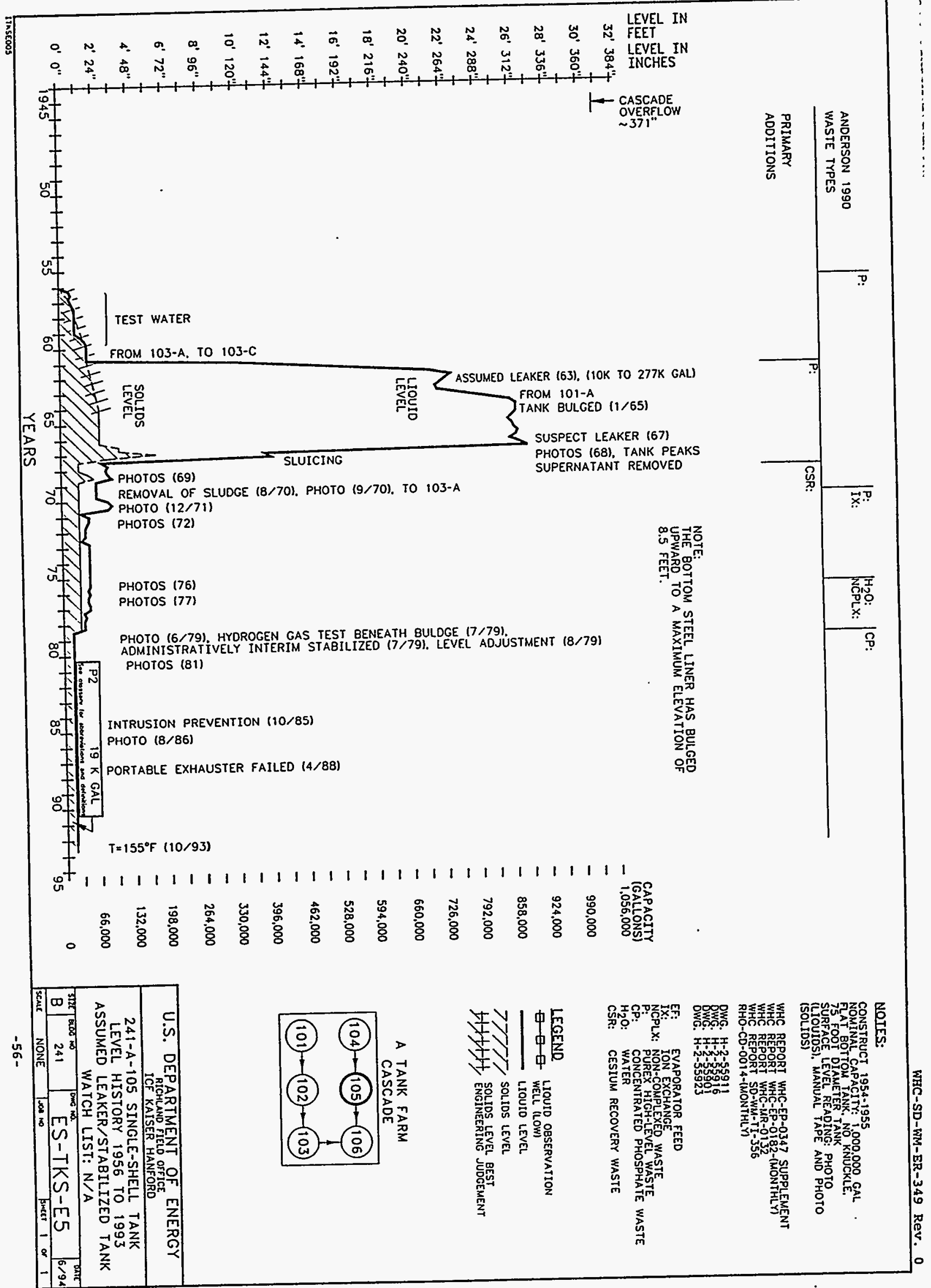


WHC-SD-WM-ER-349, Rev. 0

\begin{tabular}{|c|c|c|c|}
\hline \multicolumn{4}{|c|}{ Single-Shell Tank 241-A-105 } \\
\hline \multicolumn{4}{|c|}{ Solids Composite Inventory Estimate } \\
\hline 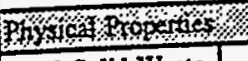 & $\% \% \% \%$ & $\% \% \% \% \% \%$ & $\%$ \\
\hline Total Solid Waste & \multicolumn{3}{|c|}{$\frac{\% \% \%}{1.00 \mathrm{E}+05 \mathrm{~kg} \quad(37 \mathrm{kgal})}$} \\
\hline Hear load & \multicolumn{3}{|c|}{$10.96 \mathrm{~kW}(3.74 \mathrm{E}+04 \mathrm{BTU} / \mathrm{hr})$} \\
\hline Bulk Density & \multicolumn{3}{|c|}{$1.39(g / \infty)$} \\
\hline Void Fraction & \multicolumn{3}{|c|}{0.78} \\
\hline Water wh\% & \multicolumn{3}{|c|}{53.44} \\
\hline TOC wt\% C (wet) & \multicolumn{3}{|c|}{0.00} \\
\hline \multicolumn{4}{|l|}{ Ghentiction on } \\
\hline \begin{tabular}{|l|l}
$\mathrm{Na}^{+1}$ & \\
\end{tabular} & 5.87 & $9.69 \mathrm{E}+04$ & $9.71 E+03$ \\
\hline $\mathrm{Al}^{+3}$ & 0 & 0 & 0 \\
\hline $\mathrm{Fe}^{43}($ total Fe $)$ & 3.01 & $1.21 \mathrm{E}+05$ & $1.21 \mathrm{E}+04$ \\
\hline $\mathrm{Cr}^{+3}$ & 0 & $\because \quad 0$ : & 0 \\
\hline $\mathrm{Bi}^{+3}$ & 아 & \begin{tabular}{l|l}
0 & \\
\end{tabular} & 0 \\
\hline $\mathrm{La}^{43}$ & 요 & 0 & 0 \\
\hline $\mathrm{Ce}^{+3}$ & 0 & o) & 0 \\
\hline $\mathrm{Zr}$ (as $\left.\mathrm{ZrO}(\mathrm{OH})_{2}\right)$ & of & 0 & 0 \\
\hline $\mathrm{Pb}^{+2}$ & of & 0 & 0 \\
\hline $\mathrm{Ni}^{+2}$ & 인 & 0 & 0 \\
\hline $\mathrm{Sr}^{42}$ & 아 & 告 & 0 \\
\hline $\mathrm{Mn}^{+\infty}$ & of & 요 & 0 \\
\hline $\mathrm{Ca}^{+2}$ & 0. & of & 0 \\
\hline $\mathrm{R}^{+1}$ & o & o & 0 \\
\hline $\mathrm{OH}^{-1}$ & 9.04 & $1.10 \mathrm{E}+05$ & $1.11 E+04$ \\
\hline $\mathrm{NO}^{-1}$ & 0.43 & $1.93 \mathrm{E}+04$ & $1.93 \mathrm{E}+03$ \\
\hline $\mathrm{NO}_{2}^{-1}$ & 0 & 0 & 0 \\
\hline $\mathrm{CO}^{-2}$ & $7.88 \mathrm{E}-02$ & $3.40 \mathrm{E}+03$ & $3.40 \mathrm{E}+02$ \\
\hline $\mathrm{PO}^{-3}$ & 0 & 인 & 0 \\
\hline $\mathrm{SO}^{-2}$ & 0.36 & $2.48 \mathrm{E}+04$ & $2.49 \mathrm{E}+03$ \\
\hline $\mathrm{Si}\left(\right.$ as $\left.\mathrm{SiO}_{3}{ }^{-2}\right)$ & 2.36 & $4.76 \mathrm{E}+04$ & 4.77E+03 \\
\hline$F^{-1}$ & of & 0 & 0 \\
\hline $\mathrm{c}^{-1}$ & 요 & 이 & 0 \\
\hline $\mathrm{C}_{6} \mathrm{H}_{5} \mathrm{O}_{7}^{-3}$ & 0 & of & 0 \\
\hline $\mathrm{EDTA}^{-1}$ & 0 & of & 0 \\
\hline EEDTA $^{\cdot 3}$ & 0 & 0) & 0 \\
\hline NTA $^{-3}$ & 0 & 0 & 0 \\
\hline glycolate & o) & 0 & 0 \\
\hline acetate ${ }^{-1}$ & 0 & 0 & 0 \\
\hline oxalate.2 & 0 & 0 & 0 \\
\hline DBP & 인 & 0 & 0 \\
\hline $\mathrm{NPH}$ & 요 & 0 & 0 \\
\hline $\mathrm{CCl}_{4}$ & 0 & 요 & 0 \\
\hline hexone & 0 & 이 & 0 \\
\hline $\mathrm{Fe}(\mathrm{CN})_{6}^{-1}$ & 0 & $0(s-m o l)$ & \\
\hline Paloforitcout & Hats & \%/\%, \% & \%4\% \\
\hline $\mathrm{Pu}$ & & $2.61(\mathrm{uCi} / \mathrm{g})$ & $4.36(\mathrm{~kg})$ \\
\hline $\mathrm{U}$ & $2.92 \mathrm{E}-02(\mathrm{M})$ & $4.99 \mathrm{E}+03(\mu \mathrm{g} / \mathrm{g})$ & $4.99 \mathrm{E}+02(\mathrm{~kg})$ \\
\hline Cs & $0.72(\mathrm{C} / 2)$ & $5.14 \mathrm{E}+02(\mu \mathrm{Ci} / \mathrm{g})$ & $5.15 \mathrm{E}+04(\mathrm{Ci})$ \\
\hline & $22.11(\mathrm{Ci} / \mathrm{L})$ & $1.59 \mathrm{E}+04(\mu \mathrm{CV} / \mathrm{g})$ & $1.59 \mathrm{E}+06(\mathrm{Ci})$ \\
\hline
\end{tabular}

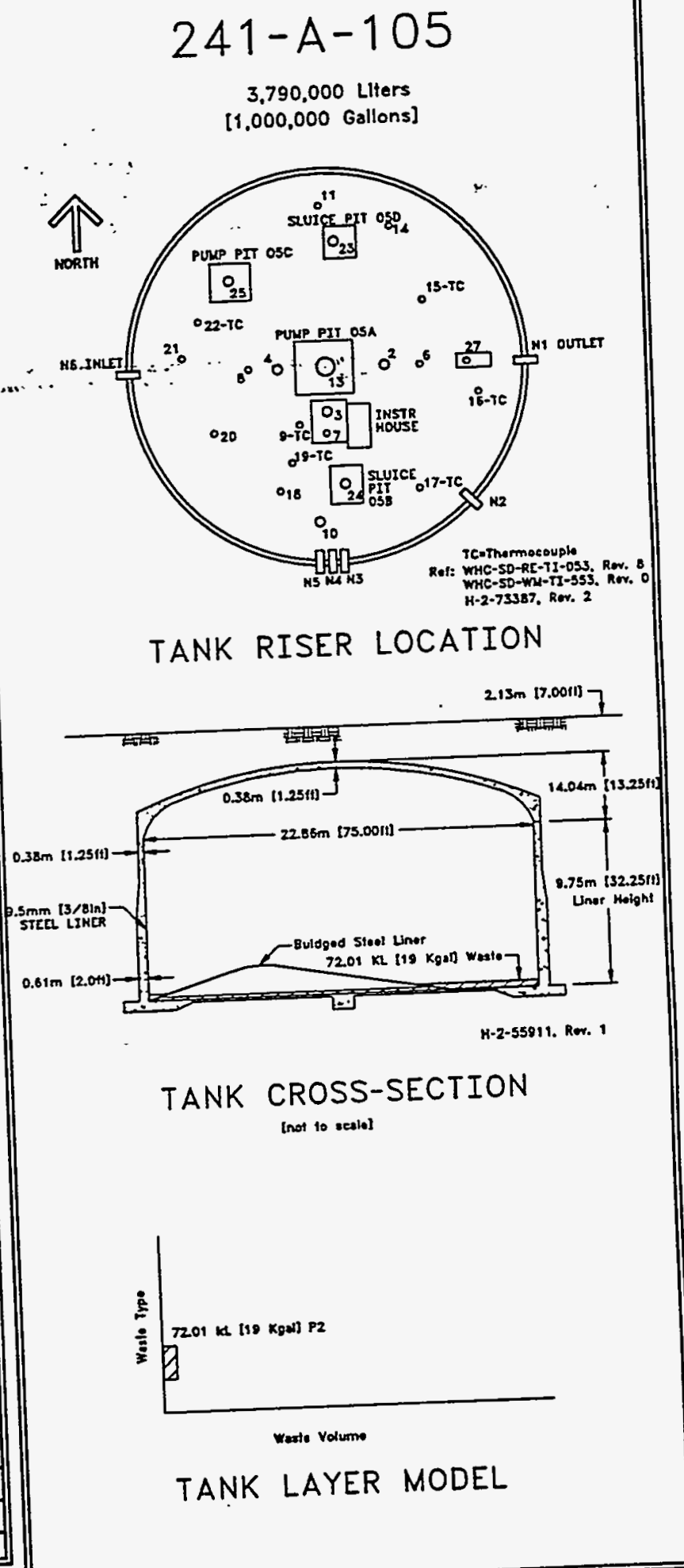

cencent

- Comporite inventory excludes supercatans, dank Layering Model (TLM).

Unkoowns in tank inventory are assigned by Tank Layering Moded (ILM). 


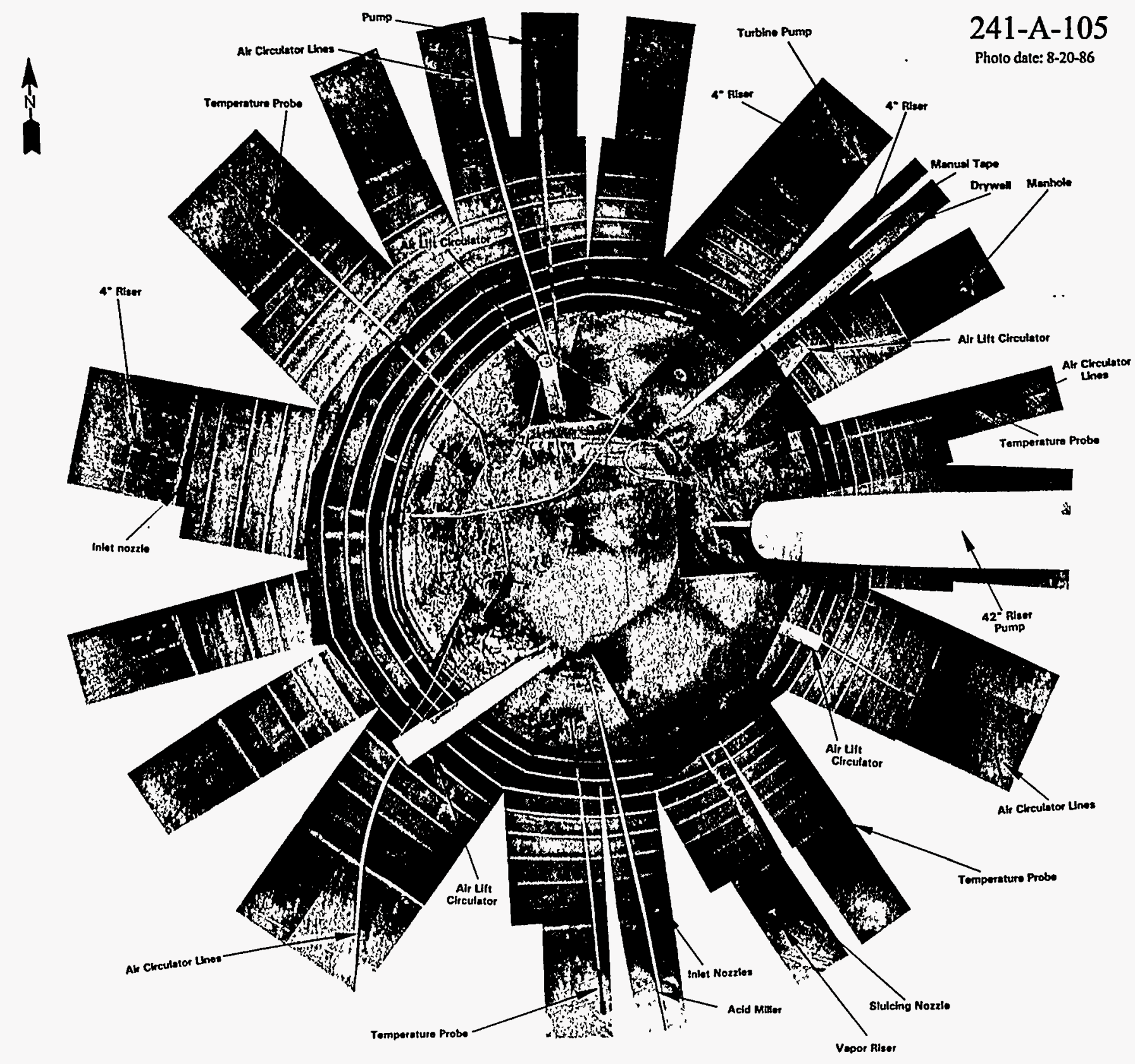


WHC-SD-WM-ER-349, Rev. 0

2.6 Tank 241-A-106

2.6.1 241-A-106 Tank History

2.6.1.1 Waste History Tank 241-A-106

Tank 241-A-106 received deentrained and condensate waste from the boiling waste tanks in the A Tank Farm. from the first quarter of 1957 and until the third quarter of 1960. $\because$ Presently, the tank waste is classified as concentrated phosphate. Tank 241-A-106 was declared inactive in August 1980. Interim stabilization was administratively completed in August 1982 and intrusion prevention was completed in December 1982. The tank is categorized as sound. (See sketch ES-TKS-E6 for, a. graphical representation of the Tank, 241-A-106 level history.)

2.6.1.2 Temperature History 241-A-106

The single thermocouple tree in Tank $241-\mathrm{A}-106$ has 18 thermocouples to record temperature data in riser 14 . A sum of the squares regression line fit for all thermocouples shows a slightly negative, near zero slope $\pm 25.86^{\circ} \mathrm{F}$ with an average $r$ square value of 0.14 . Abrupt high and low temperatures are observed between 1989 and 1991 for all thermocouples. From October 1976 to present, the median temperature is $104^{\circ} \mathrm{F}$ with a minimum of $50.2^{\circ} \mathrm{F}$ and a maximum of $246^{\circ} \mathrm{F}$. Refer to the supporting document for a more thorough review of the temperature data (Brevick 1994).

\subsubsection{Integrity of Tank 241-A-106}

Tank 241-A-106 is categorized as sound and is interim stabilized with intrusion prevention completed. The surface level in Tank 241-A-106 is monitored with a Food Instrument Corporation gauge through riser 6. For more information on surface levels see supporting documents (Brevick 1994).

Seven drywells are identified for 241-A-106. Data and graphical representations of the active drywell from January 1990 to the present can be found in the supporting document (Brevick 1994).

\subsubsection{Current Status of Tank 241-A-106}

Tank 241-A-106 entered service in 1957 and currently stores 125,000 gal of waste. The waste is comprised entirely of sludge with no pumpable liquid remaining. The tank is identified as a low-heat load tank with active ventilation. Tank 241-A-106 is equipped to receive waste cascaded from Tank 241-A-103 and -105 and is last in the cascade flow series. The following plan view and tank cross section depict the approximate waste level and riser configuration. Tank 241-A-106 has 21 tank dome risers and four are available for use: two 12-in. risers (nos.4, and 17), one 4-in. riser (no.7), and one 6-in. riser (no.20). 


\subsubsection{Inventory estimate $241-\mathrm{A}-106$}

The following tank layer volume approximation was derived from the Ios Alamos National Laboratories Waste Status and Transaction Record Summary (Agnew 1994). The estimated inventory of tank 241-A-106 is also presented.

2.6:2.2 In-Tank Photograph 241-A-106

$i$

The following photograph of Tank 241-A-106 shows a grey to yellow sludge surface with no visible supernatant. The surface level is about 4 ft deep.

2.6.3. Synopsis. Tank $241-A_{-1}=6 \ldots$

(To be completed.) 


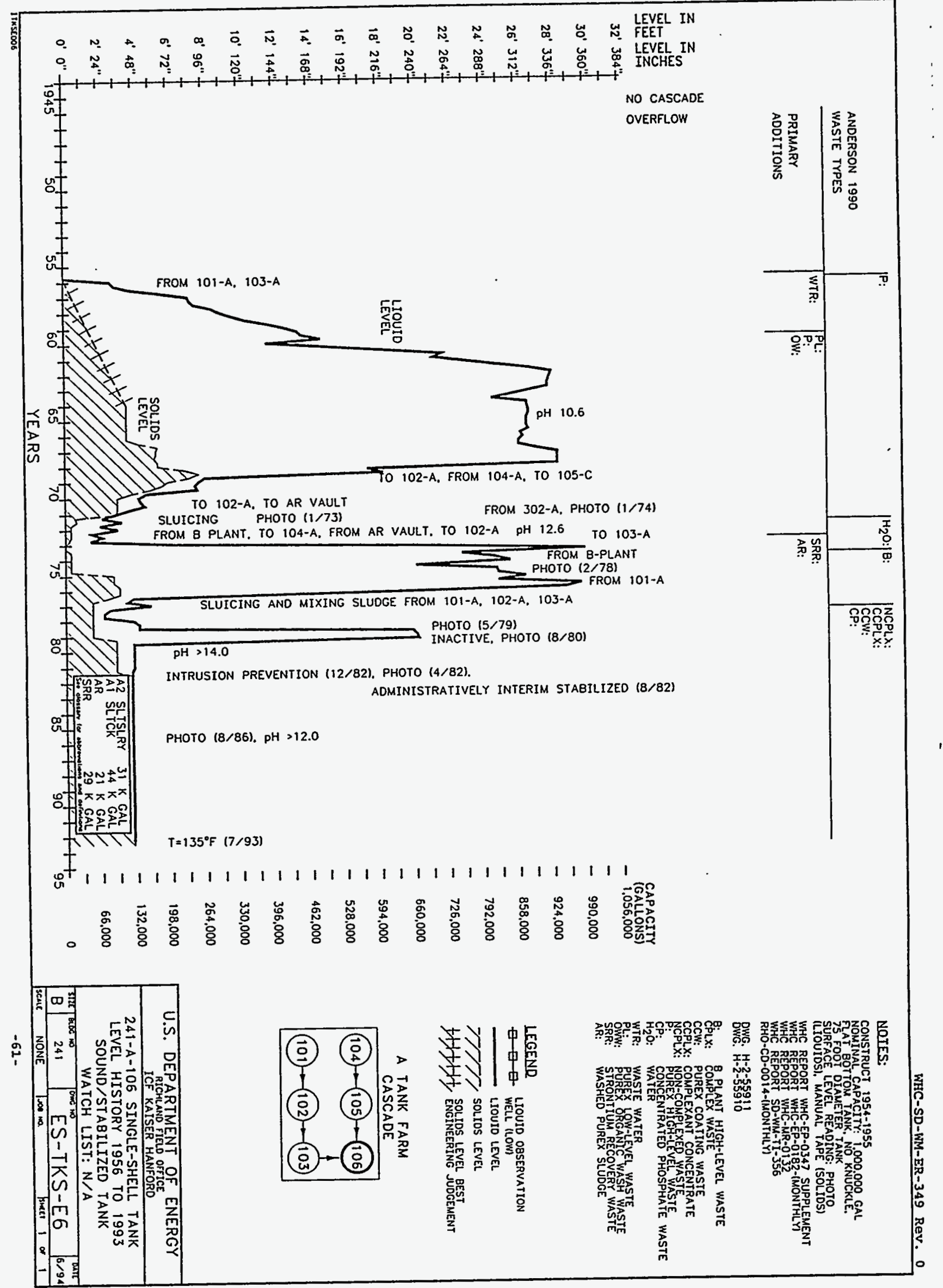


WHC-SD-WM-ER-349, Rev. 0

\begin{tabular}{|c|c|c|c|}
\hline \multicolumn{4}{|c|}{ Single-Shell Tank 241-A-106 } \\
\hline \multicolumn{4}{|c|}{ Solids Composite Inventory Estimate } \\
\hline \multicolumn{4}{|c|}{ 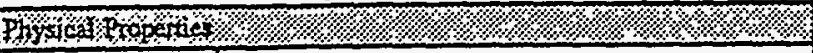 } \\
\hline Total Solid Waste & \multicolumn{3}{|c|}{$6.89 \mathrm{E}+05 \mathrm{~kg}(37 \mathrm{kgal})$} \\
\hline Heat load & \multicolumn{3}{|c|}{$10.12 \mathrm{~kW}(3.45 \mathrm{E}+0.4 \mathrm{BTU} / \mathrm{hr})$} \\
\hline Bulk Density & \multicolumn{3}{|c|}{$1.46(g / c)$} \\
\hline Void Fraction & \multicolumn{3}{|c|}{0.54} \\
\hline Waler wr\% & \multicolumn{3}{|c|}{32.56} \\
\hline TOC wr\% C (wet) & \multicolumn{3}{|c|}{1.14} \\
\hline \multicolumn{4}{|c|}{ 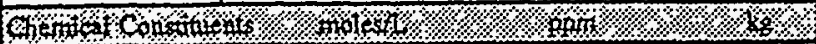 } \\
\hline $\mathrm{Na}^{+1}$ & 9.48 & $1.50 \mathrm{E}+05$ & $1.03 E+05$ \\
\hline $\mathrm{Al}^{* 3}$ & 0.48 & $8.92 \mathrm{E}+03$ & $6.15 E+03$ \\
\hline $\mathrm{Fe}^{+3}($ total $\mathrm{Fe})$ & 0.36 & $1.39 \mathrm{E}+04$ & $9.58 E+03$ \\
\hline $\mathrm{Cr}^{+3}$ & 3.84E-03 & $\therefore 1.37 \mathrm{E}+02$ & $\because 94.59$ \\
\hline $\mathrm{Bi}^{+3}$ & 0 & 0 & 0 \\
\hline $\mathrm{La}^{+3}$ & 0) & 0] & 0 \\
\hline $\mathrm{Ce}^{+3}$ & 0] & 0) & 0 \\
\hline $\mathrm{Zr}\left(\mathrm{as} \mathrm{ZrO}(\mathrm{OH})_{2}\right)$ & 0 & 0) & 0 \\
\hline $\mathrm{Pb}^{42}$ & 0 & 0 & 0 \\
\hline $\mathrm{Ni}^{+2}$ & 9.81E-03 & $3.95 \mathrm{E}+02$ & $2.72 \mathrm{E}+02$ \\
\hline$\widehat{S r^{42}}$ & 0 & 0 & 0 \\
\hline $\mathrm{Mn}^{+4}$ & 0 & 0 & 0 \\
\hline $\mathrm{Ca}^{42}$ & 0 & 0 & 0 \\
\hline $\mathrm{R}^{+1}$ & $6.20 \mathrm{E}-03$ & $1.67 \mathrm{E}+02$ & $1.15 \mathrm{E}+02$ \\
\hline $\mathrm{OH}^{-1}$ & 2.83 & $3.30 \mathrm{E}+04$ & $2.27 \mathrm{E}+04$ \\
\hline $\mathrm{NO}^{-\mathrm{I}}$ & 2.66 & 1.13E+05 & $7.79 E+04$ \\
\hline $\mathrm{NO}^{2.2}$ & 0.20 & $6.32 E+03$ & $4.35 \mathrm{E}+03$ \\
\hline $\mathrm{CO}^{2}{ }^{2}$ & 0.35 & $1.44 \mathrm{E}+04$ & $9.89 \mathrm{E}+03$ \\
\hline$\overline{\mathrm{PO} 4^{3}}$ & 0.24 & $1.56 \mathrm{E}+04$ & $1.07 \mathrm{E}+04$ \\
\hline $\mathrm{SO}^{\prime 2}$ & 1.46 & $9.63 E+04$ & $6.64 \mathrm{E}+04$ \\
\hline $\mathrm{Si}\left(\mathrm{as} \mathrm{SiO}_{3}{ }^{-2}\right)$ & 0.71 & $1.36 \mathrm{E}+04$ & $9.40 \mathrm{E}+03$ \\
\hline$F^{-1}$ & 0.31 & $4.10 \mathrm{E}+03$ & $2.82 \mathrm{E}+03$ \\
\hline $\mathrm{c}^{-1}$ & $1.21 \mathrm{E}-02$ & $2.94 \mathrm{E}+02$ & $2.02 E+02$ \\
\hline $\mathrm{C}_{6} \mathrm{H}_{8} \mathrm{O}_{7}{ }^{3}$ & $1.63 \mathrm{E}-02$ & $2.11 \mathrm{E}+03$ & $1.45 \mathrm{E}+03$ \\
\hline EDTA & $3.13 \mathrm{E}-02$ & $6.19 \mathrm{E}+03$ & $4.27 \mathrm{E}+03$ \\
\hline HEDTA $^{.3}$ & $6.26 \mathrm{E}-02$ & $1.18 \mathrm{E}+04$ & $8.12 \mathrm{E}+03$ \\
\hline $\mathrm{NTA}^{-3}$ & 0 & 0 & 0 \\
\hline glycolate & $8.96 \mathrm{E}-02$ & $4.62 \mathrm{E}+03$ & $3.18 \mathrm{E}+03$ \\
\hline acetate $^{-1}$ & $1.89 \mathrm{E}-02$ & $7.65 \mathrm{E}+02$ & $5.27 \mathrm{E}+02$ \\
\hline oxalate & 0 & 0 & 0 \\
\hline DBP & 0 & 요 & 0 \\
\hline $\mathrm{NPH}$ & 0 & 0 & 0 \\
\hline $\mathrm{CCl}_{1}$ & 0 & 0 & 0 \\
\hline hexone & 0 & 0 & 0 \\
\hline $\mathrm{Fe}(\mathrm{CN})_{6}{ }^{4}$ & 0 & $0(\mathrm{~g}-\mathrm{mol})$ & \\
\hline \multicolumn{4}{|c|}{ 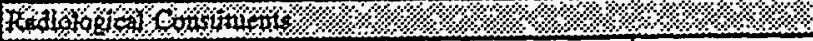 } \\
\hline Pu & & $1.39(\mu \mathrm{Ci} / \mathrm{g})$ & $15.98(\mathrm{~kg})$ \\
\hline $\mathbf{U}$ & $2.21 \mathrm{E}-02(M)$ & $3.60 \mathrm{E}+03(\mu \mathrm{g} / \mathrm{g})$ & $2.48 \mathrm{E}+03(\mathrm{~kg})$ \\
\hline$\overline{C s}$ & $0.30(\mathrm{Ci} / \mathrm{L})$ & $2.07 \mathrm{E}+02(\mu \mathrm{C} i / g)$ & $1.42 \mathrm{E}+05(\mathrm{Ci})$ \\
\hline$\underline{S}$ & $2.96(\mathrm{Ci} / \mathrm{L})$ & $2.03 \mathrm{E}+03(\mu \mathrm{Ci} / \mathrm{g})$ & $1.40 \mathrm{E}+06(\mathrm{Ci})$ \\
\hline
\end{tabular}

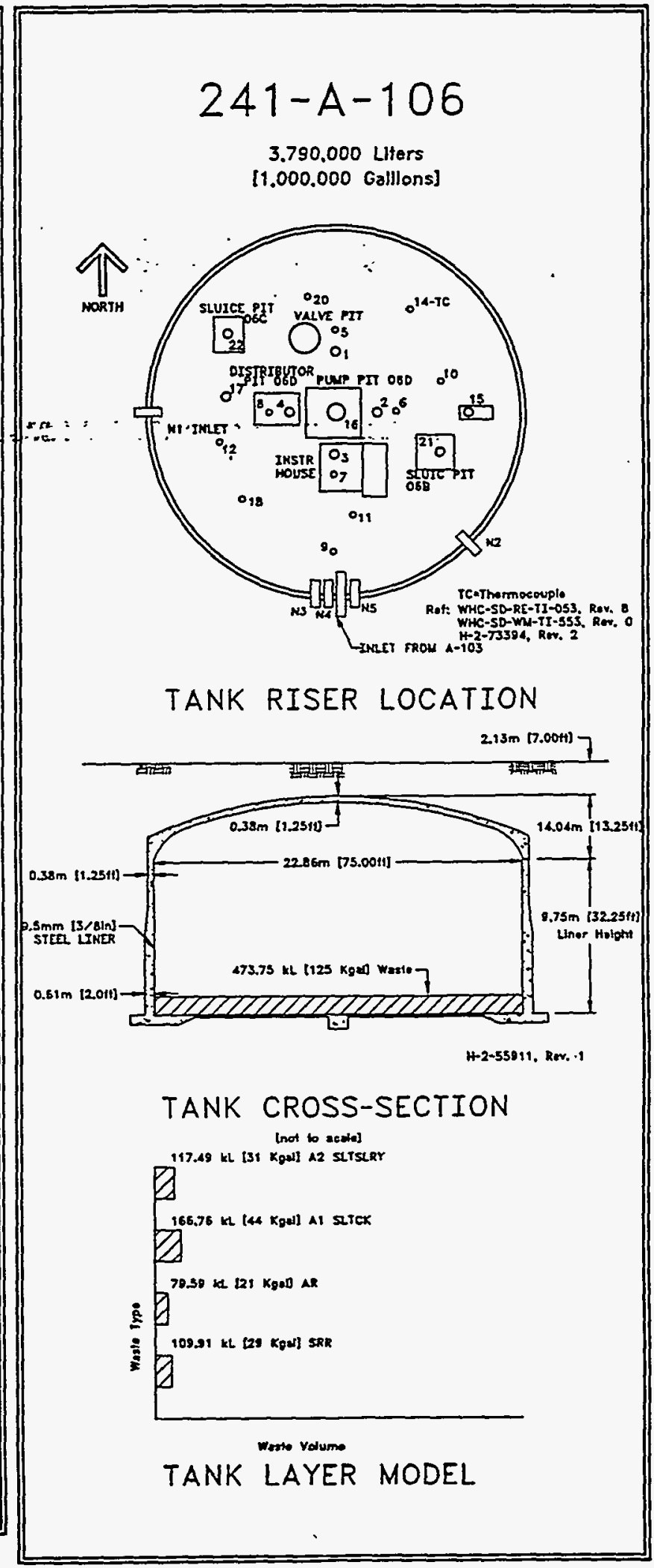

- Composite inventory exchudes supernatant, diatomacoous earth, and cenct
Unknowns in tank inventory are assigned by Tank Layering Model (TLM). 
WHC-SD-WM-ER-349 Rev. 0

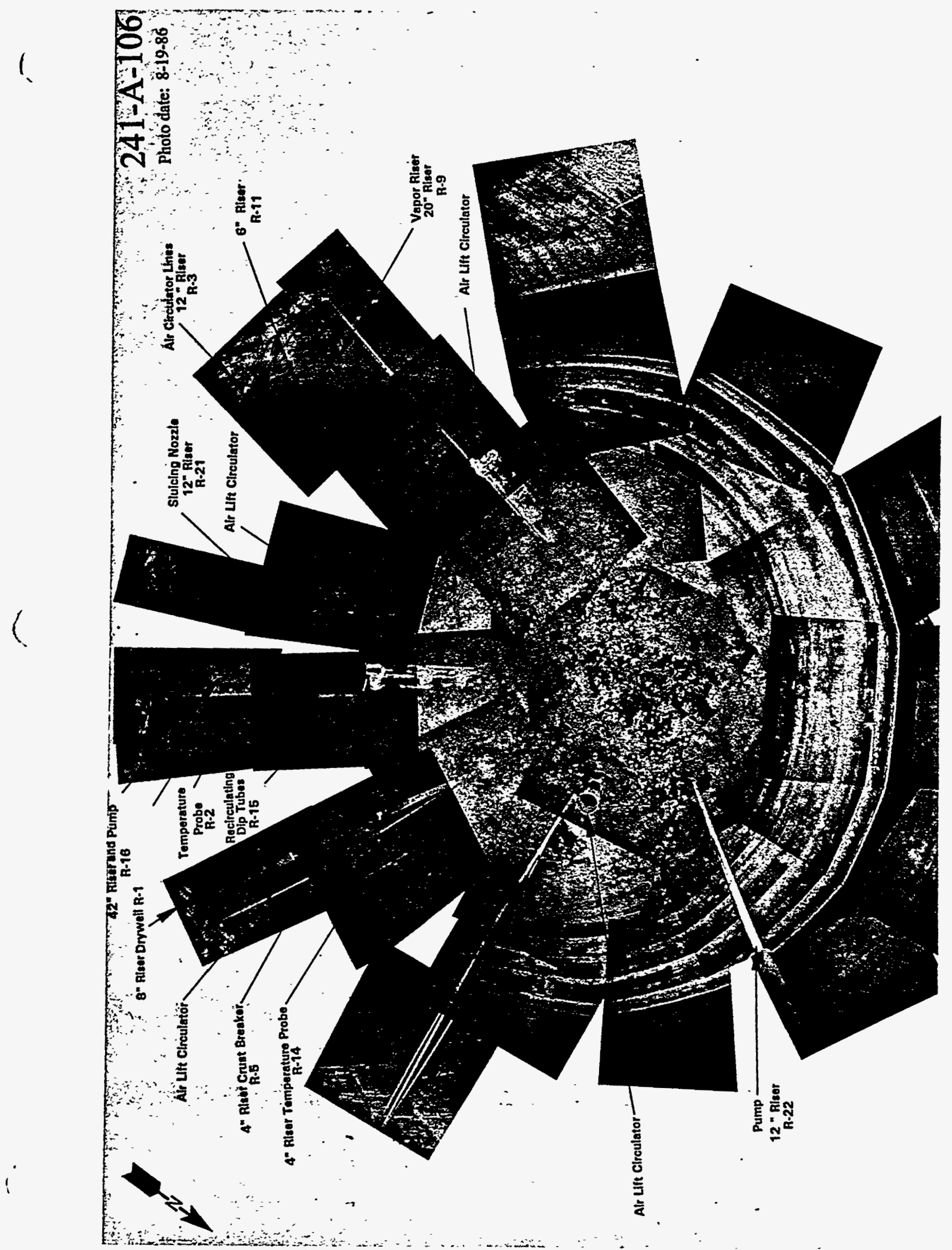




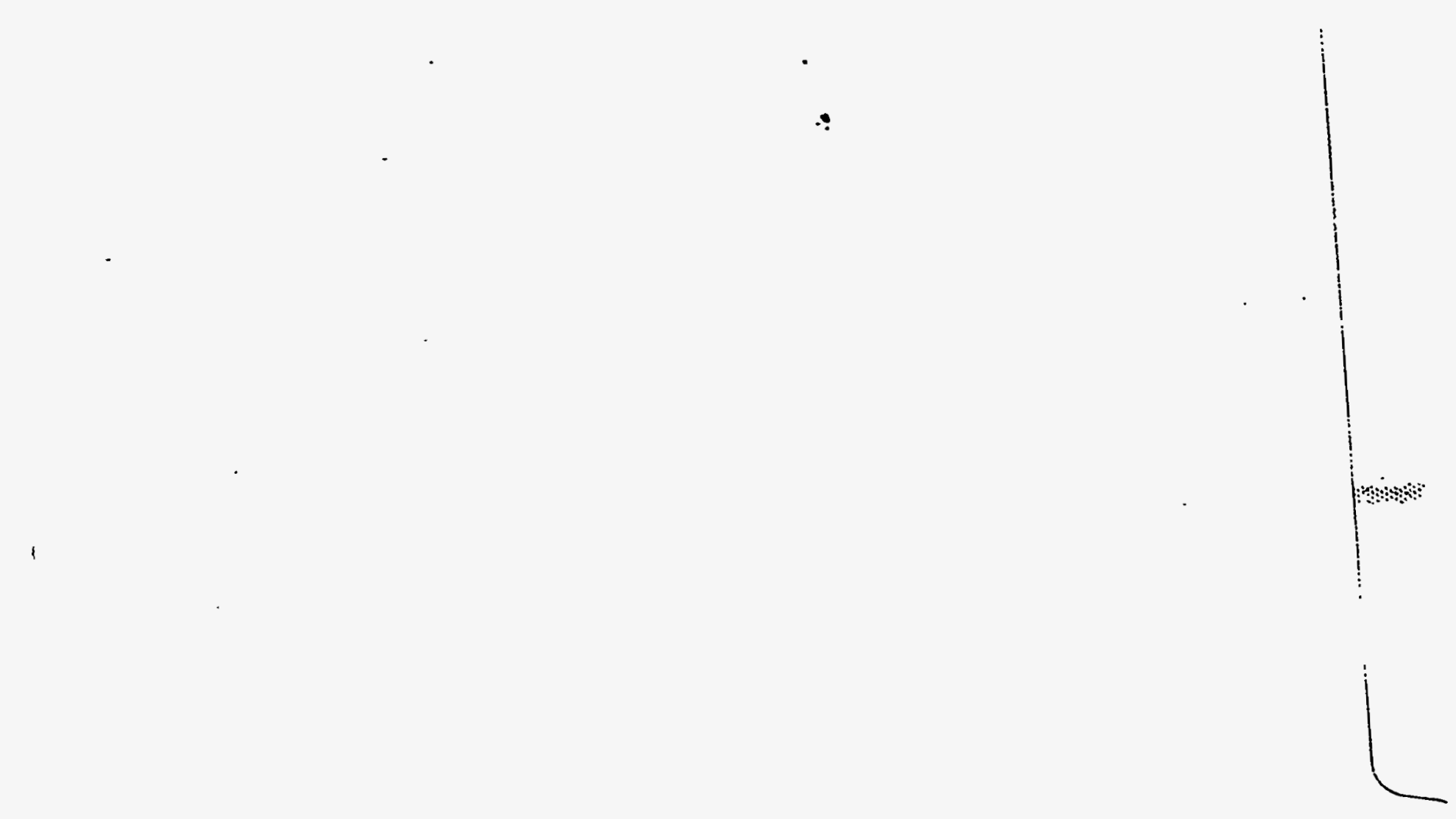




\subsection{AX Tank Farm}

\subsubsection{AX Tank Farm History}

The AX Tank Farm is located east of Buffalo Avenue, west of Canton Avenue, and north of the A Tank Farm. The AX Tank Farm contains four 100 series; $1,000,000$ gal; 75-ft diameter single-shell tanks. Except for a grid of drain slots below the SST liner used for leak detection and no cascade overflow lines between tanks, the AX tanks. were designed similar to the flat bottom tanks in the $A$.Tank.Farm. The SSTs were designed for PUREX and $B$ Plant aging waste, which is boiling or self concentrating with a maximum fluid temperature of $250^{\circ} \mathrm{F}$ and a 5-10 year boiling period. The AX Tank Farm is the fifth and final generation of SSTs to be built on the Hanford.site.

The color 1993 aerial photograph of the AX Tank Farm shows 100 series tank orientation, a diversion station, valve pits, a vehicle crossing pad, and a north arrow. The valve pit and diversion box marked with 241-AY are used for the 24I-AY double-shell tank farm located west of the 241-AX Tank Farm. Finaliy, no cascade overflow lines are shown on the aerial photograph because the tanks were not equipped with cascade overflow lines. 


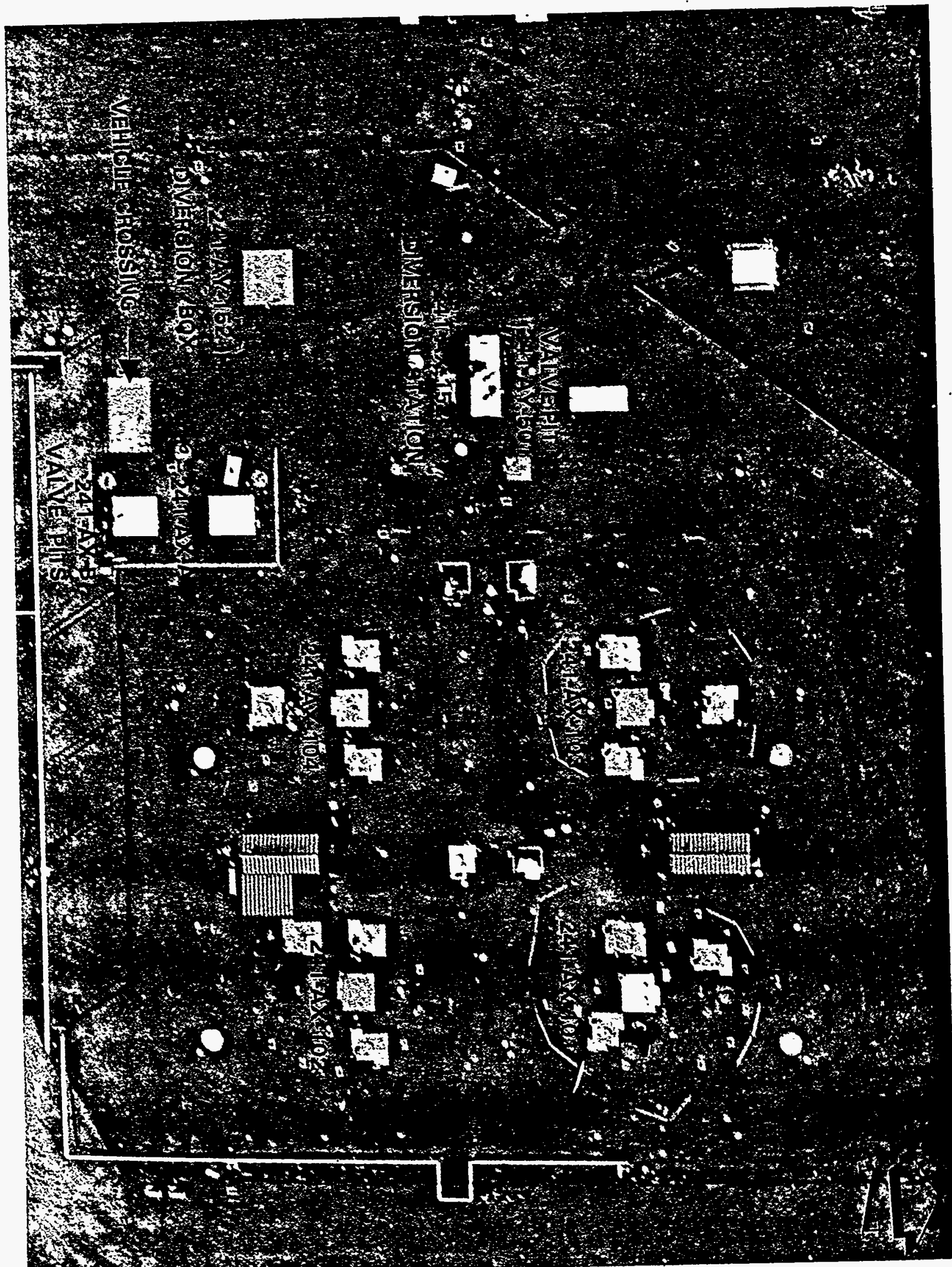




\subsubsection{AX Tank Farm Waste History}

The AX Tank Farm was designed for storage of self-concentrating waste. PUREX organic and high-level waste was stored in Tank 241-AX103, while B Plant high-level waste was stored in Tanks 241-AX-101 and 102. Tank sluicing was used to reduce the amount of strontium in the sludge and the amount of cesium in the liquid. These two radioactive isotopes were found to be the main heat generating sources in the $A$ and AX tanks. The A and AX Tank Farms were sluiced in the early 1970s. The sluiced waste was sent to the $A R$ sludge processing vault. Tanks 241-AX101, -102 , and -103 were sluiced to a small heel and released to be saltcake waste receivers. After the AX tanks were sluiced in the 1970s, Tank 241-AX-104 was found to be leaking and it was removed from service.

$3.0: 1: 2 \cdots$ AX Tark-Farm-Temperature-fistory $\cdots \cdots \cdots$

Each of the four tanks in the AX Tank Farm contains one thermocouple tree with a minimum of 18 thermocouple probes. Tank 241AX-102 has 18 probes, 8 of which have temperature readings recorded. Tanks 241-AX-101 and -103 are on the Hydrogen Watch Iist and have $a$ weekly temperature reading requirement. Tanks 241-AX-102 and -104 have a semiannual reading requirement.

\subsubsection{AX Tank Farm Integrity}

The four $1 \mathrm{Mgal}$ tanks in the AX Tank Farm are out of service. As of JuIy 1993, Tanks 241-AX-101 and 103 are categorized as sound and Tanks 241-AX-102 and 104 are assumed leakers.

The AX Tank Farm has 31 leak detection wells that were drilled from 1974 to 1978. The AX Tank Farm layout on the following page includes information on the peak drywell, tank integrity, and tank isolation. The drywell information is based on summarized data prior to 1987 and data collected from January 1990 to the present.

\subsubsection{Current Status of AX Tank Farm}

Two tanks in the AX Tank Farm are identified on the Hydrogen Watch Iist: Tanks 241-AX-101 and -103 were officially added in January 1991 and are declared unreviewed safety questions because of the potential consequence of a radiological release resulting from a flammable gas burn.

The total volume of waste in the AX Tank Farm is 906,000 gal: 3,000 gal of supernatant; 233,000 gal saltslurry; 633,000 gal of saltcake; 7,000 gal of unknown solids; and 40,000 gal of sludge. 


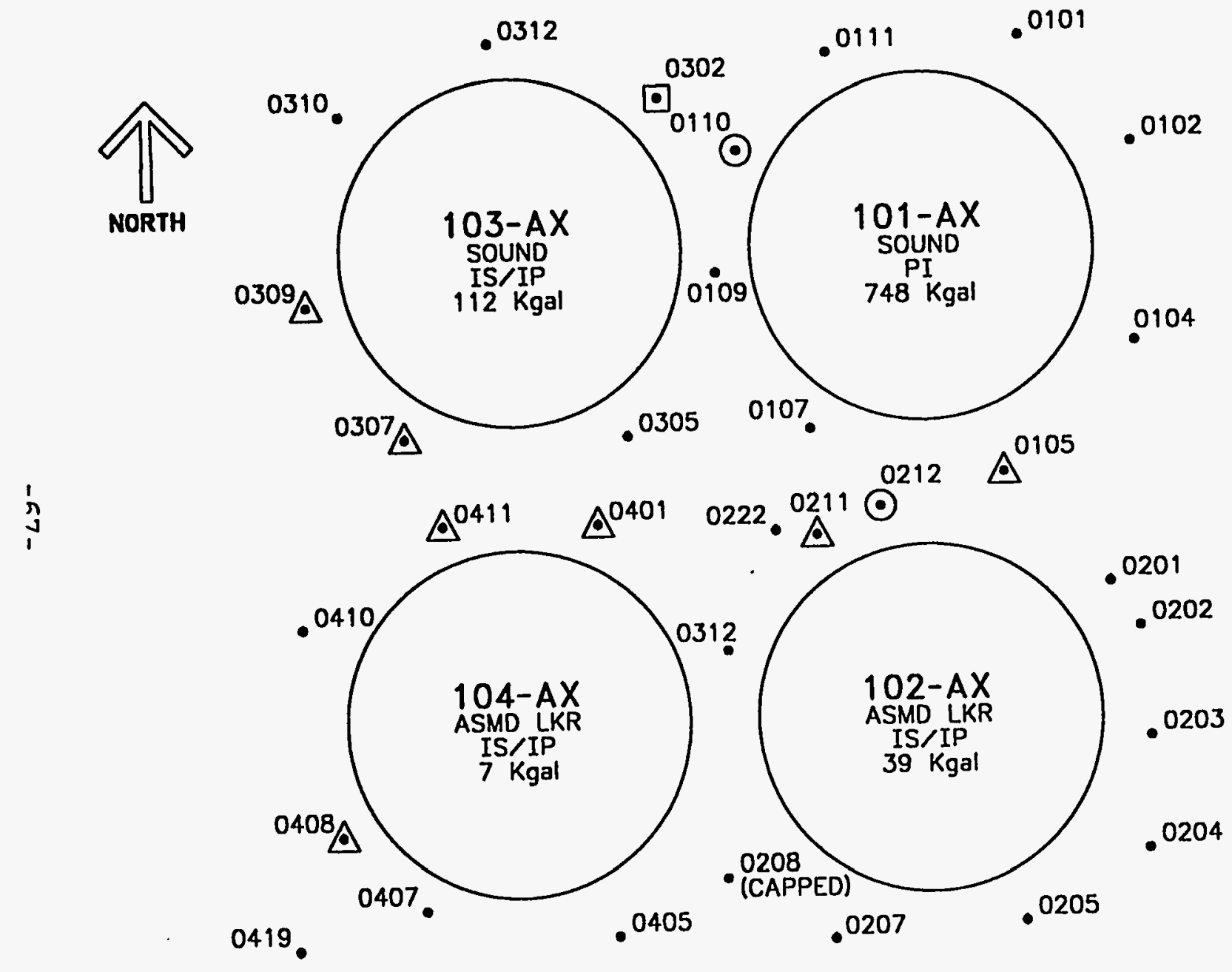

LEGEND
SOUND - CATEGORIZATION
ASMD LKR - CATEGORIZATION
PI - PARTIAL ISOLATED
IS - INTERIM ISLATED
IP INTRUSION PREVENTION
XX KGaI - TOTAL WASTE
- CASCADE. FLOW
- DRY WELL LOCATION
$\triangle$ - PAST ACTIVITY
$\odot-$ ACTIVITY < $200 \mathrm{c} / \mathrm{S}$
$\square-$ ACTIVITY > $200 \mathrm{c} / \mathrm{S}$

241-AX FARM 
3.1 Tank 241-AX-101

3.1.1 241-AX-101 Tank History

3.1.1.1 Waste History Tank 241-AX-101

Activity in Tank 241-AX-101 began when it was filled with PUREX waste in the first quarter of 1965. Activity ceased when the tank was deactivated on November 3, 1980. Partial isolation was completed in December 1982, but the tank is awaiting interim stabilization. The tank integrity is classified as sound: (See sketch ES-TKS-E7 for a graphical representation of the Tank 241-AX-101 level history.)

3.1.1.2 ... Temperature. History. 241-AX-1.01 .......

Tank 241-AX-101 has 19 thermocouple probes on a single thermocouple tree in riser $9 B$. Other risers previously used to recording temperature data were; 7A, 7B, 7C, 7D, 11A, 11B, 11C, 13A, 13B, and 13C. The fixst available, high or only waste temperature reading in May 1969 was approximately $240^{\circ} \mathrm{F}$. A sum of the squares regression line fit for thermocouples 1 through 10 starting in 1976 shows an overall zero slope $\pm 9.6^{\circ} \mathrm{F}$ with an average $I$ square value of 0.06 . However, a sum of the squares regression line fit for thermocouples 11 through 18 shows a slightly negative near zero slope $\pm 12.2^{\circ} \mathrm{F}$ with an average $r$ square value of 0.22 . An annual temperature undulation is evident for thermocouples 11 through 18 starting in January 1991. From October 1976 to present, the median temperature was $129^{\circ} \mathrm{F}$ with a minimum of $65^{\circ} \mathrm{F}$ and a maximum of $168^{\circ} \mathrm{F}$. Refer to the supporting document for a more thorough review of the temperature data (Brevick 1994).

\subsubsection{Integrity of Tank 241-AX-101}

Tank 241-AX-101 is categorized as sound and is partially isolated. The surface level in Tank $241-A X-101$ is monitored with a Food Instrument Corporation gauge through riser $8 \mathrm{C}$. A photographic evaluation is used to determine liquid waste volume and a Food Instrument Corporation gauge is used to determine solid waste volume. For more information on surface levels see supporting documents (Brevick 1994).

Eight drywells are identified for 241-AX-101. Graphical representations of the active drywells from January 1990 to the present can be found in the supporting document (Brevick 1994).

\subsubsection{Current Status of Tank 241-AX-101}

Tank 241-AX-101 entered service in 1965 and currently stores 748,000 gal of waste. The waste is comprised of 223,000 gal of saltslurry; 512,000 gal of saltcake; 13,000 gal of sludge; and no supernatant with 298,000 gal of pumpable interstitial liquid remaining. The tank has been on the Hydrogen watch List since January 1991 and is passively ventilated. The tank is categorized as sound with partial interim isolation completed. Tanks in the AX Tank Farm do not cascade. The following plan view and tank cross section depict the approximate waste level and riser 
configuration. Tank 241-AX-101 has a total of 59 risers. Ten risers are available for use: one 12-in. riser (no.3A), one 4-in. riser (no.6), and eight 6-in. risers (nos. 8A, 8B, 8D, 8E, 8F, 8G, 9C, and 9F).

\subsubsection{Inventory estimate 241-AX-101}

- The following tank layer volume approximation was derived from the Los Alamos National Laboratories Waste Status and Transaction Record

* Summary (Agnew 1994). The estimated inventory of Tank 241-AX-101 is also presented.

\subsubsection{In-Tank Photograph 241-AX-101}

The - Tank. 241-AX-1.01...photo : showsma + yellow-grey. to. grey saltcake surface with no liquid showing. The tank" contains approximately 750,000 gal of waste which converts to approximately $22.5 \mathrm{ft}$ deep. The heating coil in the top right corner was used to keep the waste from cooling too quickly, thus preventing the thermal gradient limitations on the steel and concrete surrounding the tank from being exceeded. The typical airlift circulator shown in the bottom right represents the other unlabeled circulators in the photo.

\subsubsection{Synopsis Tank 241-AX-101}

(To be completed.) 
WHC-SD-WM-ER-349, Rov, $O$

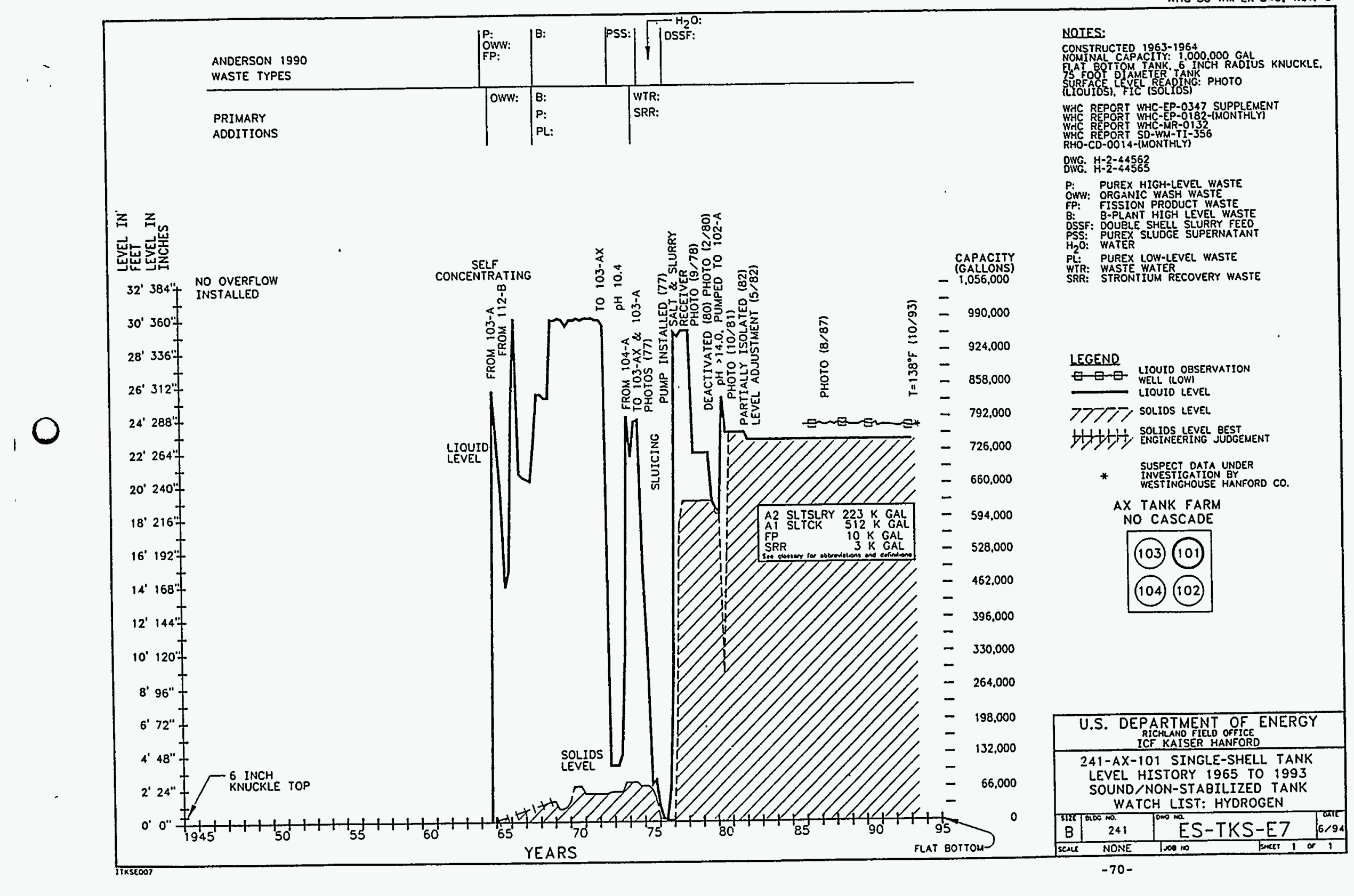




\begin{tabular}{|c|c|c|c|}
\hline \multicolumn{4}{|c|}{ Single-Shell Tank 241-AX-101 } \\
\hline \multicolumn{4}{|c|}{ Solids Composite Inventory Estimate } \\
\hline 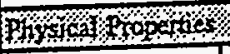 & 8. & $\% \% \% \%$ & \\
\hline Total Solid Waste & \multicolumn{3}{|c|}{$4.42 \mathrm{E}+06 \mathrm{~kg}(748 \mathrm{kgal})$} \\
\hline Heat load & \multicolumn{3}{|c|}{$9.42 \mathrm{~kW} \quad(3.21 \mathrm{E}+04 \mathrm{BTU} / \mathrm{hr})$} \\
\hline Bulk Density & \multicolumn{3}{|c|}{$1.56(g / \propto)$} \\
\hline Void Fraction & \multicolumn{3}{|c|}{0.27} \\
\hline Water ort\% & \multicolumn{3}{|c|}{9.16} \\
\hline TOC wt\% C (wet) & \multicolumn{3}{|c|}{0.18} \\
\hline \multicolumn{4}{|c|}{ 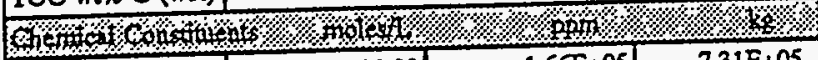 } \\
\hline $\mathrm{Na}^{41}$ & 11.23 & $1.66 \mathrm{E}+05$ & $7.31 \mathrm{E}+05$ \\
\hline $\mathrm{Al}^{+3}$ & 0.60 & $1.03 \mathrm{E}+04$ & $4.56 \mathrm{E}+04$ \\
\hline $\mathrm{Fe}^{43}($ total Fe) & $\begin{array}{r}4.35 \mathrm{E}-02 \\
\end{array}$ & $1.56 \mathrm{E}+03$ & $6.88 \mathrm{E}+03$ \\
\hline$C^{t^{3} \ldots \ldots \ldots \ldots}$ & $\because \cdot 7.48 \mathrm{E}-03$ & $\therefore \mathrm{arn}, \mathrm{i}-249 \mathrm{E}+02$. & $\therefore \triangle A 11: 10 \mathrm{E}+0 \%$ \\
\hline $\mathrm{Bi}^{+3}$ & \begin{tabular}{r|r}
0 \\
\end{tabular} & 0 & $\begin{array}{r}0 \\
\end{array}$ \\
\hline $\mathrm{La}^{43}$ & of & 요 & 0 \\
\hline $\mathrm{Ce}^{43}$ & 요 & 0 & 0 \\
\hline $\mathrm{Zr}$ (as $\left.\mathrm{ZrO}(\mathrm{OH})_{2}\right)$ & 0) & 0 & 0 \\
\hline $\mathrm{Pb}^{+2}$ & 0 & 0 & 0 \\
\hline $\mathrm{Ni}^{+2}$ & $1.91 \mathrm{E}-02$ & $7.18 \mathrm{E}+02$ & $3.17 \mathrm{E}+03$ \\
\hline $\mathrm{Sr}^{+2}$ & of & 0 & 0 \\
\hline $\mathrm{Mn}^{-4}$ & of & of & 0 \\
\hline $\mathrm{Ca}^{+2}$ & 0 & of & .0 \\
\hline $\mathrm{R}^{+1}$ & $7.71 \mathrm{E}-03$ & $1.93 \mathrm{E}+02$ & $8.53 E+02$ \\
\hline $\mathrm{OH}^{\cdot 1}$ & 2.30 & $2.51 E+04$ & $1.11 \mathrm{E}+05$ \\
\hline $\mathrm{NO}^{-1}$ & 3.05 & $1.21 \mathrm{E}+05$ & $5.35 \mathrm{E}+05$ \\
\hline $\mathrm{NO}^{-1}$ & 0.25 & $7.31 E+03$ & $3.23 \mathrm{E}+04$ \\
\hline $\mathrm{CO}^{-2}$ & 0.35 & $1.36 \mathrm{E}+04$ & $6.02 \mathrm{E}+04$ \\
\hline $\mathrm{PO}^{-3}$ & 0.40 & $2.45 \mathrm{E}+04$ & $1.08 \mathrm{E}+05$ \\
\hline $\mathrm{SO}^{-2}$ & 2.66 & $1.64 \mathrm{E}+05$ & $7.24 \mathrm{E}+05$ \\
\hline $\mathrm{Si}\left(\mathrm{as} \mathrm{SiO}_{3}^{-2}\right)$ & $3.80 \mathrm{E}-02$ & $6.84 \mathrm{E}+02$ & $3.02 \mathrm{E}+03$ \\
\hline $\mathrm{F}^{-1}$ & 0.39 & $4.74 \mathrm{E}+03$ & $2.09 \mathrm{E}+04$ \\
\hline$a^{-1}$ & $1.50 \mathrm{E}-02$ & $3.40 \mathrm{E}+02$ & $1.50 \mathrm{E}+03$ \\
\hline $\mathrm{C}_{6} \mathrm{H}_{3} \mathrm{O}_{7} \cdot 3$ & 2.02E-02 & $2.45 \mathrm{E}+03$ & $1.08 \mathrm{E}+04$ \\
\hline EDTA $^{-1}$ & 5.41E-04 & 99.94 & $4.41 E+02$ \\
\hline HEDTA ${ }^{-3}$ & 1.11E-03 & $1.94 \mathrm{E}+02$ & $8.58 \mathrm{E}+02$ \\
\hline NTA $^{-3}$ & 0 & 0 & 0 \\
\hline Blycolare & 3.47E-02 & $1.67 \mathrm{E}+03$ & $7.37 \mathrm{E}+03$ \\
\hline acetate $^{-1}$ & $2.34 \mathrm{E}-02$ & $8.86 \mathrm{E}+02$ & $3.91 E+03$ \\
\hline oxalate ${ }^{-2}$ & 0 & 0 & 0 \\
\hline DBP & 0 & 0 & 0 \\
\hline NPH & of & 0 & 0 \\
\hline $\mathrm{CCL}_{4}$ & of & of & 0 \\
\hline hezone & of & 0 & 0 \\
\hline $\mathrm{Fe}(\mathrm{CN})_{6}{ }^{4}$ & 0 & $0(\mathrm{~g}-\mathrm{mol})$ & \\
\hline \multicolumn{4}{|c|}{ 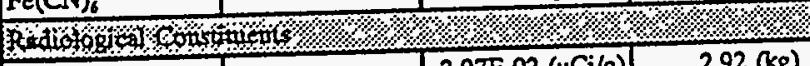 } \\
\hline $\mathrm{Pu}$ & & $3.97 \mathrm{E}-02(\mathrm{uCi} / \mathrm{g})$ & $2.92(\mathrm{~kg})$ \\
\hline $\mathrm{U}$ & $2.90 \mathrm{E}-02(\mathrm{M})$ & $4.43 \mathrm{E}+03(\mu \mathrm{g} / \mathrm{g})$ & $1.96 \mathrm{E}+04(\mathrm{~kg})$ \\
\hline Cs & $0.24(\mathrm{Ci} / \mathrm{L})$ & $1.56 \mathrm{E}+02(\mu \mathrm{Ci} / \mathrm{B})$ & $6.87 \mathrm{E}+05(\mathrm{Ci})$ \\
\hline Sr & $0.32(\mathrm{C} / \mathrm{L}) \mathrm{I}$ & $2.08 \mathrm{E}+02(\mu \mathrm{Ci} / \mathrm{g})$ & $9.19 \mathrm{E}+05(\mathrm{C})$ \\
\hline
\end{tabular}

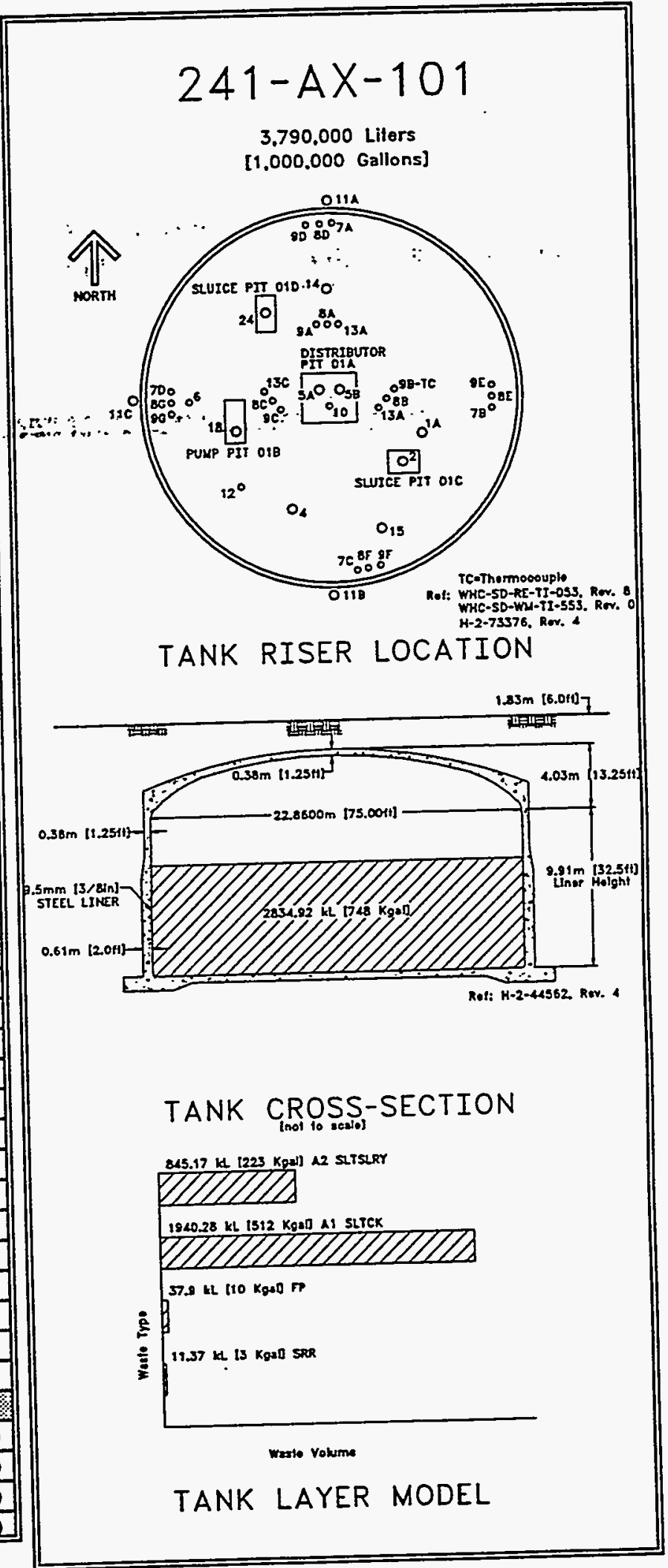

- Conposite inventory exchudes superratant, dialomacoous earth, and cemen

Unkoowns in lank inventory are assigned by Tank Layering Model (TLM). 


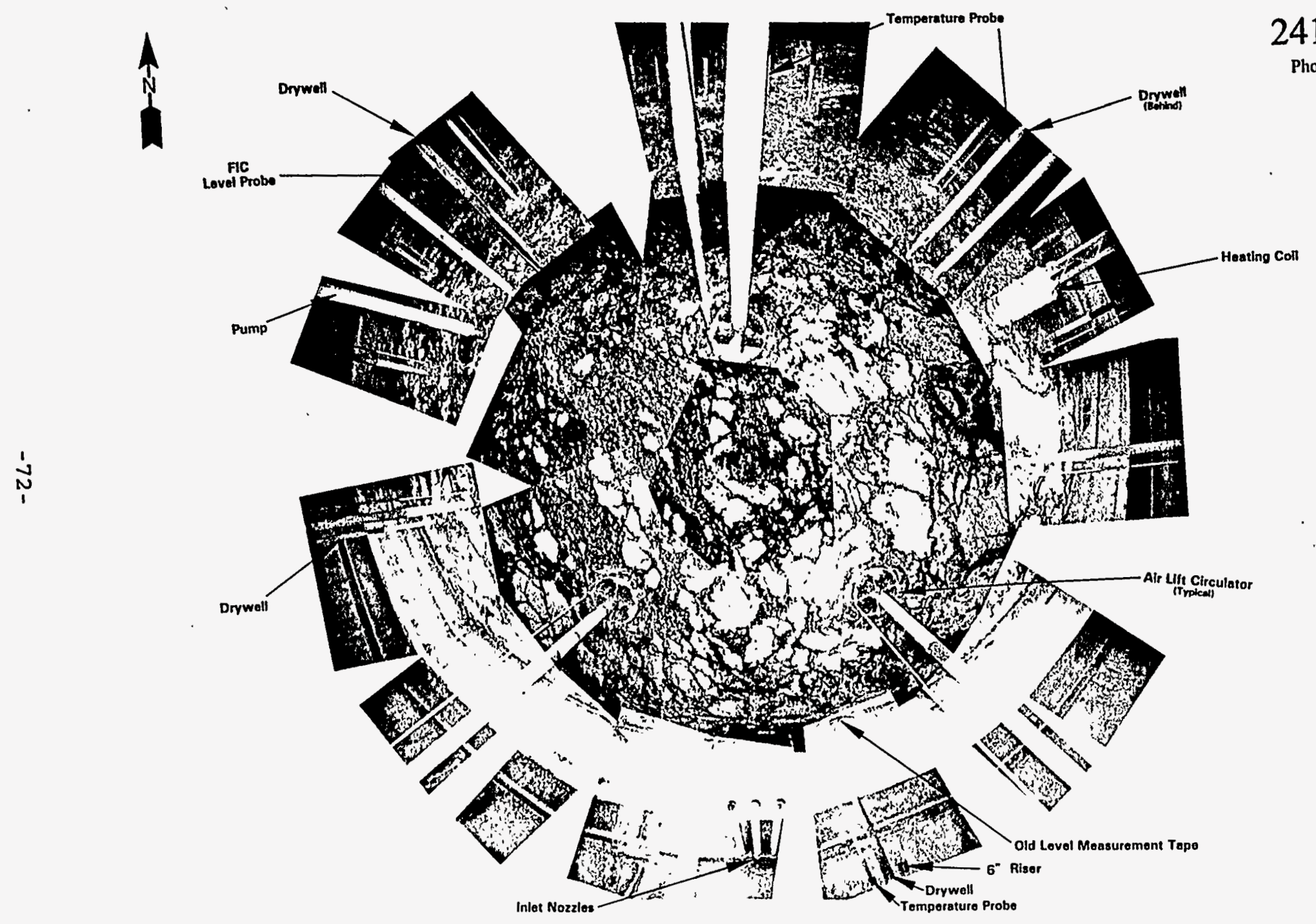

241-AX-101

Photo date: 8-18-87 
WHC-SD-WM-ER-349, Rev. 0

\subsection{Tank 241-AX-102}

\subsubsection{1-AX-102 Tank History}

\subsubsection{Waste History Tank 241-AX-102}

Tank 241-AX-102 had a water heel left over from construction for the last two quarters. of 1965 and the first two quarters of 1966 . The tank then received.PUREX high-level. waste and organic wash waste in the third quarter of 1966 which continued until the fourth quarter of 1968.

The tank was declared inactive in 1980 and intrusion prevention was completed in 1982. A level adjustment was made in the fourth quarter of 1983. In 1988, the tank was declared an assumed leaker. (See Sketch ES-TKS-E8 "foI"a'graphical- representation" of the Tank 241-AX-102 level history.)

\subsubsection{Temperature History 241-AX-102}

The single thermocouple tree in Tank 241-AX-102 has 18 thermocouple probes to record temperature data in riser $9 \mathrm{C}$. Other risers previously used for temperature readings were $7 \mathrm{~A}, 7 \mathrm{~B}, 7 \mathrm{C}, 7 \mathrm{D}, 11 \mathrm{~A}, 1 \mathrm{~B}, 1 \mathrm{C}, 13 \mathrm{~A}$, 13B, and 13C. The first available high or only waste temperature reading in July 1969 was approximately $200^{\circ} \mathrm{F}$. A sum of the squares regression line fit starting in 1990 is applicable only to thermocouple 5 which shows an overall zero slope \pm 10.4 with an $I$ square value of 0.06. From January 1990 to present, the high temperature was $131^{\circ} \mathrm{F}$ and the low was $73^{\circ} \mathrm{F}$ with a median temperature of $91^{\circ} \mathrm{F}$. By September 1993, thermocouple 5 was designated as the only working probe and the control box for the thermocouple tree was determined to be contaminated. Refer to the supporting document for a more thorough review of the temperature data (Brevick 1994).

\subsubsection{Integrity of Tank 241-AX-102}

Tank 241-AX-102 is categorized as an assumed leaker and is interim stabilized with intrusion prevention completed. The surface level in Tank 241-AX-102 is monitored quarterly with a manual tape. The manual tape is used to determine liquid waste volume while a sludge measurement device is used for solid waste volume. A figure that graphically represents the surface level measurements from January 1991 to the present can be found in the supporting documents (Brevick 1994). The surface level plot for the past year has a decreasing trend. The surface level peaking at 15-in. during the fourth quarter of 1992 and steadily decreasing to 9.5-in. during the fourth quarter of 1993. Two inaccurate data points that have been superseded by apparent "reruns" are also included on the plot. In May 1989, Tank 241-AX-102 had a decrease criteria limit that was exceeded and an unusual occurrence report was issued. The decrease was attributed to settling solids in the tank after it was pumped.

Ten drywells are identified for tank 241-AX-102. Data and graphical representations of the active drywells from January 1990 to 
WHC-SD-WM-ER-349, Rev. 0

the present can be found in the supporting document (Brevick 1994).

3.2.2 Current Status of Tank 241-AX-102

Tank 241-AX-102 entered service in 1966 and currently stores 39,000 gal of waste. The waste is comprised of 3,000 gal of supernatant; $7,000 \mathrm{gal}$ of unknown waste; $23,000 \mathrm{gal}$ of saltcake; and $6,000 \mathrm{gal}$ of sludge with 3,000 gal of pumpable liquid remaining. The tank is

- identified as a low-heat load tank, is passively ventilated, and is categorized as an assumed leaker with interim stabilization and intrusion prevention completed. Tanks in the AX Tank Farm do not cascade. The following plan view and tank cross section depict the approximate waste level and riser configuration. Tank 241-AX-102 has 58 risers. and ten risers are. available for use: one 16-in. riser (no.3A),

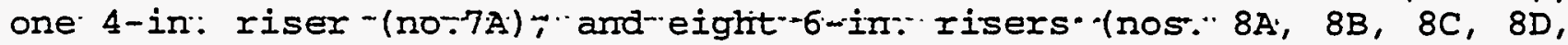
$8 \mathrm{E}, 8 \mathrm{~F}, 8 \mathrm{G}$, and $9 \mathrm{~F})$.

\subsubsection{Inventory estimate 241-AX-102}

The following tank layer volume approximation was derived from the Los Alamos National Laboratories Waste Status and Transaction Record Summary (Agnew 1994). The estimated inventory of Tank 241-AX-102 is also presented.

\subsubsection{In-Tank Photograph 241-AX-102}

The Tank 241-AX-102 photo shows a reddish-brown to black surface with very small amounts of supernatant, saltcake, and sludge. The tank contains about 40,000 gal of waste which converts to approximately $11 / 2 \mathrm{ft}$ deep. The typical airlift circulator shown in the bottom right represents the other unlabeled circulators in the photo.

3.2.3 Synopsis Tank 241-AX-102

(To be completed.) 
C

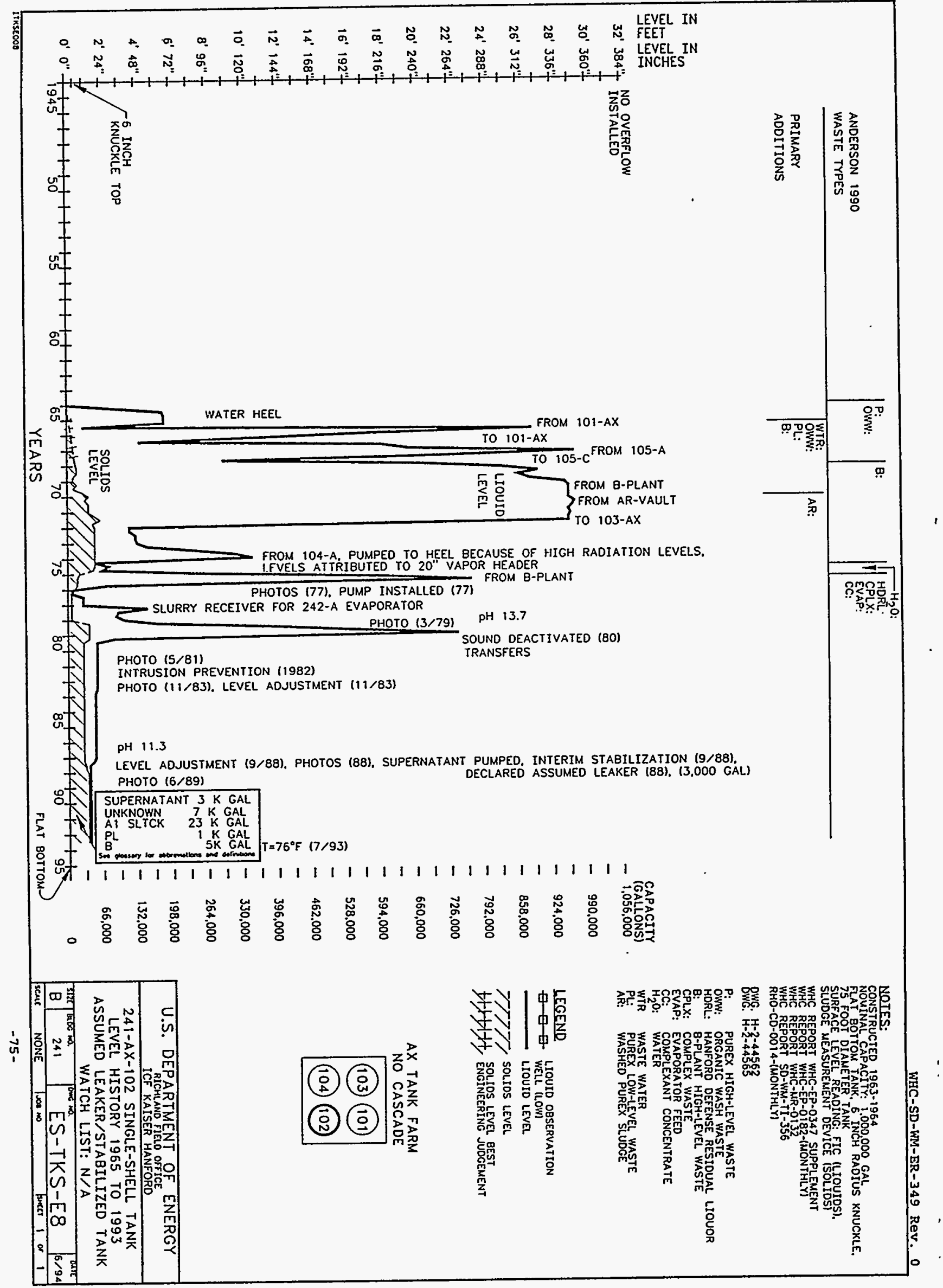




\begin{tabular}{|c|c|c|c|}
\hline \multicolumn{4}{|c|}{ Single-Shell Tank 241-AX-102 } \\
\hline \multicolumn{4}{|c|}{ Solids Composite Inventory Estimate } \\
\hline \multicolumn{4}{|c|}{ 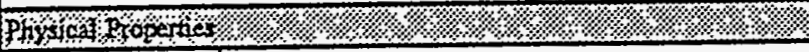 } \\
\hline Total Solid Waste & \multicolumn{3}{|c|}{$2.04 \mathrm{E}+05 \mathrm{~kg}(36 \mathrm{kgal})$} \\
\hline Heat load & \multicolumn{3}{|c|}{$4.85 \mathrm{~kW}(1.65 \mathrm{E}+04 \mathrm{BTU} / \mathrm{hr})$} \\
\hline Bulk Density & \multicolumn{3}{|c|}{$1.50(\mathrm{~g} / \mathrm{cc})$} \\
\hline Void Fraction & \multicolumn{3}{|c|}{0.28} \\
\hline Waler or\% & \multicolumn{3}{|c|}{15.92} \\
\hline TOC wr\% C (wet) & \multicolumn{3}{|c|}{0.06} \\
\hline \multicolumn{4}{|c|}{ 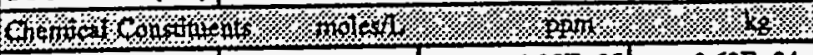 } \\
\hline \begin{tabular}{|l|l|}
$\mathrm{Na}^{+1}$ & \\
\end{tabular} & 8.37 & $1.28 \mathrm{E}+05$ & $2.62 E+04$ \\
\hline $\mathrm{Al}^{+3}$ & 0.37 & $6.74 \mathrm{E}+03$ & $1.38 \mathrm{E}+03$ \\
\hline $\mathrm{Fe}^{43}($ lotal Fe $)$ & 0.89 & $3.33 \mathrm{E}+04$ & $6.80 \mathrm{E}+03$ \\
\hline $\mathrm{Cr}^{+3} \cdot \ldots$ & $8.40 \mathrm{E}-03$ & $\therefore 291 \mathrm{E}+02$ & 2059.51 \\
\hline$\overline{B i^{+3}}$ & 0 & 0 & 0 \\
\hline $\mathrm{La}^{+3}$ & 0 & 0] & 0 \\
\hline $\mathrm{Ce}^{+3}$ & of & of & 0 \\
\hline $\mathrm{Zr}$ (as $\left.\mathrm{ZrO}(\mathrm{OH})_{2}\right)$ & 0 & 0 & 0 \\
\hline $\mathrm{Pb}^{\circ 2}$ & 1.04E-04 & 14.30 & 2.92 \\
\hline $\mathrm{Ni}^{+2}$ & $2.11 \mathrm{E}-02$ & $8.26 \mathrm{E}+02$ & $1.69 \mathrm{E}+02$ \\
\hline $\mathrm{Sr}^{+2}$ & 0 & 0 & 0 \\
\hline $\mathrm{Mn}^{+\infty}$ & 0 & of & 0 \\
\hline $\mathrm{Ca}^{+2}$ & 0 & 0 & 0 \\
\hline $\mathrm{R}^{41}$ & 2.69E-03 & 70.20 & 14.35 \\
\hline $\mathrm{OH}^{2}$ & 3.99 & $4.53 \mathrm{E}+04$ & $9.25 E+03$ \\
\hline $\mathrm{NO}^{-1}$ & 1.13 & $4.69 \mathrm{E}+04$ & $9.59 \mathrm{E}+03$ \\
\hline $\mathrm{NO}^{-1}$ & $8.52 \mathrm{E}-02$ & $2.61 \mathrm{E}+03$ & $5.34 \mathrm{E}+02$ \\
\hline $\mathrm{CO}^{2 \cdot}$ & 0.14 & $5.65 \mathrm{E}+03$ & $1.16 \mathrm{E}+03$ \\
\hline $\mathrm{PO}^{-3}$ & 0.37 & $2.34 \mathrm{E}+04$ & $4.78 \mathrm{E}+03$ \\
\hline $504^{-2}$ & 2.77 & $1.78 \mathrm{E}+05$ & $3.63 E+04$ \\
\hline $\mathrm{Si}$ (as $\mathrm{SiO}_{3}^{-2}$ ) & 0 & 0 & 0 \\
\hline$F^{-1}$ & 0.13 & $1.70 \mathrm{E}+03$ & $3.47 \mathrm{E}+02$ \\
\hline $\mathrm{Cl}^{-1}$ & 5.17E-03 & $1.22 \mathrm{E}+02$ & 24.94 \\
\hline $\mathrm{C}_{6} \mathrm{H}_{3} \mathrm{O}_{7}{ }^{3}$ & 8.13E-03 & $1.02 \mathrm{E}+03$ & $2.09 \mathrm{E}+02$ \\
\hline EDTA $^{-1}$ & 0 & 0 & 0 \\
\hline HEDTA ${ }^{3}$ & $8.42 \mathrm{E}-06$ & 1.54 & 0.31 \\
\hline $\mathrm{NTA}^{-3}$ & 0 & 0 & 0 \\
\hline glycolate & $1.18 \mathrm{E}-02$ & $5.90 \mathrm{E}+02$ & $1.21 E+02$ \\
\hline acetate $^{-1}$ & $8.07 \mathrm{E}-03$ & $3.17 \mathrm{E}+02$ & 64.90 \\
\hline Oxalate & 0 & o & 0 \\
\hline DBP & 익 & 0 & 0 \\
\hline $\mathrm{NPH}$ & 의 & 0 & 0 \\
\hline $\mathrm{CCl}_{4}$ & 아 & 0) & 0 \\
\hline hexone & 0) & 0 & 0 \\
\hline $\mathrm{Fe}(\mathrm{CN})_{6}^{-4}$ & 01 & $0(\mathrm{~g}-\mathrm{mol})$ & \\
\hline \multicolumn{4}{|c|}{ 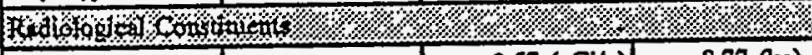 } \\
\hline Pu & & $2.57(\mu \mathrm{Ci} / 8)$ & $8.77(\mathrm{~kg})$ \\
\hline $\mathbf{U}$ & $1.25 \mathrm{E}-02(\mathrm{M})$ & $1.99 \mathrm{E}+03(1 \mathrm{vg} / \mathrm{g})$ & $4.06 \mathrm{E}+02(\mathrm{~kg})$ \\
\hline Cs & $0.11(\mathrm{C} / \mathrm{L})$ & $75.53(1 / \mathrm{Ci} / \mathrm{g})$ & $1.54 \mathrm{E}+04(\mathrm{Ci})$ \\
\hline $\mathbf{S r}$ & $5.20(\mathrm{C} / \mathrm{L})$ & $3.47 \mathrm{E}+03(\mu \mathrm{CJ} / \mathrm{g})$ & $7.09 \mathrm{E}+05(\mathrm{C})$ \\
\hline
\end{tabular}

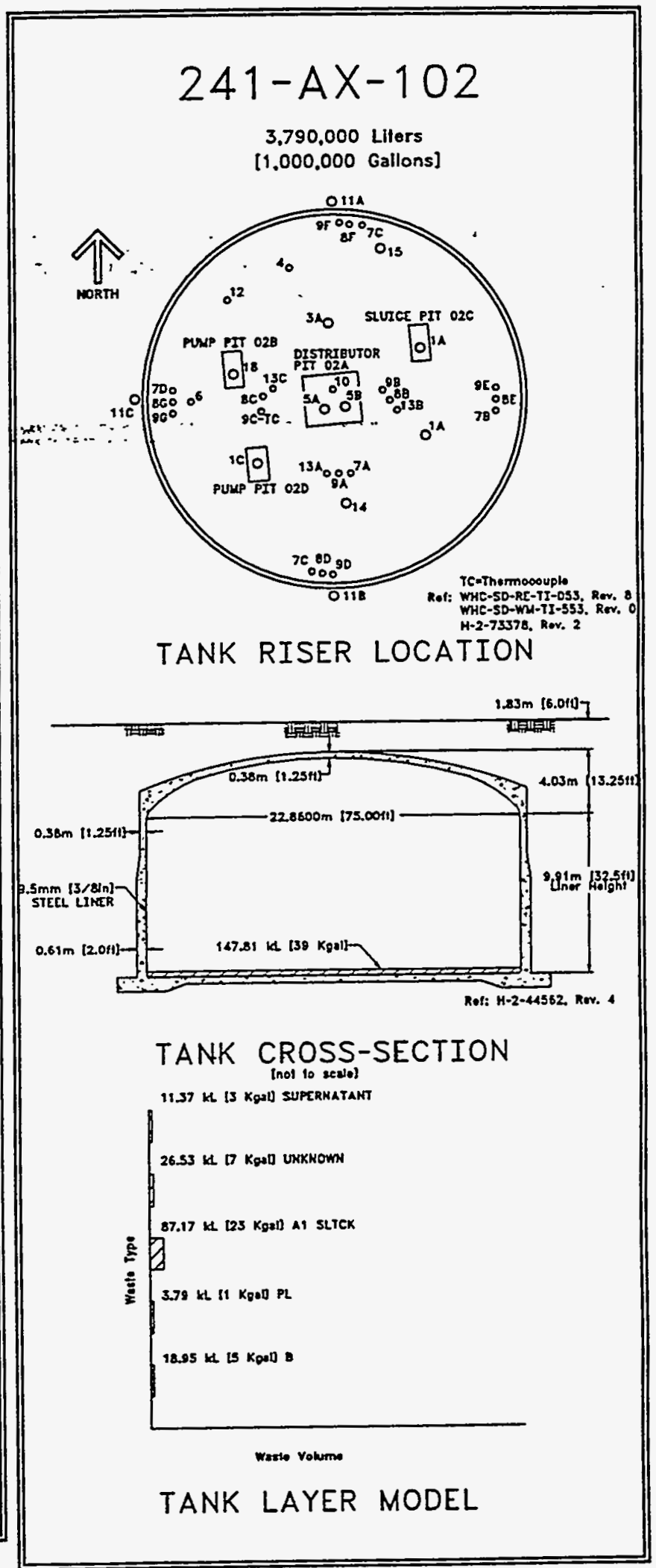


WHC-SD-WM-ER-349 Rev. 0

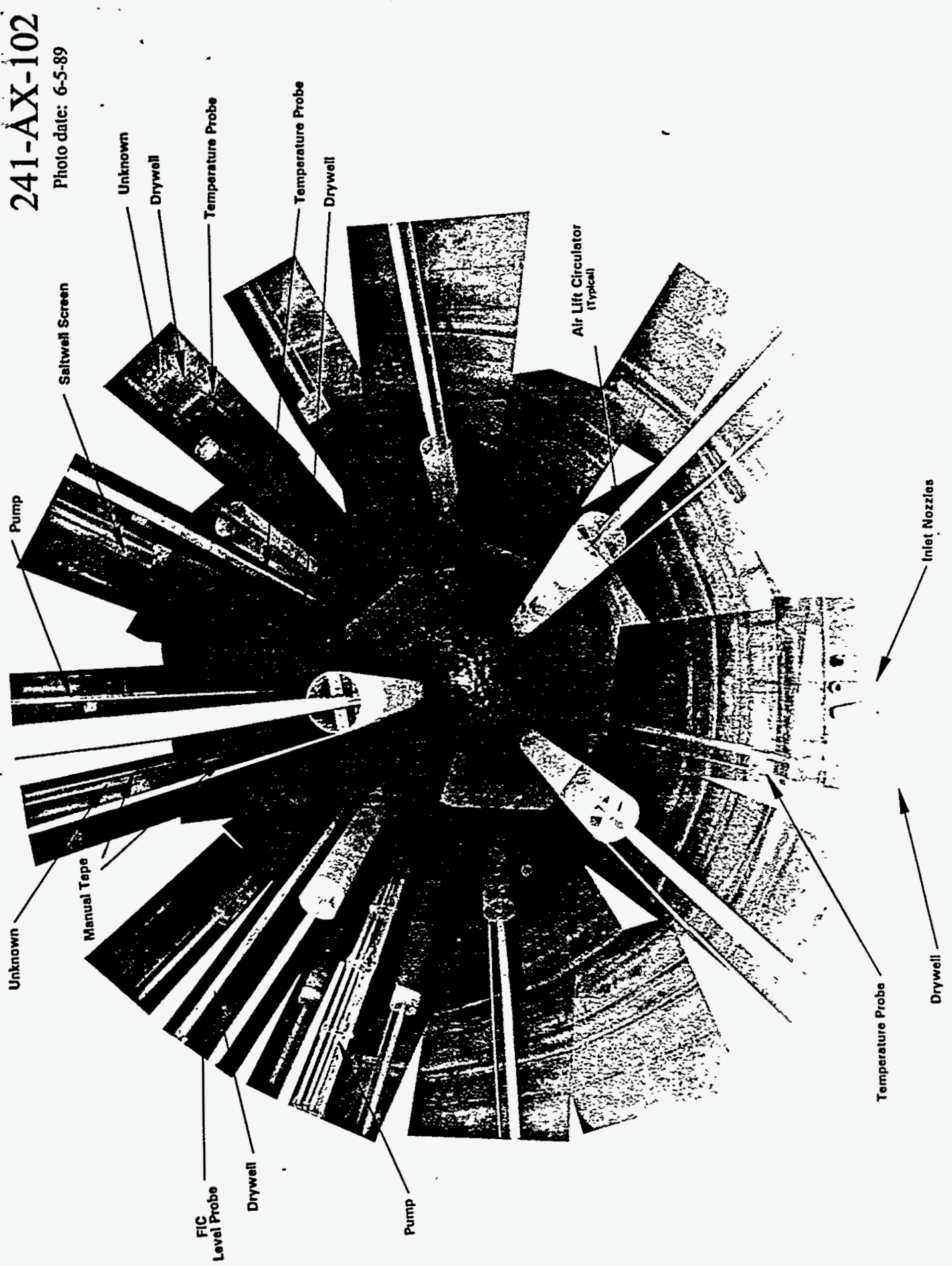




\subsubsection{1-AX-103 Tank History}

\subsubsection{Waste History Tank 241-AX-103}

Activity in Tank 241-AX-103 began when it received PUREX waste from the first quarter of 1965 through the last quarter of $1972 \ldots$ : In October '1980, T Tank 241-AX-1.03 became inactive and:a level adjustment was made. Intrusion prevention was completed in 1982: A level adjustment was made in August 1987 and the tank was declared interim stabilized in August 1978. (See sketch ES-TKS-E9 for a graphical representation of the Tank 241-AX-103 level history.)

3.3.1.2 \% Temperature History $24 I-A X=I 03 \ldots \ldots$

The single thermocouple tree in Tank 241-AX-103 has 18 thermocouples to record temperature data in riser $13 \mathrm{C}$. other previously used risers for temperature readings are $7 A, 7 B, 7 C, 7 D, 9 A, 9 B, 11 A$, 11B, 11C, 13A, and 13B. The first available average waste temperature reading in January 1965 was approximately $185^{\circ} \mathrm{F}$. A sum of the squares regression line fit of thermocouples 1 through 16 starting in 1976 shows an overall zero slope $\pm 7.4^{\circ} \mathrm{F}$ with an $r$ square value of 0.28 . Thermocouples 17 and 18 do not contain enough data points for an accurate regression or variability analysis. From october 1976 to present, the median temperature is $92^{\circ} \mathrm{F}$ with a minimum of $58^{\circ} \mathrm{F}$ and a maximum of $148^{\circ} \mathrm{F}$. Arnual temperature undulations for thermocouples 1 through 6 are apparent after January 1991. Refer to the supporting document for a more thorough review of the temperature data (Brevick 1994).

\subsubsection{Integrity of Tank 241-AX-103}

Tank 241-AX-103 is categorized as sound and is interim stabilized with intrusion prevention completed. The surface level in Tank 241-AX-103 is monitored with Food Instrument Corporation gauge through riser 9B. A Food Instrument Corporation gauge is used to determine liquid waste volume and a sludge measurement device is used for solid waste volume. A figure that graphically represents the surface level measurements from January 1991 to the present can be found in the supporting documents (Brevick 1994). The surface level remained steady during this time, with readings ranging from 39.1 to 39.7-in. An occurrence report was issued in March 1979 due to a liquid level increase in a leak detection pit. The cause for the intrusion was attributed to groundwater seepage through the drain bellows assembly into the leak detection pit.

Six drywells are identified for tank 241-Ax-103. Graphical representations of the active drywells from January 1990 to the present can be found in the supporting document (Brevick 1994). 
3.3.2 Current Status of Tank 241-AX-103

Tank 241-AX-103 entered service in 1965 and currently stores $112,000 \mathrm{gal}$ of waste. The waste is comprised of 106,000 gal of saltcake; 6,000 gal of sludge; and no supernatant with 3,000 gal of pumpable interstitial liquid remaining. The tank has been on the Hydrogen Watch list since January 1991 and is passively ventilated. The tank is categorized as sound with interim stabilization and intrusion prevention : completed. Tanks in the AX Tank Farm do not cascade. The following plan view and tank cross section depict the approximate waste level and riser configuration. Tank 241-AX-103 has 57 risers and eight risers are available for use: one 16-in. riser (no.3A), and seven 6-in. risers (nos. 8B, 8D, 8E, 8F, 8G, 9F, and 9G).

\section{$3.3 .2 .1^{\cdots}$ Inventory estimate $241-\mathrm{AX}=103+\cdots \cdots$}

The following tank layer volume approximation was derived from the Los Alamos National Laboratories Waste Status and Transaction Record Summary (Agnew 1994). The estimated inventory of Tank 241-AX-103 is also presented.

\subsubsection{In-Tank Photograph 241-AX-103}

The Tank 241-AX-103 photo shows a grey saltcake/sludge surface with about 118,000 gal of waste which converts to approximately 3 ft deep. The typical airlift circulator shown in the bottom right represents the other unlabeled circulators in the photo.

\subsubsection{Synopsis Tank 241-AX-103}

(To be completed.) 


\section{C:}

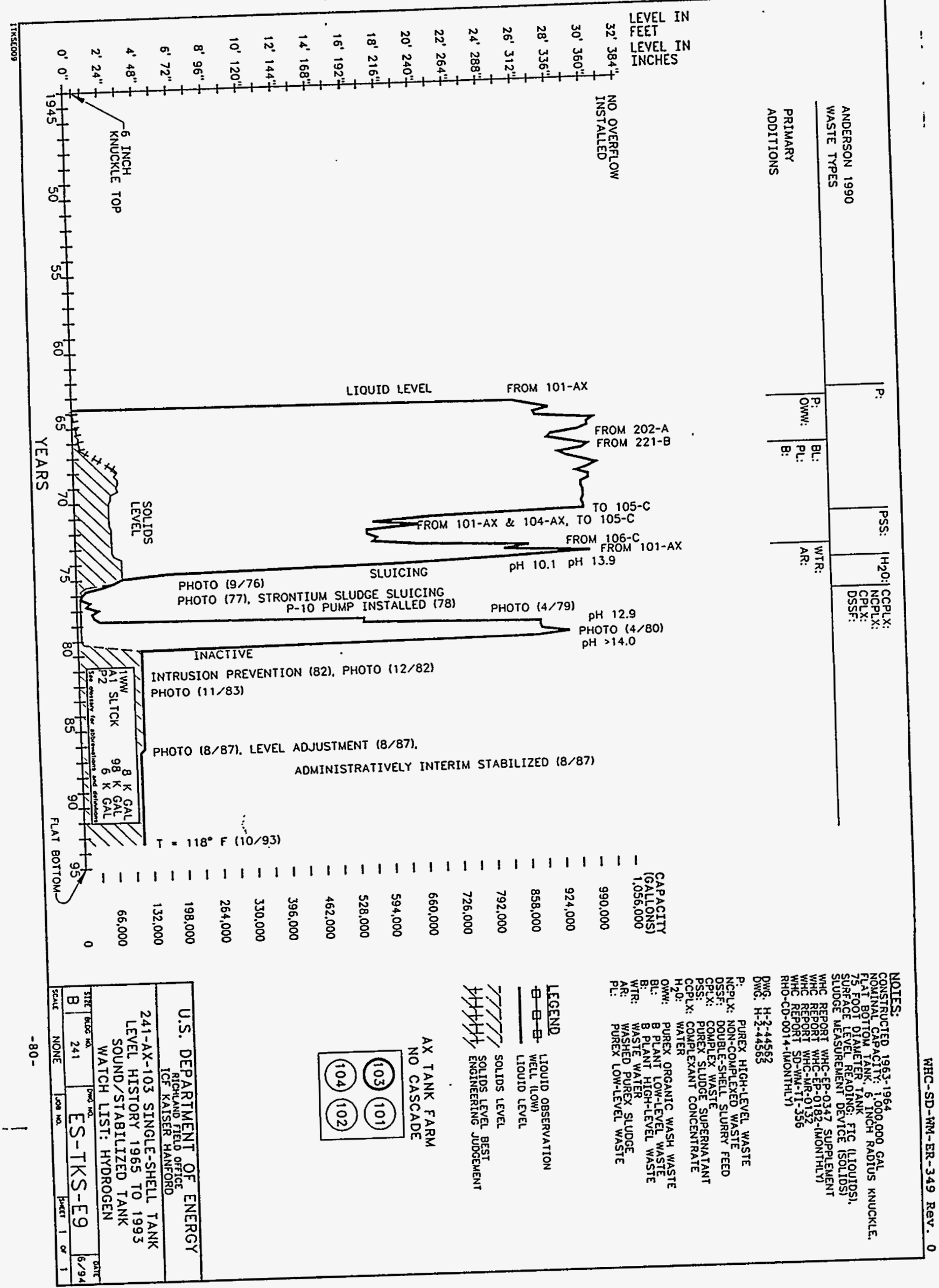




\begin{tabular}{|c|c|c|c|}
\hline \multicolumn{4}{|c|}{ Single-Shell Tank 241-AX-103 } \\
\hline \multicolumn{4}{|c|}{ Solids Composite Inventory Estimate } \\
\hline \multicolumn{4}{|c|}{ 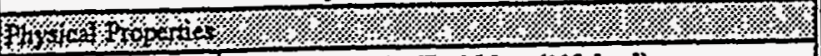 } \\
\hline Tocal Solid Waste & \multicolumn{3}{|c|}{$6.25 \mathrm{E}+05 \mathrm{~kg}(112 \mathrm{kgal})$} \\
\hline Heat load & \multicolumn{3}{|c|}{$8.12 \mathrm{~kW}(277 \mathrm{E}+04 \mathrm{BTU} / \mathrm{hr})$} \\
\hline Bulk Density & \multicolumn{3}{|c|}{$1.48(g / \infty)$} \\
\hline Void Fraction & \multicolumn{3}{|c|}{0.23} \\
\hline Water wr\% & \multicolumn{3}{|c|}{13.59} \\
\hline TOC wr\% C (wet) & \multicolumn{3}{|c|}{0.02} \\
\hline \multicolumn{4}{|c|}{ 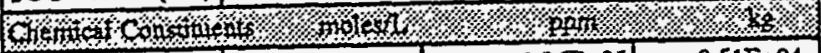 } \\
\hline \begin{tabular}{|l|l|}
$\mathrm{Na}^{+1}$ & \\
\end{tabular} & 8.73 & $1.36 \mathrm{E}+05$ & $8.51 \mathrm{E}+04$ \\
\hline $\mathrm{Al}^{+3}$ & 6.05E-02 & $1.11 E+03$ & $6.92 \mathrm{E}+02$ \\
\hline $\mathrm{Fe}^{\mathrm{s}}(\mathrm{total} \mathrm{Fe})$ & 0.38 & $1.42 \mathrm{E}+04$ & $8.91 \mathrm{E}+03$ \\
\hline $\mathrm{Cr}^{4}+\ldots \ldots$ & $-.956 \mathrm{E}: 03$ & $3.3 \cdots 3.37 \mathrm{E}+02$ & $\pi 2.11 E+02:$ \\
\hline $\mathrm{Bi}^{+3}$ & 0 & 0 & 0 \\
\hline $\mathrm{La}^{+3}$ & 0 & 요 & 0 \\
\hline $\mathrm{Ce}^{43}$ & of & of & 0 \\
\hline $\mathrm{Zr}\left(\mathrm{as} \mathrm{ZrO}(\mathrm{OH})_{2}\right)$ & 0 & 0 & 0 \\
\hline $\mathrm{Pb}^{+2}$ & 0 & 0 & 0 \\
\hline $\mathrm{Ni}^{+2}$ & $2.44 \mathrm{E}-02$ & $9.70 \mathrm{E}+02$ & $6.07 \mathrm{E}+02$ \\
\hline$S r^{42}$ & 0 & 0 & 0 \\
\hline $\mathrm{Mn} \mathrm{n}^{+4}$ & 이 & of & 0 \\
\hline $\mathrm{Ca}^{42}$ & 0 & 0 & 0 \\
\hline $\mathrm{K}^{+1}$ & $8.45 \mathrm{E}-04$ & 22.40 & 14.01 \\
\hline $\mathrm{OH}^{-1}$ & 1.44 & $1.66 \mathrm{E}+04$ & $1.04 \mathrm{E}+04$ \\
\hline $\mathrm{NO}^{-3}$ & 0.35 & $1.45 E+04$ & $9.09 \mathrm{E}+03$ \\
\hline $\mathrm{NO}^{-1}$ & $2.49 \mathrm{E}-02$ & $7.78 \mathrm{E}+02$ & $4.86 \mathrm{E}+02$ \\
\hline $\mathrm{CO}^{-2}$ & $5.65 \mathrm{E}-02$ & $2.30 \mathrm{E}+03$ & $1.44 \mathrm{E}+03$ \\
\hline $\mathrm{PO}^{-3}$ & 0.40 & $2.56 \mathrm{E}+04$ & $1.60 \mathrm{E}+04$ \\
\hline $\mathrm{SO}^{\cdot 2}$ & 3.21 & $2.09 \mathrm{E}+05$ & $1.31 \mathrm{E}+05$ \\
\hline $\mathrm{Si}\left(\mathrm{as} \mathrm{SiO}_{3}^{-2}\right)$ & 0.30 & $5.62 \mathrm{E}+03$ & $3.52 \mathrm{E}+03$ \\
\hline$F^{-3}$ & $3.98 \mathrm{E}-02$ & $5.12 \mathrm{E}+02$ & $3.20 \mathrm{E}+02$ \\
\hline$a^{-2}$ & $1.54 \mathrm{E}-03$ & 36.96 & 23.11 \\
\hline $\mathrm{C}_{8} \mathrm{H}_{5} \mathrm{O}_{7}^{-3}$ & $2.26 \mathrm{E}-03$ & $2.90 \mathrm{E}+02$ & $1.81 \mathrm{E}+02$ \\
\hline EDTA $^{-1}$ & 0 & 0 & 0 \\
\hline HEDTA ${ }^{3}$ & $2.69 \mathrm{E}-06$ & 0.50 & 0.31 \\
\hline $\mathrm{NTA}^{-3}$ & 0 & 0 & 0 \\
\hline Blycolate ${ }^{-1}$ & 3.77E- 03 & $1.91 \mathrm{E}+02$ & $1.20 \mathrm{E}+02$ \\
\hline acelate ${ }^{-1}$ & $2.39 \mathrm{E}-03$ & 95.52 & 59.74 \\
\hline Ozalate ${ }^{-2}$ & 0 & 0 & 0 \\
\hline $\mathrm{DBP}$ & 0 & of & 0 \\
\hline NPH & 임 & 0 & 0 \\
\hline $\mathrm{Cl}_{4}$ & 0 & 0 & 0 \\
\hline hexone & 요 & 0 & 0 \\
\hline $\mathrm{Fe}(\mathrm{CN})_{6}^{-1}$ & ol & $0(8-\mathrm{mol})$ & \\
\hline \multicolumn{4}{|c|}{ 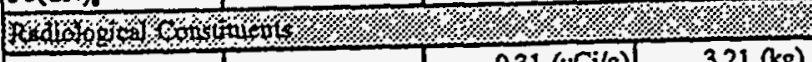 } \\
\hline $\mathrm{Pu}$ & & $0.31(\mu \mathrm{Ci} / g)$ & $3.21(\mathrm{~kg})$ \\
\hline$U$ & 1.07E-02 (M) & $1.73 \mathrm{E}+03(\mathrm{\mu g} / \mathrm{g})$ & $1.08 \mathrm{E}+03(\mathrm{~kg})$ \\
\hline Cs & $0.11(\mathrm{Ci} / \mathrm{L})$ & $76.22(1 \mathrm{MC} / \mathrm{g})$ & $4.77 \mathrm{E}+04(\mathrm{C})$ \\
\hline $\mathrm{Sr}$ & $2.76(\mathrm{Ci} / \mathrm{L})$ & $1.87 \mathrm{E}+03(\mu \mathrm{Cl} / \mathrm{g})$ & $1.17 \mathrm{E}+06(\mathrm{Ci})$ \\
\hline
\end{tabular}

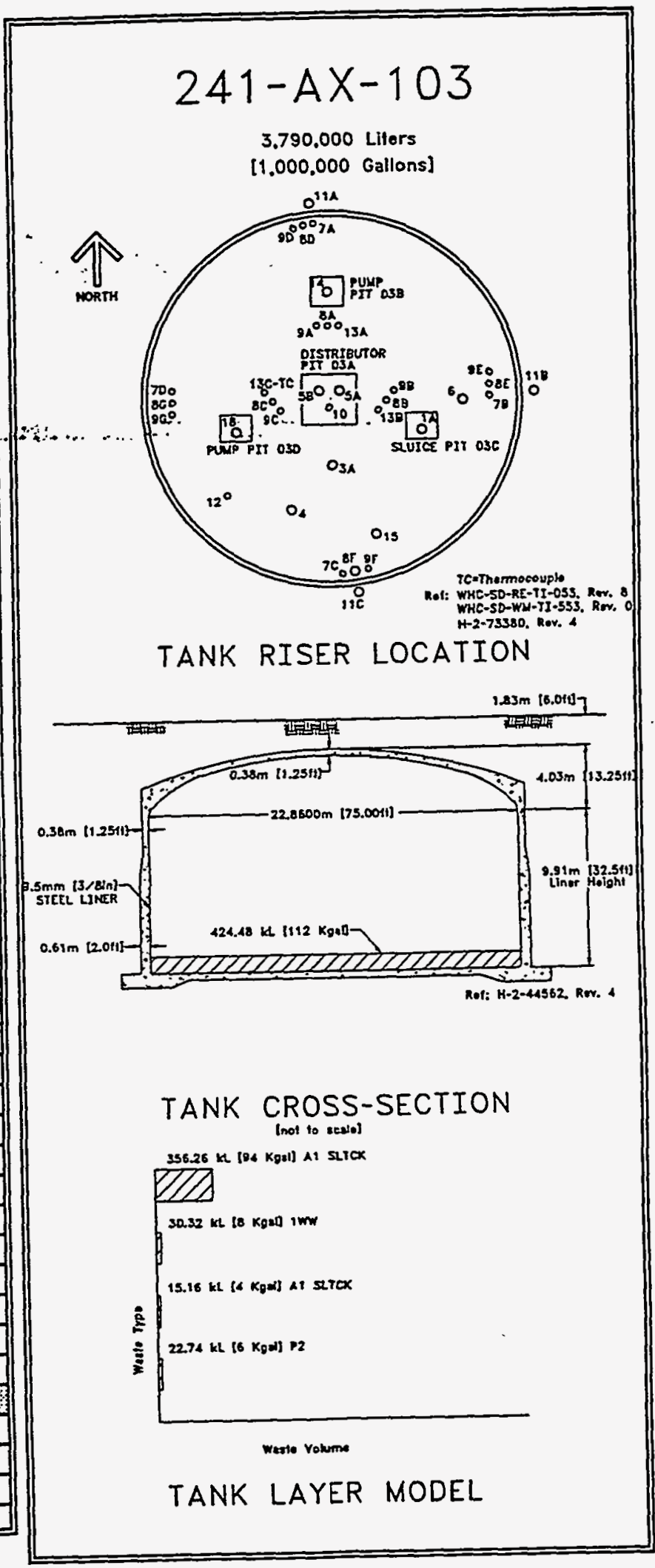




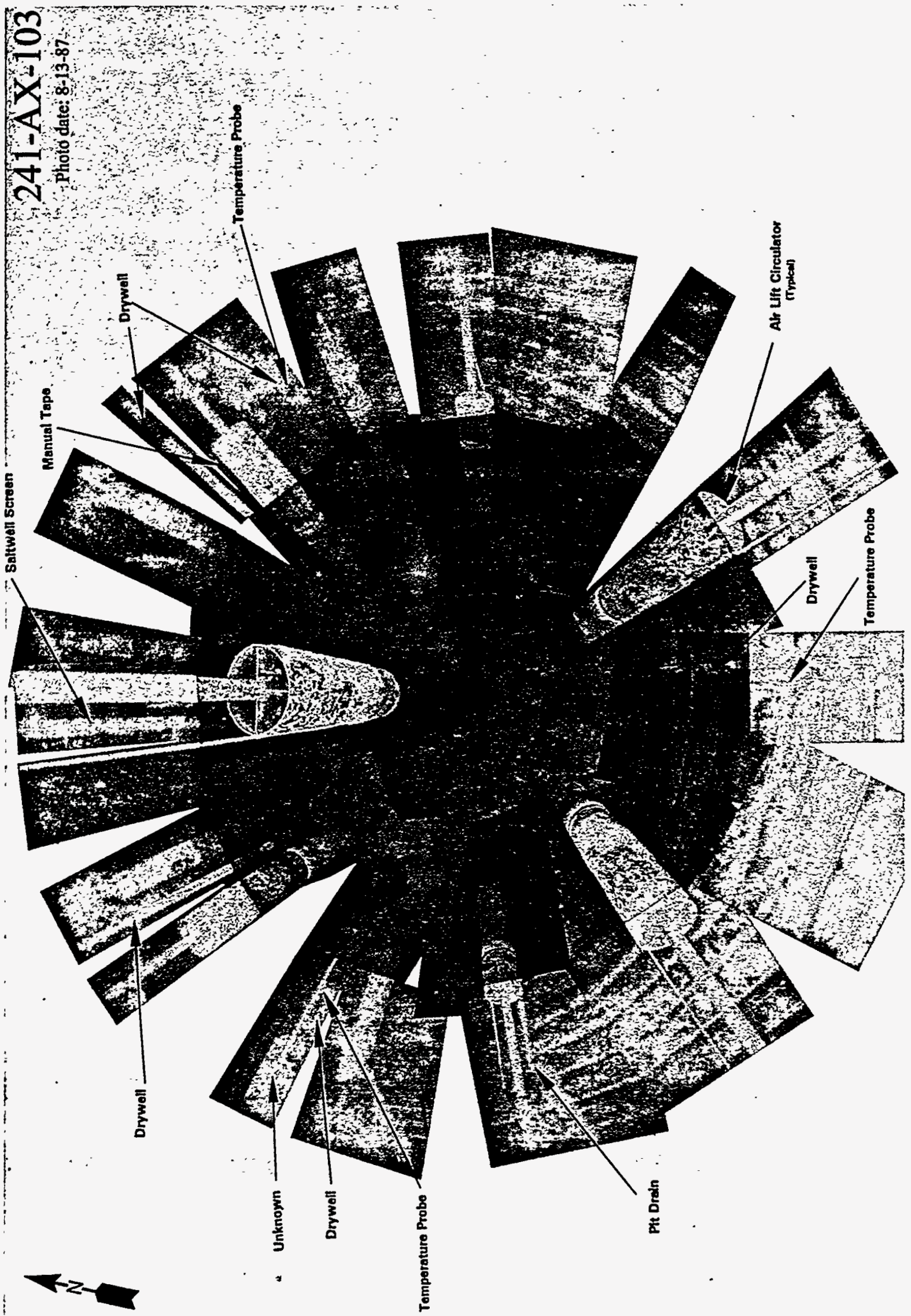


WHC-SD-WM-ER-349, ReV. 0

3.4 Tank 241-AX-104

3.4.1 241-AX-104 Tank History

3.4.1.1 Waste History Tank 241-AX-104

Activity began in Tank 241-AX-104 when it received PUREX waste between the third. quarter of 1965 and the fourth quarter of 1972. The tank was declared an assumed leaker in 1977 with an approximate 8,000 gal leak volume. The leak was attributed to a vapor line and vessel vent header. Interim isolation and interim stabilization were completed in December 1982. (See sketch ES-TKS-EIO for a graphical representation of the Tank 241-AX-104 Ievel history.)

$3.4: 1.2$ : Temperature History $241-4 x-104: \cdots$

The single thermocouple tree in Tank 241-AX-104 has 18 thermocouple probes in riser 9C. Other previously used risers for temperature readings were $7 \mathrm{~A}, 7 \mathrm{~B}, 11 \mathrm{~A}, 11 \mathrm{~B}, 11 \mathrm{C}, 13, \mathrm{~A}, 13 \mathrm{~B}$, and 13C. The first available average waste temperature reading in september 1966 was approximately $195^{\circ} \mathrm{F}$. A sum of the squares regression line fit for all the thermocouples starting in 1976 shows an overall zero slope $\pm 12.6^{\circ} \mathrm{F}$ with an $I$ square value of 0.05 . From October 1976 to present, the median tank temperature is $96^{\circ} \mathrm{F}$ with a minimum of $68^{\circ} \mathrm{F}$ and a maximum of $242^{\circ} \mathrm{F}$. Refer to the supporting document for a more thorough review of the temperature data (Brevick 1994).

\subsubsection{Integrity of Tank 241-AX-104}

Tank 241-AX-104 is categorized as an assumed leaker and is interim stabilized with intrusion prevention completed. The surface level in Tank 241-AX-104 is monitored quarterly with a manual tape through riser 9A. A graphical representation of the surface level measurements from January 1991 to the present can be found in the supporting documents (Brevick 1994). The surface level has remained steady with the readings ranging between 1.25 and 4 in. An occurrence report was issued in January 1976 due to increased drywell activity. The activity was attributed to migration of a vapor header leak identified from a preliminary ARHCO occurrence report issued in April 1975.

Eight drywells are identified for tank 241-AX-104, and none are currently active.

3.4.2 Current Status of Tank 241-AX-104

Tank 241-AX-104 entered service in 1966, and currently stores 7,000 gal of non-complexed waste. The waste is all sludge with no pumpable liquid remaining. It is identified as a low-heat load tank that is passively ventilated. The tank is categorized as an assumed leaker with interim stabilization and intrusion prevention completed. Tanks in the AX Tank Farm do not cascade. The Eollowing plan view and tank cross section depict the approximate waste level and riser configuration. Tank 241-AX-104 has 60 risers and seven are available for use: one 14- 
WHC-SD-WM-ER-349, Rev. 0

in. riser (no.3A), four 6-in. risers (nos. 8B, 8D, 8F, and $8 \mathrm{G}$ ), and two 4 -in. risers (nos. $16 \mathrm{~B}$ and $16 \mathrm{C}$ ).

3.4.2.1 Inventory estimate 241-AX-104

The following tank layer volume approximation was derived from the Los Alamos National Laboratories Waste Status and Transaction Record Summary (Agnew 1994). The estimated inventory of Tank 241-AX-104 is also presented.

\subsubsection{In-Tank Photograph 241-AX-104}

The Tank 241-AX-104 photo shows a thin layer of sludge with about 7,000 .gal. of .waste. which converts.to..approximately. 0.5. ft thick. The surface color varies from white to redaish-browr." "The "typical airlift circulator shown in the bottom right represents the other unlabeled circulators in the photo.

3.4.3 Synopsis Tank 241-AX-104

(To be completed.) 


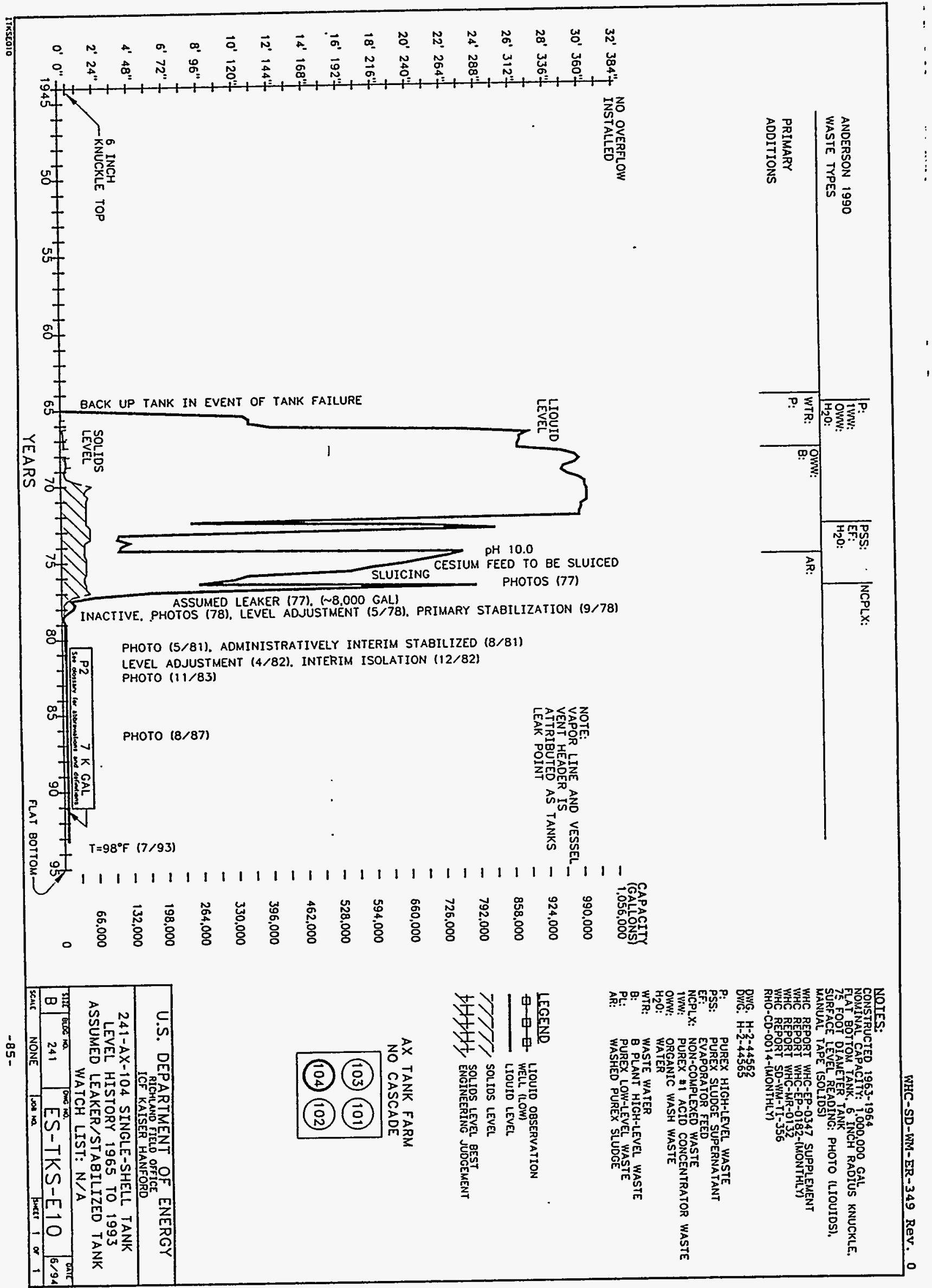


WHC-SD-WM-ER-349, ReV. 0

\begin{tabular}{|c|c|c|c|}
\hline \multicolumn{4}{|c|}{ Single-Shell Tank 241-AX-104 } \\
\hline \multicolumn{4}{|c|}{ Solids Composite Inventory Estimate } \\
\hline \multicolumn{4}{|c|}{ 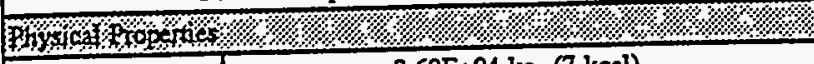 } \\
\hline Total Solid Waste & \multicolumn{3}{|c|}{$3.69 \mathrm{E}+04 \mathrm{~kg}(7 \mathrm{kgal})$} \\
\hline Heat load & \multicolumn{3}{|c|}{$4.04 \mathrm{~kW}(1.38 \mathrm{E}+04 \mathrm{BTU} / \mathrm{hr})$} \\
\hline Bulk Density & \multicolumn{3}{|c|}{$1.39(\mathrm{~g} / \mathrm{cc})$} \\
\hline Void Fraction & \multicolumn{3}{|c|}{0.78} \\
\hline Water wr\%. & \multicolumn{3}{|c|}{53.44} \\
\hline TOC wr\% C (wet) & \multicolumn{3}{|c|}{0.00} \\
\hline \multicolumn{4}{|c|}{ 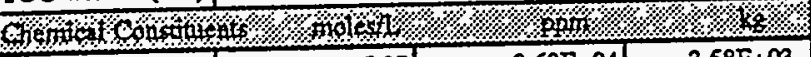 } \\
\hline $\mathrm{Na}^{+1}$ & 5.87 & $9.69 \mathrm{E}+04$ & $3.58 \mathrm{E}+03$ \\
\hline $\mathrm{Al}^{+3}$ & of & of & 0 \\
\hline $\mathrm{Fe}^{43}(\mathrm{total} \mathrm{Fe})$ & 3.01 & $1.21 \mathrm{E}+05$ & $4.45 \mathrm{E}+03$ \\
\hline $\mathrm{Cr}^{\mathbf{3}^{3}}: \mathrm{C}$ & $\because \therefore 0$ & & $\therefore \quad \therefore$ \\
\hline$\overline{\mathrm{Bi}^{+3}}$ & of & of & 0 \\
\hline La & 0 & of & 0 \\
\hline $\mathrm{Ce}^{43}$ & of & 0 & 0 \\
\hline $\mathrm{Zx}\left(\operatorname{as~} \mathrm{ZrO}(\mathrm{OH})_{2}\right)$ & 0) & of & 0 \\
\hline $\mathrm{Pb}^{+2}$ & 0 & 0 & 0 \\
\hline$\widehat{\mathrm{Ni}^{+2}}$ & 0 & 0 & 0 \\
\hline $\mathrm{Sr}^{+2}$ & 0 & of & 0 \\
\hline $\mathrm{Mn}^{+2}$ & 0 & 0 & 0 \\
\hline$\overline{\mathrm{Ca}^{42}}$ & 0 & 0 & 0 \\
\hline $\mathrm{K}^{+1}$ & 0 & . 0 & 0 \\
\hline $\mathrm{OH}^{\cdot 1}$ & 9.04 & $1.10 \mathrm{E}+05$ & 4.07E+03 \\
\hline $\mathrm{NO}^{-1}$ & 0.43 & $1.93 \mathrm{E}+04$ & $7.12 \mathrm{E}+02$ \\
\hline $\mathrm{NO}^{-1}$ & of & 0 & 0 \\
\hline $\mathrm{CO}^{-2}$ & $7.88 \mathrm{E}-02$ & $3.40 \mathrm{E}+03$ & $1.25 \mathrm{E}+02$ \\
\hline $\mathrm{PO}^{3}$ & of & o & 0 \\
\hline$\overline{\mathrm{SO}_{4}^{-2}}$ & 0.36 & $2.48 \mathrm{E}+04$ & $9.17 \mathrm{E}+02$ \\
\hline $\mathrm{Si}\left(\mathrm{as} \mathrm{SiO}_{3}{ }^{-2}\right)$ & 2.36 & $4.76 \mathrm{E}+04$ & $1.76 \mathrm{E}+03$ \\
\hline$F^{-1}$ & 0 & 0 & 0 \\
\hline $\mathrm{C}^{-1}$ & 0 & 0 & 0 \\
\hline $\mathrm{C}_{6} \mathrm{H}_{3} \mathrm{O}_{7}{ }^{3}$ & 0 & 0 & 0 \\
\hline EDTA $^{-1}$ & 0 & 0 & 0 \\
\hline HEDTA $^{.3}$ & of & 0 & 0 \\
\hline $\mathrm{NTA}^{.3}$ & 0] & 0 & 0 \\
\hline glycolate & of & 아 & 0 \\
\hline acelate $^{-1}$ & 0 & of & 0 \\
\hline oxalate-2 & 0 & 0 & 0 \\
\hline DBP & of & of & 0 \\
\hline $\mathrm{NPH}$ & 0 & of & 0 \\
\hline $\mathrm{CC}_{2}$ & of & 0 & 0 \\
\hline hexone & of & 0 & 0 \\
\hline $\mathrm{Fe}(\mathrm{CN})_{6}{ }^{d}$ & 0 & $0(\mathrm{~g}-\mathrm{mol})$ & \\
\hline \multirow{2}{*}{\multicolumn{4}{|c|}{ 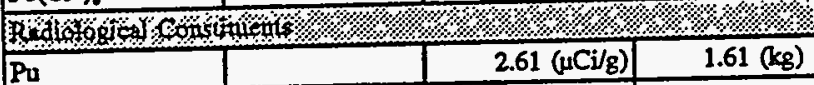 }} \\
\hline & & & \\
\hline $\bar{U}$ & $2.92 \mathrm{E}-02 \mathrm{M})$ & $4.99 \mathrm{E}+03(\mu \mathrm{g} / \mathrm{g})$ & $1.84 \mathrm{E}+02(\mathrm{~kg})$ \\
\hline$\overline{C s}$ & $0.72(\mathrm{Ci} / \mathrm{L})$ & $5.14 \mathrm{E}+02(\mu \mathrm{Ci} / \mathrm{g})$ & $1.90 \mathrm{E}+04(\mathrm{Ci})$ \\
\hline$S_{\mathbf{r}}$ & 22.11 (Cin) & $1.59 \mathrm{E}+04(\mu \mathrm{Ci} / \mathrm{g})$ & $5.86 \mathrm{E}+05(\mathrm{Ci})$ \\
\hline
\end{tabular}

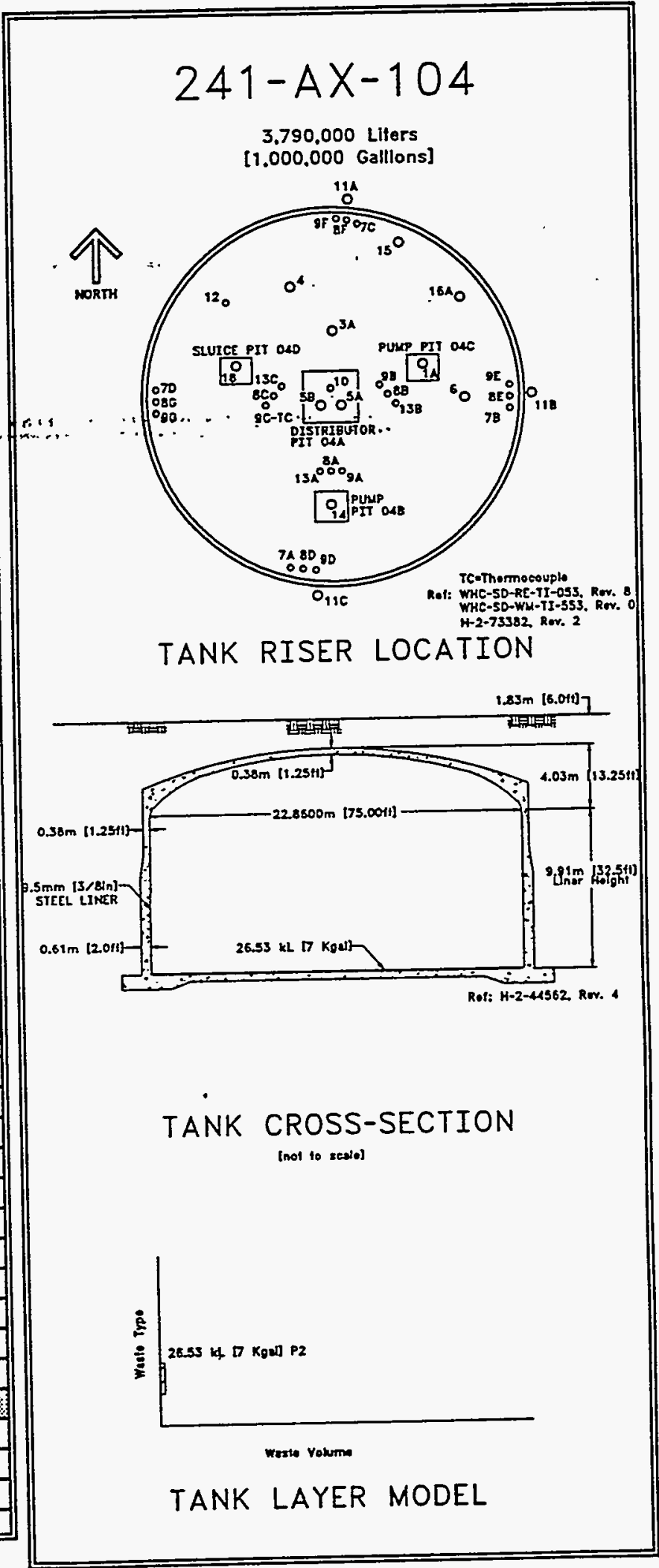




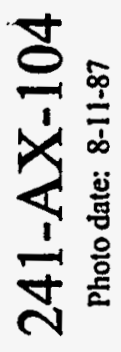

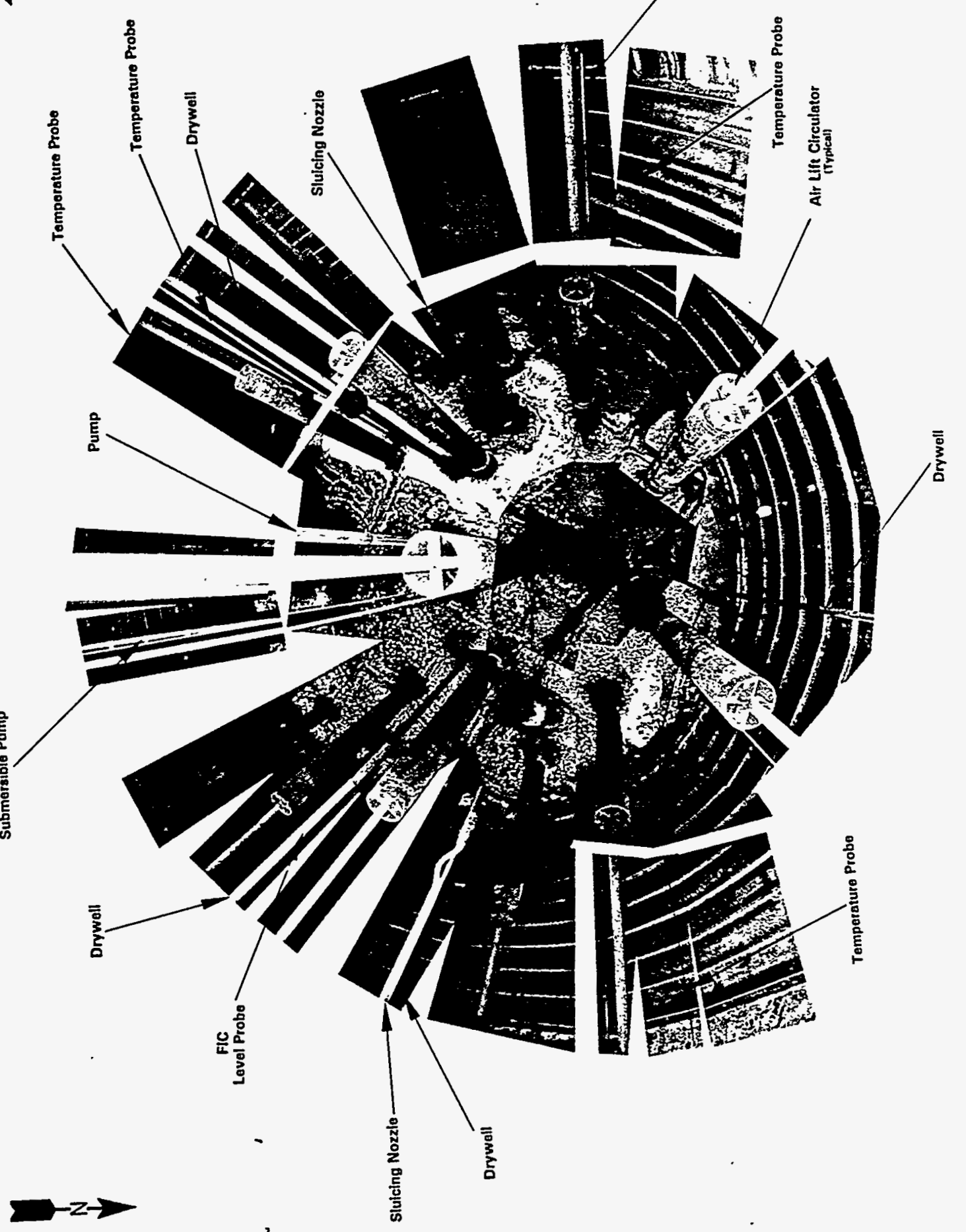


$\boldsymbol{\infty}$

골

蛋

,

sos

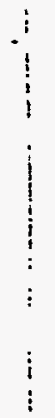




\subsubsection{B Tank Farm History}

The 241-B Tank Farm was constructed between 1943 and 1944 and is located east of Baltimore Avenue and north of the $B$ Evaporator in the 200-East Area. The B Tank Farm contains twelve 100 series; 530,000-gal; 75-ft diameter single-shell tanks and four 200 series; 55,000-gal; 20-ft diameter single-shell tanks. Built as a first generation, the $B$ Tank Farm was designed for non-boiling waste tanks with a maximum fluid temperature of $220^{\circ} \mathrm{F}$. The cascade overflow lines connect a series of three tanks. Because the tanks are in a three-by-four arrangement, there are four groups of cascading tanks. A cascade group consists of three.. tanks.. in. a step.. configuration.... The. cascade overflow. height is approximately $188^{\prime}$ in. from the tank bottom. There are tie lines between the smaller 55,000-gal tanks. The tie lines are at the same elevation which allowed the tanks to overflow and equalize tank volumes.

A 1993 color aerial photograph of the B Tank Farm shows the tank orientation, a diversion box, and a north arrow. The arrows between tanks represent the cascade overflow lines and the flow direction.

\subsubsection{B Tank Farm Waste History}

The B Tank Farm received waste from B Plant, first-and second-cycle waste, and evaporator bottoms waste. Tanks 241-B-102, -103, -106, -108, -109, and -112 were modified to accept in-tank solidification waste evaporator bottoms. Tanks 241-B-101, -102 , and -103 were sluiced in 1953 for uranium recovery. The sluiced waste was sent to the 244-BXR process vault. After deactivation, liquid was pumped from Tanks 241-B$102,-105,-107$, and -110 to Tank 241-B-102. 


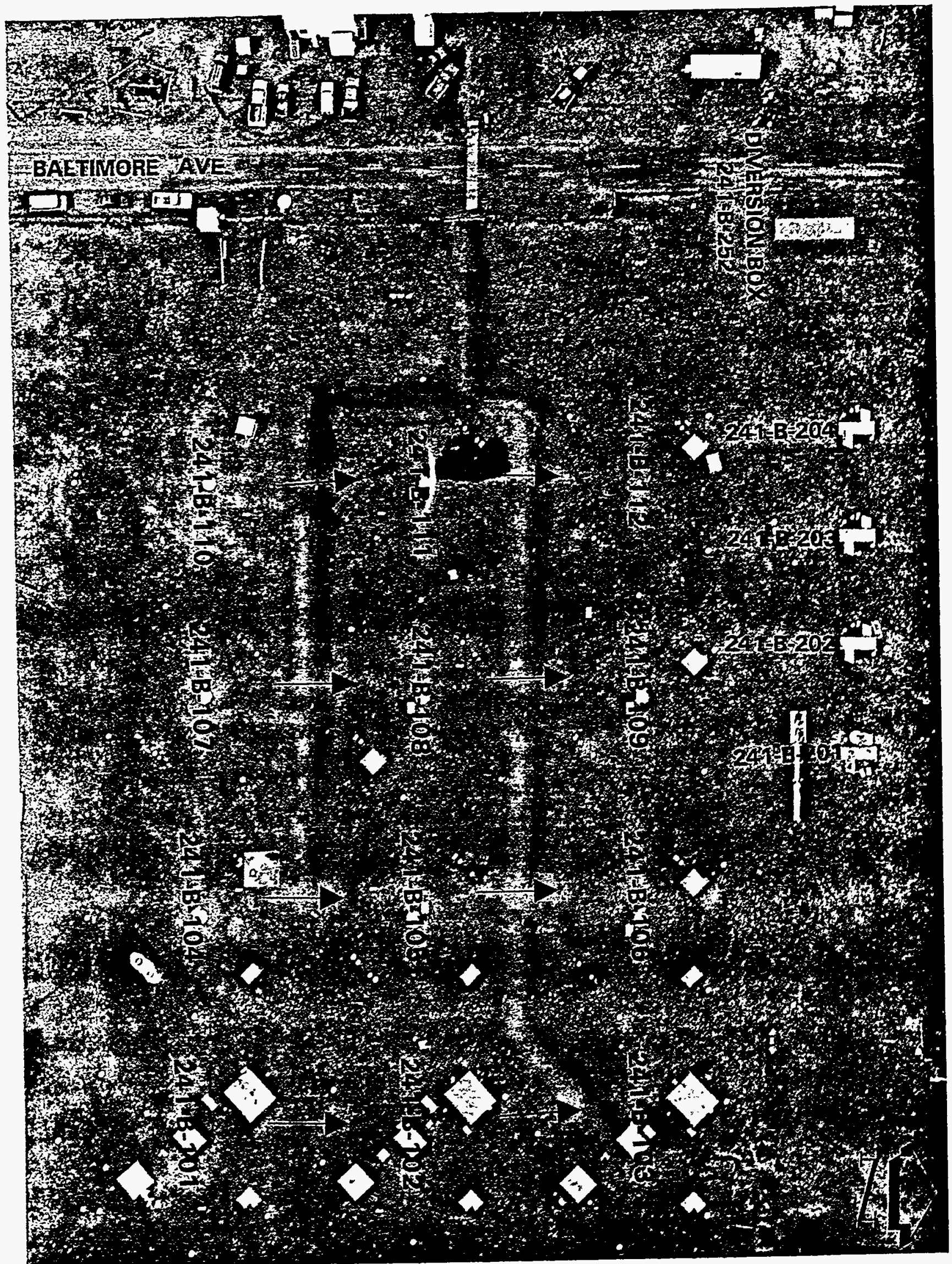

mae $\dashv$ yue $\perp g$ 
WHC-SD-WM-ER-349, Rev. 0

\subsubsection{B Tank Farm Temperature History}

Each B tank contains one thermocouple tree and each tree has between 12 and 17 thermocouple probes. Tank 241-B-103 is the only tank on the Organic Salts watch List for critical temperature data monitoring. The tank was added to the organic Salts Watch Iist officially in January 1991 and is monitored weekly. Temperatures for the remaining tanks in the $B$ Tank Farm are monitored semiannually.

\subsubsection{B Tank Farm Integrity}

The twelve 530,000-gal tanks and the four 55,000-gal tanks in the B Tank Farm are out of service. As of July 1993, Tanks 241-B-102, -104, $-106, . .-108, . .-109 .$, and. $-202 .$. are categorized as sound and .Tanks 241-B-101, $-103 ;-105 ;-107 \%-110 \%-111 \%-112,-201 ;-203 \%$ and -204 are assumed leakers. Tank integrity surveillance methods include liquid observation wells, surface level measurements, and leak detection wells (drywells).

The B Tank Farm has 52 leak detection wells that were drilled from 1944 to 1974. Seven drywells are not tank-specific. Drywells 20-00-01 and 20-00-05 have readings greater than the $50 \mathrm{c} / \mathrm{s}$ background radiation. The drywells are monitored monthly, yearly, or on request with scintillation, shielded scintillation, and Geiger-Mueller probes. Drywells associated with assumed leaking tanks are monitored for migration of contamination. If increasing drywell activity has not exceeded action criteria, appropriate personnel will determine if increased monitoring is required.

The following figure represents the B Tank Farm layout including the peak drywell, tank integrity information, and tank status information. The drywell information is based on data collected prior to 1986, and on current data from January 1990 to the present.

\subsubsection{Current Status of B Tank Farm}

Tank 241-B-103 was added to the Organic Salts Watch Iist officially in January 1991. Organic salt tanks are a safety concerns because high organic concentrations in the tanks could support an exothermic reaction at elevated temperatures and result in a potential release of high-level waste. Tanks on the organic salt watch list tanks must be monitored for temperature on a weekly basis. Low-heat load tanks (i.e., <40,000 Btu/hr) include Tanks 241-B-101, -102, -104, -105, -106, -107, -108, 109, -110, -111, -112, -201, -202, -203, and -204 . Low-heat load tanks are monitored for temperature semiannually. The total volume of waste in the B Tank Farm is $2 ; 058,000$ gal: 15,000 gal of supernatant; 770,000 gal of saltcake; 130,000 gal of unknown solids; and 1,143,000 gal of sludge. 

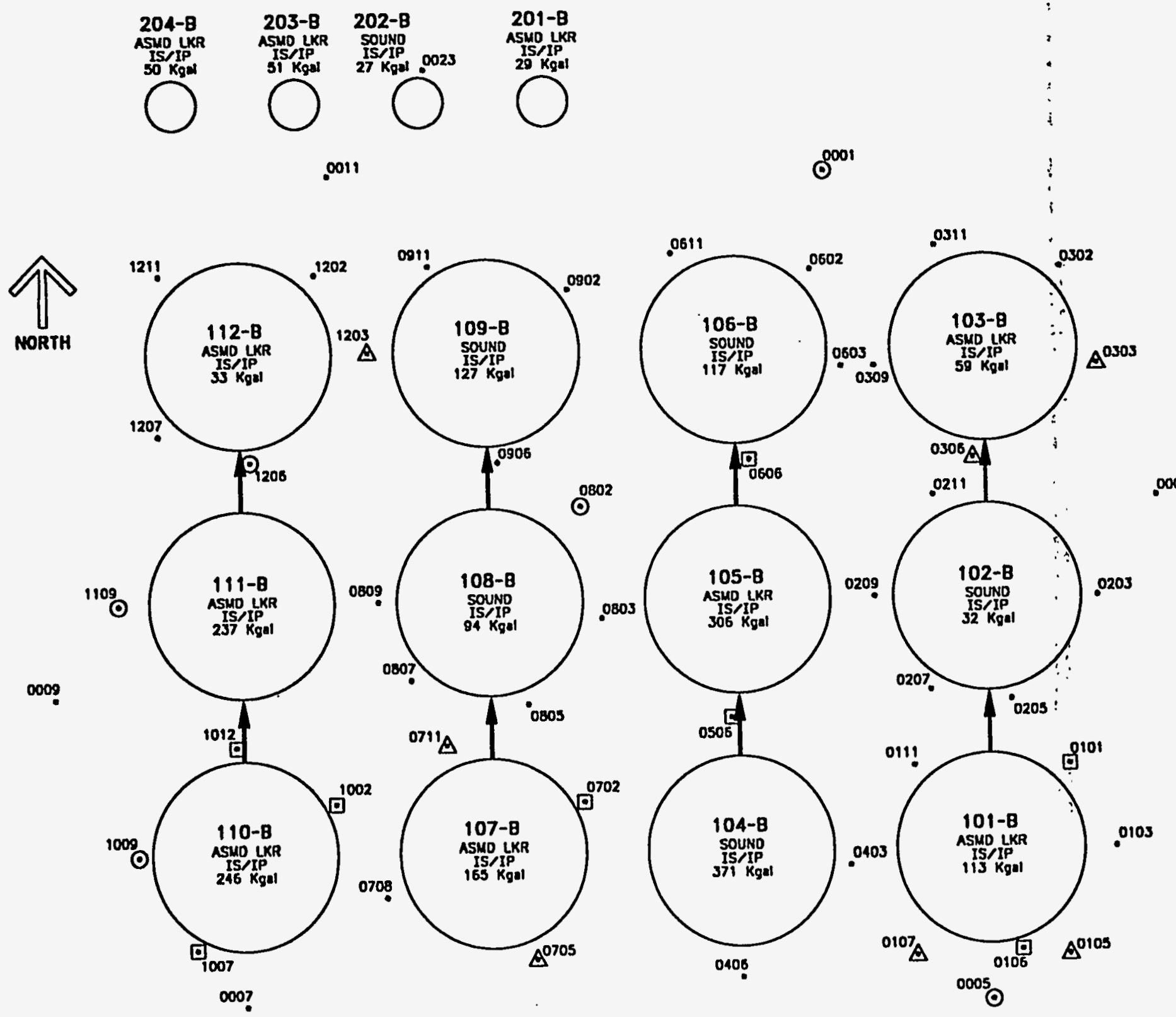

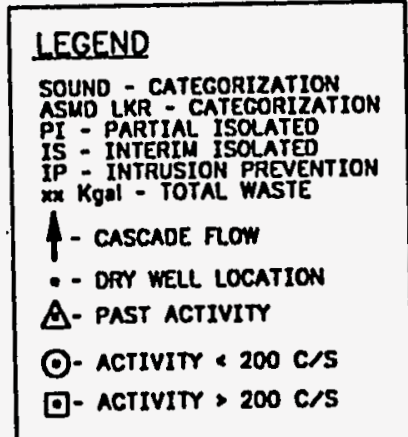


WHC-SD-WM-ER-349, Rev. 0

\subsection{Tank $241-\mathrm{B}-101$}

4.1.1 241-B-101 Tank History

4.1.1.1 Waste History Tank 241-B-101

Activity in Tank 241-B-101 began when it was filled with metal waste from May 1945 to October 1945. Activity ceased when the tank was declared inactive in:1977. A $P-10$. pump, used in saltwell pumping, was removed from Tank 241-B-101 in 1978. Interim stabilization was completed after supernatant pumping (with a flex and float pump) was completed in March 1981. Intrusion prevention was completed in May 1981 and a level adjustment was made in April 1982. Presently, the tank waste. is. non-complexed....... (See...sketch.. ES-TKS-E11. for a graphical representation 'of the' Tank $24 \mathrm{I}$-B-101"levez history?t.

\subsubsection{Temperature History 241-B-101}

The single thermocouple tree in Tank 241-B-I01 has 17 thermocouple probes in riser 9. The average temperature of the first recorded data for thermocouples 1 through 14 is $117^{\circ} \mathrm{F}$. A sum of the squares regression line fit for thermocouples 1 through 12 starting in 1974 shows a 0.02 overall slope $\pm 11.8^{\circ} \mathrm{F}$ with an average $r$ square value of 0.001 . $\mathrm{A}$ regression analysis on thermocouples 13 and 14 is not an accurate assessment of the data due to the concentration of data points between 1974 and 1976 and the sparseness of other data points throughout the time period. Not enough data points exist for thermocouples 15 through 17 to give any conclusive information about in-tank temperature trenas. From May 1974 to present, the median temperature is $95^{\circ} \mathrm{F}$ with a minimum of $40^{\circ} \mathrm{F}$ and a maximum of $137^{\circ} \mathrm{F}$. Refer to the supporting document for a more thorough review of the temperature data (Brevick 1994).

\subsubsection{Integrity of Tank 241-B-101}

Tank 241-B-101 is categorized as an assumed leaker and is interim stabilized with intrusion prevention completed. The surface level in Tank 241-B-101 is monitored with a Food Instrument corporation gauge through riser 8 . The liquid waste volume is determined by $a$ photographic evaluation and the solid waste volume is determined by a Food Instrument Corporation gauge. For more information on surface levels see supporting documents (Brevick 1994).

Six drywells are identified for tank 241-B-101. Data and graphical representations of the active drywells from January 1990 to the present can be found in the supporting document (Brevick 1994). Each graph includes the peak c/s (some wells have multiple peaks), the depth at which the peak occurred, and the date of the reading.

4.1.2 Current Status of Tank 24I-B-10I

Tank 241-B-101 entered service in May 1945 and currently stores $113,000 \mathrm{gal}$ of waste. The waste is comprised of 10,000 gal of unknown waste; 28,000 gal of sludge; 75,000 gal of saltcake with no pumpable 
liquid remaining. The tank is identified as a low-heat load tank, is passively ventilated, and is an assumed leaker with interim stabilization and intrusion prevention completed. Tank 241-B-101 is equipped to cascade to Tank 241-B-102 and is first in the three-tank cascade flow series. The following plan view and tank cross section depict the approximate waste level and riser configuration. Tank 241-B101 has 12 risers and one 12-in. riser (no.2) is available for use.

\section{1 .2 .1 Inventory estimate $241-B-101$}

The following tank layer volume approximation was derived from the Los Alamos National Laboratories Waste status and Transaction Record Summary (Agnew 1994). The estimated inventory of Tank 241-B-101 is also presented...:

\subsubsection{In-Tank Photograph 241-B-101}

The Tank 241-B-101 photo shows a black sludge surface with no visible liquid. The tank contains approximately 112,000 gal of waste which converts to approximately $3 \not 2 \mathrm{ft}$ deep.

4.1.3 Synopsis Tank 241-B-101

(To be completed.) 


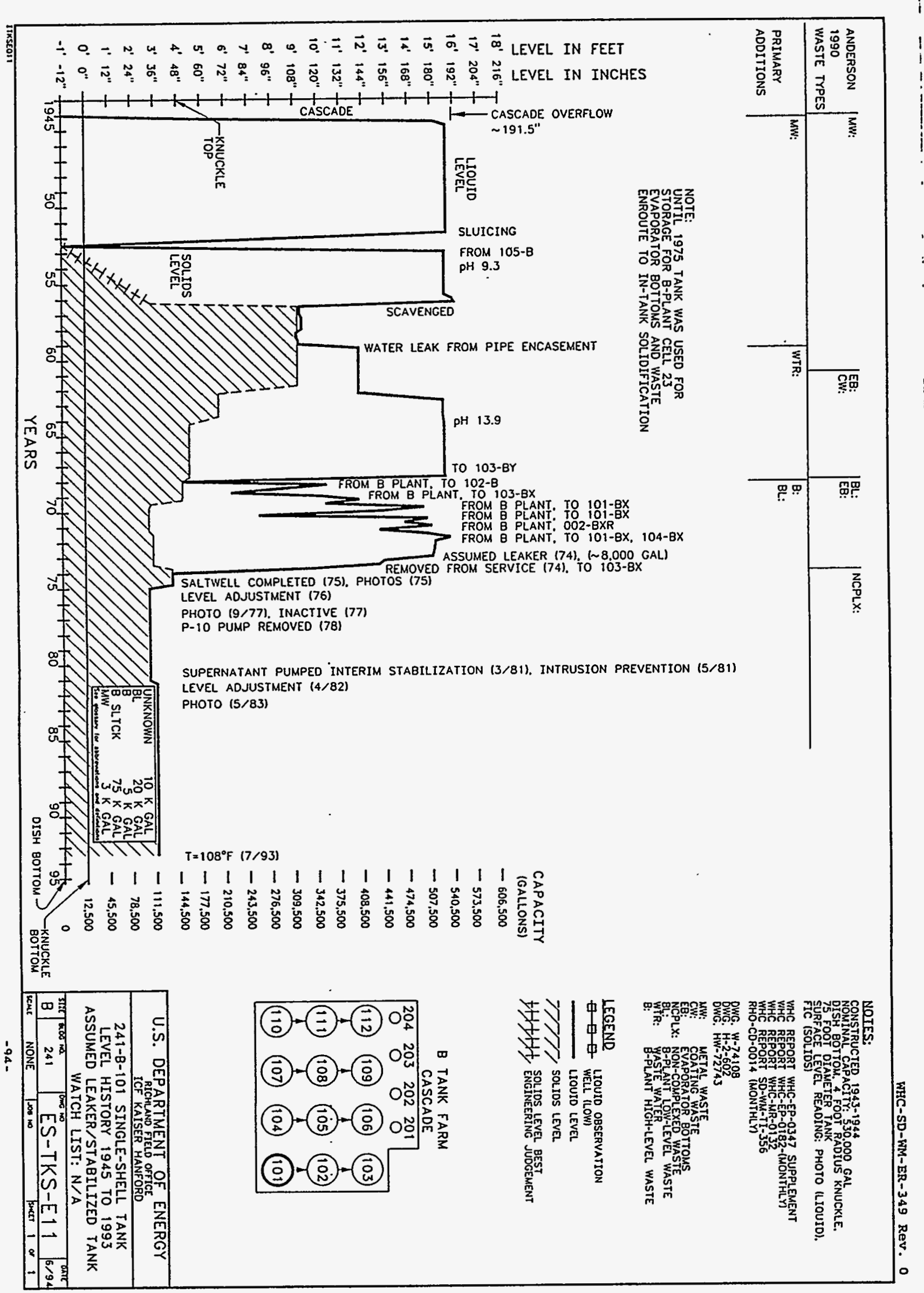




\begin{tabular}{|c|c|c|c|}
\hline \multicolumn{4}{|c|}{ Single-Shell Tank 241-B-101 } \\
\hline \multicolumn{4}{|c|}{ Solids Composite Inventory Estimate } \\
\hline Whychos & & \%: & $\%$ \\
\hline Total Solid Warte & \multicolumn{3}{|c|}{$6.40 \mathrm{E}+05 \mathrm{~kg}(113 \mathrm{kgal})$} \\
\hline \begin{tabular}{|l|} 
Heal load \\
\end{tabular} & \multicolumn{3}{|c|}{$15.92 \mathrm{~kW} \quad(5.43 \mathrm{E}+04 \mathrm{BTU} / \mathrm{hr})$} \\
\hline Bulk Density & \multicolumn{3}{|c|}{$1.50(g / \infty)$} \\
\hline Void Fraction & \multicolumn{3}{|c|}{0.62} \\
\hline Water $w 1 \%$ & \multicolumn{3}{|c|}{37.28} \\
\hline TOC w1\% C (wet) & \multicolumn{3}{|c|}{0.08} \\
\hline 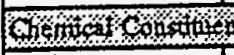 & \multicolumn{3}{|c|}{$4 \%$ ppro $/$. } \\
\hline $\mathrm{Na}^{.1}$ & 8.23 & \multirow{2}{*}{$-1.27 \mathrm{E}+05$} & $8.09 \mathrm{E}+04$ \\
\hline $\mathrm{Al}^{+3}$ & 0.61 & & $7.08 \mathrm{E}+03$ \\
\hline $\mathrm{Fe}^{43}$ (tols Fe) & 0.81 & $\frac{1.11 \mathrm{E}+04}{3.01 \mathrm{E}+04}$ & $1.92 \mathrm{E}+04$ \\
\hline$C^{4 ! 3}$ & $\therefore .658 \mathrm{E}-05$ & $\because \because: \div: 229$ & $\because \therefore: \quad 146:$ \\
\hline $\mathrm{Bi}^{+3}$ & 0 & 0 & 0 \\
\hline $\mathrm{La}^{43}$ & 0 & 0 & 0 \\
\hline $\mathrm{Ce}^{43}$ & 0 & 0 & 0 \\
\hline $\mathrm{Zx}\left(\mathrm{as} \mathrm{ZrO}(\mathrm{OH})_{2}\right)$ & 0 & 0 & 0 \\
\hline $\mathrm{Pb}^{+2}$ & $8.85 \mathrm{E}-06$ & 1.23 & 0.78 \\
\hline$\widehat{\mathrm{Ni}^{+2}}$ & 5.41E-02 & $2.13 \mathrm{E}+03$ & $1.36 \mathrm{E}+03$ \\
\hline $\mathrm{St}^{42}$ & 0 & 0 & 0 \\
\hline $\mathrm{Mn}^{+\infty}$ & of & 0 & 0 \\
\hline $\mathrm{Ca}^{+2}$ & 0 & 0 & 0 \\
\hline $\mathrm{R}^{+1}$ & 0 & 0 & 0 \\
\hline $\mathrm{OH}^{-1}$ & 4.57 & $5.19 \mathrm{E}+04$ & $3.32 E+04$ \\
\hline $\mathrm{NO3}^{-1}$ & 2.46 & $1.02 \mathrm{E}+05$ & $6.54 \mathrm{E}+04$ \\
\hline $\mathrm{NO2}^{-3}$ & $3.39 \mathrm{E}-02$ & $1.04 E+03$ & $6.67 \mathrm{E}+02$ \\
\hline $\mathrm{CO}^{-2}$ & 0.52 & $2.10 \mathrm{E}+04$ & $1.34 \mathrm{E}+04$ \\
\hline $\mathrm{PO}^{\cdot 3}$ & 0.81 & $5.12 \mathrm{E}+04$ & $3.27 \mathrm{E}+0.4$ \\
\hline $54^{-2}$ & 0.59 & $3.79 \mathrm{E}+04$ & $2.43 E+04$ \\
\hline $\mathrm{Si}\left(\right.$ as $\left.\mathrm{SiO}_{3}{ }^{-2}\right)$ & 0.53 & $9.97 \mathrm{E}+03$ & $6.38 \mathrm{E}+03$ \\
\hline $\mathrm{F}^{-1}$ & $4.44 \mathrm{E}-02$ & $5.65 E+02$ & $3.61 E+02$ \\
\hline $\mathrm{a}^{-1}$ & $8.08 \mathrm{E}-03$ & $1.91 E+02$ & $1.22 \mathrm{E}+02$ \\
\hline $\mathrm{C}_{8} \mathrm{H}_{5} \mathrm{O}_{7}^{-3}$ & $3.27 \mathrm{E}-03$ & $4.13 \mathrm{E}+02$ & $2.64 \mathrm{E}+02$ \\
\hline EDTA $^{-4}$ & 0 & 0 & 0 \\
\hline HEDTA $^{-3}$ & 0 & 0 & 0 \\
\hline NTA $^{-3}$ & 0 & 0 & 0 \\
\hline Blycolate & $3.92 \mathrm{E}-02$ & $1.97 \mathrm{E}+03$ & $1.26 \mathrm{E}+03$ \\
\hline acetate & 0 & 0 & 0 \\
\hline oxalate ${ }^{-2}$ & 0 & of & 0 \\
\hline DBP & 0 & 요 & 0 \\
\hline NPH & 0 & 요 & 0 \\
\hline $\mathrm{CCl}_{4}$ & 0 & 0 & 0 \\
\hline hexone & 0 & 0 & 0 \\
\hline $\mathrm{Fe}(\mathrm{CN})_{6}^{-1}$ & 0 & $0(\mathrm{~g}-\mathrm{mol})$ & \\
\hline Rolologital & ments & \% & א/ \\
\hline $\mathrm{Pu}$ & & $1.25(\mu \mathrm{Ci} / \mathrm{g})$ & $13.29(\mathrm{~kg})$ \\
\hline $\mathrm{U}$ & $4.66 \mathrm{E}-02(\mathrm{M})$ & $7.42 \mathrm{E}+03(\mathrm{\mu g} / \mathrm{g})$ & $4.75 \mathrm{E}+03(\mathrm{~kg})$ \\
\hline Cs & $1.58 \mathrm{E}-02(\mathrm{Ci} / \mathrm{L})$ & $10.57(\mu \mathrm{Ci} / \mathrm{g})$ & $6.76 \mathrm{E}+03(\mathrm{Ci})$ \\
\hline$S \mathbf{S}$ & $5.51(\mathrm{Ci} / \mathrm{L})$ & $3.69 \mathrm{E}+03(\mathrm{uCJ} / \mathrm{g})$ & $2.36 \mathrm{E}+06(\mathrm{C})$ \\
\hline
\end{tabular}

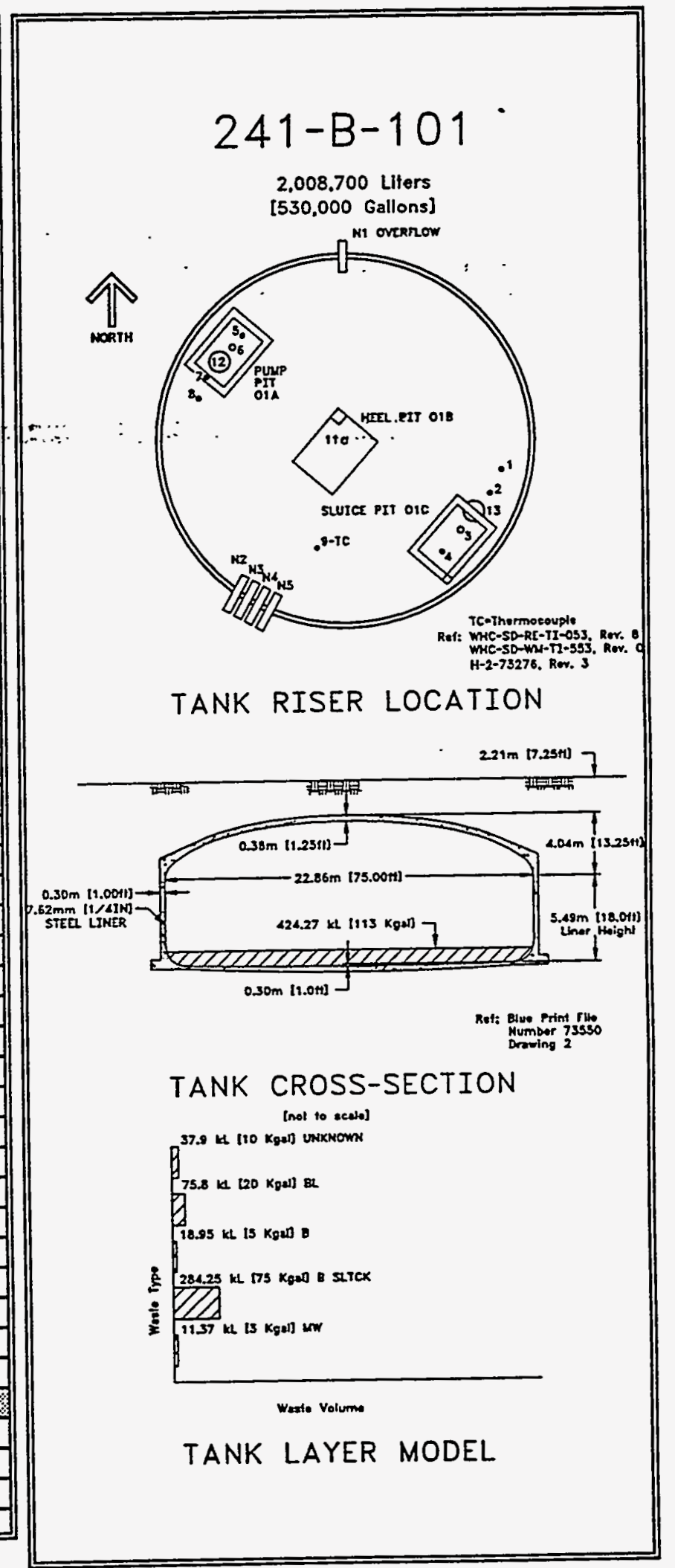

- Composite inventory exchudes supernatant, distomacosus earth, and cemen

Unknowas in tank inventory are assigned by Tank Layering Model (ILM). 

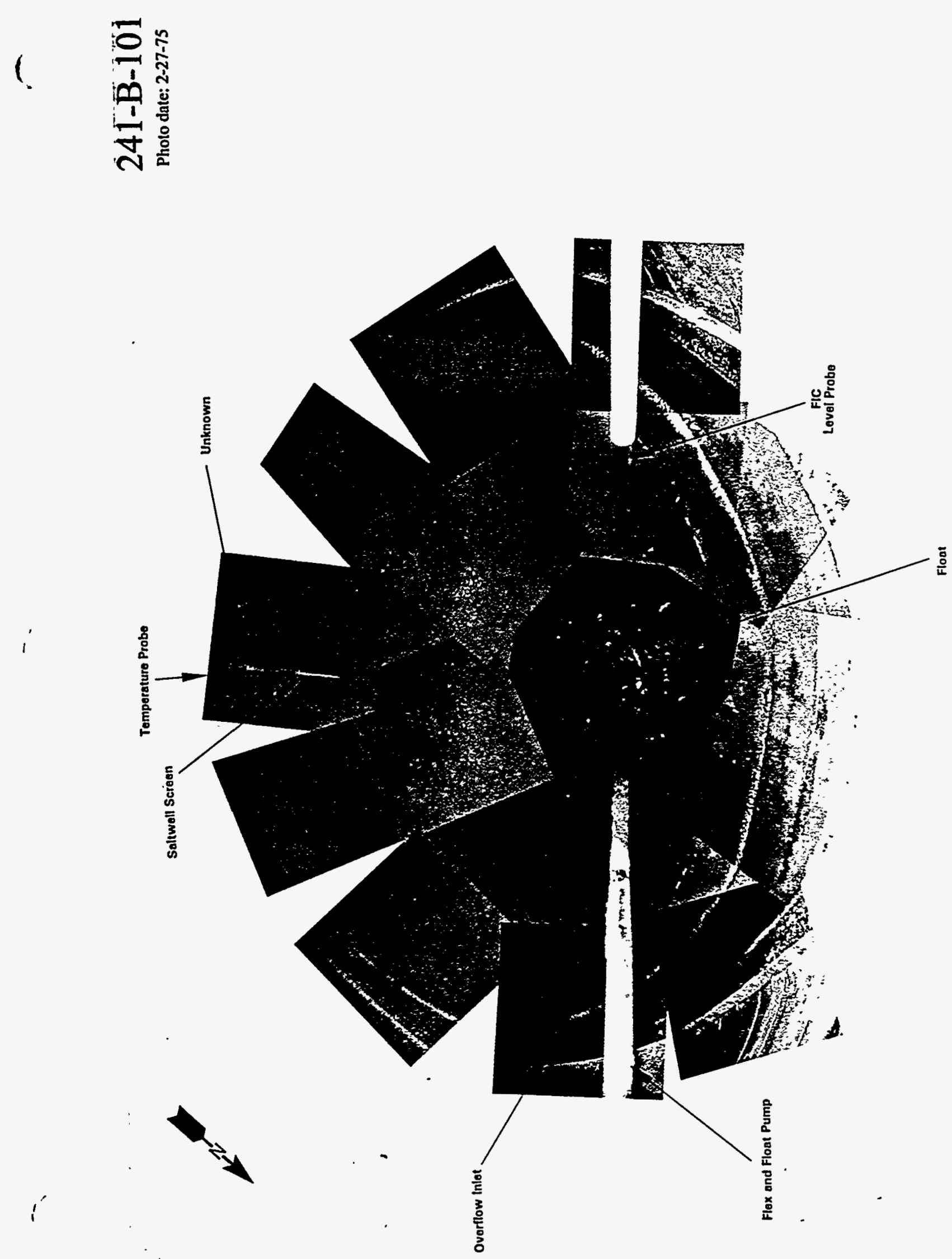
WHC-SD-WM-ER-349, Rev. 0

\subsection{Tank 241-B-102}

\subsubsection{1-B-102 Tank History}

\subsubsection{Waste History Tank 241-B-102}

Activity began in Tank 241-B-102 when it was filled with metal waste from October to December 1945: “In the third quarter of 1978, a level adjustment was made and the tank became inactive. In August 1985, a second level adjustment was made and interim stabilization was achieved after saltwell pumping was complete. In September 1985, intrusion prevention was completed. (See sketch ES-TKS-E12 for a graphical representation of the Tank 241-B-102 level history.)

4.2:1:2 . Temperature History $241+B=102 \ldots \ldots \ldots$

The single thermocouple tree in Tank 241-B-102 has 12 thermocouple probes to record temperature data in riser 4 . The mean temperature of the first recorded daily data was $72^{\circ} \mathrm{F}$. A sum of the squares regression for all the thermocouples starting in 1974 shows a slightly negative near zero slope $\pm 12.5^{\circ} \mathrm{F}$ with an average $I$ square value of 0.01 . From May 1974 to present, the median temperature is $68^{\circ} \mathrm{F}$ with a minimum of $50^{\circ} \mathrm{F}$ and a maximum of $107^{\circ} \mathrm{F}$. Refer to the supporting document for a more thorough review of the temperature data (Brevick 1994).

\subsubsection{Integrity of Tank 241-B-102}

Tank 241-B-102 is categorized as sound and is interim stabilized with intrusion prevention completed. The Tank 241-B-102 surface level is monitored with a Food Instrument corporation gauge through riser 1. A figure that graphically represents the surface level measurements from January 1991 to the present can be found in the supporting documents (Brevick 1994). The surface level for the past 3 years has remained steady and the readings range between 7.2 and 7 -in.

Five drywells are identified for tank 241-B-102, none of which are considered active.

\subsubsection{Current Status of Tank 241-B-102}

Tank 241-B-102 entered service in October 1945 and currently stores 32,000 gal of waste. The waste is comprised of 4,000 gal of supernatant; 24,000 gal of saltcake; 4,000 gal of sludge with no pumpable liquid remaining. The tank is identified as a low-heat load tank, is passively ventilated, and is categorized as sound with interim stabilization and intrusion prevention completed. Tank 241-B-102 is equipped to cascade to Tank $241-B-103$ and is second in the three-tank cascade series. The following plan view and tank cross section depict the approximate waste level and riser configuration. Tank 241-B-102 has 10 risers and $12-$ in. riser no.7 is available for use. 
4.2.2.1 Inventory estimate 241-B-102

The following tank layer volume approximation was derived from the Los Alamos National Laboratories Waste Status and Transaction Record Summary (Agnew 1994). The estimated inventory of Tank 241-B-102 is also presented.

\subsubsection{In-Tank Photograph 241-B-102}

The Tank 241-B-102 photo shows a thin, translucent orange Iiquid surface over a reddish-brown saltcake/sludge surface. The tank contains approximately $32,000 \mathrm{gal}$ of waste which converts to approximately $1 \mathrm{ft}$ deep. Chunks of wood make up some of the debris directly under the camera.. The rings above the debris arexormed "by " condensation dripping from the end of a riser.

\subsubsection{Synopsis Tank 241-B-102}

(To be completed.) 


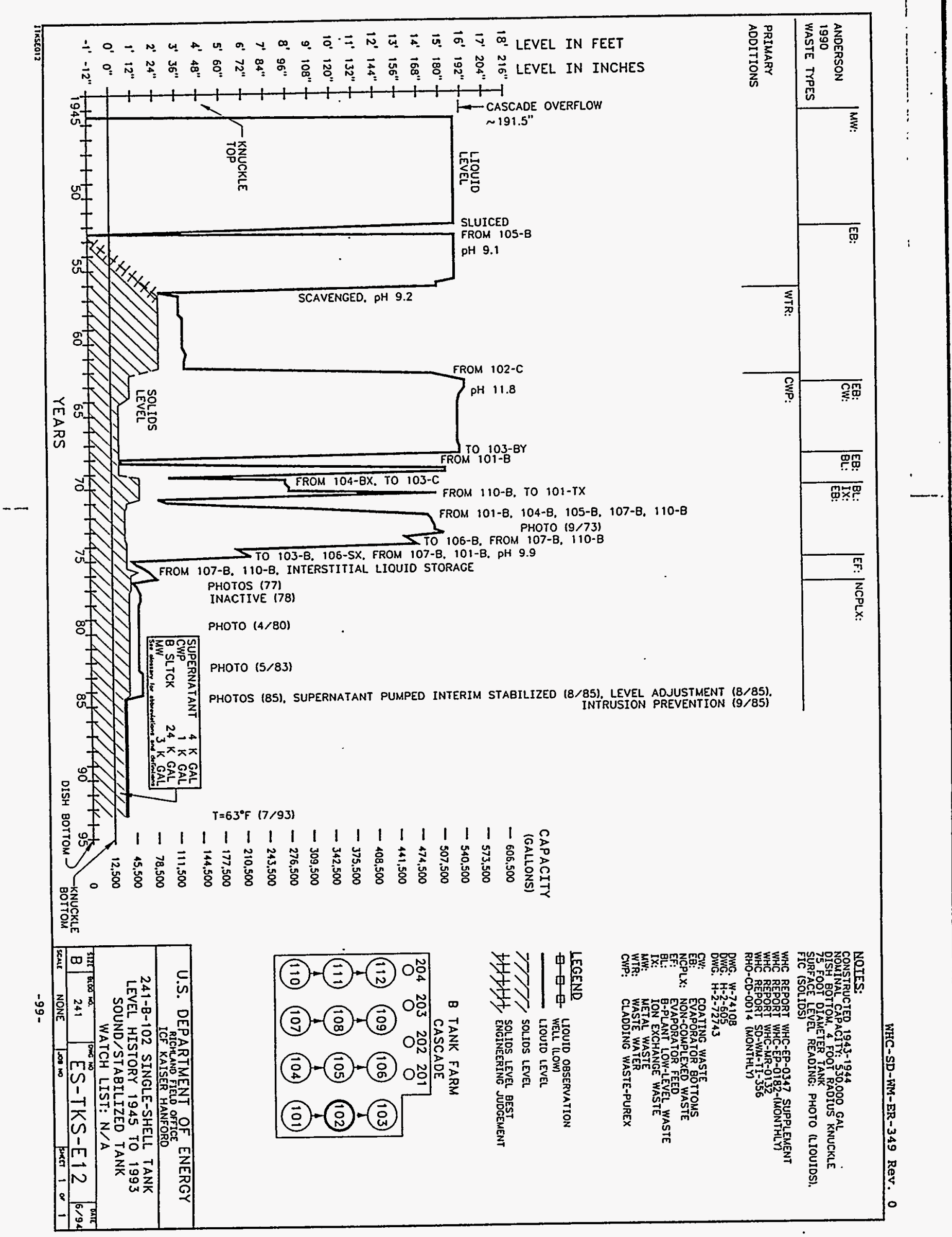




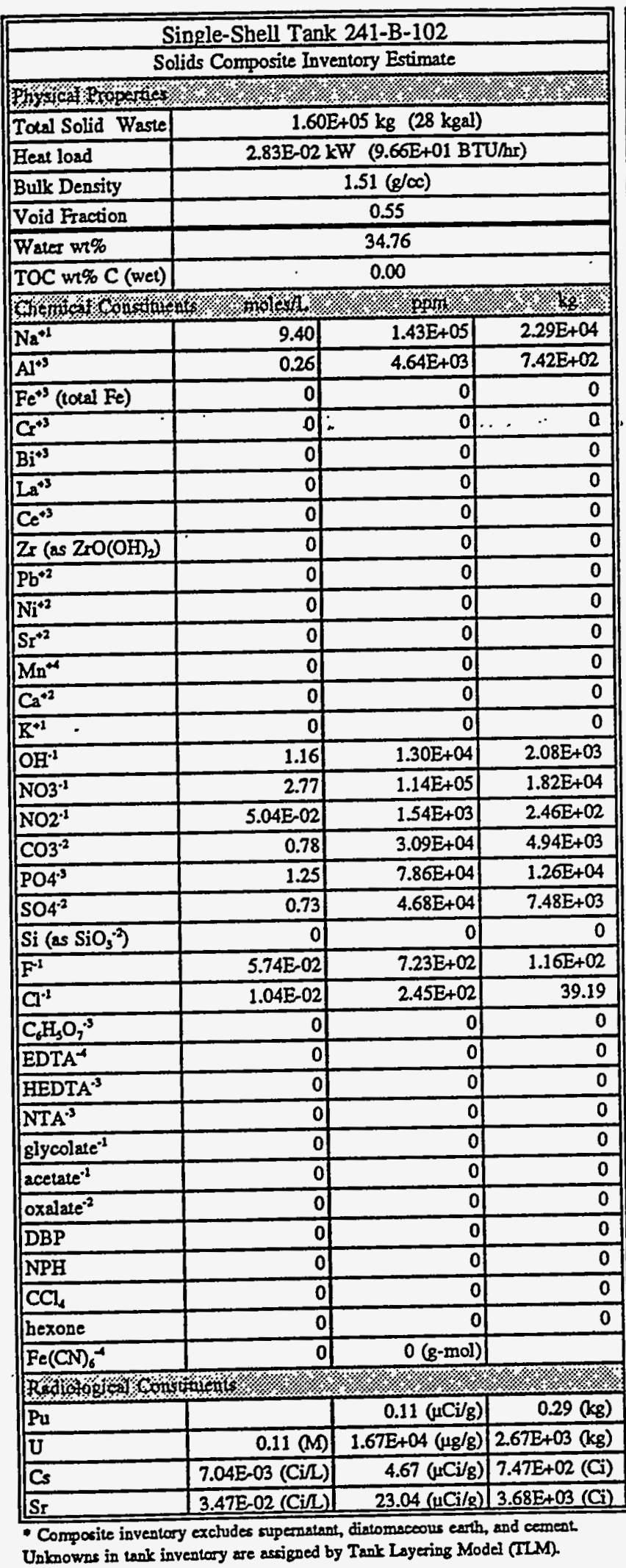

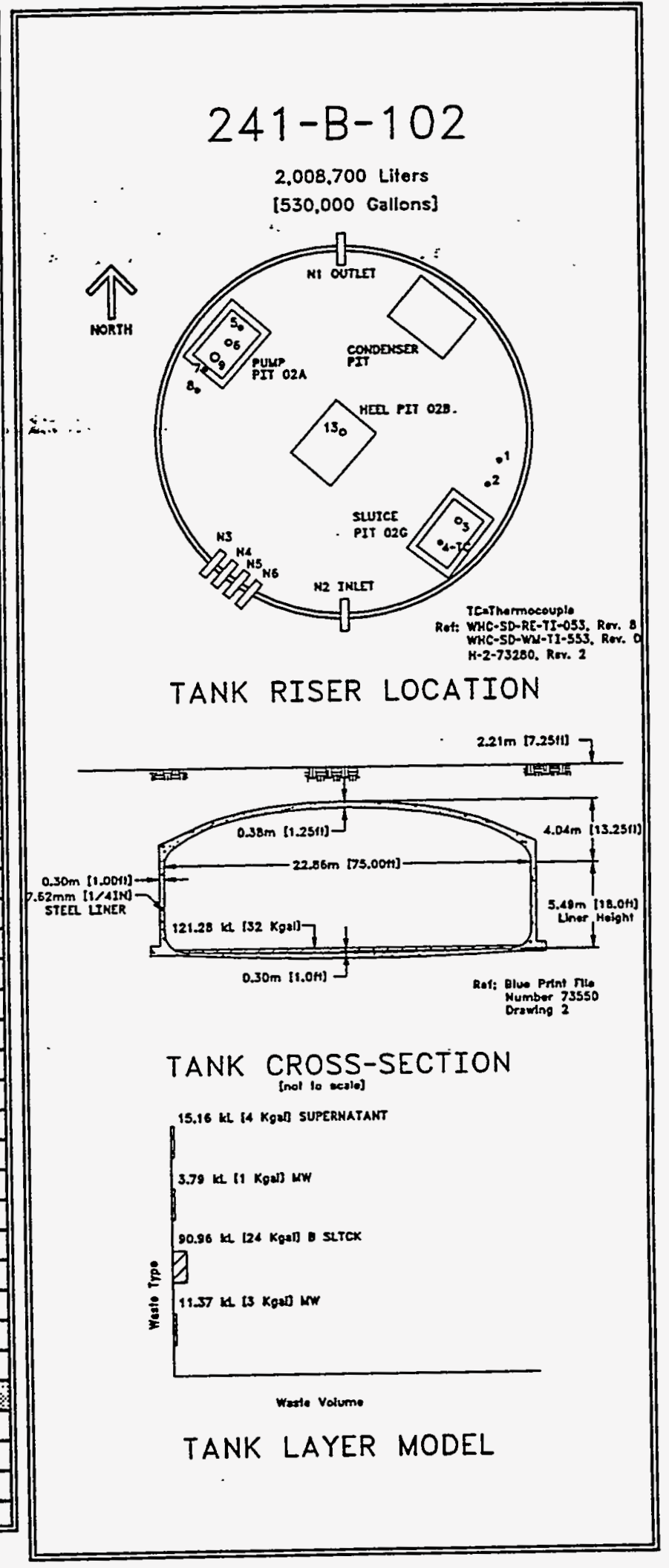




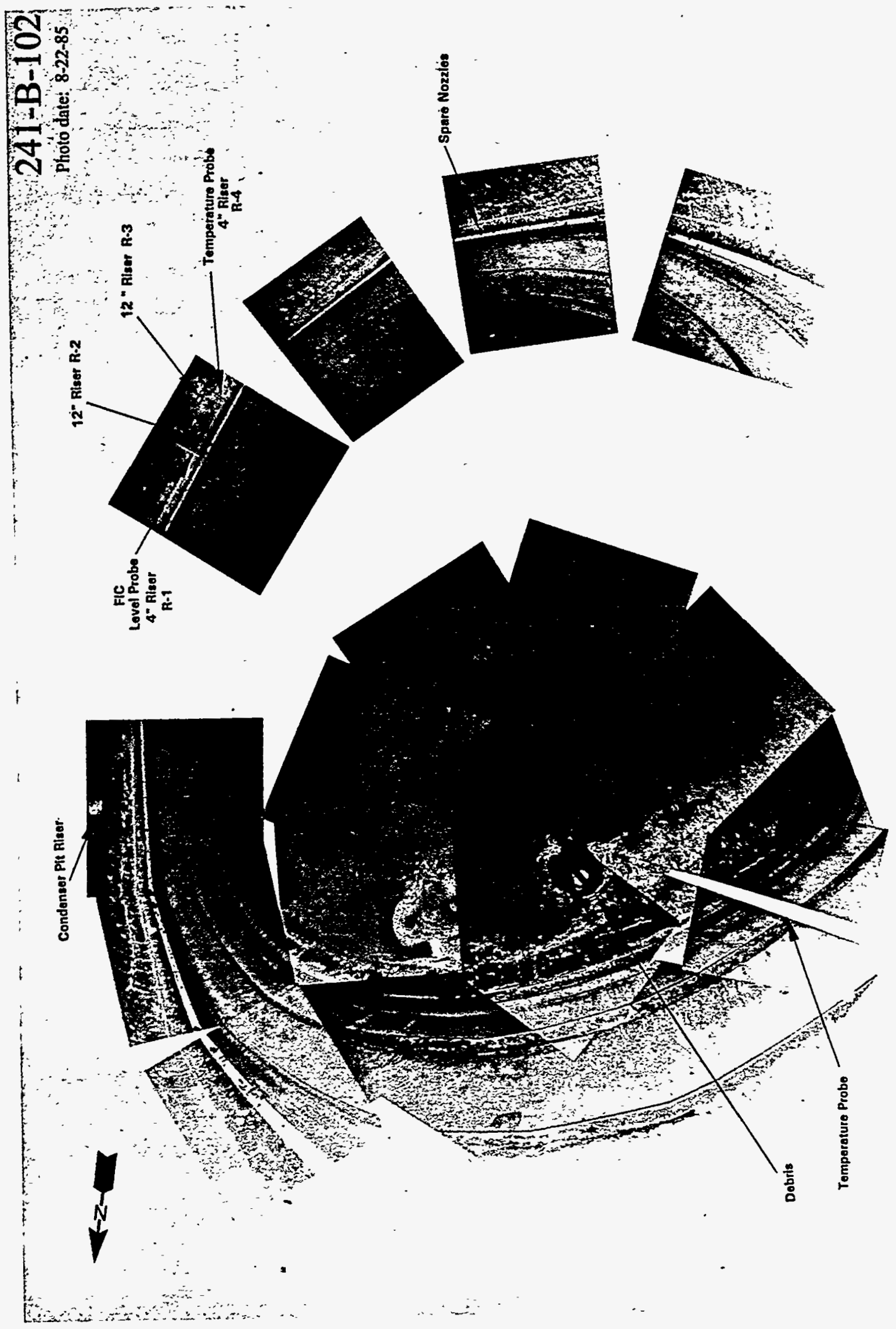


WHC-SD-WM-ER-349, Rev. 0

\subsection{Tank 241-B-103}

\subsubsection{1-B-103 Tank History}

\subsubsection{Waste History Tank 241-B-103}

Activity began in Tank 241-B-103 when it was filled with metal waste between December 1945 and-March 1946. In 1978, tank 241-B-103 was pronounced an assumed leaker of approximately 8,000 gal. The tank was declared inactive in $1978^{\circ}$ and presently contains non-complexed waste. Interim stabilization was achieved after supernatant pumping in February 1985, and intrusion prevention was completed in september of the same year. (See sketch ES-TKS-E13 for a graphical representation of the Tank .241-B,-103. level. history.........

\subsubsection{Temperature History 241-B-103}

The single thermocouple tree in Tank 241-B-103 has 13 thermocouple probes to record temperature data in riser 4 . The mean temperature of the first data taken for thermocouples 1 through 12 was $76.5^{\circ} \mathrm{F}$. A sum of the squares regression line fit for the first 12 thermocouples starting in 1974 shows a slightly negative near zero slope $\pm 4.3^{\circ} \mathrm{F}$ with an average $x$ square value of 0.075 . Not enough data are available for thermocouples 13 and 14 to do an accurate regression and variability analysis. Annual temperature undulations are apparent after January 1991. From september 1974 to present, the median temperature is $62^{\circ} \mathrm{F}$ with a minimum of $40^{\circ} \mathrm{F}$ and a maximum of $199^{\circ} \mathrm{F}$. Refer to the supporting document for a more thorough review of the temperature data (Brevick 1994).

\subsubsection{Integrity of Tank $241-B-103$}

Tank 241-B-103 is categorized as an assumed leaker and is interim stabilized with intrusion prevention completed. The Tank 241-B-102 surface level is monitored with a food Instrument corporation gauge through riser 1. For more information on surface levels see supporting documents (Brevick 1994).

Five drywells are identified for tank 241-B-103, none of which are considered active.

\subsubsection{Current Status of Tank 241-B-103}

Tank 241-B-103 entered service in December 1945 and currently stores 59,000 gal of waste. The waste is comprised of 3,000 gal of sludge; 56,000 gal of saltcake with no pumpable liquid remaining. The tank has been on the Organic Salts Watch Iist since January 1991, is passively ventilated, and is categorized as an assumed leaker with interim stabilization and intrusion prevention completed. Tank 241-B103 is third in the three-tank cascade flow series. Tank 241-B-103 was not equipped to cascade to another tank. The following plan view and tank cross section depict the approximate waste level and riser configuration. Tank 241-B-103 10 risers and 12-in. riser no.2 is 
available for use.

4.3.2.1 Inventory estimate 241-B-103

The following tank layer volume approximation was derived from the Los Alamos National Laboratories Waste Status and Transaction Record Summary (Agnew 1994). The estimated inventory of Tank 241-B-103 is also presented.

\subsubsection{In-Tank Photograph 241-B-103}

The Tank 241-B-103 photo shows a black sludge surface with little pools of supernatant. The tank contains approximately 59,000 gal of waste-which: converts to about:-1. ft deep." The "temperature probe in the background is encrusted with solids halfway between the waste surface and the riser. The tank is on the Organic Salts watch List.

4.3.3 Synopsis Tank 241-B-103

(To be completed.) 


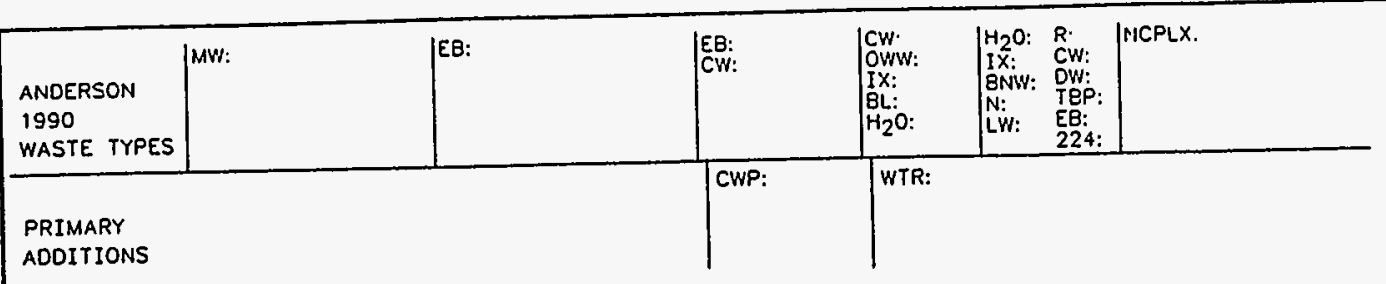

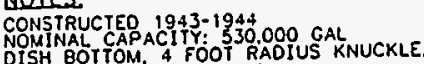

75 FOOT DIAMETER TANK
SIC
SURACE LEVEL READING: FIC

WHC REPORT WHC-EP-0347 SUPPLEMENT

WHC REPORT WHC-EP-0347
WHC REPORT WHC-EP-0182-
WHC REPORI WHC-MR-0132
WHC REP

(MHO-CD-0014 (MONTHLY)

OWG. W-74108

CW: COAYING WASTE
EB: EVAORATORTEOTOMS
OW: OECONTAMINATION WASTE

R: KEEOX WASTE WASTE

Ni: N-REACTOR WASTE

OWW: ORGANIC WASH WASTE

IX: O-PLANT LOW LEVEL WAS

H20: WATER

NCPLX: NON-COMPLEXEO WASTE

APACITY

CWP: CLADING WASTE-PUREX

(GALLONS)

LEGEND

- 606.500

E- LIOUTO OBSERVATION

- 573,500

18' 216" $T^{\prime}$ 을

商 종

$17^{\prime} 204^{\prime \prime}$
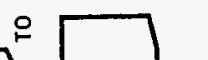

15'180"

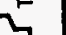

T7P7, SOLIDS LEVEL

$-507.500$

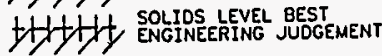

$-474.500$

B TANK FARM

$-441.500$

CASCADE

$-408.500$

\begin{tabular}{cccc|}
204 & 203 & 202 & 201 \\
0 & 0 & 0 & 0
\end{tabular}

$12^{\prime} 144^{\prime \prime}-$

$10^{\circ} 120^{\prime \prime}+8$

$g^{\prime} 108^{\prime \prime}+$

8' 96" † 긍

7 84"

5. $60^{\prime \prime}$

4' $48^{\prime \prime}$

3' $36^{\prime \prime}$

2. 24"

1' 12"

$\begin{array}{cc}0^{\prime} & 0^{\prime \prime} \\ -1^{\circ} & -12^{\prime \prime}\end{array}$

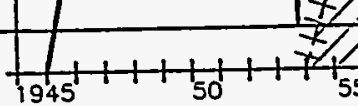

50

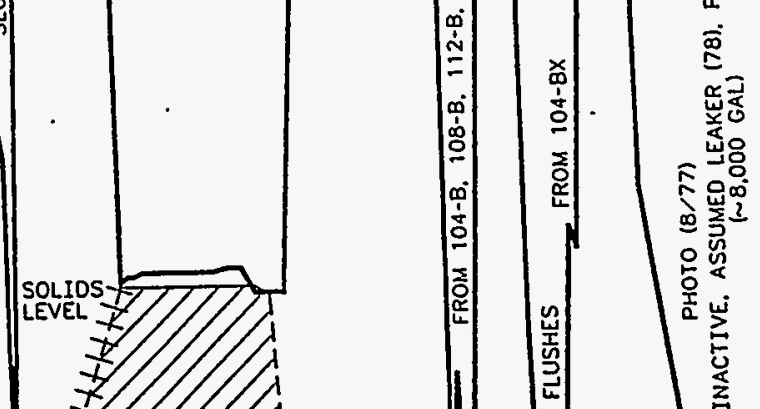

..-
-375.500
$-342.500^{\circ}$

$-309.500$

(112) (109)

$-276.500$

(111) 108 105

年通

$\overline{\overline{3}}-243.500$

응 -210.500

$\overbrace{110}^{1} I_{104}^{1}$

$=-177,500$

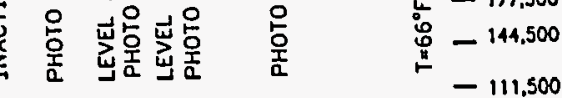

- 78,500

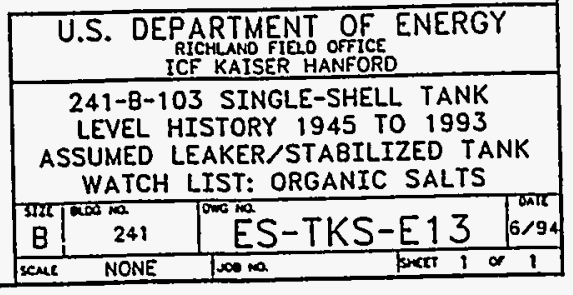

$-104-$ 


\begin{tabular}{|c|c|c|c|}
\hline \multicolumn{4}{|c|}{ Single-Shell Tank 241-B-103 } \\
\hline \multicolumn{4}{|c|}{ Solids Composite Inventory Estimate } \\
\hline \multicolumn{4}{|c|}{ 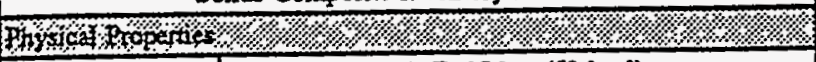 } \\
\hline Total Solid Waste & \multicolumn{3}{|c|}{$3.34 \mathrm{E}+05 \mathrm{~kg}(59 \mathrm{kgal})$} \\
\hline Heat load & \multicolumn{3}{|c|}{$3.28 \mathrm{E}-02 \mathrm{~kW}(1.12 \mathrm{E}+02 \mathrm{BTU} / \mathrm{hr})$} \\
\hline Bulk Density & \multicolumn{3}{|c|}{$1.49(\mathrm{~g} / \infty)$} \\
\hline Void Fraction & \multicolumn{3}{|c|}{0.57} \\
\hline Water wt\% & \multicolumn{3}{|c|}{33.09} \\
\hline TOC wt\% C (wet) & \multicolumn{3}{|c|}{0.00} \\
\hline \multicolumn{4}{|c|}{ 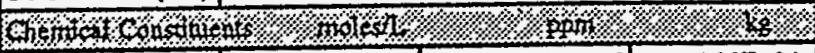 } \\
\hline \begin{tabular}{|l|l|}
$\mathrm{Na}^{4+3}$ \\
\end{tabular} & 9.55 & $1.47 \mathrm{E}+05$ & $4.90 \mathrm{E}+04$ \\
\hline $\mathrm{Al}^{+3}$ & $5.84 \mathrm{E}-02$ & $1.06 \mathrm{E}+03$ & $3.52 \mathrm{E}+02$ \\
\hline $\mathrm{Fe}^{\mathrm{43}}(\mathrm{total} \mathrm{Fe})$ & of & 0 & 0 \\
\hline$C_{1}^{43} \cdot \ldots \ldots \ldots$ & $\therefore \ldots \therefore \ldots 0$ & $\because \therefore \ldots$ & 9 \\
\hline $\mathrm{Bi}^{+3}$ & 0 & 요 & 0 \\
\hline $\mathrm{La}^{43}$ & of & of & 0 \\
\hline $\mathrm{Ce}^{43}$ & of & 0 & 0 \\
\hline $\mathrm{Zr}\left(\mathrm{as} \mathrm{ZrO}(\mathrm{OH})_{2}\right)$ & 0) & 이 & 0 \\
\hline $\mathrm{Pb}^{42}$ & of & 0) & 0 \\
\hline $\mathrm{Ni}^{2+2}$ & 0) & of & 0 \\
\hline$S r^{42}$ & 0 & of & 0 \\
\hline $\mathrm{Mn}^{+1}$ & of & 0 & 0 \\
\hline $\mathrm{Ca}^{+2}$ & 0 & of & 0 \\
\hline $\mathrm{K}^{+1}$ & 0 & 0 & 0 \\
\hline $\mathrm{OH}^{-1}$ & 0.37 & $4.26 \mathrm{E}+03$ & $1.42 \mathrm{E}+03$ \\
\hline $\mathrm{NO3}^{-1}$ & 3.04 & $1.26 \epsilon+05$ & $4.21 \mathrm{E}+04$ \\
\hline $\mathrm{NO}^{-1}$ & $4.85 \mathrm{E}-02$ & $1.49 \mathrm{E}+03$ & $4.98 \mathrm{E}+02$ \\
\hline $\cos ^{-2}$ & 0.70 & $2.80 \mathrm{E}+04$ & $9.35 \mathrm{E}+03$ \\
\hline $\mathrm{PO}^{.3}$ & 1.19 & $7.55 \mathrm{E}+04$ & $2.52 \mathrm{E}+04$ \\
\hline $504^{-2}$ & 0.81 & $5.21 \mathrm{E}+04$ & $1.74 E+04$ \\
\hline $\mathrm{Si}\left(\right.$ as $\left.\mathrm{SiO}_{3}^{-2}\right)$ & 0 & 0 & 0 \\
\hline $\mathrm{F}^{2}$ & $6.35 \mathrm{E}-02$ & $8.08 \mathrm{E}+02$ & $2.70 \mathrm{E}+02$ \\
\hline $\mathrm{C}^{-1}$ & $1.16 \mathrm{E}-02$ & $2.74 \mathrm{E}+02$ & 91.44 \\
\hline $\mathrm{C}_{6} \mathrm{H}_{3} \mathrm{O}_{7}{ }^{-3}$ & 0 & 0 & 0 \\
\hline EDTA & 0 & 0 & 0 \\
\hline HEDTA ${ }^{-3}$ & a & 0 & 0 \\
\hline $\mathrm{NTA}^{.3}$ & 0) & 0 & 0 \\
\hline glycolate & 0 & 0 & 0 \\
\hline aceture ${ }^{-1}$ & 요 & 0 & 0 \\
\hline oxalate.2 & 의 & 0 & 0 \\
\hline DBP & 0] & 0 & 0 \\
\hline NPH & 의 & 0 & 0 \\
\hline $\mathrm{Cl}_{4}$ & 0 & 0 & 0 \\
\hline hexone & of & 0 & 0 \\
\hline $\mathrm{Fe}(\mathrm{CN})_{6}^{-{ }^{-1}}$ & 0 & $0(\mathrm{~g}-\mathrm{mol})$ & \\
\hline \multicolumn{4}{|c|}{ 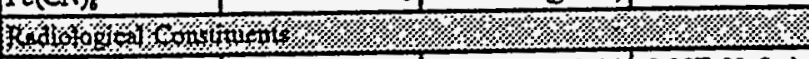 } \\
\hline $\mathrm{Pu}$ & & $7.15 \mathrm{E}-03(\mathrm{uCi} / \mathrm{g})$ & $3.98 \mathrm{E}-02(\mathrm{~kg})$ \\
\hline $\mathrm{U}$ & $6.60 \mathrm{E}-02(\mathrm{M})$ & $1.05 E+04(\mu \mathrm{g} / \mathrm{g})$ & $3.51 \mathrm{E}+04(\mathrm{~kg})$ \\
\hline Cs & $7.59 \mathrm{E}-03(\mathrm{Ci} / \mathrm{L})$ & $5.08(1 \mathrm{Ci} / \mathrm{B})$ & $1.69 \mathrm{E}+03(\mathrm{Ci})$ \\
\hline $\mathrm{Sr}$ & $1.65 \mathrm{E}-02(\mathrm{Ci} / \mathrm{L})$ & $11.04(\mu \mathrm{Ci} / \mathrm{g})$ & $3.68 \mathrm{E}+03(\mathrm{Ci})$ \\
\hline
\end{tabular}

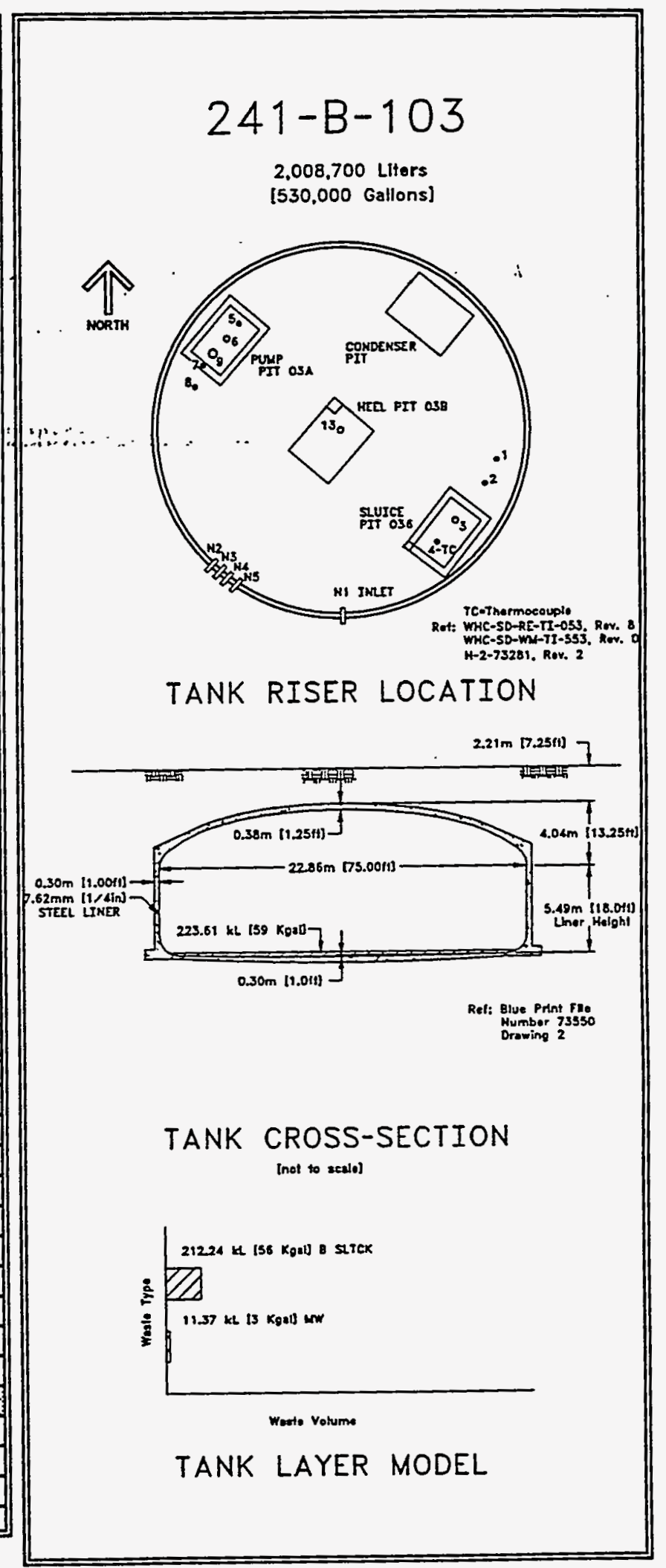

$6 / 94$

$6 / 94$ 


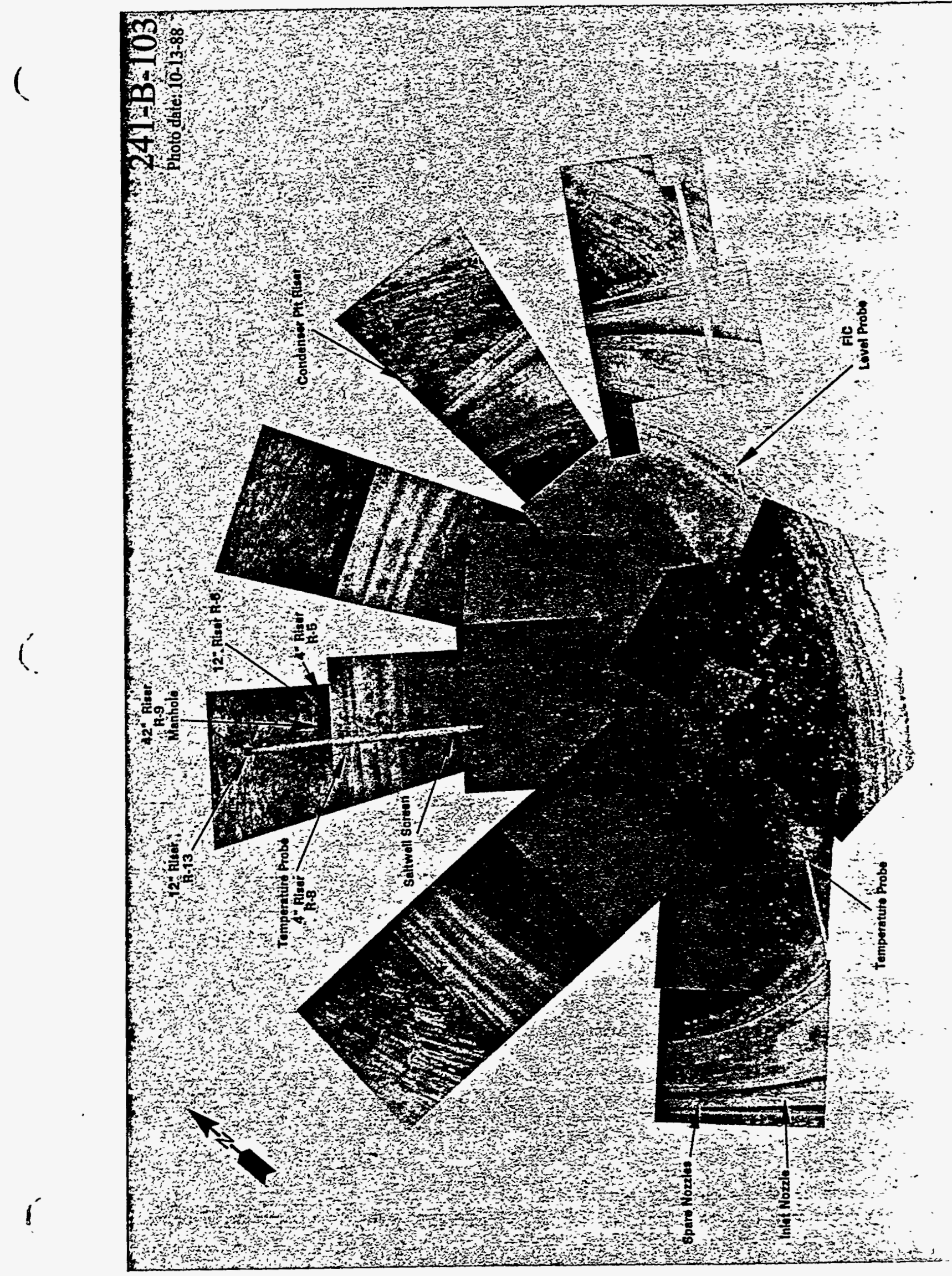


4.4 Tank 241-B-104

4.4.1 241-B-104 Tank History

\subsubsection{Waste History Tank 241-B-104}

Activity began in Tank 241-B-104 when it was filled with second cycle waste between August 1946: and February. 1947. During the fourth quarter of 1977. and the first quarter of 1978, a salt well was installed in Tank 241-B-104. The tank was declared inactive in 1978. Presently, the tank contains non-complexed waste. A P-10 pump was installed in the third quarter of 1978, a level adjustment was made in January 1984, and the tank was declared interim stabilized after it was saltwell pumped in. June 1985. A level adjustment was made in June 1985 and

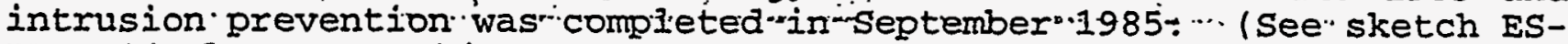
TKS-E14 for a graphical representation of the Tank 241-B-104 level history.)

\subsubsection{Temperature History 241-B-104}

Tank 241-B-104 contains a single thermocouple tree with 12 thermocouple probes in riser 5 . The mean temperature of the first recorded data for thermocouples 1 through 11 was $63^{\circ} \mathrm{F}$. A sum of the squares regression line fit for the first 11 thermocouples starting in 1975 shows an overall zero slope $\pm 11.4^{\circ} \mathrm{F}$ with an average $I$ square value of 0.02. From April 1975 to present, the median temperature is $66^{\circ} \mathrm{F}$ with a minimum of $52^{\circ} \mathrm{F}$ and a maximum of $122^{\circ} \mathrm{F}$. Refer to the supporting document for a more thorough review of the temperature data (Brevick 1994).

\subsubsection{Integrity of Tank 241-B-104}

Tank 241-B-104 is categorized as sound and is interim stabilized with intrusion prevention completed. The Tank 241-BL104 surface level is monitored quarterly with a manual tape through riser 8 . The figure graphically representing the surface level measurements from January 1991 to the present can be found in the supporting documents (Brevick 1994). The surface level for the past 3 years has remained steady and the readings range between 132 and 131.75 -in.

Two drywelis are identified for tank 241-B-104, none of which are considered active.

\subsubsection{Current status of Tank 241-B-104}

Tank 241-B-104 entered service in August 1946 and currently stores 371,000 gal of waste. The waste is comprised of 1,000 gal of supernatant; 61,000 gal of saltcake; 90,000 gal of unknown waste; 219,000 gal of sludge; with 40,000 gal of pumpable liquid remaining. The tank is identified as a low-heat load tank, is passively ventilated, and is categorized as sound with interim stabilization and intrusion prevention completed. Tank $241-B-104$ is equipped to cascade to Tank 241-B-105 and is first in the three-tank cascade flow series. The 
following plan view and tank cross section depict the approximate waste level and riser configuration. Tank 241-B-104 10 risers and two 12-in. risers nos.2 and 3 are available for use.

\subsubsection{Inventory estimate 241-B-104}

The following tank layer volume approximation was derived from Los Alamos National Laboratories Waste Status and Transaction Record Summary

$\therefore$ (Agnew 1994). The estimated inventory of Tank 241-B-104 is also presented.

\subsubsection{In-Tank Photograph 241-B-104}

The Tank -241-B-1.04 photo shows a-thin; .bright.yellow liquid surface with an off-white sludge/salticake emerging. Thie tank contains about $372,000 \mathrm{gal}$ of waste which converts to almost $11 \mathrm{ft}$ deep. The debris in the bottom of the picture contains sludge measurement weights, old sample bottles, and some old level measurement tape. The white spot to the left of the debris is a result of the camera flash.

\subsubsection{Synopsis Tank 241-B-104}

(To be completed.) 

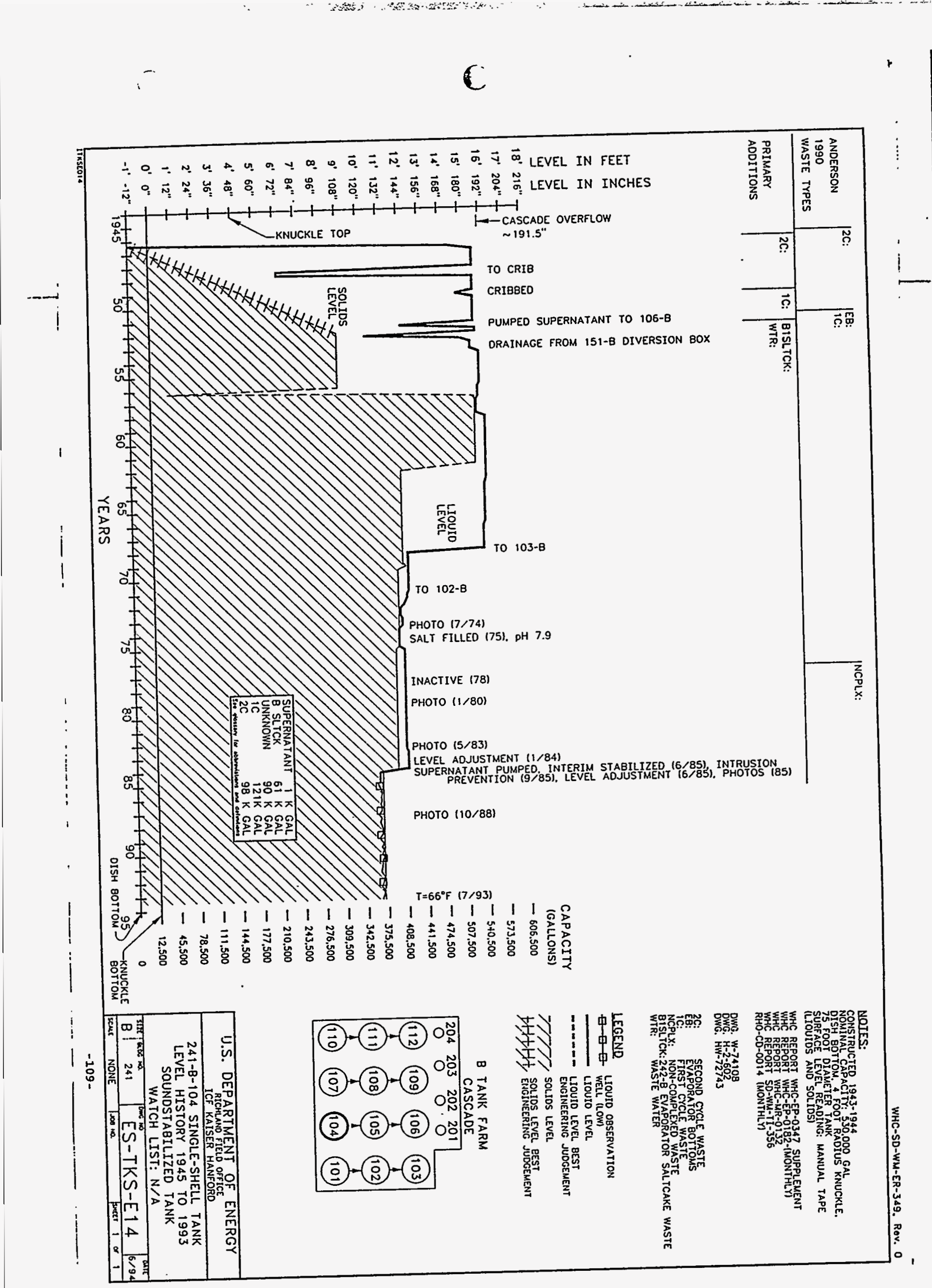


\begin{tabular}{|c|c|c|c|}
\hline \multicolumn{4}{|c|}{ Single-Shell Tank 241-B-104 } \\
\hline \multicolumn{4}{|c|}{ Solids Composite Inventory Estimate } \\
\hline \multicolumn{4}{|c|}{ 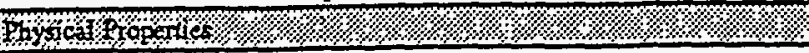 } \\
\hline Total Solid Waste & \multicolumn{3}{|c|}{$1.44 \mathrm{E}+06 \mathrm{~kg}(280 \mathrm{kgal})$} \\
\hline Heat load & \multicolumn{3}{|c|}{$4.76 \mathrm{E}-02 \mathrm{~kW}(1.62 \mathrm{E}+02 \mathrm{BTU} / \mathrm{hr})$} \\
\hline Bulk Density & \multicolumn{3}{|c|}{$1.36(\mathrm{~g} / \mathrm{cc})$} \\
\hline Void Fraction & \multicolumn{3}{|c|}{0.62} \\
\hline Wates on & \multicolumn{3}{|c|}{59.82} \\
\hline TOC wr\% C (wet) & \multicolumn{3}{|c|}{0.00} \\
\hline \multicolumn{4}{|c|}{ 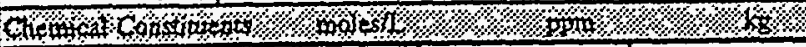 } \\
\hline \begin{tabular}{|l|l}
$\mathrm{Na}^{\mathrm{at}}$ & $\mathrm{T}$ \\
\end{tabular} & 6.67 & $1.13 \mathrm{E}+05$ & $1.63 E+05$ \\
\hline $\mathrm{Al}^{+3}$ & 0.14 & $2.83 \mathrm{E}+03$ & $4.09 \mathrm{E}+03$ \\
\hline $\mathrm{Fe}^{+3}$ (total Fe) & 0.22 & $8.95 \mathrm{E}+03$ & $1.29 \mathrm{E}+04$ \\
\hline $\mathrm{Cr}^{-3}$ & $1.15 \mathrm{E}=02$ & $\because . .47 \mathrm{E}_{ \pm} 02$ & $\because \therefore 6: 31 E_{4} 02$ \\
\hline $\mathrm{Bi}^{+3}$ & $9.56 \mathrm{E}-02$ & $1.47 \mathrm{E}+04$ & $2.12 \mathrm{E}+04$ \\
\hline Lat3 & 0 & 0 & 0 \\
\hline $\mathrm{Ce}^{43}$ & 0 & 0 & 0 \\
\hline $\mathrm{Zx}$ (as $\left.\mathrm{ZrO}(\mathrm{OH})_{2}\right)$ & $1.26 \mathrm{E}-02$ & $8.45 E+02$ & $1.22 \mathrm{E}+03$ \\
\hline $\mathrm{Pb}^{+2}$ & of & 0 & 0 \\
\hline $\mathrm{Ni}^{* 2}$ & of & 0 & 0 \\
\hline $\mathrm{Sr}^{+2}$ & of & 0 & 0 \\
\hline $\mathrm{Mn}^{+4}$ & of & 0 & 0 \\
\hline $\mathrm{Ca}^{+2}$ & 0] & 0 & 0 \\
\hline $\mathrm{R}^{+1}$ & 0 & 0 & 0 \\
\hline $\mathrm{OH}^{-1}$ & 1.24 & $1.55 \mathrm{E}+04$ & $2.24 \mathrm{E}+04$ \\
\hline $\mathrm{NO}^{-1}$ & 1.02 & $4.66 \mathrm{E}+04$ & $6.72 \mathrm{E}+04$ \\
\hline $\mathrm{NO}^{-1}$ & 5.77E-02 & $1.95 \mathrm{E}+03$ & $2.81 \mathrm{E}+03$ \\
\hline $\mathrm{CO}^{-2}$ & 0.13 & $5.84 \mathrm{E}+03$ & $8.43 \mathrm{E}+03$ \\
\hline $\mathrm{PO}^{-3}$ & 1.51 & $1.05 \mathrm{E}+05$ & $1.52 \mathrm{E}+05$ \\
\hline $\mathrm{SO}^{-2}$ & 0.21 & $1.51 \mathrm{E}+04$ & 2.17E+04 \\
\hline $\mathrm{Si}\left(\right.$ as $\left.\mathrm{SiO}_{3}^{-2}\right)$ & 0.31 & $6.40 \mathrm{E}+03$ & $9.24 \mathrm{E}+03$ \\
\hline $\mathrm{F}^{1}$ & 0.13 & $1.80 \mathrm{E}+03$ & $2.60 \mathrm{E}+03$ \\
\hline$a^{\cdot 1}$ & $2.65 \mathrm{E}-03$ & 69.02 & 99.61 \\
\hline $\mathrm{C}_{6} \mathrm{H}_{3} \mathrm{O}_{7}^{-3}$ & 0 & 0 & 0 \\
\hline EDTA $^{-1}$ & 요 & 0 & 0 \\
\hline HEDTA ${ }^{-3}$ & 0 & 0 & 0 \\
\hline NTA ${ }^{3}$ & 요 & 0 & 0 \\
\hline Blycolate & 01 & 0 & 0 \\
\hline ecetate ${ }^{-1}$ & 可 & 0 & 0 \\
\hline oxalate & of & 0 & 0 \\
\hline $\mathrm{DBP}$ & 의 & 0 & 0 \\
\hline NPH & 0 & 0 & 0 \\
\hline $\mathrm{CCl}_{4}$ & 0 & 0 & 0 \\
\hline hexone & 0) & 0 & 0 \\
\hline $\mathrm{Fe}(\mathrm{CN})_{6}{ }^{2}$ & 0 & $0(\mathrm{~g}-\mathrm{mol})$ & \\
\hline \multicolumn{4}{|c|}{ 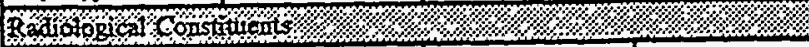 } \\
\hline Pu & & $7.37 \mathrm{E}-02(\mu \mathrm{Ci} / \mathrm{g})$ & $1.77(\mathrm{~kg})$ \\
\hline $\mathrm{U}$ & $2.87 \mathrm{E}-02(M)$ & $5.02 \mathrm{E}+03(\mu \mathrm{g} / \mathrm{g})$ & $7.24 \mathrm{E}+03(\mathrm{~kg})$ \\
\hline Cs & $2.12 \mathrm{E}-03(\mathrm{Ci} / \mathrm{L})$ & $1.56(\mu \mathrm{Ci} / \mathrm{g})$ & $2.25 \mathrm{E}+03(\mathrm{C})$ \\
\hline Sr & $5.19 \mathrm{E}-03(\mathrm{Ci} / \mathrm{L})$ & $3.81(\mathrm{\mu Ci} / \mathrm{s})$ & $5.50 \mathrm{E}+03(\mathrm{Ci})$ \\
\hline
\end{tabular}

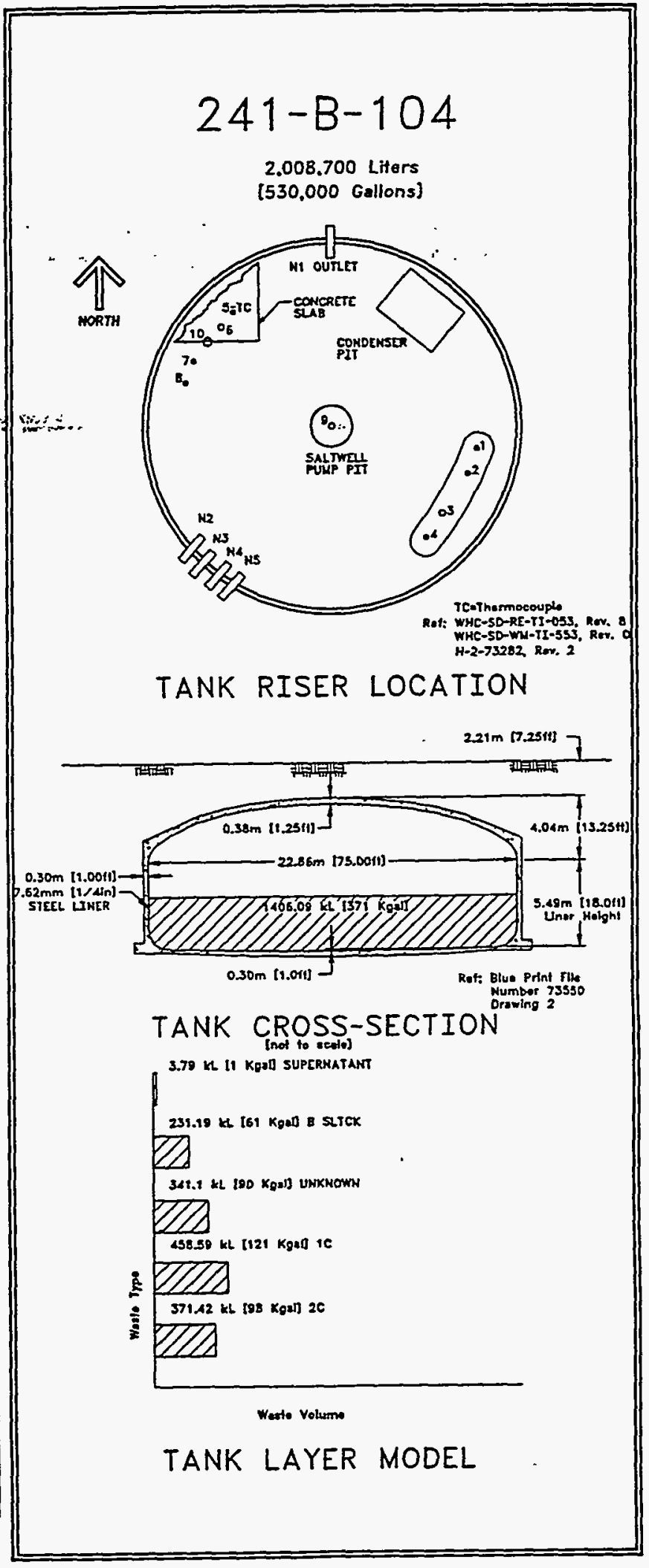

- Composite inventory excludes supersatant, diatomscoous earh, and cemeal

Unkoowns in tank inventory are not ass 
WHC-SD-WM-ER-349 Rev. 0

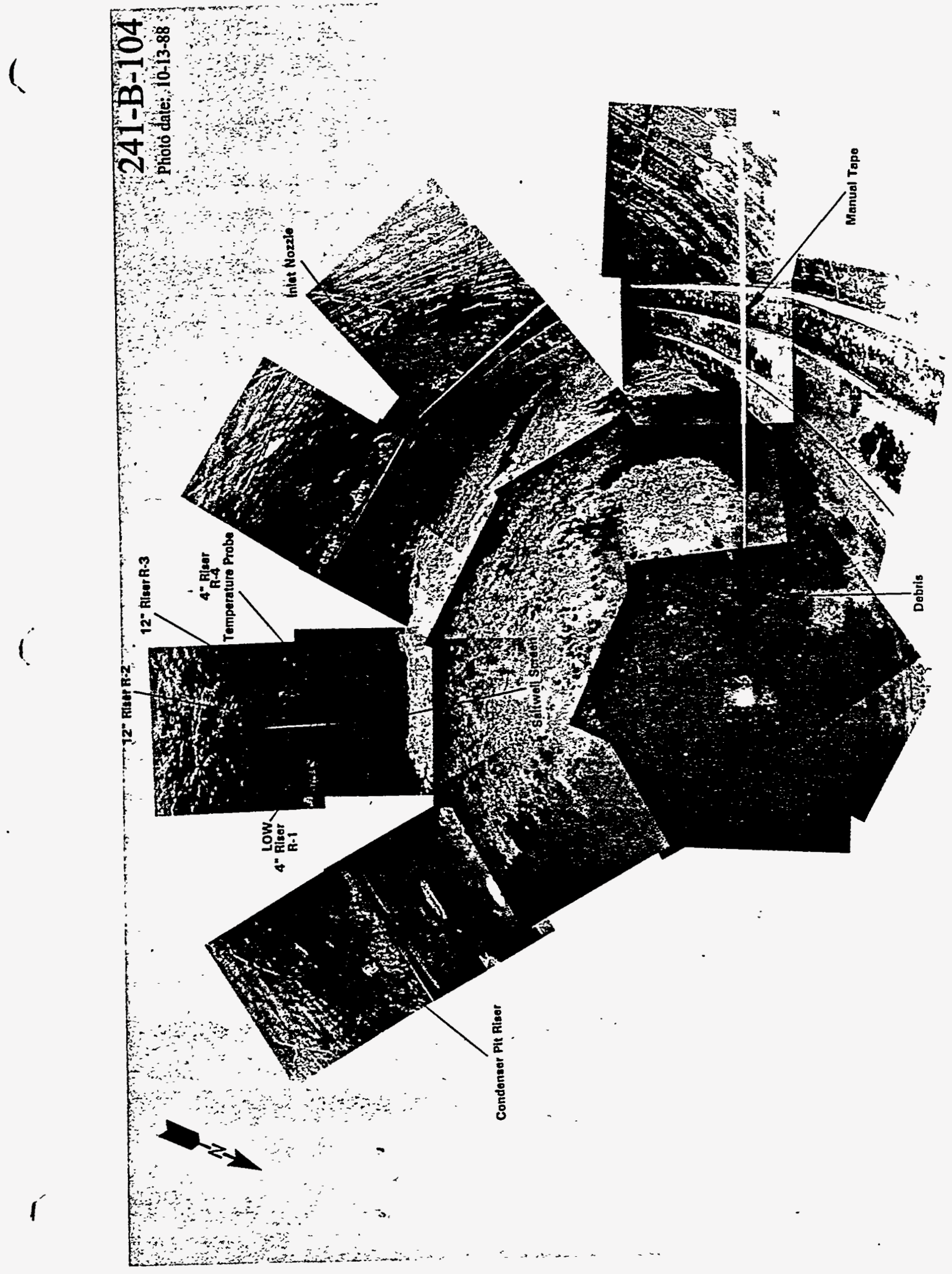


WHC-SD-WM-ER-349, Rev. 0

\subsection{Tank 241-B-105}

4.5.1 241-B-105 Tank History

4.5.1.1 Waste History Tank 241-B-105

Tank 241-B-105 began operating in February 1947 and was filled with second-cycle waste from tank 241-B-104 via the cascade line by August 1947. Tank 241-B-105 was declared an assumed leaker in 1978 with a leak volume of approximately 8,000 gai. During the same year; Tank 241B-105 was considered inactive and primary stabilized. Interim stabilization and a level adjustment occurred in December 1984. Intrusion prevention was completed in October 1985. (See sketch ES-TKSE15 for a graphical representation of the Tank 241-B-105 level history.)

4.5.1.2 Temperature History 241-B-105

The single thermocouple tree in Tank 241-B-105 has 13 thermocouple probes to measure temperature data in riser 15. The mean temperature of the first recorded data for thermocouples 1 through 11 was $65^{\circ} \mathrm{F}$. A sum of the squares regression line fit for the first 11 thermocouples starting in 1976 shows an overall zero slope $\pm 10.4^{\circ} \mathrm{F}$ with an average $r$ square value of 0.1 . A regression and variability analysis is not valid for thermocouple 12 because a large amount of error is induced from the few data points available and an outlying data point common to the first 11 thermocouples. Not enough data are available for a regression or variability analysis on thermocouple 13. From April 1976 to present, the median tank temperature is $67^{\circ} \mathrm{F}$ with a minimum of $51^{\circ} \mathrm{F}$ and a maximum of $107^{\circ} \mathrm{F}$. Refer to the supporting document for a more thorough review of the temperature data (Brevick 1994).

\subsubsection{Integrity of Tank 241-B-105}

Tank 241-B-105 is categorized as an assumed leaker and is interim stabilized with intrusion prevention completed. The Tank 241-B-102 surface level is monitored quarterly with a manual tape through riser 14. A figure that graphically represents the surface level measurements from January 1991 to the present can be found in the supporting documents (Brevick 1994). The surface level for the past 3 years has an increasing trend as the readings have steadily increased from 41.5 in. during the first quarter of 1991 to 42.5 in. during the fourth quarter of 1993 .

One drywell is idendified for tank 241-B-105 and the data and graphical representation for from January of 1990 to present can be found in the supporting document (Brevick 1994).

\subsubsection{Current status of Tank 241-B-105}

Tank 241-B-105 entered service in January 1947 and currently contains 306,000 gal of waste. The waste is comprised of $278,000 \mathrm{gal}$ of saltcake; 28,000 gal of sludge; and no supernatant or pumpable liquid remaining. The tank is identified as a low-heat load tank, is passively 
WHC-SD-WM-ER-349, Rev . 0

ventilated, and is categorized as an assumed leaker with interim stabilization and intrusion prevention completed. Tank 241-B-105 is equipped to cascade to Tank 241-B-106 and is second in the three-tank cascade flow series. The following plan view and tank cross section depict the approximate waste level and riser configuration. Tank 241-B105 has 12 risers and three are readily available for use: 12-in. risers nos. 3,6 and 7 .

\subsubsection{Inventory estimate 241-B-105}

The following tank layer volume approximation was derived from the Los Alamos National Laboratories Waste Status and Transaction Record Summary (Agnew 1994). The estimated inventory of Tank 241-B-105 is also presented..

\subsubsection{In-Tank Photograph 241-B-105}

The Tank 241-B-105 photo shows a white to light yellow saltcake surface with a small amount of liquid showing at the base of the saltwell screen. The tank contains about 306,000 gal of waste which converts to approximately $9 \mathrm{ft}$ deep. The depression in the center probably resulted from the liquid being pumped out and the saltcake surface collapsing to fill the void.

4.5.3 Synopsis Tank 241-B-105

(To be completed.) 


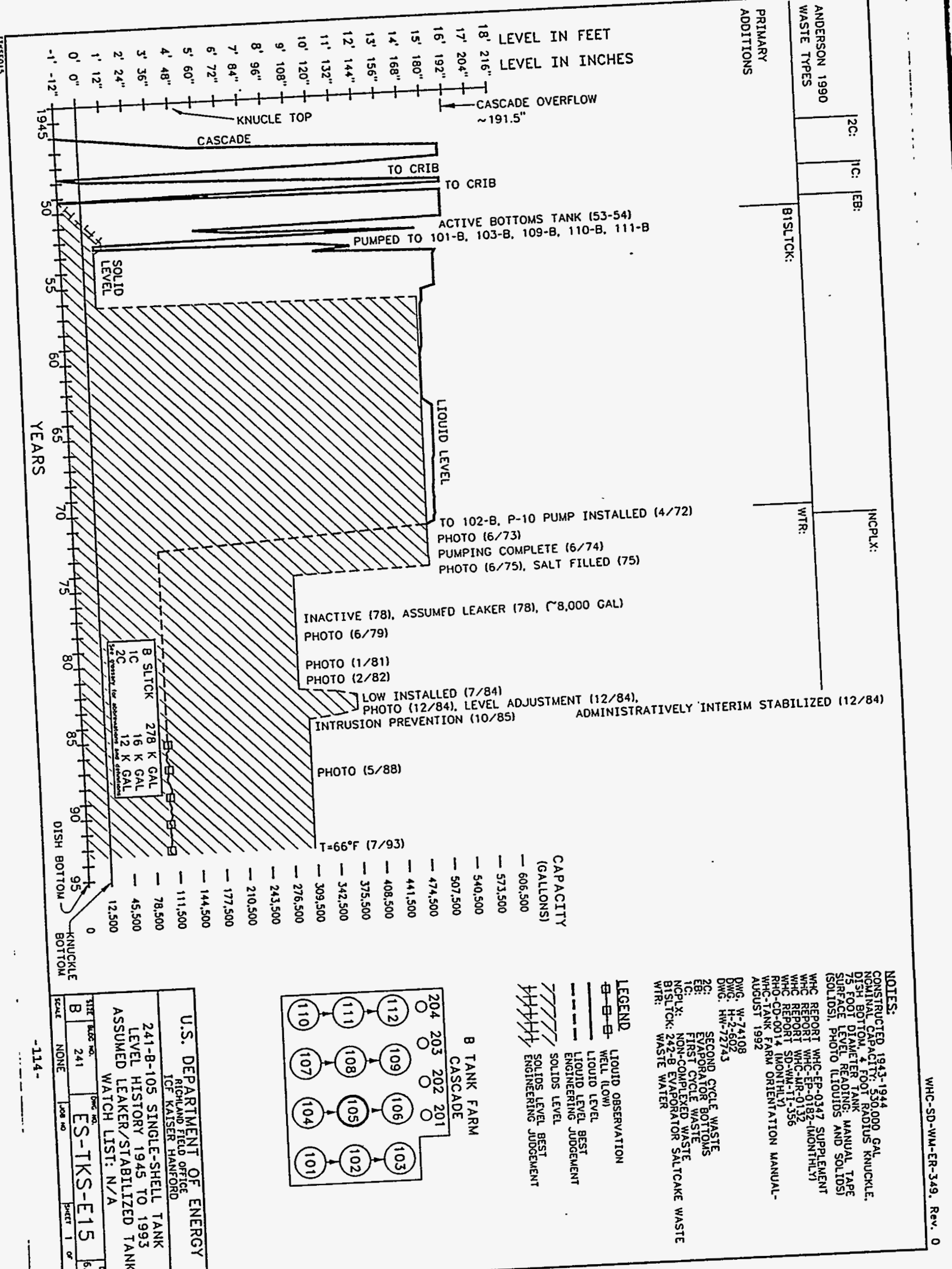


WHC-SD-WM-ER-349, Rev. O

\begin{tabular}{|c|c|c|c|}
\hline \multicolumn{4}{|c|}{ Single-Sheil Tank 241-B-105 } \\
\hline \multicolumn{4}{|c|}{ Solids Composite Inventory Estimate } \\
\hline Physulfopties? & א\%/\% & \% & \\
\hline Total Solid Waste & \multicolumn{3}{|c|}{$1.70 \mathrm{E}+06 \mathrm{~kg}(306 \mathrm{kgal})$} \\
\hline Heat load & \multicolumn{3}{|c|}{ 4.37E-02 kW (1.49E $+02 \mathrm{BTU} / \mathrm{hr})$} \\
\hline Bulk Density & \multicolumn{3}{|c|}{$1.47(g / \infty)$} \\
\hline Void Fraction & \multicolumn{3}{|c|}{0.59} \\
\hline Water wr\% & \multicolumn{3}{|c|}{35.55} \\
\hline TOC wr\% C (wet) & \multicolumn{3}{|c|}{0.00} \\
\hline \multicolumn{4}{|c|}{ 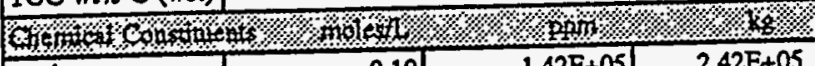 } \\
\hline $\mathrm{Na}^{41}$ & 9.10 & $1.42 E+05$ & $2.42 \mathrm{E}+05$ \\
\hline $\mathrm{Al}^{+3}$ & $7.16 \mathrm{E}-02$ & $1.32 \mathrm{E}+03$ & $2.24 \mathrm{E}+03$ \\
\hline $\mathrm{Fe}^{\text {ts }}$ (10tal Fe) & 2.53E-02 & $9.61 E+02$ & $1.64 \mathrm{E}+03$ \\
\hline$a^{43}$ & $1.34 \mathrm{E}-03-2$ & 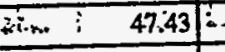 & $2 \ldots .80 .21$ \\
\hline $\mathrm{Bi}^{+3}$ & $1.11 \mathrm{E}-02$ & $1.58 \mathrm{E}+03$ & $2.69 \mathrm{E}+03$ \\
\hline $\mathrm{La}^{+3}$ & 0 & 0 & 0 \\
\hline $\mathrm{Ce}^{43}$ & 0 & 0 & 0 \\
\hline $\mathrm{Zr}$ (as $\mathrm{ZrO}\left(\mathrm{OH}_{2}\right)$ & $1.53 \mathrm{E}-03$ & 94.80 & $1.61 \mathrm{E}+02$ \\
\hline $\mathrm{Pb}^{42}$ & of & 0 & 0 \\
\hline $\mathrm{Ni}^{+2}$ & of & of & 0 \\
\hline $\mathrm{Sr}^{+2}$ & of & of & 0 \\
\hline $\mathrm{Mn}^{+4}$ & of & of & 0 \\
\hline $\mathrm{Ca}^{42}$ & of & of & 0 \\
\hline $\mathrm{K}^{+1}$ & 0 & $\begin{array}{l}. \quad 0 \\
\end{array}$ & 0 \\
\hline $\mathrm{OH}^{-1}$ & 0.35 & $4.04 E+03$ & $6.88 \mathrm{E}+03$ \\
\hline $\mathrm{NO}^{-1}$ & 2.95 & $1.24 \mathrm{E}+05$ & $2.12 \mathrm{E}+05$ \\
\hline $\mathrm{NO}^{-2}$ & $5.20 \mathrm{E}-02$ & $1.63 \mathrm{E}+03$ & $2.77 \mathrm{E}+03$ \\
\hline $\mathrm{CO}^{-2}$ & 0.55 & $2.26 \mathrm{E}+04$ & $3.84 \mathrm{E}+04$ \\
\hline $\mathrm{PO}^{\cdot 3}$ & 1.15 & $7.41 \mathrm{E}+04$ & $1.26 E+05$ \\
\hline $\mathrm{SO}^{-2}$ & 0.78 & $5.08 \mathrm{E}+04$ & $8.65 \mathrm{E}+04$ \\
\hline $\mathrm{Si}$ (as $\mathrm{SiO}_{3}^{-2}$ ) & $3.58 \mathrm{E}-02$ & $6.85 E+02$ & $1.17 \mathrm{E}+03$ \\
\hline$F^{-1}$ & $7.42 \mathrm{E}-02$ & $9.59 \mathrm{E}+02$ & $1.63 E+03$ \\
\hline $\mathrm{Cl}^{-1}$ & $1.11 \mathrm{E}-02$ & $2.67 \mathrm{E}+02$ & $4.54 E+02$ \\
\hline $\mathrm{C}_{6} \mathrm{H}_{3} \mathrm{O}_{7}{ }^{3}$ & 0 & 0 & 0 \\
\hline EDTA ${ }^{-1}$ & 0. & 0 & 0 \\
\hline EIEDTA $^{-3}$ & 0 & of & 0 \\
\hline $\mathrm{NTA}^{-3}$ & of & 0 & 0 \\
\hline glycolate $e^{-1}$ & 0 & 0 & 0 \\
\hline acetate & of & 0] & 0 \\
\hline oxalate & of & of & 0 \\
\hline $\mathrm{DBP}$ & of & of & 0 \\
\hline NPH & of & 0 & 0 \\
\hline $\mathrm{Cl}_{4}$ & 0 & of & 0 \\
\hline hexone & of & 0 & 0 \\
\hline $\mathrm{Fe}(\mathrm{CN})_{6}{ }^{4}$ & 0 & $0(\mathrm{~g}-\mathrm{mol})$ & \\
\hline 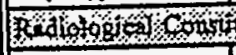 & ment $/ \% / \%$ & \%/\%/ \% & \%, \\
\hline $\mathrm{Pu}$ & & $7.81 \mathrm{E}-03(\mu \mathrm{Ci} / \mathrm{g})$ & $0.22(88)$ \\
\hline $\mathrm{U}$ & $2.90 \mathrm{E}-02(\mathrm{M})$ & $4.70 \mathrm{E}+07(\mu \mathrm{g} / \mathrm{g})$ & $8.00 \mathrm{E}+03(\mathrm{~kg})$ \\
\hline Cs & $7.16 \mathrm{E}-03(\mathrm{Ci} / \mathrm{L})$ & $4.87(\mu \mathrm{Ci} / \mathrm{g})$ & $8.29 \mathrm{E}+03(\mathrm{Ci})$ \\
\hline $\mathrm{Sr}$ & $6.18 \mathrm{E}-04(\mathrm{C} i \mathrm{~L})$ & $0.42(\mu \mathrm{C} / g)$ & $7.16 \mathrm{E}+02(\mathrm{Ci})$ \\
\hline
\end{tabular}

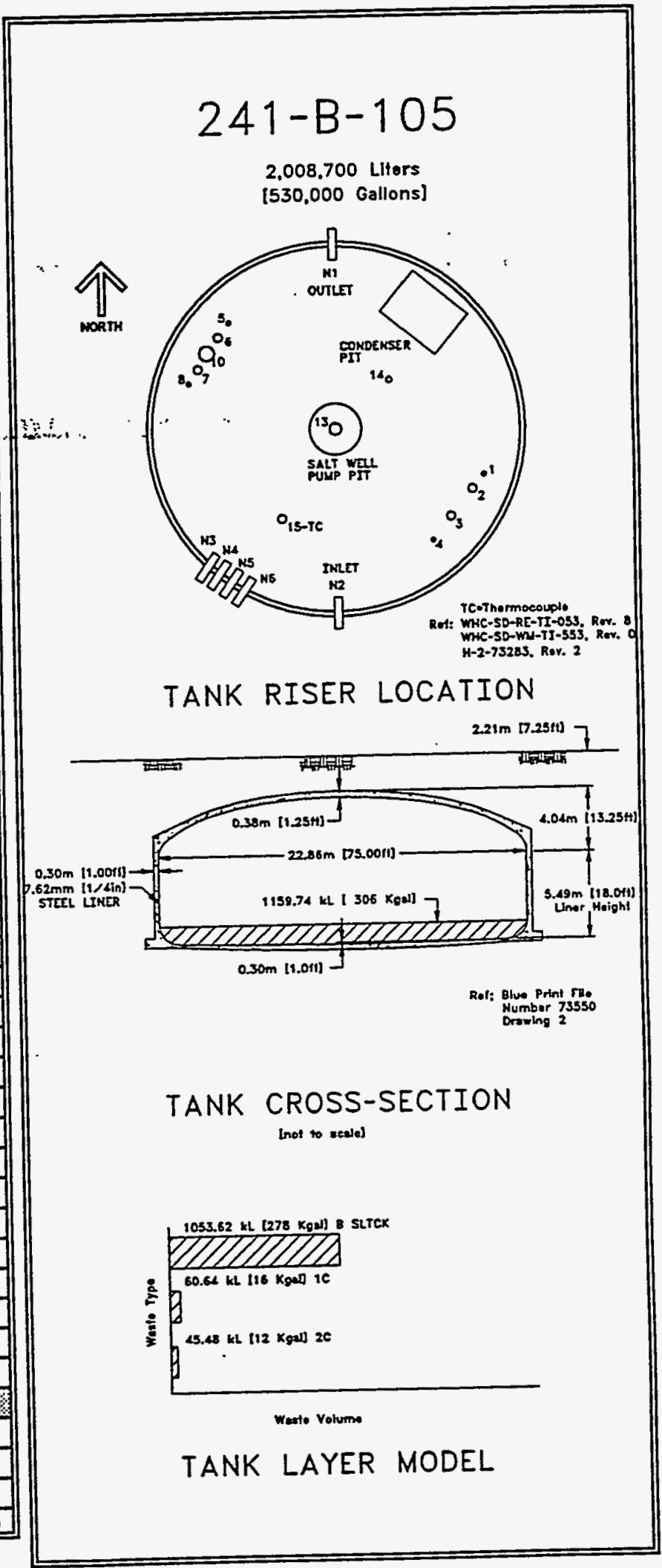


WHC-SD-WM-ER-349 Rev. 0

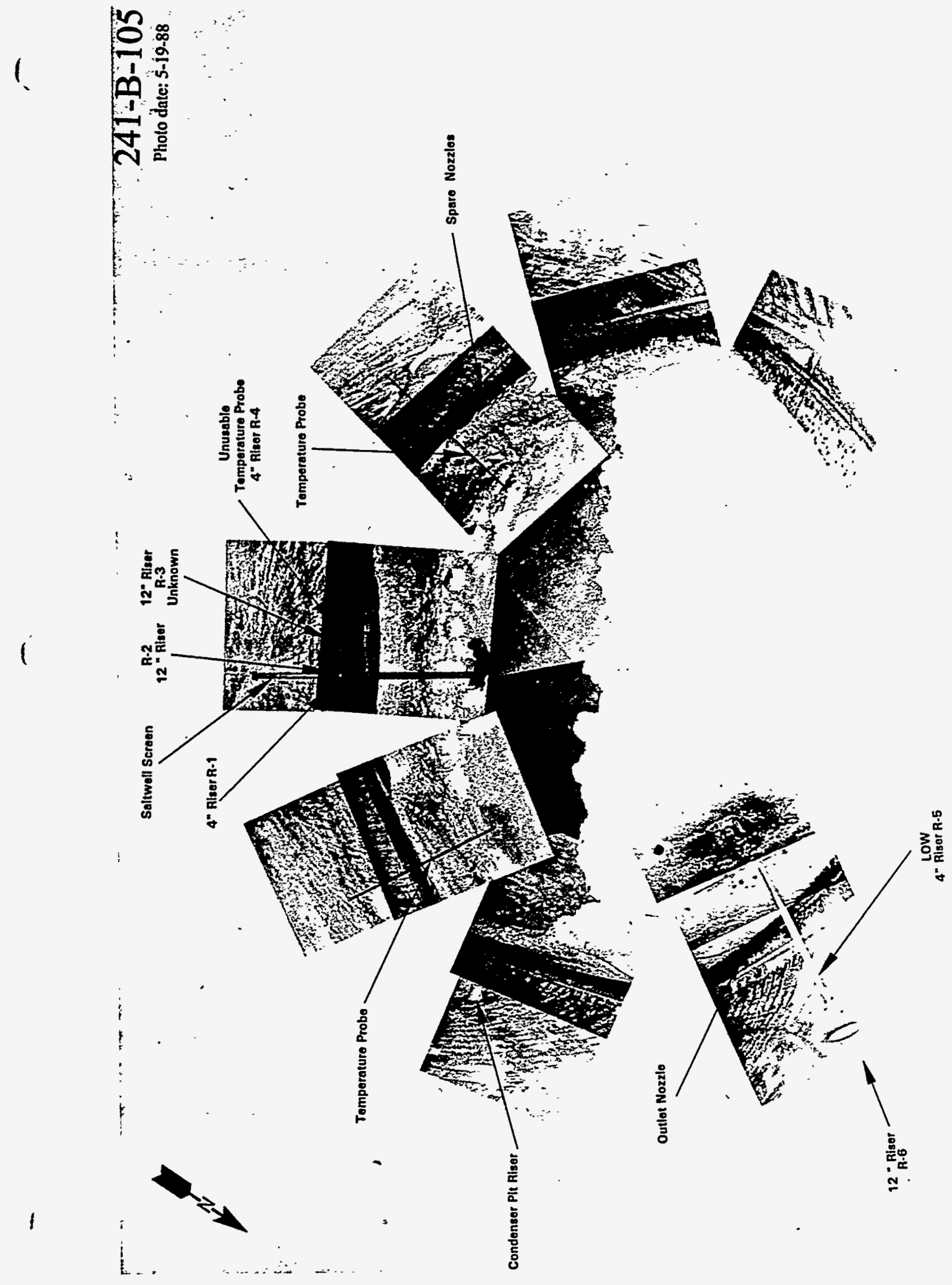


4.6 Tank $241-B-106$

4.6.1 241-B-106 Tank History

\subsubsection{Waste History Tank 241-B-106}

Tank 241-B-106 was filled with second-cycle waste from August 1947 to May 1948. The tank was declared inactive. in 1978. In the fourth quarter of 1978, the P-10 pump was removed: A level adjustment was made in December 1978. In 1979, Tank 241-B-106 was determined to be primary stabilized. Interim stabilization was completed with supernatant pumping and a level adjustment was made in March 1985. In October 1985, intrusion prevention was completed. (See sketch ES-TKS-E16 for a graphical representation of the Tank :241-B-106. level. history..)

\subsubsection{Temperature History 241-B-106}

The single thermocouple tree in Tank 241-B-106 has 13 thermocouple probes to record temperature data in riser 4 . The mean temperature of the first recorded data for thermocouples 1 through 12 was $64^{\circ} \mathrm{F}$. A sum of the squares regression line fit for the first 12 thermocouples starting in 1974 shows an overall zero slope $\pm 10.6^{\circ} \mathrm{F}$ with an $r$ square value of 0.004 . From september 1974 to current, the median tank temperature is $64^{\circ} \mathrm{F}$ with a minimum of $43^{\circ} \mathrm{F}$ and a maximum of $107^{\circ} \mathrm{F}$. Refer to the supporting document for a more thorough review of the temperature data (Brevick 1994).

\subsubsection{Integrity of Tank 241-B-106}

Tank 241-B-106 is categorized as sound and is interim stabilized with intrusion prevention completed. The Tank 241-B-102 surface level is monitored with a Food Instrument Corporation gauge through riser 1. A Eigure that graphically represents the surface level measurements from January 1991 to the present can be found in the supporting documents (Brevick 1994). An occurrence report was issued in 1978 when the liquid level exceeded the decrease criteria. The surface level for the past 3 years has remained steady and the readings range between 39.6 and 38 in.

Four drywell are identified for tank 241-B-106. A graphical representation of the active drywell from January 1990 to the present can also be found in the supporting document (Brevick 1994).

\subsubsection{Current status of Tank 241-B-106}

Tank 241-B-106 entered service in September 1947 and currently stores 117,000 gal of waste. The waste is comprised of 1,000 gal of supernatant; 116,000 gal of saltcake; and no supernatant or pumpable liquid remaining. The tank is identified as a low-heat load tank, is passively ventilated, and is categorized as sound with interim stabilization and intrusion prevention completed. Tank 241-B-106 is third in the three-tank cascade flow series. The following plan view and tank cross section depict the approximate waste level and riser 
configuration. Tank 241-B-106 has 10 risers and three 12-in. risers (nos.2, 3 and 7) are available for use.

\subsubsection{Inventory estimate 241-B-106}

The following tank layer volume approximation was derived from the Los Alamos National Laboratories Waste Status and Transaction Record Summary (Agnew 1994). The estimated inventory of Tank 241-B-106 is also presented.

\subsubsection{In-Tank Photograph 241-B-106}

The Tank 241-B-106 photo shows a thin liquid surface over redaish-

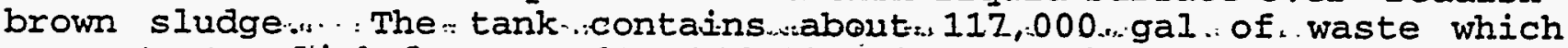
converts to slightly more than 3"ft deep. The white spot at the bottom center of the photo is a result of the camera flash. Although a spare inlet nozzle is shown on two pictures, only one nozzle exists.

4.6.3 Synopsis Tank 241-B-106

(To be completed.) 


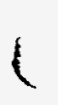

\begin{tabular}{|c|c|c|c|}
\hline \multicolumn{4}{|c|}{ Single-Shell Tank 241-B-106 } \\
\hline \multicolumn{4}{|c|}{$\begin{array}{c}\text { Single-Shell Iank 241-D-100 } \\
\text { Solids Composite Inventory Estimate }\end{array}$} \\
\hline \multicolumn{4}{|c|}{ 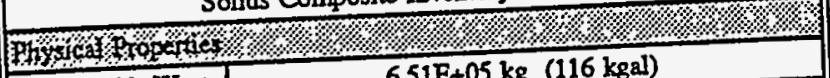 } \\
\hline Total Solid Waste & \multicolumn{3}{|c|}{$6.51 \mathrm{E}+05 \mathrm{~kg}(116 \mathrm{kgal})$} \\
\hline Heat load & \multicolumn{3}{|c|}{$1.61 \mathrm{E}-02 \mathrm{~kW}(5.50 \mathrm{E}+01 \mathrm{BTU} / \mathrm{hr})$} \\
\hline Bulk Density & \multicolumn{3}{|c|}{$1.48(g / \infty)$} \\
\hline Void Fraction & \multicolumn{3}{|c|}{0.59} \\
\hline Water wt\% & \multicolumn{3}{|c|}{32.33} \\
\hline TOC wr\% C (wet) & \multicolumn{3}{|c|}{0.00} \\
\hline 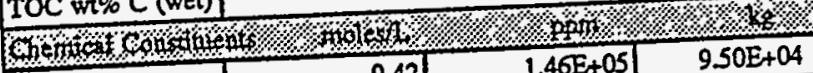 & \multicolumn{3}{|c|}{$4 \%$} \\
\hline $\mathrm{Na}^{+2}$ & 9.42 & $1.46 E+05$ & $9.50 \mathrm{E}+04$ \\
\hline $\mathrm{Al}^{+3}$ & $6.16 \mathrm{E}-02$ & $1.12 \mathrm{E}+03$ & $7.29 \mathrm{E}+02$ \\
\hline $\mathrm{Fe}^{+3}$ (total Fe) & of & 0 & 0 \\
\hline $\mathrm{Cr}^{+\mathrm{S}^{2}} \cdot \cdots$ & $\cdots \cdots: 0$ & $\cdots \cdots \times: \cdot$ & 0 \\
\hline $\mathrm{Bi}^{+3}$ & of & 0 & 0 \\
\hline $\mathrm{La}^{43}$ & of & 우 & 0 \\
\hline $\mathrm{Ce}^{+3}$ & 0 & of & 0 \\
\hline $2 \mathrm{r}\left(\operatorname{as~} 2 \mathrm{O}(\mathrm{OH})_{2}\right)$ & of & 0 & 0 \\
\hline $\mathrm{Pb}^{+3}$ & of & 0 & 0 \\
\hline $\mathrm{Ni}^{+2}$ & of & 요 & 0 \\
\hline $\mathrm{Sr}^{+2}$ & of & of & 0 \\
\hline $\mathrm{Mn}^{\text {+4 }}$ & 0 & of & 0 \\
\hline $\mathrm{Ca}^{+2}$ & 0) & of & 0 \\
\hline $\mathrm{K}^{41}$ & 0 & 인 & 0 \\
\hline $\mathrm{OH}^{2}$ & 0.23 & $2.64 \mathrm{E}+03$ & $1.72 \mathrm{E}+03$ \\
\hline $\mathrm{NO}^{-1}$ & 3.20 & $1.34 \mathrm{E}+05$ & $8.72 \mathrm{E}+04$ \\
\hline $\mathrm{NO}^{-1}$ & 5.11E-02 & $1.58 \mathrm{E}+03$ & $1.03 E+03$ \\
\hline $\cos ^{-2}$ & 0.61 & $2.46 \mathrm{E}+04$ & $1.60 \mathrm{E}+04$ \\
\hline $\mathrm{PO}^{\cdot 3}$ & 1.10 & $7.02 \mathrm{E}+04$ & $4.57 \mathrm{E}+04$ \\
\hline $\mathrm{SO}^{-2}$ & 0.85 & $5.52 \mathrm{E}+04$ & $3.59 \mathrm{E}+04$ \\
\hline $\mathrm{Si}$ (as $\mathrm{SiO}_{3}{ }^{2}$ ) & 0 & 0 & 0 \\
\hline $\mathrm{F}^{1}$ & $6.69 \mathrm{E}-02$ & $8.57 E+02$ & $5.58 E+02$ \\
\hline $\mathrm{Cl}^{1}$ & 1.22E-02 & $2.91 \mathrm{E}+02$ & $1.89 \mathrm{E}+02$ \\
\hline $\mathrm{C}_{6} \mathrm{H}_{5} \mathrm{O}_{7}{ }^{-3}$ & 0 & 0 & 0 \\
\hline EDTA & of & 0 & 0 \\
\hline FEDTA ${ }^{3}$ & 0 & 0 & 0 \\
\hline$N_{T A} A^{-3}$ & 0 & 0 & 0 \\
\hline Slycolate & of & 0 & 0 \\
\hline acetate ${ }^{-1}$ & 0 & 0 & 0 \\
\hline oxalate ${ }^{-2}$ & 0 & 0 & 0 \\
\hline $\mathrm{DBP}$ & of & 0 & 0 \\
\hline $\mathrm{NPH}$ & 0) & 0 & 0 \\
\hline $\mathrm{CCl}_{4}$ & of & of & 0 \\
\hline bexone & 0 & 0 & 0 \\
\hline $\mathrm{Fe}(\mathrm{CN})_{6}^{-1}$ & 0 & $0(\mathrm{~g}-\mathrm{mol})$ & \\
\hline Kabogós & Heth & \% \%/ & \%/\%/ \\
\hline Pu & & $0(\mu \mathrm{Ci} / g)$ & ) $\quad 0(\mathrm{~kg})$ \\
\hline$\overline{\mathbf{u}}$ & $2.92 \mathrm{E}-02(\mathrm{M})$ & $4.68 \mathrm{E}+03(\mathrm{\mu g} / \mathrm{g})$ & $3.05 \mathrm{E}+03(\mathrm{~kg})$ \\
\hline Cs & $7.83 \mathrm{E}-03(\mathrm{Ci} / \mathrm{L})$ & $5.28(\mu \mathrm{Ci} / \mathrm{g})$ & 3) $3.44 \mathrm{E}+03(\mathrm{Ci})$ \\
\hline Sr & $0(\mathrm{Ci} / \mathrm{L})$ & $0(\mu \mathrm{Ci} / g)$ & a) $\quad 0$ (C) \\
\hline
\end{tabular}

\section{$241-B-106$ \\ 2.008.700 Liters \\ [530,000 Gallons]}

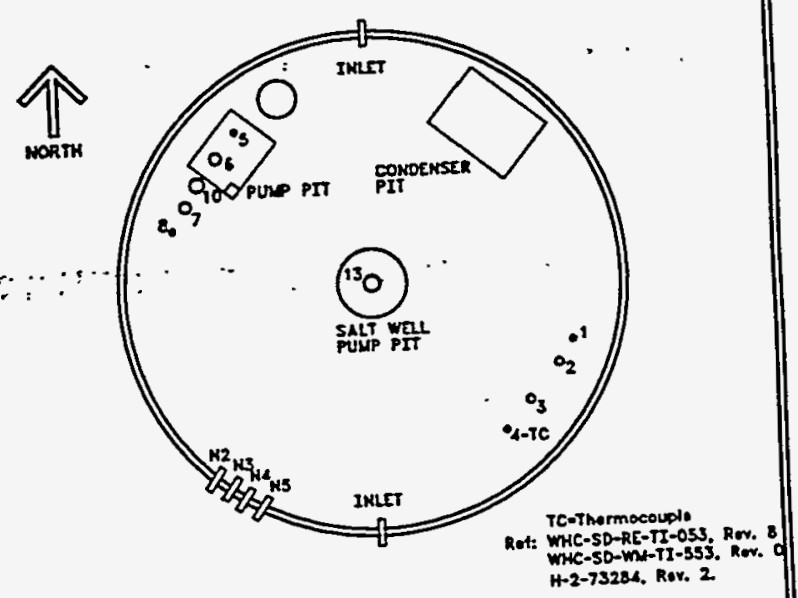

TANK RISER LOCATION

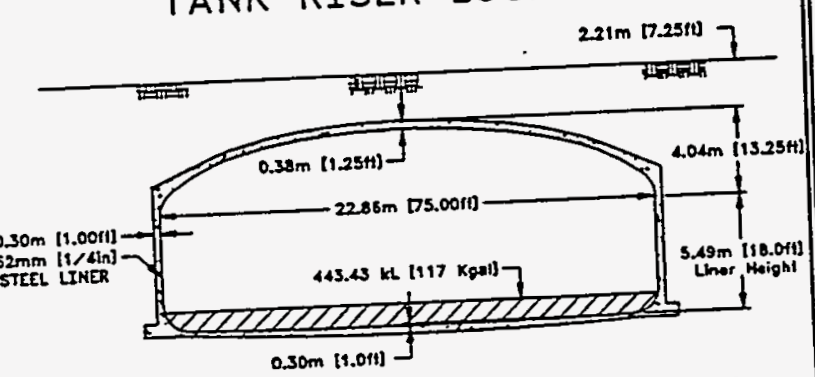

Rof: Blue Print rate

Draving 2

\section{TANK CROSS-SECTION \\ (not to ecens)}

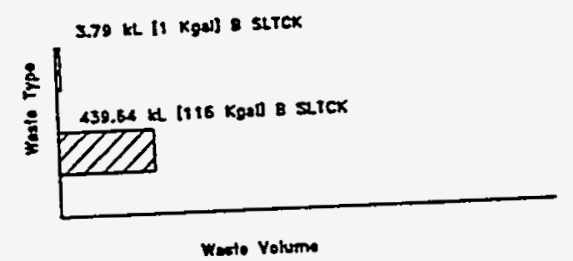

TANK LAYER MODEL 
WHC-SD-WM-ER-349 Rev. 0

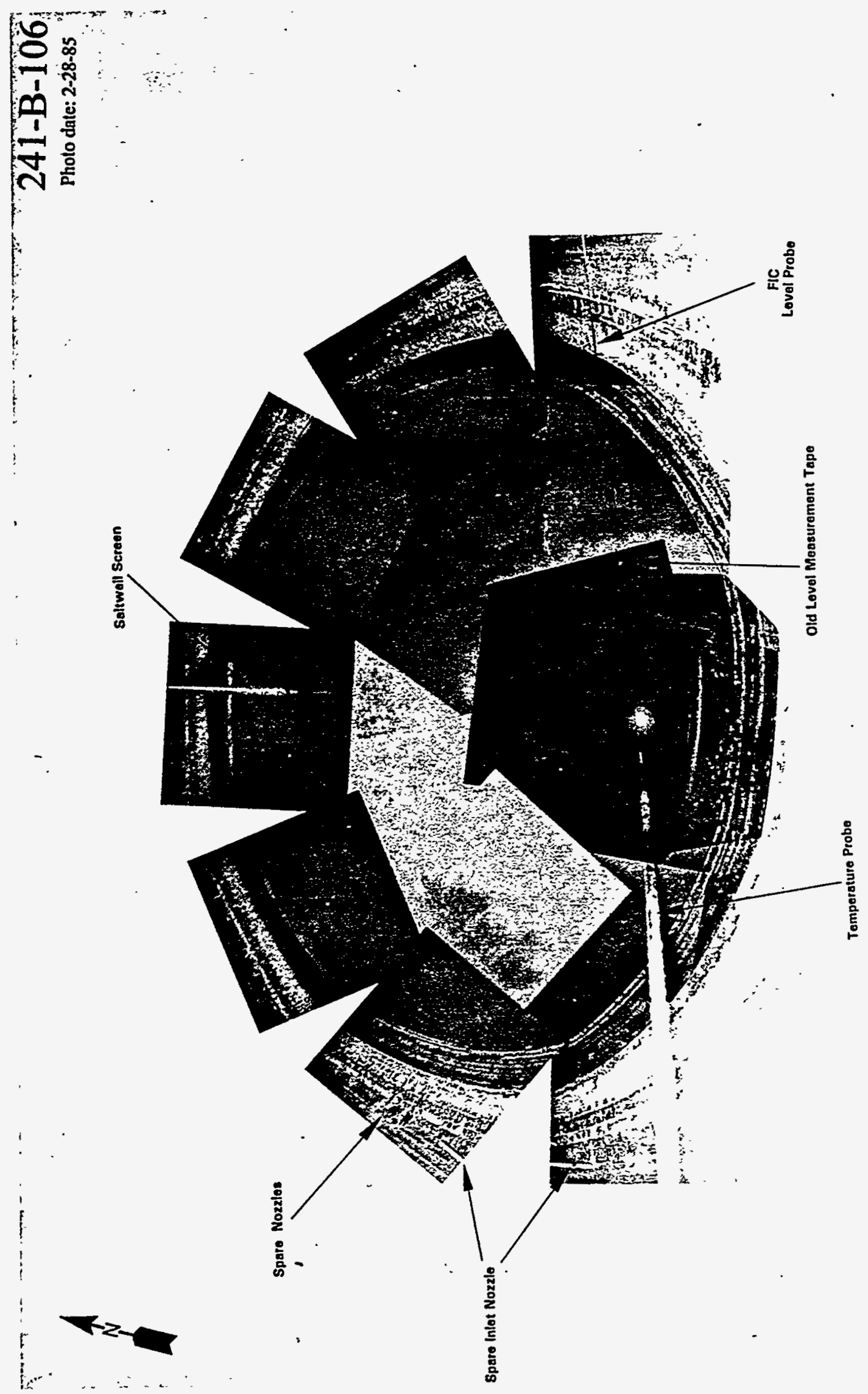




\subsubsection{1-B-107 Tank History \\ 4.7.1.1 Waste History Tank 241-B-107}

Tank 241-B-107 was filled with first-cycle waste from May 1945 to october 1945. In 1972, a P-10 pump was installed in Tank 241-B-107. The -tank was assumed to be a suspect leaker.in the. first quarter of 1973. The tank was removed from service in the second quarter of 1975. In the first quarter of 1977 ; saltwell pumping was completed. The tank was declared inactive in 1978. The tank was primary stabilized in 1979. After leaking approximately 8,000 gal, Tank 241-B-107 was declared an assumed. Ieaker in 19.80 ....... In. the. first. quarter of 1980, a lëvë adjüstment was madë." partial isolation was completed in 1982 and interim stabilization was completed after saltwell pumping. A level adjustment was made in March 1985. In October 1985, intrusion prevention was completed. (See sketch ES-TKS-E17 for a graphical representation of the Tank 241-B-107 level history.)

\subsubsection{Temperature History $241-\mathrm{B}-107$}

Tank 241-B-107 contains one thermocouple tree with 13 thermocouple probes in riser 3 . The mean temperature of the first recorded data for thermocouples 1 through 11 was $70^{\circ} \mathrm{F}$. A sum of the squares regression line fit for the first 11 thermocouples starting in 1975 shows an overall zero slope $\pm 9.8 \circ \mathrm{F}$ with an average $r$ square value of 0.03 . Not enough data are available for an accurate regression analysis of thermocouples 12 and 13. From May 1975 to present, the median temperature is $65^{\circ} \mathrm{F}$ with a minimum of $50^{\circ} \mathrm{F}$ and a maximum of $124^{\circ} \mathrm{F}$. Refer to the supporting document for a more thorough review of the temperature data (Brevick 1994).

\subsubsection{Integrity of Tank 241-B-107}

Tank 241-B-107 is categorized as an assumed leaker and is interim stabilized with intrusion prevention completed. The Tank 241-B-107 surface level is monitored quarterly with a manual tape through riser 8 . A figure that graphically represents the surface level measurements from January 1991 to the present can be found in the supporting documents (Brevick 1994). The surface level for the past 3 years has remained steady with the readings ranging from 54.5 to 55 -in:

Four drywells are identified for tank 241-B-107. A graphical representation of the active drywell from January 1990 to the present can be found in the supporting document (Brevick 1994). The graph includes the peak $\mathrm{c} / \mathrm{s}$, the depth at which the peak occurred, and the date of the reading. 
4.7.2 Current Status of Tank 241-B-107

Tank 241-B-107 entered service in May 1945 and currently stores $165,000 \mathrm{gal}$ of waste. The waste is comprised of $1,000 \mathrm{gal}$ of supernatant; 164,000 gal of sludge; and no supernatant with 7,000 gal of pumpable liquid remaining. The tank is identified as a low-heat load tank, is passively ventilated, and is categorized as an assumed leaker with interim stabilization and intrusion prevention completed. Tank 241-B-107 is equipped to cascade to Tank 241-B-108 and is first in the three-tank cascade flow series. The following plan view and tank cross section depict the approximate waste level and riser configuration. Tank 241-B-107 has 11 risers and four are available for use: three 12in. risers nos.2, 6 , and 7 ; and one 4-inch riser No.5.

\subsubsection{Inventory estimate 241-B-107}

The following tank layer volume approximation was derived from the Los Alamos National Laboratories Waste Status and Transaction Recora Summary (Agnew 1994). The estimated inventory of Tank 241-B-107 is also presented.

\subsubsection{In-Tank Photograph 241-B-107}

The Tank 241-B-107 photo shows an off-white to dark brown sludge surface with pools of supernatant. The tank contains about. 165,000 gal of waste which converts to approximately 4.5 ft deep. The discarded temperature probe is a result of equipment being cut off. As the old temperature probe was pulled out, it was measured for radiation. When a certain limit is reached, the section remaining in the tank is cut off and allowed to fall back into the tank.

4.7.3 Synopsis Tank 241-B-107

(To be completed.) 


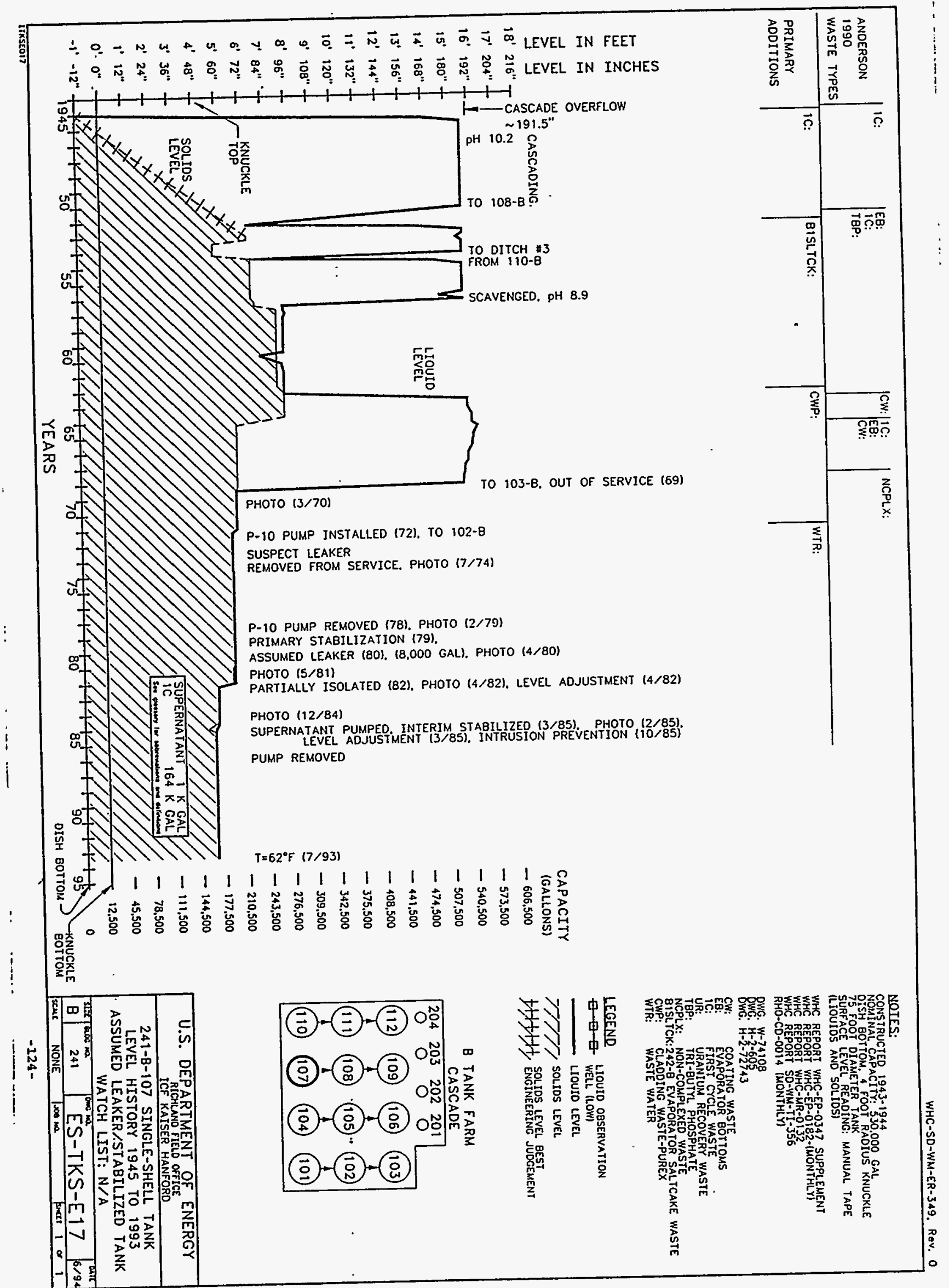




\begin{tabular}{|c|c|c|c|}
\hline \multicolumn{4}{|c|}{ Single-Shell Tank 241-B-107 } \\
\hline \multicolumn{4}{|c|}{ Solids Composite Inventory Estimate } \\
\hline \multicolumn{4}{|c|}{ 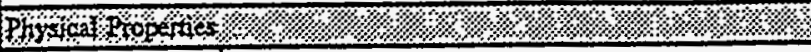 } \\
\hline Total Solid Waste & \multicolumn{3}{|c|}{$8.29 \mathrm{E}+05 \mathrm{~kg}(164 \mathrm{kgal})$} \\
\hline Heat load & \multicolumn{3}{|c|}{$4.18 \mathrm{E}-02 \mathrm{~kW}(1.43 \mathrm{E}+02 \mathrm{BTU} / \mathrm{hr})$} \\
\hline Bulk Density & \multicolumn{3}{|c|}{$1.34(g / \infty)$} \\
\hline Void Fraction & \multicolumn{3}{|c|}{0.58} \\
\hline Water wh\% & \multicolumn{3}{|c|}{68.44} \\
\hline TOC wr\% C (wet) & \multicolumn{3}{|c|}{0.00} \\
\hline \multicolumn{4}{|c|}{ 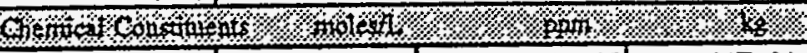 } \\
\hline $\mathrm{Na}^{+1}$ & 5.82 & $1.00 \mathrm{E}+05$ & $8.31 \mathrm{E}+04$ \\
\hline $\mathrm{Al}^{+3}$ & 0.30 & $6.06 \mathrm{E}+03$ & $5.02 E+03$ \\
\hline $\mathrm{Fe}^{43}$ (total Fe) & 0.22 & $9.15 \mathrm{E}+03$ & $759 \mathrm{E}+03$ \\
\hline $\mathrm{Cr}^{+3}$ & $1.46 \mathrm{E}-02$ & $\therefore \div \cdots \cdot 5.68 \mathrm{E}+02$ & 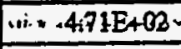 \\
\hline $\mathrm{Bi}^{+33}$ & 0.10 & $1.60 \mathrm{E}+04$ & $1.33 \mathrm{E}+04$ \\
\hline $\mathrm{La}^{+3}$ & 0 & 0 & 0 \\
\hline $\mathrm{Ce}^{43}$ & 0 & 0 & 0 \\
\hline $\mathrm{Zx}$ (as $\left.\mathrm{ZrO}(\mathrm{OH})_{2}\right)$ & $2.92 \mathrm{E}-02$ & $1.99 \mathrm{E}+03$ & $1.65 \mathrm{E}+03$ \\
\hline $\mathrm{Pb}^{+2}$ & 0 & 0 & 0 \\
\hline $\mathrm{Ni}^{+2}$ & 0 & 0 & 0 \\
\hline $\mathrm{Sr}^{+2}$ & 0 & 0] & 0 \\
\hline $\mathrm{Mn}^{+4}$ & 0 & 0 & 0 \\
\hline $\mathrm{Ca}^{+2}$ & 0 & 0 & 0 \\
\hline $\mathrm{K}^{+1}$ & 0 & 0 & 0 \\
\hline $\mathrm{OH}^{-1}$ & 1.55 & $1.97 \mathrm{E}+04$ & $1.64 \mathrm{E}+04$ \\
\hline $\mathrm{NO}^{-1}$ & 0.10 & $4.86 \mathrm{E}+03$ & $4.03 \mathrm{E}+03$ \\
\hline $\mathrm{NO}^{-2}$ & 0.11 & $3.71 \mathrm{E}+03$ & $3.08 \mathrm{E}+03$ \\
\hline $\mathrm{CO}^{-2}$ & 0 & 0 & 0 \\
\hline $\mathrm{PO}^{.3}$ & 1.77 & $1.26 \mathrm{E}+05$ & $1.04 \mathrm{E}+05$ \\
\hline $\mathrm{SO}^{-2}$ & $3.72 \mathrm{E}-02$ & $2.67 \mathrm{E}+03$ & $2.22 \mathrm{E}+03$ \\
\hline $\mathrm{Si}$ (as $\mathrm{SiO}_{3}{ }^{2}$ ) & 0.28 & $5.83 \mathrm{E}+03$ & $4.84 \mathrm{E}+03$ \\
\hline $\mathrm{F}^{-1}$ & 0.14 & $2.01 E+03$ & $1.67 \mathrm{E}+03$ \\
\hline $\mathrm{Cl}^{-1}$ & 0 & 0 & 0 \\
\hline $\mathrm{C}_{6} \mathrm{H}_{5} \mathrm{O}_{7}{ }^{3}$ & 0 & 0 & 0 \\
\hline EDTA $^{\alpha}$ & 요 & 0 & 0 \\
\hline HEDTA $^{-3}$ & 0 & 이 & 0 \\
\hline NTA $^{-3}$ & 0 & 0 & 0 \\
\hline glycolate & 0 & 0 & 0 \\
\hline acelste-1 & 0 & 이 & 0 \\
\hline oxalate-2 & 0 & 01 & 0 \\
\hline DBP & 요 & 0 & 0 \\
\hline NPH & 이 & 0 & 0 \\
\hline $\mathrm{Cl}_{4}$ & of & 0 & 0. \\
\hline hexone & 0 & 0 & 0 \\
\hline $\mathrm{Fe}(\mathrm{CN})_{6}^{-4}$ & 0 & $0(\mathrm{~g}-\mathrm{mol})$ & \\
\hline \multicolumn{4}{|c|}{ 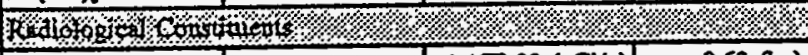 } \\
\hline $\mathrm{Pu}$ & & $4.45 \mathrm{E}-02(\mu \mathrm{Ci} / \mathrm{g})$ & $0.62(\mathrm{~kg})$ \\
\hline $\mathrm{U}$ & $0(M)$ & $0(\mu g / g)$ & $0(\mathrm{~kg})$ \\
\hline Cs & 8.65E-04 (Ci/L) & $0.65(\mu \mathrm{Ci} / \mathrm{B})$ & $5.37 \mathrm{E}+02(\mathrm{Ci})$ \\
\hline 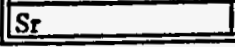 & $9.40 \mathrm{E}-03(\mathrm{Ci} / \mathrm{L})$ & $7.03(\mu \mathrm{Ci} / \mathrm{g})$ & $5.83 \mathrm{E}+03(\mathrm{Ci})$ \\
\hline
\end{tabular}

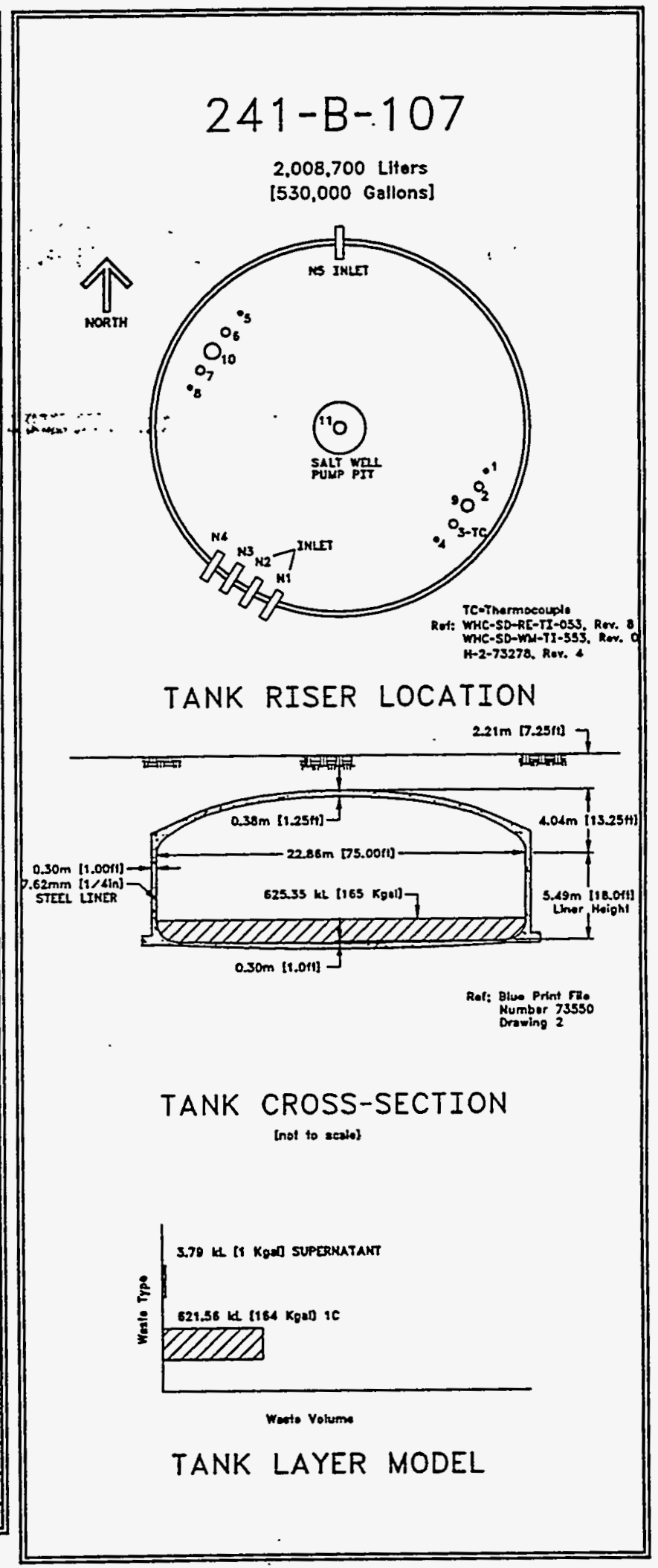



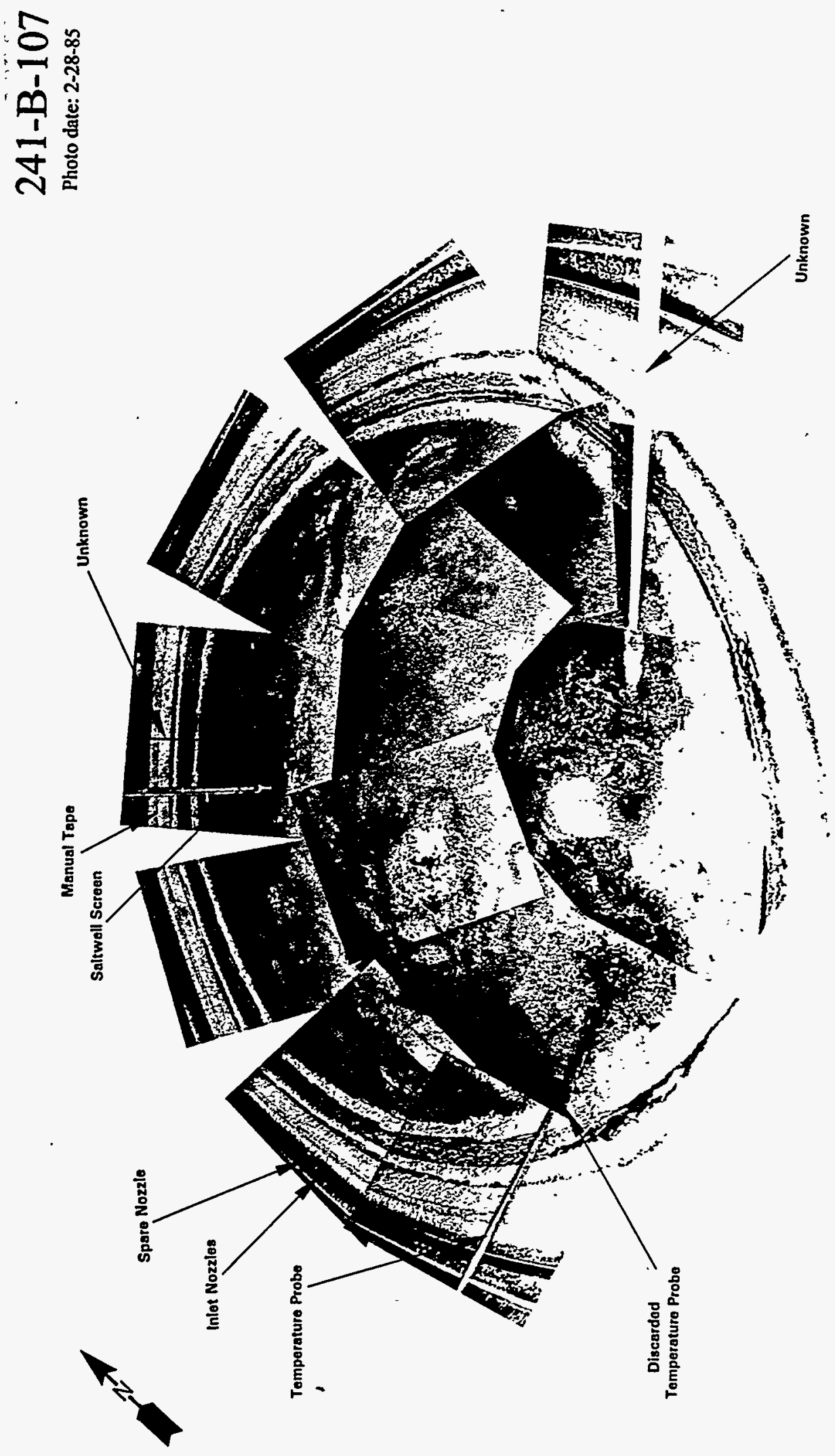
WHC-SD-WM-ER-349, Rev. 0

4.8 Tank 241-B-108

4.8.1 241-B-108 Tank History

4.8.1.1 Waste History Tank 241-B-108

Tank 241-B-108 was filled with first-cycle waste from the fourth quarter of 1945 to January 1946. In 1978, the tank was inactive. Supernatant pumping and interim stabilization were completed and a level adjustment was made in May 1985. In October 1985, intrusion prevention was completed. (See sketch ES-TKS-E18 for a graphical representation of the Tank 241-B-108 level history.)

\subsubsection{Temperature History 241-B-108}

4.....................

The single thermocouple tree in Tank 241-B-108 has 12 thermocouple probes to record temperature data in riser 5 . The mean temperature of the first recorded readings was $69^{\circ} \mathrm{F}$. A sum of the squares regression line fit for thermocouples 1 and 3 through 12 starting in 1974 shows a slightly negative near zero slope $\pm 10^{\circ} \mathrm{F}$ with an average square value of 0.07 . Not enough data are available for an accurate regression and variability analysis on thermocouple 2. From September 1974 to present, the median temperature for the probes is $66^{\circ} \mathrm{F}$ with a minimum of $50^{\circ} \mathrm{F}$ and a maximum of $102^{\circ} \mathrm{F}$. Refer to the supporting document for a more thorough review of the temperature data (Brevick 1994).

\subsubsection{Integrity of Tank 241-B-108}

Tank 241-B-108 is categorized as sound and is interim stabilized with intrusion prevention completed. The Tank 241-B-108 surface level is monitored with a Food Instrument Corporation gauge through riser 8 . For more information on surface levels see supporting documents (Brevick 1994).

Five dryells are identified for tank 241-B-108. A graphical representation of the active arywell from January 1990 to the present can be found in the supporting document (Brevick 1994).

\subsubsection{Current Status of Tank 241-B-108}

Tank 241-B-108 entered service in 1945 and currently stores 94,000 gal waste. The waste is comprised of $60,000 \mathrm{gal}$ of saltcake; $34,000 \mathrm{gal}$ of sludge; no supernatant with no pumpable liquid remaining. The tank is identified as a low-heat load tank, is passively ventilated, and is categorized as sound with interim stabilization and intrusion prevention completed. Tank 241-B-108 is equipped to cascade to Tank 241-B-109 and is second in the three-tank cascade flow series. The following plan view and tank cross section depict the approximate waste level and riser configuration. Tank $241-B-108$ has 11 risers and three $12-i n$. risers (nos.3, 6 and 7 ) are available for use. 
4.8.2.1 Inventory estimate 241-B-108

The following tank layer volume approximation was derived from the Ios Alamos National Laboratories Waste Status and Transaction Record Summary (Agnew 1994). The estimated inventory of Tank 241-B-108 is also presented. :

4.8.2.2 In-Tank Photograph 241-B-108

The Tank 241-B-108 photo shows a grey-brown sludge surface with a very small pool of supernatant around the base of the saltwell screen. The tank contains about 94,000 gal of waste which converts to approximately 2.5 ft deep. The red spots to the left and right of the tank may result. from.a. plastic.resin that is. sprayed on equipment as it is removed to help prevent the spread of radiation contamination to workers and the environment.

4.8.3 Synopsis Tank 241-B-108

(To be completed.) 


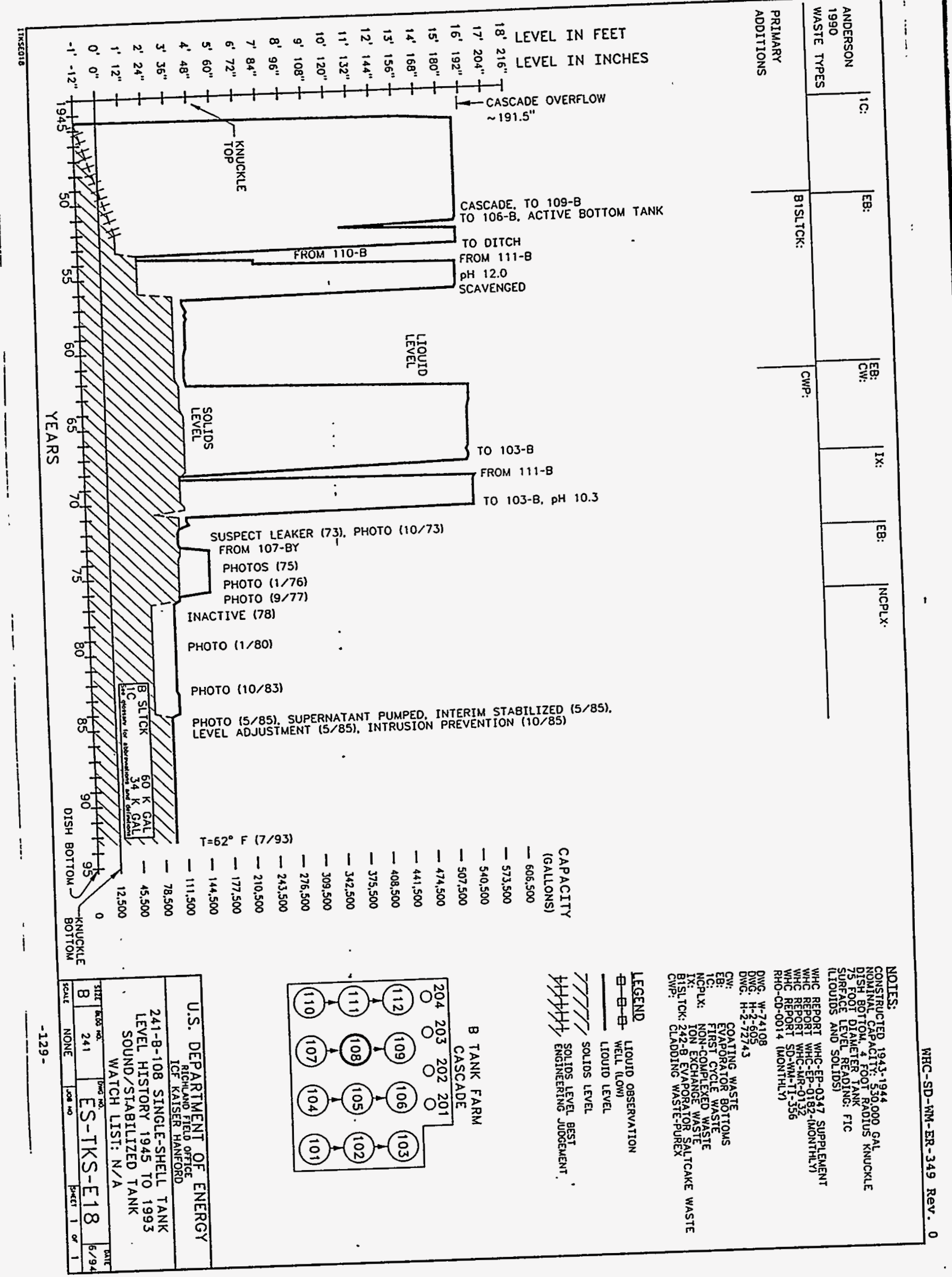




\begin{tabular}{|c|c|c|c|}
\hline \multicolumn{4}{|c|}{ Single-Shell Tank 241-B-108 } \\
\hline \multicolumn{4}{|c|}{ Solids Composite Inventory Estimate } \\
\hline \multicolumn{4}{|c|}{ 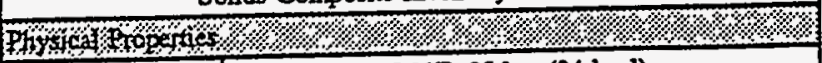 } \\
\hline Total Solid Waste & \multicolumn{3}{|c|}{$5.09 \mathrm{E}+05 \mathrm{~kg}(94 \mathrm{kgal})$} \\
\hline Eeat load & \multicolumn{3}{|c|}{$1.70 \mathrm{E}-02 \mathrm{~kW}(5.80 \mathrm{E}+01 \mathrm{BTU} \mathrm{hr})$} \\
\hline Bulk Density & \multicolumn{3}{|c|}{$1.43(g / \infty)$} \\
\hline Void Fraction & \multicolumn{3}{|c|}{0.59} \\
\hline Water wt\% & \multicolumn{3}{|c|}{45.39} \\
\hline TOC wr\% C (wet) & \multicolumn{3}{|c|}{0.00} \\
\hline \multicolumn{4}{|c|}{ 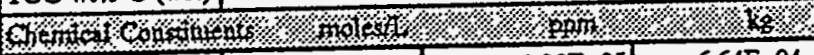 } \\
\hline $\mathrm{Na}^{+1}$ & 8.12 & $1.30 \mathrm{E}+05$ & $6.64 \mathrm{E}+04$ \\
\hline $\mathrm{Al}^{+3}$ & 0.15 & $2.79 \mathrm{E}+03$ & $1.42 \mathrm{E}+03$ \\
\hline $\mathrm{Fe}^{+\mathrm{s}}$ (total Fe) & 7.92E-02 & $3.09 \mathrm{E}+03$ & $157 \mathrm{E}+03$ \\
\hline$c^{3}{ }^{3}=\ldots$ & $\therefore \quad 5.28 \mathrm{E}-03$ & $\dot{\gamma}_{2},-1.92 E+02$ & $\therefore$ if $\therefore 97.69:$ \\
\hline $\mathrm{Bi}^{+3}$ & 3.70E-02 & $5.40 \mathrm{E}+03$ & $2.75 \mathrm{E}+03$ \\
\hline $\mathrm{La}^{43}$ & o & 0 & 0 \\
\hline $\mathrm{Ce}^{43}$ & 0 & 0 & 0 \\
\hline $\mathrm{Zr}\left(\mathrm{as} \mathrm{ZrO}(\mathrm{OH})_{2}\right)$ & $1.06 \mathrm{E}-02$ & $6.74 E+02$ & $3.43 \mathrm{E}+02$ \\
\hline $\mathrm{Pb}^{+2}$ & 0 & 0 & 0 \\
\hline $\mathrm{Ni}^{* 2}$ & of & 0 & 0 \\
\hline $\mathrm{Sr}^{+2}$ & of & 0] & 0 \\
\hline $\mathrm{Mn}$ & of & 0 & 0 \\
\hline $\mathrm{Ca}^{42}$ & of & of & 0 \\
\hline $\mathrm{K}^{+1}$ & 0 & $\therefore \quad 0$ & 0 \\
\hline $\mathrm{OH}^{\cdot 1}$ & 0.71 & $8.42 \mathrm{E}+03$ & $4.28 \mathrm{E}+03$ \\
\hline $\mathrm{NO}^{-1}$ & 2.08 & $9.03 E+04$ & $4.60 \mathrm{E}+04$ \\
\hline $\mathrm{NO}^{-1}$ & $7.16 \mathrm{E}-02$ & $2.30 \mathrm{E}+03$ & $1.17 \mathrm{E}+03$ \\
\hline $\cos ^{-2}$ & 0.39 & $1.63 \mathrm{E}+04$ & $8.29 \mathrm{E}+03$ \\
\hline $\mathrm{PO}^{-3}$ & 1.34 & $8.90 \mathrm{E}+04$ & $4.53 \mathrm{E}+04$ \\
\hline $\mathrm{SO}^{\cdot 2}$ & 0.56 & $3.74 \mathrm{E}+04$ & $1.90 \mathrm{E}+04$ \\
\hline $\mathrm{Si}\left(\right.$ as $\left.\mathrm{SiO}_{3}{ }^{-2}\right)$ & 0.10 & $1.97 \mathrm{E}+03$ & $1.00 \mathrm{E}+03$ \\
\hline $\mathrm{F}^{\prime}$ & 9.38E-02 & $1.25 \mathrm{E}+03$ & $6.34 \mathrm{E}+02$ \\
\hline $\mathrm{Cl}^{-1}$ & 7.77E-03 & $1.93 E+02$ & 97.97 \\
\hline $\mathrm{C}_{6} \mathrm{H}_{3} \mathrm{O}_{7} \cdot 3$ & 0 & 0 & 0 \\
\hline EDTA $^{-4}$ & 의 & of & 0 \\
\hline HEDTA ${ }^{-3}$ & 0) & of & 0 \\
\hline NTA $^{\prime 3}$ & of & of & 0 \\
\hline glycolate $^{-1}$ & 요 & of & 0 \\
\hline acelate $^{-1}$ & 0 & 0 & 0 \\
\hline oxalate ${ }^{-2}$ & of & 0 & 0 \\
\hline DBP & 0 & 0 & 0 \\
\hline NPH & of & 0 & 0 \\
\hline $\mathrm{CCl}_{4}$ & of & of & 0 \\
\hline hexone & 0 & 0 & 0 \\
\hline $\mathrm{Fe}(\mathrm{CN})_{6}{ }^{+}$ & 01 & $0(\mathrm{~g}-\mathrm{mol})$ & \\
\hline \multicolumn{4}{|c|}{ 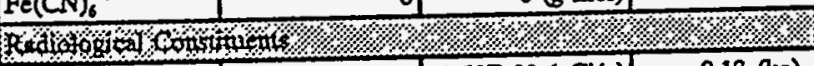 } \\
\hline $\mathrm{Pu}$ & & $1.50 \mathrm{E}-02(\mu \mathrm{Ci} / \mathrm{g})$ & $0.13(\mathrm{~kg})$ \\
\hline $\mathrm{U}$ & $1.86 \mathrm{E}-02(\mathrm{M})$ & $3.10 \mathrm{E}+03(1 \mathrm{~g} / \mathrm{g})$ & $1.58 \mathrm{E}+03(\mathrm{~kg})$ \\
\hline Cs & $5.31 \mathrm{E}-03(\mathrm{Ci} / \mathrm{L})$ & $3.71(\mu \mathrm{Ci} / g)$ & $1.89 \mathrm{E}+03(\mathrm{Ci})$ \\
\hline & $3.40 \mathrm{E}-03(\mathrm{Ci} / \mathrm{L})$ & $2.38(\mu \mathrm{Ci} / \mathrm{g})$ & $1.21 \mathrm{E}+03(\mathrm{Ci})$ \\
\hline
\end{tabular}

- Composite invertory exchudes supersatant, diatomacoous earth, and cement Unkrowes in tank inventory are assigned by Tank Laycriog Model (TLM).

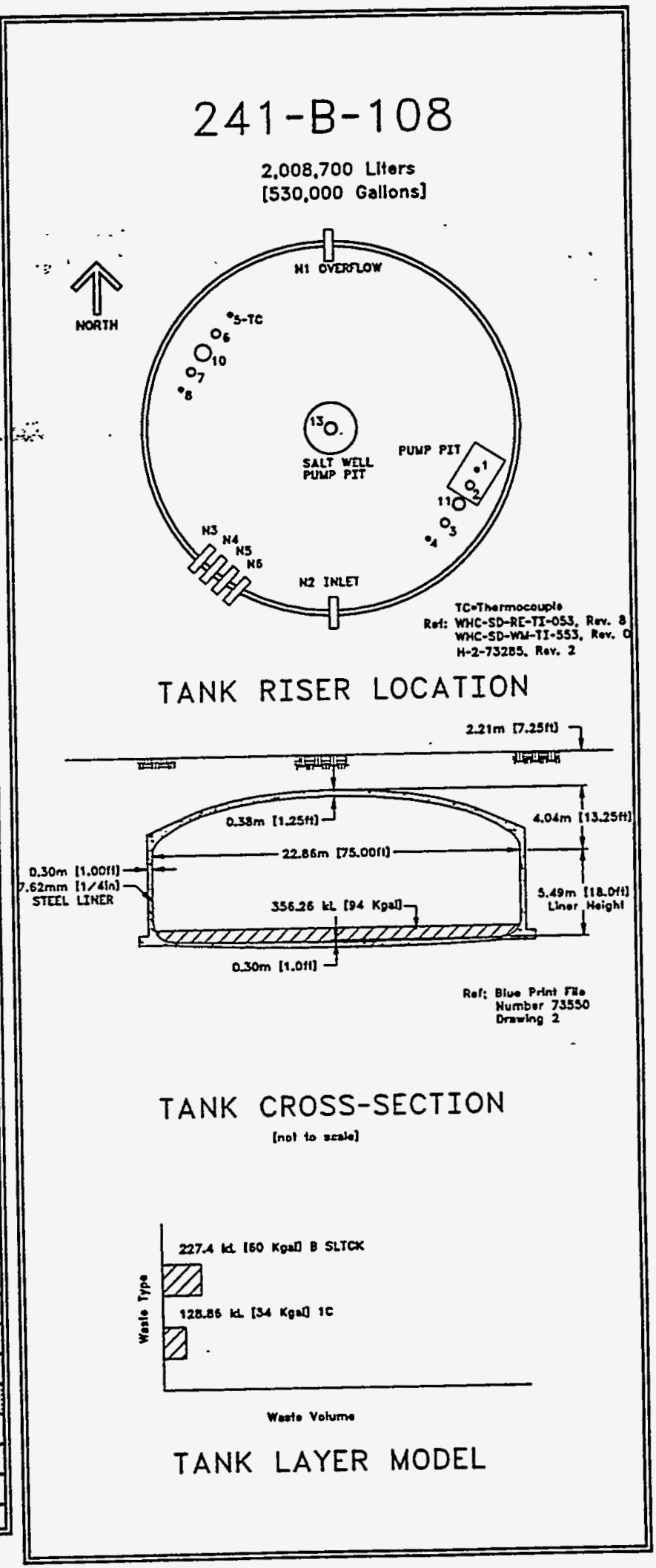

$6 / 94$ 
WHC-SD-WM-ER-349 Rev. 0

( $\quad \frac{9}{9}$

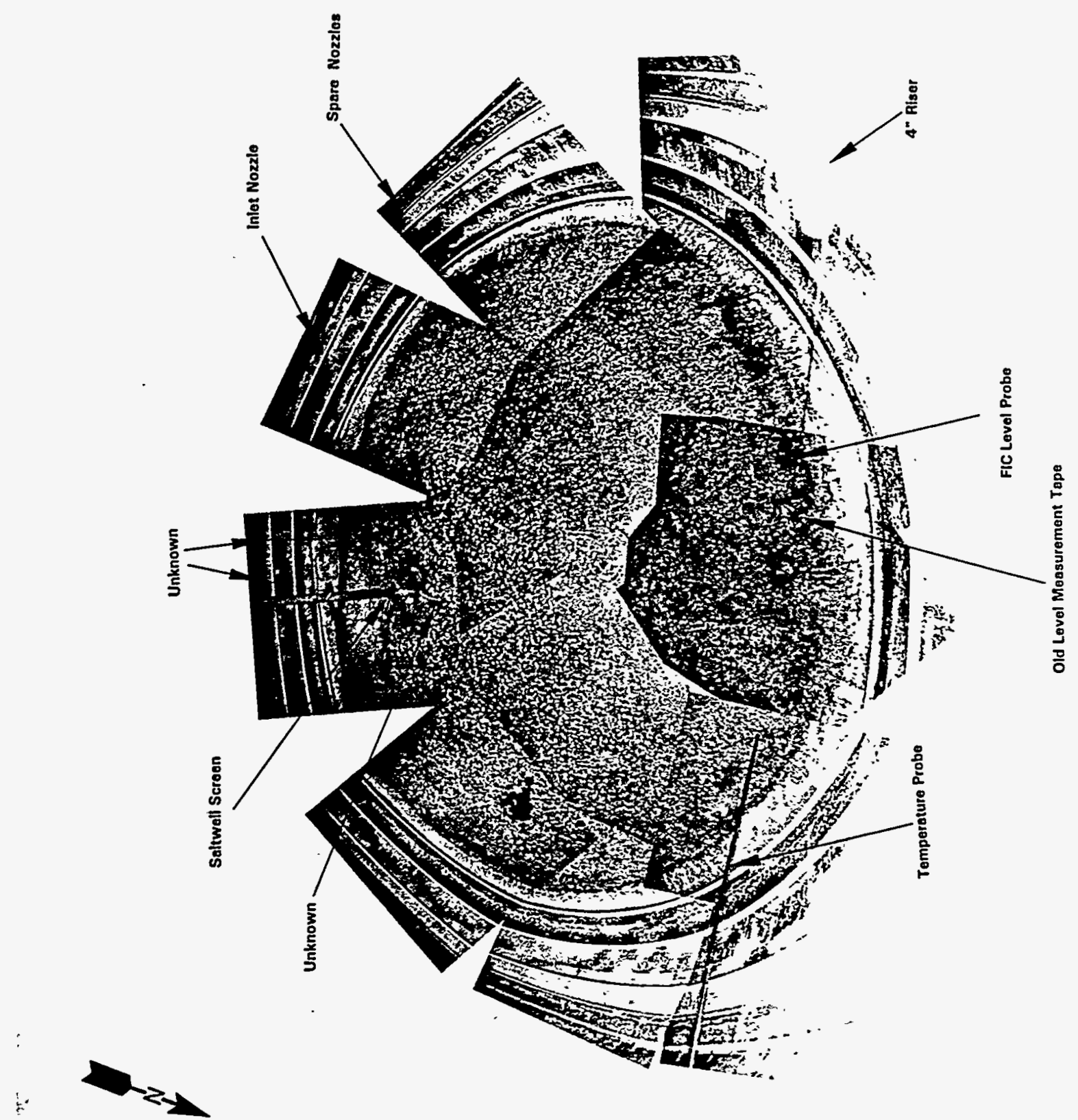


WHC-SD-WM-ER-349, ReV. 0

4.9 Tank 241-B-109

4.9.1 241-B-109 Tank History

\subsubsection{Waste History Tank 241-B-109}

Tank 241-B-109 was filled with first-cycle waste in January 1946 and received cascade waste from. Tank B-108 in 1946. The tank was declared inactive in 1978. Tank 241-B-109 was declared interim stabilized in April 1985 after supernatant pumping was completed. A level adjustment was made in April 1985 and intrusion prevention was completed in October 1985. (See sketch ES-TKS-E19 for a graphical representation of the Tank 241-B-109 level history.)

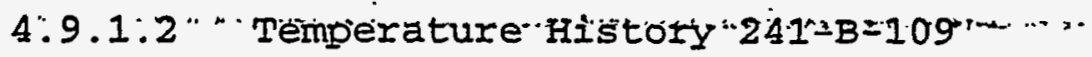

The single thermocouple tree in Tank 241-B-109 has 12 thermocouple probes to record temperature data in riser 1 . The mean temperature of the first recorded daily readings was $72^{\circ} \mathrm{F}$. A sum of the squares regression line fit for the data starting in 1974 shows a slightly negative, near zero slope $\pm 9{ }^{\circ} \mathrm{F}$ with an average $r$ square value of 0.14 . From April 1974 to present, the median temperature from all probes over the time span of available data is $69^{\circ} \mathrm{F}$ with a minimum of $53^{\circ} \mathrm{F}$ and a maximum of $104^{\circ} \mathrm{F}$. Refer to the supporting document for a more thorough review of the temperature data (Brevick 1994).

\subsubsection{Integrity of Tank 241-B-109}

Tank 241-B-109 is categorized as sound and is interim stabilized with intrusion prevention completed. The in Tank 241-B-109 surface level is monitored quarterly with a manual tape through riser 3 . A figure that graphically represents the surface level measurements from January 1991 to the present can be found in the supporting documents (Brevick 1994). The surface level readings for the past 3 years have increased steadily 41-in. during the first and second quarters of 1991 to 41.5-in. during the third and fourth quarters of 1993.

Three drywells are identified for tank 241-B-109, none of which are considered active.

\subsubsection{Current Status of Tank 241-B-109}

Tank 241-B-109 entered service in January of 1946 and currently stores 127,000 gal of waste. The. waste is comprised of 30,000 gal of unknown waste; 13,000 gal of sludge; and 84,000 gal of saltcake with no pumpable liquid remaining. The tank is identified as a low-heat load tank, is passively ventilated, and is categorized as sound with interim stabilization and intrusion prevention completed. Tank 241-B-109 is third in the three-tank cascade series. The following plan view and tank cross section depict the approximate waste level and riser configuration. Tank 241-B-109 has 11 tank dome risers and two 12-in. risers nos.2 and 7 are available for use. 
4.9.2.1 Inventory estimate 241-B-109

The following tank layer volume approximation was derived from the Ios Alamos National Iaboratories Waste Status and Transaction Record Summary (Agnew 1994). The estimated inventory of Tank 241-B-109 is also presented.

4.9.2.2 In-Tank Photograph 241-B-109

The Tank 241-B-109 photo shows a black and white sludge surface with no visible liquid. The tank contains about 127,000 gal of waste which converts to approximately 3.5 ft deep. The tank waste level was adjusted as a result of the photo.

4.9.3 Synopsis Tänk 241-B-109

(To be completed.) 


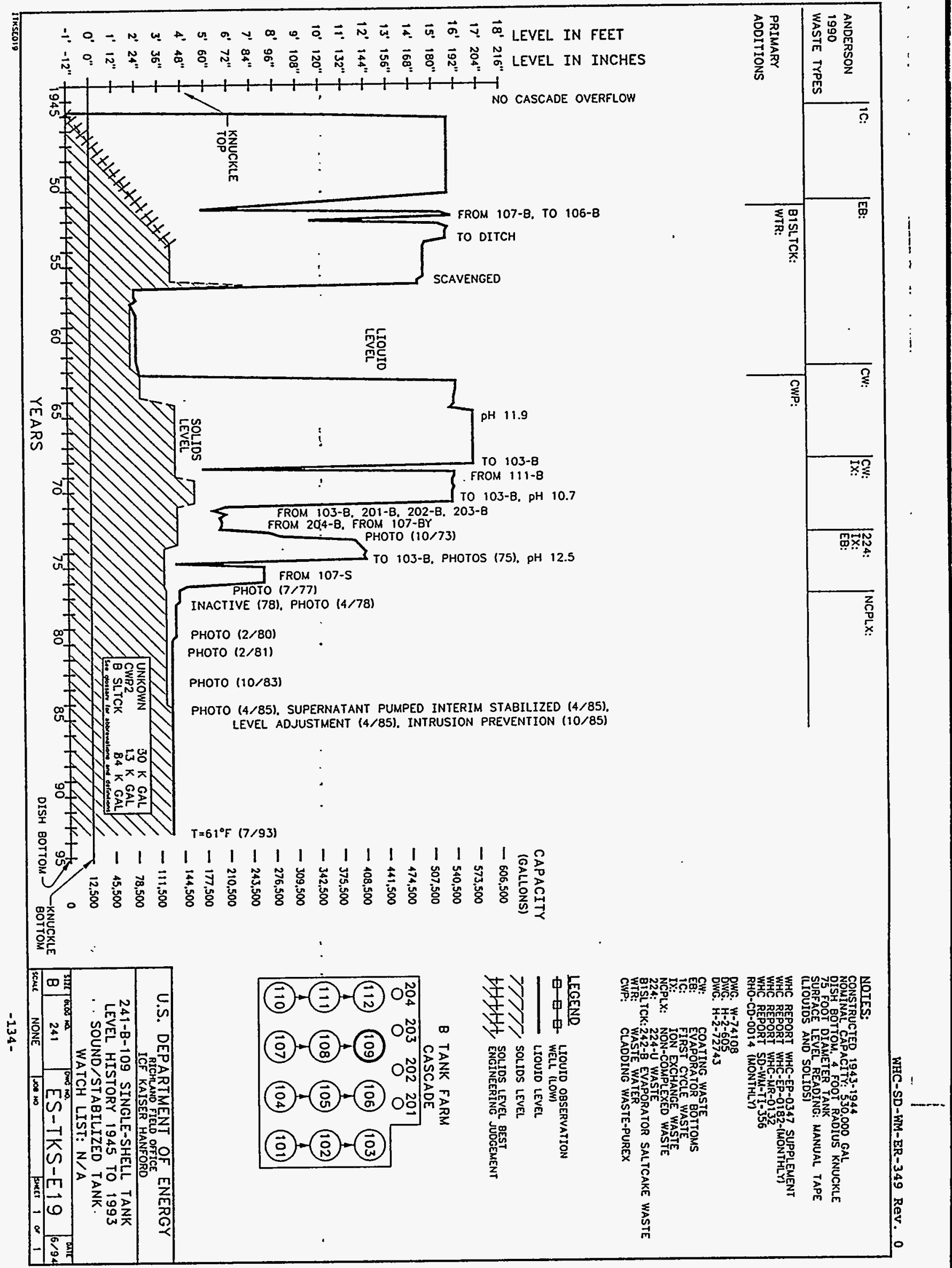




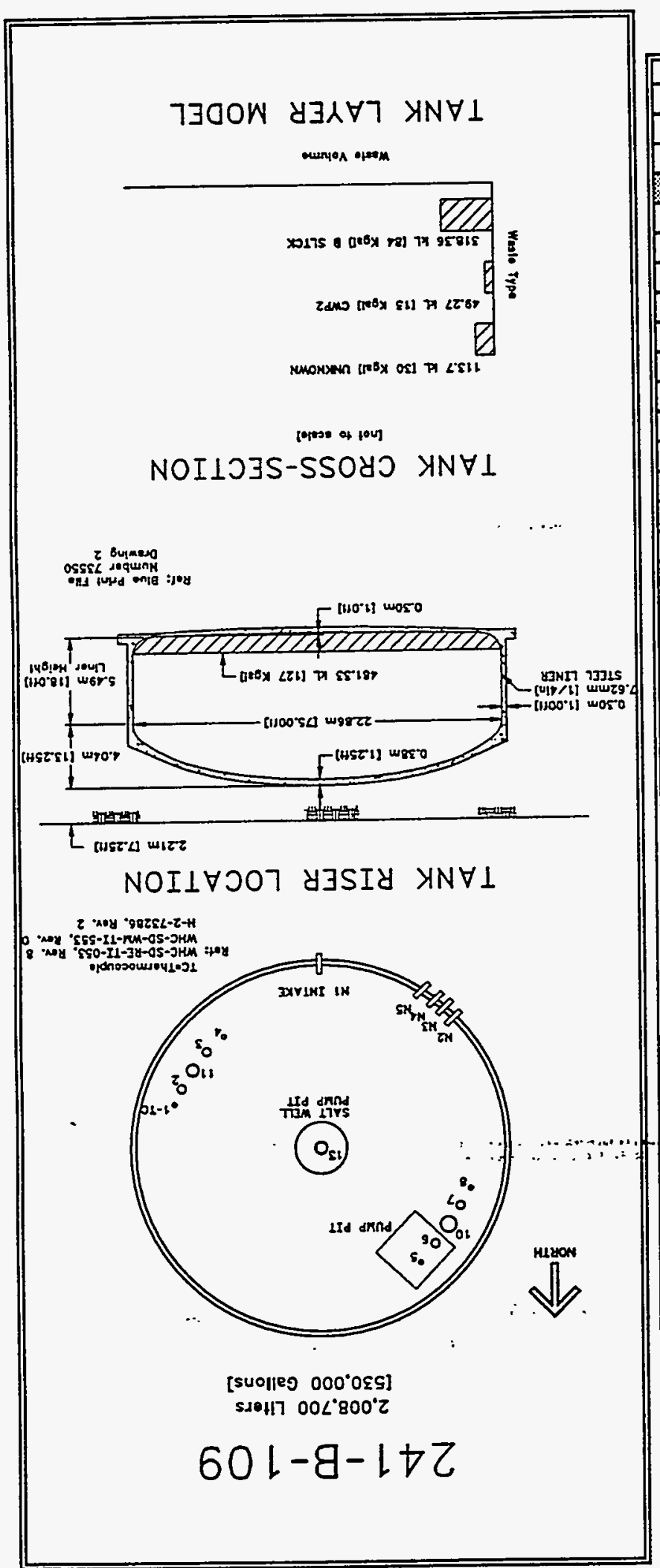

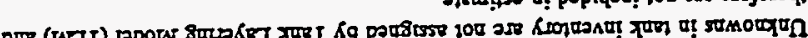

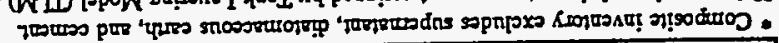

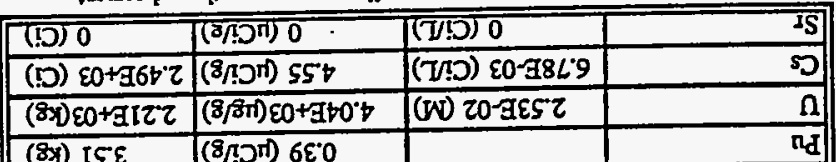

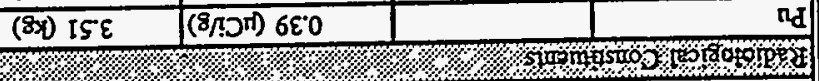

\begin{tabular}{|c|c|c|c|}
\hline & $($ [ow-8) 0 & 0 & $r^{\prime}(N D)>A$ \\
\hline 0 & 0 & 0 & วนันхวน \\
\hline 0 & 0 & 0 & 100 \\
\hline 0 & 0 & 0 & HdN \\
\hline 0 & 0 & 0 & dga \\
\hline 0 & 0 & 0 & $z .018[8 \times 0$ \\
\hline 0 & 0 & 0 & 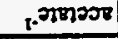 \\
\hline 0 & 0 & 0 & I. गT:00K $\mathrm{I}^{8}$ \\
\hline
\end{tabular}

NOI1OJS-SSOYO YNN $\forall 1$

\begin{tabular}{|l|l|l|l|l|}
\hline 0 & 0 & 0 \\
\hline 0 & 0 & 0 \\
\hline 0
\end{tabular}

\begin{tabular}{|c|c|c|c|}
\hline 0 & 0 & 0 & E.VIOGH \\
\hline 0 & 0 & 0 & $r \forall I d a$ \\
\hline 0 & 0 & 0 & $\varepsilon^{6} \mathrm{O}^{5} \mathrm{H}^{2} \mathrm{~S}$ \\
\hline $20+\exists L E T$ & $20+E I S Z$ & $20-\bar{A} 50^{\circ} \mathrm{I}$ & $r . D$ \\
\hline $20+7+00 t$ & $20+900$ & $20-908^{\circ} \mathrm{S}$ & $t^{2}$ \\
\hline
\end{tabular}

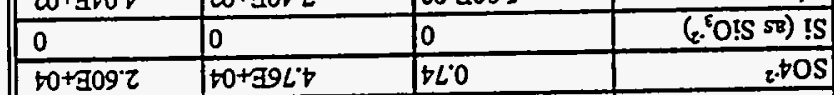

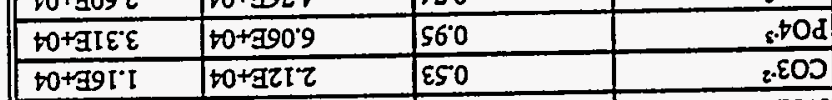

\begin{tabular}{|c|c|c|c|}
\hline$\varepsilon 0+\exists \subset I^{\prime} I$ & $\varepsilon 0+\bar{a} \varepsilon \Gamma^{2} Z$ & $20-706^{\circ} 9$ & $.20 \mathrm{~N}$ \\
\hline $10+3+69$ & $50+78 \Gamma^{\circ} \mathrm{I}$ & $\varepsilon 8^{\circ} \mathrm{Z}$ & r.EON \\
\hline & $50+5062$ & 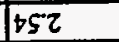 & r.HO \\
\hline
\end{tabular}

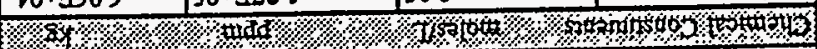

\begin{tabular}{|c|c|}
\hline $00^{\circ} 0$ & (12M) כ \% \\
\hline $29{ }^{\circ} \varsigma \varepsilon$ & $\%$ INEM \\
\hline $09^{\circ} 0$ & 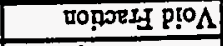 \\
\hline$(00 / 8) 66^{\circ} I$ & Sutisurd XIng \\
\hline 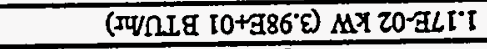 & PEOI TEOH \\
\hline 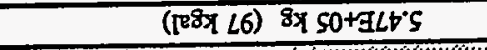 & D2STM PIIOS [R2OI \\
\hline K. & 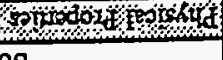 \\
\hline 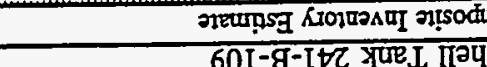 & \\
\hline
\end{tabular}




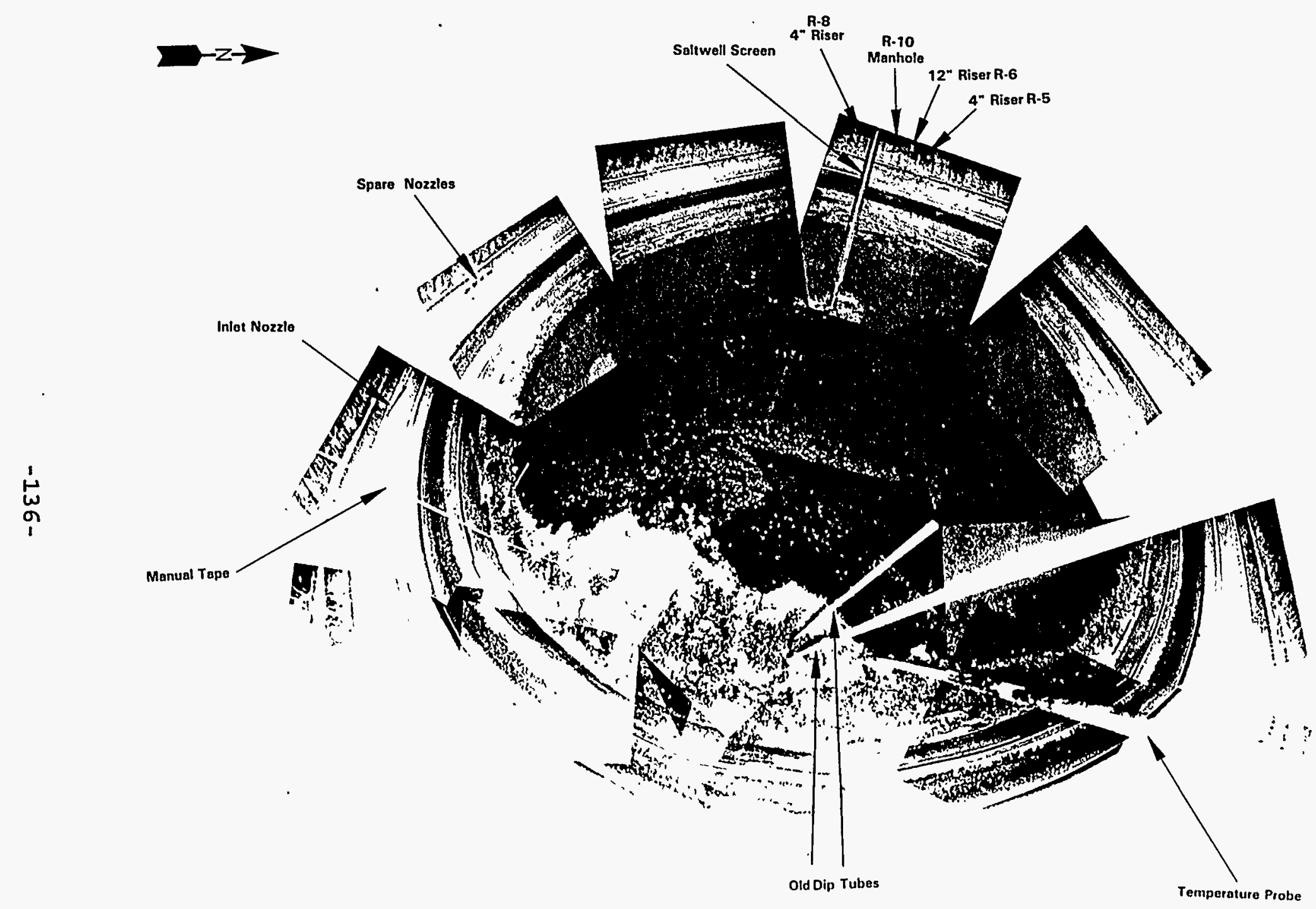

Photo datc: 4-2-85 
WHC-SD-WM-ER-349, Rev. 0

4.10 Tank 241-B-110

4.10.1 241-B-110 Tank History

4.10.1.1 Waste History Tank 241-B-110

Tank 241-B-110 was to filled with second-cycle waste from May 1945 until the third quarter of 1952. . The tank became a suspect leaker in the first quarter of 1973 and was removed from service in the second quarter of 1975. Saltwell pumping began in 1972 and was completed in 1978. The tank was declared inactive in 1978 was assumed to be leaking in 1984 with a leak volume of 10,000 gals. Interim stabilization was completed in December 1984, a level adjustment was made in April 1985, and intrusion prevention was in place in October 1985. (See sketch ES-

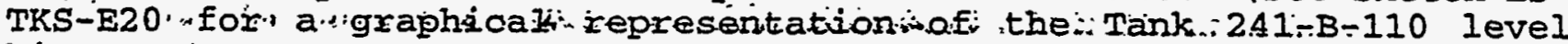
history.)

\subsubsection{Temperature History $241-B-110$}

The single thermocouple tree in Tank 241-B-110 contains 12 thermocouple probes to measure temperature data in riser 8 . The mean temperature of the first recorded data for thermocouples 1 through 8 was $79^{\circ} \mathrm{F}$. A sum of the squares regression line fit for the first 11 thermocouples starting in 1975 shows an overall zero slope $\pm 10.83^{\circ} \mathrm{F}$ with an average $I$ square value of 0.002 . Not enough data points exist in thermocouple 12 for an accurate regression and variability analysis. From May 1975 to present, the median temperature from all the probes is $75^{\circ} \mathrm{F}$ with a minimum of $55^{\circ} \mathrm{F}$ and a maximum of $121.2^{\circ} \mathrm{F}$. Refer to the supporting document for a more thorough review of the temperature data (Brevick 1994).

\subsubsection{Integrity of Tank $241-\mathrm{B}-110$}

Tank 241-B-110 is categorized as an assumed leaker and is interim stabilized with intrusion prevention completed. The surface level in Tank 241-B-110 is monitored quarterly with-a manual tape through riser 5. A figure that graphically represents the surface level measurements from January 1991 to the present can be found in the supporting documents (Brevick 1994). Surface level monitoring was out of compliance from January of 1993 to November of 1993. Data for the plot was obtained before the surface level monitoring resumed. The surface level has remained steady with the readings ranging from 87.25 to $85-$ in. On January 2, 1994, a reading was obtained of 85.5-in. (not shown on plot).

Four drywells are identified for tank 241-B-110. Data and graphical representations of the active drywells from January 1990 to the present can be found in the supporting document (Brevick 1994).

\subsubsection{Current Status of Tank 241-B-110}

Tank 241-B-110 entered service in May 1945 and currently stores 246,000 gal of non-complexed waste. The waste is comprised of 1,000 gal 
of supernatant; $245,000 \mathrm{gal}$ of sludge; and no saltcake with $17,000 \mathrm{gal}$ of pumpable liquid remaining. The tank is identified as a low-heat load tank, is passively ventilated, and is categorized as an assumed leaker with interim stabilization and intrusion prevention completed. Tank 241-B-110 is equipped to cascade to Tank 241-B-111 and is first in the three-tank cascade series. The following plan view and tank cross section depict the approximate waste level and riser configuration. Tank 241-B-110 has 12 risers and four risers are available for use: three 12-in. risers (nos. 3, 6 and 7) and one 4-in. riser (no.4).

\subsubsection{Inventory estimate 241-B-110}

The following tank layer volume approximation was derived from Los Alamos National. Laboratories Waste.Status..and.Transaction Record Summary (Agnew 1994)\% The estimated"'inventory of Tank'241-B-110 is also presented.

\subsubsection{In-Tank Photograph 241-B-110}

The Tank 241-B-110 photo shows a reddish-brown sludge with a thin layer of liquid on the surface. The tank contains approximately 246,000 gal of waste which converts to slightly more than 7 ft deep.

\subsubsection{Synopsis Tank 241-B-110}

(To be completed.) 


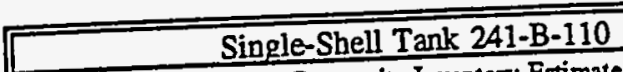
Solids Composite Inventory Estimate

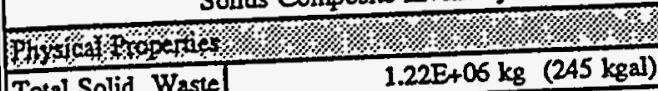

\begin{tabular}{|c|c|}
\hline Total Solid Waste & $1.22 \mathrm{E}+06 \mathrm{~kg}(245 \mathrm{kgal})$ \\
\hline & $1.17 \mathrm{~kW}(4.01 \mathrm{E}+03 \mathrm{BTU} / \mathrm{hr})$ \\
\hline
\end{tabular}

Bulk Density

Void Fraction

Water wr\%

TOC wr\% C (wet)

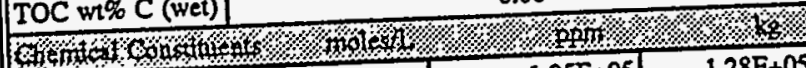

\begin{tabular}{|l|r|r|r|}
\hline $\mathrm{Na}^{+1}$ & 6.02 & $1.05 \mathrm{E}+05$ & $1.28 \mathrm{E}+05$ \\
\hline $\mathrm{Al}^{43}$ & 0 & 0 & 0 \\
\hline
\end{tabular}

\begin{tabular}{|c|c|c|c|}
\hline $\mathrm{Al}^{+3}$ & 0 & & \\
\hline $\mathrm{Fe}^{3}(\mathrm{got}, \mathrm{Fe})$ & 0.37 & $1.59 \mathrm{E}+04$ & $1.94 \mathrm{E}+04$ \\
\hline
\end{tabular}

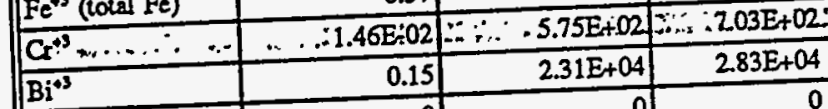

$\mathrm{La}^{43}$

$\mathrm{Ce}^{43}$

$\mathrm{Zc}$ (as $\left.\mathrm{Z} \mathrm{O}(\mathrm{OH})_{2}\right)$

$\mathrm{Pb}^{+2}$

$\mathrm{Ni}^{42}$

$\mathrm{Sr}^{* 2}$

$\mathrm{Mn}^{+1}$

\begin{tabular}{|l|r|}
\hline $\mathrm{Ca}^{42}$ & \\
\hline $\mathrm{K}^{+1}$ & \\
\hline $\mathrm{OR}^{-1}$ & 1.5 \\
\hline
\end{tabular}

NO3

\begin{tabular}{|r|r|}
\hline $\mathrm{NO}^{-1}$ & \\
\hline $\mathrm{CO}^{.2}$ & $6.44 \mathrm{E}-04$ \\
\hline $\mathrm{PO}^{-3}$ & 1.44 \\
\hline
\end{tabular}

$\mathrm{PO4}$

$\mathrm{SO}^{-2}$

\begin{tabular}{|c|c|c|c|}
\hline $\mathrm{SO}_{4}^{2}$ & 0.56 & $1.19 \mathrm{E}+04$ & $1.46 \mathrm{E}+04$ \\
\hline $\mathrm{Si}\left(\operatorname{as~} \mathrm{SiO}_{3}{ }^{-2}\right)$ & 0.15 & $2.18 E+03$ & $2.67 \mathrm{E}+03$ \\
\hline$F^{1}$ & & 0 & \\
\hline
\end{tabular}

F

$\mathrm{C}_{6} \mathrm{H}_{5} \mathrm{O}_{7}{ }^{5}$

EDTA

HEDTA ${ }^{3}$

NTA $^{-3}$

glycolate ${ }^{-1}$

acetate $^{-1}$

oxalate ${ }^{-2}$

DBP

NPH

$\mathrm{CCl}$

hexone

$\mathrm{Fe}(\mathrm{CN})_{6}{ }^{2}$

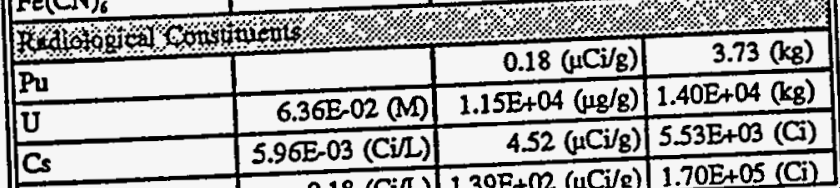

\begin{tabular}{|l|l|l}
\hline $\mathrm{Sr}$ & $0.18(\mathrm{CiN})$ & $1.39 \mathrm{E}+02(\mu \mathrm{Ci} / \mathrm{g})$ \\
\hline
\end{tabular}

- Conposite inventory excludes supernatast, diatomaceous earth, and cermed

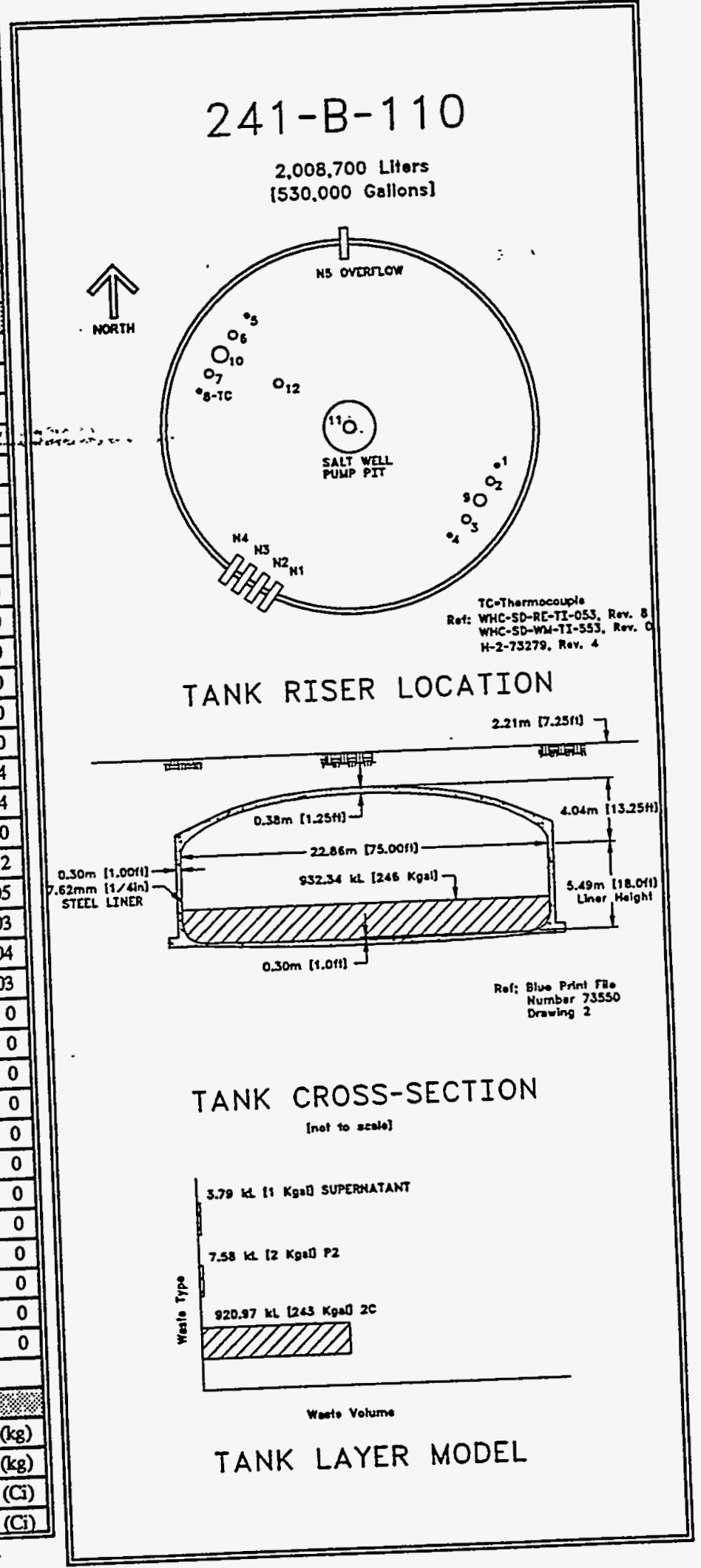

$6 / 94$ 
WHC-SD-WM-ER-349 Rev. 0

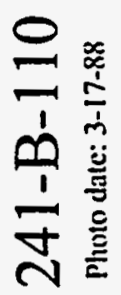

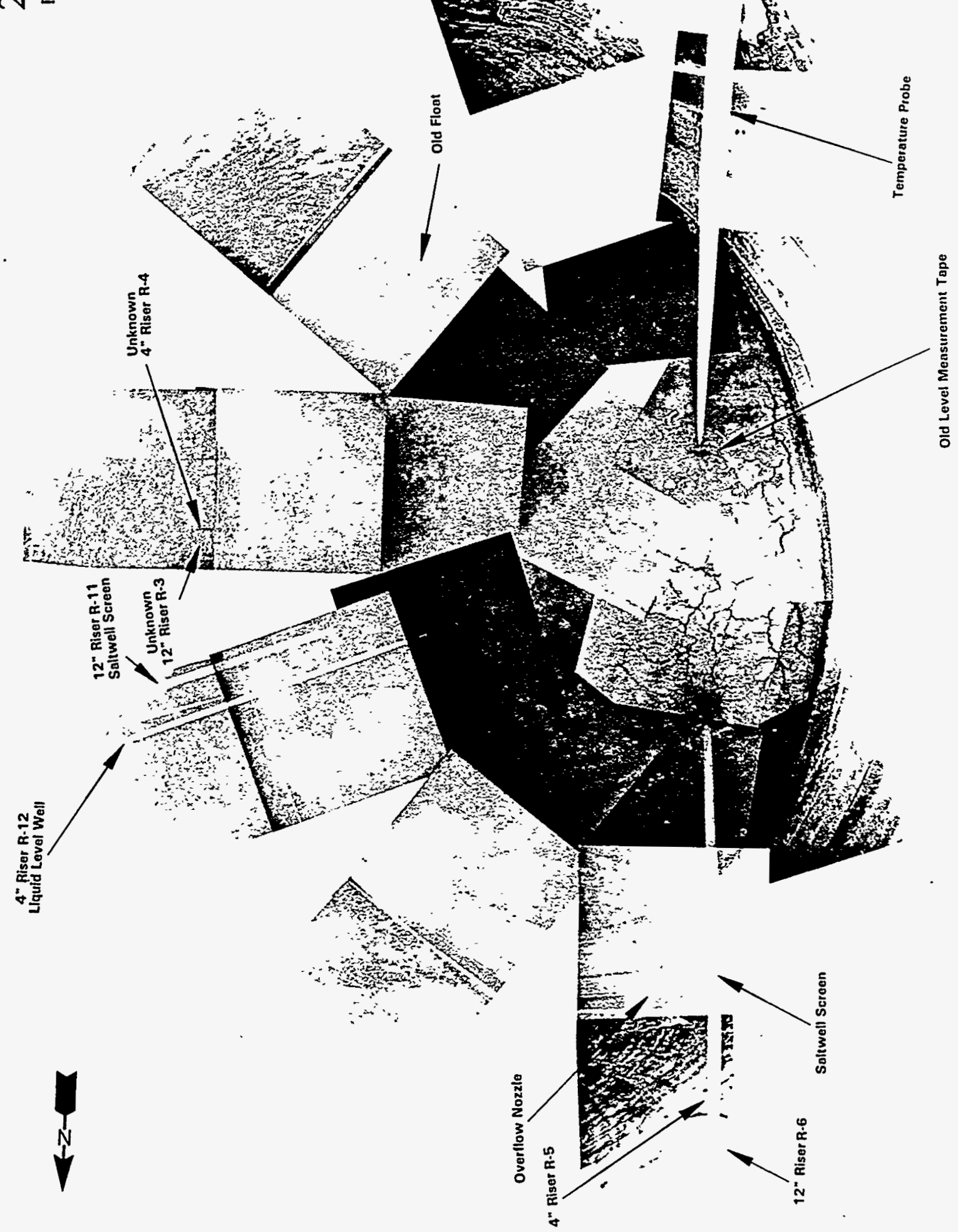


4.11.1 241-B-111 Tank History

\subsubsection{Waste History Tank 241-B-111}

Tank 241-B-111 was filled with second-cycle waste from December 1945 to April 1946. In the second quarter of 1976, the tank was removed from service. During the second and third quarters of 1977, the tank was inactive with a minimum heel. In 1978, Tank 241-B-111 was considered an assumed leaker after leaking approximately $8,000 \mathrm{gal}$. In June 1985, supernatant was pumped, the tank was declared interim stabilized, and a level adjustment was made. In October 1985, intrusion. prevention was completed.. (See sketch ES-TKS-E21 for a

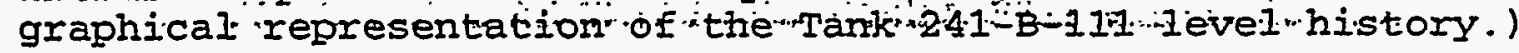

\subsubsection{Temperature History 241-B-111}

Tank 241-B-111 contains a single thermocouple tree with 12 thermocouples to measure the tank temperatures in riser 8 . The mean temperature of the first recorded data from thermocouples 1 through 11 was $85^{\circ} \mathrm{F}$. A sum of the squares regression line fit of all the thermocouples shows a slightly negative, near zero slope $\pm 9.4^{\circ} \mathrm{F}$ with an average $x$ square value of 0.13. From April 1975 to present, the median temperature is $81^{\circ} \mathrm{F}$ with a minimum of $55^{\circ} \mathrm{F}$ and a maximum of $98^{\circ} \mathrm{F}$. Refer to the supporting document for a more thorough review of the temperature data (Brevick 1994).

\subsubsection{Integrity of Tank 241-B-111}

Tank 241-B-111 is categorized as an assumed leaker and is interim stabilized with intrusion prevention completed. The Tank 241-B-111 surface level is monitored with a Food Instrument Corporation gauge through riser 1. For more information on surface levels see supporting documents (Brevick 1994).

One drywell is identified for tank 241-B-111, and a graphical representation from January 1990 to the present can be found in the supporting documents (Brevick 1994).

\subsubsection{Current Status of Tank 241-B-111}

Tank 241-B-111 entered service in November 1945 and currently stores 237,000 gal of non-complexed waste. The waste is comprised of 1,000 gal of supernatant; 236,000 gal of sludge; and no saltcake with $16,000 \mathrm{gal}$ of pumpable liquid remaining. The tank is identified as a low-heat load tank, is passively ventilated, and is categorized as an assumed leaker with interim stabilization and intrusion prevention completed. Tank 241-B-111 is equipped to cascade to Tank 241-B-112 and is second in the three-tank cascade flow series. The following plan view and tank cross section depict the approximate waste level and riser configuration. Tank $241-B-111$ has 11 risers and three are available for use: two 12-in. risers (nos.3 and 6 ) and one 4-in. riser (no.4). 


\subsubsection{Inventory éstimate $241-\mathrm{B}-111$}

The following tank layer volume approximation was derived from the Los Alamos National Iaboratories Waste Status and Transaction Record Summary (Agnew 1994). The estimated inventory of Tank 241-B-111 is also presented.

\subsubsection{In-Tank Photograph 241-B-111}

The Tank 241-B-111 photo shows a very dark brown sludge surface with pockets of supernatant in places. The tank contains about 237,000 gal of waste which converts to approximately 7 ft deep. The recirculating dip tube had been cut off at the dome and sealed. The tank level. was : adjusted; as $\times$ a :xesult of: the :photo:...

\subsubsection{Synopsis Tank 241-B-111}

(To be completed.) 


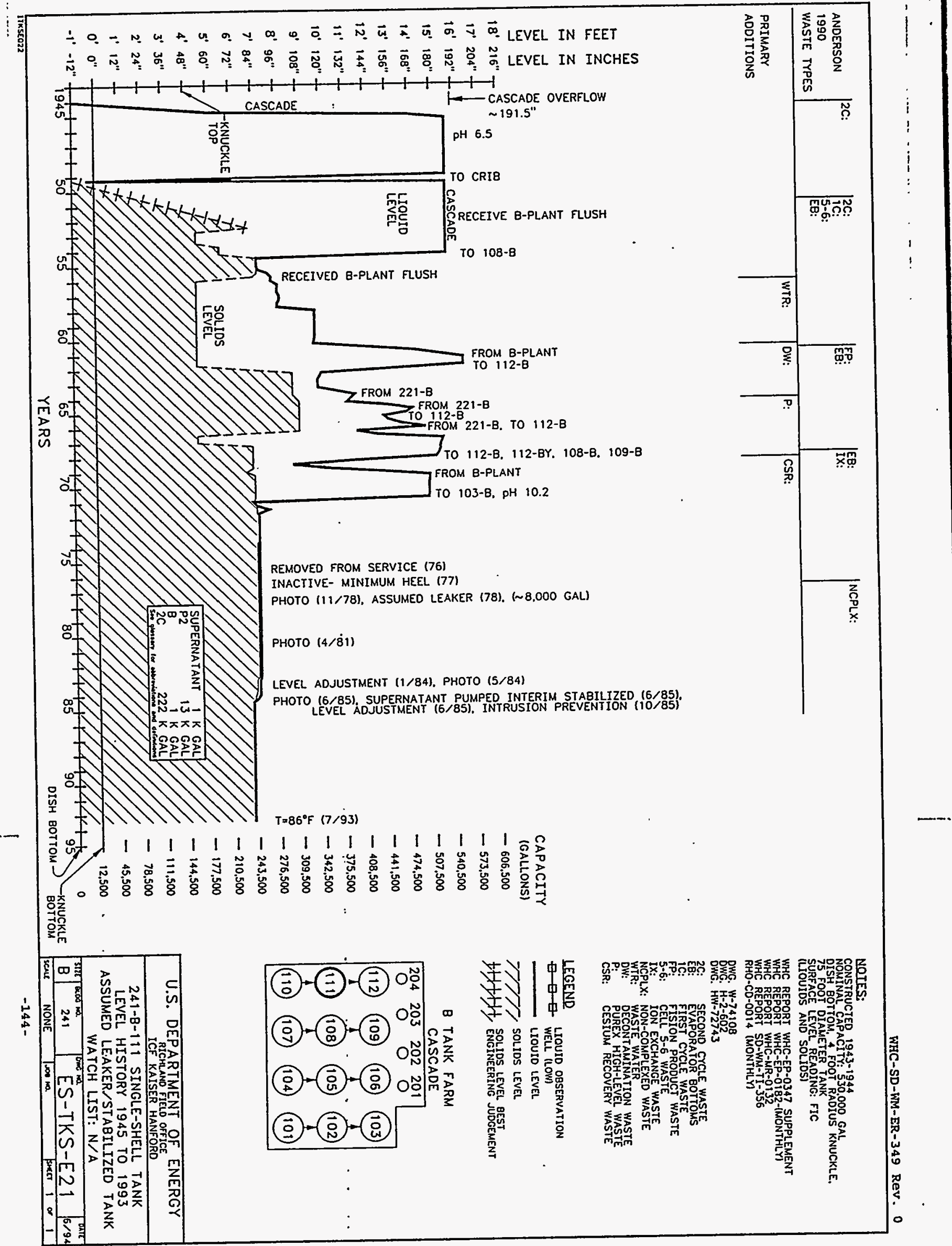


WHC-SD-WM-ER-349, Rev. 0

\begin{tabular}{|c|c|c|c|}
\hline \multicolumn{4}{|c|}{ Single-Shell Tank 241-B-111 } \\
\hline \multicolumn{4}{|c|}{ Solids Composite Inventory Estimate } \\
\hline 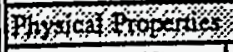 & প২/ / / & \% & $\% \% \% \%$ \\
\hline Total Solid Waste & \multicolumn{3}{|c|}{$1.18 \mathrm{E}+06 \mathrm{~kg}(236 \mathrm{kgal})$} \\
\hline Heat load & \multicolumn{3}{|c|}{$8.47 \mathrm{~kW}(2.89 \mathrm{E}+04 \mathrm{BTU} / \mathrm{hr})$} \\
\hline Bulk Density & \multicolumn{3}{|c|}{$1.32(\mathrm{~g} / \propto)$} \\
\hline Void Fraction & \multicolumn{3}{|c|}{0.69} \\
\hline Water wt\% & \multicolumn{3}{|c|}{65.52} \\
\hline TOC wr\% C (wet) & \multicolumn{3}{|c|}{0.00} \\
\hline \multicolumn{4}{|c|}{ 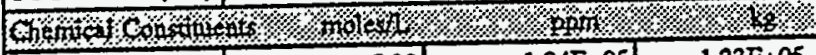 } \\
\hline $\mathrm{Na}^{+1}$ & 5.99 & $1.04 \mathrm{E}+05$ & $1.23 \mathrm{E}+05$ \\
\hline $\mathrm{Al}^{+3}$ & 5.17E-03 & $1.05 \mathrm{E}+02$ & $1.25 \mathrm{E}+02$ \\
\hline $\mathrm{Fe}^{+3}$ (total $\mathrm{Fe}$ ) & 0.52 & $221 E+04$ & $2.61 \mathrm{E}+04$ \\
\hline $\mathrm{Cr}^{+3}$ & $1.38 \mathrm{E}-02$ & $\therefore \quad 5,44 \mathrm{E}+02$ & $\because \cdots .63 \mathrm{E}+02$ \\
\hline $\mathrm{Bi}^{+3}$ & 0.14 & $2.19 \mathrm{E}+04$ & $258 \mathrm{E}+04$ \\
\hline $\mathrm{La}^{43}$ & 0 & 0 & 0 \\
\hline $\mathrm{Ce}^{43}$ & 요 & of & 0 \\
\hline $\mathrm{Zx}$ (as $\left.\mathrm{2rO}(\mathrm{OH})_{2}\right)$ & 0 & 0 & 0 \\
\hline $\mathrm{Pb}^{42}$ & 8.47E-07 & 0.13 & 0.16 \\
\hline $\mathrm{Ni}^{+22}$ & $6.30 \mathrm{E}-06$ & 0.28 & 0.33 \\
\hline $\mathrm{Sr}^{+2}$ & o & 0 & 0 \\
\hline$\overline{\mathrm{Mn}^{4+4}}$ & of & 0) & 0 \\
\hline $\mathrm{Ca}^{42}$ & of & 0) & 0 \\
\hline$\overline{\mathrm{R}^{+1}}$ & 0 & $\therefore \quad 0$ & 0 \\
\hline $\mathrm{OH}^{\cdot 1}$ & 2.00 & $2.57 \mathrm{E}+04$ & $3.03 E+04$ \\
\hline $\mathrm{NO}^{-1}$ & 0.78 & $3.64 \mathrm{E}+04$ & $4.30 \mathrm{E}+04$ \\
\hline $\mathrm{NO} 2^{2}$ & 0 & 0 & 0 \\
\hline $\mathrm{CO}^{-2}$ & 4.66 -03 & $2.11 E+02$ & $2.50 \mathrm{E}+02$ \\
\hline $\mathrm{PO}^{-3}$ & 1.36 & $9.79 \mathrm{E}+04$ & $1.16 \mathrm{E}+05$ \\
\hline $504^{-2}$ & $5.14 \mathrm{E}-02$ & $3.73 \mathrm{E}+03$ & $4.41 \mathrm{E}+03$ \\
\hline $\mathrm{Si}\left(\right.$ as $\left.\mathrm{SiO}_{3}{ }^{2}\right)$ & 0.64 & $1.36 \mathrm{E}+04$ & $1.61 E+04$ \\
\hline $\mathrm{F}^{-1}$ & 0.14 & $2.06 \mathrm{E}+03$ & $2.44 \mathrm{E}+03$ \\
\hline $\mathrm{Ca}^{\cdot 1}$ & 0 & 0 & 0 \\
\hline $\mathrm{C}_{6} \mathrm{H}_{3} \mathrm{O}_{3}{ }^{3}$ & 3.15E-05 & 4.50 & 5.32 \\
\hline EDTA $^{-4}$ & o & of & 0 \\
\hline HEDTA $^{-3}$ & 0 & 0 & 0 \\
\hline $\mathrm{NTA}^{.3}$ & 0 & 0 & 0 \\
\hline glycolate & 이 & 0 & 0 \\
\hline acetate & 0 & of & 0 \\
\hline oxalate ${ }^{-2}$ & 의 & 0 & 0 \\
\hline DBP & of & 요 & 0 \\
\hline $\mathrm{NPH}$ & 0 & of & 0 \\
\hline $\mathrm{CC}$ & of & 0 & 0 \\
\hline hexone & 0 & 0 & 0 \\
\hline $\mathrm{Fe}(\mathrm{CN})_{t}^{-1}$ & 01 & $0(\mathrm{~g}-\mathrm{mol})$ & \\
\hline \multicolumn{4}{|c|}{ 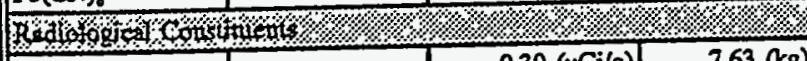 } \\
\hline $\mathrm{Pu}$ & & $0.39(\mu \mathrm{Ci} / \mathrm{g})$ & $7.63\left(\mathrm{~kg}_{8}\right)$ \\
\hline $\bar{U}$ & $6.17 \mathrm{E}-02(\mathrm{M})$ & $1.11 E+04(\mu \mathrm{g} / \mathrm{g})$ & $1.31 \mathrm{E}+04(\mathrm{~kg})$ \\
\hline Cs & 4.05E-02(Cin) & $30.66(\mathrm{aCi} / \mathrm{g})$ & $3.62 \mathrm{E}+04(\mathrm{Ci})$ \\
\hline$S_{r}$ & $1.38(\mathrm{Ci} / \mathrm{L})$ & $1.04 \mathrm{E}+03(\mathrm{uCV} / \mathrm{g})$ & $1.23 \mathrm{E}+06(\mathrm{Ci})$ \\
\hline
\end{tabular}

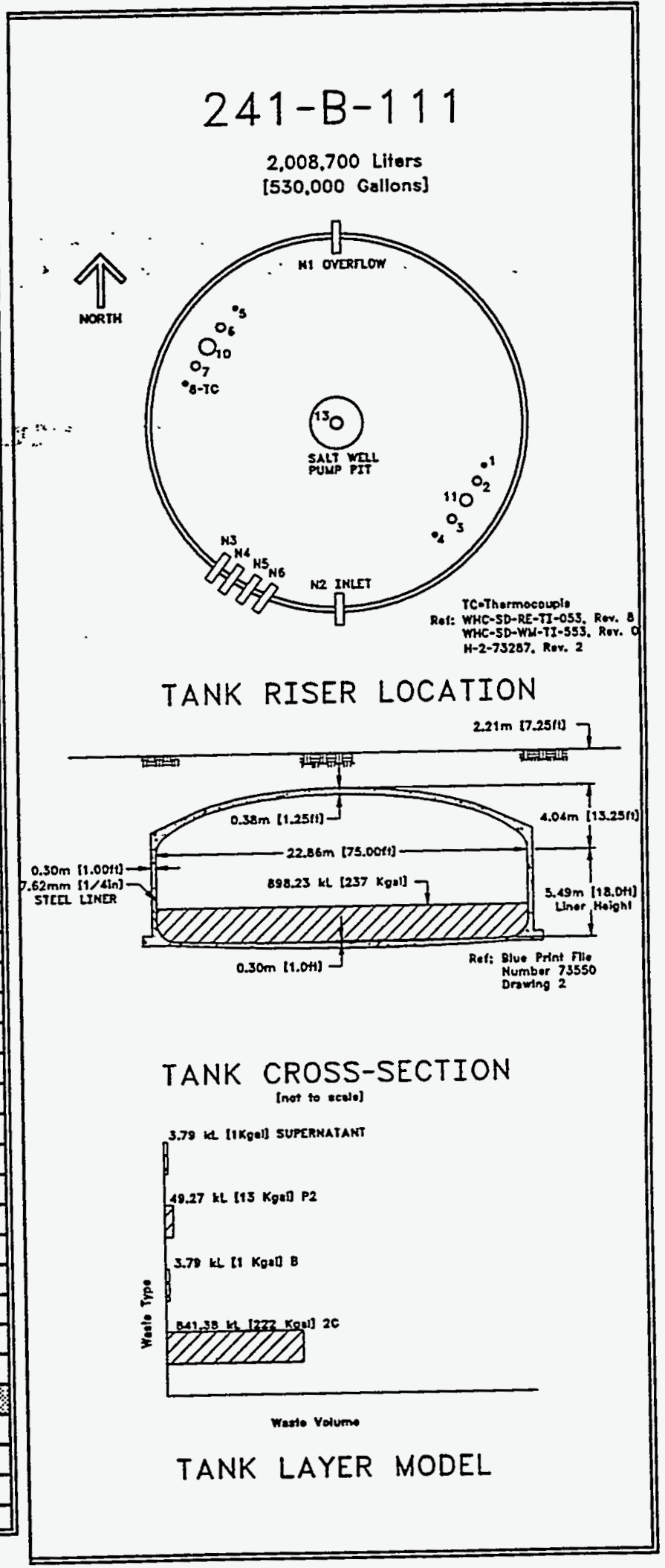


WHC-SD-WM-ER-349 Rev. 0
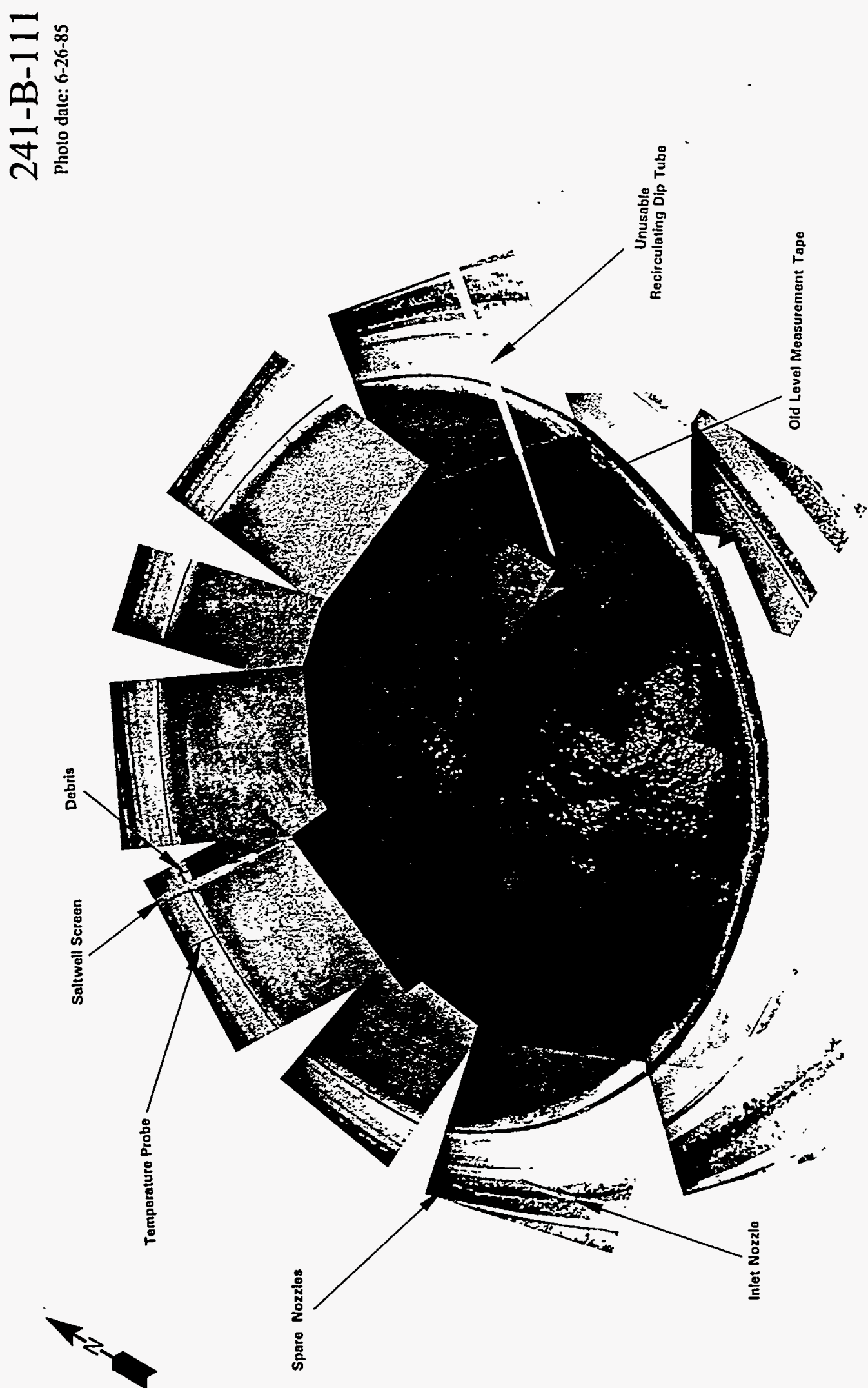


\subsubsection{1-B-112 Tank History}

\subsubsection{Waste History Tank 241-B-112}

Tank 241-B-112 was filled with second-cycle waste from April 1946 to August:1946. . The tank was . inactive in.19.78 but was declared an assumed leaker after leaking approximately.8,000 gal of waste. After supernatant pumping, interim stabilization was completed and a level adjustment was made in May 1985. Intrusion prevention was completed in June 1985. (See sketch ES-TKS-E22 for a graphical representation of the Tank 241-B-112 level history.)

\section{$4.12: 1: 2 \cdots$ Tenperáture History $241-B=112+\cdots$}

Tank 241-B-112 has a single thermocouple tree with 12 thermocouple probes to measure the temperatures in riser 1. The mean temperature of the first daily recorded readings was $77^{\circ} \mathrm{F}$. A sum of the squares regression.line fit for thermocouples 1, 3, and 5 through 12 starting in 1974 shows a slightly negative, near zero slope $\pm 10^{\circ} \mathrm{F}$ with an average $r$ square value of 0.22 . From September 1974 to current, the median probe temperature is $76^{\circ} \mathrm{F}$ with a minimum of $56^{\circ} \mathrm{F}$ and a maximum of $101^{\circ} \mathrm{F}$. Refer to the supporting document for a more thorough review of the temperature data (Brevick 1994).

\subsubsection{Integrity of Tank $241-\mathrm{B}-112$}

Tank 241-B-112 is categorized as an assumed leaker and is interim stabilized with intrusion prevention completed. The surface level in Tank 241-B-112 is monitored with a Food Instrument Corporation gauge through riser 4. A figure that graphically represents the surface level measurements from January 1991 to the present can be found in the supporting documents (Brevick 1994). The surface level plot depicts an increasing trend with the readings ranging from 7.3 to $7.5-i n$. during the first quarter of 1991 and increasing from 7.8 to $7.9-i n$. during the fourth quarter of 1993.

Five arywells are identified for tank 241-B-112. A graphical representation of the active drywell from January 1990 to the present can be found in the same supporting document. The graph includes the peak c/s, the depth at which the peak occurred, and the date of the reading.

\subsubsection{Current Status of Tank 241-B-112}

Tank 241-B-112 entered service in April 1946 and currently stores $33,000 \mathrm{gal}$ of waste. The waste is comprised of 3,000 gal of supernatant; 16,000 gal of saltcake; 14,000 gal of sludge with no pumpable liquid remaining. The tank is identified as a low-heat load tank, is passively ventilated, and is categorized as an assumed leaker with interim stabilization and intrusion prevention completed. Tank 241-B-112 is third in the three-tank cascade flow series. The following 
plan view and tank cross section depict the approximate waste level and riser configuration. Tank-B-112 has 11 tank dome risers and three 2-in. risers nos. 2,3 and 7 are available for use.

\subsubsection{Inventory estimate 241-B-112}

The following tank layer volume approximation was derived from the Los Alamos National Laboratories Waste Status and Transaction Record Summary (Agnew 1994). The estimated inventory of Tank 241-B-112 is also presented.

\subsubsection{In-Tank Photograph 241-B-112}

The Tank 2.41-B-112, photo.shows, a. layer of dark supernatant covering a brown/black sludge'. Thè tank contains approximately 33;000 gal of waste which converts to slightly less than 1 ft deep.

\subsubsection{Synopsis Tank 241-B-112}

(To be completed.) 


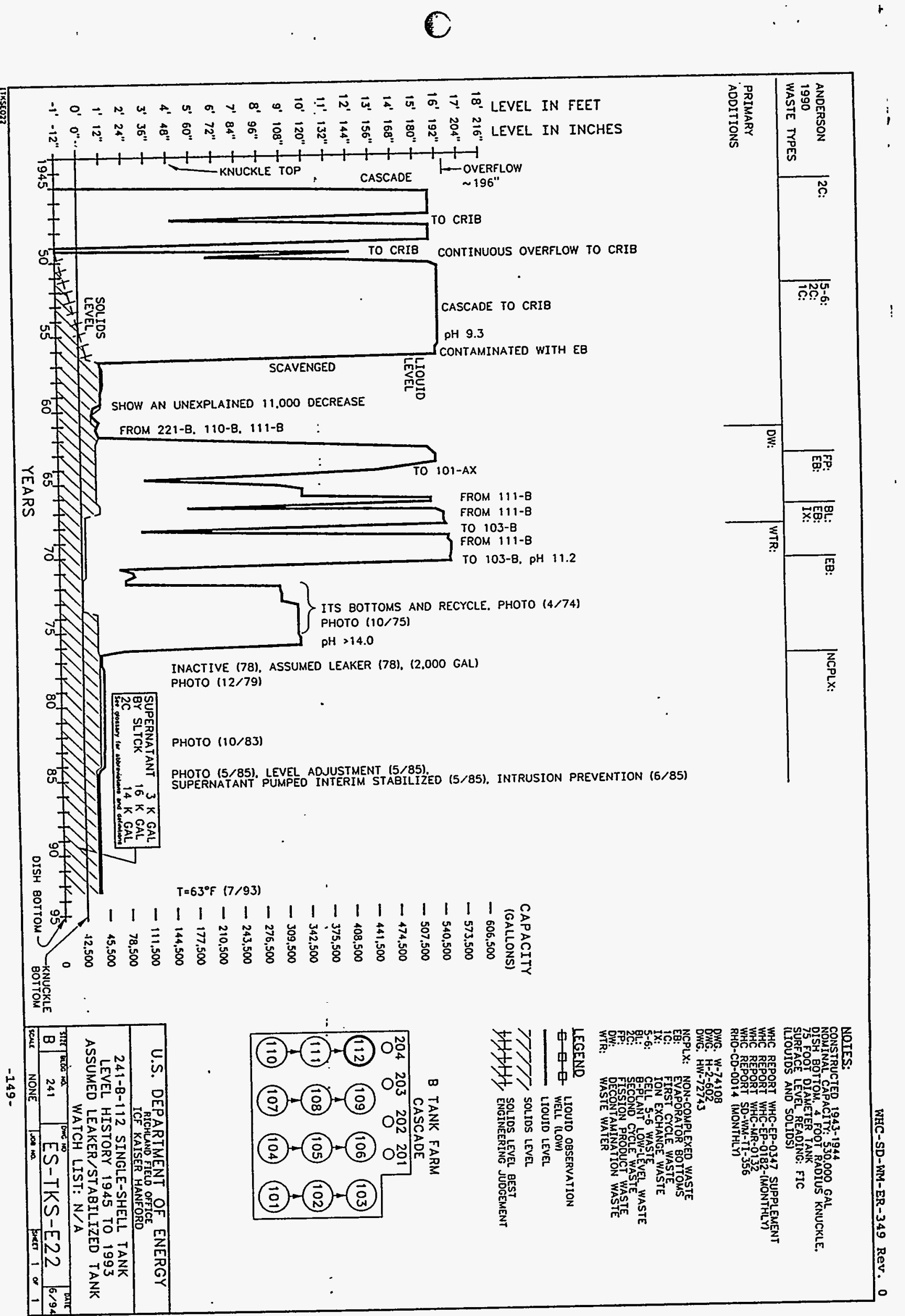


WHC-SD-WM-ER-349, Rev. 0

\begin{tabular}{|c|c|c|c|}
\hline \multicolumn{4}{|c|}{ Single-Shell Tank 241-B-112 } \\
\hline \multicolumn{4}{|c|}{ Solids Composite Inventory Estimate } \\
\hline 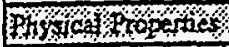 & 8 & $18 \% 1 \%$ & $\% \% \%$ \\
\hline Total Solid Waste & \multicolumn{3}{|c|}{$1.61 \mathrm{E}+05 \mathrm{~kg}(30 \mathrm{kgal})$} \\
\hline Heat load & \multicolumn{3}{|c|}{$0.11 \mathrm{~kW}(3.69 \mathrm{E} \div 02 \mathrm{BTU} / \mathrm{hr})$} \\
\hline Bulk Density & \multicolumn{3}{|c|}{$1.41(\mathrm{~g} / \infty)$} \\
\hline Void Fraction & \multicolumn{3}{|c|}{0.69} \\
\hline Water wt\% & \multicolumn{3}{|c|}{48.81} \\
\hline TOC wt\% C (wes) & \multicolumn{3}{|c|}{0.03} \\
\hline \multicolumn{4}{|c|}{ 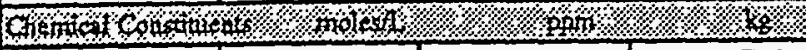 } \\
\hline $\mathrm{Na}^{+1}$ & 8.84 & $1.44 \mathrm{E}+05$ & $2.31 \mathrm{E}+04$ \\
\hline $\mathrm{Al}^{+3}$ & 0.20 & $3.84 \mathrm{E}+03$ & $6.17 \mathrm{E}+02$ \\
\hline $\mathrm{Fe}^{43}$ (total Fe) & 0.16 & $6.51 \mathrm{E}+03$ & $1.04 E+03$ \\
\hline$c^{* 3}, \ldots \ldots \ldots$ & $\therefore \because 6.86 \mathrm{E}-03$ & $\therefore \therefore 2.52 \mathrm{~B}+02$ & $\because \because 40.52$ \\
\hline $\mathrm{Bi}^{+3}$ & 6.86E-02 & $1.01 \mathrm{E}+04$ & $1.63 \mathrm{E}+03$ \\
\hline $\mathrm{La}^{+3}$ & 0 & 0 & 0 \\
\hline $\mathrm{Ce}^{43}$ & 0 & 0 & 0 \\
\hline $\mathrm{Zx}$ (as $\left.\mathrm{ZrO}(\mathrm{OH})_{2}\right)$ & 0 & 0 & 0 \\
\hline $\mathrm{Pb}^{+2}$ & 0) & 0 & 0 \\
\hline $\mathrm{Ni}^{22}$ & 0 & 익 & 0 \\
\hline$S \mathrm{st}^{+2}$ & 0) & 0 & 0 \\
\hline $\mathrm{Mn}^{+4}$ & of & 0 & 0 \\
\hline $\mathrm{Ca}^{+2}$ & of & 0 & 0 \\
\hline $\mathrm{K}^{+1}$ & $1.40 \mathrm{E}-03$ & 38.70 & 6.21 \\
\hline $\mathrm{OH}^{-1}$ & 1.38 & $1.66 E+04$ & $2.66 E+03$ \\
\hline $\mathrm{NO}^{-1}$ & 4.80 & $2.11 \mathrm{E}+05$ & $3.38 E+04$ \\
\hline $\mathrm{NO}^{-1}$ & 0.14 & $4.70 \mathrm{E}+03$ & $7.54 \mathrm{E}+02$ \\
\hline $\mathrm{CO}^{-2}$ & 0.22 & $9.31 E+03$ & $1.49 E+03$ \\
\hline $\mathrm{PO}^{.3}$ & 0.75 & $5.04 \mathrm{E}+04$ & $8.09 E+03$ \\
\hline $\mathrm{SO}^{-2}$ & 0.25 & $1.73 E+04$ & $2.78 E+03$ \\
\hline $\mathrm{Si}\left(\right.$ as $\mathrm{SiO}_{3}{ }^{-2}$ ) & 0.25 & $5.04 \mathrm{E}+03$ & $8.10 \mathrm{E}+02$ \\
\hline $\mathrm{F}^{-1}$ & 0.36 & $4.89 \mathrm{E}+03$ & $7.85 \mathrm{E}+02$ \\
\hline $\mathrm{C}^{\cdot 1}$ & $8.75 \mathrm{E}-03$ & $2.19 \mathrm{E}+02$ & 35.18 \\
\hline $\mathrm{C}_{6} \mathrm{H}_{3} \mathrm{O}_{7}^{-3}$ & 0 & 0 & 0 \\
\hline EDTA & 0 & 이 & 0 \\
\hline HEDTA $^{.3}$ & 0 & of & 0 \\
\hline $\mathrm{NTA}^{-3}$ & 0 & 0 & 0 \\
\hline glycolate & 0 & 0 & 0 \\
\hline acetate ${ }^{-1}$ & $1.85 \mathrm{E}-02$ & $7.74 \mathrm{E}+02$ & $1.24 E+02$ \\
\hline oxalate-2 & 0 & 0 & 0 \\
\hline$\overline{D B P}$ & 0 & of & 0 \\
\hline $\mathrm{NPH}$ & 0 & 0 & 0 \\
\hline $\mathrm{CCl}_{4}$ & 0 & of & 0 \\
\hline hexone & 0] & o & 0 \\
\hline $\mathrm{Fe}(\mathrm{CN}){ }_{i}^{-1}$ & 0 & $0(\mathrm{~g}-\mathrm{mol})$ & \\
\hline \multicolumn{4}{|c|}{ 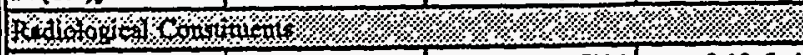 } \\
\hline $\mathrm{Pu}$ & & $7.04 \mathrm{E}-02(\mu \mathrm{Ci} / \mathrm{g})$ & $0.19(\mathrm{~kg})$ \\
\hline $\mathrm{U}$ & $4.24 \mathrm{E}-02(\mathrm{M})$ & $7.14 \mathrm{E}+03(\mu \mathrm{g} / \mathrm{g})$ & $1.15 \mathrm{E}+03(\mathrm{~kg})$ \\
\hline Cs & $0.20(\mathrm{Ci} / \mathrm{L})$ & $1.42 \mathrm{E}+02(\mu \mathrm{Ci} / \mathrm{g})$ & $2.28 \mathrm{E}+04(\mathrm{Ci})$ \\
\hline $\mathrm{Sr}$ & $1.51 \mathrm{E}-03(\mathrm{Ci} / \Omega)$ & $1.07(\mathrm{uC} / \mathrm{g})$ & $1.71 \mathrm{E}+02(\mathrm{Ci})$ \\
\hline
\end{tabular}

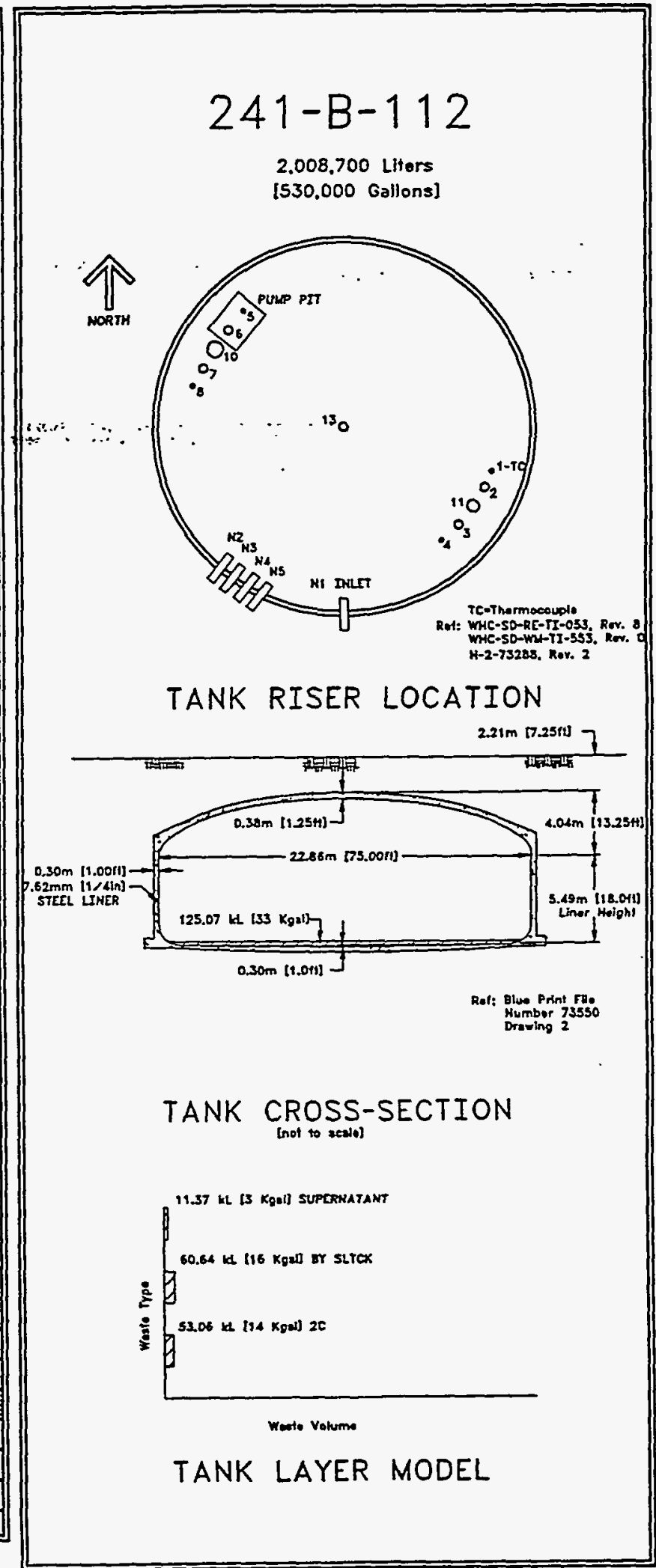

Composite inventory excludes supermath, dist 


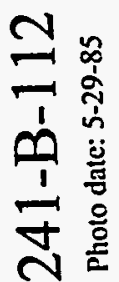

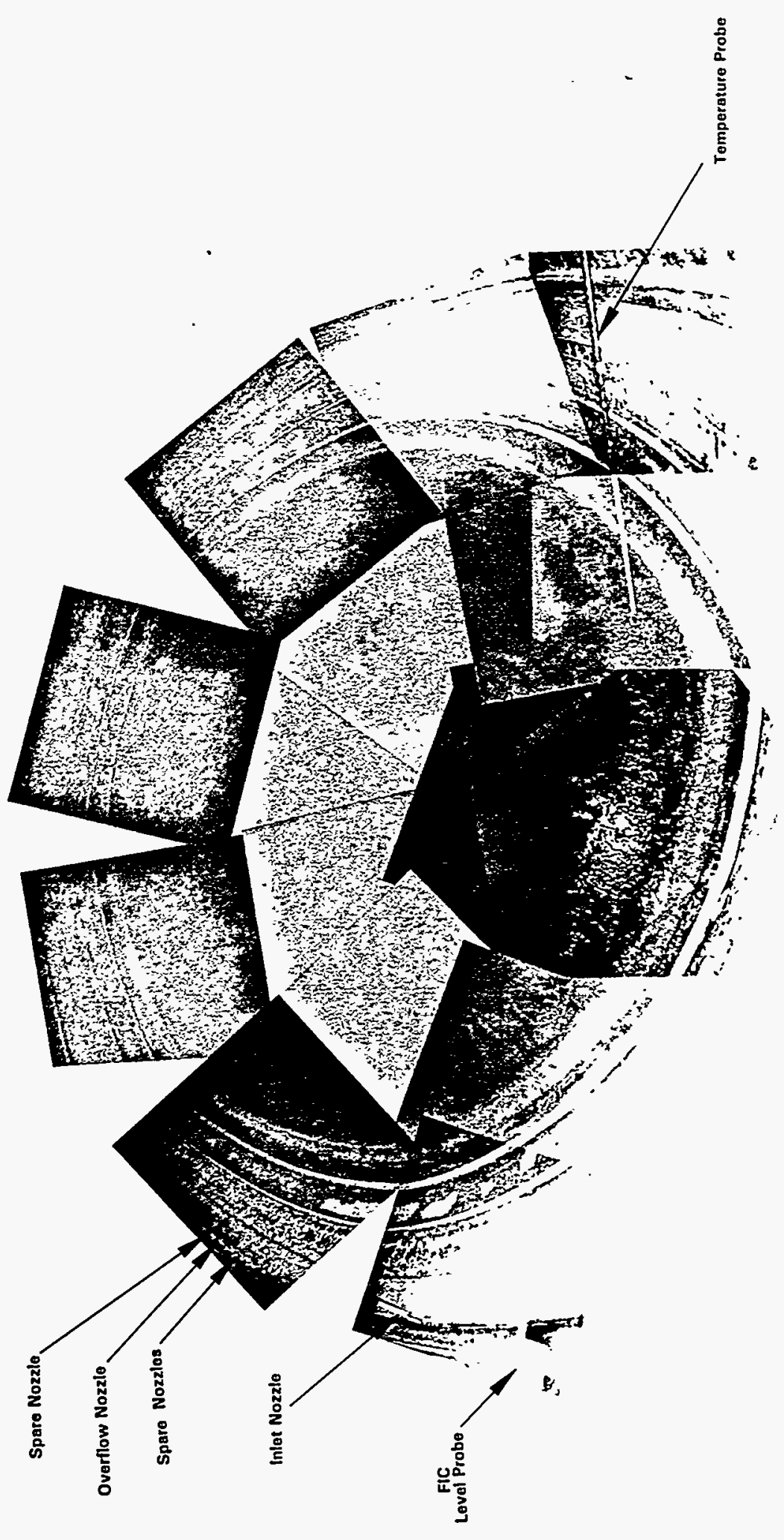




\subsubsection{Waste History Tank 241-B-201}

Tank 241-B-201 began filling with 224 waste in 1952 and was actively cascading.to a crib.. The. tank was identified as a suspect leaker in first quarter of 1973 ... Saltwel1 pumping began in 1974 and was completed in 1975. In the second quarter of 1975, Tank 241-B-201 was removed from service. The tank integrity was questionable in the first quarter of 1977 and again in 1979. The tank was declared inactive and was primary stabilized in the first quarter of 1978. A P-10 pump was removed from the tank in 1978. A level adjustment occurred in 1979 and

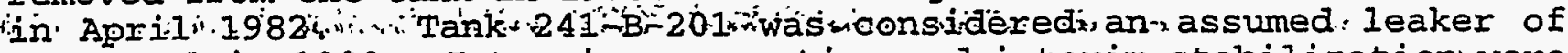
$1,200 \mathrm{gal}$ in 1980 . Intrusion prevention and interim stabilization were completed in May 1981. (See sketch ES-TKS-E23 for a graphical representation of the Tank 241-B-201 level history.)

\subsubsection{Temperature History 241-B-201}

The single thermocouple tree has 12 thermocouple probes to measure temperature data. The mean temperature of the first recorded data for thermocouples 1 through 11 was $63^{\circ} \mathrm{F}$. A sum of the squares regression line fit for the data shows a slight decrease in temperature with a moderate amount of variability. The median temperature from all the probes over the time span of available data is $62^{\circ} \mathrm{F}$ with a minimum of $53^{\circ} \mathrm{F}$ and a maximum of $112^{\circ} \mathrm{F}$. Refer to the supporting document for a more thorough review of the temperature data (Brevick 1994).

\subsubsection{Integrity of Tank 241-B-201}

Tank 241-B-201 is categorized as an assumed leaker and is interim stabilized with intrusion prevention completed. The surface level in Tank 241-B-201 is monitored daily with a manual tape through riser 8 . A figure that graphically represents the surface level measurements from January 1991 to the present can be found in the supporting documents (Brevick 1994). Since October 31, 1993, the surface level readings have ranged between 151.5 and 157.25 -in., with two readings violating the surface decrease limits (i.e. 151.5 and 152 in.). The 5.25-in. required addition to the CASS reading was not done, although it is necessary because the new surface level tape is too short. The two readings within the acceptable range when the 5.25-in. are added. Tank 241-B-201 has no liquid observation well or drywells.

\subsubsection{Current Status of Tank 241-B-201}

Tank 241-B-201 was constructed in 1943-44 and currently stores 29,000 gal of waste. The waste is comprised of 1,000 gal of supernatant; $28,000 \mathrm{gal}$ of sludge; with no pumpable liquid remaining. The tank is identified as a low-heat load tank, is passively ventilated, and is categorized as an assumed leaker with interim stabilization and intrusion prevention completed. Tank 241-B-201 is not in a cascade 
WHC-SD-WM-ER-349, Rev. 0

series. The following plan view and tank cross section depict the approximate waste level and riser configuration. Tank 241-B-201 has 8 risers and two two 12-in. risers (nos.2 and7) are available for use.

\subsubsection{Inventory estimate 241-B-201}

The following tank layer volume approximation was derived from Los Alamos National Laboratories Waste Status and Transaction Record Summary (Agnew 1994). The estimated inventory of Tank 241-B-201 is also presented.

\subsubsection{In-Tank Photograph 241-B-201}

The.. Tank.. 241-B-201 - photo. shows.... supernatant. surface over a reddish-brown slidge. The tank contains about 29,000 gal of waste which converts to approximately 12.5 ft deep. The haziness of the photo is a result of poor film quality.

4.13.3 Synopsis Tank 241-B-201

(To be completed.) 
- DวL-

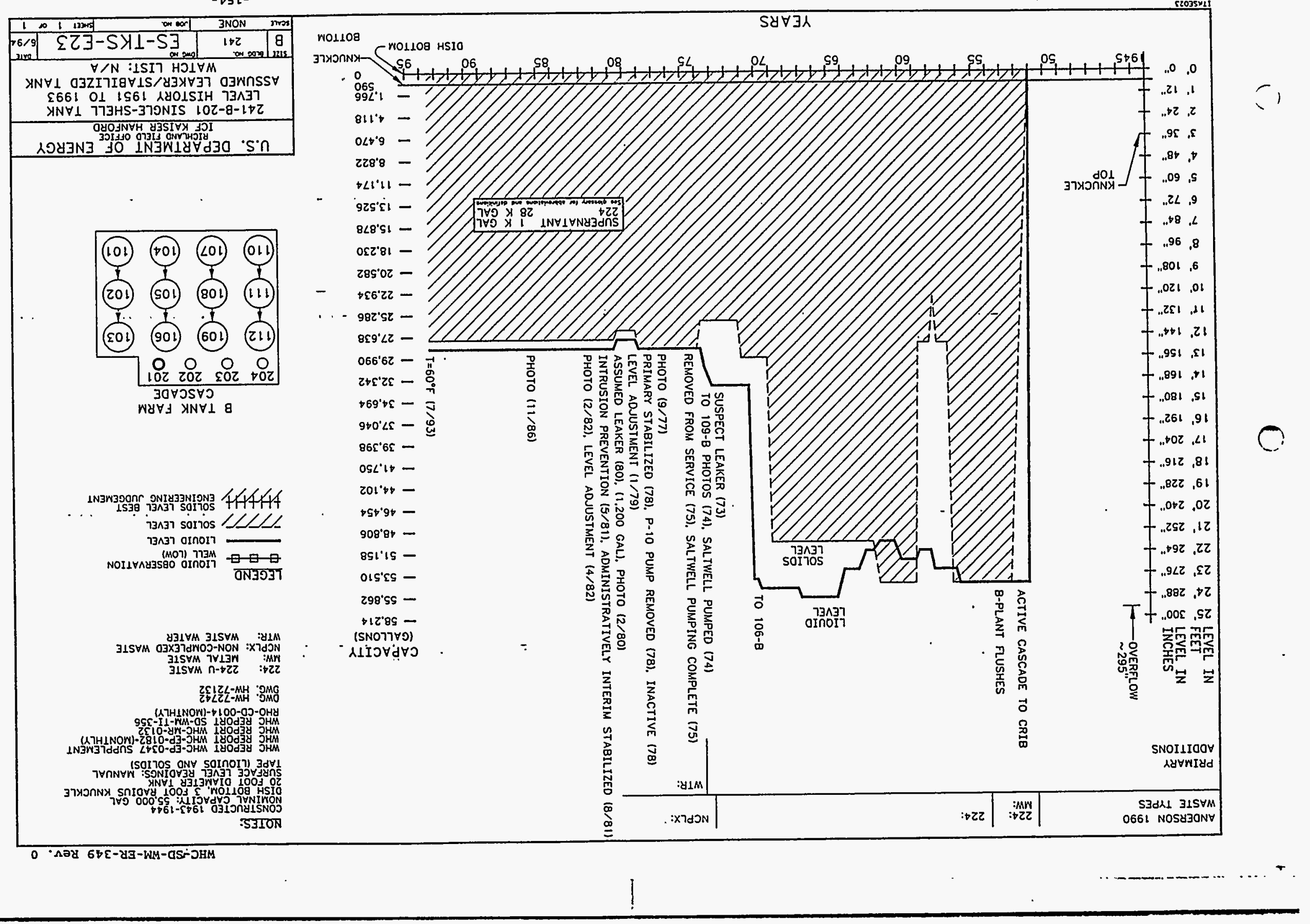




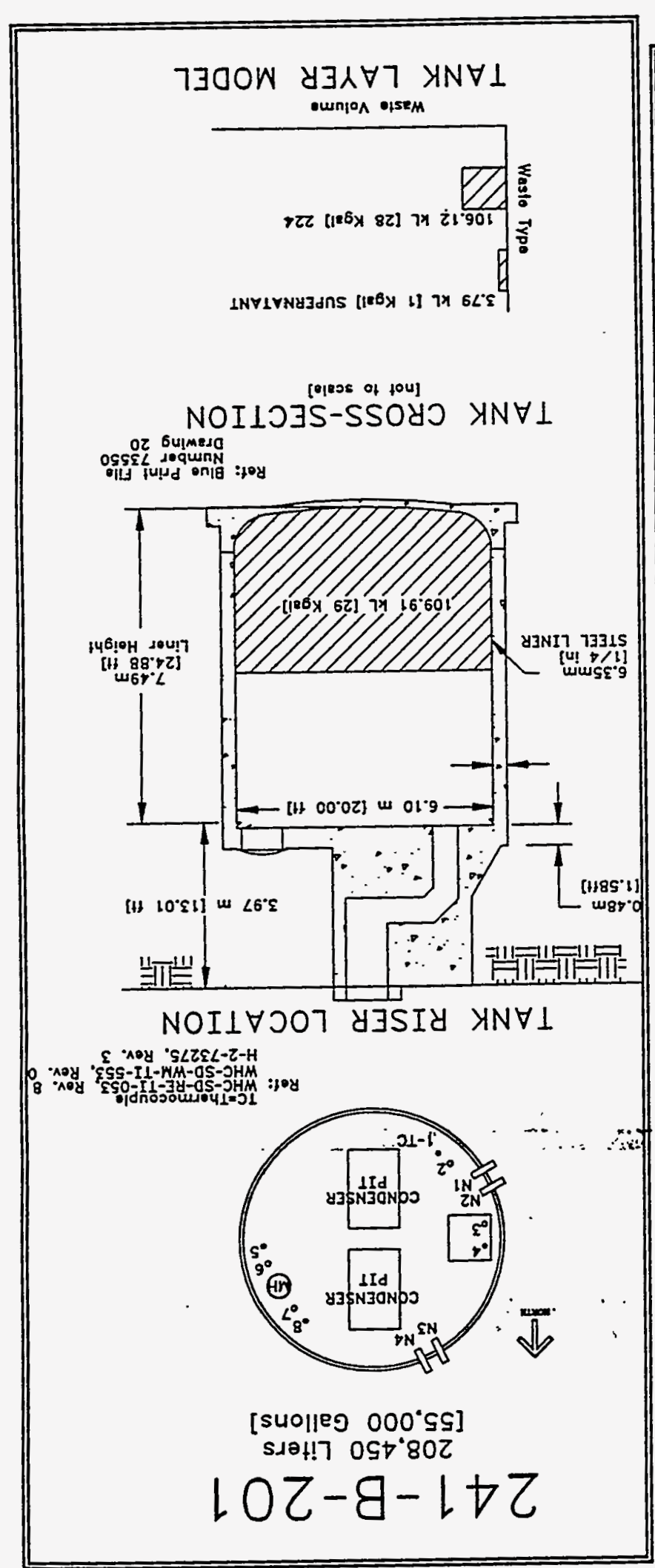

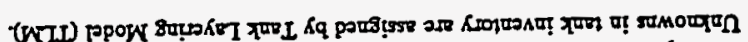

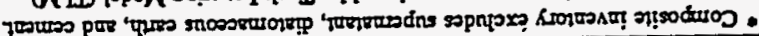

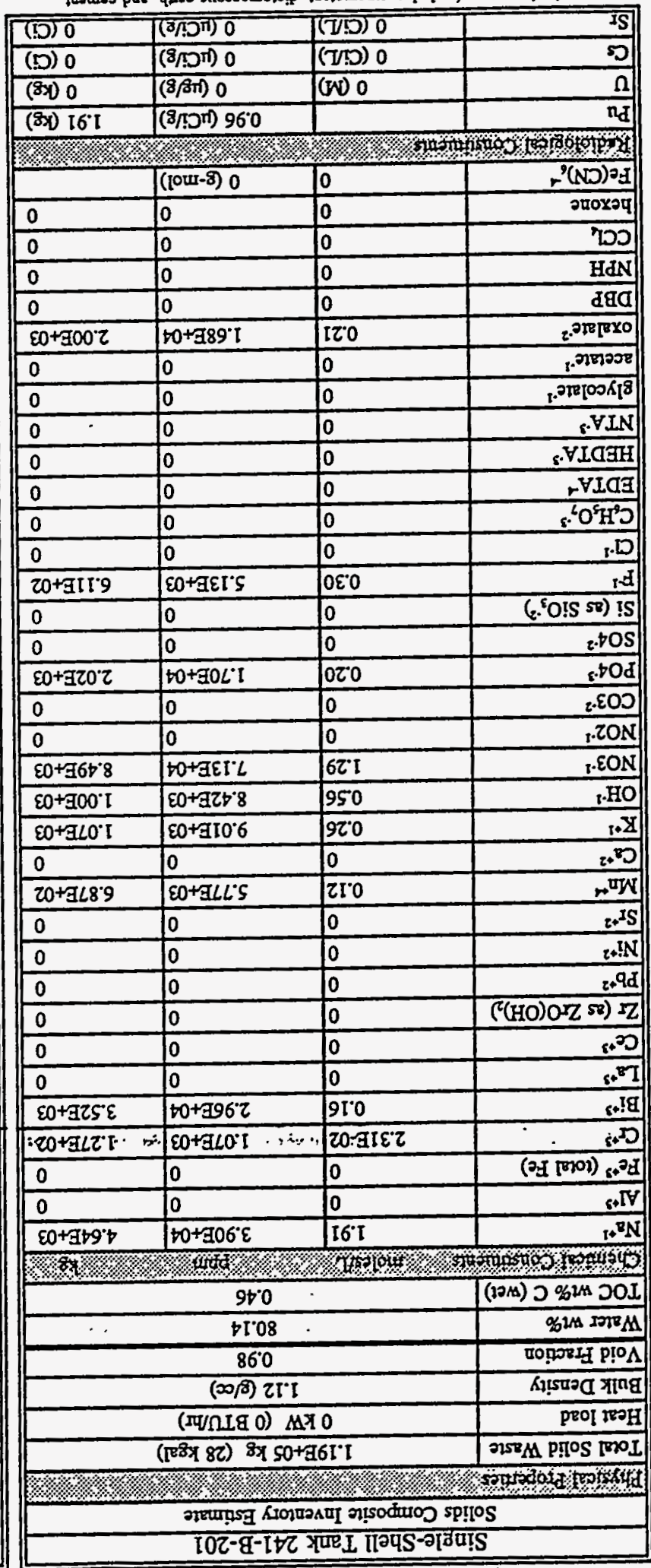



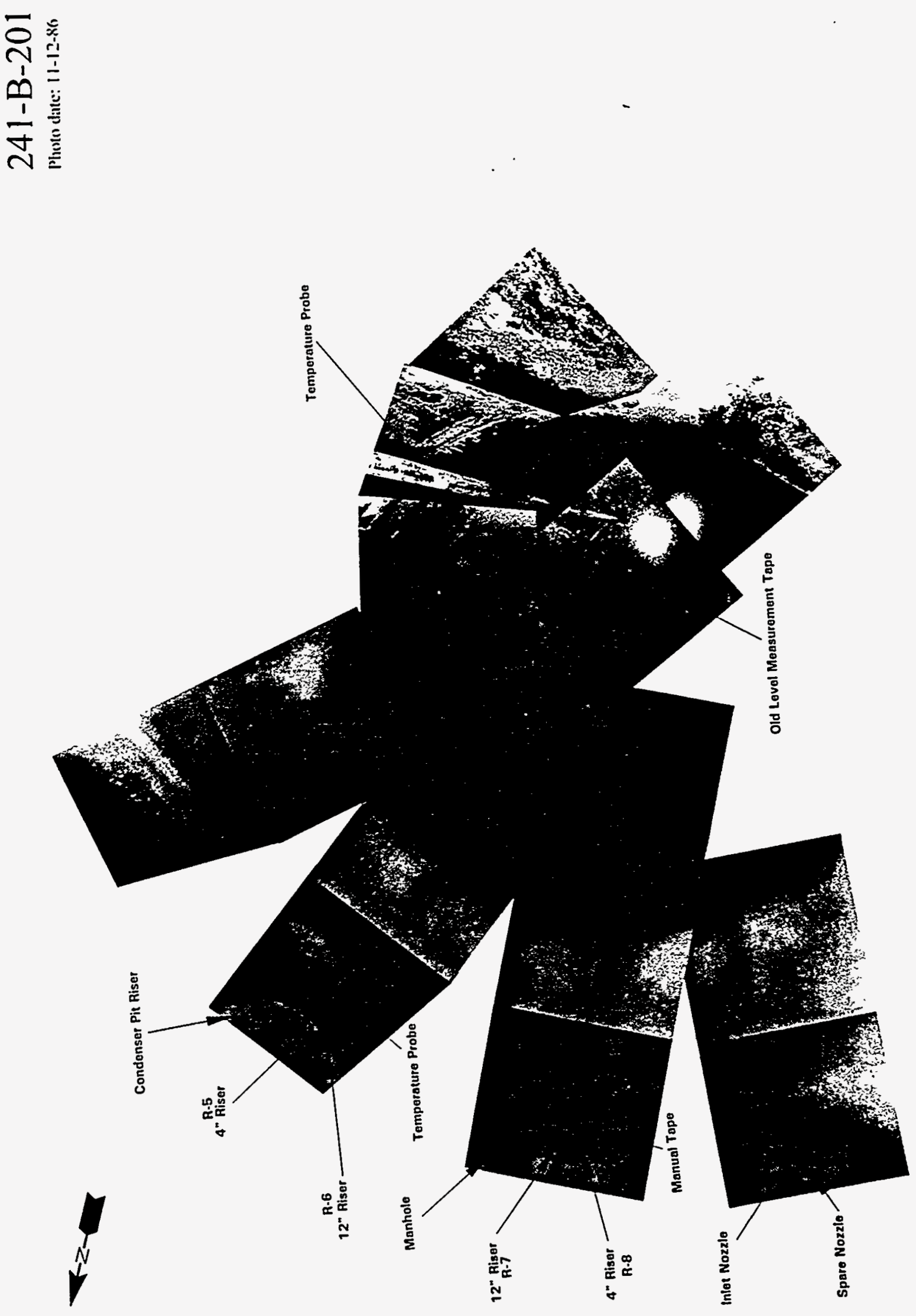


\subsubsection{1-B-202 Tank History}

4.14.1.1 Waste History Tank 241-B-202

Tank 241-B-202 was filled with 224 waste in 1951 and actively cascaded to a crib from the first quarter of. 1951 until the second quarter of 1955.. During the third quarter: of 1976, use of tank 241-B202 was restricted. The tank was considered inactive the first quarter of 1978. The tank was interim stabilized in May 1985 and intrusion prevention was in place in June 1985. In 1990, adjustments were made due to past inconsistencies. (See sketch ES-TKS-E24 for a graphical representation of the Tank 241-B-2.02 . level history.) )

\subsubsection{Temperature History 241-B-202}

The single thermocouple tree has 12 thermocouple probes to measure temperature data. The mean temperature of the first recorded data for thermocouples 1 through 11 was $72^{\circ} \mathrm{F}$. A sum of the squares regression line fit for the data shows a slight decrease in temperature with a moderate amount of variability. The median probe temperature over the time span of available data is $63^{\circ} \mathrm{F}$ with a minimum of $51^{\circ} \mathrm{F}$ and a maximum of $110^{\circ} \mathrm{F}$. Refer to the supporting document for a more thorough review of the temperature data (Brevick 1994).

\subsubsection{Integrity of Tank 241-B-202}

Tank 241-B-202 is categorized as sound and is interim stabilized with intrusion prevention completed. The Tank 241-B-202 surface level is monitored with a manual tape through riser 8 on a daily basis. A figure that graphically represents the surface level measurements from January 1991 to the present can be found in the supporting documents (Brevick 1994). The surface level for the past 3 years has an increasing trend trend. The surface level during the first quarter of 1991 was 144in. and had steadily increased to 145.5 in. as of the fourth quarter of 1993.

An occurrence report was issued in February 1993 due to the increasing surface level exceeding the criteria. A new photograph package was initiated in May 1993 to investigate the possibility of intrusion. A temporary 145.25-in. baseline value was established to remove the tank from the alert list. Tank 241-B-202 does not have a liquid observation well or drywells.

\subsubsection{Current Status of Tank 241-B-202}

Tank 241-B-202 was constructed in 1943-44 and currently stores $27,000 \mathrm{gal}$ of waste. The waste is comprised entirely of sludge with no pumpable liquid remaining. The tank is identified as a low-heat load tank, is passively ventilated, and is categorized as sound with interim stabilization and intrusion prevention completed. Tank 241-B-202 is not in a cascade flow series but was connected to Tank 241-B-203 with a tie line. The following plan view and tank cross section depict the 
approximate waste level and riser configuration. Tank 241-B-202 has 9 risers and four are available for use: three 12-in. risers (nos.2, 3 and 6) and one 4-in. riser (no.5).

\subsubsection{Inventory estimate 241-B-202}

The following tank layer volume approximation was derived from the Los Alamos National Laboratories Waste Status and Transaction Record :Summary (Agnew 1994). The estimated inventory of Tank 241-B-202 is also presented.

\subsubsection{In-Tank Photograph 241-B-202}

The Tank 241-B-202. phato. shows-dark orange, supernate with a bright yellow sludge. The tank contains about 27,000 gaI of waste which converts to approximately $11.5 \mathrm{ft}$ deep. The camera flash is clearly visible to the left of the temperature probe.

\subsubsection{Synopsis Tank 241-B-202}

(To be completed.) 
$-65 t-$

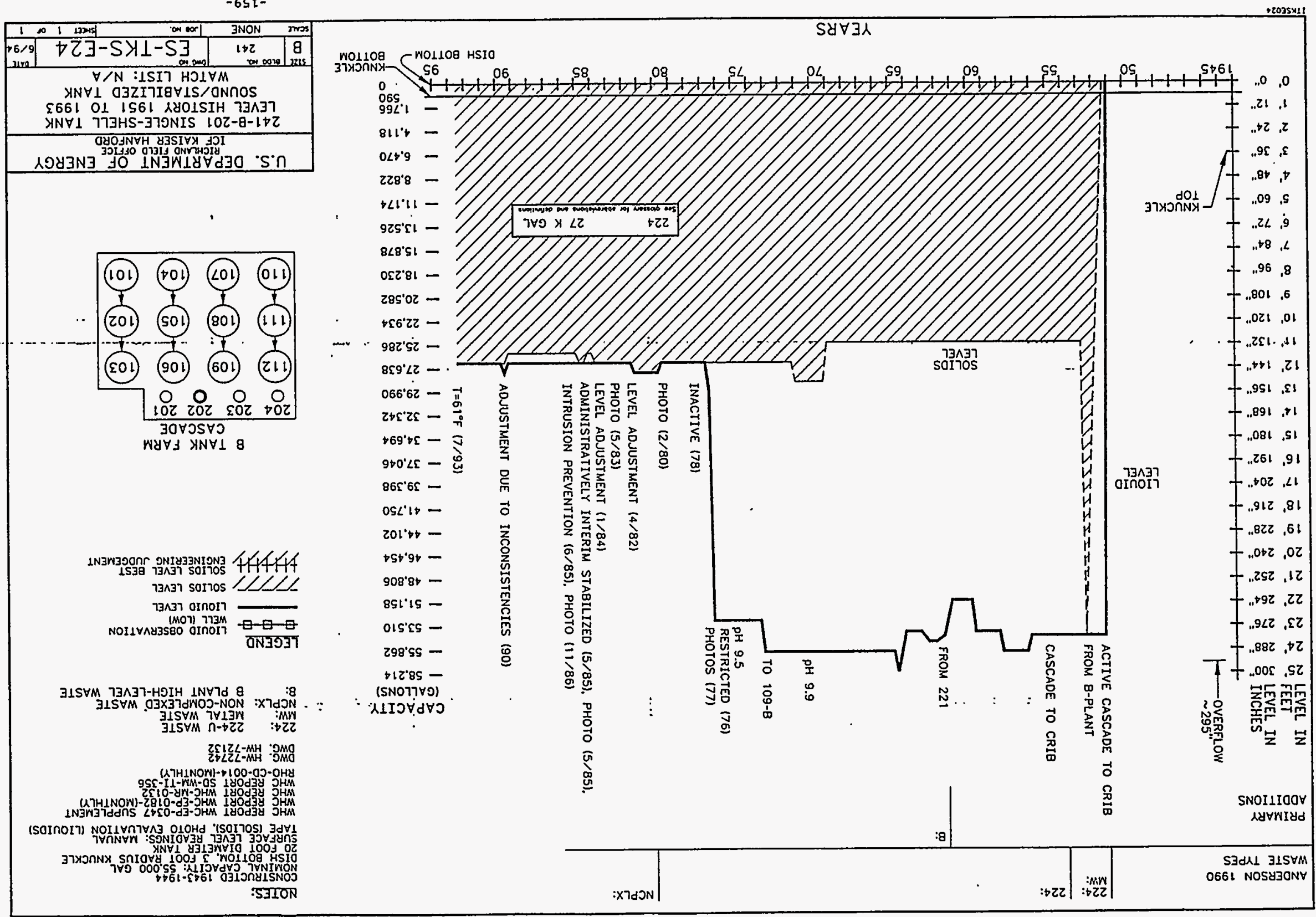

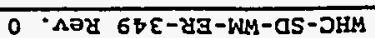


WHC-SD-WM-ER-349, Rev. 0

\begin{tabular}{|c|c|c|c|}
\hline \multicolumn{4}{|c|}{ Single-Shell Tank 241-B-202 } \\
\hline \multicolumn{4}{|c|}{ Solids Composite Inventory Estimate } \\
\hline 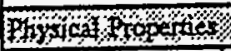 & \%ং & 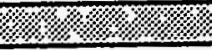 & ঋ \\
\hline Total Solid Waste & \multicolumn{3}{|c|}{$1.15 \mathrm{E}+05 \mathrm{~kg}(27 \mathrm{kgal})$} \\
\hline Heat load & \multicolumn{3}{|c|}{$0 \mathrm{~kW}(0 \mathrm{BTU} / \mathrm{hr})$} \\
\hline Bulk Density & \multicolumn{3}{|c|}{$1.12(g / \infty)$} \\
\hline Void Fraction & \multicolumn{3}{|c|}{0.98} \\
\hline Water wt\% & \multicolumn{3}{|c|}{80.14} \\
\hline TOC wr\% C (wet) & \multicolumn{3}{|c|}{0.46} \\
\hline \multicolumn{4}{|c|}{ 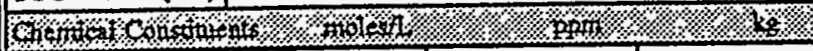 } \\
\hline $\mathrm{Na}^{*+1}$ & 1.91 & $3.90 E_{+}+04$ & $4.48 \mathrm{E}+03$ \\
\hline $\mathrm{Al}^{+3}$ & 0 & 0 & 0 \\
\hline $\mathrm{Fe}^{+3}($ (total Fe) & 0 & 0 & 0 \\
\hline $\mathrm{Cr}^{3}$ & $2.31 \mathrm{E}-02$ & 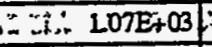 & S. $2=1.23 \mathrm{E}+02$ \\
\hline $\mathrm{Bi}^{3+3}$ & 0.16 & $2.96 E+04$ & $3.40 \mathrm{E}+03$ \\
\hline $2 \mathrm{~s}^{+3}$ & of & 0 & 0 \\
\hline $\mathrm{Ce}^{+3}$ & 0 & 0 & 0 \\
\hline $\mathrm{Zr}$ (as $\left.\mathrm{ZrO}(\mathrm{OH})_{2}\right)$ & 0 & 0 & 0 \\
\hline $\mathrm{Pb}^{+2}$ & of & 0 & 0 \\
\hline$\widehat{N i^{2-2}}$ & 0 & 0 & 0 \\
\hline$\widehat{\mathrm{Sr}^{+2}}$ & 0 & 0 & 0 \\
\hline$\widehat{\mathrm{Mn}^{+1}}$ & 0.12 & $5.77 \mathrm{E}+03$ & $6.62 \mathrm{E}+02$ \\
\hline$\overline{\mathrm{Ca}^{+2}}$ & 0 & 0 & 0 \\
\hline $\mathrm{K}^{21}$ & 0.26 & $9.01 E+03$ & $1.03 E+03$ \\
\hline$\widehat{\mathrm{OH}^{2}}$ & 0.56 & $8.42 \mathrm{E}+03$ & $9.66 \mathrm{E}+02$ \\
\hline$\widehat{\mathrm{NO}^{-1}}$ & 1.29 & $7.13 \mathrm{E}+04$ & $8.18 \mathrm{E}+03$ \\
\hline $\mathrm{NO}^{-1.3}$ & 0 & 0 & 0 \\
\hline $\mathrm{CO}^{-2}$ & 0 & 0 & 0 \\
\hline $\mathrm{PO}^{-3}$ & 0.20 & $1.70 E+04$ & $1.95 \mathrm{E}+03$ \\
\hline$\widehat{\mathrm{SO}_{4}^{-2}}$ & 0 & 0 & 0 \\
\hline $\mathrm{Si}\left(\right.$ as $\left.\mathrm{SiO}_{3}{ }^{2}\right)$ & 0 & 0 & 0 \\
\hline$\overline{F^{I}}$ & 0.30 & $5.13 \mathrm{E}+03$ & $5.89 \mathrm{E}+02$ \\
\hline$\overline{\mathrm{C}^{-1}}$ & 0 & 0 & 0 \\
\hline $\mathrm{C}_{6} \mathrm{H}_{3} \mathrm{O}_{7}{ }^{3}$ & 0 & 이 & 0 \\
\hline EDTA $^{-1}$ & 0 & 0 & 0 \\
\hline HEDTA $^{3}$ & 0 & 0 & 0 \\
\hline NTA $^{-3}$ & 0 & o) & 0 \\
\hline \begin{tabular}{|l|l|l} 
Blycolate $^{-1}$ \\
\end{tabular} & 0 & of & 0 \\
\hline acetate & 0 & 0 & 0 \\
\hline oxalate & 0.21 & $1.68 \mathrm{E}+04$ & $1.93 E+03$ \\
\hline DBP & 0 & 0 & 0 \\
\hline $\mathrm{NPH}$ & 0 & 0 & 0 \\
\hline $\mathrm{CCl}_{4}$ & 0 & 0 & 0 \\
\hline hexone & 요 & 0 & 0 \\
\hline $\mathrm{Fe}(\mathrm{CN})_{6}^{-1}$ & 0 & $0(g-m o l)$ & \\
\hline \multicolumn{4}{|c|}{ 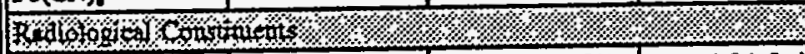 } \\
\hline $\mathrm{Pu}$ & & $0.96(\mu \mathrm{Ci} / \mathrm{g})$ & $1.84(\mathrm{~kg})$ \\
\hline $\mathrm{U}$ & $O(\mathrm{M})$ & $O\left(\mu g^{\prime} / g\right)$ & $0(\mathrm{~kg})$ \\
\hline$\overline{c s}$ & $0(C ; / L)$ & $.0(\mathrm{aCj} / \mathrm{g})$ & $0(\mathrm{Ci})$ \\
\hline $\mathrm{Sr}$ & $0(\mathrm{Ci} / \mathrm{L})$ & $0(\mu \mathrm{Ci} / g)$ & $0(\mathrm{Ci})$ \\
\hline
\end{tabular}

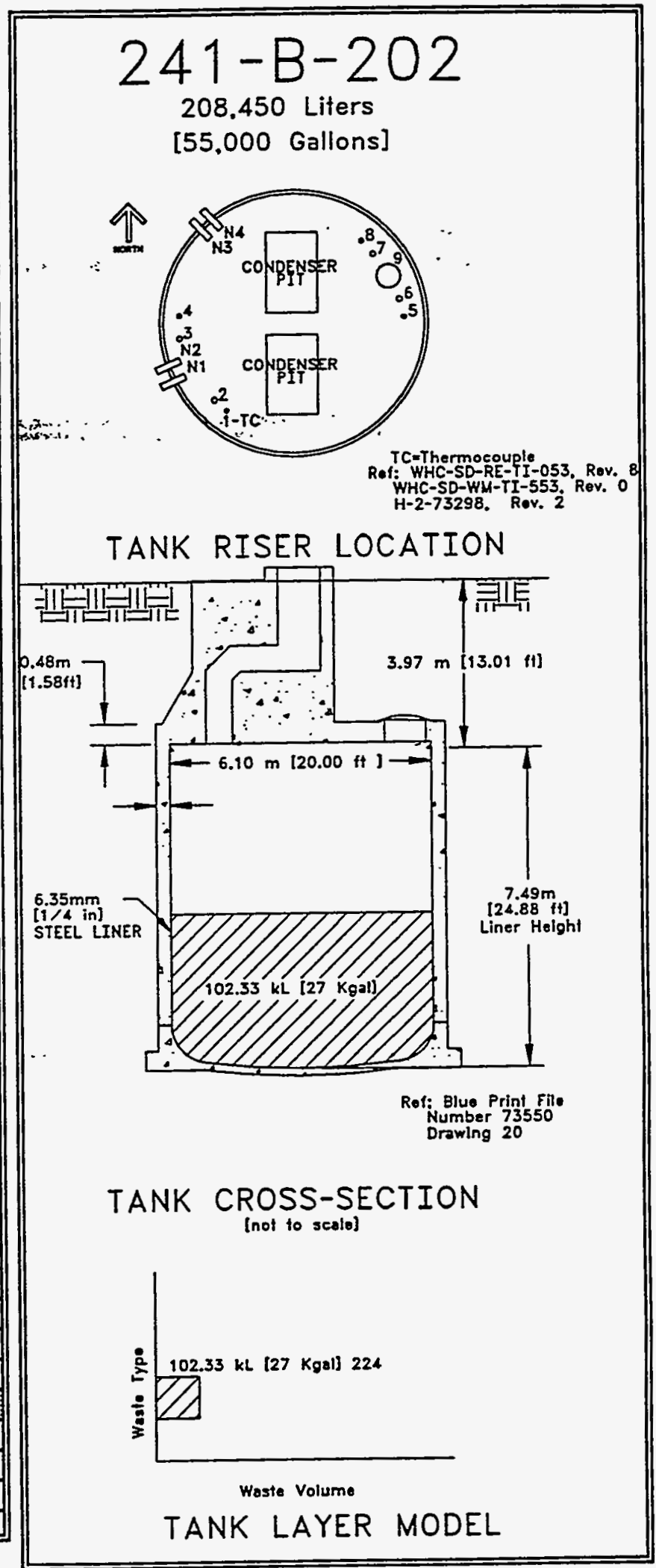

Compocile inventery exeludes supernatant, diatomsceous earth, and cernent 


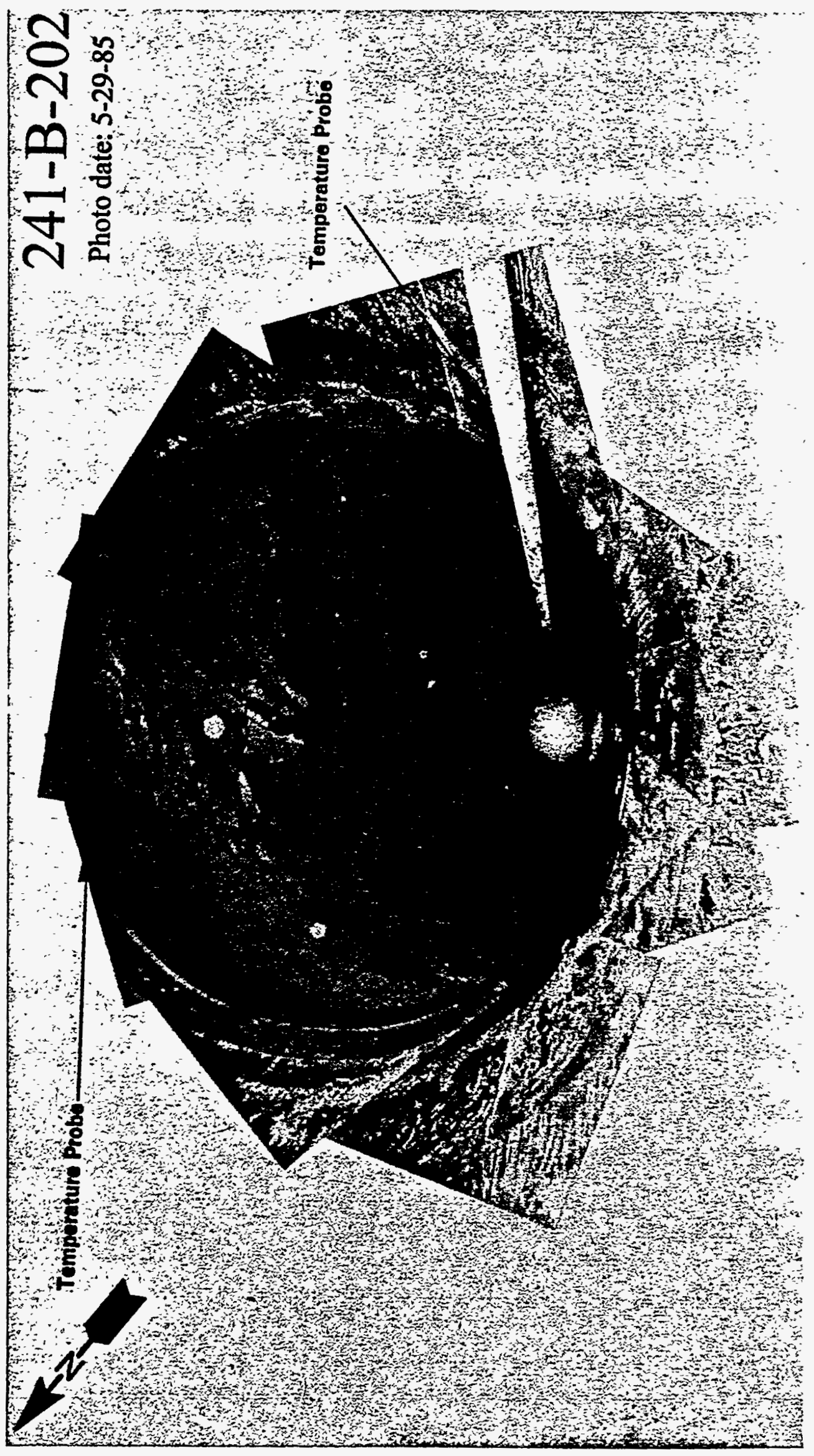


WHC-SD-WM-ER-349, ReV. 0

4.15 Tank 241-B-203

\subsection{5 .1 \\ $241-B-203$ \\ Tank History}

\subsubsection{Waste History Tank 241-B-203}

Tank 241-B-203 was filled with 224 waste in 1952 . In the third quarter of $1976, \cdots$ tank use was restricted with no intention for reuse. In 1977, the tank was inactive and a level adjustment was made. Tank 241-B-203 was declared an assumed leaker in 1983. A level adjustment was made in January 1984 and the tank was interim stabilized in June 1984. Intrusion prevention was in place in June 1985. (See sketch ESTKS-E25 for a graphical representation of the Tank 241-B-203 level history....

\subsubsection{Temperature History 241-B-203}

Tank 241-B-203 contains a single thermocouple tree with 12 thermocouple probes to measure temperature data. The mean temperature of the first recorded data for thermocouples 1 through 11 was $72^{\circ} \mathrm{F}$. A sum of the squares regression line fit for the data shows a slight decrease in temperature with a small to moderate amount of variability. The median probe temperature over the time span of available data is $63^{\circ} \mathrm{F}$ with a minimum of $48^{\circ} \mathrm{F}$ and a maximum of $110^{\circ} \mathrm{F}$. Refer to the supporting document for a more thorough review of the temperature data (Brevick 1994).

\subsubsection{Integrity of Tank 241-B-203}

Tank 241-B-203 is categorized as an assumed leaker and is interim stabilized with intrusion prevention completed. The Tank 241-B-203 surface level is monitored daily with a manual tape through riser 8 . A figure that graphically represents the surface level measurements from January 1991 to the present can be found in the supporting documents (Brevick 1994). The surface level for the past 3 years has remained steady with the reading ranging between 260.5 and $259.75-i n$. . The plot indicates an inaccurate data point with an apparent rerun. Tank 241-B203 has no liquid observation well or drywells.

\subsubsection{Current Status of Tank 241-B-203}

Tank 241-B-203 was constructed in 1943-44 and currently stores $51,000 \mathrm{gal}$ of waste. The waste is comprised of $1,000 \mathrm{gal}$ of supernatant, 50,000 gal of sludge with no saltcake with no pumpable liquid. The tank is identified as a low-heat load tank, is passively ventilated, and is categorized as an assumed leaker with interim stabilization and intrusion prevention completed. Tank 241-B-203 is not in a cascade flow series but was connected to Tank 241-B-202 and -204 with tie lines. The following plan view and tank cross section depict the approximate waste level and riser configuration. Tank 241-B-203 has 9 risers and four are available for use: three 12-in. risers (nos. 2, 3 , and 6) and one 4-in. riser (no. 5).

$$
-162-
$$




\subsubsection{Inventory estimate 241-B-203}

The following tank layer volume approximation was derived from the Los Alamos National Laboratories Waste Status and Transaction Record Summary (Agnew 1994). The estimated inventory of Tank 241-B-203 is also presented.

\subsubsection{In-Tank Photograph 241-B-203}

Tank 241-B-203 photo shows a thin supernatant surface with dark brown sludge underneath. The tank contains approximately 51,000 gal of waste which converts to slightly over 21 ft deep. Because the tank is full and the dome is flat, the photos were taken horizontally across the tank toward the. other side.to. show..the. waste. and.the. dome.. The tank level was adjusted as a result of the photo. The inlet nozzle and temperature probe were overexposed because they were too close to the Elash.

\subsubsection{Synopsis Tank 241-B-203}

(To be completed.) 
WHC-SD-WM-ER-349 Rev. 0

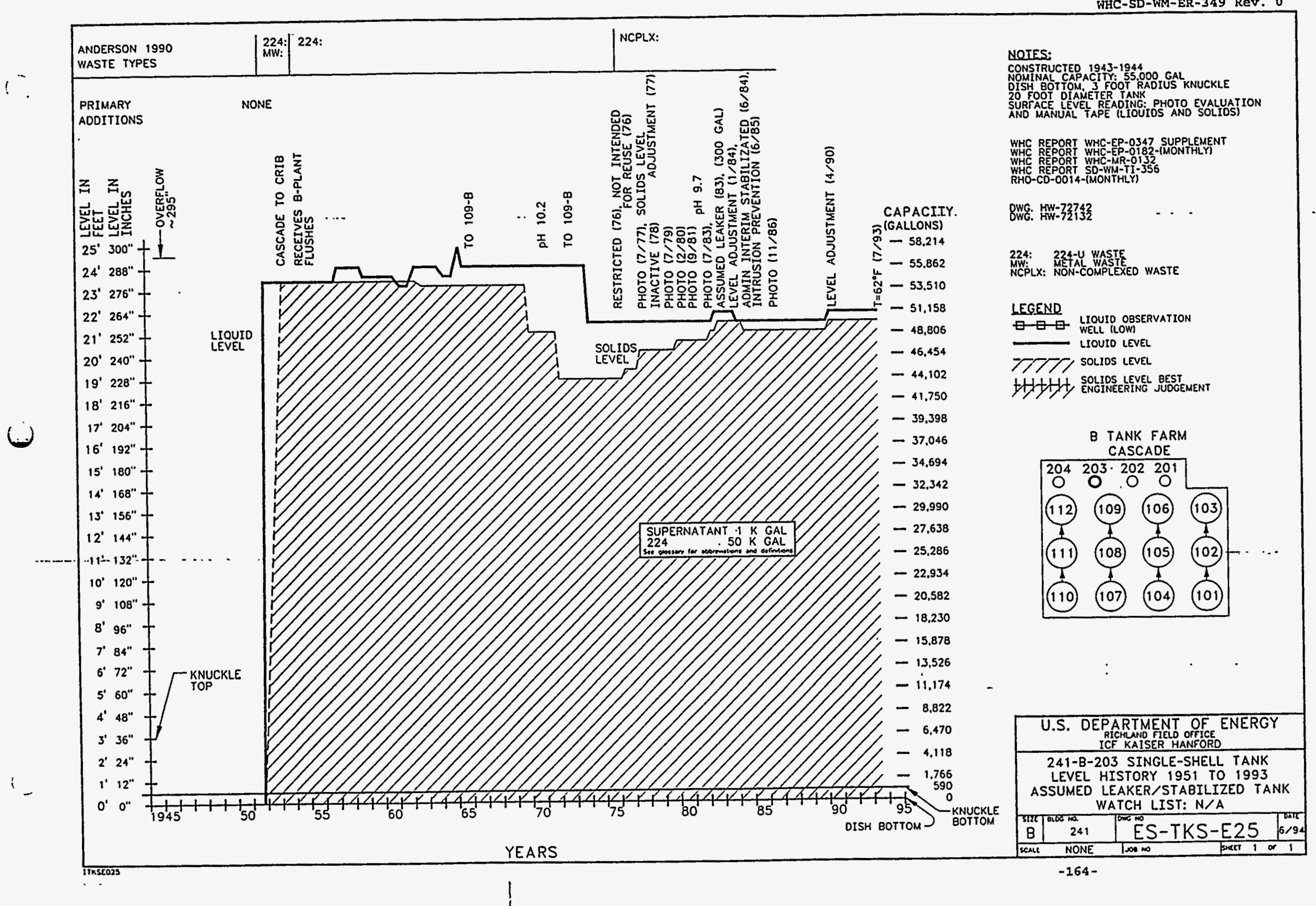




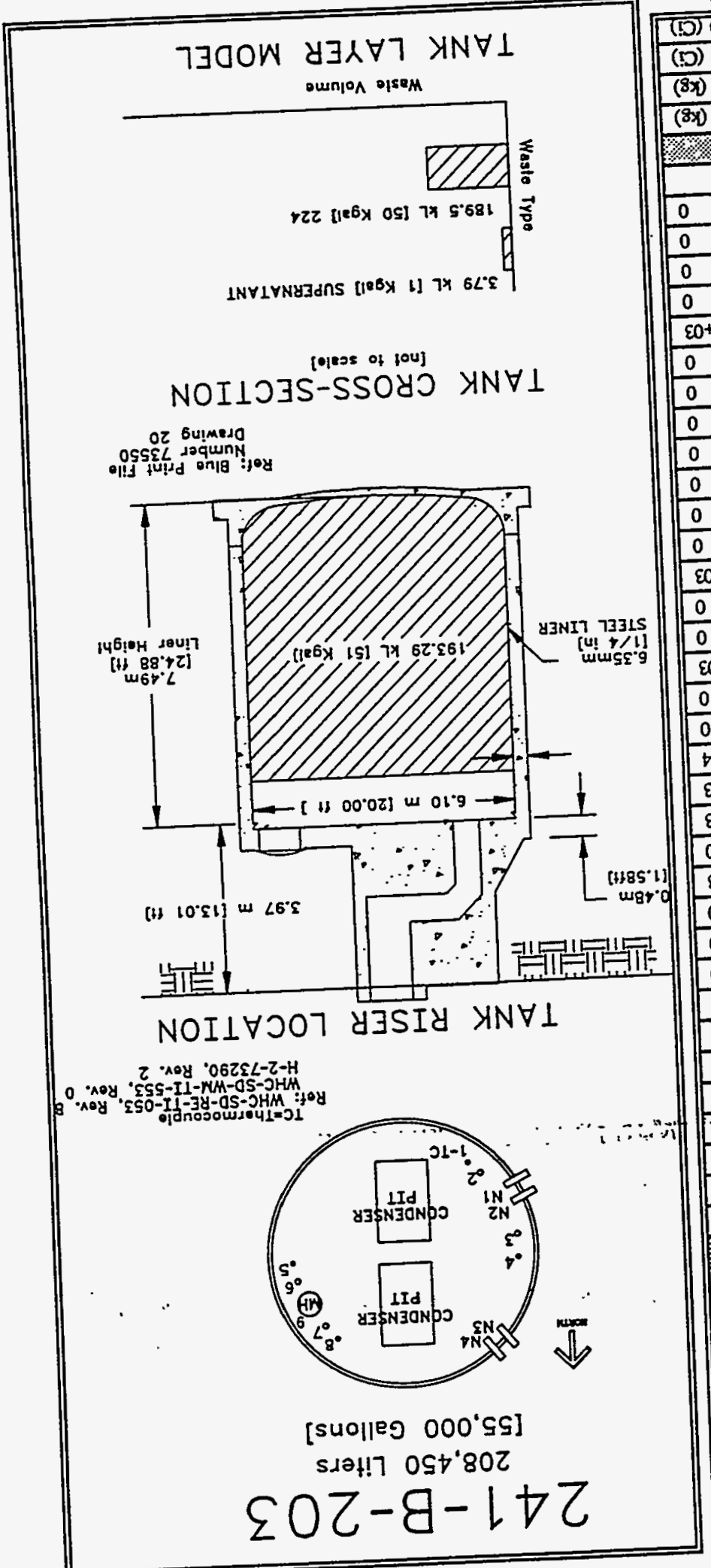

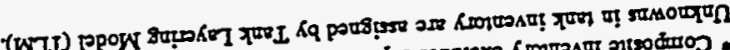

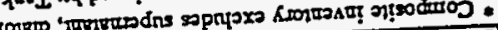

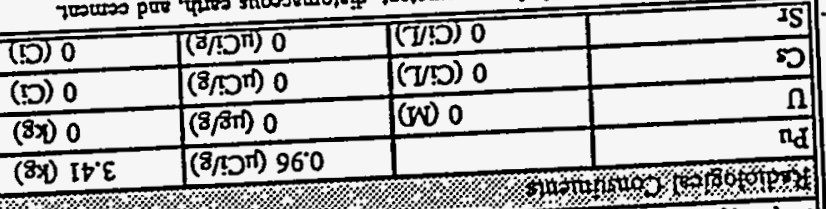

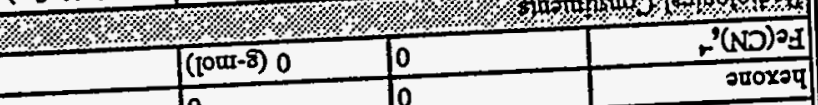

\begin{tabular}{ll}
\hline 0 \\
\hline 0 \\
\hline 0 \\
\hline 0 \\
\hline 0 \\
\hline 0 \\
\hline 0 \\
\hline 0 \\
\hline 0 \\
\hline
\end{tabular}

\begin{tabular}{l|l|l}
\hline & 0 & 0 \\
\hline $0+$ ZLSE & 0 & 0 \\
\hline $0+389^{\circ} I$ & 1 \\
\hline 0 & 0 & 0 \\
& 0 & 0 \\
& 0 & 0
\end{tabular}

\begin{tabular}{|l|l|l|}
\hline & 0 \\
\hline & 0 \\
\hline
\end{tabular}

\begin{tabular}{|c|c|c|c|}
\hline & 0 & 0 & \\
\hline+3601 & $50+\mathcal{Z} E I S$ & $0 \varepsilon^{\circ} 0$ & rat \\
\hline & 0 & 10 & $\left(6^{5} 0 ! S 58\right) ! S$ \\
\hline & 10 & 0 & .t.0OS \\
\hline
\end{tabular}

\section{$+2\left[9^{\circ} \varepsilon\right.$}

\begin{tabular}{|c|c|}
\hline$\varepsilon 0+\Xi โ 9^{\circ} \varepsilon$ & $10+20 L^{\prime} I$ \\
\hline 0 & 0 \\
\hline 0 & 0 \\
\hline 8 & $50+3 E I^{\circ} l$ \\
\hline
\end{tabular}

\begin{tabular}{|c|c|c|c|}
\hline 0 & 0 & 10 & t.20N \\
\hline $50+3251$ & $50+3 \varepsilon I^{\circ} L$ & $6 \tau^{\circ} 1$ &.$E O N$ \\
\hline$\varepsilon 0+26 L I$ & $\varepsilon 0+32 t^{\circ} 8$ & 950 & $\mathrm{r} \cdot \mathrm{HO}$ \\
\hline $80+926.1$ & $60+310^{\circ} 6$ & $92^{\circ} 0$ & $i+\mathrm{Z}$ \\
\hline 0 & 0 & 10 & $2+85$ \\
\hline$\varepsilon 0+\mathcal{I} \varepsilon \tau I$ & $E O+Z L L ' S$ & $25^{\circ} 0$ & $c^{\square W N}$ \\
\hline 0 & 0 & 10 & $20^{15}$ \\
\hline 0 & 0 & 0 & $2+\mathbb{N}$ \\
\hline & & 10 & $2+9 d$ \\
\hline
\end{tabular}

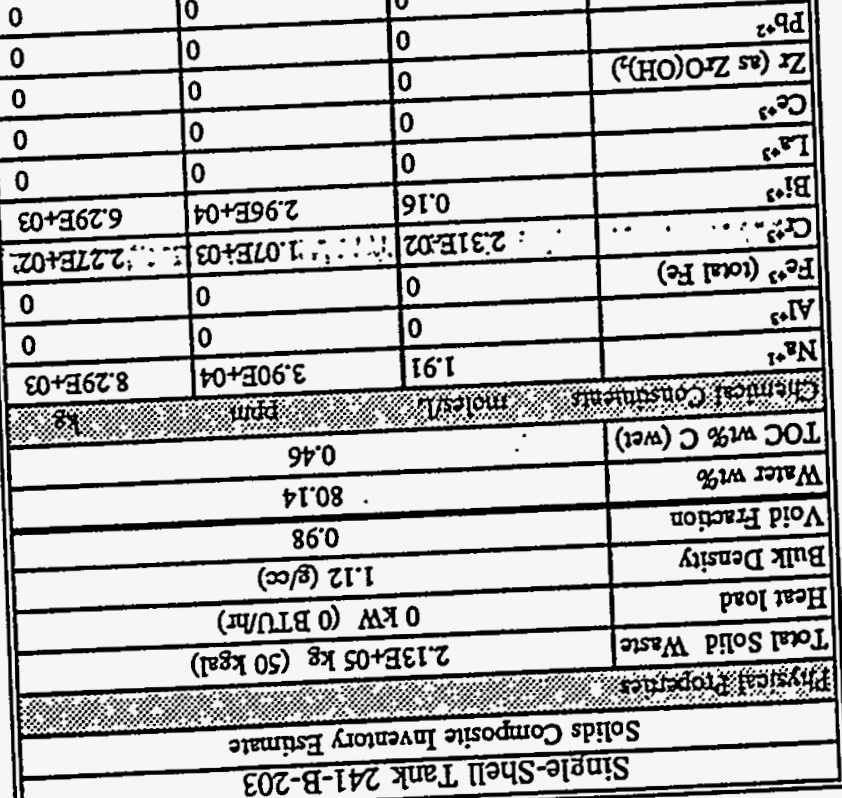


WHC-SD-WM-ER-349 Rev. 0

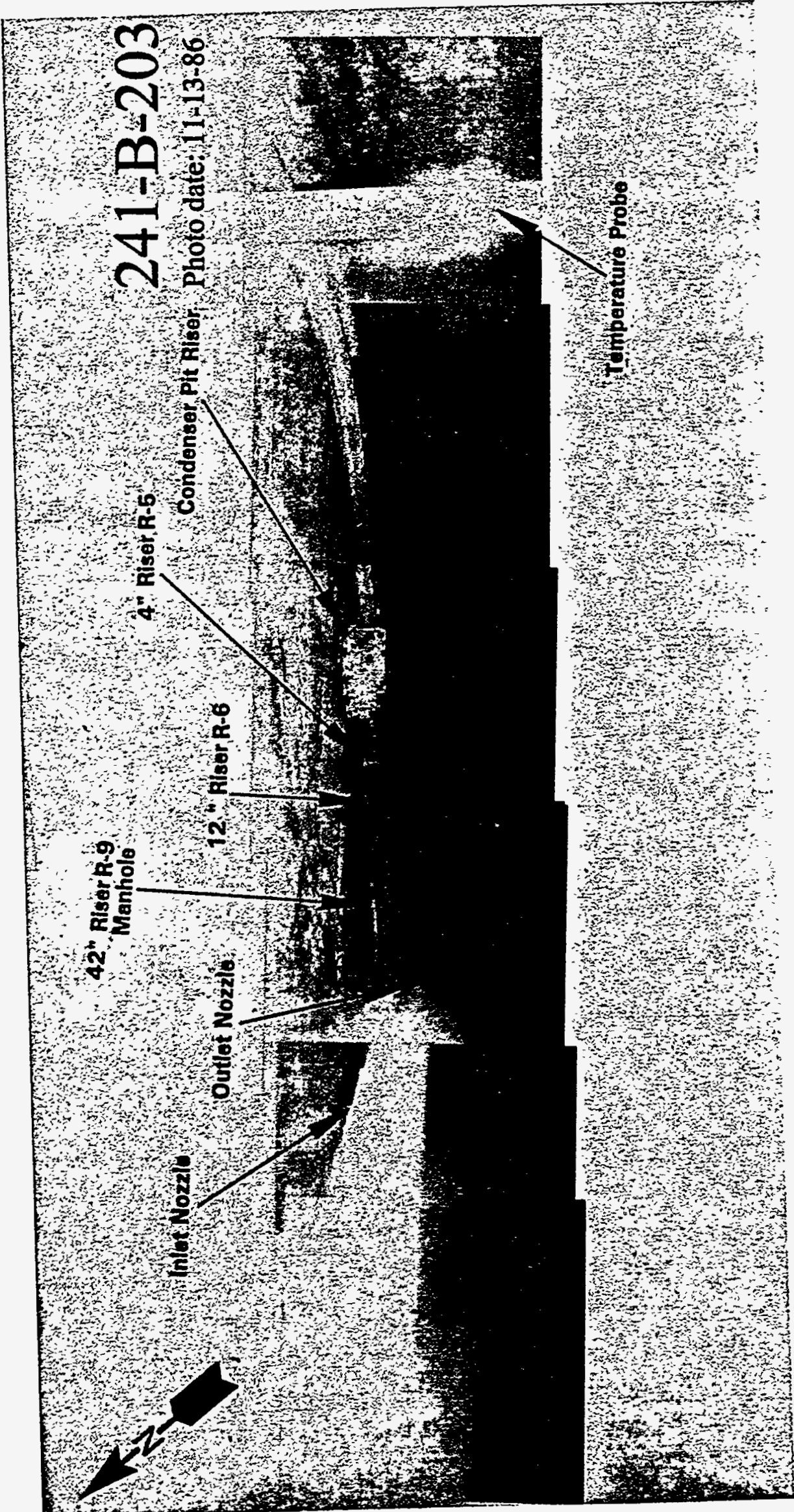




\subsubsection{1-B-204 Tank History}

\subsubsection{Waste History Tank 241-B-204}

Tank 241-B-204 was filled with 224 waste in 1952. During the first quarter of 19.77, tank use was restricted and at the beginning of 1978, the tank was. considered inactive. Tank 241-B-204 was considered an assumed leaker of 400 gal in 1984. The tank was interim stabilized in June 1984 and intrusion prevention was in place in June 1985. (See sketch ES-TKS-E26 for a graphical representation of the Tank 241-B-204 level history.)

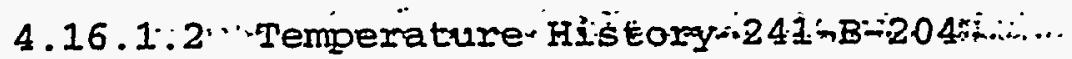

Tank 241-B-204 contains a single thermocouple tree with 12 thermocouple probes to measure temperature data. The mean temperature of the first recorded data for thermocouples 1 through 11 was $70^{\circ} \mathrm{F}$. A sum of the squares regression line fit for thermocouples 1 through 11 shows a slight temperature decrease with a small to moderate amount of variability. Not enough data from thermocouple 12 are available for an accurate regression and variability analysis. The median probe temperature over the time span of available data is $62^{\circ} \mathrm{F}$ with a minimum of $45^{\circ} \mathrm{F}$ and a maximum of $110^{\circ} \mathrm{F}$. Refer to the supporting document for a more thorough review of the temperature data (Brevick 1994).

\subsubsection{Integrity of Tank 241-B-204}

Tank 241-B-204 is categorized as an assumed leaker and is interim stabilized with intrusion prevention completed. The Tank 241-B-204 surface level is monitored daily with a manual tape through riser 8. A figure that graphically represents the surface level measurements from January 1991 to the present can be found in the supporting documents (Brevick 1994). The surface level for the past 3 years remained steady with the readings ranging between 256 and 256.25-in: Tank 241-B-204 has no liquid observation well or drywells.

\subsubsection{Current Status of Tank 241-B-204}

Tank 241-B-204 was constructed in 1943-44 and currently stores $50,000 \mathrm{gal}$ of non-complexed waste. The waste is comprised of 1,000 gal of supernatant and 49,000 gal of sludge with no saltcake or pumpable liquid. The tank is identified as a low-heat load tank, is passively ventilated, and is categorized as an assumed leaker with interim stabilization and intrusion prevention completed. Tank 241-B-204 is not in a cascade flow series but is connected to Tank 241-B-203 with a tie line. The following plan view and tank cross section depict the approximate waste level and riser configuration. Tank 241-B-204 has 9 risers and three are readily available for use: two 12-in. risers (nos. 2 and 6 ) and one 4-in. riser (no. 5). 


\subsubsection{Inventory estimate 241-B-204}

The following tank layer volume approximation was derived from the Los Alamos National Laboratories Waste Status and Transaction Record Summary (Agnew 1994). The estimated inventory of Tank 241-B-204 is also presented.

\section{.4 .16 .2 .2 In-Tank Photograph 241-B-204}

The Tank 241-B-204 photo shows a thin supernatant surface with. a dark orange sludge underneath. The tank contains approximately 50,000 gal of waste which converts to approximately $21 \mathrm{ft}$ deep. The inlet nozzle and temperature probe are overexposed because they are close to the Elash...

\subsubsection{Synopsis Tank 241-B-204}

(To be completed.) 
69I-

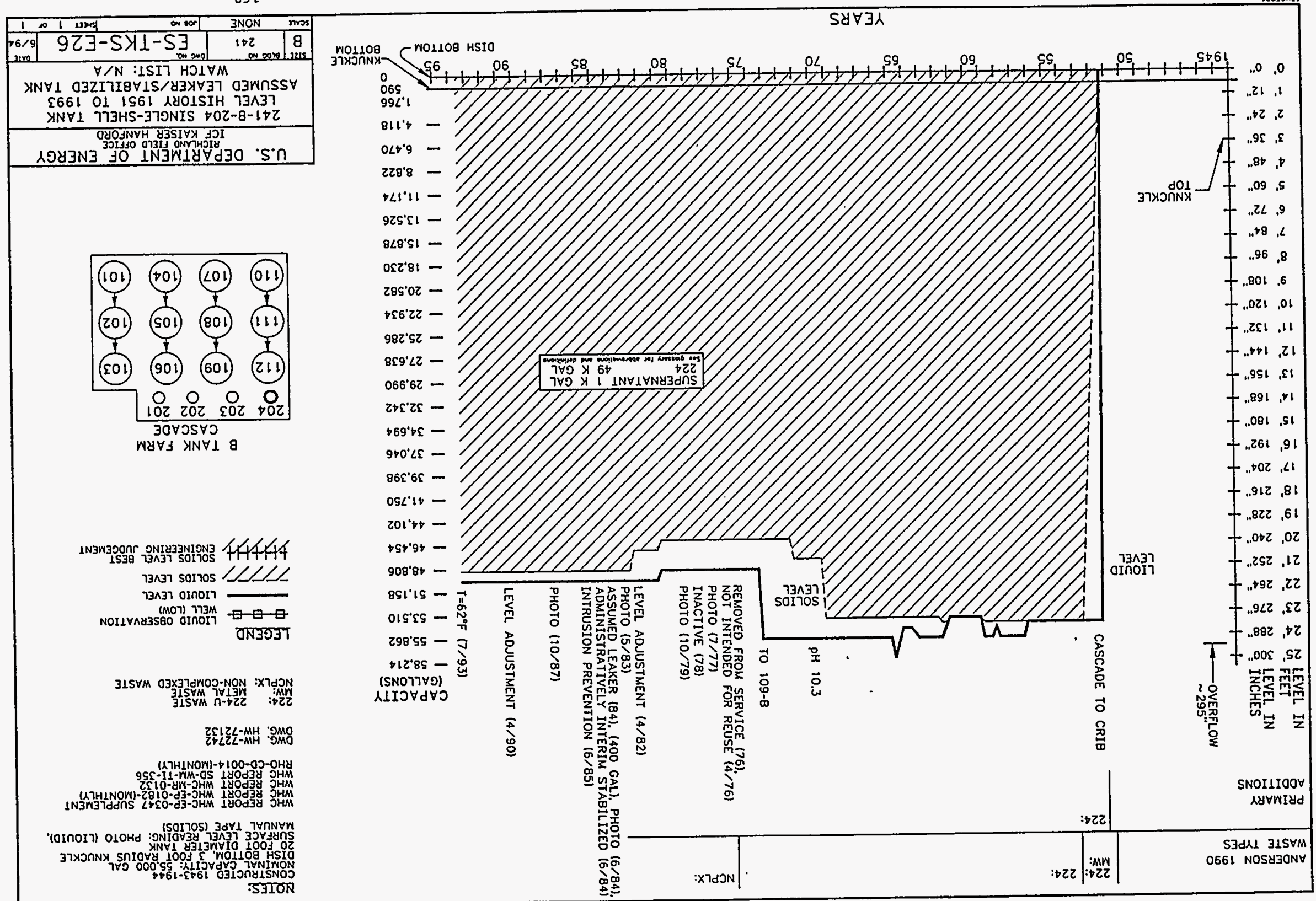




\begin{tabular}{|c|c|c|c|}
\hline \multicolumn{4}{|c|}{ Single-Shell Tank 241-B-204 } \\
\hline \multicolumn{4}{|c|}{ Solids Composite Inventory Estimate } \\
\hline \multicolumn{4}{|c|}{ 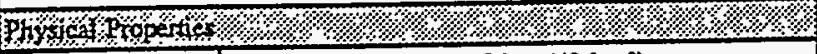 } \\
\hline Total Solid Waste & \multicolumn{3}{|c|}{$2.08 \mathrm{E}+05 \mathrm{~kg}(49 \mathrm{kgal})$} \\
\hline Heal load & \multicolumn{3}{|c|}{$0 \mathrm{~kW}(0 \mathrm{BTU} / \mathrm{hr})$} \\
\hline Bulk Density & \multicolumn{3}{|c|}{$1.12(g / \infty)$} \\
\hline Void Fraction & \multicolumn{3}{|c|}{0.98} \\
\hline Waler wr\% : : & \multicolumn{3}{|c|}{80.14} \\
\hline TOC wt\% C (wet) & \multicolumn{3}{|c|}{0.46} \\
\hline \multicolumn{4}{|c|}{ 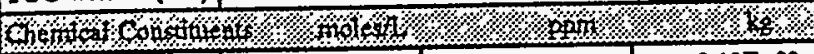 } \\
\hline $\mathrm{Na}^{4+1}$ & 1.91 & $3.90 \mathrm{E}+04$ & $8.13 \mathrm{E}+03$ \\
\hline $\mathrm{Al}^{+3}$ & 0 & 0 & 0 \\
\hline $\mathrm{Fe}^{+3}$ (total Fe) & 0 & $\begin{array}{r}0 \\
0\end{array}$ & \begin{tabular}{r|}
0 \\
\end{tabular} \\
\hline $\mathrm{Cr}^{33}$ & $231 \mathrm{E}-02$ & $+\therefore 1.07 E_{+}+83$ & $\therefore-x^{2} 23 E+02+$ \\
\hline $\mathrm{Bi}^{i^{5}}$ & 0.16 & $2.96 \mathrm{E}+04$ & $6.16 \mathrm{E}+03$ \\
\hline $\mathrm{La}^{43}$ & of & 0 & 0 \\
\hline $\mathrm{Ce}^{+3}$ & 可 & 0 & 0 \\
\hline $\mathrm{Z} x\left(\mathrm{as} \mathrm{ZrO}(\mathrm{OH})_{2}\right)$ & 이 & 0] & 0 \\
\hline $\mathrm{Pb}^{+2}$ & 0 & 0. & 0 \\
\hline $\mathrm{Ni}^{+2}$ & 0 & 0 & 0 \\
\hline $\mathrm{Sr}^{42}$ & 0 & 0 & 0 \\
\hline$\overline{\mathrm{Mn}^{+4}}$ & 0.12 & $5.77 \mathrm{E}+03$ & $1.20 \mathrm{E}+03$ \\
\hline $\mathrm{Ca}^{+2}$ & 0 & 0 & 0 \\
\hline $\mathrm{K}^{+1}$ & 0.26 & $9.01 E+03$ & $1.88 \mathrm{E}+03$ \\
\hline $\mathrm{OH}^{.1}$ & 0.56 & $8.42 \mathrm{E}+03$ & $1.75 \mathrm{E}+03$ \\
\hline $\mathrm{NO}^{-1}$ & 1.29 & $7.13 E+04$ & $1.49 \mathrm{E}+04$ \\
\hline $\mathrm{NO}^{-1}$ & 0 & 0 & 0 \\
\hline $\mathrm{CO}^{2 \cdot}$ & 0 & 0 & 0 \\
\hline $\mathrm{PO}^{-3}$ & 0.20 & $1.70 \mathrm{E}+04$ & $3.54 \mathrm{E}+03$ \\
\hline $\mathrm{SO}^{-2}$ & 0 & 0 & 0 \\
\hline $\mathrm{Si}$ (as $\mathrm{SiO}_{3}^{-2}$ ) & 0 & 0 & 0 \\
\hline $\mathrm{F}^{-1}$ & 0.30 & $5.13 \mathrm{E}+03$ & $1.07 \mathrm{E}+03$ \\
\hline $\mathrm{Cl}^{.1}$ & of & 0 & 0 \\
\hline $\mathrm{C}_{6} \mathrm{H}_{5} \mathrm{O}_{7}^{\cdot 3}$ & 0 & of & 0 \\
\hline $\mathrm{EDTA}^{-}$ & 요 & of & 0 \\
\hline HEDTA $^{-3}$ & 0 & 0 & 0 \\
\hline NTA $^{-3}$ & 요 & 0 & 0 \\
\hline glycolate & 0 & 0 & 0 \\
\hline acetate ${ }^{-1}$ & 0 & 0 & 0 \\
\hline oxalate ${ }^{-2}$ & 0.21 & $1.68 \mathrm{E}+04$ & $3.50 \mathrm{E}+03$ \\
\hline DBP & 0 & 0 & 0 \\
\hline $\mathrm{NPH}$ & 요 & 0 & 0 \\
\hline $\mathrm{CCl}_{4}$ & 0 & of & 0 \\
\hline hexone & 0 & 0 & 0 \\
\hline $\mathrm{Fe}(\mathrm{CN})_{6}^{-1}$ & 0 & $0(\mathrm{~g}-\mathrm{mol})$ & \\
\hline \multicolumn{4}{|c|}{ 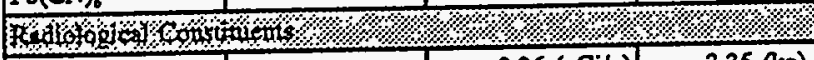 } \\
\hline $\mathrm{Pu}$ & & $0.96(\mu \mathrm{Ci} / g)$ & $3.35(\mathrm{~kg})$ \\
\hline $\mathrm{U}$ & $0(M)$ & $0(\mu \mathrm{g} / \mathrm{g})$ & $0(\mathrm{~kg})$ \\
\hline Cs & $0(\mathrm{Ci} / \mathrm{L})$ & $0(\mu \mathrm{Ci} / \mathrm{g})$ & $0(\mathrm{Ci})$ \\
\hline$\overline{S r}$ & $0(\mathrm{Ci} / \mathrm{L})$ & $0(\mu \mathrm{Ci} / \mathrm{g})$ & $0(\mathrm{Ci})$ \\
\hline
\end{tabular}

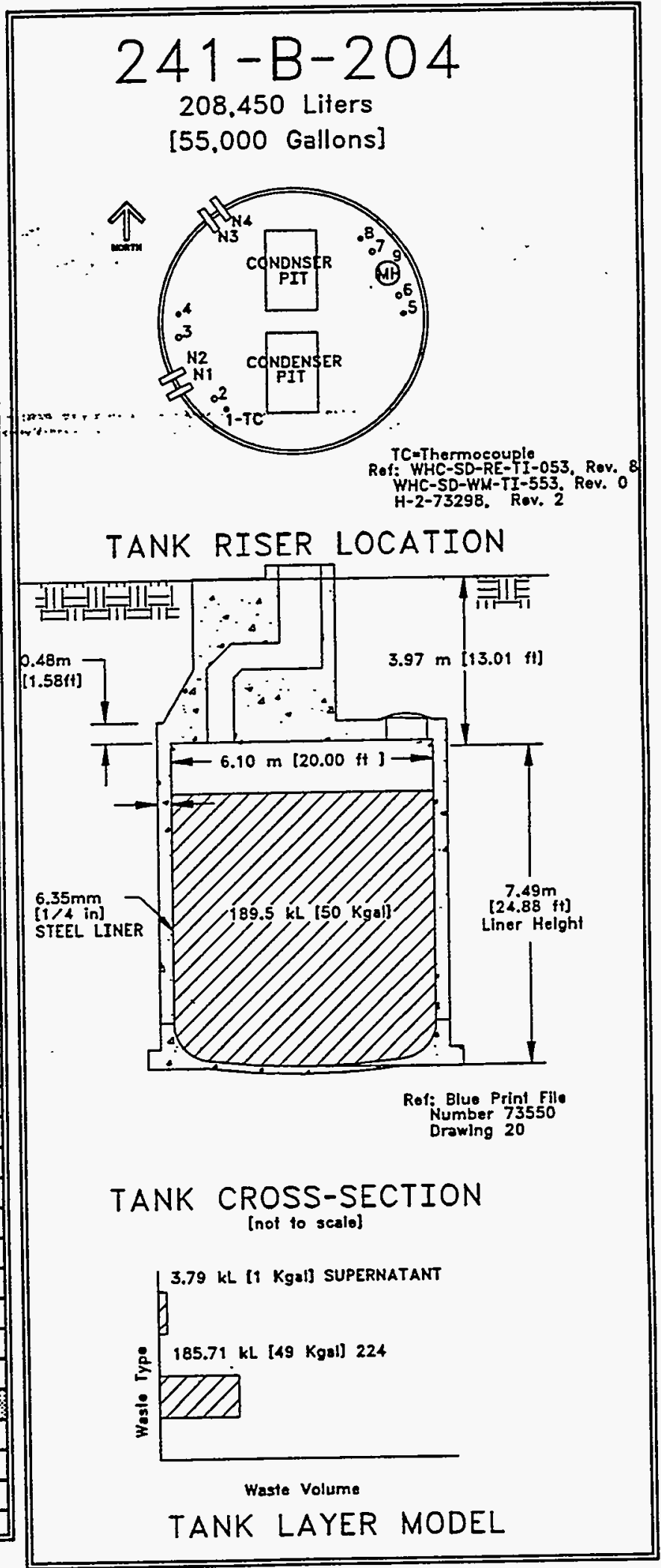




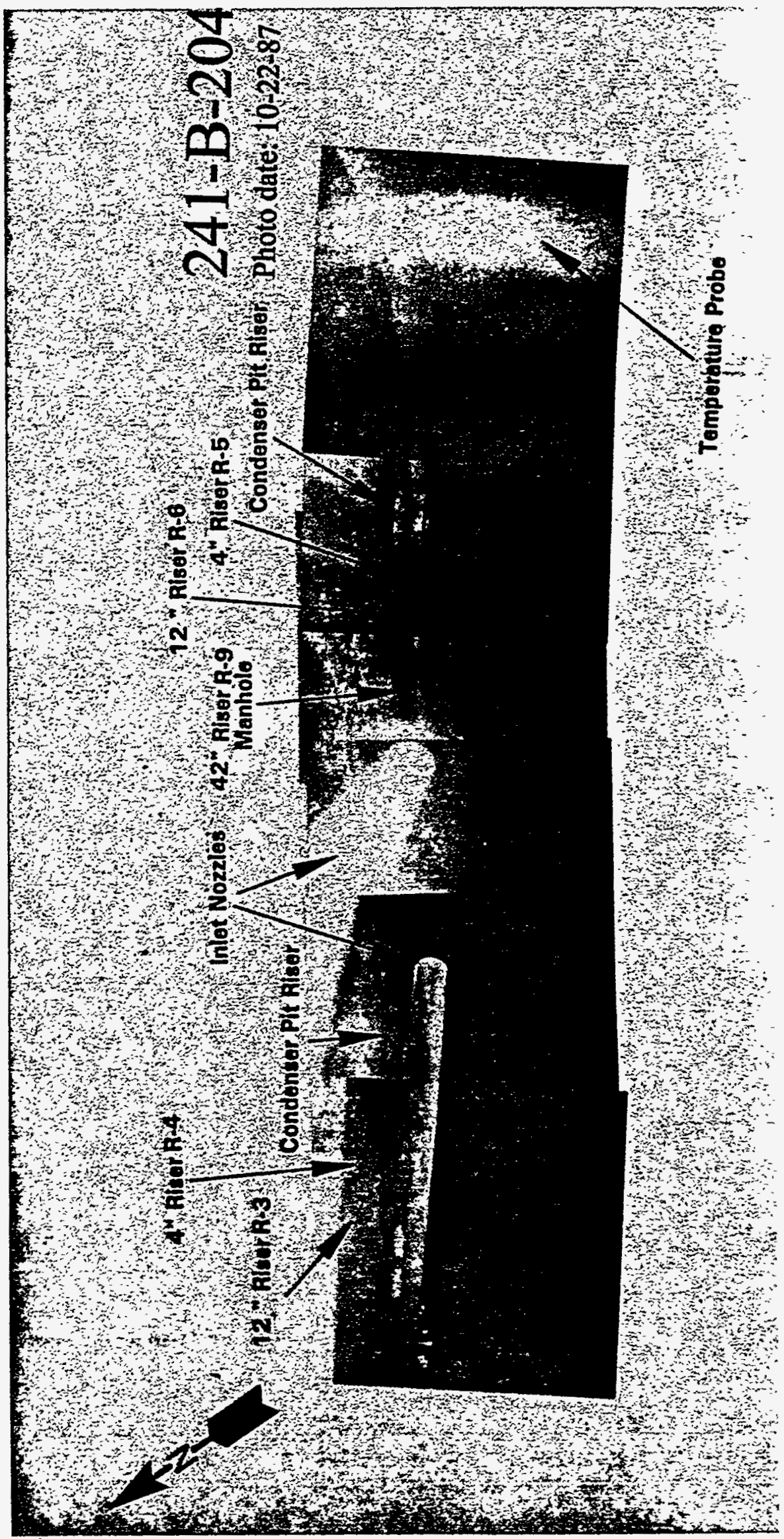




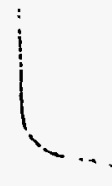

是
文
疍
总

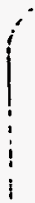




\subsection{BX Tank Farm}

\subsubsection{BX Tank Farm History}

The BX Tank Farm was constructed between 1946 and 1947, south of the BY Tank Farm and west of Baltimore Avenue in the 200-East Area. The BX Tank Farm contains twelve 100 series; 530,000-gal; 75-ft diameter single-shell tanks. The tanks have an operating depth of $17 \mathrm{ft}$. Two years after construction of the $B,: C, T$, and $U$ Tank Farms, the BX Tank Farm was designed. The cascade overflow Iines connect a series of three tanks and the end of the cascade series is hooked to the first cascade tank in the BY Tank Farm. The tanks are in a three-by-four arrangement and there are four groups of cascading tanks. A cascade group consists of three tanks. in. step , configuration... "The rcascade overflow height is approximately 188 in. from the tank bottom:

A 1993 color aerial photograph of the BX Tank Farm shows the tank orientation, a receiver valve, a transfer box, and a north arrow. The arrows between tanks represent the cascade overflow lines and the flow direction. 
WHC-SD-WM-ER-349 Rev. 0

\section{BX Tank Farm}

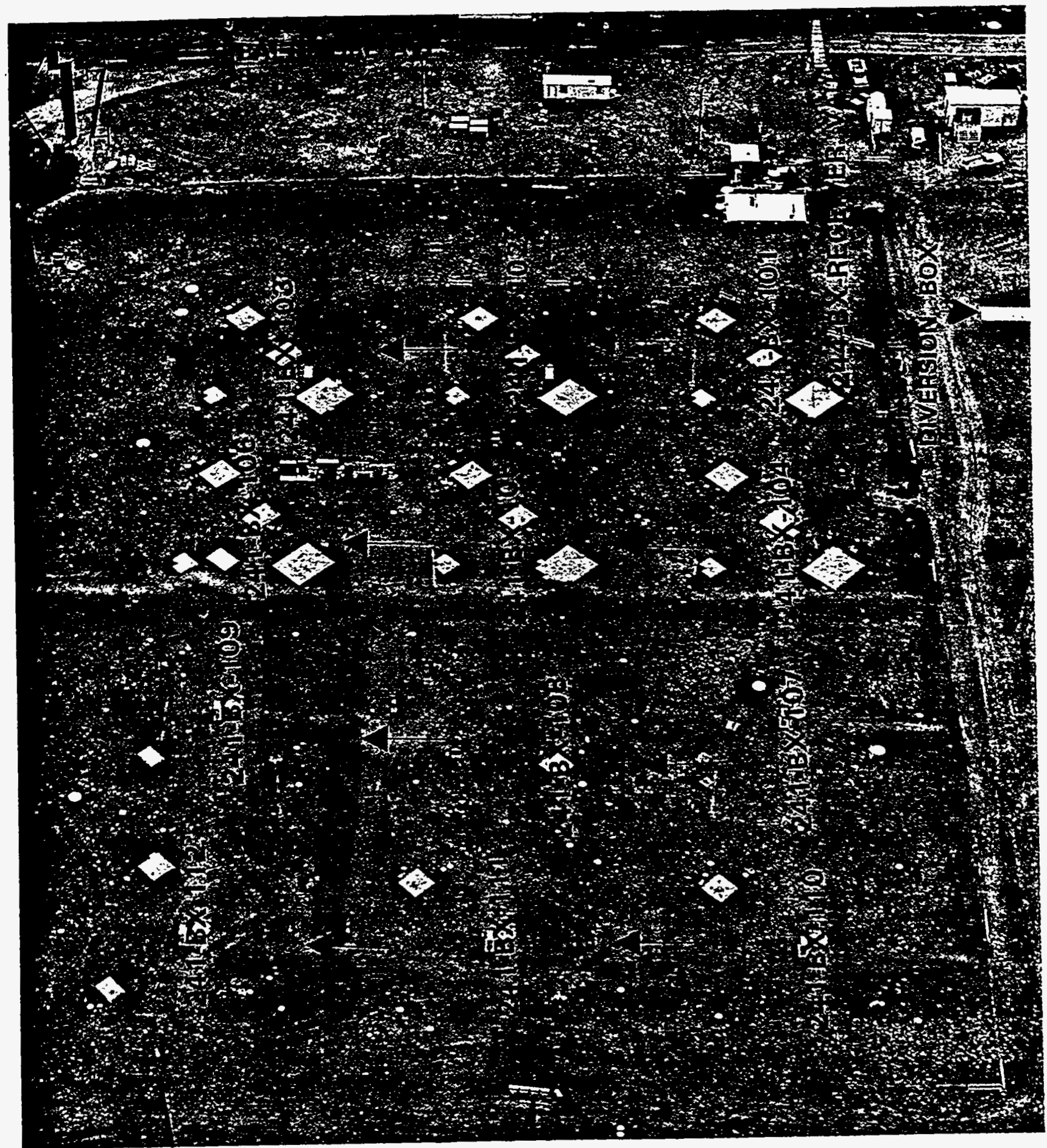


WHC-SD-WM-ER-349, Rev. 0

\subsubsection{BX Tank Farm Waste History}

Tanks 241-BX-101 through -106 received B Plant metal waste and U Plant waste. Tanks 241-BX-107 through -112 received B-Plant first cycle waste and cell 23 concentrator waste. Tanks 241-BX-101 through -106 were sluiced for uranium recovery between 1953 and 1955. The BXR process vault processed sluiced waste during the sluicing campaign. Tank 241-BX-110 received in-tank solidification bottoms waste during the first in-tank solidification program.

\subsubsection{BX Tank Farm Temperature History}

Each tank in the BX Tank Farm contains a single thermocouple tree with 11 to 14 thermocouple.probes s. Tanks .241-BX-102, -106, -110, and 111 are on the Ferrocyanide Watch Iist and have weekly temperature reading requirements. The remaining $B X$ tanks have semiannual requirements. No specific thermocouple elevations are available for Tanks 241-BX-101, -103, -104, -107 , and -109. The tanks currently have moderate temperatures near $70^{\circ} \mathrm{F}$.

\subsubsection{BX Tank Farm Integrity}

The twelve 530,000-gal tanks in the BX Tank Farm are out of service. As of July 1993, Tanks 241-BX-103, -104, -105, -106, -107, 109, - -112 were categorized as sound and Tanks 241-BX-101, -102, -108, 110, -111were categorized as assumed leakers. Tank integrity surveillance methods consist of liquid observation wells, surface level measurements, and leak detection wells (i.e., drywells).

The BX Tank Farm has 76 leak detection wells that were drilled from 1947 to 1977. Eight wells are not tank-specific. Drywells 21-00-02 (no longer active), 21-00-09 (no longer active), 21-00-21, and 21-00-22 have or had readings greater than the $50 \mathrm{c} / \mathrm{s}$ background radiation. The drywells are monitored monthly, yearly, or on request with scintillation or Geiger-Mueller probes. Drywells associated with assumed leaker tanks are monitored for contamination migration. Criteria limits do not apply where new radiation peaks occur.

The following illustration of the BX Tank Farm layout includes information on the drywell peaks, tank integrity, and tank status. The drywell information is based on summarized data prior to 1987 and from data collected between January 1990 and the present.

\subsubsection{Current Status of BX Tank Farm}

Two tanks in the BX Tank Farm are on the Ferrocyanide watch List. Tanks 241-BX-102 and -106 were listed in January 1991 and have been declared unreviewed safety questions because their explosion potential exceeds previously reported safety analysis consequences. Tanks 241-BX110 and -111 were removed from the Ferrocyanide watch List and are monitored on a weekly basis. The total volume of waste in the BX Tank Farm is 1,509,000 gal: 31,000 gal of supernatant; 221,000 gal of saltcake; 198,000 gal of unknown solids; and $1,059,000$ gal of sludge. 


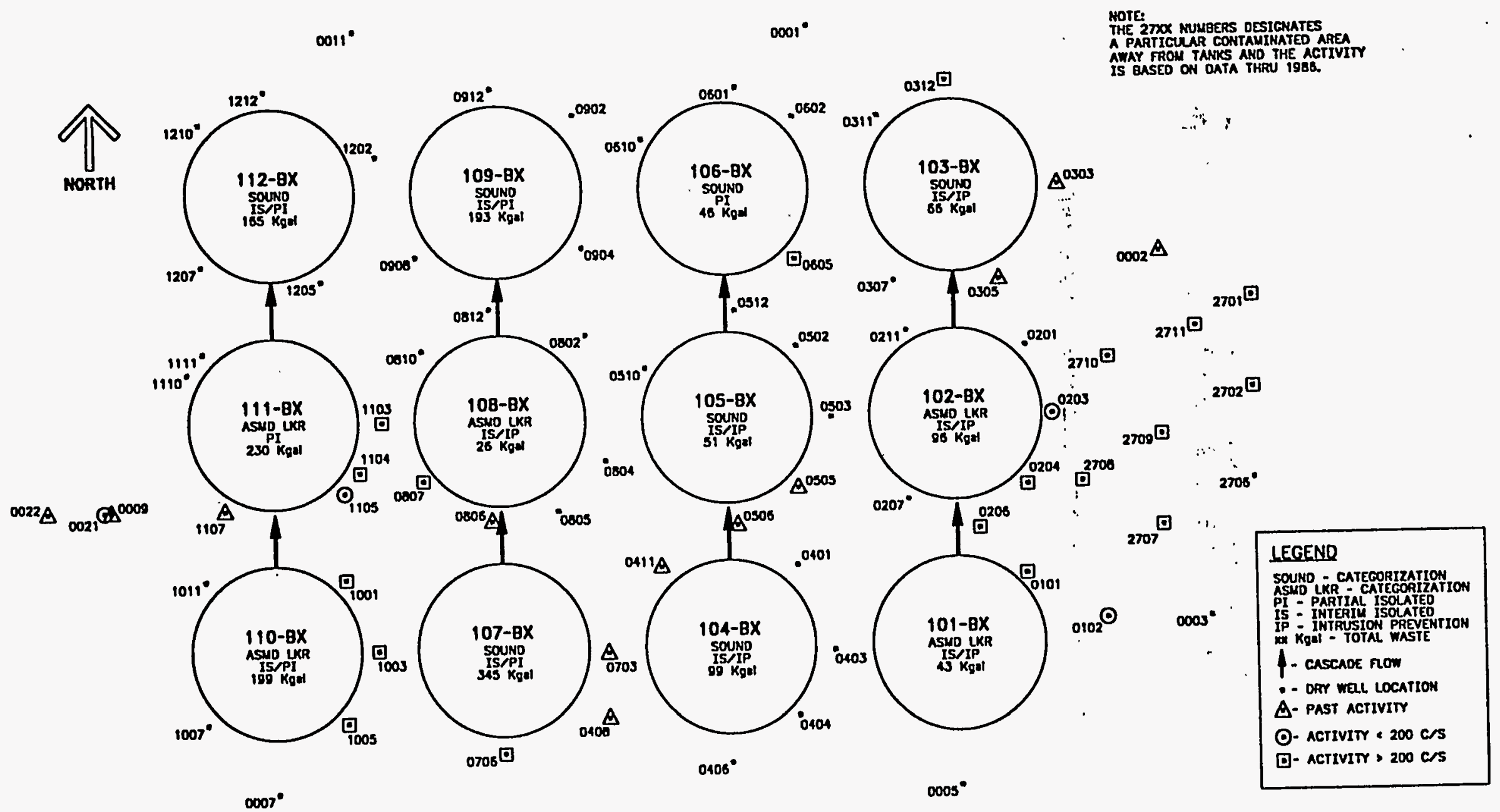




\subsection{Tank 241-BX-101}

\subsubsection{1-BX-101 Tank History}

\subsubsection{Waste History Tank 241-BX-101}

Tank 241-BX-101 was filled with metal waste from January to June 1948. The tank was a suspect leaker in 1973.. In 1974, a -P-10 pump was installed in Tank 241-BX-101... In the fourth quarter of 197.7, a saltwell was installed in the tank. The tank was deactivated and primary stabilized in 1978. The tank was interim stabilized in September 1978, intrusion prevention was completed in May 1981, and a level adjustment was made in April 1982. (See sketch ES-TKS-E27 for a graphical representation of..the., Tank..241-BX-101_level. history.)... .

\subsubsection{Temperature History 241-BX-101}

The single thermocouple tree in Tank 241-BX-101 has 14 probes to record temperature data. The mean temperature of the first daily recorded readings was $26.5^{\circ} \mathrm{F}$. A sum of the squares regression line fit for the first 12 thermocouples shows no overall temperature change and a large amount of variability. Not enough data points are available for an accurate regression and variability analysis on thermocouples 13 and 14. The median temperature is $70^{\circ} \mathrm{F}$ with a minimum of $47^{\circ} \mathrm{F}$ and a maximum of $86^{\circ} \mathrm{F}$. Refer to the supporting document for a more thorough review of the temperature data (Brevick 1994).

\subsubsection{Integrity of Tank 241-BX-101}

Tank 241-BX-101 is categorized as an assumed leaker and is interim stabilized with intrusion prevention completed. The Tank 241-BX-101 surface level is monitored daily with a manual tape through riser 8 . A figure that graphically represents the surface level measurements from January 1991 to the present can be found in the supporting documents (Brevick 1994). The surface level data for the past 3 years range between 9.5 and $12 \mathrm{in}$.

Two arywells are identified for tank 241-BX-101. Graphical representations of the active drywelis from January 1990 to the present can be found in the supporting document (Brevick 1994). Each graph includes the peak $\mathrm{c} / \mathrm{s}$ (some wells have multiple peaks), the depth at which the peak occurred, and the date of the reading.

\subsubsection{Current Status of Tank 241-BX-101}

Tank 241-BX-101 entered service in January 1948 and currently stores 43,000 gal of waste. The waste is comprised of 1,000 gal of supernatant and 13,000 gal of unknown waste; 29,000 gal of sludge; with no saltcake or pumpable liquid remaining. The tank is identified as a low-heat load tank, is passively ventilated, and is categorized as an assumed leaker with interim stabilization and intrusion prevention completed. Tank 241-BX-101 is equipped to cascade to 241-BX-102 and is first in the three-tank cascade series. The following plan view and

$$
-176-
$$


WHC-SD-WM-ER-349, Rev. 0

tank cross section depict the approximate waste level and riser configuration. Tank 241-BX-101 has 10 risers, and 12-in. riser no.7 is available for use.

\subsubsection{Inventory estimate 241-BX-101}

The following tank layer volume approximation was derived from the Los Alamos National Laboratories Waste Status and Transaction Record Summary (Agnew 1994). The estimated inventory of Tank 241-BX-101 is also presented.

\subsubsection{In-Tank Photograph 241-BX-101}

The Tank 241-BX=101. photo. shows. a.dark brown .sludge ring around the perimeter and a major portion of the surface covered with translucent reddish-brown liquid. The tank contains approximately 1,000 gal of supernatant and $42,000 \mathrm{gal}$ of sludge which measures approximately 2 ft in depth. A flex and float pump descends into the sluage in the lower left corner.

\subsubsection{Synopsis Tank 241-BX-101}

(To be completed.) 
WHC-SD-WM-ER-349 ReV. 0

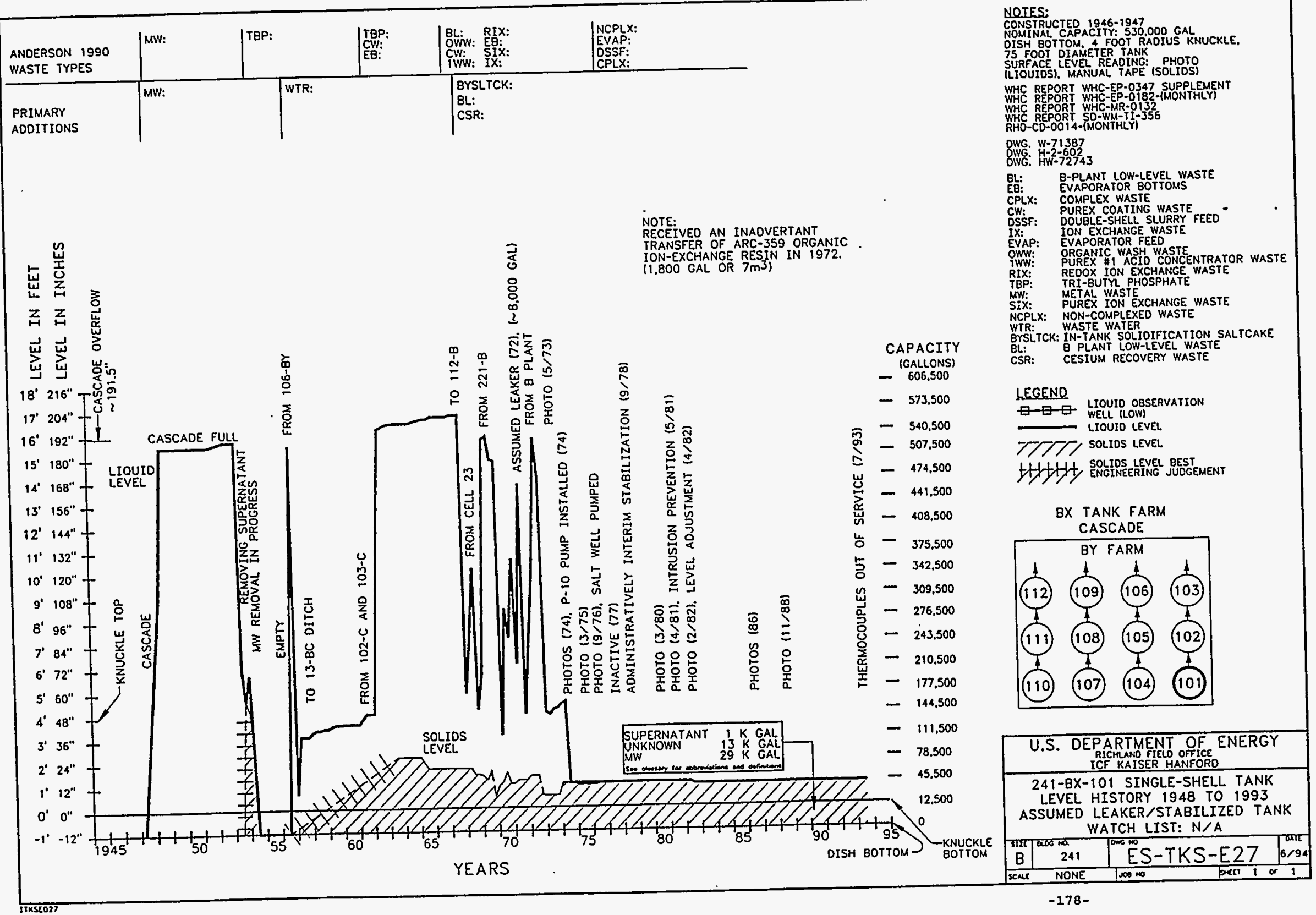




\begin{tabular}{|c|c|c|c|}
\hline \multicolumn{4}{|c|}{ Single-Shell Tank 241-BX-101 } \\
\hline \multicolumn{4}{|c|}{ Solids Composite Inventory Estimate } \\
\hline \multicolumn{4}{|c|}{ 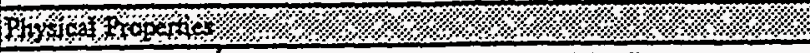 } \\
\hline Tous Solid Waste & \multicolumn{3}{|c|}{$2.60 \mathrm{E}+05 \mathrm{~kg}(42 \mathrm{kgal})$} \\
\hline Heal load & \multicolumn{3}{|c|}{$5.06 \mathrm{~kW}(1.73 \mathrm{E}+04 \mathrm{BTU} / \mathrm{hr})$} \\
\hline Bulk Density & \multicolumn{3}{|c|}{$1.64(g / \infty)$} \\
\hline Void Fraction & \multicolumn{3}{|c|}{0.36} \\
\hline Water wr\% & \multicolumn{3}{|c|}{46.90} \\
\hline TOC w1\% C (wet) & \multicolumn{3}{|c|}{0.09} \\
\hline \multicolumn{4}{|c|}{ 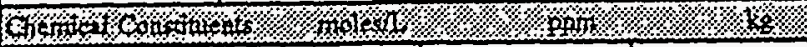 } \\
\hline \begin{tabular}{|l|l|l|l|}
$\mathrm{Na}^{+1}$ & \\
\end{tabular} & 10.19 & $1.43 \mathrm{E}+05$ & 3.72E+04 \\
\hline $\mathrm{Al}^{+3}$ & 0.60 & $9.96 E+03$ & $2.59 E+03$ \\
\hline $\mathrm{Fe}^{43}(\operatorname{total} \mathrm{Fe})$ & 0.62 & $2.11 E+04$ & $5.50 \mathrm{E}+03$ \\
\hline $\mathrm{Cr}^{+3}$ & 4.575-08 & $1.45 \mathrm{E}-03$ & $\therefore .378 \mathrm{E}-04$ \\
\hline $\mathrm{Bi}^{+3}$ & of & 0 & 0 \\
\hline $\mathrm{La}^{43}$ & 요 & 요 & 0 \\
\hline $\mathrm{Ce}^{43}$ & 0 & 0 & 0 \\
\hline $\mathrm{Zr}$ (as $\left.\mathrm{ZrO}(\mathrm{OH})_{2}\right)$ & 0] & 0 & 0 \\
\hline $\mathrm{Pb}^{+2}$ & 0 & 0 & 0 \\
\hline $\mathrm{Ni}^{+2}$ & $6.30 \mathrm{E}-02$ & $2.26 \mathrm{E}+03$ & $5.88 \mathrm{E}+02$ \\
\hline $\mathrm{Sr}^{+2}$ & 0 & 0 & 0 \\
\hline $\mathrm{Mn}^{4+4}$ & 0] & 0 & 0 \\
\hline $\mathrm{Ca}^{+2}$ & 0 & 0] & 0 \\
\hline $\mathbf{K}^{+1}$ & 0 & 0 & 0 \\
\hline $\mathrm{OH}^{1}$ & 6.02 & $6.25 E+04$ & $1.63 E+04$ \\
\hline $\mathrm{NO}^{-1}$ & 0.40 & $1.51 \mathrm{E}+04$ & $3.92 \mathrm{E}+03$ \\
\hline $\mathrm{NO}^{-1}$ & 0 & 0 & 0 \\
\hline $\mathrm{CO}^{\cdot 2}$ & 1.69 & $6.19 \mathrm{E}+04$ & $1.61 E+04$ \\
\hline $\mathrm{PO}^{-3}$ & 1.99 & $1.15 \mathrm{E}+05$ & $3.00 E+04$ \\
\hline $\mathrm{SO}^{-2}$ & 5.47E-02 & $3.21 \mathrm{E}+03$ & $8.35 E+02$ \\
\hline $\mathrm{Si}\left(\right.$ as $\left.\mathrm{SiO}_{3}{ }^{-2}\right)$ & 0.62 & $1.06 \mathrm{E}+04$ & $2.76 \mathrm{E}+03$ \\
\hline $\mathrm{F}^{-1}$ & 0 & 0 & 0 \\
\hline $\mathrm{Cl}^{-1}$ & 0 & 0 & 0 \\
\hline $\mathrm{C}_{6} \mathrm{H}_{5} \mathrm{O}_{7}{ }^{3}$ & $3.43 \mathrm{E}-03$ & $3.96 \mathrm{E}+02$ & $1.03 \mathrm{E}+02$ \\
\hline EDTA & 0 & 0 & 0 \\
\hline HEDTA ${ }^{3}$ & 0 & 0 & 0 \\
\hline $\mathrm{NTA}^{-3}$ & 0 & 0 & 0 \\
\hline Blycolate & $4.57 \mathrm{E}-02$ & $2.09 E+03$ & $5.45 \mathrm{E}+02$ \\
\hline acetate $^{-1}$ & of & 0 & 0 \\
\hline oxalate $e^{-2}$ & 요 & 0 & 0 \\
\hline DBP & 요 & of & 0 \\
\hline NPH & of & 0 & 0 \\
\hline $\mathrm{CCl}_{4}$ & 0 & of & 0 \\
\hline hexone & 의 & of & 0 \\
\hline $\mathrm{Fe}(\mathrm{CN})_{6}{ }^{+}$ & 0 & $0(\mathrm{~g}-\mathrm{mol})$ & \\
\hline \multicolumn{4}{|c|}{ 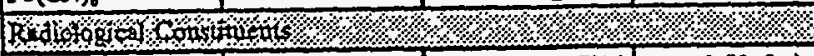 } \\
\hline Pu & & $0.58(\mathrm{uCi} / \mathrm{g})$ & $2.52(\mathrm{~kg})$ \\
\hline $\mathrm{U}$ & $0.53(\mathrm{M})$ & $7.69 \mathrm{E}+04(\mathrm{ug} / \mathrm{g})$ & $2.00 \mathrm{E}+04(\mathrm{~kg})$ \\
\hline$C_{s}$ & $2.16 \mathrm{E}-03(\mathrm{Ci} / \mathrm{L})$ & $1.32(\mu \mathrm{Ci} / \mathrm{g})$ & $3.44 \mathrm{E}+02(\mathrm{Ci})$ \\
\hline Sr & $4.72(\mathrm{Ci} / \mathrm{L})$ & $2.88 \mathrm{E}+03(\mu \mathrm{Ci} / \mathrm{g})$ & $7.51 \mathrm{E}+05(\mathrm{Ci})$ \\
\hline
\end{tabular}

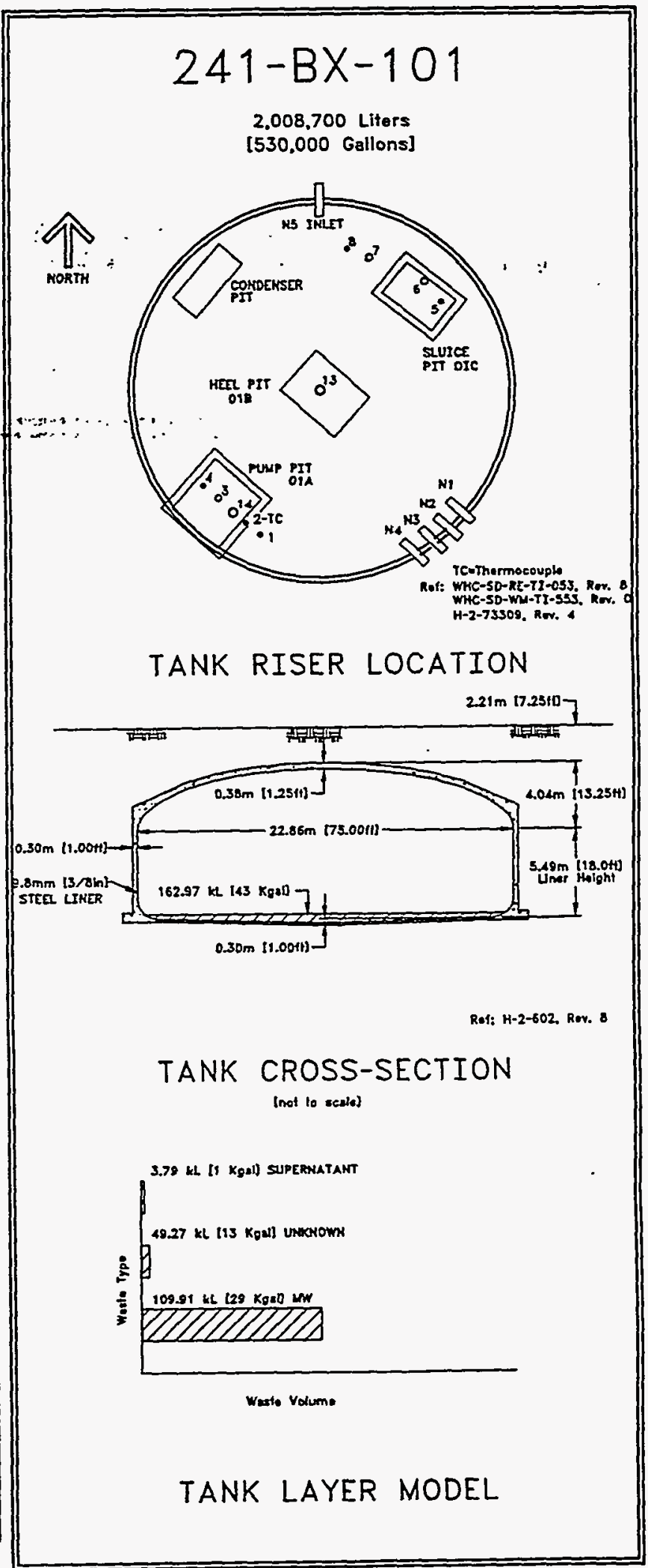

Composite inveptory exchudes supernatant, ciatomaceous earth, and cenos

Unknowns in tank inventory are acsigned by Tant Layering Model (ILM). 
WHC-SD-WM-ER-349 Rev. 0

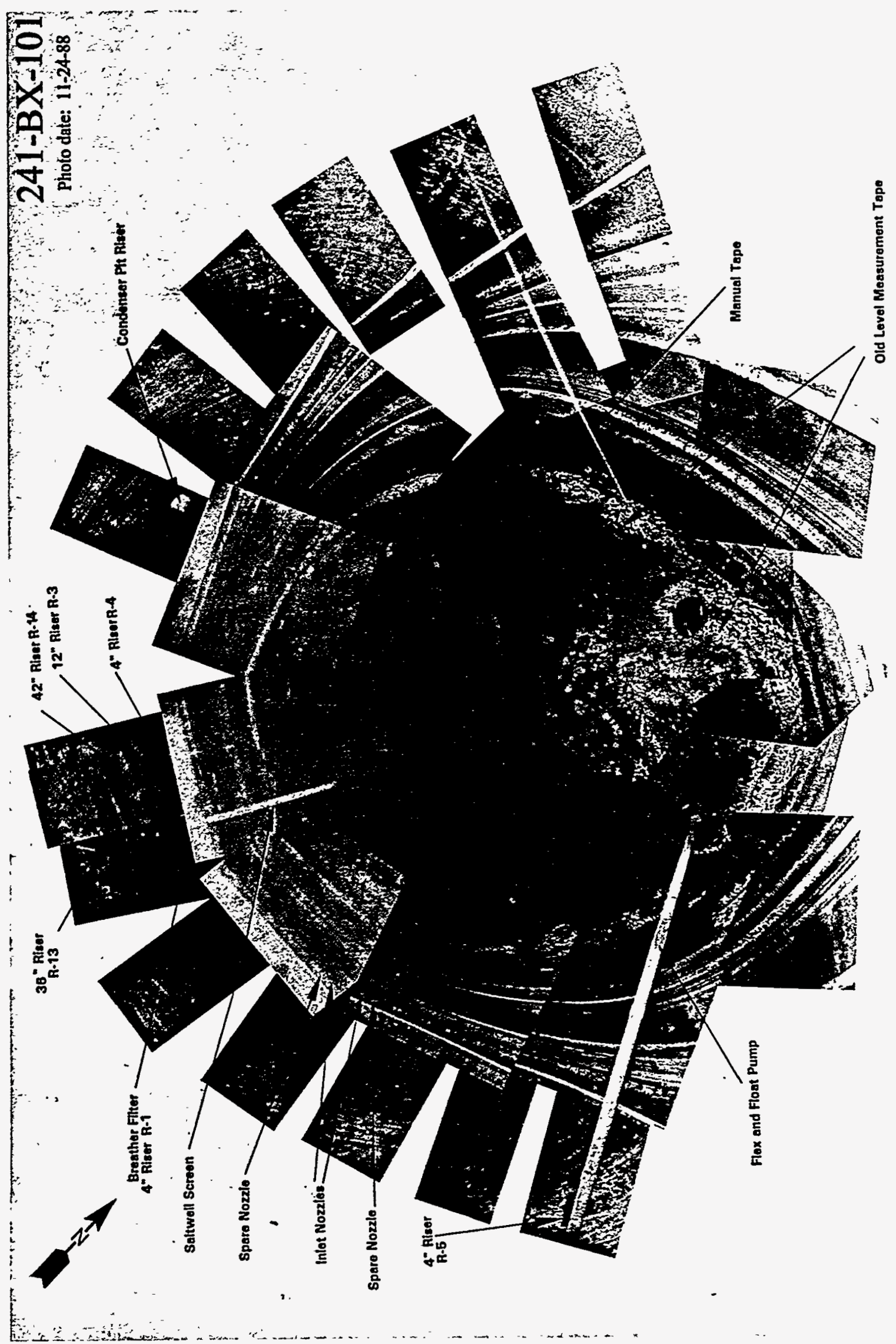


WHC-SD-WM-ER-349, Rev. 0

\subsection{Tank 241-BX-102}

\section{2 .1 \\ 241-BX-102 Tank History}

5.2.1.1 Waste History Tank 241-BX-102

Tank 241-BX-102 was filled with metal waste from June 1948 to September 1948. The tank became an assumed leaker of 70,000 gal and was taken out of service in 1971. During January 1972, approximately 95 tons of diatomaceous earth were added to absorb any remaining liquid in the tank. Intrusion prevention was completed in october 1980. The tank was declared interim stabilized in November 1978. In April 1982, a level adjustment was made. (See sketch ES-TKS-E28 for a graphical representation of the Tank $241-B \mathrm{BX}-102$, levelnhistor........

\subsubsection{Temperature History 241-BX-102}

Tank 241-BX-102 contains one thermocouple tree with 13 probes to measure in-tank temperatures. The mean temperature of the first daily recorded readings was $59^{\circ} \mathrm{F}$. A sum of the squares regression line fit for the first 12 thermocouples shows no overall temperature change and a moderate amount of variability. An annual tank temperature undulation is more evident after October 1989. Not enough data points are available for an accurate regression and variability analysis on thermocouple 13. The median temperature is $65^{\circ} \mathrm{F}$ with a minimum of $51^{\circ} \mathrm{F}$ and a maximum of $83^{\circ} \mathrm{F}$. Refer to the supporting document for a more thorough review of the temperature data (Brevick 1994).

\subsubsection{Integrity of Tank 241-BX-102}

Tank 241-BX-102 is categorized as an assumed leaker and is interim stabilized with intrusion prevention completed. The Tank 241-BX-102 surface level is monitored quarterly with a manual tape through riser 7 . A figure that graphically represents the surface level measurements from January 1991 to the present can be found in the supporting documents (Brevick 1994). The surface level for the past 3 years has remained steady with the readings ranging between 28.5 and 28 -in.

Six drywells are identified for tank 241-BX-102. Graphical representations of the drywell data for each active drywell from January 1990 to the present can be found in the supporting document (Brevick 1994). Each graph includes the peak c/s (some wells have multiple peaks), the depth at which the peak occurred, and the date of the reading.

\subsubsection{Current Status of Tank 241-BX-102}

Tank 241-BX-102 entered service in June 1948 and currently stores $96,000 \mathrm{gal}$ of non-complexed waste. The waste is comprised of $39,000 \mathrm{gal}$ of unknown waste; 17,000 gal of diatomaceous earth; 40,000 gal of sludge with no pumpable liquid remaining. The tank is identified on the Ferrocyanide watch List, is passively ventilated, and is categorized as an assumed leaker with interim stabilization and intrusion prevention 
completed. Tank 241-BX-102 is equipped to cascade to Tank 241-BX-103 and is second in the three-tank cascade series. The following plan view and tank cross section depict the approximate waste level and riser configuration. Tank $241-\mathrm{BX}-102$ has 10 risers, and 12 -in. riser No.7 is available for use.

\subsubsection{Inventory estimate 241-BX-102}

- The following tank layer volume approximation was derived from the Los Alamos National Laboratories Waste Status and Transaction Record Summary (Agnew 1994). The estimated inventory of Tank 241-BX-102 is also presented.

\subsubsection{2- In-Tank, Photograph-241-BX-102m...}

The Tank 241-BX-102 photo shows a surface of white cracked sludge. Approximately $96,000 \mathrm{gal}$ (i.e., approximately.5 ft of sludge) are in the tank. The true color cannot be determined by the photo due to poor film quality. The surface perforations resulted from equipment removal.

5.2.3 Synopsis Tank 241-BX-102

(To be completed.) 


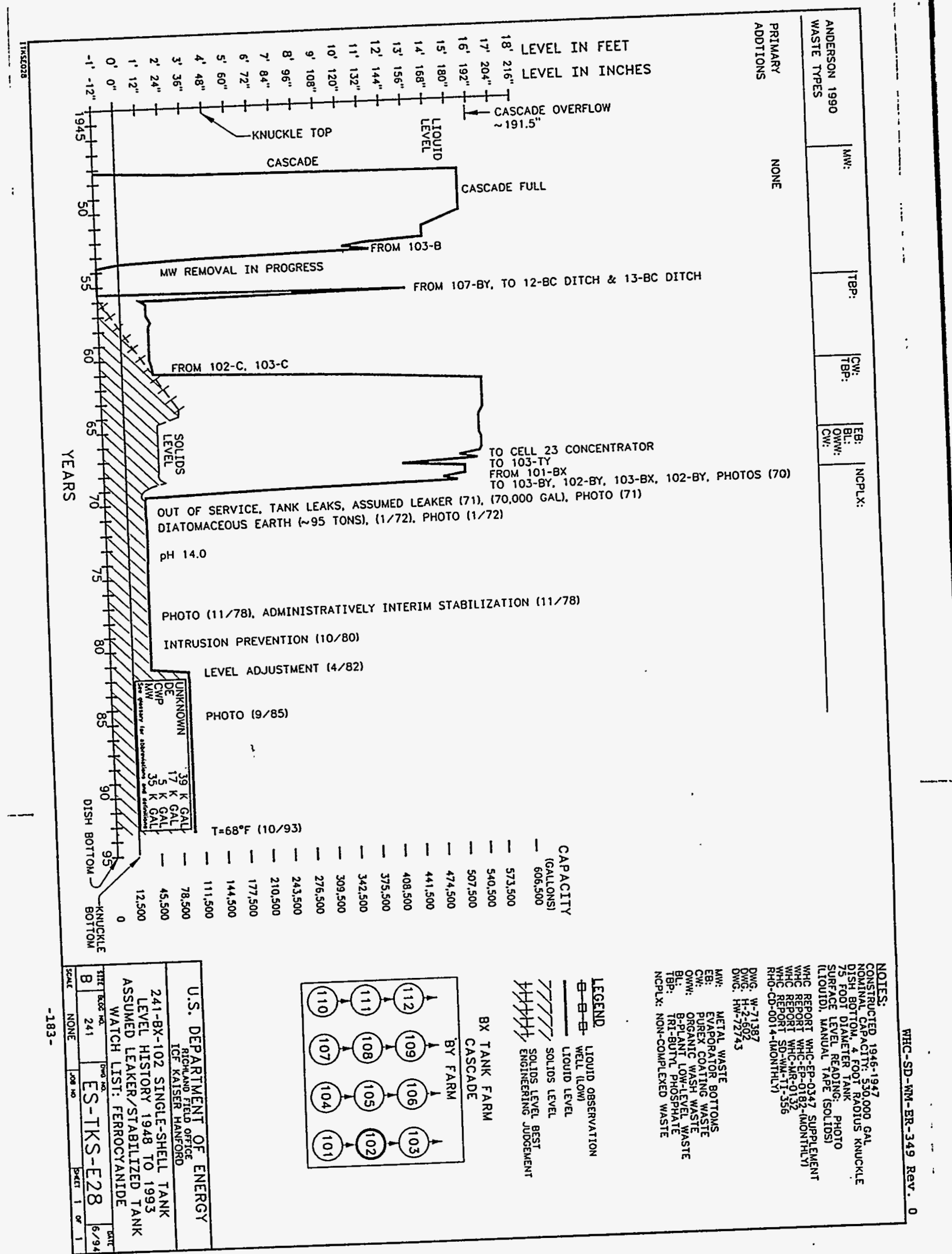




\begin{tabular}{|c|c|c|c|}
\hline \multicolumn{4}{|c|}{ Single-Shell Tank 241-BX-102 } \\
\hline \multicolumn{4}{|c|}{ Solids Composite Inventory Estimate } \\
\hline 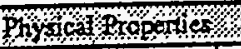 & \%, & \% \% \% \% & \% \\
\hline \begin{tabular}{|l|l} 
Tolal Solid Warte \\
\end{tabular} & \multicolumn{3}{|c|}{$2.53 \mathrm{E}+05 \mathrm{~kg}(40 \mathrm{kgal})$} \\
\hline Heal load & \multicolumn{3}{|c|}{$0.29 \mathrm{~kW}(9.95 \mathrm{E}+02 \mathrm{BTU} / \mathrm{hr})$} \\
\hline Bulk Density & \multicolumn{3}{|c|}{$1.67(g / \infty)$} \\
\hline Void Fraction & \multicolumn{3}{|c|}{0.25} \\
\hline Water wr\% & \multicolumn{3}{|c|}{48.45} \\
\hline TOC w1\% C (wel) & \multicolumn{3}{|c|}{0.00} \\
\hline \multicolumn{4}{|c|}{ onolest } \\
\hline \begin{tabular}{|l|l|}
$\mathrm{Na}^{+1}$ & \\
\end{tabular} & 10.57 & $1.45 \mathrm{E}+05$ & $3.68 \mathrm{E}+04$ \\
\hline $\mathrm{Al}^{+3}$ & 0.72 & $1.17 \mathrm{E}+04$ & $2.96 \mathrm{E}+03$ \\
\hline $\mathrm{Fe}^{+3}(\mathrm{todal} \mathrm{Fe})$ & 0 & 0 & 0 \\
\hline $\mathrm{C}^{+3}$ & 0|: & of & 0 \\
\hline $\mathrm{Bi}^{-3}$ & \begin{tabular}{l|l}
0 \\
\end{tabular} & 요 & 0 \\
\hline$\overline{\mathrm{La}^{3}}$ & 0 & 0 & 0 \\
\hline $\mathrm{Ce}^{+3}$ & 0) & 0 & 0 \\
\hline $\mathrm{Zx}\left(\mathrm{as} \mathrm{ZrO}(\mathrm{OH})_{2}\right)$ & of & of & 0 \\
\hline $\mathrm{Pb}^{+2}$ & of & of & 0 \\
\hline$\widehat{\mathrm{Ni}^{+2}}$ & 0] & 묘 & 0 \\
\hline$S r^{42}$ & 0) & 0 & 0 \\
\hline$\overline{\mathrm{Mn}^{+\infty}}$ & 0] & 0 & 0 \\
\hline $\mathrm{Ca}^{42}$ & 이 & 0 & 0 \\
\hline $\mathrm{K}^{+1}$ & 0 & 0 & 0 \\
\hline $\mathrm{OH}^{-1}$ & 4.86 & $4.94 \mathrm{E}+04$ & $1.25 \mathrm{E}+04$ \\
\hline $\mathrm{NO}^{-1}$ & 6.73E-02 & $2.49 \mathrm{E}+03$ & $6.32 \mathrm{E}+02$ \\
\hline $\mathrm{NO}^{-1}$ & $2.31 \mathrm{E}-02$ & $6.35 \mathrm{E}+02$ & $1.61 \mathrm{E}+02$ \\
\hline $\mathrm{CO}^{3-2}$ & 2.06 & $7.38 \mathrm{E}+04$ & $1.87 \mathrm{E}+04$ \\
\hline$\overline{\mathrm{PO}^{3} \cdot 3}$ & 2.52 & $1.43 \mathrm{E}+05$ & $3.62 \mathrm{E}+04$ \\
\hline $\mathrm{SO}^{-2}$ & 3.75E-02 & $2.15 \mathrm{E}+03$ & $5.45 \mathrm{E}+02$ \\
\hline $\mathrm{Si}\left(\right.$ as $\left.\mathrm{SiO}_{3}^{-2}\right)$ & of & 0 & 0 \\
\hline $\mathrm{F}^{-1}$ & 0 & of & 0 \\
\hline $\mathrm{C}^{-2}$ & 0 & 0 & 0 \\
\hline $\mathrm{C}_{6} \mathrm{H}_{3} \mathrm{O}_{7}{ }^{3}$ & 요 & of & 0 \\
\hline EDTA & 0 & of & 0 \\
\hline HEDTA $^{3}$ & 0 & 0 & 0 \\
\hline $\mathrm{NTA}^{-3}$ & 0 & 아 & 0 \\
\hline glycolate & 0 & 0 & 0 \\
\hline acetale & 요 & 0 & 0 \\
\hline oxalate & 0 & 0 & 0 \\
\hline DBP & of & of & 0 \\
\hline NPH & 의 & of & 0 \\
\hline $\mathrm{CCl}_{4}$ & 0 & 0 & 0 \\
\hline hexone & of & of & 0 \\
\hline $\mathrm{Fe}(\mathrm{CN})_{6}^{-1}$ & 0 & $0(\mathrm{~g}-\mathrm{mol})$ & \\
\hline \multicolumn{4}{|c|}{ 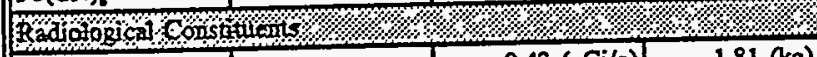 } \\
\hline Pu & & $0.43(\mu \mathrm{Ci} / \mathrm{g})$ & $1.81(\mathrm{~kg})$ \\
\hline $\bar{U}$ & $0.66(M)$ & $9.37 \mathrm{E}+04(\mu \mathrm{g} / \mathrm{g})$ & $2.38 \mathrm{E}+04(\mathrm{~kg})$ \\
\hline Cs & $2.74 \mathrm{E}-03(\mathrm{Ci} / \mathrm{L})$ & $1.64(\mu \mathrm{Ci} / \mathrm{g})$ & $4.15 \mathrm{E}+02(\mathrm{C})$ \\
\hline SI & 0.28 (Cil) & $1.69 \mathrm{E}+02(\mu \mathrm{Ci} / \mathrm{g})$ & $4.30 \mathrm{E}+04(\mathrm{Ci})$ \\
\hline
\end{tabular}

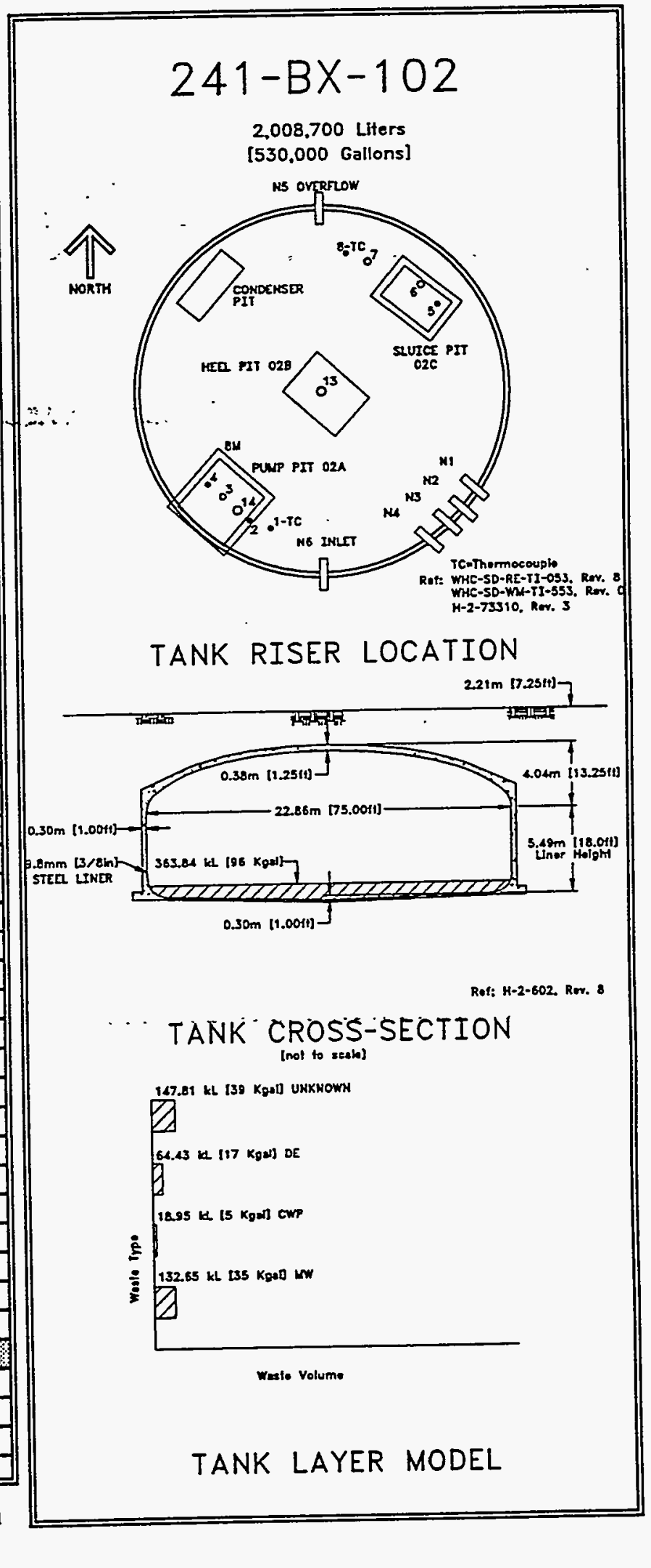




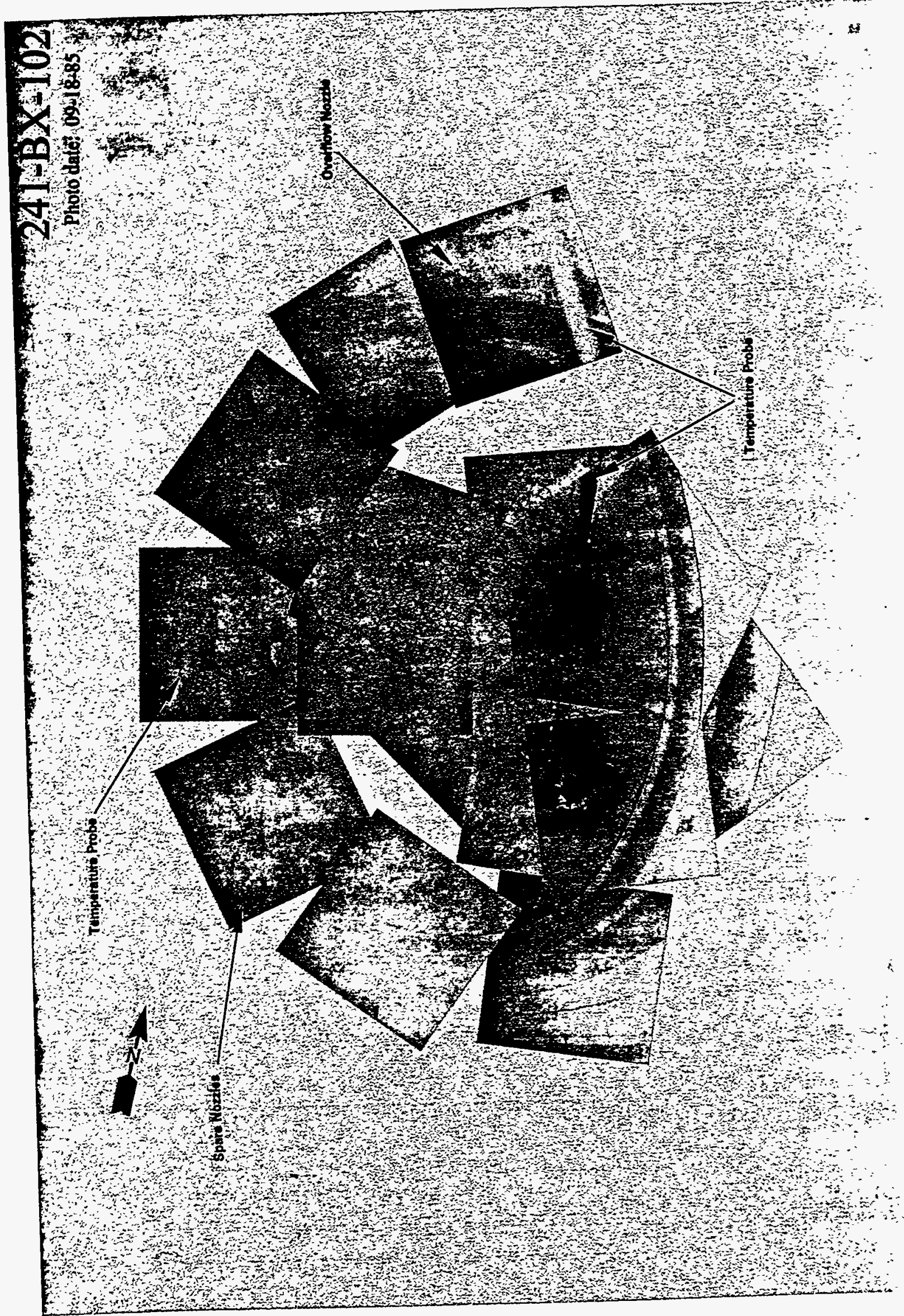


WHC-SD-WM-ER-349, Rev. 0

5.3 Tank 241-BX-103

5.3.1 241-BX-103 Tank History

5.3.1.1 Waste History Tank 241-BX-103

Tank 241-BX-103 was filled with metal waste from September 1948 to January. 1949. The tank was inactive in 1977. A saltwell was instalied in 1977. Interim stabilization and a level adjustment were completed in November 1983. In October 1985, intrusion prevention was completed. (See sketch ES-TKS-E29 for a graphical representation of the Tank 241-BX-103 level. history.)

\section{3 .1 .2 . Temperature. History: 241 - $\mathrm{BX}=10.3 . \cdots$}

There are 12 thermocouple probes to record temperature data on the single tree in Tank 241-BX-103. The mean temperature of the first recorded data was $24.5^{\circ} \mathrm{F}$. A sum of the squares regression line fit for all but the first three data points for each thermocouple shows a temperature increase with a large amount of variability. The median temperature is $64^{\circ} \mathrm{F}$ with a minimum of $59^{\circ} \mathrm{F}$ and maximum of $91^{\circ} \mathrm{F}$. Refer to the supporting document for a more thorough review of the temperature data (Brevick 1994).

\subsubsection{Integrity of Tank 241-BX-103}

Tank 241-BX-103 is categorized as sound and is interim stabilized with intrusion prevention completed. The Tank 241-BX-103 surface level is monitored with a Food Instrument Corporation gauge through riser 8 . A figure that graphically represents the surface level measurements from January 1991 to the present can be found in the supporting documents (Brevick 1994). The surface level plot for the past 3 years indicates an increasing trend with readings ranging between 19.7 and $19.8-i n$. during the first quarter of 1991 and steadily increasing to 20.25 to 20.5-in. during the fourth quarter of 199.3... An. occurrence report was issued in March 1993 when the surface level exceeded the increase limit. An investigation of the intrusion is underway. A new in-tank photograph package has been initiated to determine the route of entry.

Five drywells are identified for tank 241-BX-103. representation of the active drywell from January 1990 to the present can be found in the supporting Document (Brevick 1994). The graph includes the peak c/s (some wells have multiple peaks), the depth at which the peak occurred, and the date of the reading.

\subsubsection{Current Status of Tank 241-BX-103}

Tank 241-BX-103 entered service in September 1948 and currently stores 66,000 gal of non-complexed waste. The waste is comprised of 4,000 gal of supernatant; 8,000 gal of unknown waste; 54,000 gal of sludge, with no pumpable liquid remaining. The tank is identified as a low-heat load tank, is passively ventilated, and is categorized as sound with interim stabilization and intrusion prevention completed. Tank. 
241-BX-103 is third in the three-tank cascade series. The tank cascades to Tank 241-BY-101. The following plan view and tank cross section depict the approximate waste level and riser configuration. Tank 241$\mathrm{BX}-103$ has 10 risers and 12 -in. riser no.7 is available for use.

\subsubsection{Inventory estimate 241-BX-103}

The tank layer volume approximation that follows was derived from Ias Alamos National Laboratories Waste Status and Transaction Record Summary (Agnew 1994). The estimated inventory of Tank 241-BX-103 is also presented.

\subsubsection{In-Tank Photograph 241-BX-103}

The Tank 241-BX-103 photo shows a narrow ring of black sludge around the perimeter and most of the surface being black liquid. The tank contains approximately $4,000 \mathrm{gal}$ of supernate and $62,000 \mathrm{gal}$ of sludge which measures approximately $1.5 \mathrm{ft}$ in depth. A sluicing nozzle and Food Industry Corporation gauge are visible. The photo is not a clear representation of the tank due to photo quality.

\subsubsection{Synopsis Tank 241-BX-103}

(To be completed.) 
WHC-SD-WM-ER-349 Rev. D

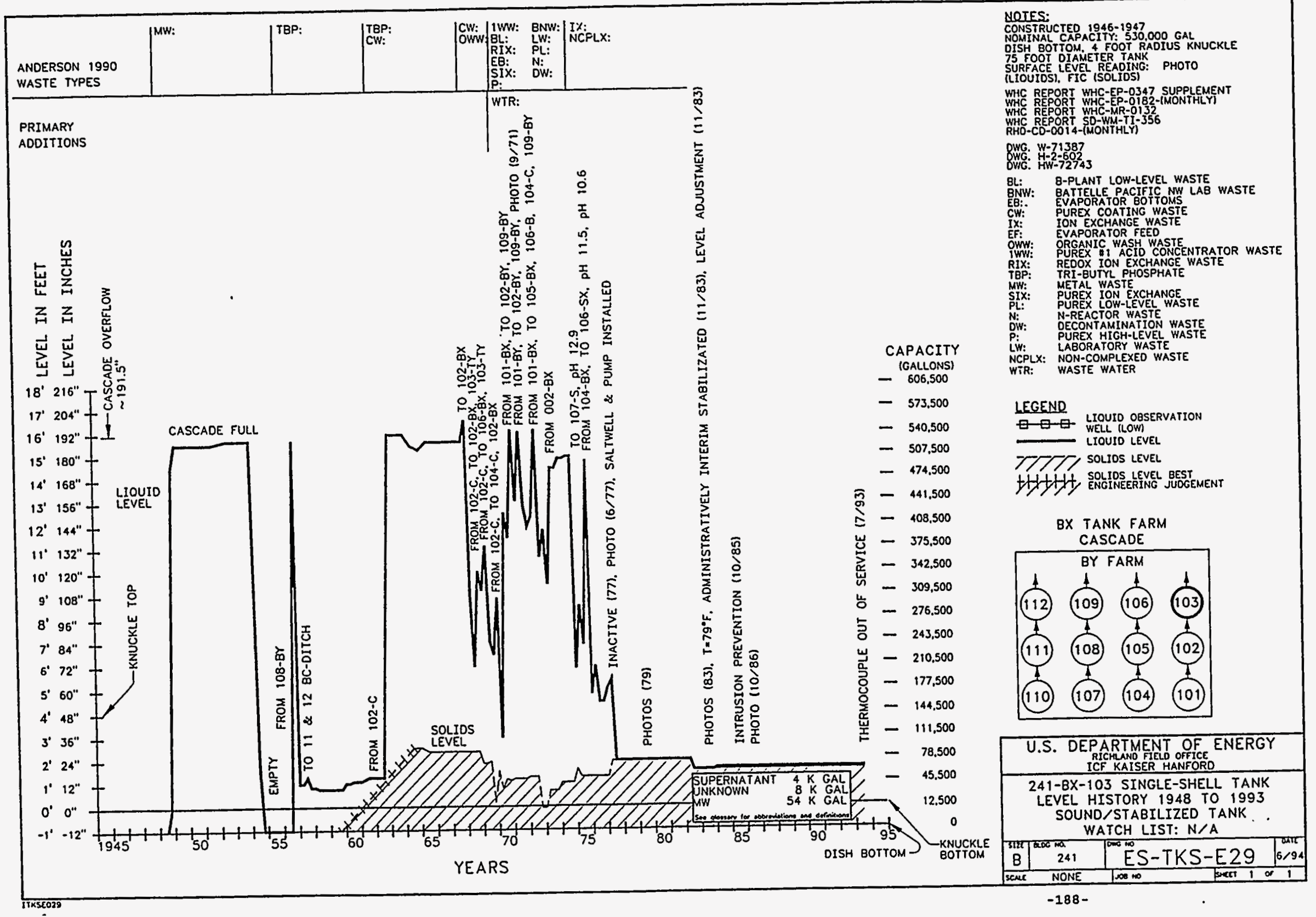




\begin{tabular}{|c|c|c|c|}
\hline \multicolumn{4}{|c|}{ Single-Shell Tank 241-BX-103 } \\
\hline \multicolumn{4}{|c|}{ Solids Composite Inventory Estimate } \\
\hline 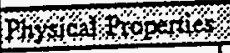 & \%/\% \% & কা: & \\
\hline Total Solid Waste & \multicolumn{3}{|c|}{$3.93 \mathrm{E}+05 \mathrm{~kg}(62 \mathrm{kgal})$} \\
\hline Eeat load & \multicolumn{3}{|c|}{$0.45 \mathrm{~kW}(1.53 \mathrm{E}+03 \mathrm{BTU} / \mathrm{hr})$} \\
\hline Bulk Density & \multicolumn{3}{|c|}{$1.67(g / \infty)$} \\
\hline Void fraction & \multicolumn{3}{|c|}{0.26} \\
\hline \begin{tabular}{|l|} 
Water wt\% \\
\end{tabular} & \multicolumn{3}{|c|}{48.49} \\
\hline TOC wr\% C (wet) & \multicolumn{3}{|c|}{0.00} \\
\hline \multicolumn{4}{|c|}{ 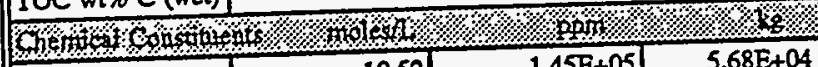 } \\
\hline $\mathrm{Na}^{+1}$ & 10.52 & $1.45 \mathrm{E}+05$ & $5.68 \mathrm{E}+04$ \\
\hline $\mathrm{Al}^{1^{3}}$ & 0.75 & $1.20 \mathrm{E}+04$ & $4.73 \mathrm{E}+03$ \\
\hline $\mathrm{Fe}^{43}$ (total $\left.\mathrm{Fe}\right)$ & 0 & 0 & 0 \\
\hline $\mathrm{Cr}^{+3 .}$ & 0 & 0 0 : : & 0 \\
\hline $\mathrm{Bi}^{+3}$ & of & of & 0 \\
\hline $2 a^{35}$ & of & 0 & 0 \\
\hline $\mathrm{Ce}^{43}$ & of & of & 0 \\
\hline $\mathrm{Zx}$ (as $\left.\mathrm{ZrO}(\mathrm{OH})_{2}\right)$ & of & 요 & 0 \\
\hline $\mathrm{Pb}^{+2}$ & 0 & 0) & 0 \\
\hline $\mathrm{Ni}^{+2}$ & 0 & 0 & 0 \\
\hline $\mathrm{Sr}^{+2}$ & 0 & 의 & 0 \\
\hline $\mathrm{Mn}^{-1}$ & of & 0 & 0 \\
\hline $\mathrm{Ca}^{* 2}$ & of & of & 0 \\
\hline $\mathrm{K}^{+1}$ & 0 & 0 & 0 \\
\hline $\mathrm{OH}^{-1}$ & 4.92 & $5.00 \mathrm{E}+04$ & $1.96 E+04$ \\
\hline $\mathrm{NO}^{-1}$ & 6.88E-02 & $2.55 \mathrm{E}+03$ & $1.00 \mathrm{E}+03$ \\
\hline $\mathrm{NO}^{-1}$ & $2.38 \mathrm{E}-02$ & $6.55 \mathrm{E}+02$ & $2.57 \mathrm{E}+02$ \\
\hline$\overline{\mathrm{CO}^{-2}}$ & 2.05 & $7.35 \mathrm{E}+04$ & $2.89 \mathrm{E}+04$ \\
\hline PO4 & 2.50 & $1.42 E+05$ & $5.58 \mathrm{E} \div 04$ \\
\hline $\mathrm{SO}^{4-2}$ & 3.73E-02 & $2.14 \mathrm{E}+03$ & $8.41 E+02$ \\
\hline $\mathrm{Si}\left(\right.$ as $\left.\mathrm{SiO}_{3}{ }^{-2}\right)$ & 0 & 0 & 0 \\
\hline$F^{-1}$ & 0 & 0 & 0 \\
\hline $\mathrm{C}^{-1}$ & 0 & 0 & 0 \\
\hline $\mathrm{C}_{6} \mathrm{H}_{3} \mathrm{O}_{2}{ }^{3}$ & of & 요 & 0 \\
\hline EDTA $^{-1}$ & 0 & 0 & 0 \\
\hline HEDTA ${ }^{.3}$ & 이 & 0 & 0 \\
\hline $\mathrm{NTA}^{-3}$ & 0 & 0 & 0 \\
\hline Blycolare & 0 & 0 & 0 \\
\hline acetate ${ }^{-3}$ & 0 & of & 0 \\
\hline oxalate $e^{-2}$ & of & 0 & 0 \\
\hline DBP & of & 0 & 0 \\
\hline NPH & of & of & 0 \\
\hline $\mathrm{CCl}_{4}$ & of & of & 0 \\
\hline hexone & of & & of \\
\hline $\mathrm{Fe}(\mathrm{CN})_{6}{ }^{-1}$ & 0 & $0(\mathrm{~g}-\mathrm{mol})$ & \\
\hline \multirow{2}{*}{\multicolumn{4}{|c|}{ 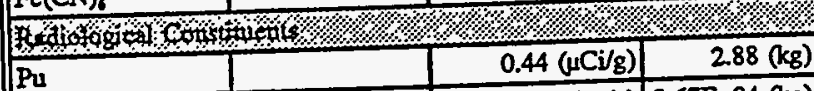 }} \\
\hline & & & \\
\hline $\mathrm{U}$ & $0.66(\mathrm{M})$ & $9.33 \mathrm{E}+04(\mu \mathrm{g} / \mathrm{g})$ & 8) $3.67 \mathrm{E}+04(\mathrm{~kg})$ \\
\hline$C_{s}$ & 2.73E-03 (CiL) & $1.63(\mu \mathrm{Ci} / \mathrm{g})$ & 3) $6.41 \mathrm{E}+02(\mathrm{Ci})$ \\
\hline Sr & 0.28 (Cin) & $1.69 \mathrm{E}+02(\mu \mathrm{C} / \mathrm{g})$ & 2) $6.63 \mathrm{E}+04$ (Ci) \\
\hline
\end{tabular}

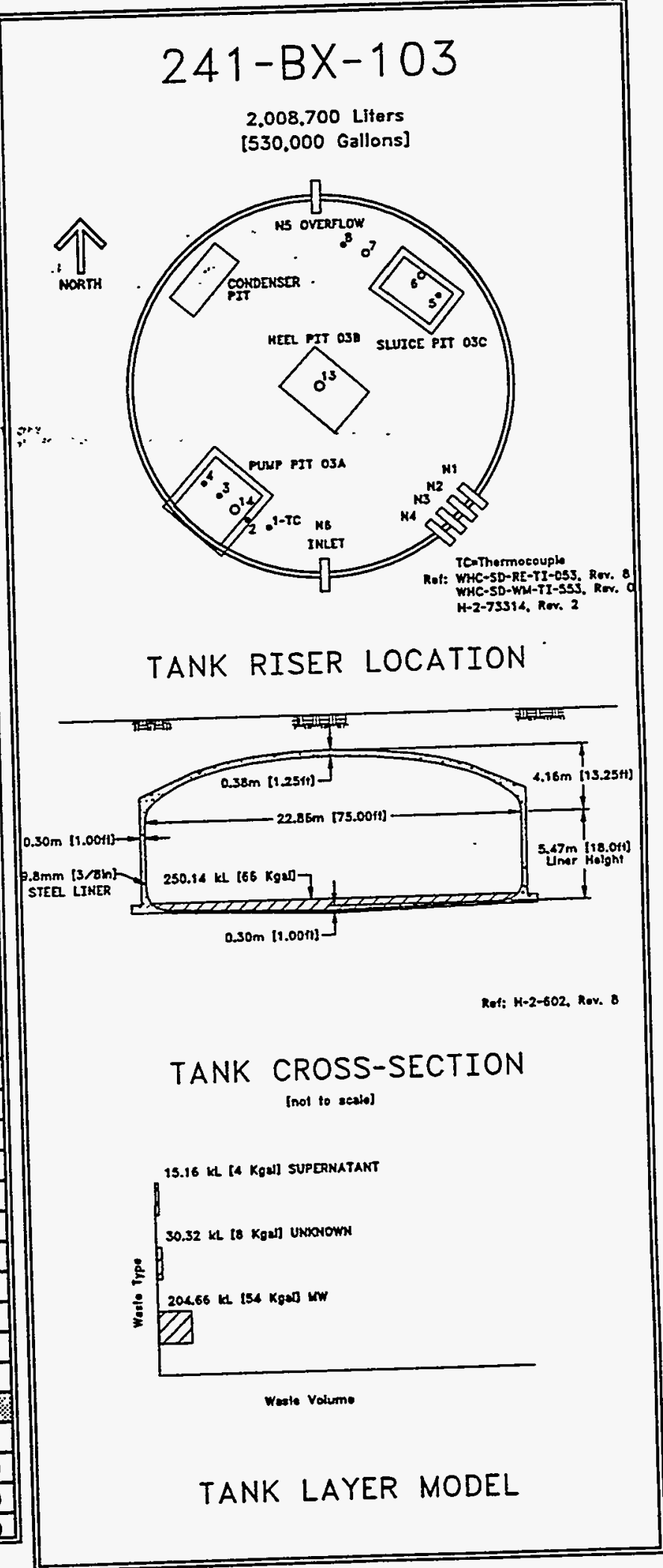


WHC-SD-WM-ER-349 Rev. 0

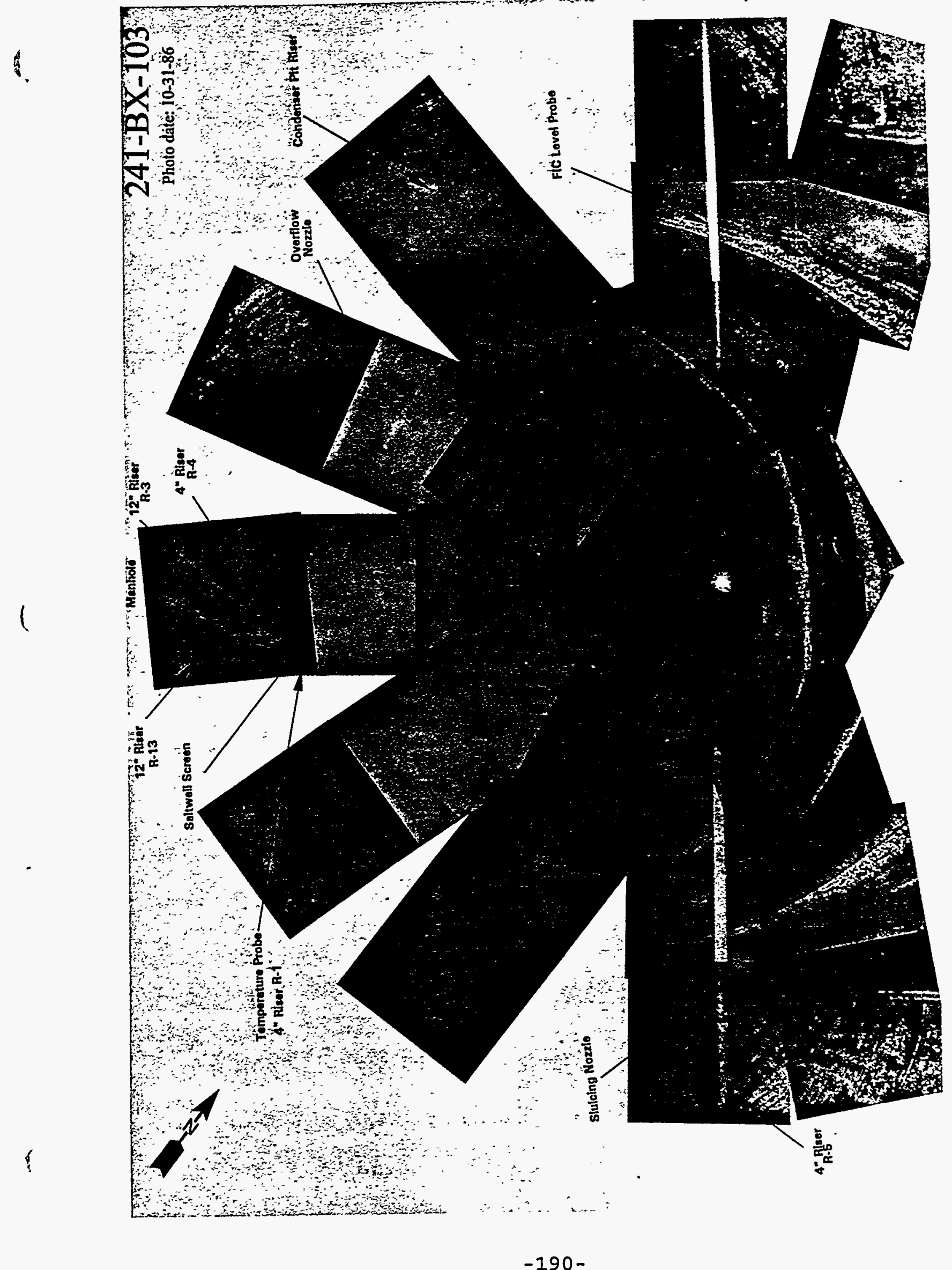


5.4.1 241-BX-104 Tank History

5.4.1.1 Waste History Tank 241-BX-104

The tank was filled with metal waste from January 1949 to April 1949. Level adjustments were performed on Tank 241-BX-104 in November 1980 and April 1982: Supernatant pumping was completed, interim stabilization was achieved, and a level adjustment was performed in September 1989. (See sketch ES-TKS-E30 for a graphical representation of the Tank 241-BX-104 level history.)

\subsection{1:2 Temperature History $24: 1-B X_{-1}-10.4: 19=$}

The single thermocouple tree in Tank $241-B X-104$ has 14 probes. The mean temperature of the first recorded data was $28^{\circ} \mathrm{F}$. A sum of the squares regression line fit shows a slight increase in temperature with a very large amount of variability. The median temperature is $77^{\circ} \mathrm{F}$ with a minimum of $41^{\circ} \mathrm{F}$ and a maximum of $124^{\circ} \mathrm{F}$. Refer to the supporting document for a more thorough review of the temperature data (Brevick 1994).

\subsubsection{Integrity of Tank 241-BX-104}

Tank 241-BX-104 is categorized as sound and is interim stabilized with intrusion prevention completed. The Tank 241-BX-104 surface level is monitored with a Food Instrument Corporation gauge through riser 8 . A figure that graphically represents surface level measurements from January 1991 to the present can be found in the supporting documents (Brevick 1994). The surface level has remained steady because no data were available for 1992 and the readings range between 31.6 and 32 in. Two erratic data points that appear on the plot are attributed to a mechanical malfunction in the automatic operation of the Food Instrument Corporation gauge.

Six drywells are identified for tank 241-BX-104, none of which are considered active.

\subsubsection{Current Status of Tank 241-BX-104}

Tank 241-BX-104 entered service in 1949 and currently stores 99,000 gal of waste. The waste is comprised of 3,000 gal of supernatant; 55,000 gal of unkrown waste; 41,000 gal of sludge; no saltcake, with 27,000 gal of pumpable liquid remaining. The tank is identified as a low-heat load tank, is passively ventilated, and is categorized as sound with interim stabilization and intrusion prevention completed. Tank 241-BX-104 is equipped to cascade to Tank 241-BX-105 and is first in the three-tank cascade series. The following plan view and tank cross section depict the approximate waste level and riser configuration. Tank 241-BX-104 has 10 risers and 12-in. riser no.7 is available for use. 
5.4.2.1 Inventory estimate 241-BX-104

The following tank layer volume approximation was derived from the Los Alamos National Laboratories Waste Status and Transaction Record Summary (Agnew 1994). The estimated inventory of Tank 241-BX-104 is also presented.

\subsubsection{In-Tank Photograph 241-BX-104}

The Tank 241-BX-104 photo shows a pock-marked glossy black sludge surface with small pools of liquid at the bases of the turbine pump and Food Instrument Corporation gauge. A submersible pump and a temperature probe can be seen in the upper left corner of the picture. Level

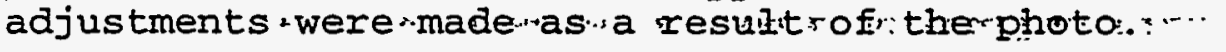

5.4.3 Synopsis Tank 241-BX-104

(To be completed.) 


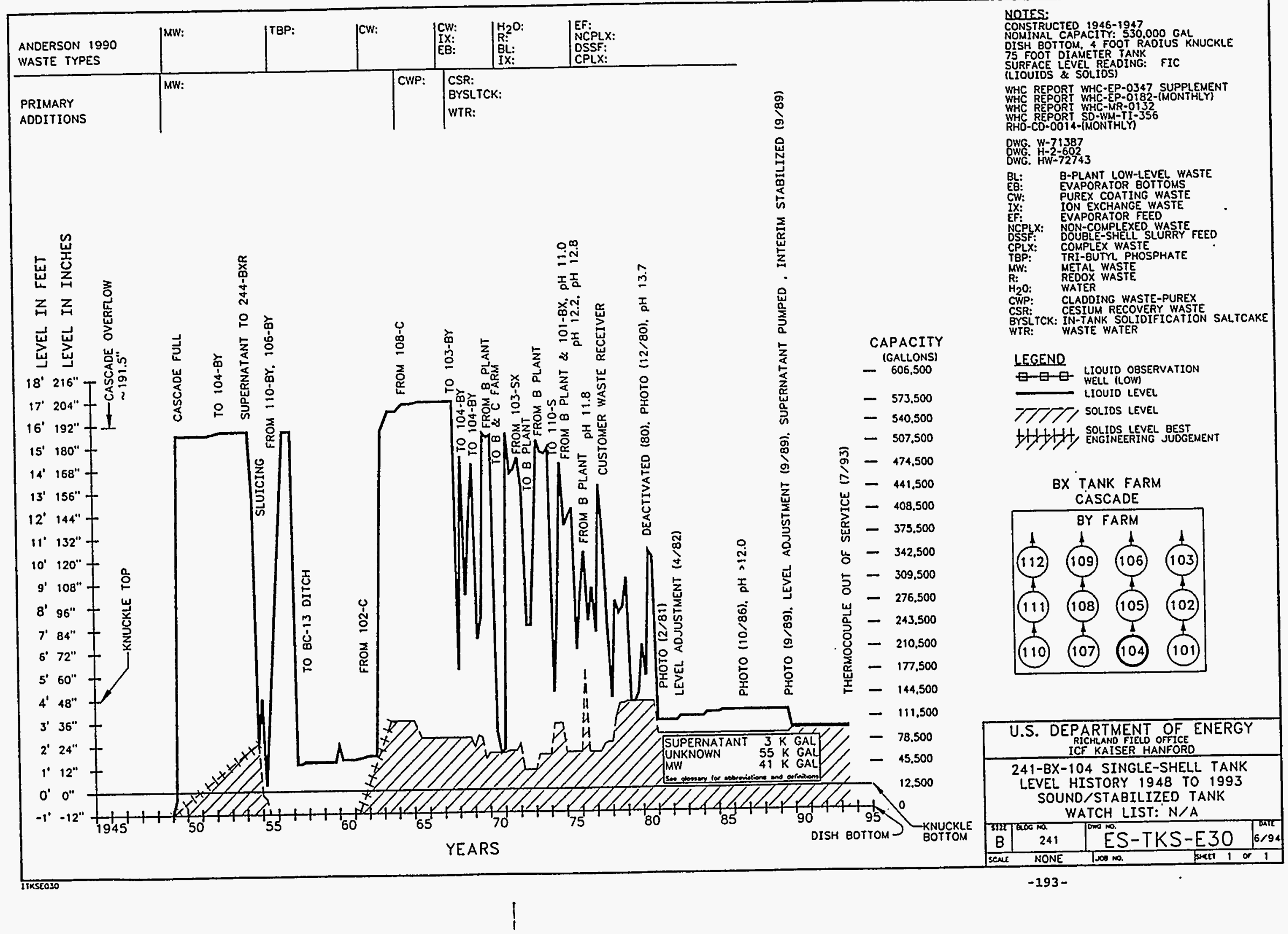




\begin{tabular}{|c|c|c|c|}
\hline \multicolumn{4}{|c|}{ Single-Shell Tank 241-BX-104 } \\
\hline \multicolumn{4}{|c|}{ Solids Composite Inventory Estimate } \\
\hline \multicolumn{4}{|c|}{ 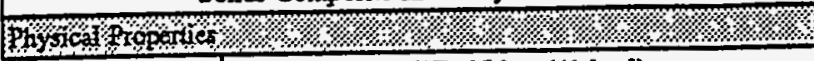 } \\
\hline Total Solid Waste & \multicolumn{3}{|c|}{$2.63 \mathrm{E}+05 \mathrm{~kg}(41 \mathrm{kgal})$} \\
\hline Heat load & \multicolumn{3}{|c|}{$0.34 \mathrm{~kW}(1.17 \mathrm{E}+03 \mathrm{BTU} / \mathrm{hr})$} \\
\hline Bulk Density & \multicolumn{3}{|c|}{$1.70(g / \infty)$} \\
\hline Void Fraction & \multicolumn{3}{|c|}{0.20} \\
\hline Water ing & \multicolumn{3}{|c|}{47.24} \\
\hline TOC wr\% C (wet) & \multicolumn{3}{|c|}{0.00} \\
\hline \multicolumn{4}{|c|}{ 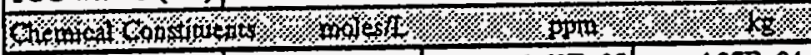 } \\
\hline \begin{tabular}{|l|l|}
$\mathrm{Na}^{+1}$ & \\
\end{tabular} & 11.98 & $1.62 \mathrm{E}+05$ & $4.27 E+04$ \\
\hline $\mathrm{Al}^{+3}$ & 0 & 0 & 0 \\
\hline $\mathrm{Fe}^{43}(\mathrm{total} \mathrm{Fe})$ & 0 & 0 & 0 \\
\hline$C^{43}, \ldots \ldots \ldots$ & $\because \cdots \cdots \cdots$ & :" & $\because \cdots$ \\
\hline $\mathrm{Bi}^{+3}$ & 0 & 0 & 0 \\
\hline $\mathrm{La}^{43}$ & 0] & 0 & 0 \\
\hline $\mathrm{Ce}^{+3}$ & of & 요 & 0 \\
\hline $2 x\left(\operatorname{asc} 20(\mathrm{OH})_{2}\right)$ & 0] & of & 0 \\
\hline $\mathrm{Pb}^{+2}$ & 0 & 0 & 0 \\
\hline $\mathrm{Ni}^{* 2}$ & 0 & 0 & 0 \\
\hline $\mathrm{Sr}^{\mathbf{2}}$ & of & of & 0 \\
\hline $\mathrm{Mn}^{+4}$ & 요 & of & 0 \\
\hline $\mathrm{Ca}^{42}$ & of & 요 & 0 \\
\hline $\mathrm{K}^{4 l}$ & 0 & of & 0 \\
\hline $\mathrm{OH}^{2}$ & 3.06 & $3.07 \mathrm{E}+04$ & $8.07 E+03$ \\
\hline $\mathrm{NO}^{-2}$ & $2.04 \mathrm{E}-02$ & $7.46 \mathrm{E}+02$ & $1.96 \mathrm{E}+02$ \\
\hline $\mathrm{NO}^{-1}$ & 0 & o & 0 \\
\hline $\mathrm{CO}^{-2}$ & 2.35 & $8.33 E+04$ & $2.19 E+04$ \\
\hline $\mathrm{PO}^{-3}$ & 2.87 & $1.61 \mathrm{E}+05$ & $4.24 \mathrm{E}+04$ \\
\hline $\mathrm{SO}^{-2}$ & $4.28 \mathrm{E}-02$ & $2.43 E+03$ & $6.38 \mathrm{E}+02$ \\
\hline $\mathrm{Si}\left(\right.$ as $\left.\mathrm{SiO}_{3}{ }^{-2}\right)$ & 0 & o & 0 \\
\hline $\mathrm{F}^{-1}$ & 0 & of & 0 \\
\hline $\mathrm{Cl}^{-1}$ & of & 0 & 0 \\
\hline $\mathrm{C}_{6} \mathrm{H}_{3} \mathrm{O}_{7}^{-3}$ & of & of & 0 \\
\hline EDTA $^{-4}$ & 요 & 0 & 0 \\
\hline HEDTA $^{-3}$ & 0 & of & 0 \\
\hline NTA $^{.3}$ & of & of & 0 \\
\hline glycolate & of & of & 0 \\
\hline acetate $^{-1}$ & of & 0 & 0 \\
\hline oxalase & o & 0 & 0 \\
\hline DBP & 요 & of & 0 \\
\hline NPH & of & of & 0 \\
\hline $\mathrm{CCl}_{4}$ & 0 & 아 & 0 \\
\hline hexone & of & of & 0 \\
\hline $\mathrm{Fe}(\mathrm{CN})_{6}^{4}$ & of & $0(\mathrm{~g}-\mathrm{mol})$ & \\
\hline \multicolumn{4}{|c|}{ 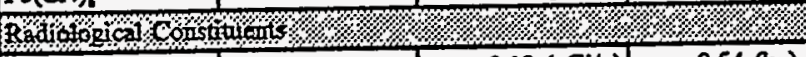 } \\
\hline $\mathrm{Pu}$ & & $0.12(\mu \mathrm{Ci} / \mathrm{g})$ & $0.54(\mathrm{~kg})$ \\
\hline $\mathrm{U}$ & $0.75(\mathrm{M})$ & $1.06 \mathrm{E}+05(\mu \mathrm{g} / \mathrm{g})$ & $2.78 \mathrm{E}+04(\mathrm{~kg})$ \\
\hline Cs & $3.13 \mathrm{E}-03(\mathrm{Ci} / \mathrm{L})$ & $1.85(\mu \mathrm{Ci} / g)$ & $4.86 \mathrm{E}+02(\mathrm{Ci})$ \\
\hline Sr & $0.32(\mathrm{cj} / \mathrm{L})$ & $1.91 \mathrm{E}+02(\mathrm{\mu Ci} / \mathrm{g})$ & $5.03 \mathrm{E}+04(\mathrm{Ci})$ \\
\hline
\end{tabular}

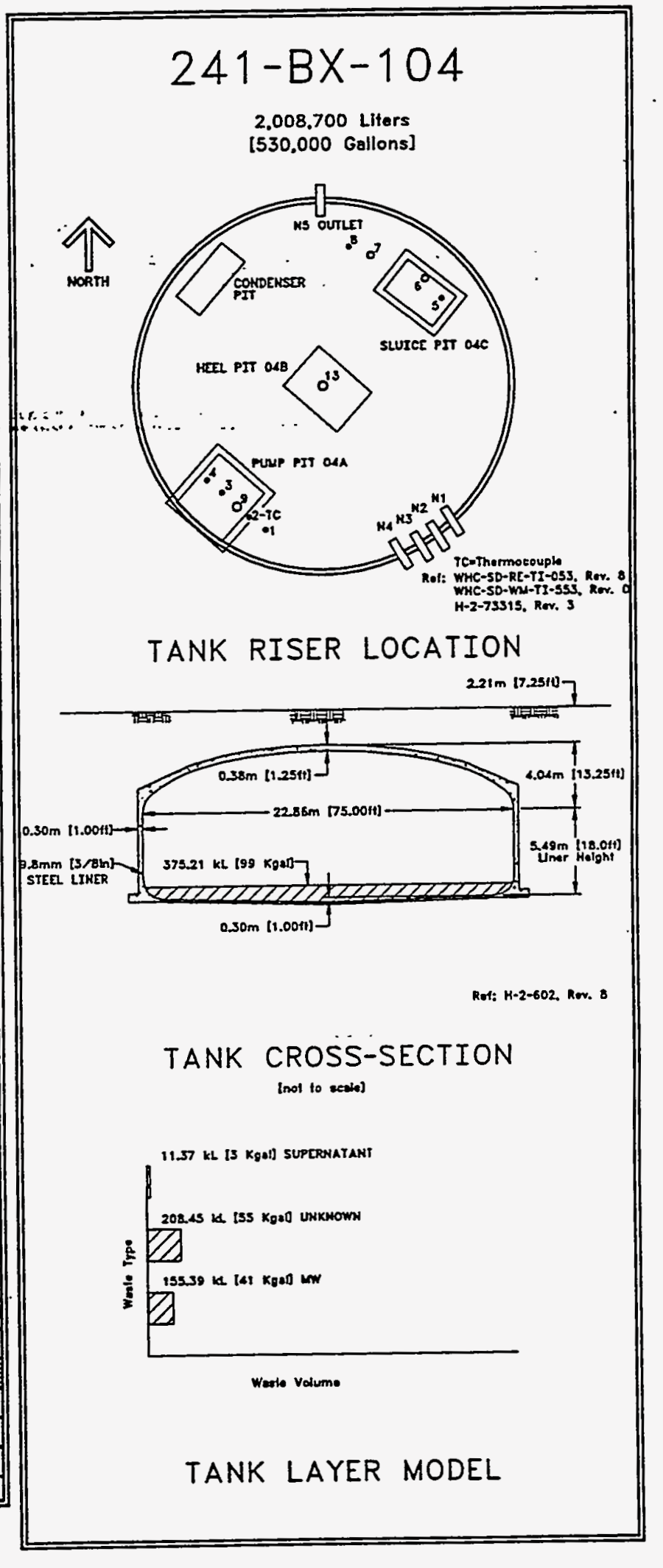


WHC-SD-WM-ER-349 Rev. 0

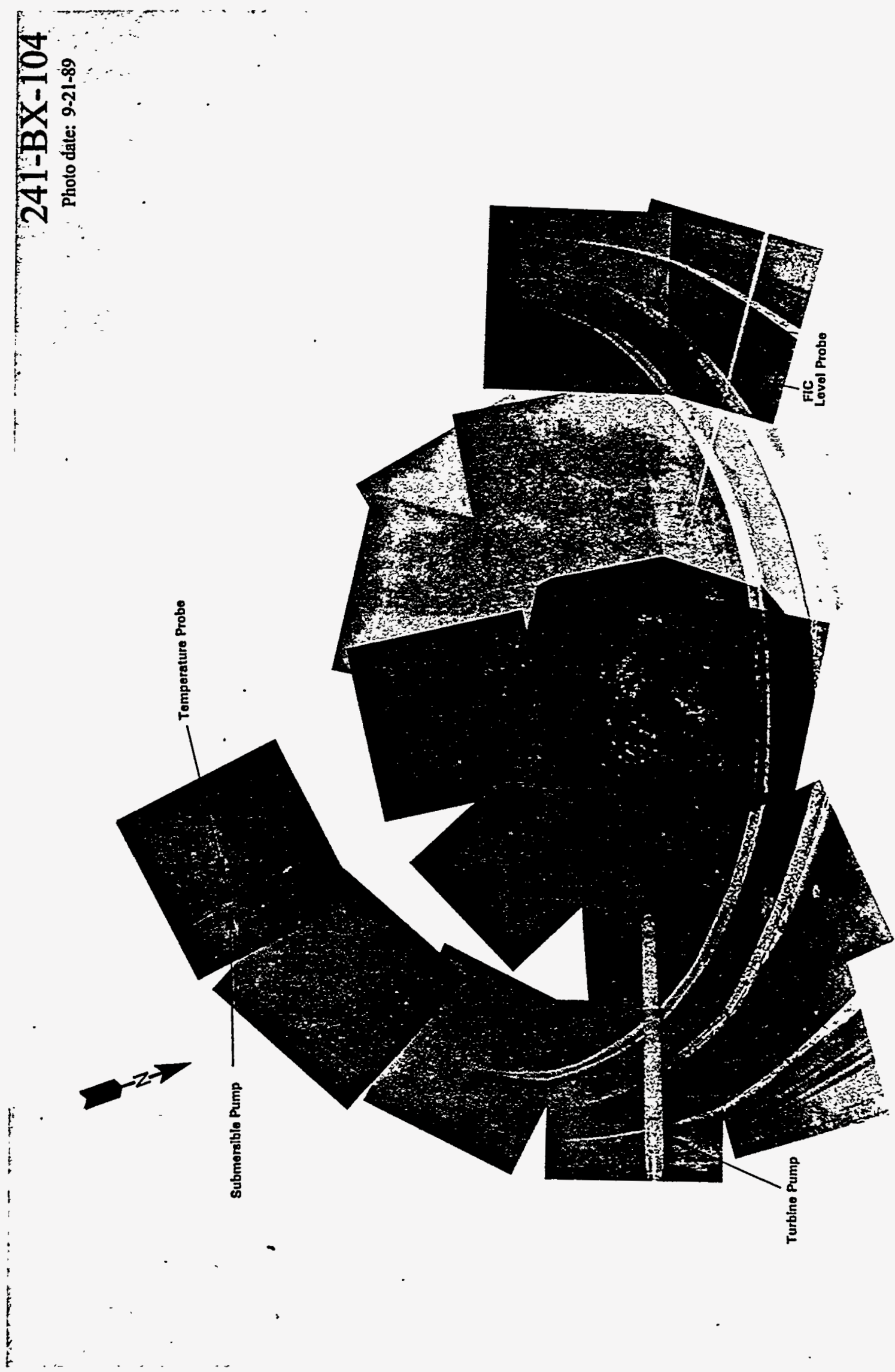


5.5 Tank 241-BX-105

\subsubsection{1-BX-105 Tank History}

\subsubsection{Waste History Tank 241-BX-105}

The tank was filled with metal waste from April 1949 to september 1949. The tank was saltwell pumped in. 1977. . A supernatant pump was used in the third quarter of 1979 and a level adjustment was made in June 1980. The tank was inactive in 1980. Interim stabilization was completed after supernatant pumping in March 1981. Intrusion prevention was completed in September 1986 and the remaining supernatant was pumped to a lower level. Due to past inconsistencies in calculations, a level adjustment...was made in 1990... (See sketch ES-TKS-E31. for a graphical representation of the "Tank $241-B X-105-1$ eve

\subsubsection{Temperature History 241-BX-105}

The single thermocouple tree in Tank 241-BX-105 contains 14 probes to measure the in-tank temperatures. The mean temperature of the first recorded data for thermocouples 1 through 12 was $46.5^{\circ} \mathrm{F}$. A sum of the squares regression line fit for thermocouples shows no overall temperature change and a large amount of variability. The median temperature is $70^{\circ} \mathrm{F}$ with a minimum of $37^{\circ} \mathrm{F}$ and a maximum of $120.2^{\circ} \mathrm{F}$. Refer to the supporting document for a more thorough review of the temperature data (Brevick 1994).

\subsubsection{Integrity of Tank 241-BX-105}

Tank 241-BX-105 is categorized as sound and is interim stabilized with intrusion prevention completed. The surface level in Tank 241-BX-105 is monitored with a Food Instrument Corporation gauge through riser 1. For more information on surface level see supporting documents (Brevick 1994).

Six drywells are identified for tank 241-BX-105, none of which-are considered active.

\subsubsection{Current Status of Tank 241-BX-105}

Tank 241-BX-105 entered service in 1949 and currently stores 51,000 gal of waste. The waste is comprised of 5,000 gal of supernatant; 46,000 gal of unknown waste; with 4,000 gal of pumpable liquid remaining. The tank is categorized as sound with interim stabilization and intrusion prevention completed. The tank is a low-heat load tank and is passively ventilated. Tank $241-\mathrm{BX}-105$ is equipped to cascade to Tank 241-BX-106 and is second in the three-tank cascade series. The following plan view and tank cross section depict the approximate waste level and riser configuration. Tank 241-BX-105 has 10 risers and 12-in. riser no.2 is available for use. 


\subsubsection{Inventory estimate 241-BX-105}

The following tank layer volume approximation was derived from the Ios Alamos National Iaboratories Waste Status and Transaction Record Summary (Agnew 1994). The estimated inventory of Tank 241-BX-105 is also presented.

\subsubsection{In-Tank Photograph 241-BX-105}

The Tank 241-BX-105 photo shows an exposed area of very dark pockmarked sludge with a shallow liquid that covers most of the surface. The only visible apparatus are a flex and float pump, a submersible pump, a Food Instrument Corporation gauge, and some debris. The photo is not.a.clear representation of .the tank due..to. poor photo quality.

5.5.3 Synopsis Tank 241-BX-105

(To be completed.) 
$-86 \tau-$

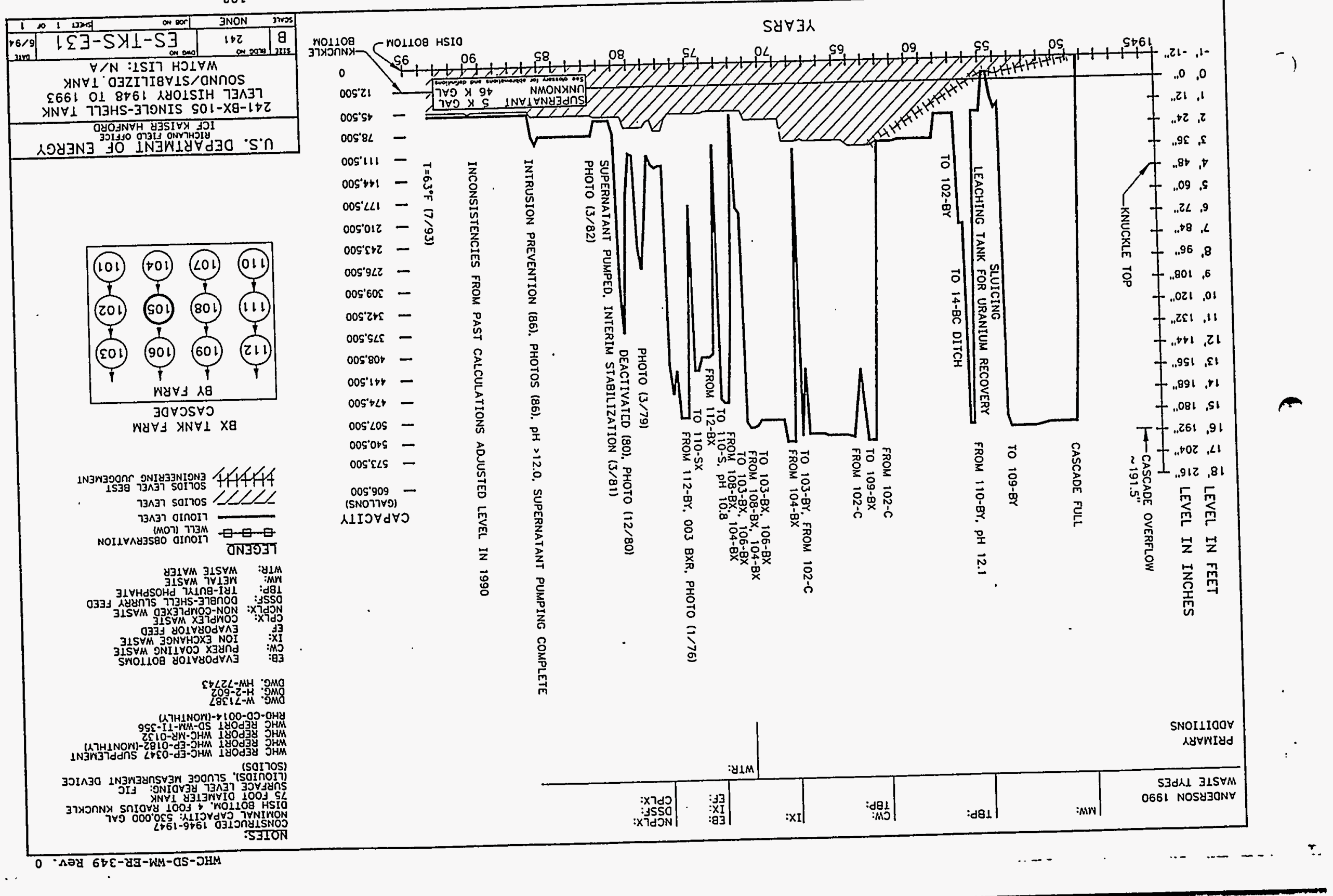


WHC-SD-WM-ER-349， Rev. 0

\begin{tabular}{|c|c|c|c|}
\hline \multicolumn{4}{|c|}{ Single-Shell Tank 241-BX-105 } \\
\hline \multicolumn{4}{|c|}{ Solids Composite Inventory Estimate } \\
\hline \multicolumn{4}{|c|}{ 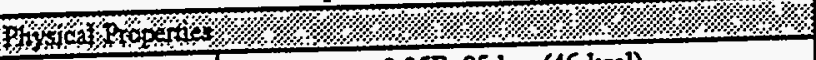 } \\
\hline Total Solid Waste & \multicolumn{3}{|c|}{$2.95 \mathrm{E}+05 \mathrm{~kg}(46 \mathrm{kgal})$} \\
\hline Hear load & \multicolumn{3}{|c|}{$0.38 \mathrm{~kW}(1.31 \mathrm{E}+03 \mathrm{BTU} / \mathrm{hr})$} \\
\hline Bulk Density & \multicolumn{3}{|c|}{$1.70(g / c)$} \\
\hline Void Fraction & \multicolumn{3}{|c|}{0.20} \\
\hline Water wt\% & \multicolumn{3}{|c|}{47.24} \\
\hline TOC wr\% C (wet) & \multicolumn{3}{|c|}{0.00} \\
\hline \multicolumn{4}{|c|}{ 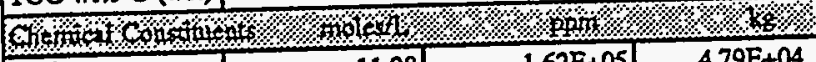 } \\
\hline \begin{tabular}{|l|l|}
$\mathrm{Na}^{+1}$ & \\
\end{tabular} & 11.98 & $1.62 \mathrm{E}+05$ & $4.79 \mathrm{E}+04$ \\
\hline $\mathrm{Al}^{+3}$ & o & 0 & 0 \\
\hline $\mathrm{Fe}^{43}(\mathrm{total} \mathrm{Fe})$ & 0 & 0 & 0 \\
\hline $\mathrm{Cr}^{+3}$ & 0] & 요 & 0 \\
\hline $\mathrm{Bi}^{+3}$ & of & of & 0 \\
\hline $\mathrm{La}^{43}$ & 0 & of & 0 \\
\hline $\mathrm{Ce}^{43}$ & of & 0 & 0 \\
\hline $\mathrm{Zx}$ (as $\left.\mathrm{Z} \mathrm{r} \mathrm{O}(\mathrm{OH})_{2}\right)$ & 0 & 0 & 0 \\
\hline $\mathrm{Pb}^{+2}$ & 0 & 0 & 0 \\
\hline $\mathrm{Ni}^{+2}$ & of & 0) & 0 \\
\hline $\mathrm{Sr}^{+2}$ & 0 & 0 & 0 \\
\hline $\mathrm{Mn}^{+4}$ & of & 이 & 0 \\
\hline $\mathrm{Ca}^{42}$ & of & 0 & 0 \\
\hline $\mathrm{K}^{+1}$ & of & . 0 & 0 \\
\hline $\mathrm{OH}^{-1}$ & 3.06 & $3.07 \mathrm{E}+04$ & $9.05 \mathrm{E}+03$ \\
\hline $\mathrm{NO3}^{-1}$ & 2.04E-02 & $7.46 \mathrm{E}+02$ & $2.20 \mathrm{E}+02$ \\
\hline $\mathrm{NO}^{-1}$ & 0 & of & 0 \\
\hline $\mathrm{CO}^{.2}$ & 2.35 & $8.33 \mathrm{E}+04$ & $2.46+04$ \\
\hline $\mathrm{PO}^{-3}$ & 2.87 & 1.61E+05 & $4.75 \mathrm{E}+04$ \\
\hline $\mathrm{SO}^{22}$ & $4.28 \mathrm{E}-02$ & $2.43 E+03$ & $7.16 E+02$ \\
\hline $\mathrm{Si}\left(\right.$ as $\left.\mathrm{SiO}_{3}{ }^{-2}\right)$ & o & 0 & 0 \\
\hline $\mathrm{F}^{-1}$ & of & 0 & 0 \\
\hline $\mathrm{Cl}^{-1}$ & of & of & 0 \\
\hline $\mathrm{C}_{6} \mathrm{H}_{5} \mathrm{O}_{7}{ }^{-3}$ & of & of & 0 \\
\hline EDTA $^{-4}$ & of & 0 & 0 \\
\hline HEDTA ${ }^{3}$ & 0 & 0 & 0 \\
\hline $\mathrm{NTA}^{-3}$ & of & 0 & 0 \\
\hline glycolate ${ }^{-1}$ & 0 & 0 & 0 \\
\hline acetate ${ }^{-1}$ & 0 & o & 0 \\
\hline oxalate & 의 & of & 0 \\
\hline $\mathrm{DBP}$ & 0 & 0 & 0 \\
\hline $\mathrm{NPH}$ & of & of & 0 \\
\hline $\mathrm{CCl}_{4}$ & 0 & of & 0 \\
\hline hexone & 0 & o & 0 \\
\hline $\mathrm{Fe}(\mathrm{CN})_{6}{ }^{-4}$ & 이 & $0(\mathrm{~g}-\mathrm{mol})$ & \\
\hline \multicolumn{4}{|c|}{ 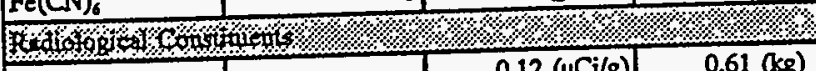 } \\
\hline Pu & & $0.12(\mu \mathrm{Ci} / \mathrm{g})$ & $0.61(\mathrm{~kg})$ \\
\hline $\mathbf{U}$ & $0.75(\mathrm{M})$ & $1.06 \mathrm{E}+05(11 \mathrm{~g} / \mathrm{B})$ & $3.12 \mathrm{E}+04(\mathrm{~kg})$ \\
\hline Cs & 3.13E-03 (CiL) & $1.85(\mu \mathrm{Ci} / \mathrm{g})$ & $5.46 \mathrm{E}+02(\mathrm{Ci})$ \\
\hline$S r$ & $0.32(\mathrm{Ci} / \mathrm{L})$ & $1.91 \mathrm{E}+02(\mu \mathrm{Ci} / \mathrm{g})$ & $5.65 \mathrm{E}+04(\mathrm{Ci})$ \\
\hline
\end{tabular}

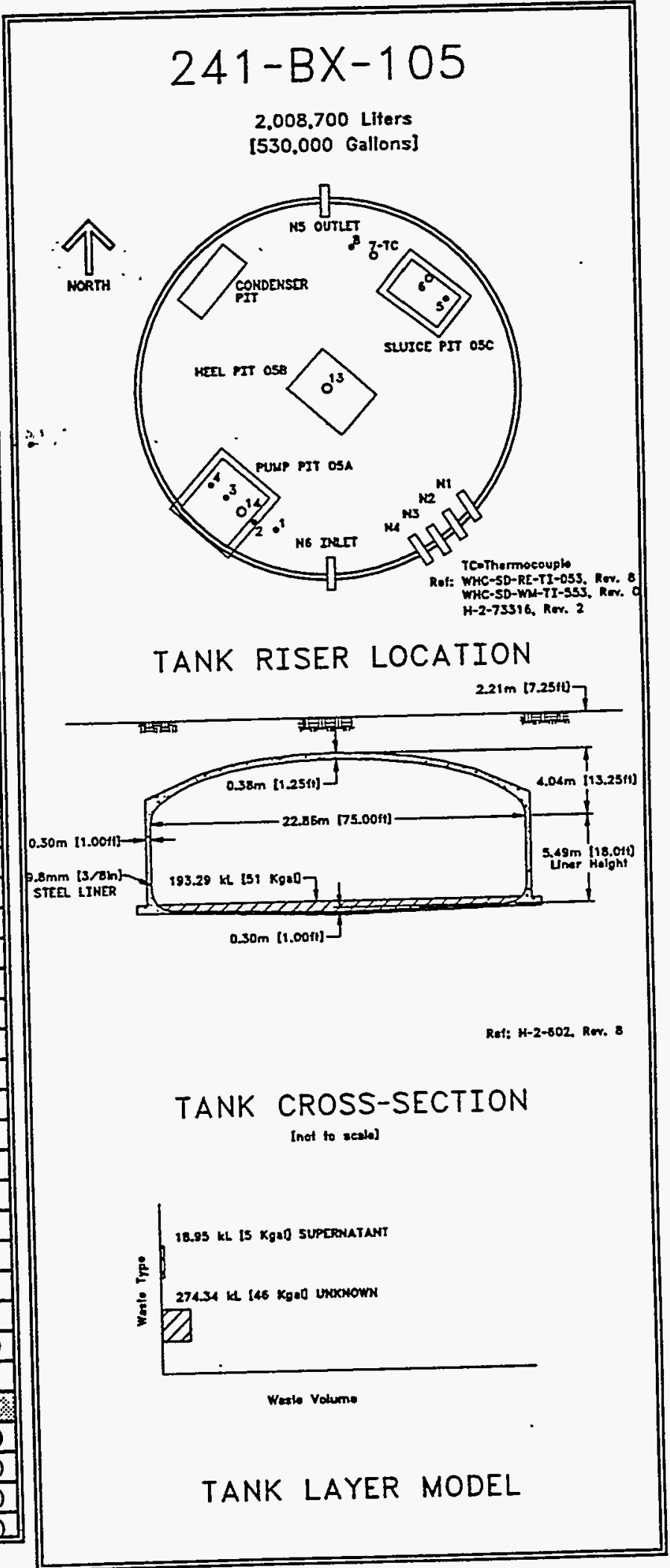

- Composite inventory exchudes supernatant, distomaceous earth, and cemeon

Unknowns in tank inventary are assigned by Tank Layering Model (TLM). 


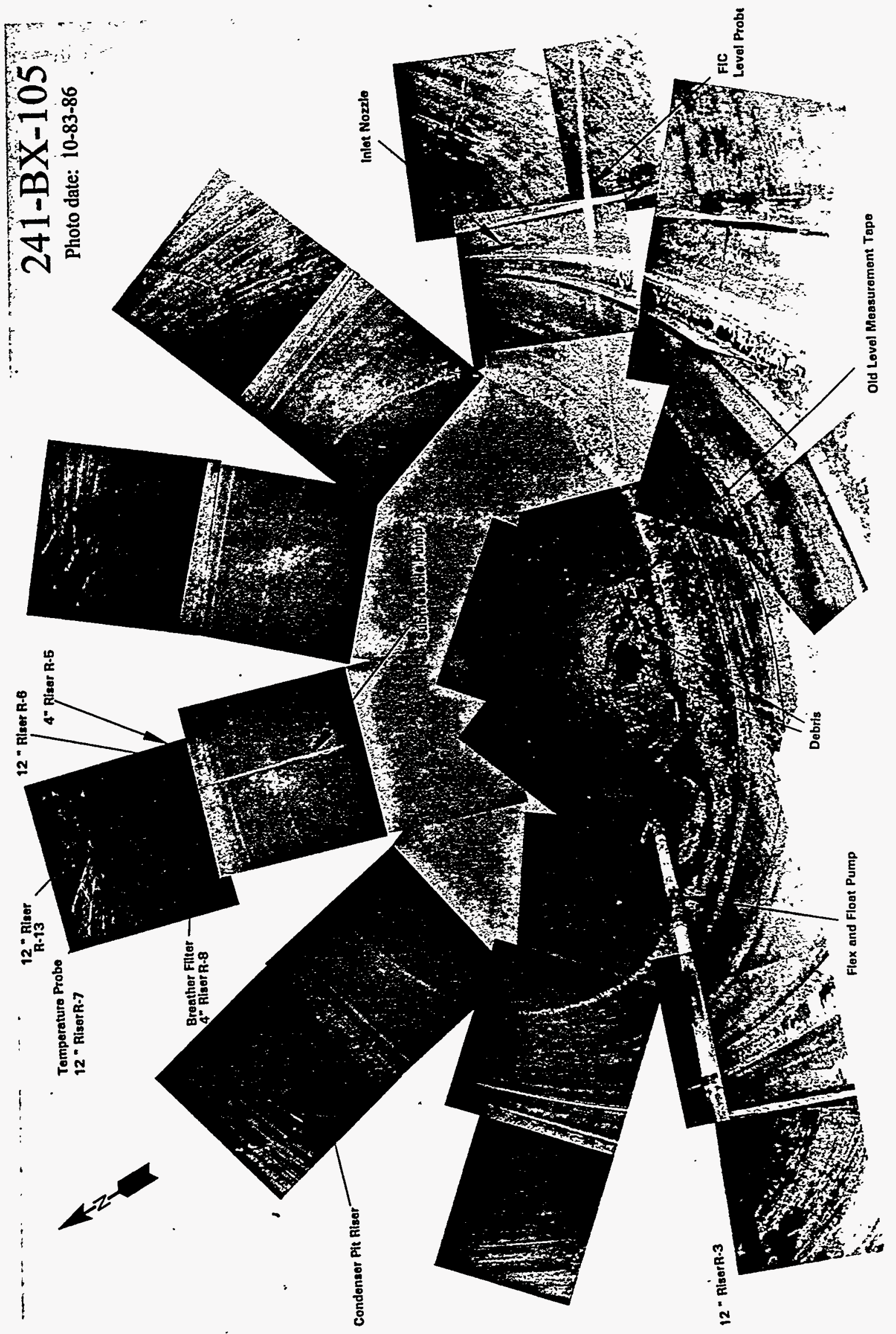


WHC-SD-WM-ER-349, Rev. 0

\subsection{Tank $241-B X-106$}

\subsubsection{1-BX-106 Tank History}

\subsubsection{Waste History Tank 241-BX-106}

Tank 241-BX-106 was filled with metal waste from September 1949 to January 1950. The tank was inactive.in 19.78.: and an open hole saltwell was installed. A: level adjustment was made in April $1982 \ldots$ The tank is sound and is awaiting stabilization and intrusion prevention. (See Sketch ES-TKS-E32 for a graphical representation of the Tank 241-BX-106 level history.)

\subsubsection{Temperature. History $241-B X-106$}

The single thermocouple tree in Tank 241-BX-106 has 14 probes to record temperature data. The mean temperature of the first recorded data for thermocouples 1 through 11 was $43^{\circ} \mathrm{F}$. A sum of the squares regression line fit for the first 12 thermocouples shows a slight temperature decrease with a moderate to large amount of variability. Not enough data points exist for an accurate regression of variability analysis on thermocouples 13 and 14. The tank has experienced an annual temperature undulation that is more evident after October 1989. The median temperature is $66^{\circ} \mathrm{F}$ with a minimum of $46.9^{\circ} \mathrm{F}$ and a maximum of $114.8^{\circ} \mathrm{F}$. Refer to the supporting document for a more thorough review of the temperature data (Brevick 1994).

\subsubsection{Integrity of Tank $241-\mathrm{BX}-106$}

Tank 241-BX-106 is categorized as sound and is partially isolated. The in Tank 241-BX-106 surface level is monitored manually and daily with a Food Instrument Corporation gauge through riser 8 , A figure that graphically represents the surface level measurements from January 1991 to the present can be found in the supporting documents (Brevick 1994). The surface level for the past 3 years has remained steady with the readings ranging between 12.2 and 13 in. Six erratic data points that were superseded with rerun data points are show on the plot.

Four drywells are identified for tank 241-BX-106. Graphical representations of the active drywell can be found in the supporting document (Brevick 1994). The graphs include the peak c/s, the depth at which the peak occurred, and the date of the reading.

\subsubsection{Current status of Tank 241-BX-106}

Tank 241-BX-106 entered service in 1949 and currently stores 46,000 gal of waste. The waste is comprised of 15,000 gal of supernatant; 5,000 gal of unknown waste; 26,000 gal of sludge; and no saltcake with $15,000 \mathrm{gal}$ of pumpable liquid remaining. The tank is identified on the Fexrocyanide watch Iist as of January 1991, is passively ventilated, and is categorized as sound with partial interim isolation completed. Tank 241-BX-106 is third in the three-tank cascade series. Tank 241-BX-106 cascades to $241-\mathrm{BY}-103$. The following plan view and tank cross section 
WHC-SD-WM-ER-349, Rev. 0

depict the approximate waste level and riser configuration. Tank 241BX-106 has 10 risers and 12-in. riser no.2 is available for use.

\subsubsection{Inventory estimate 241-BX-106}

The following tank layer volume approximation was derived from the Ios Alamos National Laboratories Waste Status and Transaction Record Summary (Agnew 1994). The estimated inventory of Tank 241-BX-106 is also presented.

\subsubsection{In-Tank Photograph 241-BX-106}

The Tank 241-BX-106 photo shows a dark liquid surface with a ring of sludge at the perimeter ..: A : clear.representation...of the current tank status is difficult to achieve because of poor photo quality.

5.6 .3 Synopsis Tank 241-BX-106

(To be completed.) 


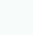
$\therefore \quad$.

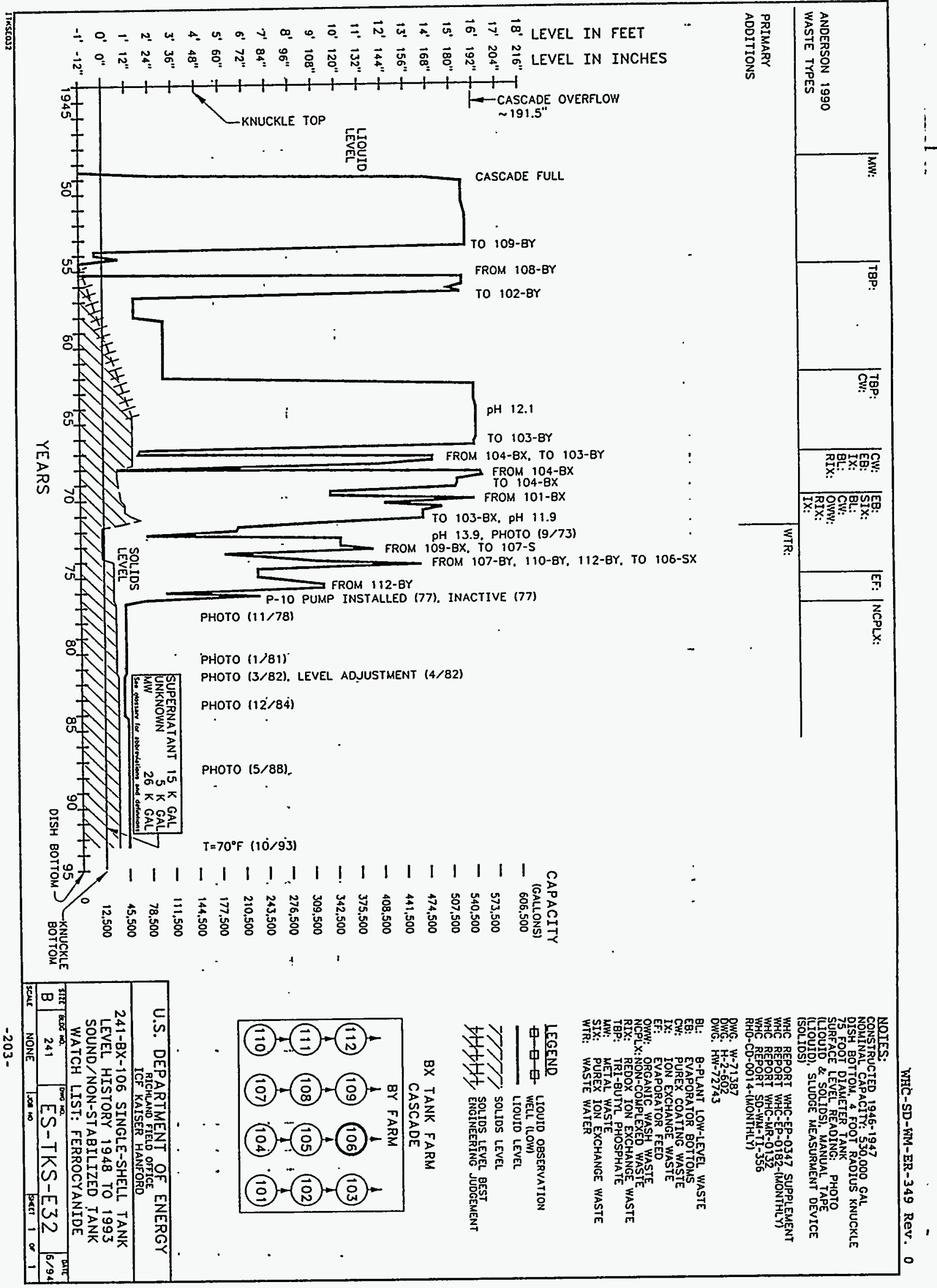


WHC-SD-WM-ER-349, Rev. 0

\begin{tabular}{|c|c|c|c|}
\hline \multicolumn{4}{|c|}{ Single-Shell Tank 241-BX-106 } \\
\hline \multicolumn{4}{|c|}{ Solids Composite Inventory Estimate } \\
\hline \multicolumn{4}{|c|}{ 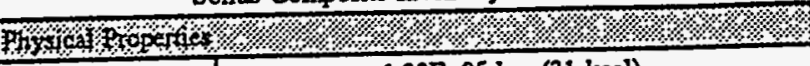 } \\
\hline Total Solid Waste & \multicolumn{3}{|c|}{$1.99 \mathrm{E}+05 \mathrm{~kg}(31 \mathrm{kgal})$} \\
\hline Heat load & \multicolumn{3}{|c|}{$0.26 \mathrm{~kW}(8.81 \mathrm{E}+02 \mathrm{BTU} / \mathrm{hr})$} \\
\hline Bulk Density & \multicolumn{3}{|c|}{$1.70(g / \propto)$} \\
\hline Void Fraction & \multicolumn{3}{|c|}{0.20} \\
\hline Water wh\% & \multicolumn{3}{|c|}{47.24} \\
\hline TOC wt\% C (wet) & \multicolumn{3}{|c|}{$0.00 \quad \cdot}$. \\
\hline \multicolumn{4}{|c|}{ 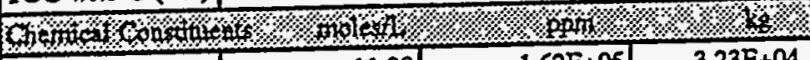 } \\
\hline $\mathrm{Na}^{+1}$ & 11.98 & $1.62 \mathrm{E}+05$ & $3.23 E+04$ \\
\hline $\mathrm{Al}^{+3}$ & 0 & 0 & 0 \\
\hline $\mathrm{Fe}^{43}$ (total Fe) & of & 0 & 0 \\
\hline $\mathrm{Cr}^{+\mathrm{S}^{3}}$ & 0 & $\therefore$ & 0 \\
\hline $\mathrm{Bi}^{45}$ & of & 0 & 0 \\
\hline $\mathrm{La}^{43}$ & of & 0 & 0 \\
\hline $\mathrm{Ce}^{+3}$ & of & 0 & 0 \\
\hline $\mathrm{Zr}\left(\mathrm{as} \mathrm{ZrO}(\mathrm{OH})_{2}\right)$ & 0 & 0 & 0 \\
\hline $\mathrm{Pb}^{+2}$ & 0 & 0 & 0 \\
\hline $\mathrm{Ni}^{+2}$ & of & 0 & 0 \\
\hline $\mathrm{Sr}^{+2}$ & 0 & 0 & 0 \\
\hline $\mathrm{Mn}^{+4}$ & 0 & 0 & 0 \\
\hline $\mathrm{Ca}^{42}$ & 0 & 0 & 0 \\
\hline $\mathrm{K}^{+1}$ & 0 & 0 & 0 \\
\hline $\mathrm{OH}^{\prime \prime}$ & 3.06 & 3.07E+04 & $6.10 \mathrm{E}+03$ \\
\hline $\mathrm{NO3}^{-1}$ & 2.04E-02 & $7.46 \mathrm{E}+02$ & $1.48 \mathrm{E}+02$ \\
\hline $\mathrm{NO}^{-1}$ & o & 0 & 0 \\
\hline $\mathrm{CO}^{-2}$ & 2.35 & $8.33 \mathrm{E}+04$ & $1.66 \mathrm{E}+04$ \\
\hline $\mathrm{PO}^{.3}$ & 2.87 & $1.61 E+05$ & $3.20 \mathrm{E}+04$ \\
\hline $\mathrm{SO}^{-2}$ & $4.28 \mathrm{E}-02$ & $2.43 E+03$ & $4.83 \mathrm{E}+02$ \\
\hline $\mathrm{Si}$ (as $\mathrm{SiO}_{3}^{-2}$ ) & 0 & 0 & 0 \\
\hline$F^{1}$ & 0 & 0 & 0 \\
\hline $\mathrm{Cl}^{\cdot 1}$ & 0 & 0 & 0 \\
\hline $\mathrm{C}_{6} \mathrm{H}_{3} \mathrm{O}_{7}{ }^{3}$ & 0 & 0 & 0 \\
\hline EDTA $^{4}$ & 0 & 0 & 0 \\
\hline HEDTA ${ }^{-3}$ & 0 & 0 & 0 \\
\hline $\mathrm{NTA}^{-3}$ & 0 & 0 & 0 \\
\hline glycolate & 0 & 0 & 0 \\
\hline acetate ${ }^{-1}$ & 0 & 0 & 0 \\
\hline oxalate ${ }^{-2}$ & 0 & 0 & 0 \\
\hline DBP & of & 0 & 0 \\
\hline NPH & of & of & 0 \\
\hline $\mathrm{CO}_{2}$ & 0 & 0 & 0 \\
\hline hexone & of & 0 & 0 \\
\hline $\mathrm{Fe}(\mathrm{CN})_{6}^{-1}$ & 0] & $0(\mathrm{~g}-\mathrm{mol})$ & \\
\hline 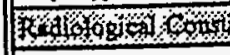 & mo $1 \%$ & \% & \% \\
\hline Pu & & $0.12(\mu \mathrm{Ci} / \mathrm{g})$ & $0.41(\mathrm{~kg})$ \\
\hline $\bar{U}$ & $0.75(\mathrm{M})$ & $1.06 \mathrm{E}+05(\mu \mathrm{g} / \mathrm{g})$ & $2.10 \mathrm{E}+04(\mathrm{~kg})$ \\
\hline Cs & $3.13 \mathrm{E}-03(\mathrm{Ci} / \mathrm{L})$ & $.1 .85(\mu \mathrm{Ci} / \mathrm{g})$ & $3.68 \mathrm{E}+02(\mathrm{Ci})$ \\
\hline $\mathrm{Sr}$ & $0.32(\mathrm{Ci} / \mathrm{L})$ & $1.91 \mathrm{E}+02(\mu \mathrm{Cl} / \mathrm{g})$ & $3.80 \mathrm{E}+04(\mathrm{Ci})$ \\
\hline
\end{tabular}

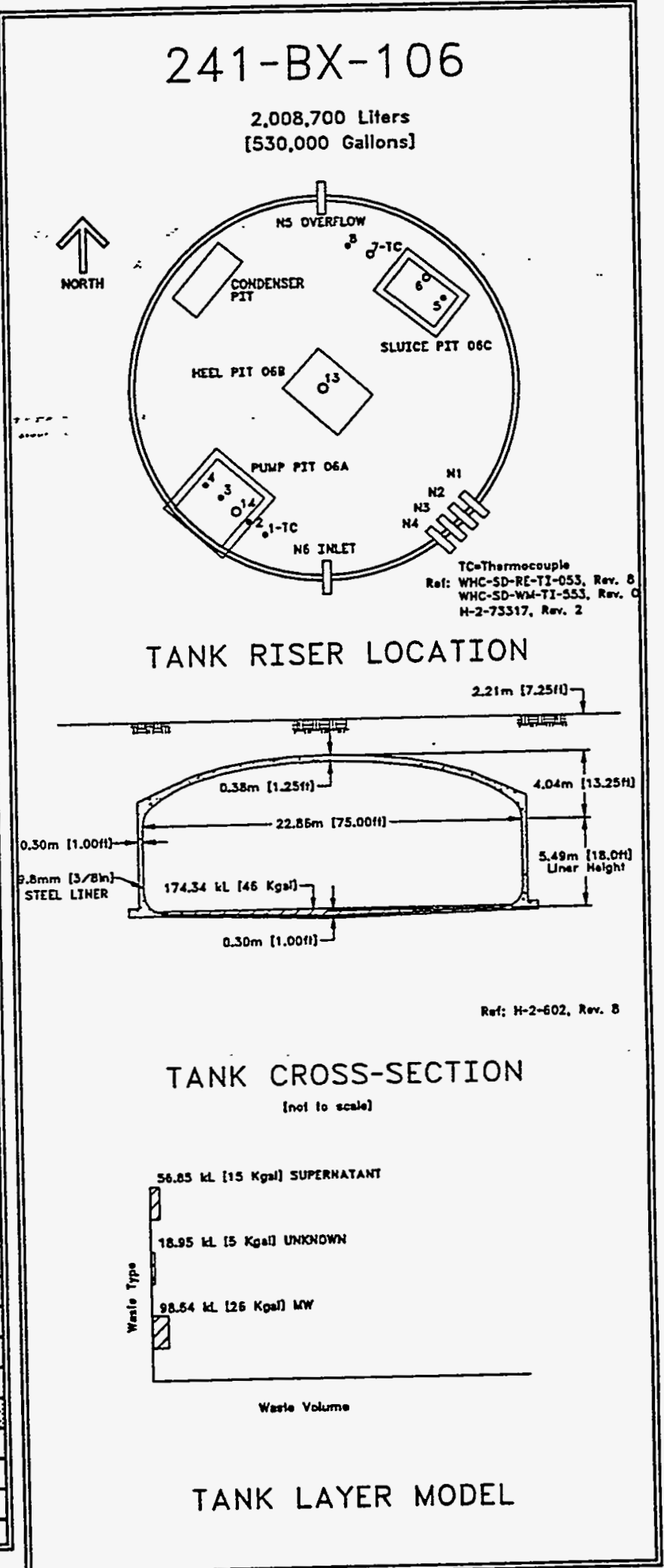

- Composite inventery exchudes cupernatant, jiatomacoous earth, and cemen

Unkowns in trak inventory are assigned by Tank Layering Model (TLM) 


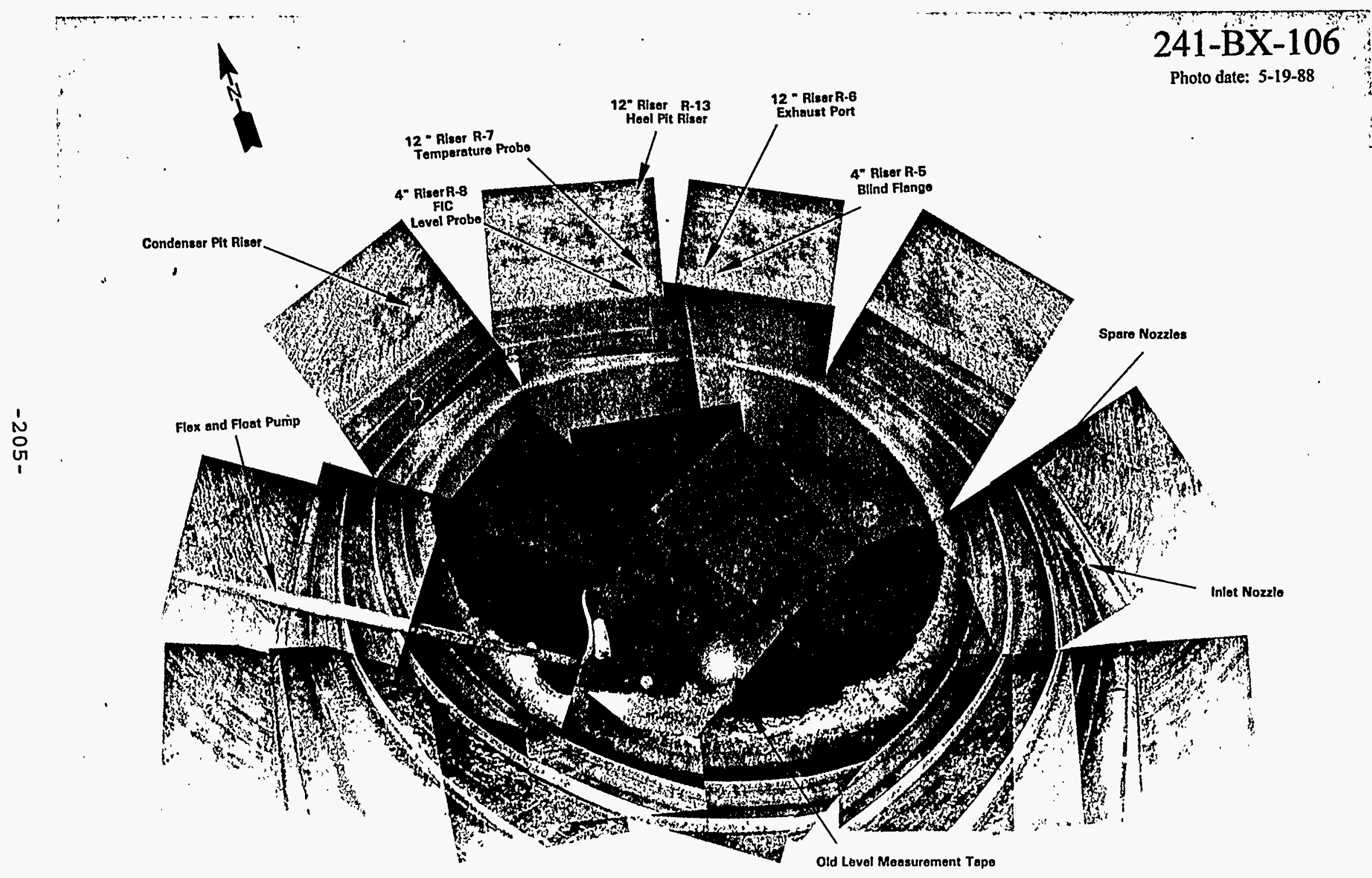




\subsection{Tank 241-BX-107}

\section{7 .1 \\ 241-BX-107 Tank History}

5.7.1.1 Waste History Tank 241-BX-107

Tank 241-BX-107 began to fill in september 1948. The tank was declared inactive in the first. quarter of 1978 . Level adjustments were completed in April 1982 and April 1990. Jet pumping was completed in September 1990 and the tank was considered interim stabilized. (See sketch ES-TKS-E33 for a graphical representation of the Tank 241-BX-107 level history.)

$5,7,1.2$ Temperațure History 241-BX-107

There are 14 thermocouple probes to record temperature data on the single tree in Tank 241-BX-107. The mean temperature of the first daily recorded readings was $64^{\circ} \mathrm{F}$. A sum of the squares regression line fit for the thermocouples shows a slight temperature increase with a moderate amount of variability. The median temperature is $69^{\circ} \mathrm{F}$ with a minimum of $46^{\circ} \mathrm{F}$ and a maximum of $88^{\circ} \mathrm{F}$. Refer to the supporting document for a more thorough review of the temperature data (Brevick 1994).

\subsubsection{Integrity of Tank 241-BX-107}

Tank 241-BX-107 is categorized as sound and is interim stabilized and partially isolated. The Tank 241-BX-107 surface level is monitored with a Food Instrument Corporation gauge through riser 8 . A figure that graphically represents the surface level measurements from January 1991 to the present can be found in the supporting documents (Brevick 1994). The surface level readings have remained steady, ranging between 123.8 and 120.3 in.

Two drywells are identified for tank 241-BX-107. Graphical representations of the active drywells from January 1990 to the present can be found in the supporting document (Brevick 1994). The graphs include the peak $\mathrm{c} / \mathrm{s}$ (some wells have multiple peaks), the depth at which the peak occurred, and the date of the reading.

\subsubsection{Current Status of Tank 241-BX-107}

Tank 241-BX-107 entered service in September 1948 and currently stores 345,000 gal of waste. The waste is comprised of 1,000 gal of supernatant; 344,000 gal of sludge; and no saltcake with 23,000 gal of pumpable liquid remaining. The tank is identified as a low-heat load tank, is passively ventilated, and is categorized as sound with interim stabilization and partial interim isolation completed. Tank 241-BX-107 is equipped to cascade to $241-B X-108$ and is first in the three-tank cascade series. The following plan view and tank cross section depict the approximate waste level and riser configuration. Tank 241-BX-107 has 12 risers and three are available for use: two 12-in. risers (nos.3 and 7 ) and one 4-in. riser (no.5). 


\subsubsection{Inventory estimate 241-BX-107}

The following tank layer volume approximation was derived from the Los Alamos National Iaboratories Waste status and Transaction Record Summary (Agnew 1994). The estimated inventory of Tank 241-BX-107 is also presented.

\subsubsection{In-Tank Photograph 241-BX-107}

The Tank 241-BX-107 photo shows a sludge surface that appears glossy with pockmarks and is light yellow. The photo shows approximately $1,000 \mathrm{gal}$ of supernatant and 344 gal of sludge which measures roughly $10 \mathrm{ft}$ in.depth. Dark yellow pools of liquid are at the base of the. Food. Instrument corporation gauge.,. a. saltwell screen, a temperature probe, and an 'old leveł measure tape:....

\section{$5.7 .3 \quad$ Synopsis Tank 241-BX-107}

(To be completed.) 


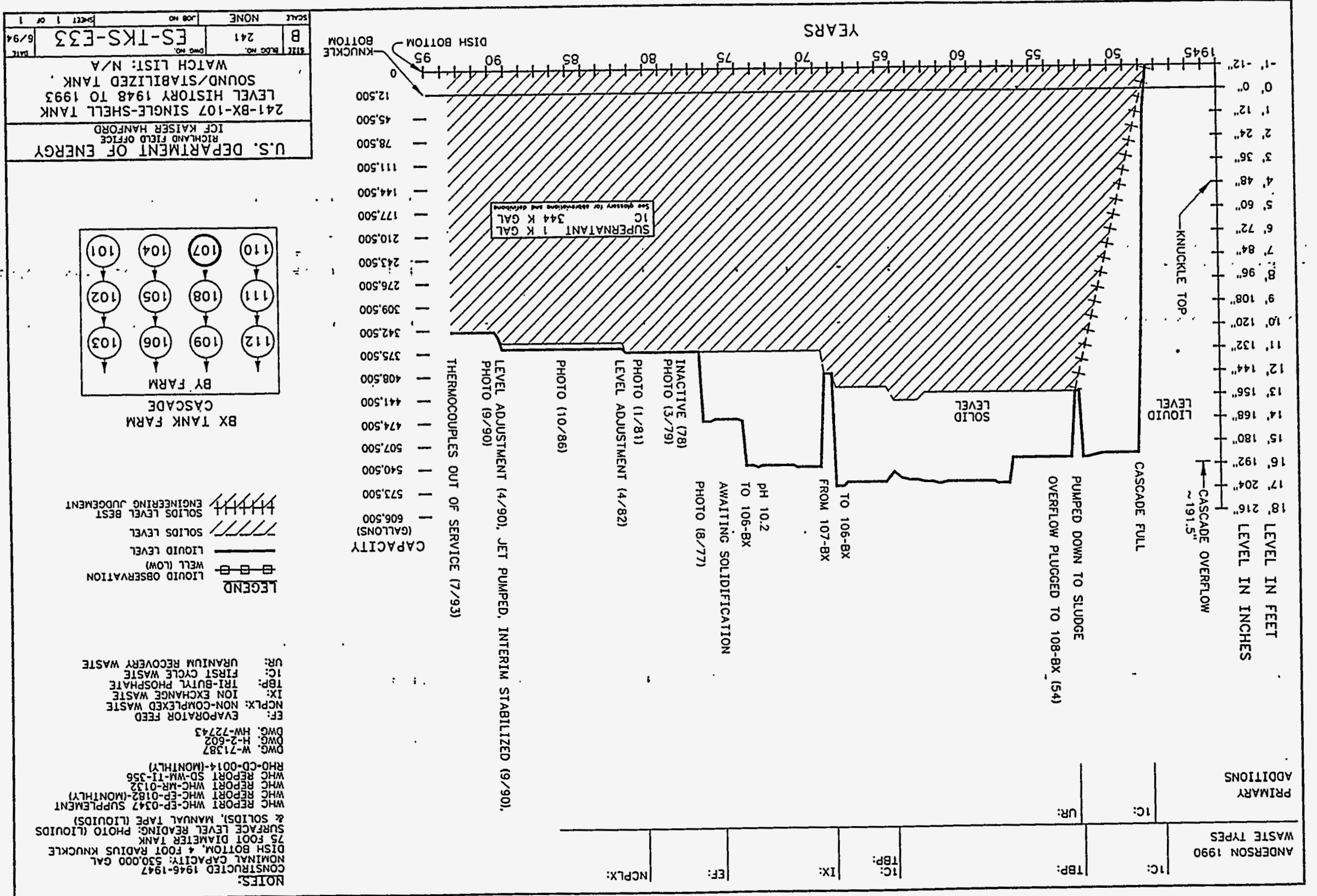

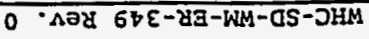




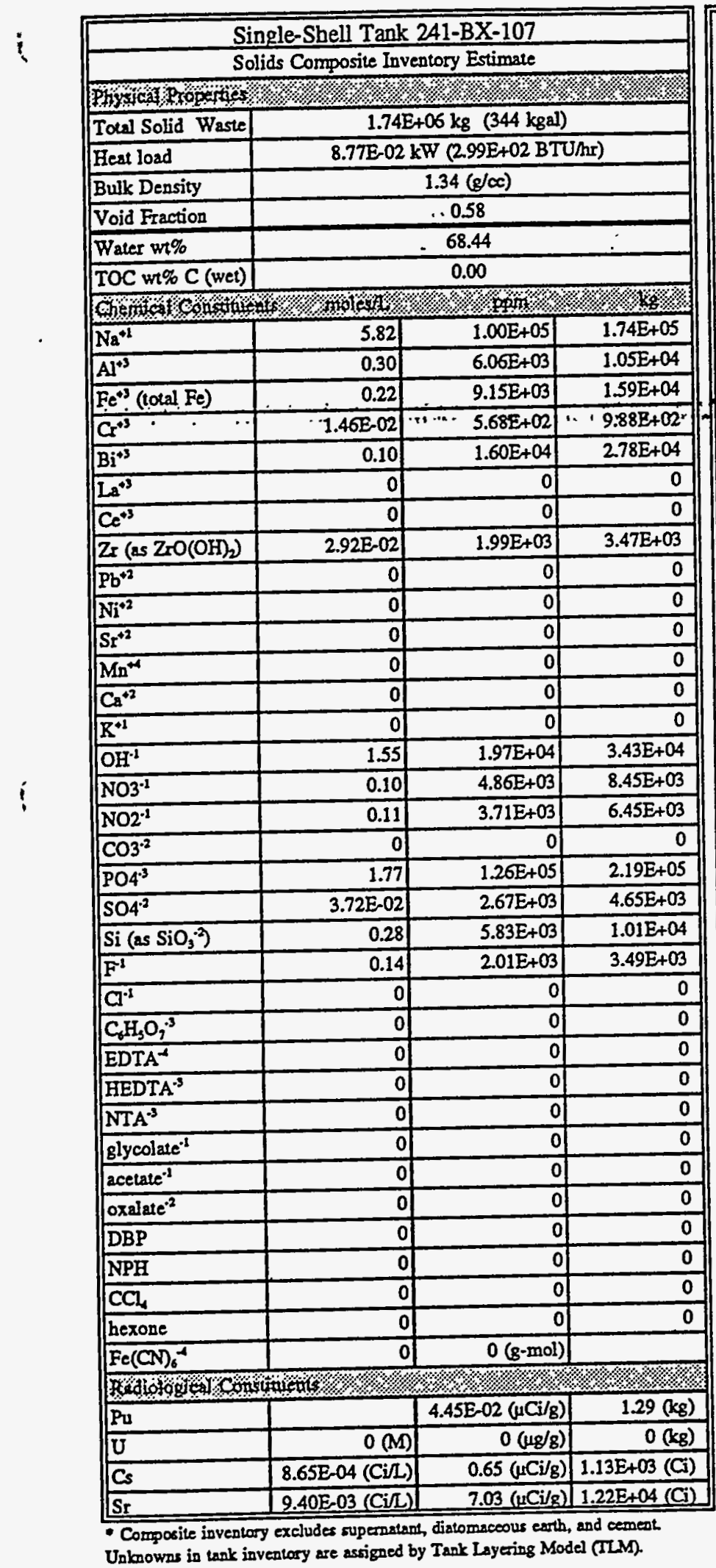

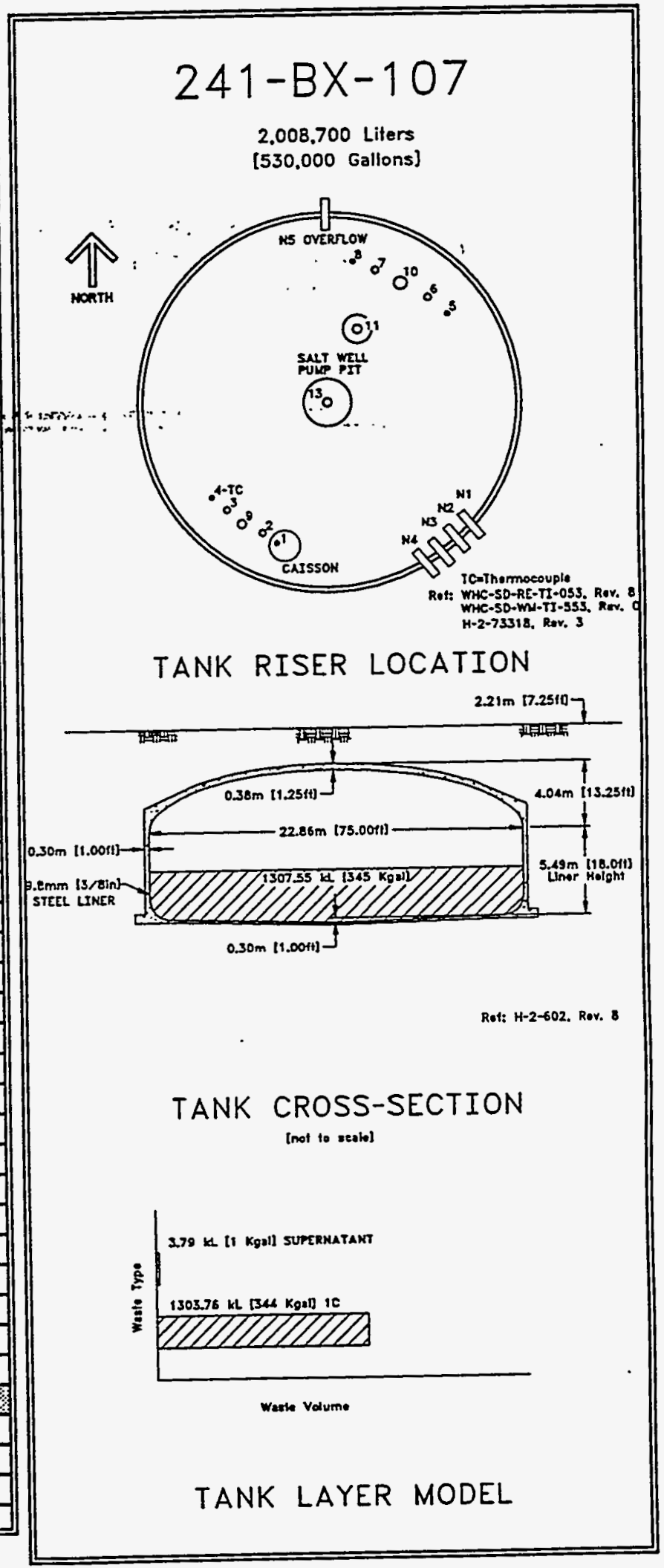


WHC-SD-WM-ER-349 Rev. 0
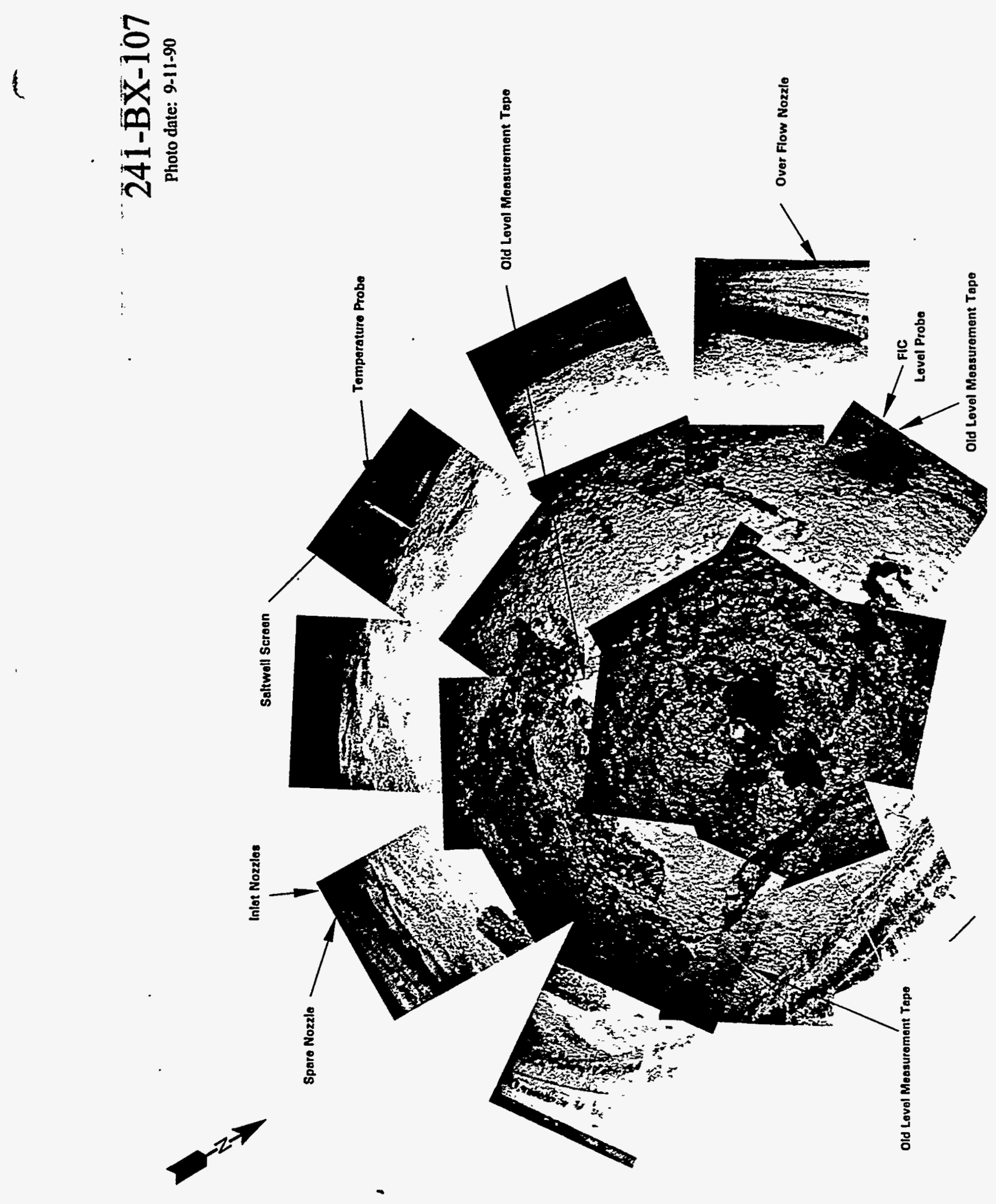
WHC-SD-WM-ER-349, Rev. 0

5.8 Tank 241-BX-108

5.8.1 241-BX-108 Tank History

5.8.1.1 Waste History Tank 241-BX-108

Tank 241-BX-108 was filled with first-cycle waste from March 1949 to September 1949. The tank was declared a suspect leaker in the fourth quarter of 1973 and was saltwell pumped. in the third quarter of 1976. The tank was declared pximary stabilized in 1978. A level adjustment was made in March 1978. Interim stabilization was completed after supernatant pumping in July 1979. A level adjustment was also made in July 1979. Intrusion prevention was completed in June 1981. Inconsistencies: from past scalculationsmeausedr-level, changes in 1990 . In-tank photograph's 'were taken on the following dätes: August 1973, two in 1974, February 1977, February 1980, April 1981, November 1982, and October 1986. (See sketch ES-TKS-E34 for a graphical representation of the Tank 241-BX-108 level history.)

\subsubsection{Temperature History 241-BX-108}

Tank 241-BX-108 contains one thermocouple tree with 14 thermocouple probes. The mean temperature of the first daily recorded readings was $18^{\circ} \mathrm{F}$. A sum of the squares regression line fit for the first 12 thermocouples shows a slight temperature increase with a moderate amount of variability. Not enough data points exist for an accurate regression of variability analysis on thermocouples 13 and 14 . The median temperature is $69^{\circ} \mathrm{F}$ with a minimum of $54^{\circ} \mathrm{F}$ and a maximum of $90^{\circ} \mathrm{F}$. Refer to the supporting document for a more thorough review of the temperature data (Brevick 1994).

\subsubsection{Integrity of Tank 241-BX-108}

Tank 241-BX-108 is categorized as an assumed leaker and is interim stabilized with intrusion prevention completed. The Tank 241-BX-108 surface level is monitored quarterly with a manual tape through riser 7 . A figure that graphically represents the surface level measurements from January 1991 to the present can be found in the supporting documents (Brevick 1994). The surface level for the past 3 years has fluctuated between 4 and 6.5 in. An occurrence report was issued in 1977 due to potential in-leakage from a broken water valve. The occurrence report indicated no visible effects of the in-leakage.

Seven drywells are identified for tank 241-BX-108. Graphical representation of the active arywell from January 1990 to the present can be found in the supporting document (Brevick 1994). The graph includes the peak $\mathrm{c} / \mathrm{s}$ (some wells have multiple peaks), the depth at which the peak occurred, and the date of the reading.

\subsubsection{Current Status of Tank 241-BX-108}

Tank 241-BX-108 entered service in 1949 and currently stores 26,000 gal of waste. The waste is comprised entirely of sludge with no 
pumpable liquid remaining. The tank is identified as a low-heat load tank, is passively ventilated, and is categorized as an assumed leaker with interim stabilization and intrusion prevention completed. Tank 241-BX-108 is equipped to cascade to Tank 241-BX-109 and is second in the three-tank cascade series. The following plan view and tank cross section depict the approximate waste level and riser configuration. Tank 241-BX-108 has 11 risers, and three 12 -in. risers nos.2, 6 and 13 are readily available for use.

\subsubsection{Inventory estimate 241-BX-108}

The following tank layer volume approximation was derived from the Los Alamos National Iaboratories Waste Status and Transaction Record

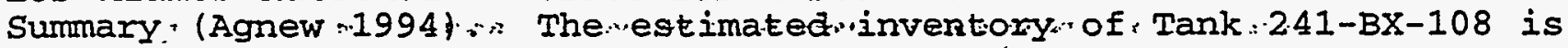
also presented.

\subsubsection{In-Tank Photograph 241-BX-108}

In the Tank 241-BX-108 photo, the sludge appears to have a small pebble surface with a pool of liquid at the center. The color ranges from cream to reddish-brown. The tank contains approximately $26,000 \mathrm{gal}$ of sludge which measures 6-in. deep. With the exception of unidentified debris and an old level measuring tape, the only apparatus seen in the tank are a temperature probe and a manual tape.

5.8 .3 Synopsis Tank 241-BX-108

(To be completed.) 
$-\varepsilon \tau z-$

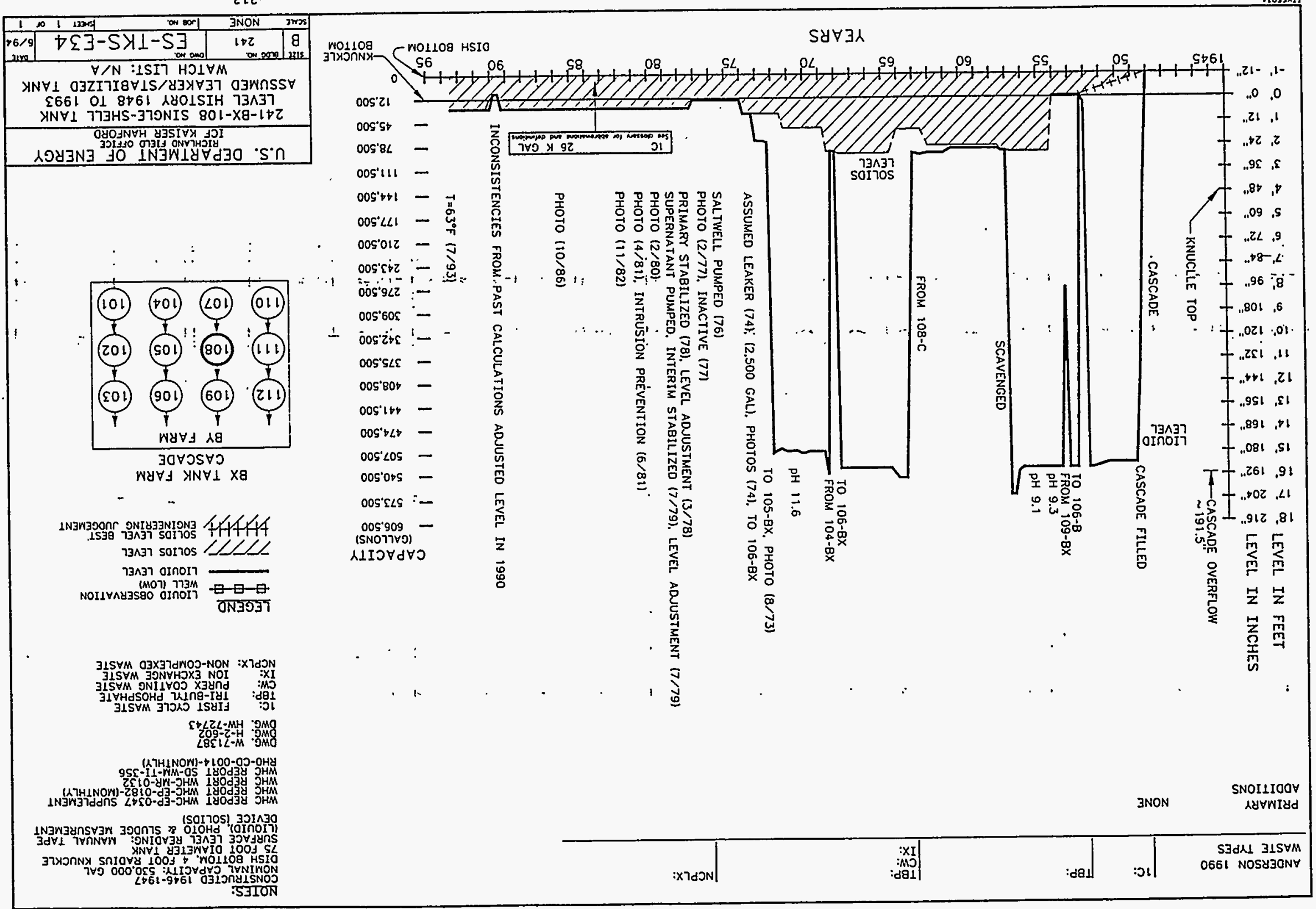




\begin{tabular}{|c|c|c|c|}
\hline \multicolumn{4}{|c|}{ Single-Shell Tank 241-BX-108 } \\
\hline \multicolumn{4}{|c|}{ Solids Composite Inventory Estimate } \\
\hline 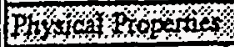 & & \%/\%\% & \\
\hline Toesl Solid Waste & \multicolumn{3}{|c|}{$1.31 \mathrm{E}+05 \mathrm{~kg}(26 \mathrm{kgal})$} \\
\hline \begin{tabular}{|l|} 
Heat load \\
\end{tabular} & \multicolumn{3}{|c|}{$6.63 \mathrm{E}-03 \mathrm{~kW}(2.26 \mathrm{E}+01 \mathrm{BTU} / \mathrm{hr})$} \\
\hline Bulk Density & \multicolumn{3}{|c|}{$1.34(g / \infty)$} \\
\hline Void Fraction & \multicolumn{3}{|c|}{0.58} \\
\hline Water wt\% & \multicolumn{3}{|c|}{68.44} \\
\hline TOC wr\% C (wet) & \multicolumn{3}{|c|}{0.00} \\
\hline \multicolumn{4}{|c|}{ 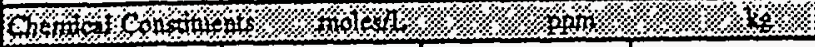 } \\
\hline $\mathrm{Na}^{+\mathrm{I}}$ & 5.82 & $1.00 \mathrm{E}+05$ & $1.32 \mathrm{E}+04$ \\
\hline$\overline{\mathrm{Al}^{+3}}$ & 0.30 & $6.06 \mathrm{E}+03$ & $7.96 \mathrm{E}+02$ \\
\hline $\mathrm{Fe}^{43}$ (total Fe) & 0.22 & $9.15 \mathrm{E}+03$ & $1.20 \mathrm{E}+03$ \\
\hline $\mathrm{Cr}^{+3}$ & $1.46 \mathrm{E}-02$ & $\because \therefore 2 . \quad 3.68 \mathrm{E}+02$ & $=\because 74.71$ \\
\hline $\mathrm{Bi}^{+3}$ & 0.10 & $1.60 \mathrm{E}+04$ & $2.10 \mathrm{E}+03$ \\
\hline $\mathrm{Ls}^{43}$ & 0 & o & 0 \\
\hline $\mathrm{Ce}^{+3}$ & 0 & 0 & \multirow{2}{*}{$2.62 E+02$} \\
\hline $\mathrm{Zr}$ (as $\left.\mathrm{ZrO}(\mathrm{OH})_{2}\right)$ & $2.92 \mathrm{E}-02$ & $1.99 \mathrm{E}+03$ & \\
\hline $\mathrm{Pb}^{42}$ & 0 & 0 & 0 \\
\hline $\mathrm{Ni}^{+2}$ & 0 & 0 & 0 \\
\hline $\mathrm{Sr}^{+2}$ & 0 & of & 0 \\
\hline $\mathrm{Mn}^{+4}$ & 0 & of & 0 \\
\hline $\mathrm{Ca}^{+2}$ & of & 0 & 0 \\
\hline$\overline{\mathrm{K}^{+1}}$ & 0 & 0 & 0 \\
\hline$\widehat{\mathrm{OH}^{\cdot 3}}$ & 1.55 & $1.97 \mathrm{E}+04$ & $2.59 \mathrm{E}+03$ \\
\hline $\mathrm{NO}^{-1}$ & 0.10 & $4.86 E+03$ & $6.39 \mathrm{E}+02$ \\
\hline $\mathrm{NO}^{.2}$ & 0.11 & $3.71 \mathrm{E}+03$ & $4.88 \mathrm{E}+02$ \\
\hline $\mathrm{CO}^{2 \cdot}$ & 0 & $\quad 0$ & 0 \\
\hline $\mathrm{PO}^{-3}$ & 1.77 & $1.26 \mathrm{E}+05$ & $1.65 E+04$ \\
\hline $\mathrm{SO}^{\cdot 2}$ & $3.72 \mathrm{E}-02$ & $2.67 \mathrm{E}+03$ & $3.51 E+02$ \\
\hline $\mathrm{Si}$ (as $\mathrm{SiO}_{3}{ }^{-2}$ ) & 0.28 & $5.83 \mathrm{E}+03$ & $7.67 E+02$ \\
\hline $\mathrm{F}^{-1}$ & 0.14 & $2.01 E+03$ & $2.64 \mathrm{E}+02$ \\
\hline $\mathrm{a}^{-1}$ & 0 & o & 0 \\
\hline $\mathrm{C}_{6} \mathrm{H}_{3} \mathrm{O}_{7}{ }^{3}$ & o & 0 & 0 \\
\hline EDTA ${ }^{-4}$ & 0 & 요 & 0 \\
\hline HEDTA ${ }^{-3}$ & o & of & 0 \\
\hline $\mathrm{NTA}^{-3}$ & 0 & of & 0 \\
\hline glycolate & of & of & 0 \\
\hline scetate ${ }^{-1}$ & of & 0 & 0 \\
\hline oxalate ${ }^{-2}$ & of & 0 & 0 \\
\hline DBP & of & 요 & 0 \\
\hline NPH & 0 & 0 & 0 \\
\hline $\mathrm{CCl}_{4}$ & 이 & 0 & 0 \\
\hline hexone & 0 & 0 & 0 \\
\hline $\mathrm{Fe}(\mathrm{CN})_{6}^{-1}$ & 0 & $0(\mathrm{~g}-\mathrm{mol})$ & \\
\hline 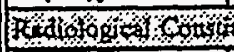 & 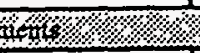 & \% $/ \% / \%$ & \% \\
\hline Pu & & $4.45 \mathrm{E}-02(\mu \mathrm{Ci} / \mathrm{g})$ & $9.76 \mathrm{E}-02(\mathrm{~kg})$ \\
\hline$U$ & $0(M)$ & $0(\mu \mathrm{g} / \mathrm{g})$ & $0\left(\mathrm{~kg}_{\mathrm{g}}\right.$ \\
\hline Cs & $8.65 \mathrm{E}-04(\mathrm{Ci} / \mathrm{L})$ & $0.65(\mu \mathrm{Ci} / g)$ & $85.11(\mathrm{Ci})$ \\
\hline Sr & $9.40 \mathrm{E}-03(\mathrm{Ci} / \mathrm{L})$ & $7.03(\mu \mathrm{Ci} / \mathrm{g})$ & $9.25 \mathrm{E}+02(\mathrm{Ci})$ \\
\hline
\end{tabular}

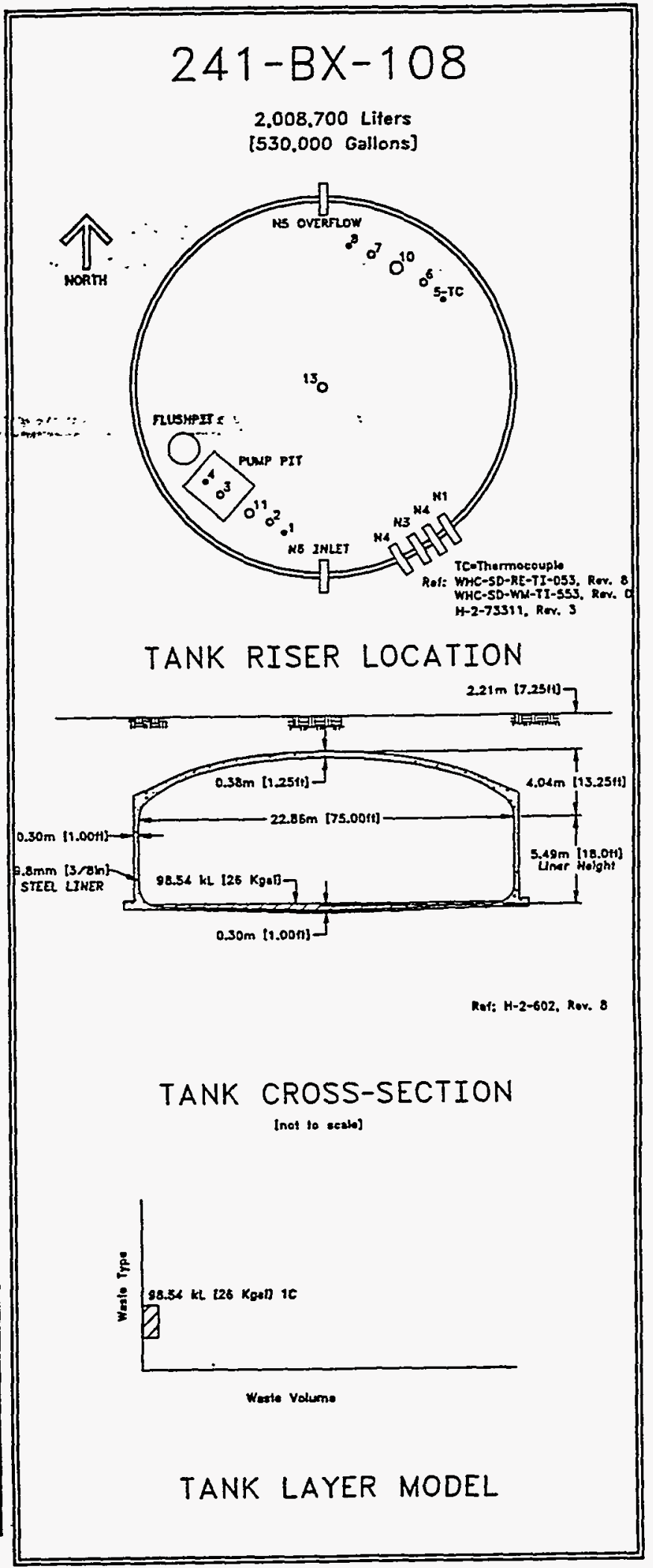

- Conpasite inventory exchudes supernatant, diatomaceous earth, and cement

Untoowss in tank inventory are assigned by Tank Layering Model (TLM). 


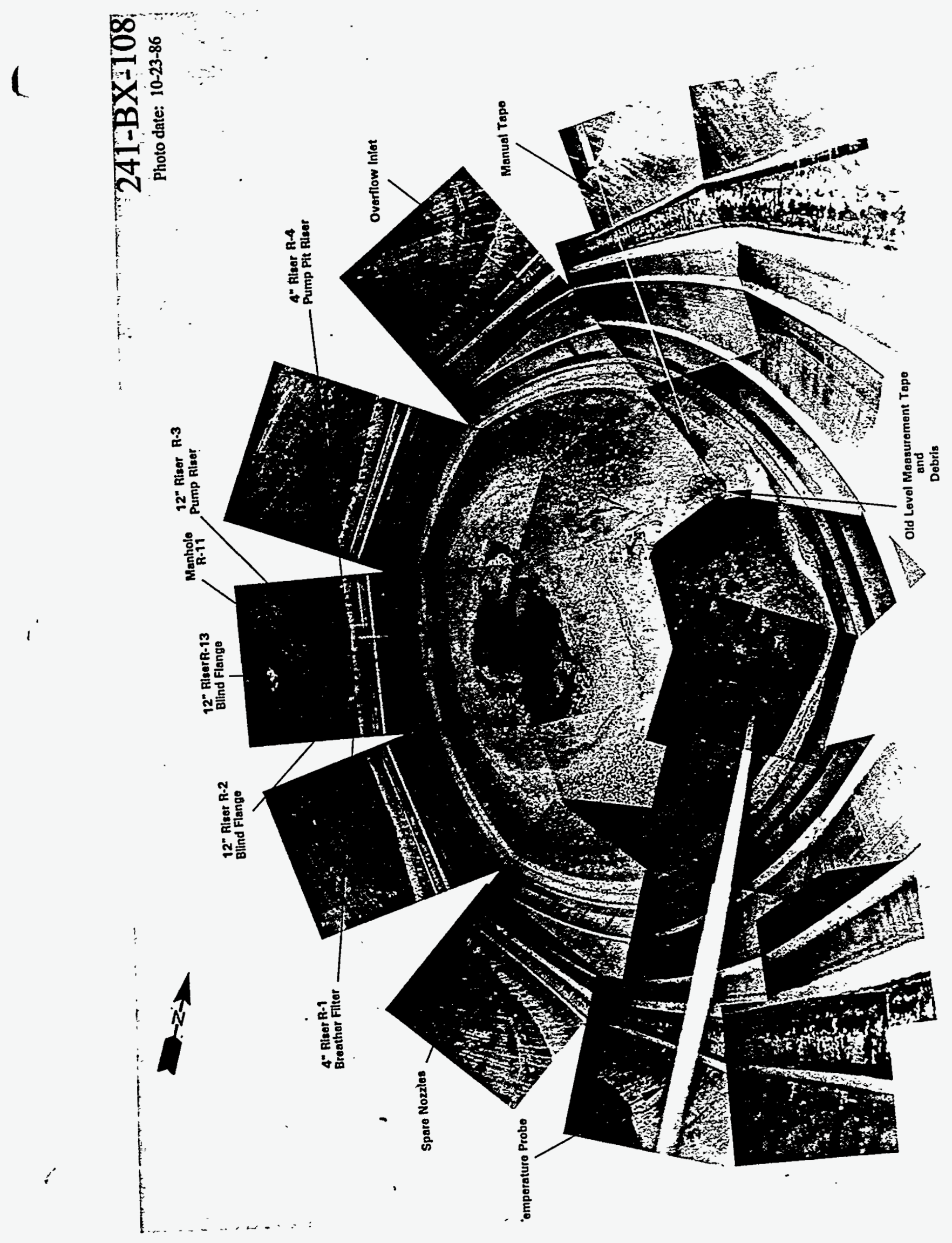




\subsubsection{1-BX-109 Tank History}

5.9.1.1 Waste History Tank 241-BX-109

The tank was filled from the 241-BX-108 cascade line with firstcycle waste from November 1950 to the first quarter of 1951 . In 1978 , the tank was inactive, a saltwell was.installed, and a pump was removed. A level adjustment was made in April 1982. The tank was interim stabilized in september 1990 after supernatant pumping was completed. Another level adjustment was made in september 1990. (See sketch ES-TKS-E35 for a graphical representation of the Tank 241-BX-109 level history.

\subsubsection{Temperature History 241-BX-109}

A single thermocouple tree in Tank 241-BX-109 contains 11 thermocouple probes to measure in-tank temperatures. A regression and variability assessment is not possible with only one data point available for each thermocouple. The median temperature was $76^{\circ} \mathrm{F}$ with a minimum of $74^{\circ} \mathrm{F}$ and a maximum of $76.7^{\circ} \mathrm{F}$. Refer to the supporting document for a more thorough review of the temperature data (Brevick 1994).

\subsubsection{Integrity of Tank 241-BX-109}

Tank 241-BX-109 is categorized as sound and is interim stabilized and partially isolated. The Tank 241-BX-109 surface level is monitored with a Food Instrument Corporation gauge through riser 1. A figure that graphically represents the surface level measurements from January 1991 to the present can be found in the supporting documents (Brevick 1994). The surface level readings remained steady with the readings ranging from 65.1 to 66.8 in.

Four drywells are identified for tank 241-BX-109, none of which are considered active.

\subsubsection{Current Status of Tank 241-BX-109}

Tank 241-BX-109 entered service in 1950 and currently stores $193,000 \mathrm{gal}$ of waste. The waste is comprised entirely of sludge with 8,000 gal of pumpable interstitial liquid remaining. The tank is identified as a low-heat load tank, is passively ventilated, and is categorized as sound with interim stabilization and partial interim isolation completed. Tank 241-BX-109 is third in the three-tank cascade series. Tank 241-BX-109 cascades to Tank 241-BY-107. The following plan view and tank cross section depict the approximate waste level and riser configuration. Tank 241-BX-109 has 10 risers and four are available for use: one 4-in. riser (no.1) and three 12-in. Iisers (nos.2, 6 and 7 ). 
5.9.2.1 Inventory estimate 241-BX-109

The following tank layer volume approximation was derived from the Los Alamos National Laboratories Waste Status and Transaction Record Summary (Agnew 1994). The estimated inventory of Tank 241-BX-109 is also presented.

\subsubsection{In-Tank Photograph 241-BX-109.}

The Tank 241-BX-109 photo shows a pockmarked surface of sludge with pools and rivulets of clear brown liquid. Approximately 193,000 gal or $5.5 \mathrm{ft}$ of sludge are in the tank. Temperature probes, a Food Instrument Corporation gauge, a saltwell screen, and a pump appear in the tank. Level adjustments .were.made. as ..a. result . of..the...photo... .

5.9.3 Synopsis Tank 241-BX-109

(To be completed.) 
WHC-SD-WM-ER-349 ReV. 0

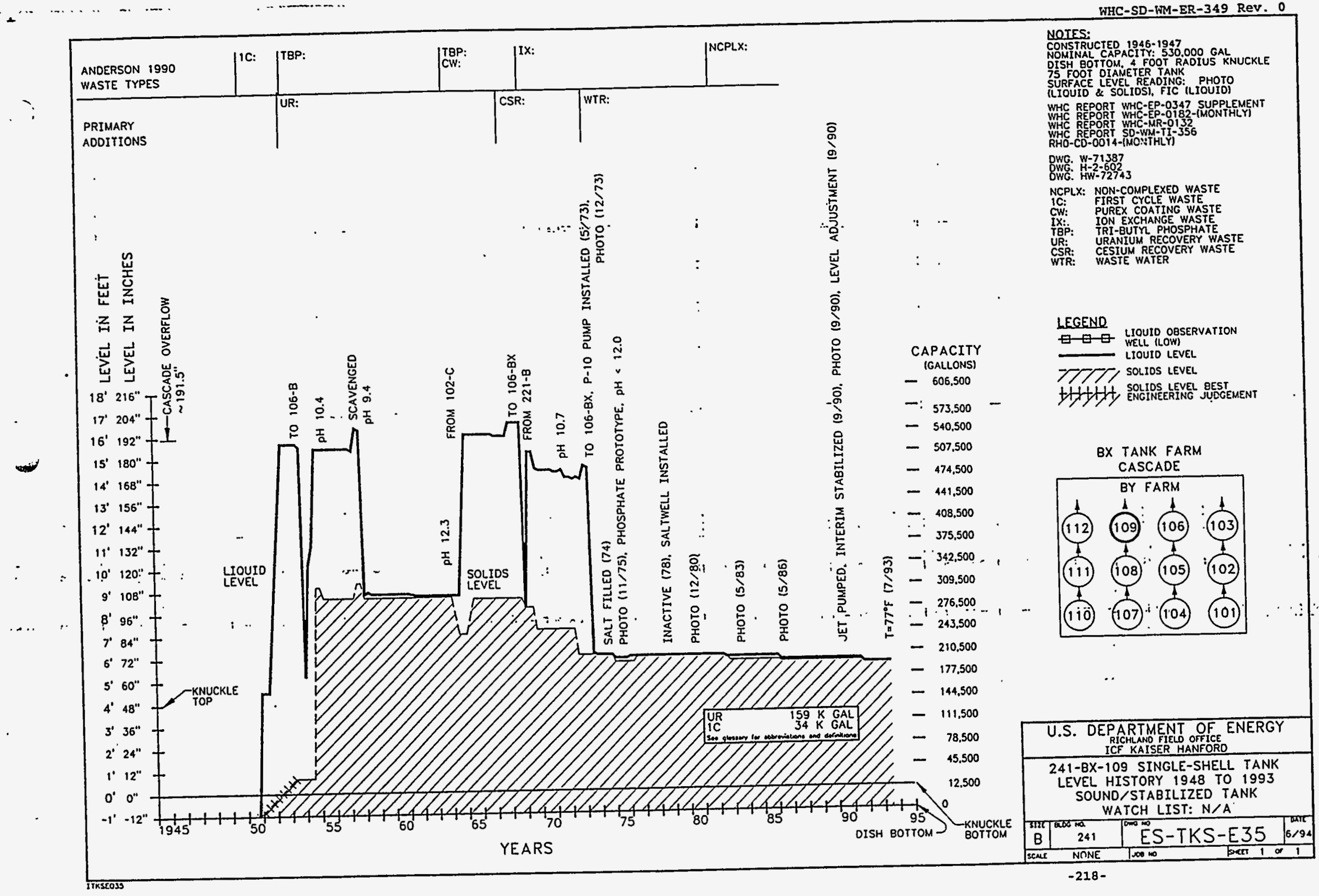




\begin{tabular}{|c|c|c|c|}
\hline \multicolumn{4}{|c|}{ Single-Shell Tank 241-BX-109 } \\
\hline \multicolumn{4}{|c|}{ Solids Composite Inventory Estimate } \\
\hline 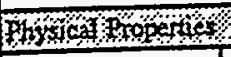 & \% & $\% \% \% \% \%$ & \%/\% \\
\hline Total Solid Waste & \multicolumn{3}{|c|}{$1.18 \mathrm{E}+06 \mathrm{~kg}(193 \mathrm{kgal})$} \\
\hline Heat load & \multicolumn{3}{|c|}{$0.47 \mathrm{~kW}(1.59 \mathrm{E}+03 \mathrm{BTU} / \mathrm{hr})$} \\
\hline Bulk Density & \multicolumn{3}{|c|}{$1.62(g / \infty)$} \\
\hline Void Fraction & \multicolumn{3}{|c|}{0.28} \\
\hline Water wr\% & \multicolumn{3}{|c|}{20.56} \\
\hline TOC wt\% C (wet) & \multicolumn{3}{|c|}{0.00} \\
\hline \multicolumn{4}{|c|}{ 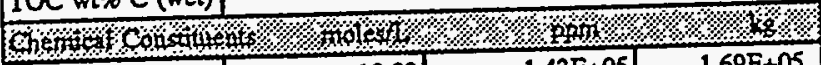 } \\
\hline $\mathrm{Na}^{41}$ & 10.03 & $1.43 E+05$ & $1.69 \mathrm{E}+05$ \\
\hline $\mathrm{Al}^{+3}$ & $5.28 \mathrm{E}-02$ & $8.82 \mathrm{E}+02$ & $1.04 \mathrm{E}+03$ \\
\hline $\mathrm{Fe}^{+3}($ total $\mathrm{Fe})$ & 0.53 & $1.84 E+04$ & $2.17 E+04$ \\
\hline$C^{+3} \ldots \ldots$ & $253 \mathrm{E}-\mathrm{D}$ & 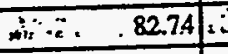 & $\therefore \therefore \quad .97 .69$ \\
\hline $\mathrm{Bi}^{+3}$ & $1.80 \mathrm{E}-02$ & $2.33 \mathrm{E}+03$ & $2.75 \mathrm{E}+03$ \\
\hline $\mathrm{La}^{+3}$ & o & 0 & 0 \\
\hline $\mathrm{Ce}^{43}$ & 0 & o & 0 \\
\hline $\mathrm{Zx}\left(\operatorname{ses} \mathrm{ZrO}(\mathrm{OH})_{2}\right)$ & $5.14 \mathrm{E}-03$ & $2.90 \mathrm{E}+02$ & $3.43 \mathrm{E}+02$ \\
\hline $\mathrm{Pb}^{+2}$ & 0 & of & 0 \\
\hline $\mathrm{Ni}^{\circ 2}$ & 요 & of & 0 \\
\hline $\mathrm{Sr}^{+2}$ & 0 & 0 & 0 \\
\hline $\mathrm{Mn}^{+4}$ & 0 & 0 & 0 \\
\hline $\mathrm{Ca}^{42}$ & 0 & 이 & 0 \\
\hline $\mathrm{K}^{4 !}$ & of & 0 & 0 \\
\hline $\mathrm{OH}^{-1}$ & 1.87 & $1.96 E+04$ & $2.32 E+04$ \\
\hline $\mathrm{NO}^{-1}$ & 0.63 & $2.42 E+04$ & $2.85 \mathrm{E}+04$ \\
\hline $\mathrm{NO}^{\cdot 3}$ & $1.90 \mathrm{E}-02$ & $5.40 \mathrm{E}+02$ & $6.38 \mathrm{E}+02$ \\
\hline $\mathrm{CO}^{.2}$ & 0.11 & $4.21 \mathrm{E}+03$ & $4.97 \mathrm{E}+03$ \\
\hline $\mathrm{PO}^{.3}$ & 1.63 & $9.58 \mathrm{E}+04$ & $1.13 \mathrm{E}+05$ \\
\hline $\mathrm{SO}^{-2}$ & 2.14 & $1.27 \mathrm{E}+05$ & $1.50 \mathrm{E}+05$ \\
\hline $\mathrm{Si}\left(2 \mathrm{~S} \mathrm{SiO}_{3}{ }^{-2}\right)$ & $4.89 \mathrm{E}-02$ & $8.49 \mathrm{E}+02$ & $1.00 \mathrm{E}+03$ \\
\hline $\mathrm{F}^{-1}$ & $2.49 \mathrm{E}-02$ & $2.92 E+02$ & $3.45 \mathrm{E}+02$ \\
\hline $\mathrm{C}^{-1}$ & $4.26 \mathrm{E}-03$ & 93.41 & $1.10 \mathrm{E}+02$ \\
\hline $\mathrm{C}_{6} \mathrm{H}_{3} \mathrm{O}_{7}^{-3}$ & 0 & 0 & $\therefore \quad 0$ \\
\hline EDTA $^{-4}$ & 0 & 0 & 0 \\
\hline HEDTA ${ }^{3}$ & 0 & 0 & 0 \\
\hline $\mathrm{NTA}^{-3}$ & 0 & 0 & 0 \\
\hline Elycolate ${ }^{-1}$ & 0 & 0 & 0 \\
\hline acetate ${ }^{-1}$ & 0 & 0 & 0 \\
\hline oxalate ${ }^{-2}$ & 0 & 0 & 0 \\
\hline DBP & 0 & 0 & 0 \\
\hline NPH & 0 & 아 & 0 \\
\hline $\mathrm{Cl}_{1}$ & 0 & 0) & 0 \\
\hline hexone & 0 & 0 & 0 \\
\hline $\mathrm{Fe}(\mathrm{CN})_{6}^{+}$ & of & $0(\mathrm{~s} \cdot \mathrm{mol})$ & \\
\hline \multirow{2}{*}{\multicolumn{4}{|c|}{ 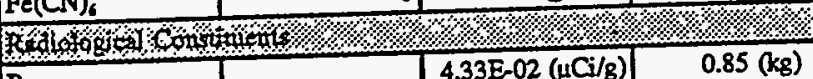 }} \\
\hline $\mathrm{Pu}$ & & & \\
\hline $\mathrm{U}$ & $2.69 \mathrm{E}-02(\mathrm{M})$ & $3.96 \mathrm{E}+03(\mu \mathrm{g} / \mathrm{g})$ & $4.67 \mathrm{E}+03(\mathrm{~kg})$ \\
\hline Cs & $1.54 \mathrm{E}-03(\mathrm{Ci} / \mathrm{L})$ & $0.96(\mu \mathrm{Cj} / \mathrm{g})$ & $1.13 E+03(\mathrm{Ci})$ \\
\hline$\overline{S r}$ & $9.36 \mathrm{E}-02(\mathrm{Ci} / \mathrm{L})$ & $57.89(\mu \mathrm{Ci} / \mathrm{g})$ & $6.84 \mathrm{E}+04(\mathrm{C})$ \\
\hline
\end{tabular}

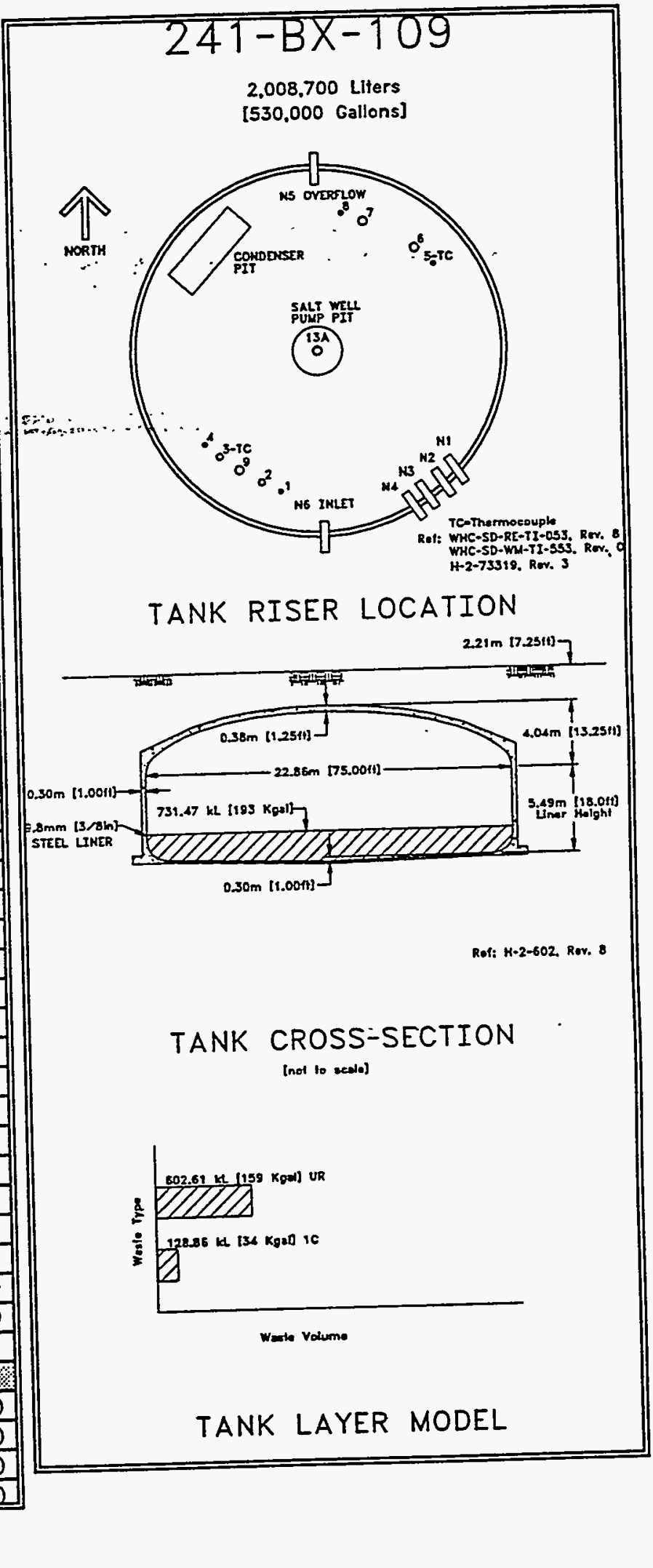


WHC-SD-WM-ER-349 Rev. 0

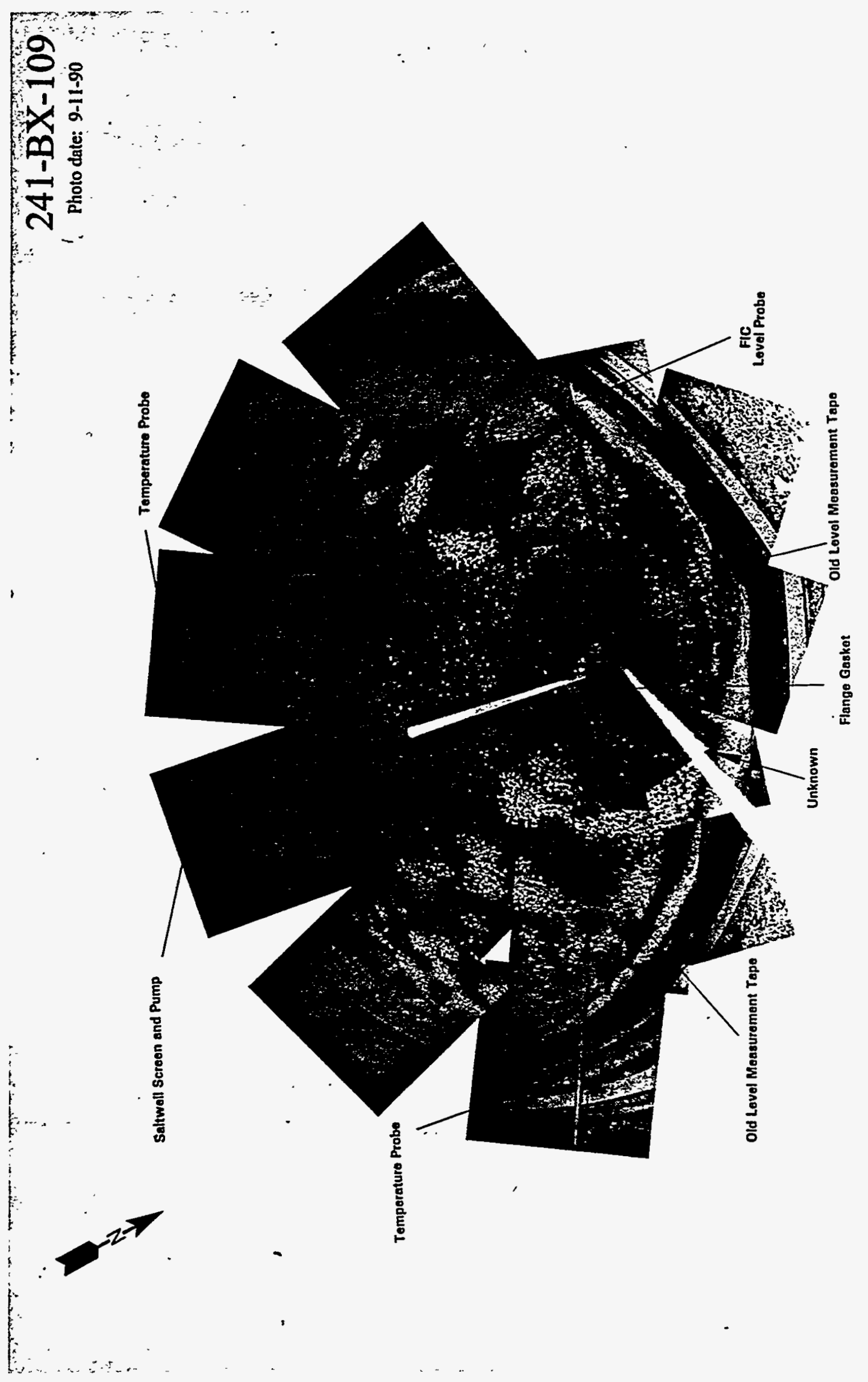


WHC-SD-WM-ER-349, Rev, 0

5.10 Tank 241-BX-110

5.10.1 241-BX-110 Tank History

5.10.1.1 Waste History Tank 241-BX-110

Tank 241-BX-110 was filled with first-cycle waste from september 1949 to January 1950. In the third and fourth quarters of 1977 and the first quarter of 1978 , the tank. was considered inactive with. the salt well installed. In the second quarter of 1979, the tank integrity was questionable. In March 1980, the tank was primary stabilized and partial isolation was completed in December 1982. A level adjustment was performed in December 1984. In August 1985, interim stabilization was achieved after. supernatant. pumping ., was , completed.. A level adjustment was performed in-Augrist-1985" (See'sketch'ES-TKS-E36 for a graphical representation of Tank 241-BX-110 level history.)

\subsubsection{Temperature History 241-BX-110}

Tank 241-BX-110 contains 12 thermocouple probes to record temperature data on a single thermocouple tree. The mean temperature of the first daily recorded readings was $125^{\circ} \mathrm{F}$. A sum of the squares regression line fit for the thermocouples shows a slight temperature decrease with a moderate to large amount of variability. The data reveal an annual temperature undulation that became evident in January 1989. The median temperature is $65.1^{\circ} \mathrm{F}$ with a minimum of $55^{\circ} \mathrm{F}$ and a maximum of $125^{\circ} \mathrm{F}$. Refer to the supporting document for a more thorough review of the temperature data (Brevick 1994).

\subsection{0 .1 .3 Integrity of Tank 241-BX-110}

Tank 241-BX-110 is categorized as an assumed leaker and is interim stabilized with partial isolation completed. The Tank 241-BX-110 surface level is monitored daily with a manual tape through riser 2 . A figure that graphically represents the surface level measurements from January 1991 to the present can be found in the supporting documents (Brevick 1994). The surface level readings for the past 3 years have remained steady, ranging from 68 to 69 in.

An occurrence report was issued in January 1980 due to a liquid level increase that exceeded the criterion. The cause of the intrusion was attributed to rapid snow melt runoff through a pump pit under construction.

Another occurrence report was issued in January 1981 due to a liquid level increase that exceeded the criterion. The cause of the intrusion was attributed to precipitation through riser 9 in the new pump pit mentioned above.

Five arywells are identified for tank 241-BX-110. Graphical representations of the active drywell from January 1990 to the present can be found in the supporting document (Brevick 1994). Each graph includes the peak c/s (some wells have multiple peaks), the depth at 
which the peak occurred, and the date of the reading.

5.10 .2 Current Status of Tank 241-BX-110

Tank 241-BX-110 entered service in 1949 and currently stores $199,000 \mathrm{gal}$ of non-complexed waste. The waste is comprised of 1,000 gal of supernatant; $42,000 \mathrm{gal}$ of saltcake; and 156,000 gal of sludge with 10,000 gal of pumpable liquid remaining. The tank is identified as a low-heat load tank, is passively ventilated, and is categorized as.an assumed leaker with interim stabilization and partial interim isolation completed. Tank 241-BX-110 is equipped to cascade to Tank 241-BX-111 and is first in the three-tank cascade series. The following plan view and tank cross section depict the approximate waste level and riser configuration.... Tank .241-BX-110.. has. 11 . risers and .12-in... risers nos.3 and 6 are readilÿ "availäble" for ùse.

\subsubsection{Inventory estimate 241-BX-110}

The following tank layer volume approximation was derived from the Los Alamos National Laboratories Waste Status and Transaction Record Summary (Agnew 1994). The estimated inventory of Tank 241-BX-110 is also presented.

\subsubsection{In-Tank Photograph 241-BX-110}

The Tank 241-BX-110 photo shows translucent pools of liquid on an irregular surface of solids. Light colored saltcake clings to the perimeter of the tank. Approximately 199,000 gal of waste are in the tank which measures 5.5 ft deep. Tank 241-BX-110 is on the Ferrocyanide Watch List.

\subsubsection{Synopsis Tank 241-BX-110}

(To be completed.) 


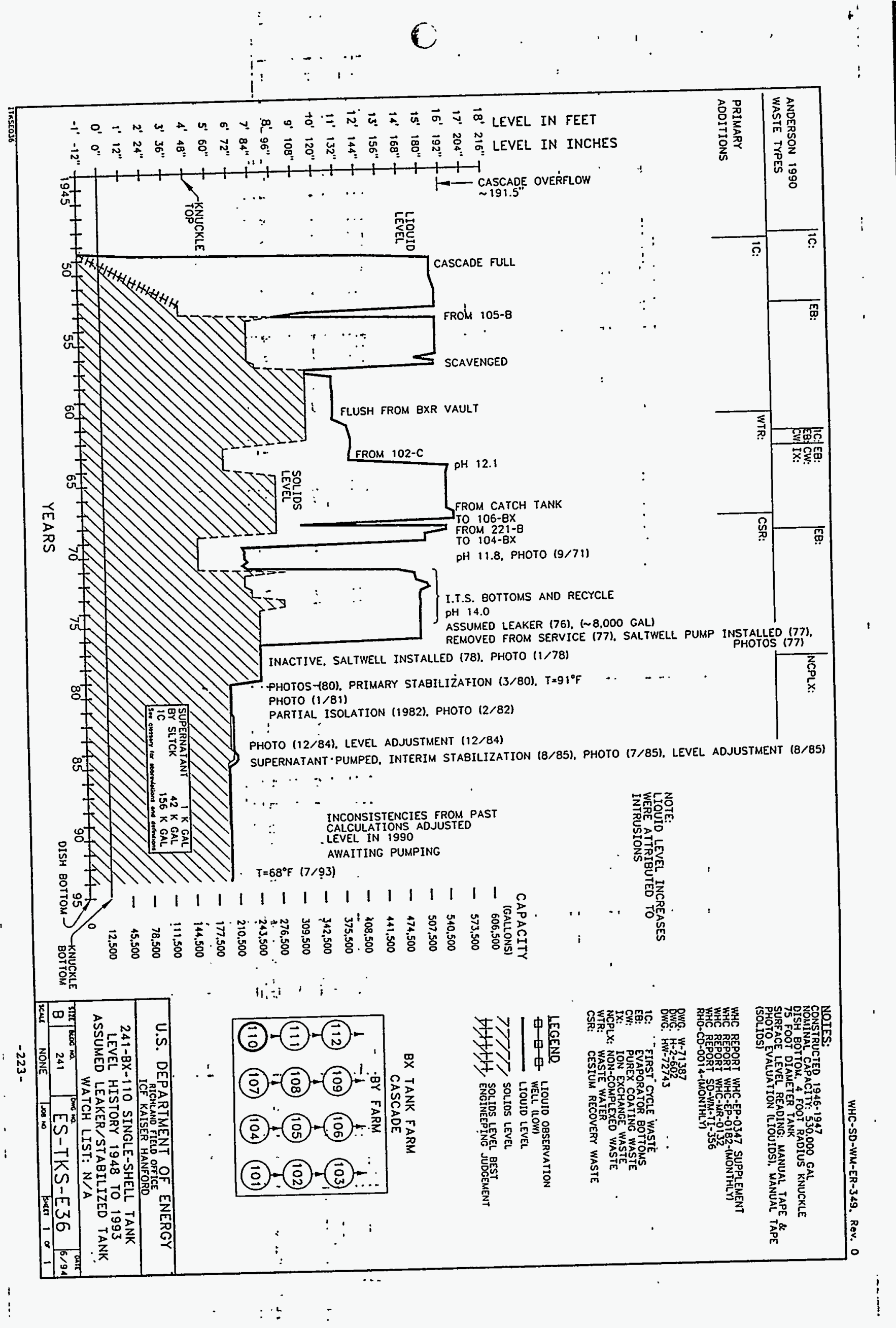




\begin{tabular}{|c|c|c|c|}
\hline \multicolumn{4}{|c|}{ Single-Shell Tank 241-BX-110 } \\
\hline \multicolumn{4}{|c|}{ Solids Composite Inventory Estimate } \\
\hline 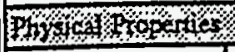 & \% & \%./\% \% & $\%$ \\
\hline Total Solid Waste & \multicolumn{3}{|c|}{$1.03 \mathrm{E}+06 \mathrm{~kg}(198 \mathrm{kgal})$} \\
\hline Heat load & \multicolumn{3}{|c|}{$0.32 \mathrm{~kW}(1.09 \mathrm{E}+03 \mathrm{BTU} / \mathrm{hr})$} \\
\hline Bulk Density & \multicolumn{3}{|c|}{$1.37(g / \propto)$} \\
\hline Void Fraction & \multicolumn{3}{|c|}{0.61} \\
\hline Water wr\% & \multicolumn{3}{|c|}{61.03} \\
\hline TOC wr\% C (wet) & \multicolumn{3}{|c|}{0.01} \\
\hline \multicolumn{4}{|c|}{ 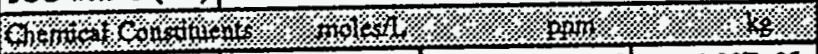 } \\
\hline $\mathrm{Na}^{* 1}$ & $\begin{array}{r}6.98 \\
\end{array}$ & \begin{tabular}{r|}
$1.17 \mathrm{E}+05$ \\
\end{tabular} & $1.20 \mathrm{E}+05$ \\
\hline $\mathrm{Al}^{+3}$ & 0.32 & $6.23 \mathrm{E}+03$ & $6.40 \mathrm{E}+03$ \\
\hline $\mathrm{Fe}^{+3}$ (total Fe) & $\begin{array}{r}0.17 \\
\end{array}$ & $7.03 \mathrm{E}+03$ & $7.22 \mathrm{E}+03$ \\
\hline $\mathrm{Cr}^{43 \ldots \ldots \ldots}$ & $\because \because \div 1,15 \mathrm{E}-02$ & $\ldots \ldots+4.36 \mathrm{E}+02$ & $\therefore-4.48 \mathrm{E}+02-$ \\
\hline $\mathrm{Bi}^{+3}$ & 8.05E-02 & $1.23 E+04$ & $1.26 \mathrm{E}+04$ \\
\hline $\mathrm{La}^{43}$ & 0 & 0 & 0 \\
\hline $\mathrm{Ce}^{43}$ & 0 & 0 & 0 \\
\hline $\mathrm{Zx}$ (as $\left.\mathrm{ZrO}(\mathrm{OH})_{2}\right)$ & $2.30 \mathrm{E}-02$ & $1.53 \mathrm{E}+03$ & $1.57 \mathrm{E}+03$ \\
\hline $\mathrm{Pb}^{\circ 2}$ & 0 & 0 & 0 \\
\hline $\mathrm{Ni}^{+2}$ & 0 & of & 0 \\
\hline $\mathrm{Si}^{+2}$ & 0 & 0) & 0 \\
\hline $\mathrm{Mn}^{+4}$ & 0] & 요 & 0 \\
\hline $\mathrm{Ca}^{42}$ & 0 & 0 & 0 \\
\hline $\mathrm{R}^{41}$ & 5.57E-04 & 15.88 & 16.31 \\
\hline $\mathrm{OH}^{-1}$ & 1.49 & $1.85 \mathrm{E}+04$ & $1.90 \mathrm{E}+04$ \\
\hline $\mathrm{NO}^{-1}$ & 1.84 & $8.35 \mathrm{E}+04$ & $8.57 \mathrm{E}+04$ \\
\hline $\mathrm{NO}^{-1}$ & 0.14 & $4.78 \mathrm{E}+03$ & $4.91 \mathrm{E}+03$ \\
\hline $\mathrm{CO}^{2 \cdot 2}$ & $8.72 \mathrm{E}-02$ & $3.82 \mathrm{E}+03$ & $3.92 \mathrm{E}+03$ \\
\hline $\mathrm{PO}^{-3}$ & 1.42 & $9.87 \mathrm{E}+04$ & $1.01 \mathrm{E}+05$ \\
\hline $\mathrm{SO}^{-2}$ & 0.12 & $8.72 \mathrm{E}+03$ & $8.96 \mathrm{E}+03$ \\
\hline $\mathrm{Si}$ (as $\left.\mathrm{SiO}_{3}{ }^{-2}\right)$ & 0.22 & $4.48 \mathrm{E}+03$ & $4.60 \mathrm{E}+03$ \\
\hline $\mathrm{F}^{-1}$ & 0.23 & $3.16 \mathrm{E}+03$ & $3.24 \mathrm{E}+03$ \\
\hline$a^{-1}$ & $3.48 \mathrm{E}-03$ & 89.93 & 92.35 \\
\hline $\mathrm{C}_{6} \mathrm{H}_{3} \mathrm{O}_{7}{ }^{3}$ & 0 & 0 & 0 \\
\hline EDTA $^{-4}$ & 0 & of & 0 \\
\hline HEDTA ${ }^{-3}$ & 0 & 0 & 0 \\
\hline NTA $^{-3}$ & 0 & 0 & 0 \\
\hline glycolate & 0 & 0 & 0 \\
\hline acetate & 7.37E-03 & $3.18 \mathrm{E}+02$ & $3.26 \mathrm{E}+02$ \\
\hline oxalate & 0 & 0 & 0 \\
\hline DBP & 0 & 0 & 0 \\
\hline NPH & 요 & 0 & 0 \\
\hline $\mathrm{CCl}_{4}$ & of & 아 & 0 \\
\hline hexone & 0 & 0 & 0 \\
\hline $\mathrm{Fe}(\mathrm{CN})_{6}{ }^{4}$ & 0 & 0 (g-mol) & \\
\hline \multicolumn{4}{|c|}{ 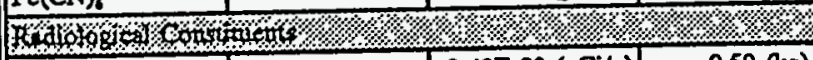 } \\
\hline Pu & & $3.42 \mathrm{E}-02(\mu \mathrm{Ci} / \mathrm{g})$ & $0.59(\mathrm{~kg})$ \\
\hline $\mathrm{U}$ & $5.02 \mathrm{E}-03(\mathrm{M})$ & $8.72 \mathrm{E}+02(\mu \mathrm{g} / \mathrm{g})$ & $8.96 \mathrm{E}+02(\mathrm{~kg})$ \\
\hline$\overline{C s}$ & 8.05E-02(CiL) & $58.78(\mu \mathrm{Ci} / \mathrm{g})$ & $6.04 \mathrm{E}+04(\mathrm{Ci})$ \\
\hline Sr & $7.40 \mathrm{E}-03(\mathrm{Ci} / \mathrm{L})$ & $5.40(\mu \mathrm{C} / \mathrm{g})$ & $5.55 \mathrm{E}+03(\mathrm{Ci})$ \\
\hline
\end{tabular}

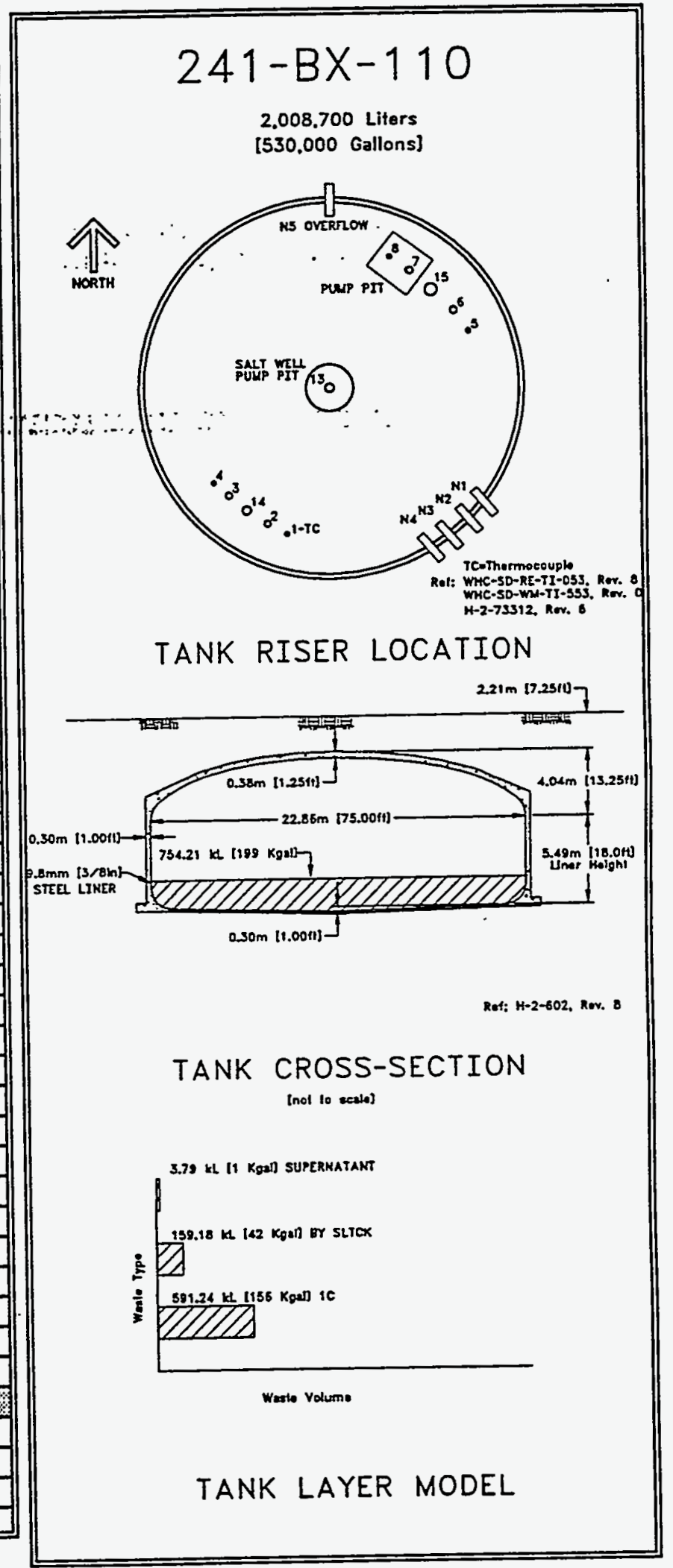

- Comporite inventory excludes supernatant, diatomacoour earth, and cement

Unkowas in tank inventory are assigned by Tank Layering Model (TLM). 


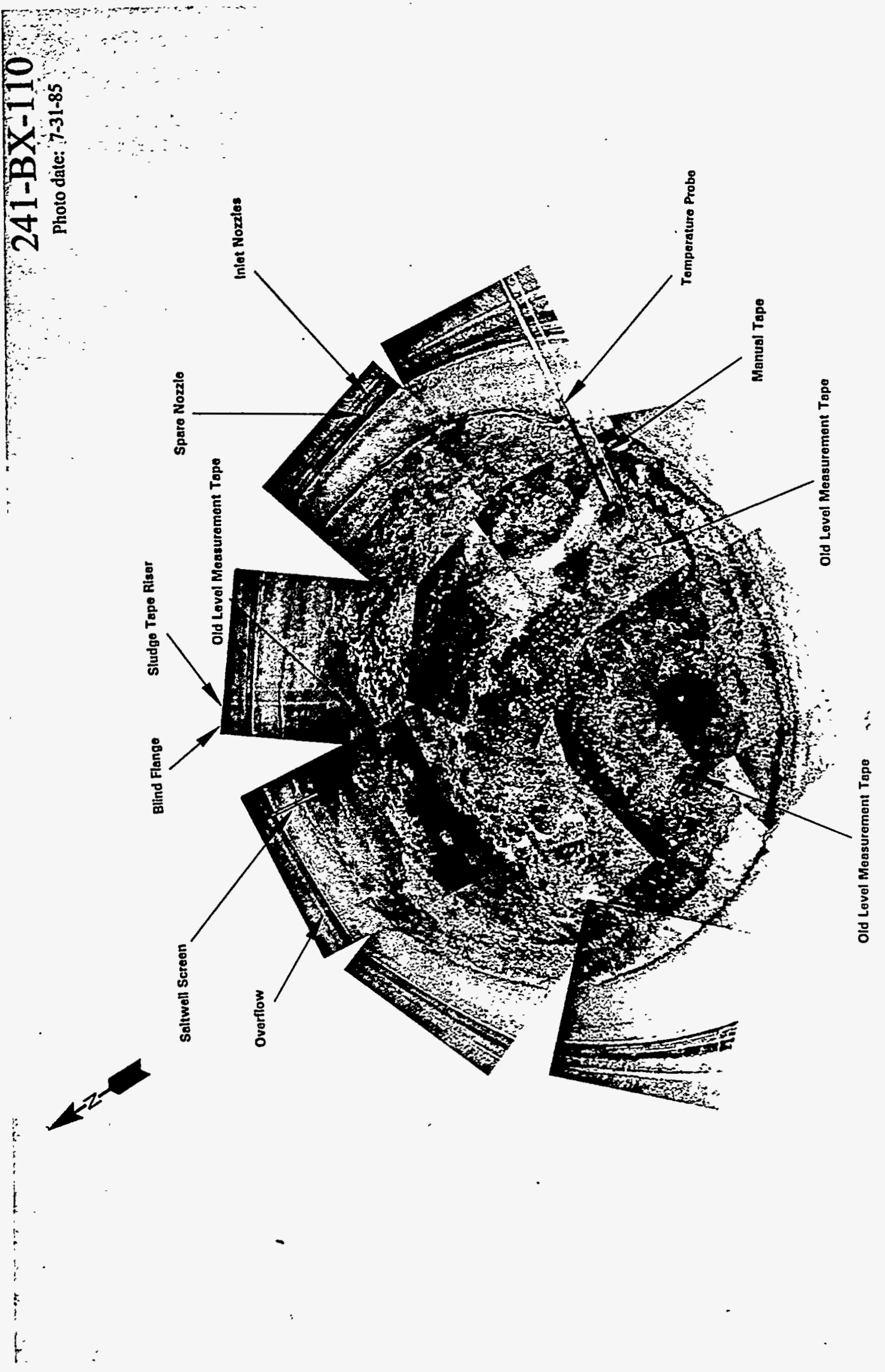




\subsection{Tank 241-BX-111}

\subsubsection{1-BX-111 Tank History}

\subsubsection{Waste History Tank 241-BX-111}

Tank 241-BX-111 was filled with first-cycle waste from Tank 241-BX110 from January to May 1950.. In the first quarter of 1978, the tank was considered inactive. The tank. was termed as having questionable integrity in the second quarter of 1978. The tank was partially isolated in 1982. In 1984, the tank was declared an assumed leaker of approximately 8,000 gal. In July 1985, supernatant pumping was unsuccessful. The tank is awaiting pumping and stabilization. The plotted.. liquid observation well. data. represent the supernatant level. The data foilow the-supernatant- level "ciosely:" (See'sketch- ES-TKS-E37 for a graphical representation of Tank 241-BX-110 level history.'

\subsubsection{Temperature History 241-BX-111}

Tank 241-BX-112 contains 12 thermocouple probes to record temperature on a single thermocouple tree. The mean temperature of the first daily recorded readings was $29^{\circ} \mathrm{F}$. A sum of the squares regression line fit for the thermocouples shows a slight temperature decrease with a moderate amount of variability. The median temperature is $67.2^{\circ} \mathrm{F}$, with a minimum of $58.7^{\circ} \mathrm{F}$ and a maximum of $89^{\circ} \mathrm{F}$. Refer to the supporting document for a more thorough review of the temperature data (Brevick 1994).

\subsubsection{Integrity of Tank 241-BX-111}

Tank 241-BX-11I is categorized as an assumed leaker and is partially isolated. A figure that graphically represents the surface level measurements from January 1991 to the present can be found in the supporting documents (Brevick 1994). During the fourth quarter of 1993, the surface level readings decreased from 80 to 74.25 in. which corresponds with the pumping efforts.

An off-normal occurrence report was issued in March 1993 due to a liquid level decrease that changed from the previous trend. The tank was declared an assumed re-leaker in April 1993 and emergency pumping efforts were initiated.

The liquid observation well for Tank 241-BX-111 is located in risex 5. Sketch ES-TKS-E37 has a graphical representation of the liquid observation well data.

Six drywells are identified for Tank 241-BX-111. Graphical representations of the active drywells from January 1990 to the present can be found in the supporting document (Brevick 1994). Each graph includes the peak c/s (some wells have multiple peaks), the depth at which the peak occurred, and the date of the reading. 
5.11 .2 Current Status of Tank 241-BX-111

Tank 241-BX-111 entered service in 1950 and currently stores 230,000 gal of waste. The waste is comprised of 19,000 gal of supernatant; 179,000 gal of saltcake; and 32,000 gal of sludge with 39,000 gal of pumpable liquid remaining. The tank is identified as a low-heat load tank, is passively ventilated, and is categorized as an assumed leaker with partial interim isolation completed. Tank 241-BX111 is equipped to cascade to Tank 241-BX-112 and is second in the three-tank cascade series. The following plan view and tank cross section depict the approximate waste level and riser configuration. Tank $241-\mathrm{BX}-111$ has 11 risers and 12 -in. risers nos.3 and 6 are available for use.

\subsubsection{Inventory estimate 241-BX-111}

The following tank layer volume approximation was derived from the Ios Alamos National Laboratories Waste Status and Transaction Record Sumnary (Agnew 1994). The estimated inventory of Tank 241-BX-111 is also presented.

\subsubsection{In-Tank Photograph 241-BX-111}

The Tank 241-BX-111 photo shows exposed saltcake clinging to the side of the tank. Solids and scum appear to be floating on the large liquid surface. The liquid is dark brown. The waste measures approximately 6 ft deep. The tank contains saltwell screens, a LOW, a temperature probe, and a manual tape. The tank is on the Ferrocyanide Watch List.

\subsubsection{Synopsis Tank 241-BX-111}

(To be completed.) 


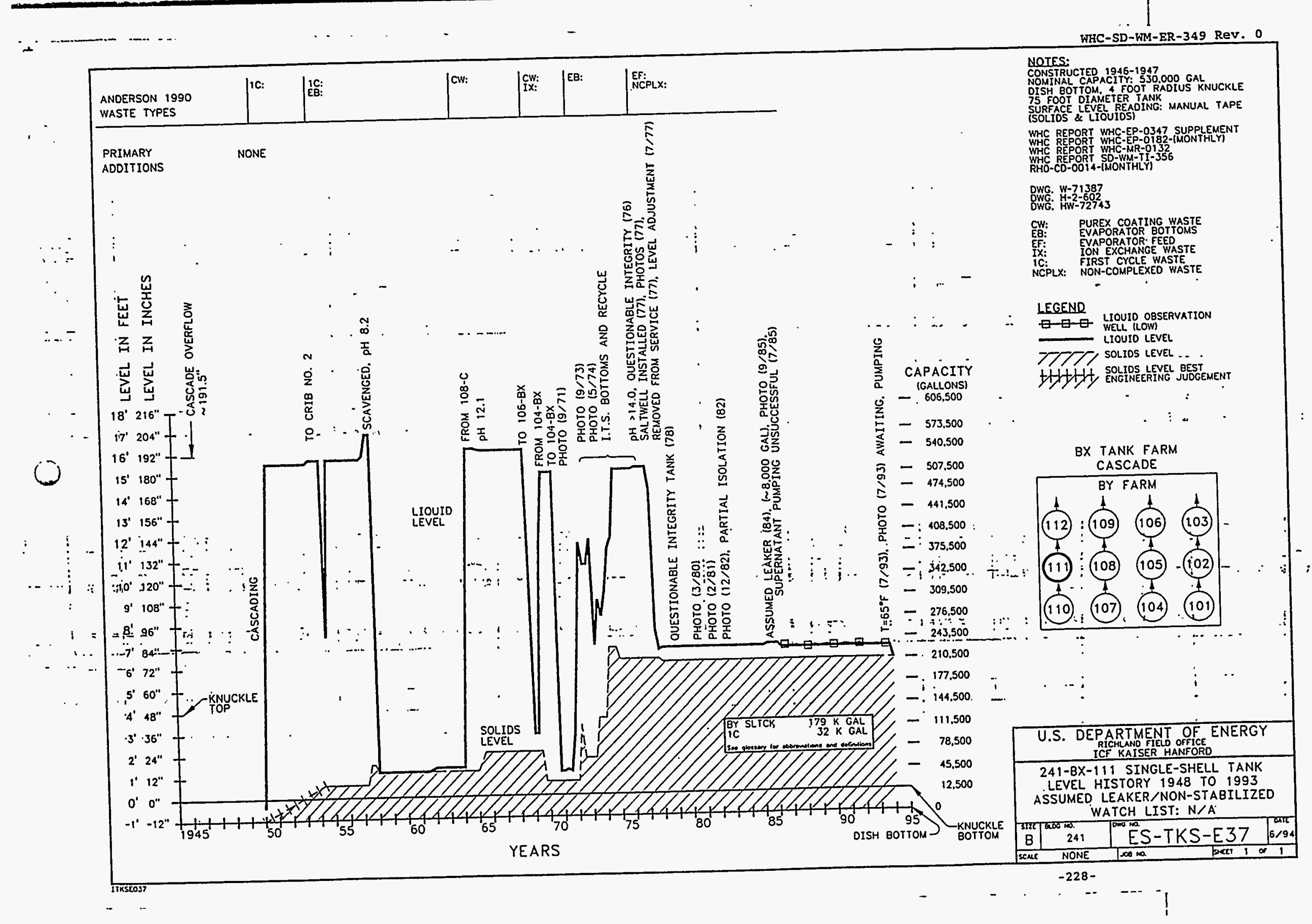


WHC-SD-WM-ER-349, ReV. 0

\begin{tabular}{|c|c|c|c|}
\hline \multicolumn{4}{|c|}{ Single-Shell Tank 241-BX-111 } \\
\hline \multicolumn{4}{|c|}{ Solids Composite Inventory Estimate } \\
\hline \multicolumn{4}{|c|}{ 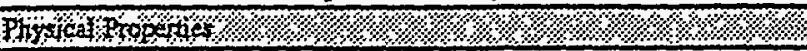 } \\
\hline Total Solid Waste & \multicolumn{3}{|c|}{$1.18 \mathrm{E}+06 \mathrm{~kg}(211 \mathrm{kgal})$} \\
\hline \begin{tabular}{|l|l} 
Heat load \\
\end{tabular} & \multicolumn{3}{|c|}{$1.20 \mathrm{~kW}(4.11 \mathrm{E}+03 \mathrm{BTU} / \mathrm{hr})$} \\
\hline Bulk Density & \multicolumn{3}{|c|}{$1.47(g / \infty)$} \\
\hline Void Fraction & \multicolumn{3}{|c|}{0.68} \\
\hline Water wi\% & \multicolumn{3}{|c|}{38.82} \\
\hline TOC wt\% C (wet) & \multicolumn{3}{|c|}{0.05} \\
\hline \multicolumn{4}{|c|}{ 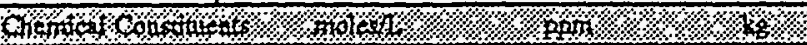 } \\
\hline $\mathrm{Na}^{+1}$ & 10.47 & $1.63 E+05$ & $1.92 E+05$ \\
\hline $\mathrm{Al}^{+3}$ & 0.37 & $6.69 E+03$ & $7.88 \mathrm{E}+03$ \\
\hline $\mathrm{Fe}^{+3}($ total $\mathrm{Fe})$ & $3.32 \mathrm{E}-02$ & $1.26 \mathrm{E}+03$ & $1.48 \mathrm{E}+03$ \\
\hline $\mathrm{Cr}^{43} \cdot:$ & $2.21 \mathrm{E} .03$ & $2: 3 . x:-78.14$ & $91.95^{\circ}$ \\
\hline $\mathrm{Bi}^{+3}$ & $1.55 \mathrm{E}-02$ & $2.20 \mathrm{E}+03$ & $2.59 \mathrm{E}+03$ \\
\hline $\mathrm{La}^{43}$ & 0 & 0 & 0 \\
\hline $\mathrm{Ce}^{+3}$ & 0 & 0 & 0 \\
\hline $\mathrm{Zr}$ (as $\left.\mathrm{ZrO}(\mathrm{OH})_{2}\right)$ & $4.43 \mathrm{E}-03$ & $2.74 \mathrm{E}+02$ & $3.23 E+02$ \\
\hline $\mathrm{Pb}^{* 2}$ & 0 & 0 & 0 \\
\hline $\mathrm{Ni}^{+2}$ & 0 & 0 & 0 \\
\hline$\overline{\mathrm{Sr}^{42}}$ & 0 & 0 & 0 \\
\hline $\mathrm{Mn}^{+4}$ & 0 & 0 & 0 \\
\hline $\mathrm{Ca}^{+2}$ & 0 & 0 & 0 \\
\hline $\mathrm{K}^{+1}$ & 2.23E-03 & 59.07 & 69.51 \\
\hline $\mathrm{OH}^{-1}$ & 1.32 & $1.52 E+04$ & $1.79 \mathrm{E}+04$ \\
\hline $\mathrm{NO}^{-1}$ & 7.06 & $2.97 \mathrm{E}+05$ & $3.50 \mathrm{E}+05$ \\
\hline $\mathrm{NO}^{-1}$ & 0.25 & $7.68 \mathrm{E}+03$ & $9.04 E+03$ \\
\hline $\mathrm{CO}^{-2}$ & 0.35 & $1.42 \mathrm{E}+04$ & $1.67 \mathrm{E}+04$ \\
\hline $\mathrm{PO}^{.3}$ & 0.39 & $2.48 \mathrm{E}+04$ & $2.92 E+04$ \\
\hline $\mathrm{SO}^{2 \cdot 2}$ & 0.39 & $2.52 \mathrm{E}+04$ & $2.96 \mathrm{E}+04$ \\
\hline $\mathrm{Si}\left(\mathrm{as} \mathrm{SiO}_{3}{ }^{-2}\right)$ & 4.21E-02 & $8.02 E+02$ & $9.44 E+02$ \\
\hline $\mathrm{F}^{1}$ & 0.49 & $6.28 E+03$ & $7.39 E+03$ \\
\hline $\mathrm{Cl}^{-1}$ & $1.39 \mathrm{E}-02$ & $3.34 \mathrm{E}+02$ & $3.94 \mathrm{E}+02$ \\
\hline $\mathrm{C}_{6} \mathrm{H}_{3} \mathrm{O}_{7}^{-3}$ & 0 & 0 & 0 \\
\hline EDTA $^{-1}$ & 0 & 0 & 0 \\
\hline FEDTA ${ }^{-3}$ & 0 & o) & 0 \\
\hline $\mathrm{NTA}^{\cdot 3}$ & 0 & 0) & 0 \\
\hline glycolase $e^{-1}$ & 0 & 0 & 0 \\
\hline acetate $^{-1}$ & $2.95 \mathrm{E}-02$ & $1.18 \mathrm{E}+03$ & $1.39 \mathrm{E}+03$ \\
\hline oxalate & 0 & 0 & 0 \\
\hline $\mathrm{DBP}$ & 0 & 0 & 0 \\
\hline NPH & 0 & 0 & 0 \\
\hline $\mathrm{CCl}_{4}$ & 0 & 0 & 0 \\
\hline hexone & 0 & 0 & 0 \\
\hline $\mathrm{Fe}(\mathrm{CN})_{6}{ }^{-1}$ & 0 & $0(\mathrm{~g}-\mathrm{mol})$ & \\
\hline \multicolumn{4}{|c|}{ 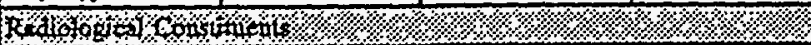 } \\
\hline \begin{tabular}{l|l}
$\mathrm{Pu}$ & \\
\end{tabular} & & $6.12 \mathrm{E}-03(\mu \mathrm{Ci} / \mathrm{g})$ & $0.12(\mathrm{~kg})$ \\
\hline 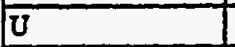 & 2.01E-02 (M) & $3.25 \mathrm{E}+03(\mu \mathrm{g} / \mathrm{g})$ & $3.82 \mathrm{E}+03(\mathrm{~kg})$ \\
\hline Cs & $0.32(\mathrm{C} / \mathrm{L})$ & $2.17 \mathrm{E}+02(\mu \mathrm{Ci} / \mathrm{g})$ & $2.55 \mathrm{E}+05(\mathrm{Ci})$ \\
\hline $\mathrm{Sr}$ & $1.42 \mathrm{E} .03(\mathrm{Ci} / \mathrm{L})$ & $0.97(\mu \mathrm{C} / \mathrm{g})$ & $1.14 \mathrm{E}+03(\mathbf{C})$ \\
\hline
\end{tabular}

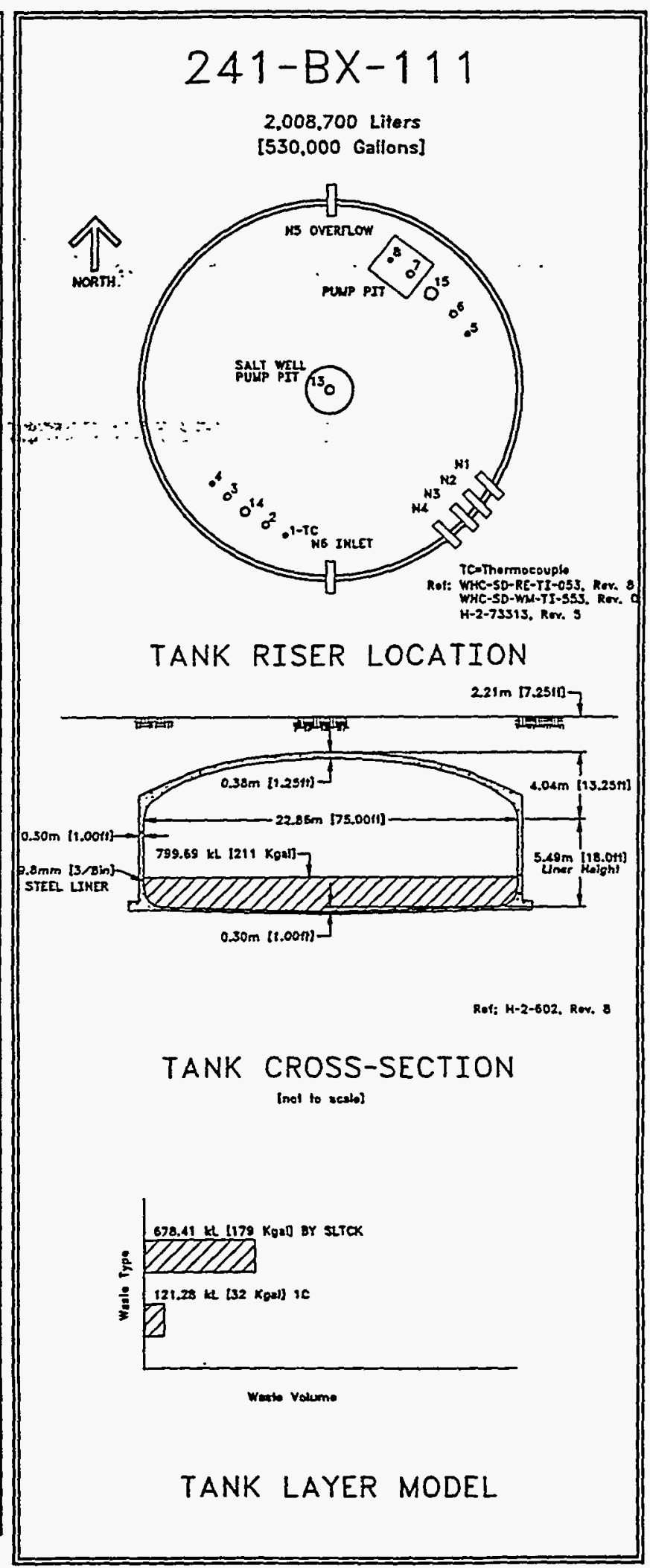


WHC-SD-WM-ER-349 Rev. 0

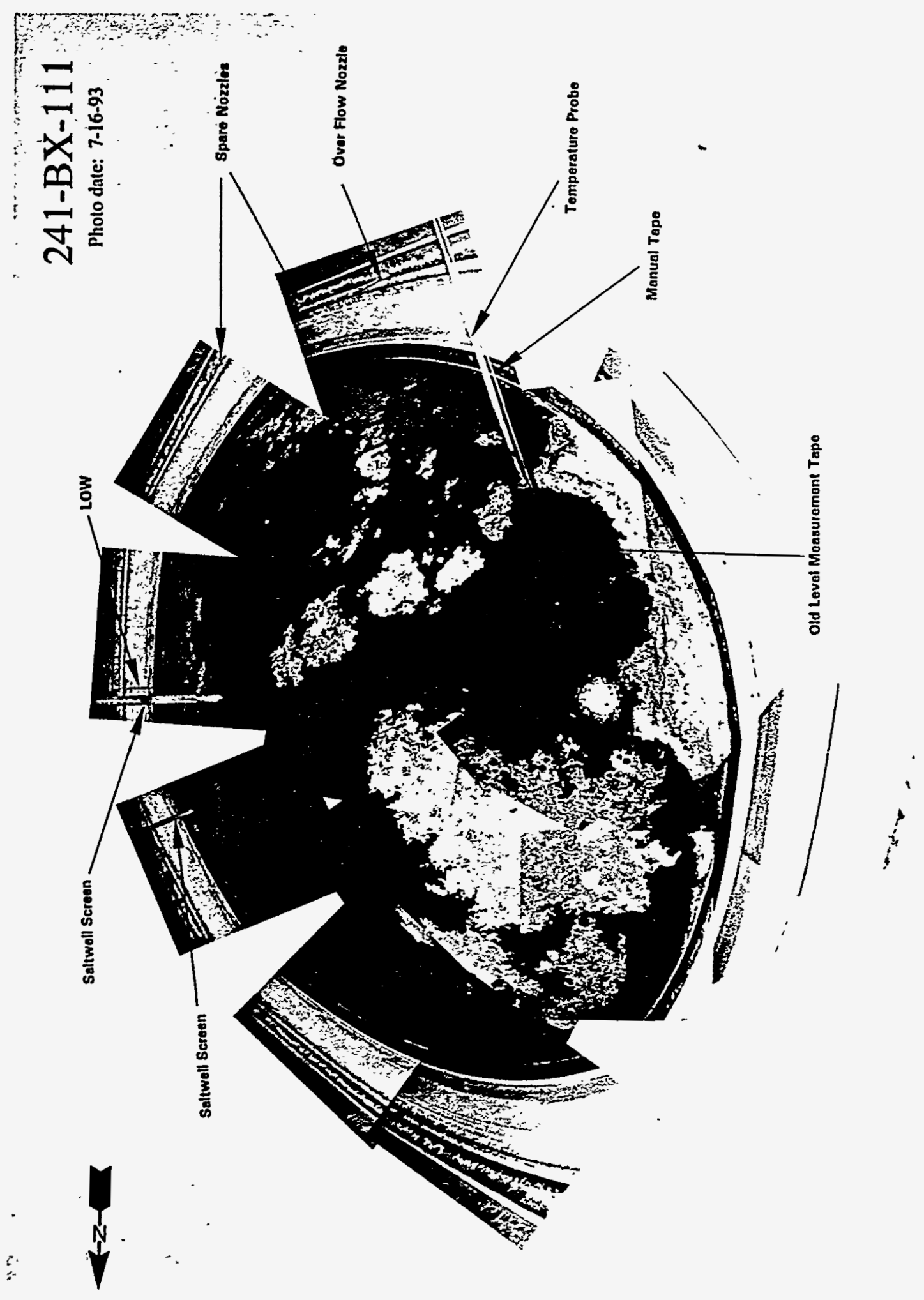


WHC-SD-WM-ER-349, Rev. 0

5.12 Tank 241-BX-112.

5.12.1 241-BX-112 Tank History

5.12.1.1 Waste History Tank 241-BX-112

Tank 241-BX-112 was filled with first-cycle waste during 1951. The tank was declared inactive in 1977. A level adjustment was made in November 1978. Interim stabilization was completed after saltwell pumping in September 1980. Another level adjustment was made in September 1990. (See sketch.ES-TKS-E38 for a graphical representation of the Tank 241-BX-112 level history.)

\subsection{2 .1 .2 Temperature History $241-\mathrm{BX}-112 \ldots \ldots$}

The single thermocouple tree in Tank 241-BX-112 contains 14 thermocouple probes to record temperature data. The mean temperature of the first data recorded for thermocouples 1 through 12 was $14^{\circ} \mathrm{F}$. A sum of the squares regression line fit for the first 12 thermocouples shows a slight temperature increase with a moderate amount of variability. The median temperature is $64^{\circ} \mathrm{F}$ with a minimum of $49^{\circ} \mathrm{F}$ and a maximum of $90^{\circ} \mathrm{F}$. Refer to the supporting document for a more thorough review of the temperature data (Brevick 1994).

\subsubsection{Integrity of Tank 241-BX-112}

Tank 241-BX-112 is categorized as sound and is interim stabilized and partially isolated. The in Tank $241-B X-112$ surface level is monitored with a Food Instrument Corporation gauge through riser 8 . A figure that graphically represents the surface level measurements from January 1991 to the present can be found in the supporting documents (Brevick 1994). The surface level for the past 3 years indicates a decreasing trend during 1993. The readings range from 55.4 to 55.3 in. during the fourth quarter of 1992 and steadily decrease to 55 in. during the fourth quarter of 1993.

Five drywells are identified for tank 241-BX-112, none of which are considered active.

\subsubsection{Current Status of Tank 241-BX-112}

Tank 241-BX-112 entered service in 1950 and currently stores 165,000 gal of waste. The waste is comprised of 1,000 gal of supernatant; $32,000 \mathrm{gal}$ of unknown waste; $132,000 \mathrm{gal}$ of sludge; and no saltcake with $2,000 \mathrm{gal}$ of pumpable liquid remaining. The tank is identified as a low heat load tank, is passively ventilated, and is categorized as sound with interim stabilization and partial interim isolation completed. Tank $241-\mathrm{BX}-112$ is third in the three-tank cascade series. Tank 241-BX-112 cascades to Tank 241-BY-110. The following plan view and tank cross section depict the approximate waste level and riser configuration: Tank 241-BX-112 has 9 risers and 12-in. risers nos.2, 3 and 7 are available for use. 
5.12.2.1 Inventory estimate 241-BX-112

The following tank layer volume approximation was derived from the Los Alamos National Laboratories Waste Status and Transaction Record Summary (Agnew 1994). The estimated inventory of Tank 241-BX-112 is also presented.

5.12 .2 .2 In-Tank Photograph 241-BX-112

The Tank 241-BX-112 photo shows exposed solids with pools of dark yellow translucent Iiquid. The tank waste is approximately 4.5 ft deep.

5.12 .3 Synopsis Tank 241-BX-112

(To be completed.) 
$-\cdot$

WHC-SD-WM-ER-349 ReV. 0

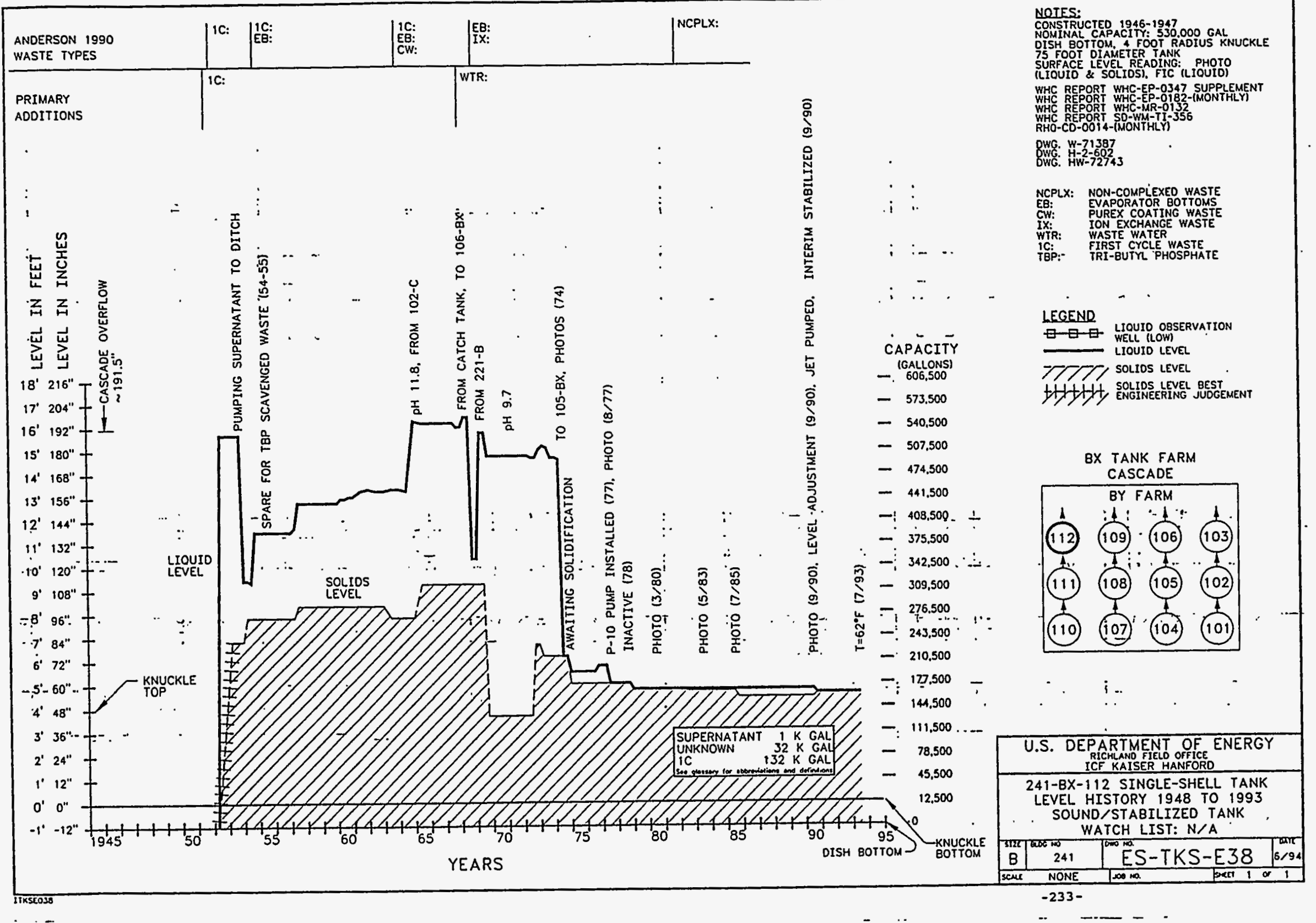


WHC-SD-WM-ER-349， Rev. 0

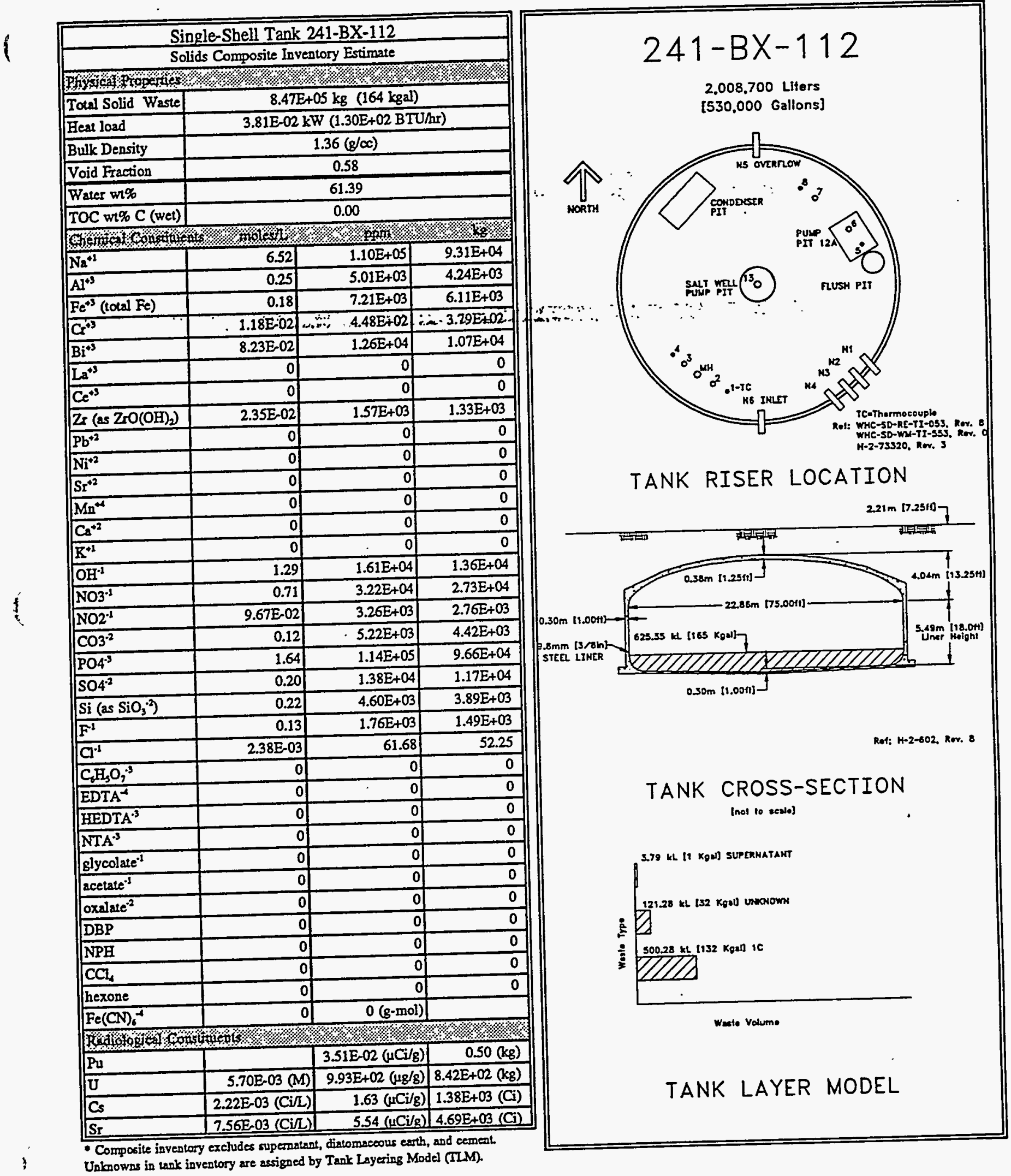




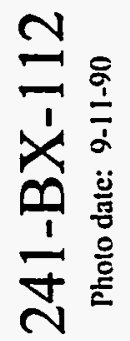

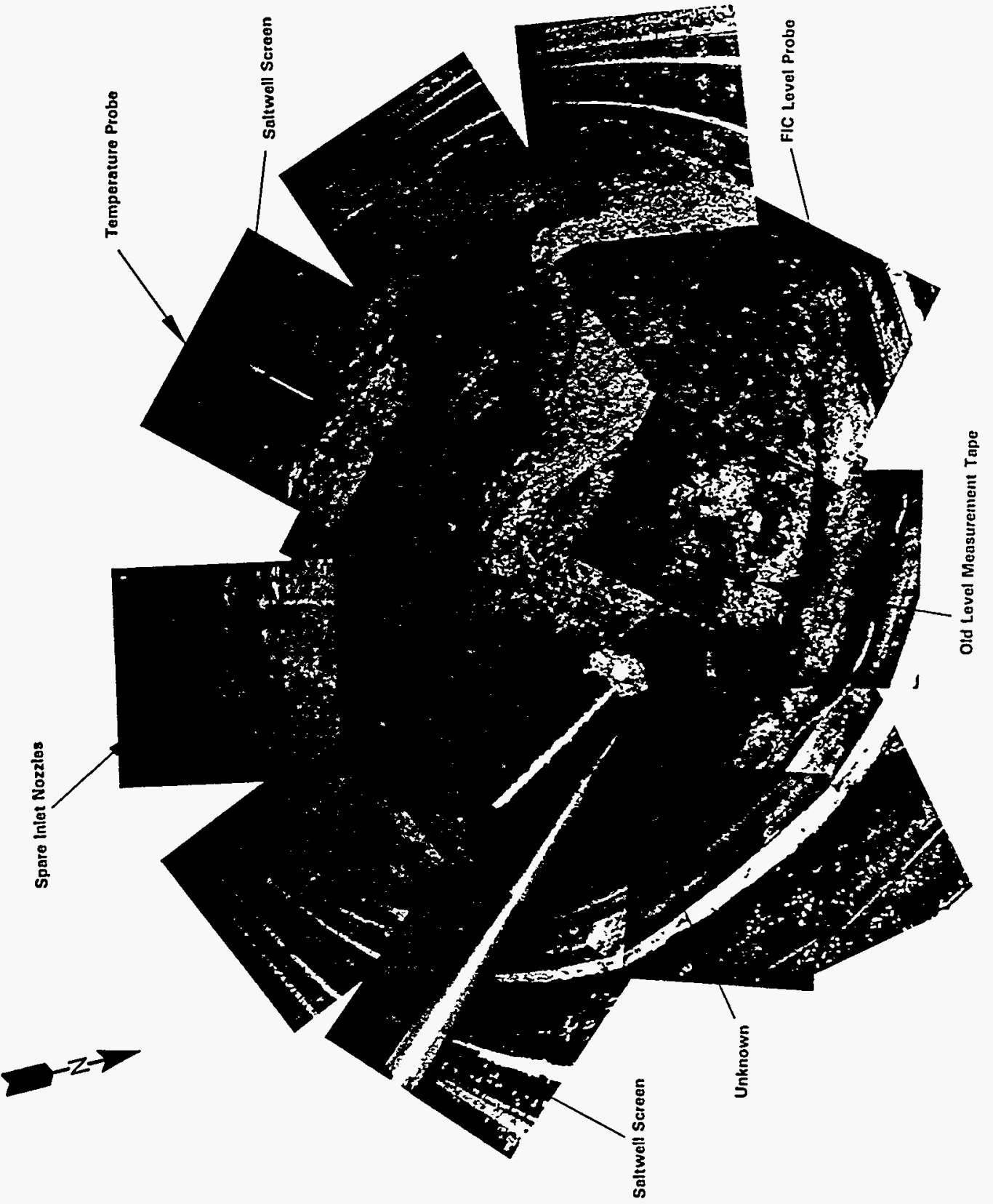


足
紊
音
至 


\subsection{BY Tank Farm}

6.0.1 BY Tank Farm History

The BY Tank Farm is located in the north-central end of the 200East exclusion area, east of Baltimore Avenue. The BY Tank Farm was constructed for the operating contractor, General Electric Company, during 1948 and 1949: Because the BY Tank Farm is a modified B Tank Farm design, the tanks are considered second generation. The BY Tank Farm contains twelve 100 series; 758,000-gal; 75-ft diameter singleshell tanks with an operating depth of $23 \mathrm{ft}$. The tanks are covered with approximately $8 \mathrm{ft}$ of overburden. The riser pattern is modified to gain more uniform access to the tank interior. The tanks were designed

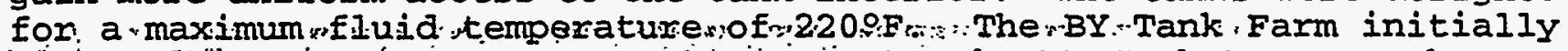
operated to back up the BX Tank Farm. In the BY Tank Farm, tanks are connected in a three-tank cascading series. The BY tanks are connected to the end tanks of the BX Tank Farm. The cascade overflow height is approximately 272 in. from the tank bottom.

The 1993 color aerial photograph of the BY Tank Farm shows the tank orientation and a north arrow. The arrows between the tanks represent the cascade overflow lines and the flow direction. 


\section{BY Tank Farm}

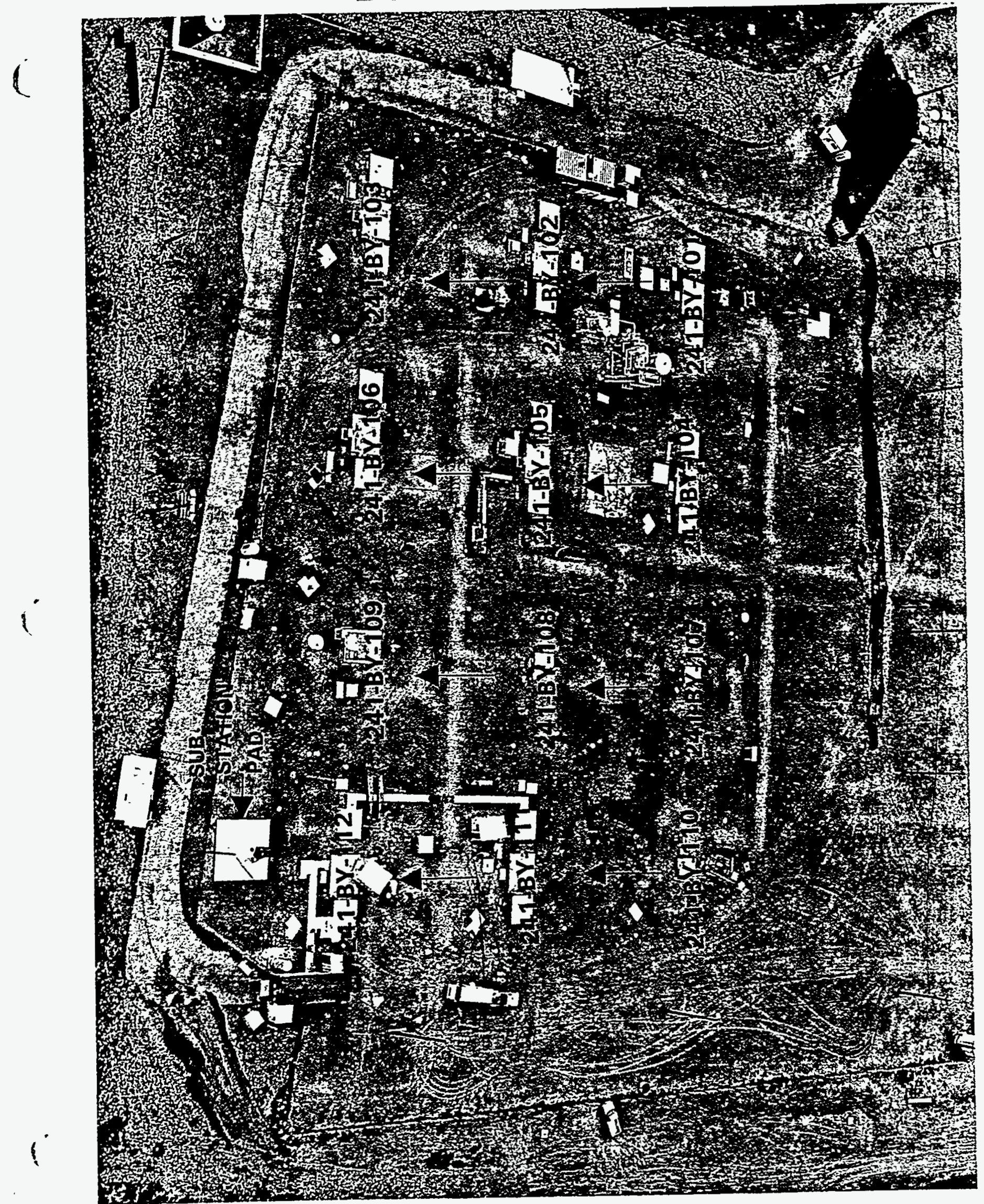




\subsubsection{BY Tank Farm Waste History}

B Plant metal wastes were stored in Tanks 241-BY-101 through -106 after the BX Tank Farm was full. Tanks 241-BY-107 through - 110 received $B$ Plant first-cycle waste and U Plant waste. Tanks 241-BY-111 and -112 were used to store metal waste for a short time. Tanks 241-BY-101, 103, and -111 received ferrocyanide wastes from the other BY tank transfers. Tank 241-BY-112 received a direct transfer from U Plant in 1957.

The sluicing operations program began in January 1954 and was completed by August 1955. The sluicing campaign had two objectives: uranium recovery and in-tank solidification preparation. Tanks within the BY.Tank.Farm were. used as. feed, staging or.. evaporator bottoms waste

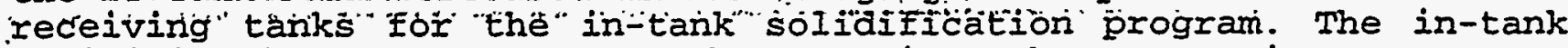
solidification program operated as an in-tank evaporation system to concentrate the waste. Tanks 241-BY-101 through $-106,-111$, and -112 were involved in sluicing operations between 1954 and 1955 .

The in-tank solidification program operated in two stages. Stage one involved placing an in-tank solidification unit in Tank 241-BY-102. The first in-tank solidification unit operated from March 1945. until August 1971 when it became a cooler for unit 2. The second in-tank solidification unit was used in conjunction with unit 1 as a cooler for Tank 241-BY-112 from August 1971 until both units were shut down in June 1974. Because of the large amount of saltcake waste created from the in-tank solidification units in the BY Tank Farm, all the BY Farm tanks were saltwell pumped.

Ferrocyanide scavenging waste was sent to the BY Tank Farm. The campaign was designed to recover strontium and cesium from metal waste. Tanks 241-BY-106, -107, -108, and -110 were used as primary settling tanks for scavenged waste, and tanks 241-BY-104 and -105 were used as settling tanks for accumulated scavenged sludge.

\subsubsection{BY Tank Farm Temperature History}

Most tanks within the BY Tank Farm have at least one thermocouple tree. Tanks 241-BY-102 and -109 do not have thermocouple trees in place. Tanks 241-BY-104, -105, -110, -111, and -112 have two thermocouple trees. Readings from tanks 241-BY-102 and -109 are not available between 1980 and 1991 indicating that the thermocouple trees may have been removed because no trees are indicated in the riser configuration document; however, readings resume in late 1991 or 1992 . Tanks 241-BY-101, -103 through -108, and -110 through -112 are former or current Ferrocyanide Watch List tanks and have a weekly temperature reading requirement. The other tanks have a semiannual temperature monitoring requirement.

\subsubsection{BY Tank Farm Integrity}

The twelve 750,000 gal tanks in the BY Tank Farm are out of service. As of JuIY 1993, Tanks 241-BY-101, 102, 104, 110, 111, and 
112were categorized as sound and Tanks 241-BY-103, 105, 106, 107, 108 were categorized as assumed leakers.

With the exception of Tank 241-BY-108, the tanks in the BY Tank Farm have liquid observation wells to monitor the interstitial liquid level. The interstitial liquid levels are monitored weekly with a neutron probe and on request with a gamma probe. The maximum deviations from the established baseline are a 0.3 -ft increase and a 0.4 -ft decrease.

Surface level monitoring for manual measurement devices in the BY Tank Farm is conducted daily or quarterly depending on the tank.

The BY Tank Farm:has :70.1eak:detection wells (i... e:., drywells) that were drilled from 1949 to 1974. Five are not tank-specific, and drywells 22-00-02 and 22-00-03 currently have readings greater than the $50 \mathrm{c} / \mathrm{s}$ background radiation. The drywells in the BY Tank Farm are monitored on a monthly, yearly, or on request basis with scintillation or Geiger-Mueller probes. Drywells associated with assumed leaking tanks are monitored for migration of contamination and the criteria limits do not apply except where new radiation peaks occur.

The following BY Tank Farm layout includes the peak drywell information, tank integrity, and tank status information. The drywell information is based on summarized data prior to 1987 and data collected from January 1990 to the present.

\subsubsection{Current Status of BY Tank Farm}

Nine tanks in the BY Tank Farm are identified on the Ferrocyanide Watch List. Tanks 241-BY-103, -104, -105, -106, -107, -108, -110, -111, and -112 were added to the list officially in January 1991 and have been declared unreviewed safety questions because their explosion potential exceeds previously reported safety analysis consequences. Ferrocyanide Watch List tanks are monitored for temperature. on a weekly basis. Tank 241-BY-101 was removed from the Ferrocyanide Watch List recently and is monitored on a weekly basis. The total volume of waste in the BY Tank Farm is $4,744,000 \mathrm{gal}: 3,704,000 \mathrm{gal}$ of saltcake; $102,000 \mathrm{gal}$ of unknown solids; and 938,000 gal of sludge. 

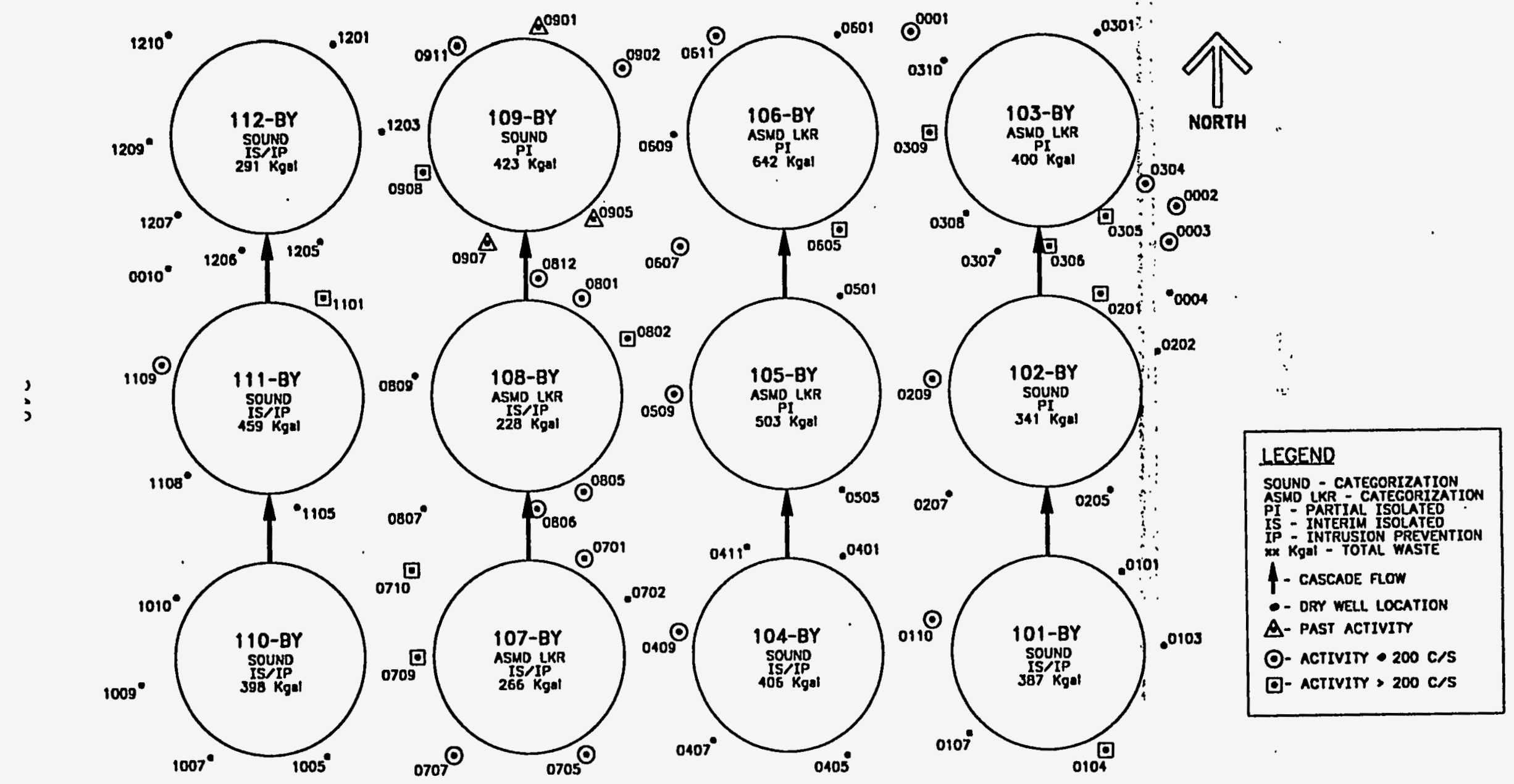

$$
\text { 241-BY FARM }
$$


WHC-SD-WM-ER-349, ReV. 0

6.1 Tank 241-BY-101

6.1.1 241-BY-101 Tank History

6.1.1.1 Waste History Tank 241-BY-101

Tank 241-BY-101 filled with metal waste from the Tank 241-BX-103 cascade overflow between March 1950: and the first quarter of 1951. The tank was saltwell pumped in the first and second quarters of 1977, and was declared inactive in the first quarter of 1978. Primary stabilization was completed in May 1980 and a level adjustment was made in April 1982. The tank was saltwell pumped, was declared interim stabilized, and had a level adjustment made in May 1984. Iiquid observation. well. data...that. represent...interstitial... levels. have been plotted." Ain engineering judgement was made-prior'to-March 1986. After interim stabilization pumping, the interstitial liquid equalizes in the tank. (See sketch ES-TKS-E39 for a graphical representation of the Tank 241-BY-101 level history.)

\subsubsection{Temperature History 241-BY-101}

The single thermocouple tree in Tank 241-BY-101 has 14 thermocouple probes to record temperature data. The mean temperature of the first daily recorded readings was $30^{\circ} \mathrm{F}$. A sum of the squares regression line fit for the data shows a temperature decrease with a moderate amount of variability. An annual temperature undulation is apparent after 1989. The median temperature is $71.2^{\circ} \mathrm{F}$ with a minimum of $43^{\circ} \mathrm{F}$ and a maximum of $115^{\circ} \mathrm{F}$. Refer to the supporting document for a more thorough review of the temperature data (Brevick 1994).

\subsubsection{Integrity of Tank 241-BY-101}

Tank 241-BY-101 is categorized as sound and is interim stabilized with intrusion prevention completed. The Tank 241-BY-101 surface level is monitored quarterly with a manual tape through riser. 5 . A figure that graphicaliy represents the surface level measurements from January 1991 to the present can be found in the supporting documents (Brevick 1994). The Tank 241-BY-101 surface level monitoring is out of compliance. The last readings were taken in June 1993. The surface level plot before this time indicates fluctuating readings ranging between 144 and 141 in.

The Iiquid observation well for Tank 241-BY-101 is located in riser 9A. The tank is monitored weekly with a neutron probe and on request with a ganma probe to determine the interstitial liquid level. Sketch ES-TKS-E39 is a graphical representation of the liquid observation well data.

Five drywells are identified for tank 241-BY-101. Graphical representations of the data for each active drywells from January 1990 to the present can be found in the supporting document (Brevick 1994). Each graph includes the peak c/s (some wells have multiple peaks), the depth at which the peak occurred, and the date of the reading. 


\subsubsection{Current Status of Tank 241-BY-101}

Tank 241-BY-101 entered service in January 1950 and currently stores $387,000 \mathrm{gal}$ of waste. The waste is comprised of $350,000 \mathrm{gal}$ of saltcake; 37,000 gal of unknown waste, with no supernatant or pumpable liquid remaining. The tank is categorized as sound with interim stabilization and intrusion prevention completed. Tank 241-BY-101 is equipped to cascade to Tank 241-BY-102 and is first in the three-tank cascade series. The following plan view and tank cross section depict the approximate waste level and riser configuration. Tank 241-BY-101 has 18 risers and 12-in. riser no.10A is available for use.

\subsubsection{Inventory estimate 241-BY-101}

The follöwing tank Iayèr volüme approximation was derived from the Los Alamos National Laboratories Waste Status and Transaction Record Summary (Agnew 1994). The estimated inventory of Tank 241-BY-101 is also presented.

\subsubsection{In-Tank Photograph 241-BY-101}

The Tank 241-BY-101 photo shows a saltcake surface and no 1iquid. The saltcake appears to be yellow to grey. The waste measures approximately 11.5 ft deep. The photo show solids clinging to the equipment from the liquid being pumped out which lowers the surface level. The in-tank solidification prototype air heater circulator is visible in the top right of the layout. The debris shown next to the liquid observation well is cutoff equipment. One possible reason why the equipment would be present is that a radiation limit is imposed on the equipment being removed. When the limit is reached, the equipment remaining inside the tank is cut off and allowed to fall back into the tank.

6.1 .3 Synopsis Tank 241-BY-101

(To be completed.) 


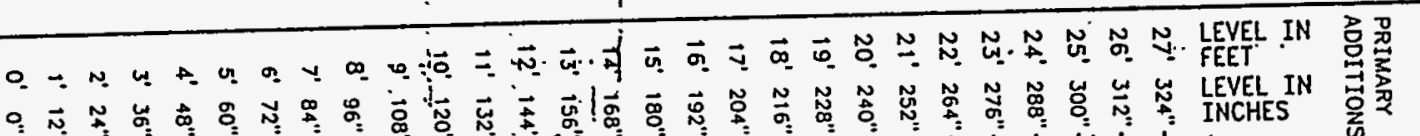

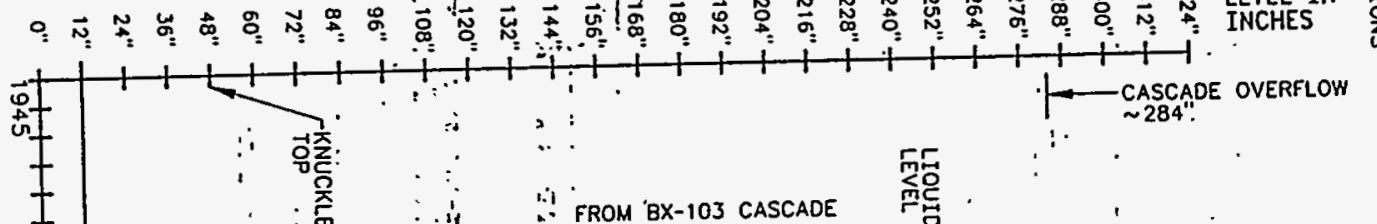
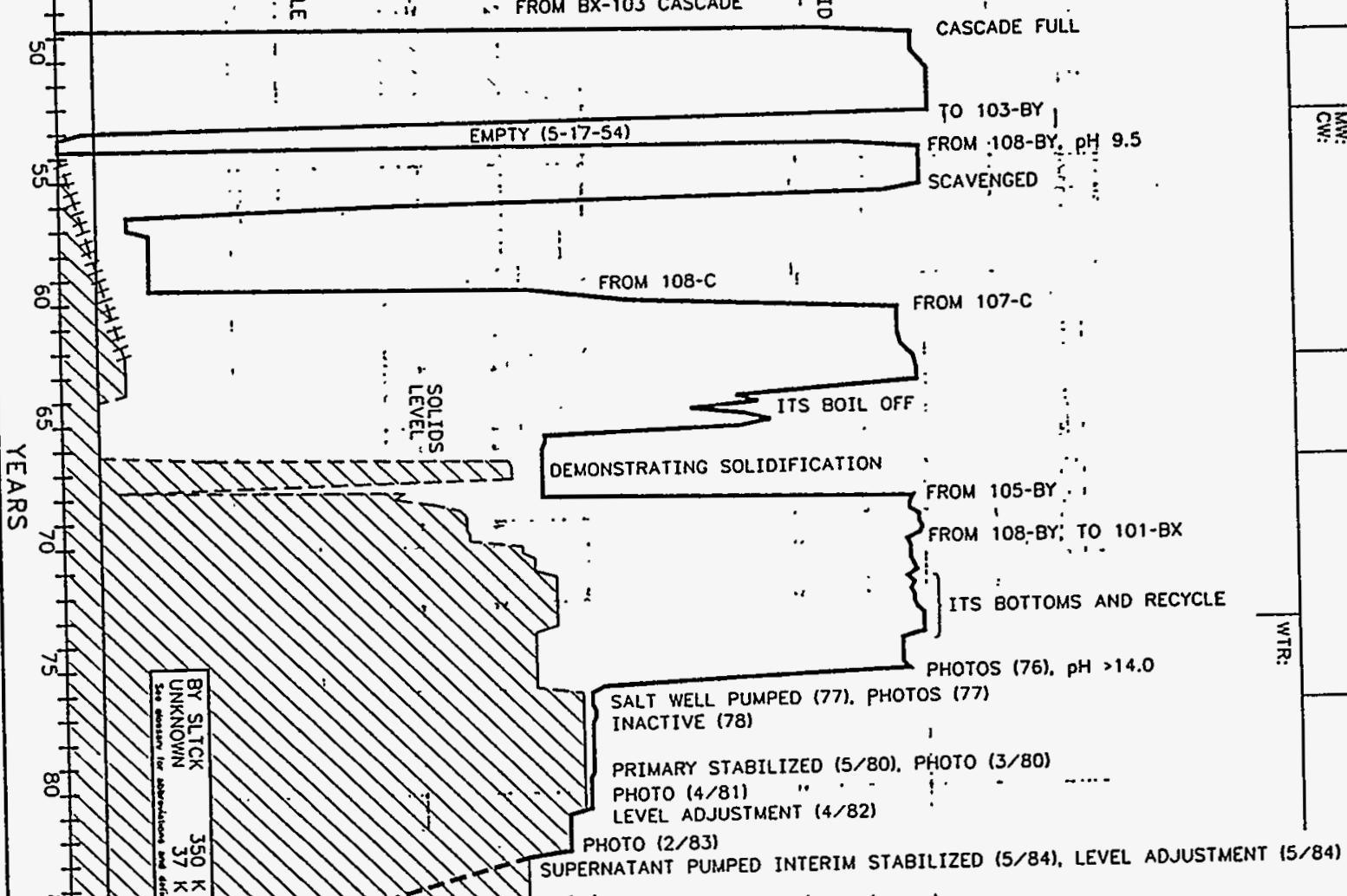

of

A)

击

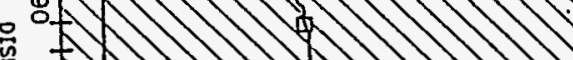

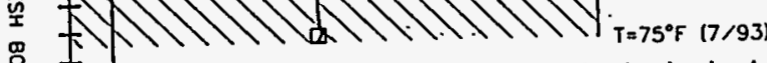

严

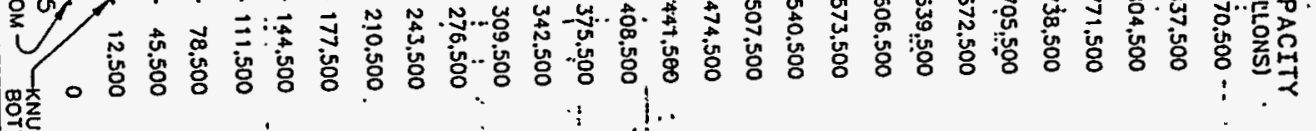

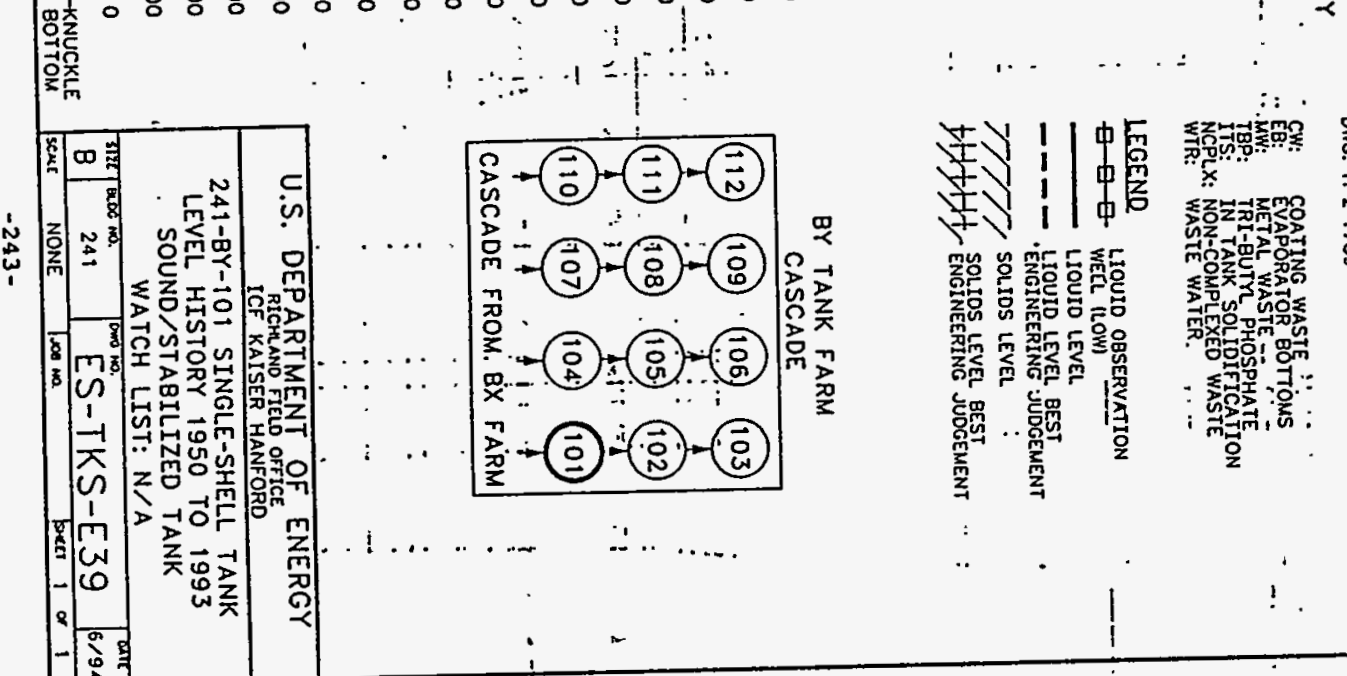




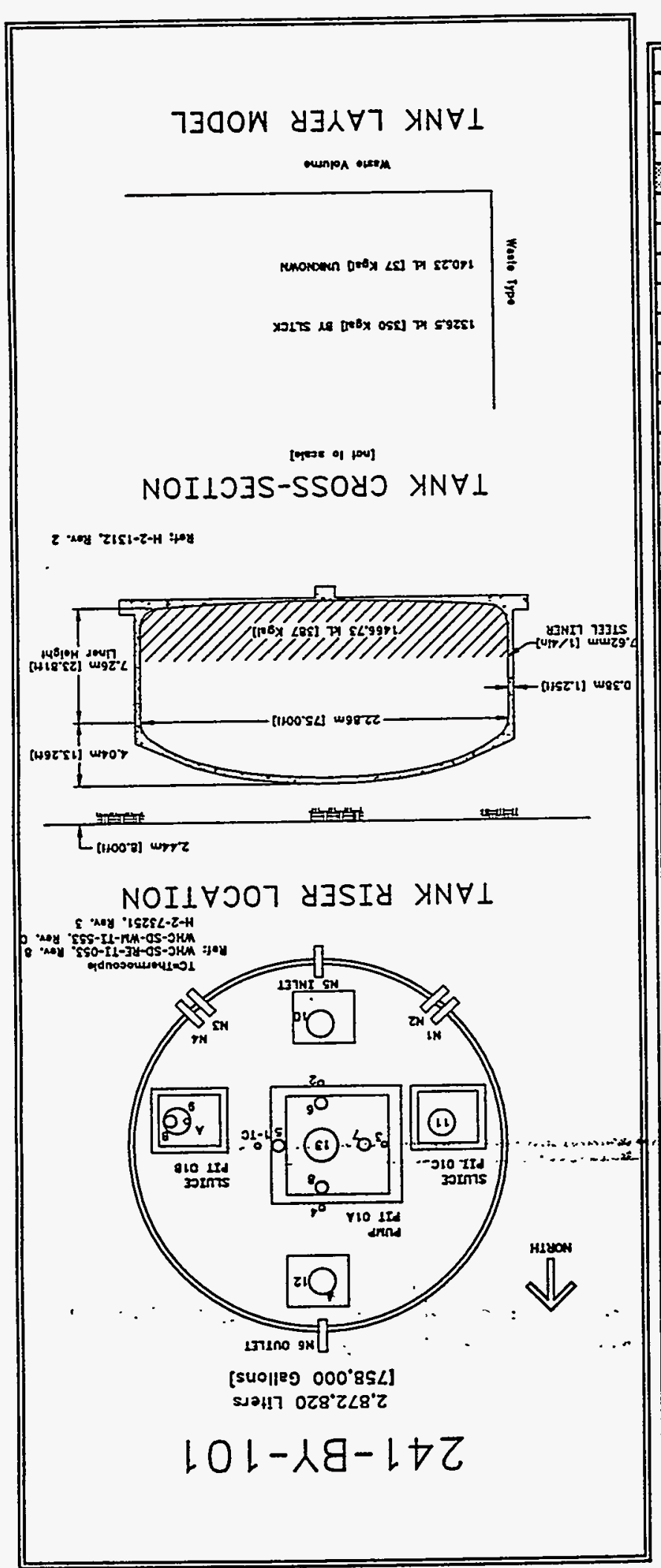

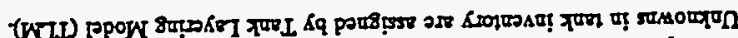

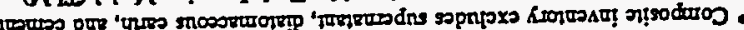

\begin{tabular}{|c|c|c|c|}
\hline (D) $50+\sqrt{25} 5 b$ & $(8 / 50)+602$ & (T/ग) 20 दूI & IS \\
\hline (D) $50+g 66^{\circ} b$ & $(8 / 50) 20+9522$ & $(T / D) ~ \downarrow \varepsilon 0$ & 5 \\
\hline$(8 x)$ t0+ggr. & $(8 / \delta \pi)$ t0+glt I & (W) 20 व $\$ \varepsilon: 6$ & $\Omega$ \\
\hline$\left(8 \times 10^{\circ} 0\right.$ & 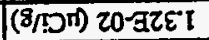 & & \\
\hline
\end{tabular}

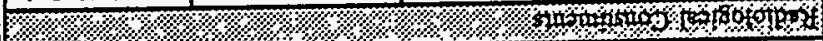

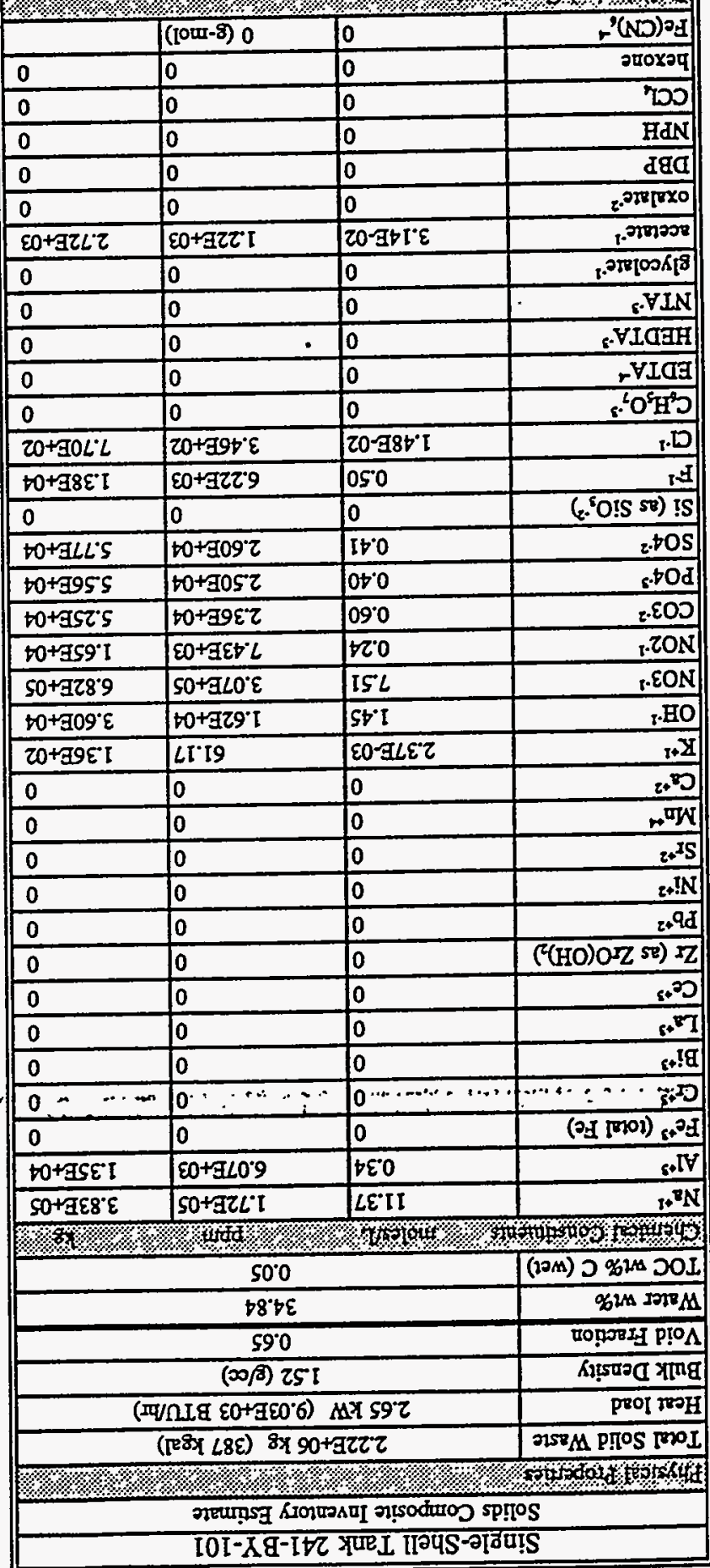




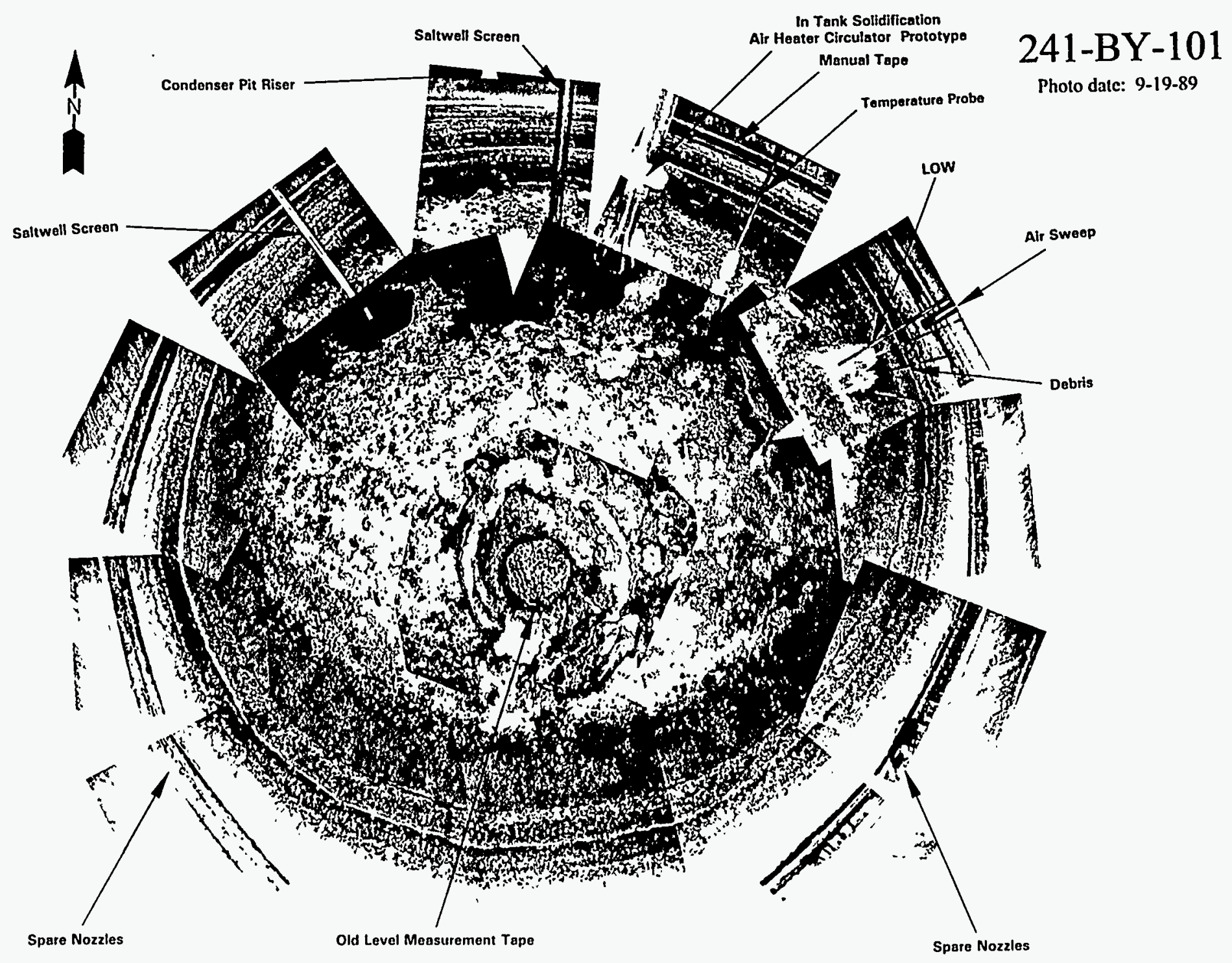


WHC-SD-WM-ER-349, Rev. 0

6.2 Tank 241-BY-102

\subsubsection{1-BY-102 Tank History}

\subsubsection{Waste History Tank. 241-BY-102}

Tank 241-BY-102 began to operate in September 1950 when it received metal wastes from the Tank 241-BY-10-1 cascade overflow. The tank was deactivated in the third quarter of 1976 and is.considered a sound tank awaiting interim stabilization. The tank was partially interim isolated in December 1982. The liquid was jet pumped on June 13, 1991. The draw down from pumping is noticeable in the solid and liquid observation well waste levels. Solids level adjustments were made in June 1978, March 1982, March 1983, and April through August 1991. The salt cake in the tank"results from 'using'the'tanks fom In-Tank-Solidification Unit Number 1 (ITS 1). (See sketch ES-TKS-E40 for a graphical representation of the Tank 241-BY-102 level history.)

\subsubsection{Temperature History 241-BY-102}

The single thermocouple tree in Tank 241-BY-102 had 14 thermocouple probes to record temperature data. The mean temperature of the first data recorded for thermocouples 1 through 10 was $47^{\circ} \mathrm{F}$. A sum of the squares regression line fit for the data shows a temperature increase with a large amount of variability. The median temperature is $71^{\circ} \mathrm{F}$ with a minimum of $25^{\circ} \mathrm{F}$ and a maximum of $125.6^{\circ} \mathrm{F}$. Refer to the supporting document for a more thorough review of the temperature data (Brevick 1994).

\subsubsection{Integrity of Tank 241-BY-102}

Tank 241-BY-102 is categorized as sound and is partially isolated. The Tank 241-BY-102 surface level is monitored daily with a manual tape through riser 5. A figure that graphically represents the surface level measurements from January 1991 to the present can be found in the supporting documents (Brevick 1994): The waste level dropped in the midale of 1991 which corresponds with the jet pumping effort conducted in June 1991. Since the current baseline was established on November 8, 1991, the surface level has remained steady between 81 and 81.25 in.

The Iiquid observation well for Tank 241-BY-102 is located in riser 1. The tank is monitored weekly with a neutron probe and on request with a gamma probe to determine interstitial liquid levels. The maximum deviations from the established baseline are a 0.3 -ft increase and a 0.4 -ft decrease. Sketch ES-TKS-E40 has a graphical representation of the liquid observation well data.

An occurrence report was issued in August 1974 for Drywell 22-0201. Increased radiation levels were attributed to horizontal migration of preexisting contamination from Tank 241-BY-103. An off-normal occurrence 10-day report was written on July 3, 1991. Drywells around Tanks 241-BY-103 and -108 showed an increase in radiation levels while waste was being transferred from Tanks 241-BY-102 and -109 to the 
WHC-SD-WM-ER-349, Rev. 0

double-contained receiver Tank 244-BX. The drywells detected waste in the transfer lines. Transfer line flushing verified that the lines were not leaking because the radiation levels decreased.

Five drywells are identified for tank 241-BY-102. Graphical representations of the data for each active drywell from January 1990 to the present can be found in the supporting document (Brevick 1994). Each graph includes the peak c/s (some wells have multiple peaks), the depth at which the peak occurred, and the date of the reading.

\subsubsection{Current Status of Tank 241-BY-102}

Tank 241-BY-102 entered service in July of 1950 and currenty stores 341,000 gal of. non-complexed..waste. The waste, is comprised of $312 ; 000^{-g a l}$ of saltcake;-29;000; gal-ofunknown waste; no supernatant or sludge, with $22,000 \mathrm{gal}$ of pumpable interstitial liquid remaining. The tank is identified as a Low Heat Load tank, is passively ventilated, and is categorized as sound with partial interim isolation completed. Tank 241-BY-102 is equipped to cascade to 241-BY-103 and is second in the three-tank cascade series. The following plan view and tank cross section depict the approximate waste level and riser configuration. Tank 241-BY-102 has 17 risers and $12-i n$. risers nos.8 and $10 \mathrm{~A}$ are available for use.

\subsubsection{Inventory estimate 241-BY-102}

The following tank layer volume approximation was derived from the Los Alamos National Laboratories Waste Status and Transaction Record Summary (Agnew 1994). The estimated inventory of Tank 241-BY-102 is also presented.

\subsubsection{In-Tank Photograph 241-BY-102}

The Tank 241-BY-102 photo shows a yellow-grey to off-white saltcake surface surrounding a liquid pool in the center of the tank. The liquid is dark brown to black but is translucent. Approximately 341,000 gal of saltcake are in the tank which measures about 10 ft deep. In the top center of the layout, the in-tank solidification 1 air heater circulator is visible. Level adjustments have been made in september 1987 as a result of the photo.

6.2.3 Synopsis Tank 241-BY-102

(To be completed.) 


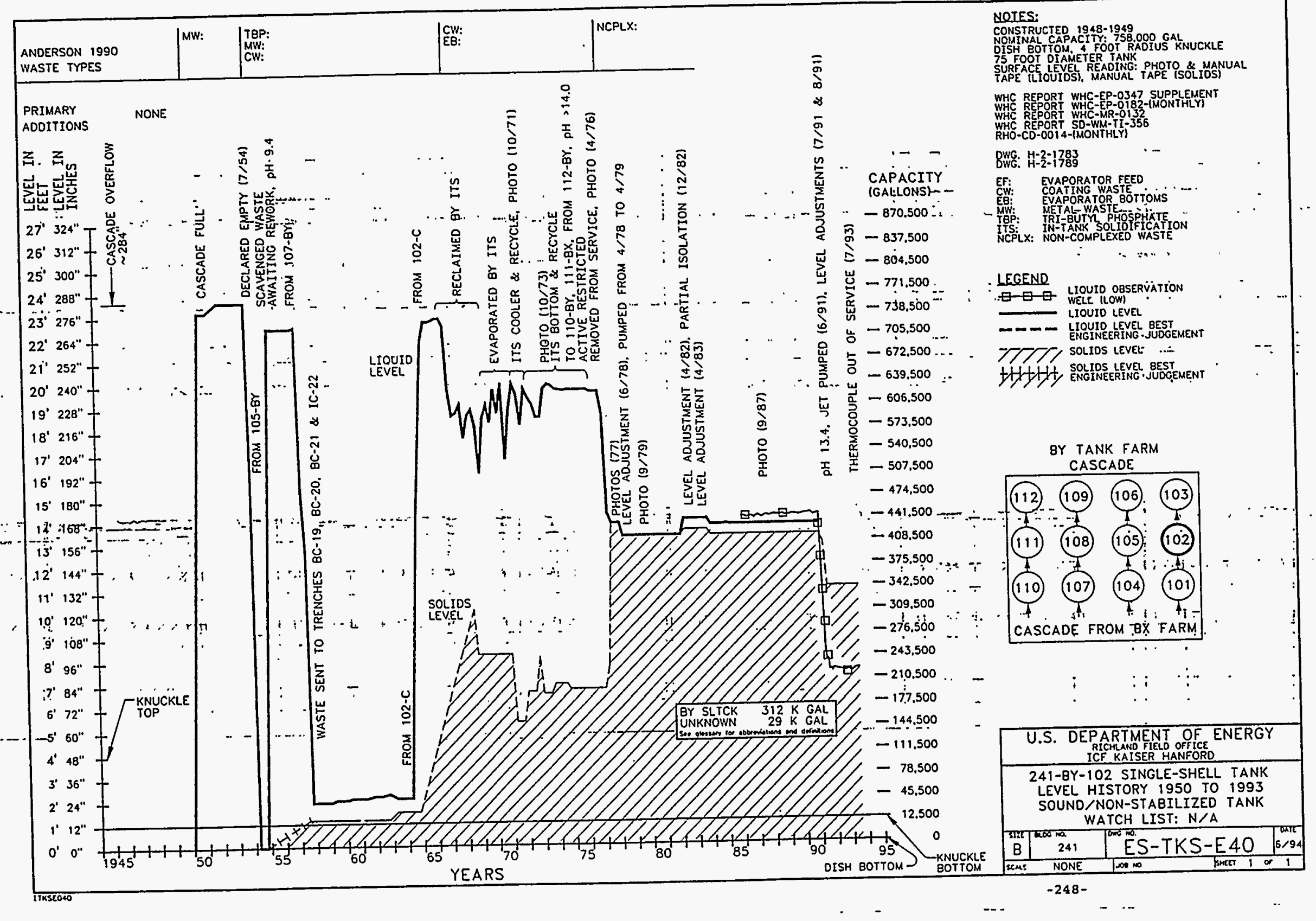


WHC-SD-WM-ER-349, Rev. 0

\begin{tabular}{|c|c|c|c|}
\hline \multicolumn{4}{|c|}{ Single-Shell Tank 241-BY-102 } \\
\hline \multicolumn{4}{|c|}{ Solids Composite Inventory Estimate } \\
\hline 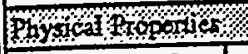 & & \%া \% \% \% & \\
\hline Total Solid Waste & \multicolumn{3}{|c|}{$1.88 \mathrm{E}+06 \mathrm{~kg}(330 \mathrm{kgal})$} \\
\hline Heat load & \multicolumn{3}{|c|}{$2.23 \mathrm{~kW}(7.63 \mathrm{E}+03 \mathrm{BTU} / \mathrm{hr})$} \\
\hline Bulk Density & \multicolumn{3}{|c|}{$151(\mathrm{~g} / \infty)$} \\
\hline Void Fraction & \multicolumn{3}{|c|}{0.67} \\
\hline Water wt\% & \multicolumn{3}{|c|}{34.28} \\
\hline TOC wt\% C (wet) & \multicolumn{3}{|c|}{0.05} \\
\hline \multicolumn{4}{|l|}{ 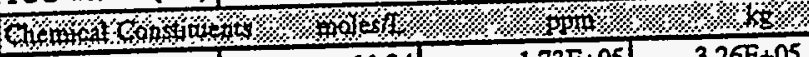 } \\
\hline \begin{tabular}{|l|l}
$\mathrm{Na}^{+1}$ & \\
\end{tabular} & 11.34 & $1.73 \mathrm{E}+05$ & $3.26 \mathrm{E}+05$ \\
\hline $\mathrm{Al}^{+3}$ & 0.36 & $6.38 \mathrm{E}+03$ & $1.20 \mathrm{E}+04$ \\
\hline $\mathrm{Fe}^{+3}($ total $\mathrm{Fe})$ & 0 & 0 & 0 \\
\hline$C^{+3}, \because \because \quad \therefore$ & $\because \because \cdots 0$ & $\because \cdots$ & $8: 2:$ \\
\hline $\mathrm{Bi}^{43}$ & 0 & 0 & 0 \\
\hline $\mathrm{La}^{+3}$ & 0 & 0 & 0 \\
\hline $\mathrm{Ce}^{+3}$ & 임 & o] & 0 \\
\hline $\mathrm{Zx}\left(\mathrm{as} \mathrm{ZrO}(\mathrm{OH})_{2}\right)$ & 0 & 이 & 0 \\
\hline $\mathrm{Pb}^{+2}$ & 이 & 0) & 0 \\
\hline $\mathrm{Ni}^{i^{2}}$ & 0 & 0 & 0 \\
\hline $\mathrm{Sr}^{+2}$ & 0 & 0 & 0 \\
\hline $\mathrm{Mn}^{+4}$ & 0 & 0 & 0 \\
\hline $\mathrm{Ca}^{42}$ & 0 & o & $\begin{array}{r}0 \\
\end{array}$ \\
\hline $\mathrm{K}^{41}$ & $2.48 \mathrm{E}-03$ & 64.29 & $1.21 E+02$ \\
\hline $\mathrm{OH}^{-1}$ & 1.37 & $1.55 \mathrm{E}+04$ & $2.91 E+04$ \\
\hline $\mathrm{NO3}^{-1}$ & 7.85 & $3.23 E+05$ & $6.08 \mathrm{E}+05$ \\
\hline $\mathrm{NO}^{2}{ }^{12}$ & 0.26 & $7.80 \mathrm{E}+03$ & $1.47 \mathrm{E}+04$ \\
\hline $\mathrm{CO}^{-2}$ & 0.52 & $2.06 \mathrm{E}+04$ & $3.88 \mathrm{E}+04$ \\
\hline $\mathrm{PO}^{.3}$ & 0.29 & $1.81 \mathrm{E}+04$ & $3.41 E+04$ \\
\hline $\mathrm{SO}^{\cdot 2}$ & 0.43 & $2.72 E+04$ & $5.12 E+04$ \\
\hline $\mathrm{Si}$ (as $\mathrm{SiO}_{3}{ }^{2}$ ) & 이 & 0 & 0 \\
\hline$F^{-1}$ & 0.52 & $6.53 E+03$ & $1.23 \mathrm{E}+04$ \\
\hline$a^{-1}$ & $1.55 \mathrm{E}-02$ & $3.64 \mathrm{E}+02$ & $6.86 \mathrm{E}+02$ \\
\hline $\mathrm{C}_{6} \mathrm{H}_{3} \mathrm{O}_{7}{ }^{-3}$ & 0 & 인 & 0 \\
\hline EDTA & 0 & 이 & 0 \\
\hline HEDTA ${ }^{-3}$ & 0 & 이 & 0 \\
\hline $\mathrm{NTA}^{-3}$ & 0 & 이 & 0 \\
\hline glycolate ${ }^{-1}$ & 0 & 0 & 0 \\
\hline acetate & $3.29 \mathrm{E}-02$ & $1.29 \mathrm{E}+03$ & $2.42 \mathrm{E}+03$ \\
\hline oxalaste-2 & 0 & 0 & 0 \\
\hline DBP & of & 0 & 0 \\
\hline NPH & 0 & 0 & 0 \\
\hline $\mathrm{CCl}_{4}$ & 0 & 요 & 0 \\
\hline hexone & 요 & 0 & 0 \\
\hline $\mathrm{Fe}(\mathrm{CN})_{6}{ }^{1}$ & o & $0(\mathrm{~g}-\mathrm{mol})$ & \\
\hline \multicolumn{4}{|c|}{ Re(CNA) } \\
\hline $\mathrm{Pu}$ & & 7.60E-03 ( $\mu \mathrm{Ci} / \mathrm{g})$ & $0.24(\mathrm{~kg})$ \\
\hline $\mathrm{U}$ & $6.35 \mathrm{E}-02(\mathrm{M})$ & $1.00 \mathrm{E}+04(\mu \mathrm{g} / \mathrm{B})$ & $1.89 \mathrm{E}+04(\mathrm{~kg})$ \\
\hline Cs & $0.36(\mathrm{Ci} / \mathrm{L})$ & $2.36 \mathrm{E}+02(\mu \mathrm{C} / \mathrm{g})$ & $4.45 \mathrm{E}+05(\mathrm{Ci})$ \\
\hline Sr & $1.77 \mathrm{E}-02(\mathrm{Ci} / \mathrm{L})$ & $11.72(\mu \mathrm{Ci} / \mathrm{g})$ & $2.21 \mathrm{E}+04(\mathrm{Ci})$ \\
\hline
\end{tabular}

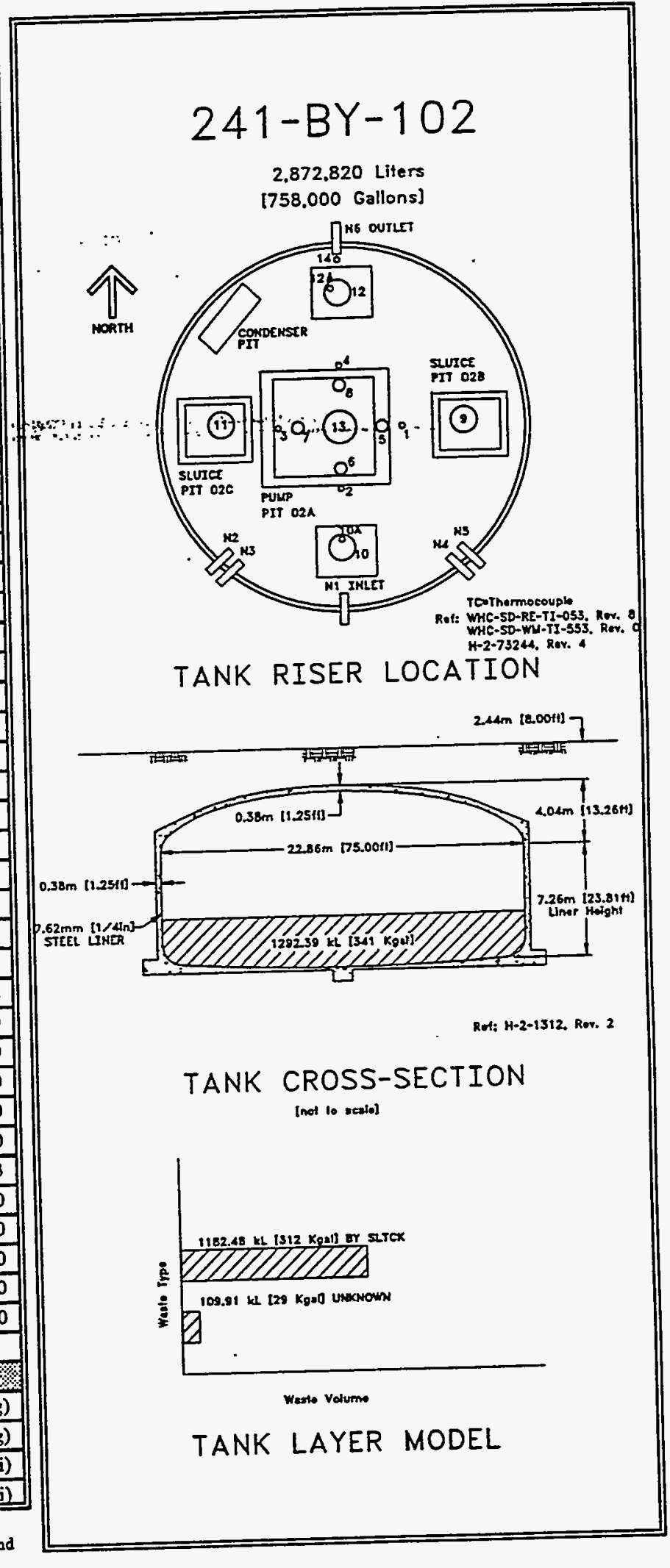

- Composite inventory exchudes supersatant, dia Tank Layering Model (TIM) and

therefore are not inchuded in the estimate. 


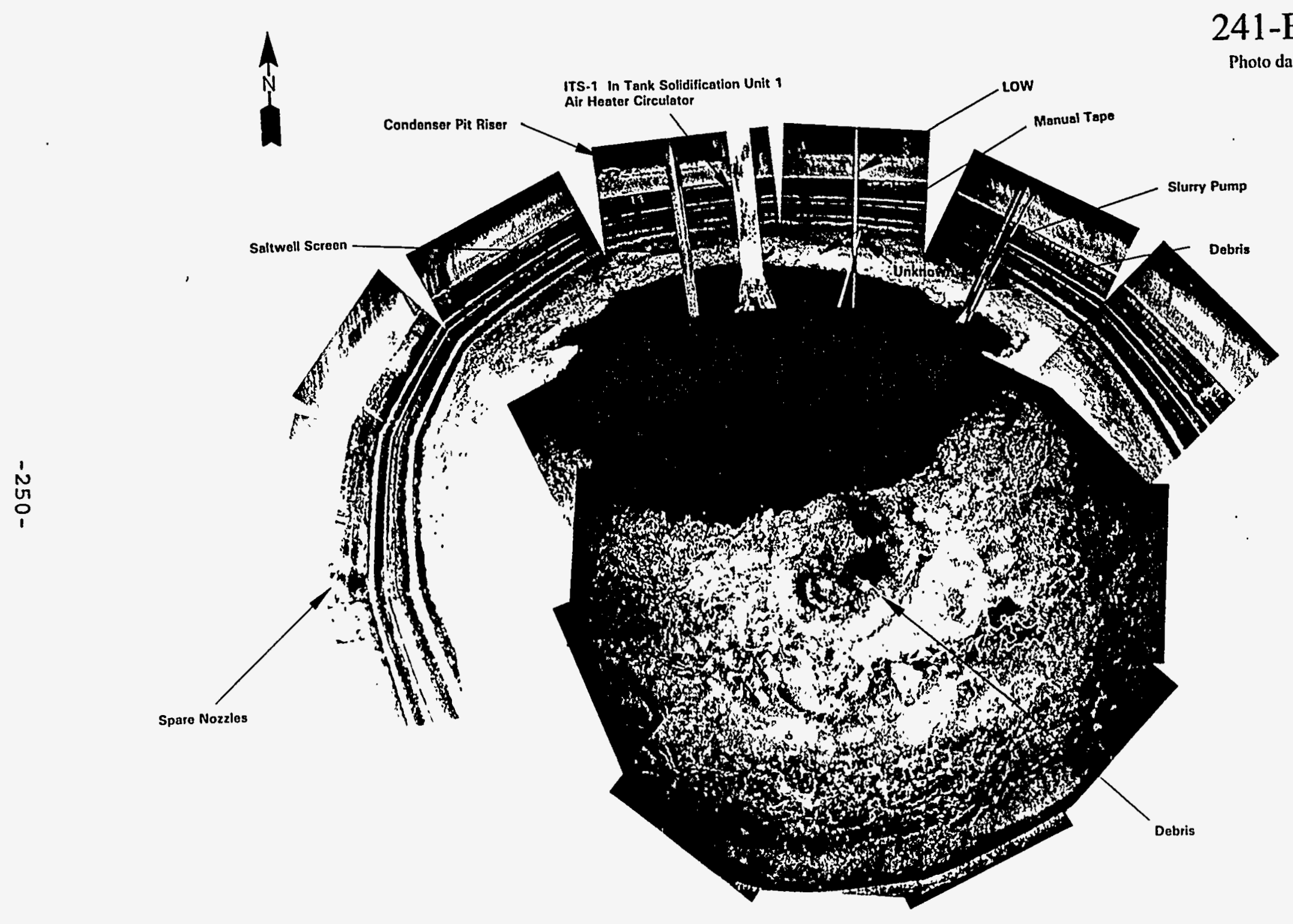




\subsubsection{1-BY-103 Tank History}

\subsubsection{Waste History Tank 241-BY-103}

Tank 241-BY-103 was filled with metal waste from Tank 241-BY-102 from October 1950 to. March 1951. The tank was declared an assumed leaker in 1973'with: a leak volume greater:than.5;000 gal.: A saltwell was installed in 1977. Primary stabilization was complete in September 1979 and a level adjustment was made in February 1980. Another level adjustment was made in March 1982 and partial isolation was completed in December 1982. A major level adjustment was made in september 1987 because, of ...jet pumping and another level adjustment. was. made in April

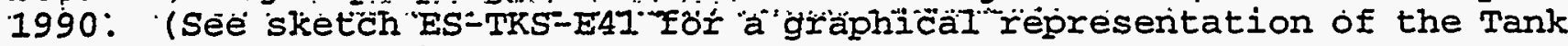
241-BY-103 level history.)

\subsubsection{Temperature History 241-BY-103}

The single thermocouple tree in Tank 241-BY-103 has 14 thermocouple probes to record temperature data. The mean temperature of the first data recorded for thermocouples 1 through 12 was $39^{\circ} \mathrm{F}$. A sum of the squares regression line fit for thermocouples 1 through 12 shows a slight increase in temperature with a large amount of variability. Annual temperature undulations are apparent in the data after January 1992. For this data set, the median temperature is $75^{\circ} \mathrm{F}$ with a minimum of $33.8^{\circ} \mathrm{F}$ and a maximum of $137^{\circ} \mathrm{F}$. Refer to the supporting document for a more thorough review of the temperature data (Brevick 1994).

\subsubsection{Integrity of Tank 241-BY-103}

Tank 241-BY-103 is categorized as an assumed leaker and is partially isolated. The surface level in Tank 241-BY-103 is monitored quarterly with a manual tape through riser 5. A figure that graphically represents the surface level measurements from January. 1991 to the present can be found in the supporting documents (Brevick 1994). The surface level plot indicates a decreasing trend with the surface level readings ranging between 151.75 and 150.75 in. during 1991 and decreasing to 149.5 to 147.75 in. during 1993. An occurrence report was issued in January 1990 due to water intrusion caused by rapid snow melt runoff through the pump pits.

The Tank 241-BY-103 liquid observation well for is located in riser 10A. 'The tank is monitored weekly with a neutron probe and on request with a gamma probe to determine interstitial Iiquid levels. The maximum deviations from the established baseline are a 0.3 -ft increase and a 0.4-ft decrease. Sketch ES-TKS-E41 has a graphical representation of the liquid observation well data.

Eight drywells are identified for tank 241-BY-103. Graphical representations of the data for each active arywell from January 1990 to the present can be found in the supporting document (Brevick 1994). Each graph includes the peak c/s (some wells have multiple peaks), the depth 
at which the peak occurred, and the date of the reading.

\subsubsection{Current Status of Tank 241-BY-103}

Tank 241-BY-103 entered service in November 1950 and currently stores $400,000 \mathrm{gal}$ of waste. The waste is comprised of $391,000 \mathrm{gal}$ of salt cake; 9,000 gal of sludge; and no saltcake with 137,000 gal of pumpable interstitial liquid remaining. The tank is identified on the Ferrocyanide watch List, is passively ventilated, and is categorized as an assumed leaker with partial interim isolation completed. Tank 241BY-103 is third in the three-tank cascade series. The following plan view and tank cross section depict the approximate waste level and riser configuration. Tank 241-BY-103 has 22 risers and three are available

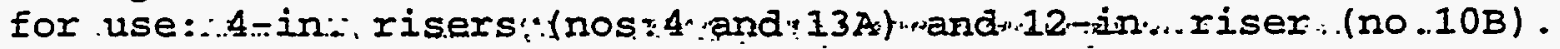

\subsubsection{Inventory estimate 241-BY-103}

The following tank layer volume approximation was derived from the Los Alamos National Laboratories Waste Status and Transaction Record Summary (Agnew 1994). The estimated inventory of Tank 241-BY-103 is also presented.

\subsubsection{In-Tank Photograph 241-BY-103}

The Tank 241-BY-103 photo shows an off-white to yellow-green saltcake surface with no evidence of liquid. The waste measures approximately $12 \mathrm{ft}$ deep. Conditions in the tank have resulted in level adjustments being made in April 1990 and August 1991 which is after the September 1989 photograph. Tank 242-BY-103 is on the Ferrocyanide Watch List.

\subsubsection{Synopsis Tank 241-BY-103}

(To be completed.) 


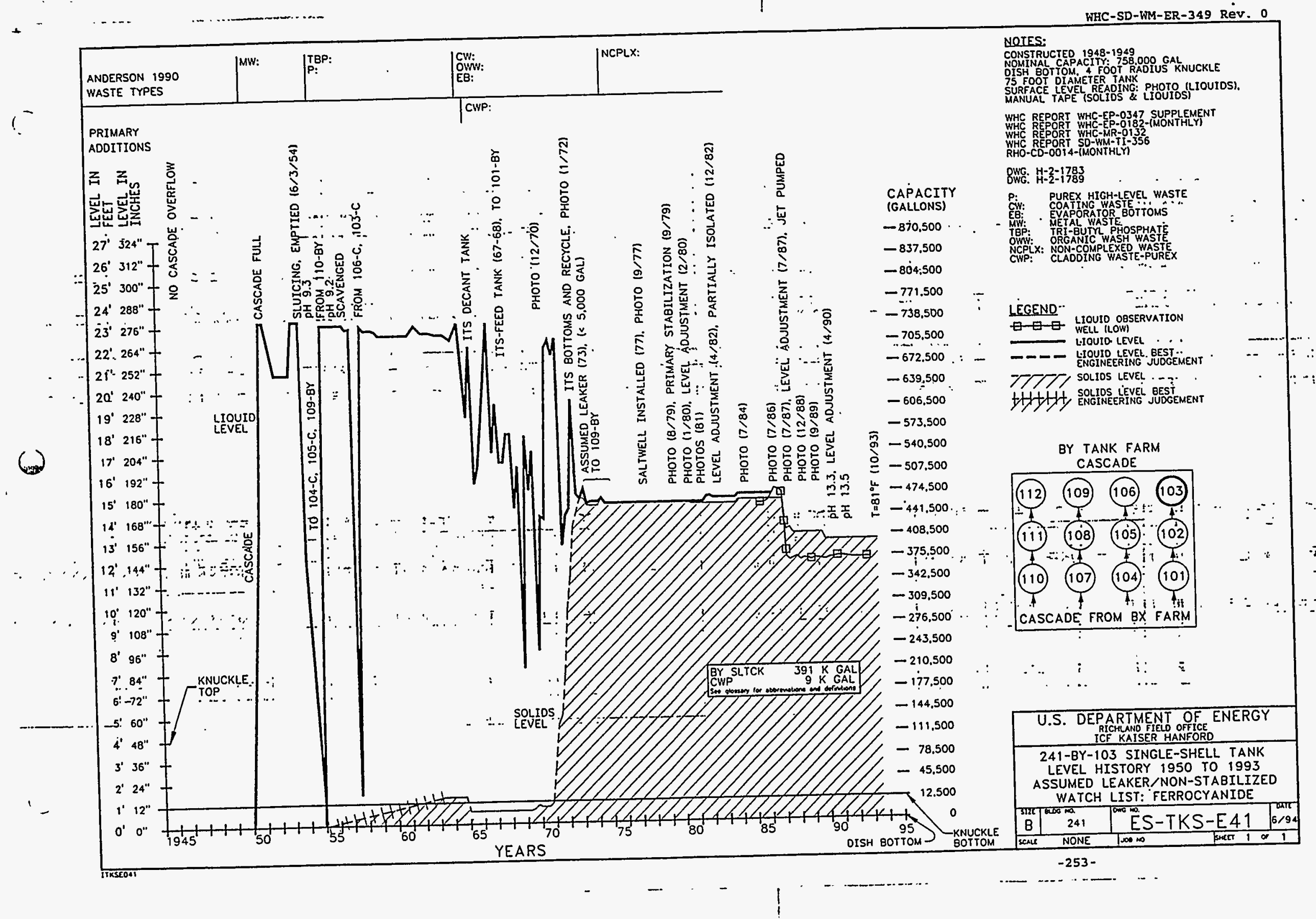




\begin{tabular}{|c|c|c|c|}
\hline \multicolumn{4}{|c|}{ Single-Shell Tank 241-BY-103 } \\
\hline \multicolumn{4}{|c|}{ Solids Composite Inventory Estimate } \\
\hline \multicolumn{4}{|c|}{ 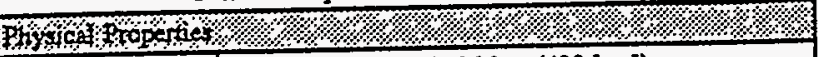 } \\
\hline Total Solid Waste & \multicolumn{3}{|c|}{$2.27 \mathrm{E}+06 \mathrm{~kg}(400 \mathrm{kgal})$} \\
\hline Heat load & \multicolumn{3}{|c|}{$2.61 \mathrm{~kW}(8.92 \mathrm{E}+03 \mathrm{BTU} / \mathrm{hr})$} \\
\hline Bulk Density & \multicolumn{3}{|c|}{$1.50(g / \infty)$} \\
\hline Void Fraction & \multicolumn{3}{|c|}{0.69} \\
\hline Water wr\% & \multicolumn{3}{|c|}{34.05} \\
\hline TOC wt\% C (wet) & \multicolumn{3}{|c|}{0.05} \\
\hline \multicolumn{4}{|c|}{ Ghentsonds } \\
\hline \begin{tabular}{|l|l|}
$\mathrm{Na}^{41}$ & \\
\end{tabular} & 11.07 & $1.70 \mathrm{E}+05$ & $3.85 \mathrm{E}+05$ \\
\hline $\mathrm{Al}^{+3}$ & 0.50 & $8.99 \mathrm{E}+03$ & $2.04 \mathrm{E}+04$ \\
\hline $\mathrm{Fe}^{+3}$ (total Fe) & 0 & 0 & 0 \\
\hline $\mathrm{Cr}^{3} \cdot \mathrm{r}$ & 0. & $\cdots \cdots$ & $\cdots$ \\
\hline $\mathrm{Bi}^{+3}$ & 0 & of & 0 \\
\hline $\mathrm{La}^{+3}$ & of & 0 & 0 \\
\hline $\mathrm{Ce}^{43}$ & of & of & 0 \\
\hline $\mathrm{Zx}$ (as $\left.\mathrm{ZrO}(\mathrm{OH})_{2}\right)$ & of & 0 & 0 \\
\hline $\mathrm{Pb}^{+2}$ & 0 & 0 & 0 \\
\hline $\mathrm{Ni}^{+2}$ & 0 & 0 & 0 \\
\hline $\mathrm{Sr}^{+2}$ & 0 & 0 & 0 \\
\hline $\mathrm{Mn}^{\mathrm{n}}$ & 0 & 0 & 0 \\
\hline $\mathrm{Ca}^{+2}$ & 0 & 0 & 0 \\
\hline $\mathrm{K}^{+1}$ & $2.56 \mathrm{E}-03$ & 66.92 & $1.52 \mathrm{E}+02$ \\
\hline $\mathrm{OH}^{-1}$ & 1.64 & $1.86 \mathrm{E}+04$ & $4.22 \mathrm{E}+04$ \\
\hline $\mathrm{NO}^{-1}$ & 8.13 & $3.36 \mathrm{E}+05$ & $7.63 \mathrm{E}+05$ \\
\hline $\mathrm{NO}^{\cdot 1}$ & 0.27 & $8.25 \mathrm{E}+03$ & $1.87 \mathrm{E}+04$ \\
\hline $\cos ^{-2}$ & 0.40 & $1.61 \mathrm{E}+04$ & $3.65 \mathrm{E}+04$ \\
\hline $\mathrm{PO}^{-3}$ & 0.13 & $8.55 \mathrm{E}+03$ & $1.94 \mathrm{E}+04$ \\
\hline $\mathrm{SO}^{-2}$ & 0.44 & $2.81 \mathrm{E}+04$ & $6.38 \mathrm{E}+04$ \\
\hline $\mathrm{Si}\left(\right.$ as $\mathrm{SiO}_{3}{ }^{-2}$ ) & 0 & 0 & 0 \\
\hline $\mathrm{F}^{-1}$ & 0.54 & $6.80 \mathrm{E}+03$ & $1.54 \mathrm{E}+04$ \\
\hline $\mathrm{Cl}^{-1}$ & $1.60 \mathrm{E}-02$ & $3.79 \mathrm{E}+02$ & $8.60 \mathrm{E}+02$ \\
\hline $\mathrm{C}_{8} \mathrm{H}_{5} \mathrm{O}_{7}{ }^{3}$ & 0 & 0 & 0 \\
\hline EDTA $^{-1}$ & 0 & 0 & 0 \\
\hline HEDTA $^{-3}$ & 0 & 0 & 0 \\
\hline NTA $^{-3}$ & of & 0 & 0 \\
\hline glycolate ${ }^{-1}$ & 0 & 0 & 0 \\
\hline acetate $^{-1}$ & $3.40 \mathrm{E}-02$ & $1.34 E+03$ & $3.04 \mathrm{E}+03$ \\
\hline oxalate ${ }^{-2}$ & 0 & 0 & 0 \\
\hline DBP & 0 & 0 & 0 \\
\hline NPH & of & 인 & 0 \\
\hline $\mathrm{CC}_{3}$ & 0 & 0) & 0 \\
\hline hexone & 0 & 0 & 0 \\
\hline $\mathrm{Fe}(\mathrm{CN})_{6}{ }^{-1}$ & 0 & $0(\mathrm{~g}-\mathrm{mol})$ & \\
\hline \multicolumn{4}{|c|}{ 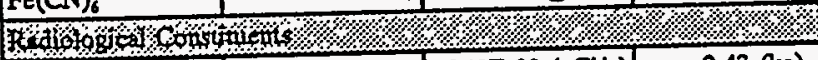 } \\
\hline $\mathbf{P u}$ & & $6.42 \mathrm{E}-02(\mu \mathrm{Ci} / \mathrm{g})$ & $2.43(\mathrm{~kg})$ \\
\hline U & 2.31E-02 (M) & $3.68 \mathrm{E}+03(\mu \mathrm{g} / \mathrm{g})$ & $8.34 \mathrm{E}+03(\mathrm{~kg})$ \\
\hline Cs & $0.37(\mathrm{Ci} / \mathrm{L})$ & $2.46 \mathrm{E}+02(\mu \mathrm{Ci} / \mathrm{g})$ & $5.57 \mathrm{E}+05(\mathrm{Ci})$ \\
\hline $\mathrm{Sr}$ & $0(\mathrm{Ci} / \mathrm{L})$ & $0(\mu \mathrm{Ci} / \mathrm{g})$ & $0(\mathrm{Ci})$ \\
\hline
\end{tabular}

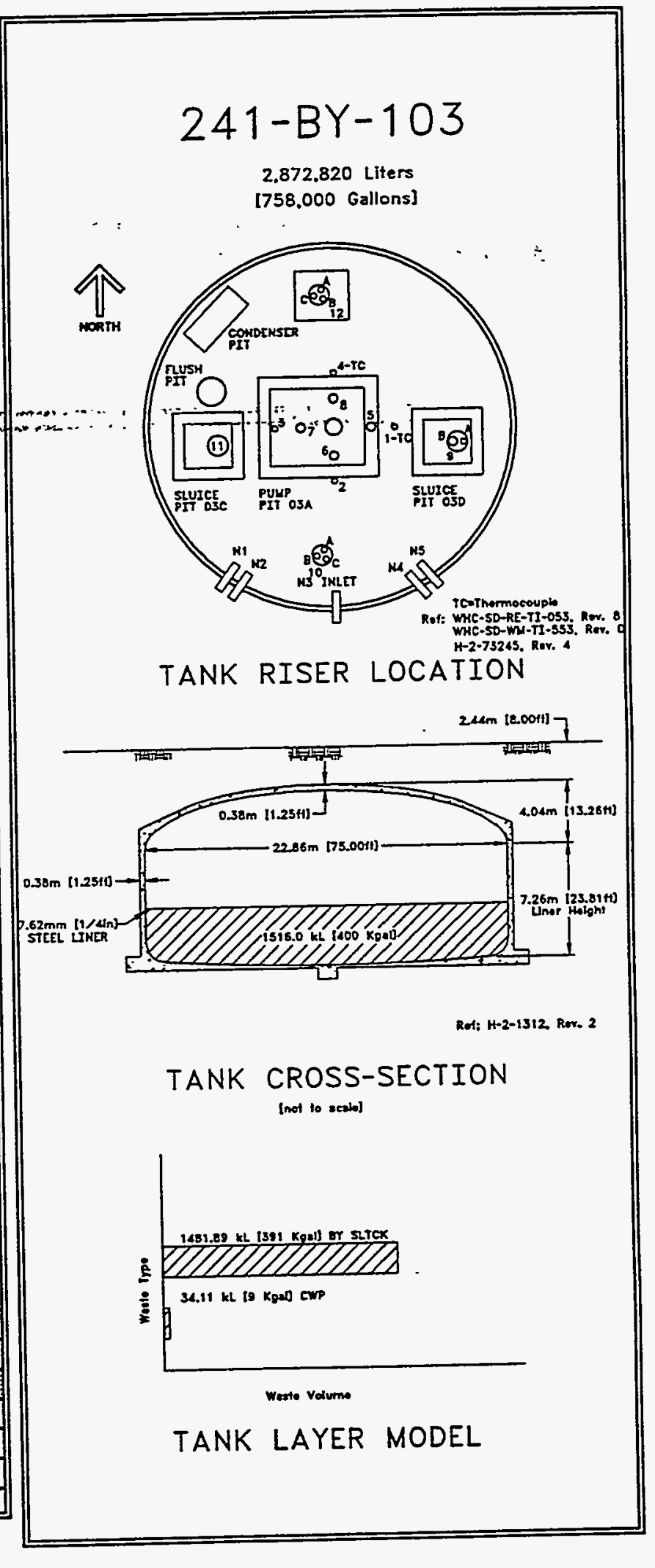




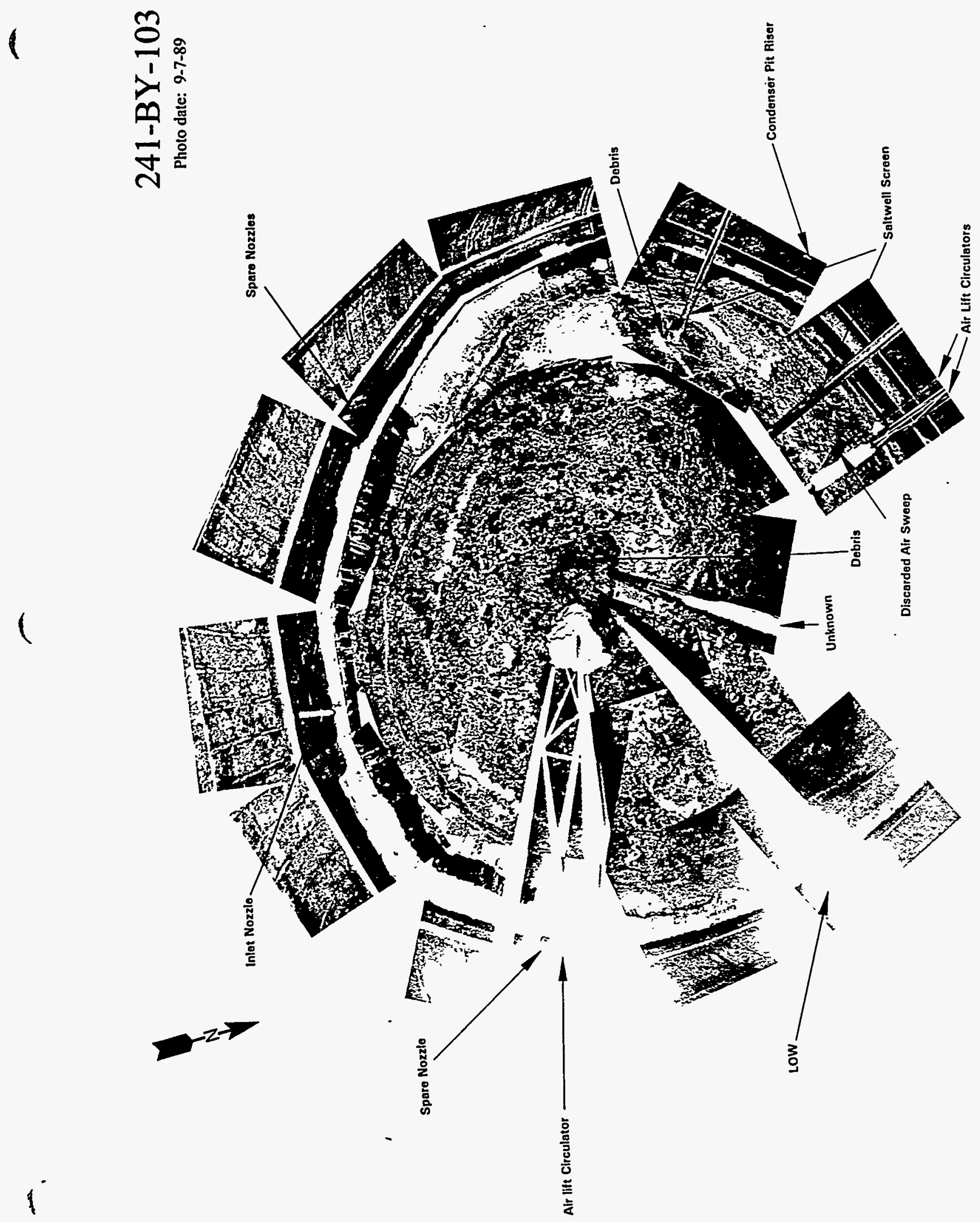


WHC-SD-WM-ER-349, Rev. 0

\subsection{Tank 241-BY-104}

\subsubsection{1-BY-104 Tank History}

\subsubsection{Waste History Tank 241-BY-104}

Metal waste was introduced to the tank in the first quarter of 1950 via the Tank 241-BX-106 cascade. A saltwell was installed in 1977 and the tank was declared inactive. in .1978. The pump was removed in 1979 . A level adjustment was made in April 1982. The tank was saltwell pumped again in May 1983 and the tank was declared interim stabilized in January 1985. Intrusion prevention was completed in september 1990. (See Sketch ES-TKS-E42 for a graphical representation of the Tank 241BY -104. level., histor.y. . .... The ., sketch.. shows...two..pH.. readings : 9.3 in

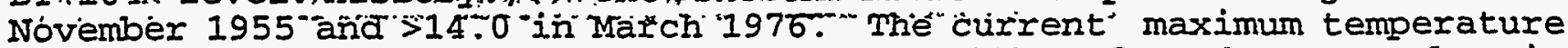
readings from October 1993 are $128^{\circ} \mathrm{F}$ and $115^{\circ} \mathrm{F}$ for thermocouples in risers 1 and $10 B$ respectively.

\subsubsection{Temperature History 241-BY-104}

Tank 241-BY-104 has two thermocouple trees. Tree 1 has 12 thermocouple probes and tree 2 has 6 thermocouple probes to record temperature data. The mean temperature of the first recorded data from thermocouple tree 1 was $69^{\circ} \mathrm{F}$, and the mean temperature from thermocouple tree 2 was $101^{\circ} \mathrm{F}$. A sum of the squares regression line fit for all the data shows a slight decrease in temperature with a moderate amount of variability. Annual temperature fluctuations are apparent in tree 2. The median temperature is $122^{\circ} \mathrm{F}$ with a minimum of $51^{\circ} \mathrm{F}$ and a maximum of $237^{\circ} \mathrm{F}$. Refer to the supporting document for a more thorough review of the temperature data (Brevick 1994).

\subsubsection{Integrity of Tank 241-BY-104}

Tank 241-BY-104 is categorized as sound and is interim stabilized with intrusion prevention completed. The Tank 241-BY-104 surface level is monitored quarterly with a manual tape through riser 5. A figure that graphicaliy represents the surface level measurements from January 1991 to the present can be found in the supporting documents (Brevick 1994). The surface level plot has fluctuating readings with a decreasing trend. The readings range from 131.75 to $131 \mathrm{in.}$ during the first quarter of 1991 and decrease to 128.59 to 128.5 in. during the fourth quarter of 1993.

The Tank 241-BY-104 liquid observation well is located in riser 10C. The tank is monitored weekly with a neutron probe and on request with a gamma probe to determine the interstitial liquid level. The maximum deviations from the established baseline are a 0.3 -ft increase and a 0.4-Ft decrease. Sketch ES-TKS-E42 has a graphical representation of the liquid observation well data.

Five drywells are identified for Tank 241-BY-104. The supporting document contains a graphical representation of the data for the active drywell from January 1990 to the present (Brevick 1994). The graph 
includes the peak c/s (this well has multiple peaks), the depth at which the peak occurred, and the date of the reading.

\subsubsection{Current Status of Tank 241-BY-104}

Tank 241-BY-104 entered service in February 1951 and currently stores $406,000 \mathrm{gal}$ of waste. The waste is comprised of 256,000 gal of saltcake and $150,000 \mathrm{gal}$ of sludge with no saltcake or pumpable liquid remaining. The tank is identified on the Ferrocyanide watch Iist as of January 1991, is passively ventilated, and is categorized as sound with interim stabilization and intrusion prevention completed. Tank 241-BY104 is equipped to cascade to Tank 241-BY-105 and is first in the threetank cascade series. The following plan view and tank cross section depict the approximate:waste levelwand .riser.configuration. Tank 241$B Y-104$ häs 15 risers and 4 -in. risers nos. 3 and $10 B$ are available for use.

\subsubsection{Inventory estimate 241-BY-104}

The following tank layer volume approximation was derived from the Los Alamos National Laboratories Waste Status and Transaction Record Summary (Agnew 1994). The estimated inventory of Tank 241-BY-104 is also presented.

\subsubsection{In-Tank Photograph 241-BY-104}

The Tank 241-BY-104 photo reveals an off-white to yellow saltcake surface interspersed with dark yellow-brown veins and a brown pool at the base of the saltwell screen. The waste measures approximately $12 \mathrm{ft}$ deep. Tank 241-BY-104 was added to the Ferrocyanide watch List in 1991.

6.4.3 Synopsis Tank 241-BY-104

(To be completed.) 


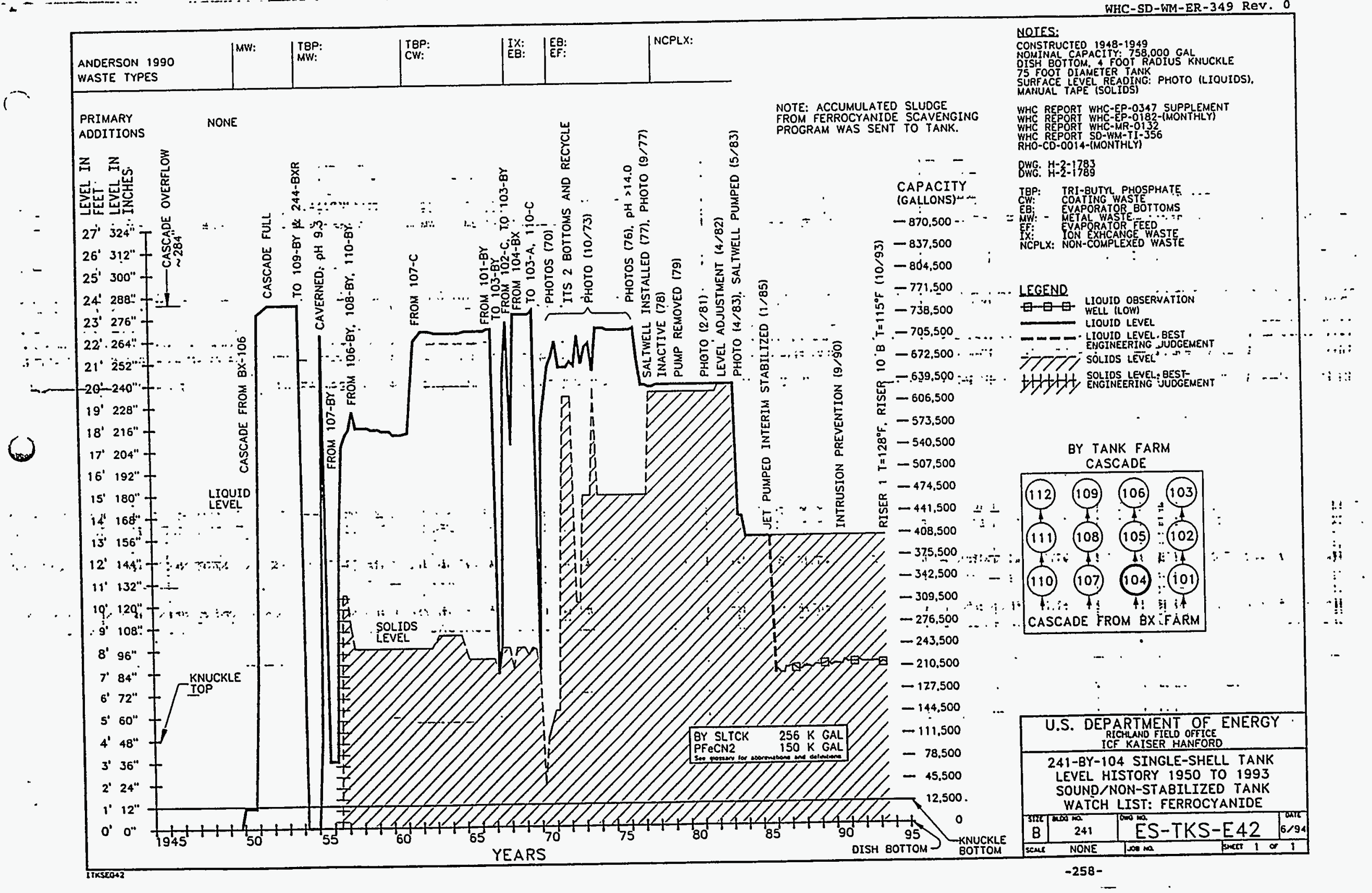


Single-Shell Tank 241-BY-104 Solids Composite Inventory Estimate

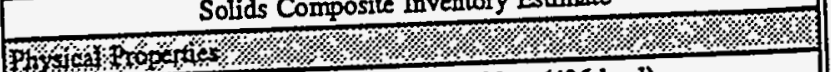
\begin{tabular}{l|l}
\hline Tousl Solid Waste & $2.29 \mathrm{E}+06 \mathrm{~kg}(406 \mathrm{kgal})$ \\
\hline
\end{tabular}

\begin{tabular}{l|l}
\hline Heat load & $2.31 \mathrm{~kW}(7.89 \mathrm{E}+03 \mathrm{BTU} / \mathrm{hr})$ \\
\hline
\end{tabular}

Bulk Density

Void Fraction

Waler wt\%

TOC w1\% C (wet)

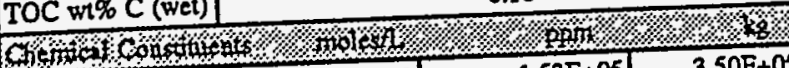

$\mathrm{Na}^{+1}$

\begin{tabular}{|l|r|r|r|}
\hline $\mathrm{A}^{+3}$ & 0.24 & $4.31 \mathrm{E}+03$ & $9.86 \mathrm{E}+03$ \\
\hline $\mathrm{Fe}^{33}$ (total $\mathrm{Fe}$ ) & 0.19 & $7.15 \mathrm{E}+03$ & $1.63 \mathrm{E}+04$ \\
\hline
\end{tabular}

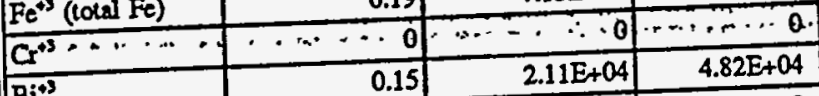

\begin{tabular}{|c|c|c|c|}
\hline$B i^{33}$ & 0.15 & $2.11 \mathrm{E}+04$ & $4.82 E+04$ \\
\hline $\mathrm{La}^{43}$ & 0 & 0 & 0 \\
\hline $\mathrm{Ce}^{43}$ & 0 & 0 & ( \\
\hline
\end{tabular}

$\mathrm{Zr}$ (as $\mathrm{ZrO}\left(\mathrm{OH}_{2}\right)$

$\mathrm{Pb}^{\circ 2}$

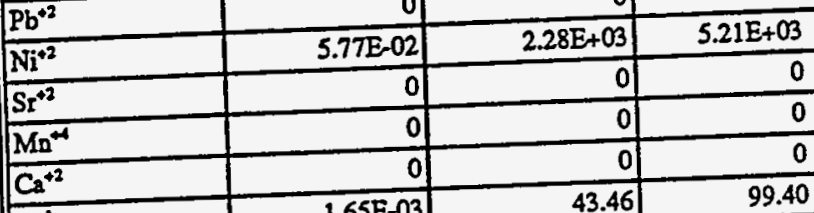

\begin{tabular}{|l|r|r|r|}
\hline $\mathrm{Ca}^{+1}$ & $1.65 \mathrm{E}-03$ & 43.46 & 99.40 \\
\hline $\mathrm{OH}^{-1}$ & 1.35 & $1.55 \mathrm{E}+04$ & $3.53 \mathrm{E}+04$ \\
\hline
\end{tabular}

\begin{tabular}{|l|r|r|r|}
\hline $\mathrm{NO}^{-1}$ & 6.07 & $2.53 \mathrm{E}+05$ & $5.78 \mathrm{E}+05$ \\
\hline $\mathrm{NO}^{-1}$ & 0.17 & $5.28 \mathrm{E}+03$ & $1.21 \mathrm{E}+04$ \\
\hline $\mathrm{CO}^{-1}$ & & & \\
\hline
\end{tabular}

$\mathrm{CO} 3$

$\mathrm{CO}^{2}$

$\mathrm{SO}^{2}$

Si (as $\left.\mathrm{SiO}_{3}{ }^{-3}\right)$

$\mathrm{F}^{1}$

\begin{tabular}{|l|r|r|r|}
\hline $\mathrm{C}^{-2}$ & $1.03 \mathrm{E}-02$ & $2.46 \mathrm{E}+02$ & $5.63 \mathrm{E}+\mathrm{O} 2$ \\
\hline $\mathrm{C}_{6} \mathrm{H}_{3} \mathrm{O}_{7}^{-3}$ & 0 & 0 & 0 \\
\hline
\end{tabular}

EDTA

EEDTA ${ }^{3}$

$\mathrm{NTA}^{-3}$

Blycolate

acelste ${ }^{-1}$

oxalate ${ }^{-2}$

DBP

NPH

$\mathrm{CCL}_{4}$

hexone

$\mathrm{Fe}(\mathrm{CN})_{6}^{4}$

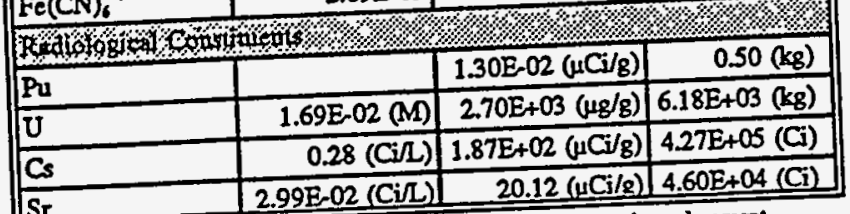

Sr exchudes supernatant, distomacoous earth, and cement

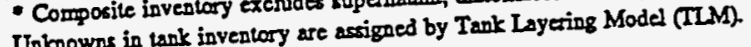

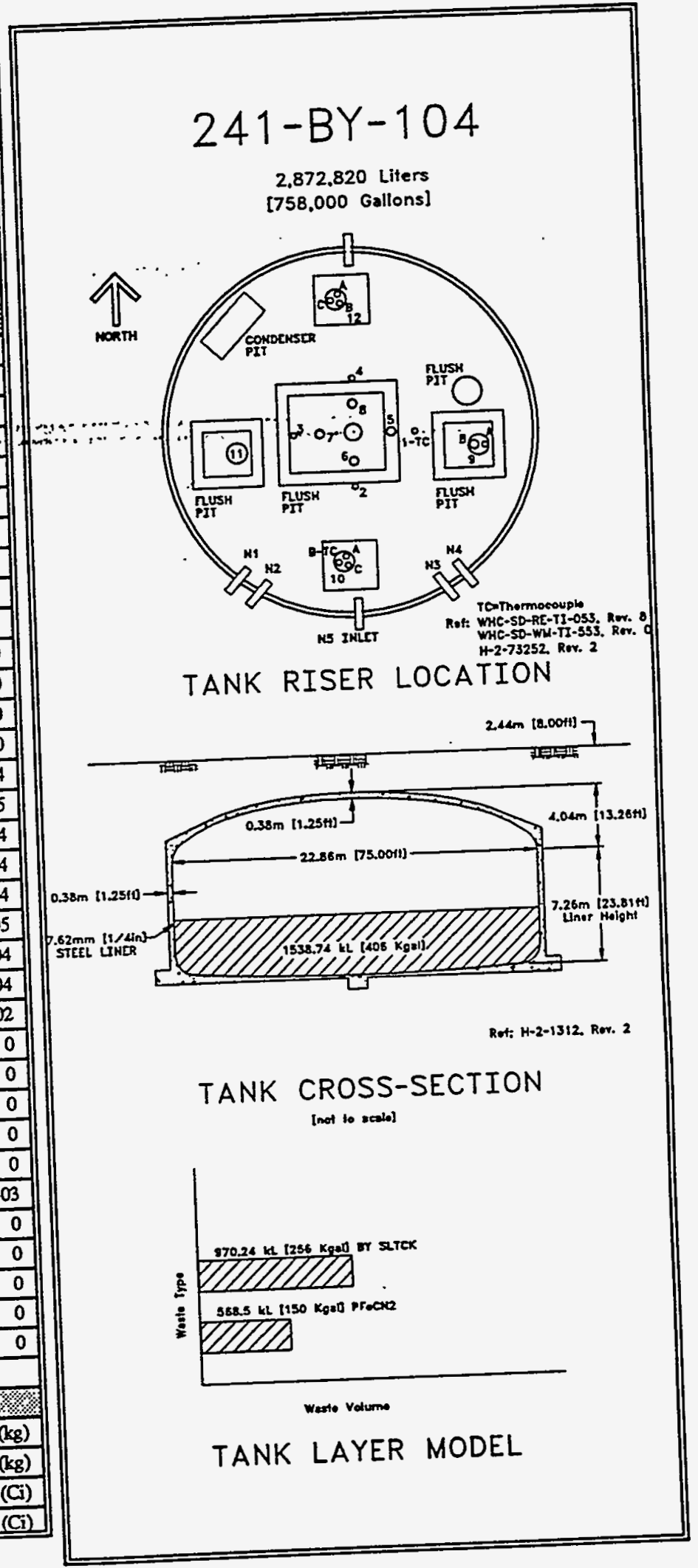

$6 / 94$ 


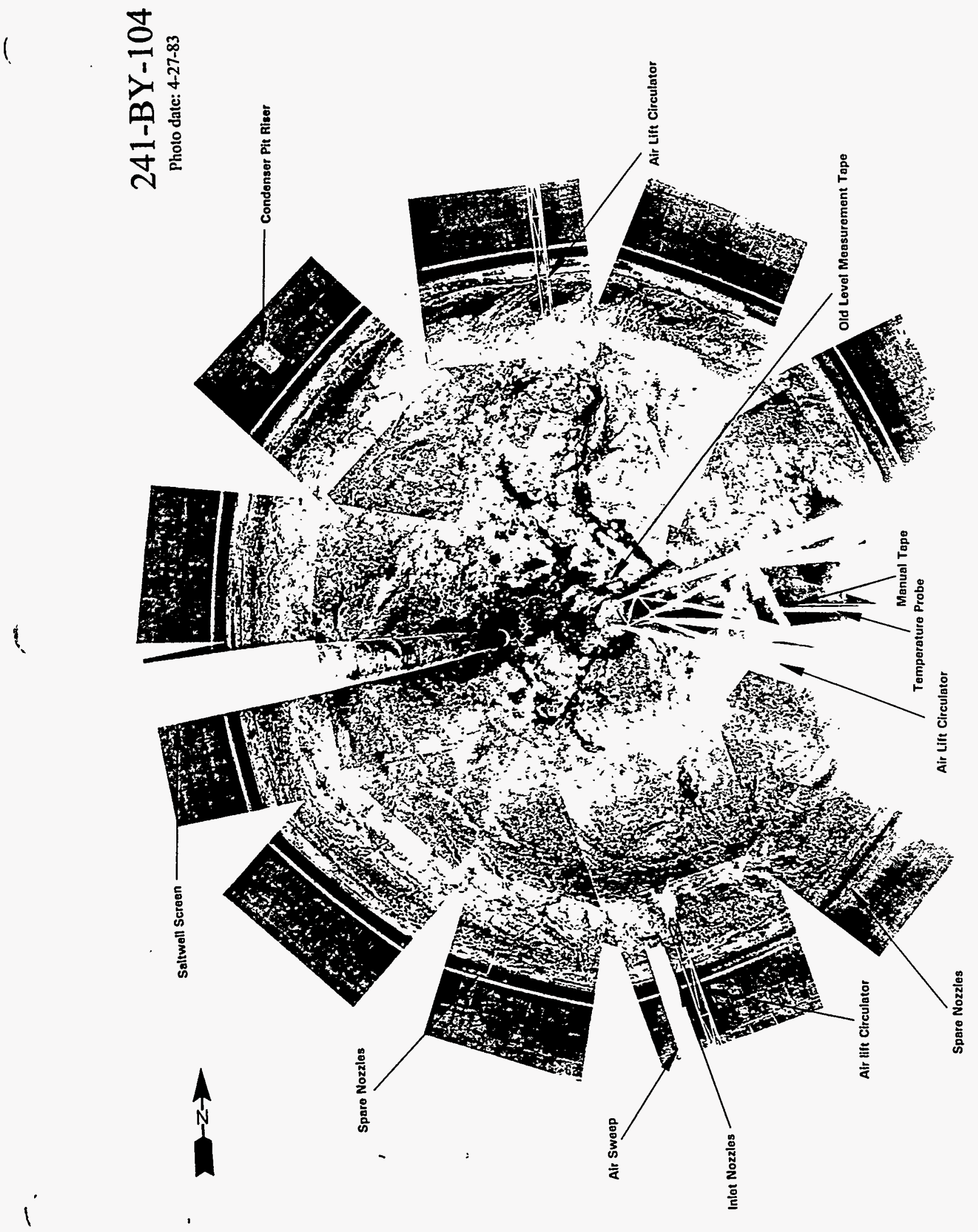


WHC-SD-WM-ER-349, Rev. 0

\subsection{Tank 241-BY-105}

6.5.1 241-BY-105 Tank History

\subsubsection{Waste History Tank 241-BY-105}

Tank 241-BY-105 was filled with metal waste from the cascade between June 1951:and the fourth quarter of 1951. The tank was removed from service in the fourth :quarter of.1974. The tank was salt well pumped from 1975' to 1976. 'Sixty-three tons of Portland cement were added in 1977. The tank had questionable integrity and was primary stabilized in 1978. A level adjustment was made in April 1982 and partial isolation was completed in December 1982. The tank was declared an.assumed. Ieaker. in 1984, with a leak, volume of approximately 8,000 gal.

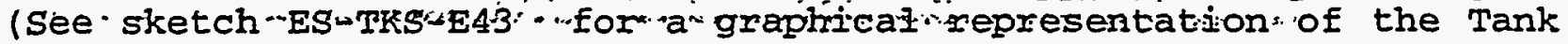
24I-BY-I05 level history.)

\subsubsection{Temperature History 241-BY-105}

Tank 241-BY-105 has two thermocouple trees. Tree 1 has 16 thermocouple probes and tree 2 has 12 thermocouple probes to record temperature data. The mean temperature of the first recorded data was $47^{\circ} \mathrm{F}$ for thermocouple tree 1 and $97^{\circ} \mathrm{F}$ for thermocouple tree 2 . A sum of the squares regression line fit for thermocouple tree 1 shows a slight decrease in temperature with a moderate amount of variability. Not enough data are available for an accurate regression analysis on thermocouple tree 2. Annual temperature fluctuations are apparent in tree 2. The median temperature is $103^{\circ} \mathrm{F}$ with a minimum of $44^{\circ} \mathrm{F}$ and a maximum of $179.6^{\circ} \mathrm{F}$. Refer to the supporting document for a more thorough review of the temperature data (Brevick 1994).

\subsubsection{Integrity of Tank 241-BY-105}

Tank 241-BY-105 is categorized as an assumed leaker and is partially isolated. The Tark 241-BY-105 surface level is monitored quarterly with a manual tape through riser 5: A figire that graphically represents the surface level measurements from January 1991 to the present can be found in the supporting documents (Brevick 1994). The surface level graph indicates fluctuating data with a decreasing trend. The readings range from. 181.75 to 181 in. during the first quarter of 1991 and decrease to 173.25 to 172 in. during the fourth quarter of 1993.

The Tank 241-BY-105 liquid observation well is located in riser 10B. The tank is monitored weekly with a neutron probe and on request with a gamma probe to determine the interstitial liquid levels. The monitoring limits are a $0.3 \mathrm{ft}$ decrease and a $0.4 \mathrm{ft}$ increase. Sketch ES-TKS-E43 has a graphical representation of the liquid observation well data.

A discrepancy report was issued in June 1993 because the interstitial liquid level increased to the criteria limit. The tank has had a slow increasing trend since 1986 but the surface level readings 
WHC-SD-WM-ER-349, Rev. 0

show a decrease. The discrepancy could be caused by solids dissolution or the formation of a depression in the solids beneath the plummet in conjunction with an intrusion.

Three drywells are identified for Tank 241-BY-105. Graphical representations of the data for each active drywell from January 1990 to the present can be found in the supporting document (Brevick 1994). Each graph includes the peak $\mathrm{c} / \mathrm{s}$, the depth at which the peak occurred, and the date of the reading.

\subsubsection{Current Status of Tank 241-BY-105}

Tank 241-BY-105 entered service in June 1951 and currently stores 503,000..gal... of. .waste.... The..waste...is...comprised. of..337,000 gal of saltcake; 166;000"gal of sludge and no supernatarit with 169;000 gal of pumpable interstitial liquid remaining. The tank is identified on the Ferrocyanide watch List, is passively ventilated, and is categorized as an assumed leaker with partial isolation completed. Tank 241-BY-105 is equipped to cascade to Tank 241-BY-106 and is second in the three-tank cascade series. The following plan view and tank cross section depict the approximate waste level and riser configuration. Tank 241-BY-105 has 19 risers and 12 -in. riser no.7 is available for use.

\subsubsection{Inventory estimate 241-BY-105}

The following tank layer volume approximation was derived from the Los Alamos National Laboratories Waste Status and Transaction Record Summary (Agnew 1994). The estimated inventory of Tank 241-BY-105 is also presented.

\subsubsection{In-Tank Photograph 241-BY-105}

The Tank 241-BY-105 photo reveals a light tan to light brown saltcake surface. The saltwell screen in the center of the photo extends down into a pool of yellow liquid. The liquid observation well, temperature probe, and airlift circulator descend into depressions of the crust. The waste measures approximately 15 ft deep.

\section{5 .3 Synopsis Tank 241-BY-105}

(To be completed.) 


\begin{tabular}{|c|c|c|c|}
\hline \multicolumn{4}{|c|}{ Single-Shell Tank 241-BY-105 } \\
\hline \multicolumn{4}{|c|}{ Solids Composite Inventory Estimate } \\
\hline \multicolumn{4}{|c|}{ 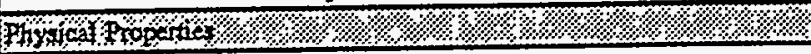 } \\
\hline Total Solid Waste & \multicolumn{3}{|c|}{$2.80 \mathrm{E}+06 \mathrm{~kg}(495 \mathrm{kgal})$} \\
\hline \begin{tabular}{|l|} 
Heat load \\
\end{tabular} & \multicolumn{3}{|c|}{$2.95 \mathrm{~kW}(1.01 \mathrm{E}+04 \mathrm{BTU} / \mathrm{hr})$} \\
\hline Bulk Density & \multicolumn{3}{|c|}{$1.50(g / \infty)$} \\
\hline Void Fraction & \multicolumn{3}{|c|}{0.67} \\
\hline Water wr\% & \multicolumn{3}{|c|}{35.23} \\
\hline TOC wt\% C (wet) & \multicolumn{3}{|c|}{0.15} \\
\hline \multicolumn{4}{|c|}{ 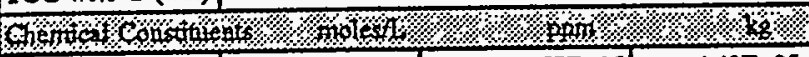 } \\
\hline $\mathrm{Na}^{* 1}$ & 10.25 & $1.57 \mathrm{E}+05$ & $4.42 \mathrm{E}+05$ \\
\hline $\mathrm{Al}^{+3}$ & 0.26 & $4.63 \mathrm{E}+03$ & $1.30 \mathrm{E}+04$ \\
\hline $\mathrm{Fe}^{+3}$ (total Fe) & 0.15 & $5.52 \mathrm{E}+03$ & $1.55 \mathrm{E}+04$ \\
\hline $\mathrm{Cx}^{3}:$ & $=0$ & $\div \quad 0$. & $\therefore 0$ \\
\hline $\mathrm{Bi}^{+3}$ & 0.12 & $1.63 \mathrm{E}+04$ & $4.56 \mathrm{E}+04$ \\
\hline $\mathrm{Lat3}^{+3}$ & 0 & 0 & 0 \\
\hline $\mathrm{Ce}^{+3}$ & 요 & of & 0 \\
\hline $\mathrm{Zr}$ (as $\left.\mathrm{ZrO}(\mathrm{OH})_{2}\right)$ & 0 & 0 & 0 \\
\hline $\mathrm{Pb}^{+2}$ & 0 & 0 & 0 \\
\hline $\mathrm{Ni}^{+2}$ & $4.48 \mathrm{E}-02$ & $1.76 E+03$ & $4.93 \mathrm{E}+03$ \\
\hline$\widehat{S r^{+2}}$ & 0 & 0 & 0 \\
\hline $\mathrm{Mn}^{+\infty}$ & 0 & 0 & 0 \\
\hline $\mathrm{Ca}^{42}$ & 0 & 0 & 0 \\
\hline $\mathrm{K}^{+1}$ & $1.79 \mathrm{E}-03$ & 46.66 & $1.31 E+02$ \\
\hline $\mathrm{OH}^{-1}$ & 1.39 & $1.58 \mathrm{E}+04$ & $4.44 E+04$ \\
\hline $\mathrm{NO}^{-1}$ & 6.30 & $2.61 E+05$ & $7.32 \mathrm{E}+05$ \\
\hline $\mathrm{NO}^{-1}$ & 0.18 & $5.66 \mathrm{E}+03$ & $1.59 \mathrm{E}+04$ \\
\hline $\mathrm{CO}^{.2}$ & 0.36 & $1.43 E+04$ & $4.00 \mathrm{E}+04$ \\
\hline $\mathrm{PO}^{.3}$ & 0.33 & $2.09 \mathrm{E}+04$ & $5.85 \mathrm{E}+04$ \\
\hline $\mathrm{SO}^{-2}$ & 0.67 & $4.33 E+04$ & $1.21 E+05$ \\
\hline $\mathrm{Si}\left(\right.$ as $\left.\mathrm{SiO}_{3}^{-2}\right)$ & 0.31 & $5.89 \mathrm{E}+03$ & $1.65 \mathrm{E}+04$ \\
\hline$F^{-1}$ & 0.41 & $5.26 \mathrm{E}+03$ & $1.48 \mathrm{E}+04$ \\
\hline $\mathrm{Cl}^{-1}$ & $1.12 \mathrm{E}-02$ & $2.64 \mathrm{E}+02$ & $7.41 \mathrm{E}+02$ \\
\hline $\mathrm{C}_{6} \mathrm{H}_{5} \mathrm{O}_{7}{ }^{-3}$ & 0 & 0 & 0 \\
\hline EDTA & of & 0 & 0 \\
\hline HEDTA ${ }^{3}$ & of & 0] & 0 \\
\hline NTA $^{-3}$ & 0 & 0 & 0 \\
\hline glycolate $e^{-1}$ & 0 & 0 & 0 \\
\hline acelate $^{-1}$ & 2.37E-02 & $9.33 E+02$ & $2.62 E+03$ \\
\hline oxalate & 0 & 0 & 0 \\
\hline DBP & 0 & 0 & 0 \\
\hline NPH & of & 0] & 0 \\
\hline $\mathrm{CC}$ & 0 & of & 0 \\
\hline hexone & 0 & $\begin{array}{r}0 \\
\end{array}$ & 0 \\
\hline $\mathrm{Fe}(\mathrm{CN})_{6}^{-1}$ & $2.24 \mathrm{E}-02$ & $4.20 \mathrm{E}+04(\mathrm{~g}-\mathrm{mol})$ & \\
\hline Waloog g & $\%$ \% & \% & $\%$ \% \\
\hline Pu & & $1.46 \mathrm{E}-02(\mu \mathrm{Ci} / \mathrm{g})$ & $0.68(\mathrm{~kg})$ \\
\hline $\mathbf{U}$ & $4.20 \mathrm{E}-02(\mathrm{M})$ & $6.68 \mathrm{E}+03(\mu \mathrm{g} / \mathrm{g})$ & $1.87 \mathrm{E}+04(\mathrm{~kg})$ \\
\hline Cs & $0.29(\mathrm{Ci} / \mathrm{L})$ & $1.92 \mathrm{E}+02(\mu \mathrm{Ci} / \mathrm{g})$ & $5.39 \mathrm{E}+05(\mathrm{C})$ \\
\hline Sr & $3.37 \mathrm{E}-02(\mathrm{Ci} / \mathrm{L})$ & $22.54(\mu \mathrm{Ci} / \mathrm{g})$ & $6.32 \mathrm{E}+04(\mathrm{C})$ \\
\hline
\end{tabular}

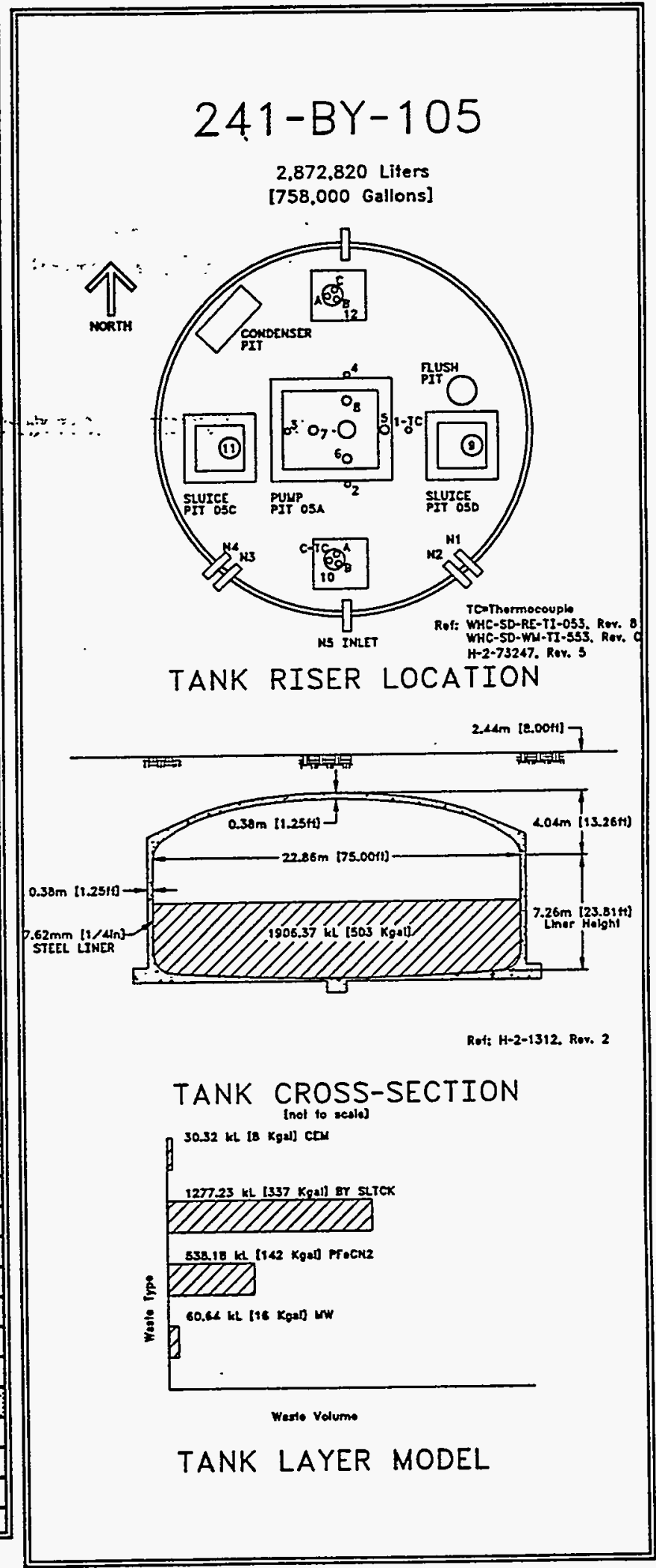

- Composite inventory excludes supernatant, diatomacoous earth, and cement Unkrowas in tank inventory are assigned by Tank Layeriag Model (TLM). 


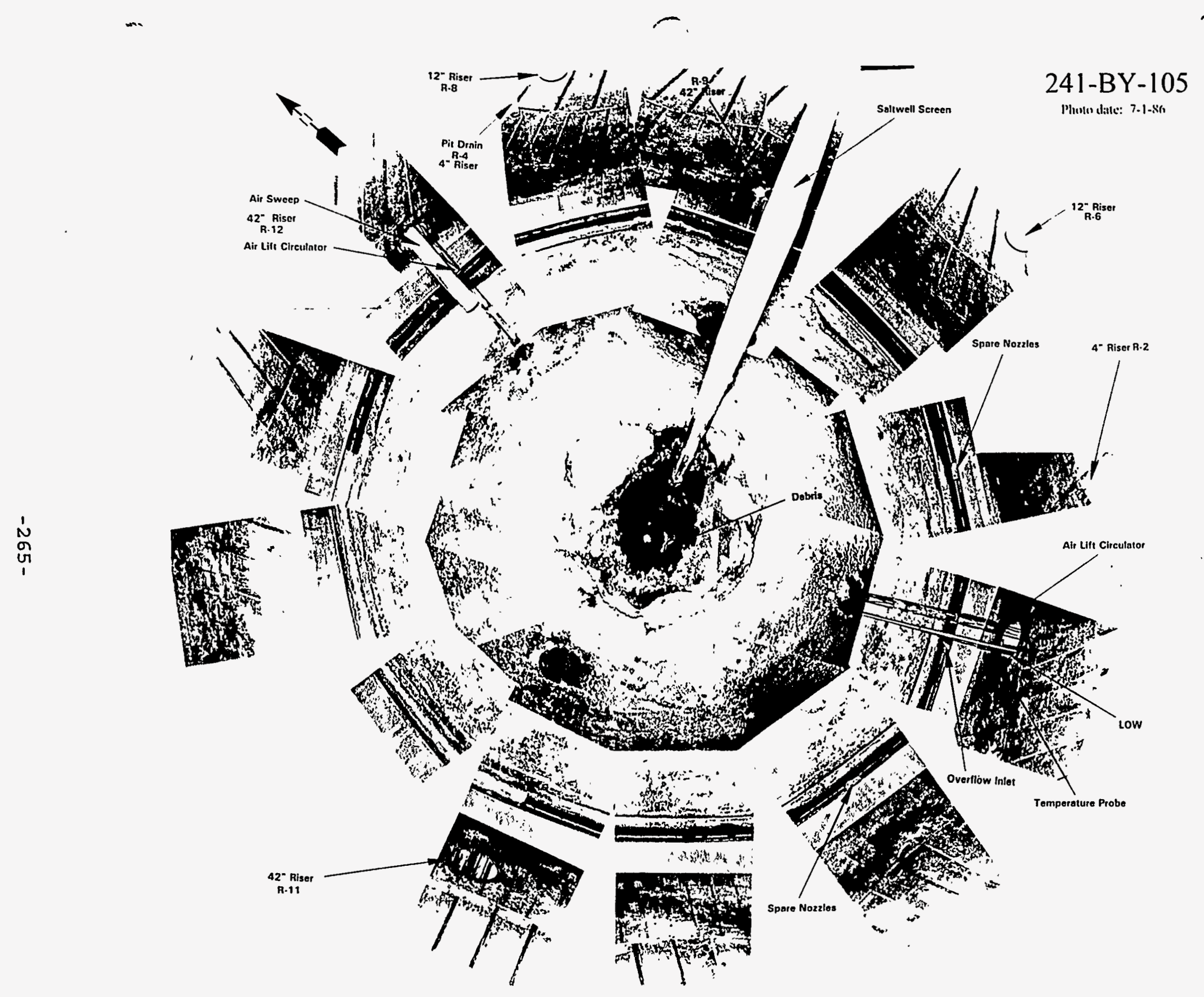


6.6.1 241-BY-106 Tank History

6.6.1.1 Waste History Tank 241-BY-106

Tank 241-BY-106 began to receive first-cycle waste in the second quarter of 1953:" Activity in the tank was restricted in the third quarter of 1976.. Saltwell pumping began in the first quarter of 1977 and the tank was declared inactive in 1977. Salt well pumping was completed in 1978. Partial isolation was complete in December 1982. The tank was declared an assumed leaker in 1984 with a leak volume of approximately $8,000 \mathrm{gal}$. Iiquid observation well data that have been

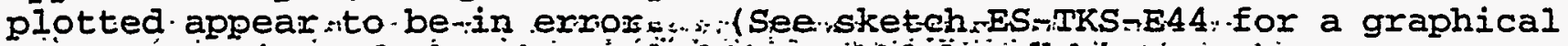
representation of the the Tank $241-B Y-106$ level history.)

\subsubsection{Temperature History 241-BY-106}

The single thermocouple tree in Tank 241-BY-106 has 12 thermocouple probes to record temperature data. The mean temperature of the first daily recorded temperature data was $60^{\circ} \mathrm{F}$. A sum of the squares regression line fit for thermocouples 1 through 6 shows a slight temperature decrease with a moderate amount of variability. Thermocouples 7 through 12 show no overall temperature change during a regression analysis; however, a moderate amount of variability exists in the data. The median temperature is $123.4^{\circ} \mathrm{F}$ with a minimum of $53^{\circ} \mathrm{F}$ and a maximum of $199.4^{\circ} \mathrm{F}$. Refer to the supporting document for a more thorough review of the temperature data (Brevick 1994).

\subsubsection{Integrity of Tank $241-B Y-106$}

Tank 241-BY-106 is categorized as an assumed leaker and is partially isolated. The in Tank 241-BY-106 surface level is monitored quarterly with a manual tape through riser 5 . Iiquid waste volume is determined by a photographic evaluation. and solid waste volume is determined by a manual tape surface level gauge and a photographic evaluation. A figure that graphically represents the surface level measurements from January 1991 to the present can be found in the supporting documents (Brevick 1994). The surface level for the last three years has remained steady with readings ranging between 244.25 and 242.5 in.

The Tank 241-BY-106 liquid observation well is located in riser 10B. The tank is monitored weekly with a neutron probe and on request with a gamma probe to determine interstitial liquid levels. The monitoring limits are a 0.3 -ft decrease and a $0.4-f t$ increase. Sketch ES-TKS-E44 has a graphical representation of the liquid observation well data.

Four drywells are identified for tank 241-BY-106. Graphical representations of the data for each active drywell from January 1990 to the present can be found in the supporting document (Brevick 1994). Each graph includes the peak c/s (some wells have multiple peaks), the 
depth at which the peak occurred, and the date of the reading.

\subsubsection{Current status of Tank 241-BY-106}

Tank 241-BY-106 entered service in 1950 and currently stores $642,000 \mathrm{gal}$ of waste. The waste is comprised of 544,000 gal of saltcake; 98,000 gal of sludge; and no supernatant with 213,000 gal of pumpable interstitial liquid remaining. The tank is identified on the Ferrocyanide watch List, is passively ventilated, and is categorized as an assumed leaker with partial isolation completed. Tank 241-BY-106 is third in the three-tank cascade series. The following plan view and tank cross section depict the approximate waste level and riser configuration. Tank 241-BY-106 has 18 risers and two are available for use: 4-in...riser.no:4:and - $12 \div$ in $:$ riser no: 7 .

\subsubsection{Inventory estimate 241-BY-106}

The following tank layer volume approximation that follows was derived from the Los Alamos National Laboratories waste status and Transaction Record Summary (Agnew 1994). The estimated inventory of Tank 241-BY-106 is also presented.

\subsubsection{In-Tank Photograph 241-BY-106}

The Tank 241-BY-106 photo shows a bright yellow saltcake surface with pools of brown liquid. Solids have formed around the airlift circulators, temperature probe, saltwell screen, and old level measure tape. The waste measures approximately $19 \mathrm{ft}$ deep. Tank 241-BY-106 is on the Ferrocyanide Watch List.

\subsubsection{Synopsis Tank 241-BY-106}

(To be completed.) 


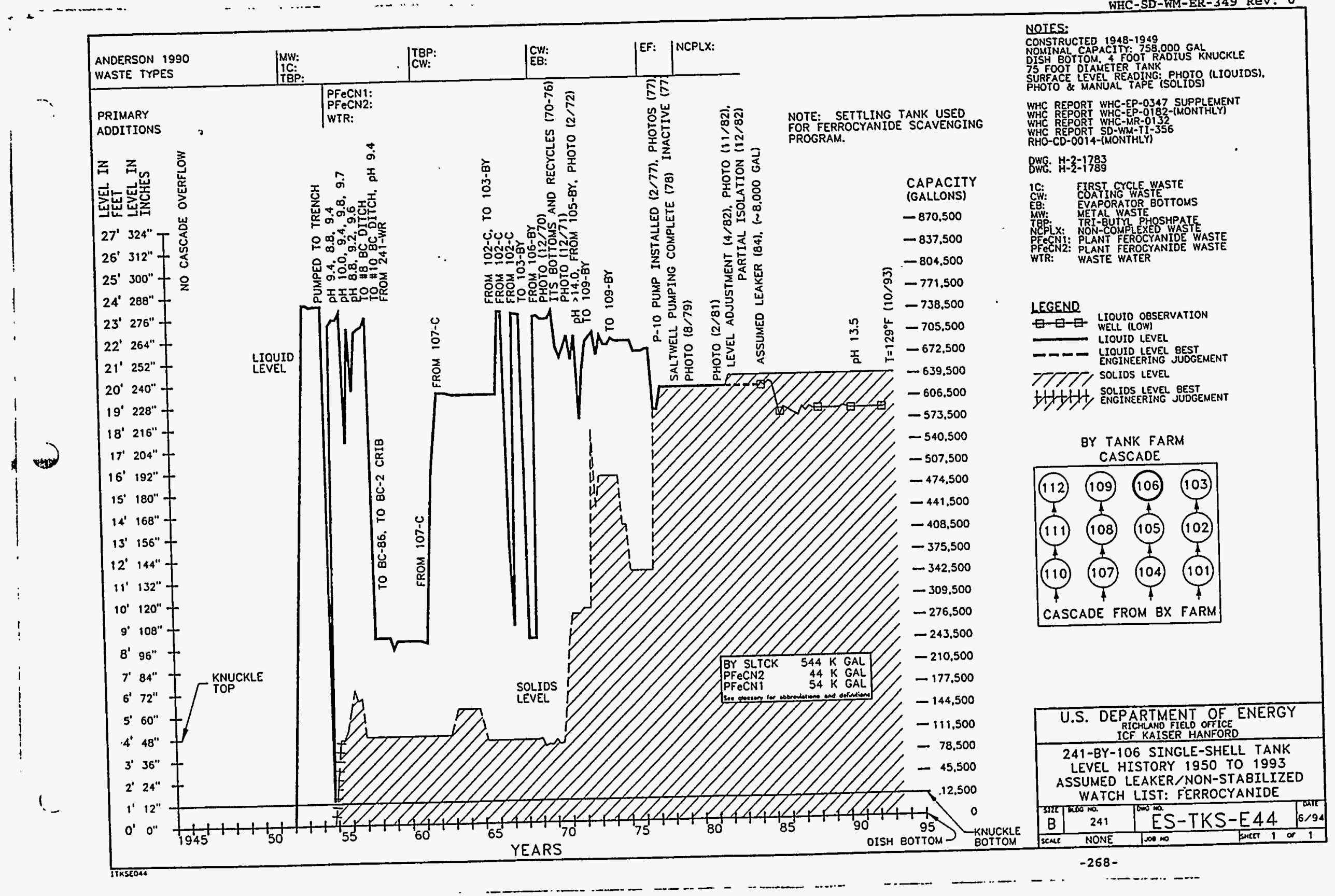




\begin{tabular}{|c|c|c|c|}
\hline \multicolumn{4}{|c|}{ Single-Shell Tank 241-BY-106 } \\
\hline \multicolumn{4}{|c|}{ Solids Composite Inventory Estimate } \\
\hline \multicolumn{4}{|c|}{ 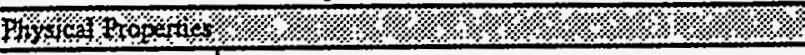 } \\
\hline Total Solid Waste & \multicolumn{3}{|c|}{$3.63 \mathrm{E}+06 \mathrm{~kg}(642 \mathrm{kgal})$} \\
\hline \begin{tabular}{|l|l} 
Heas load & \\
\end{tabular} & \multicolumn{3}{|c|}{$4.00 \mathrm{~kW}(1.36 \mathrm{E}+04 \mathrm{BTU} / \mathrm{Mr})$} \\
\hline Bulk Density & \multicolumn{3}{|c|}{$1.49(g / \infty)$} \\
\hline Void Fraction & \multicolumn{3}{|c|}{0.69} \\
\hline Water wt\% & \multicolumn{3}{|c|}{34.49} \\
\hline TOC wr\% C (wet) & \multicolumn{3}{|c|}{0.13} \\
\hline \multicolumn{4}{|c|}{ 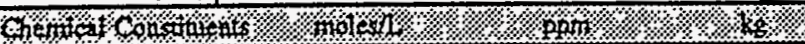 } \\
\hline $\mathrm{Na}^{+1}$ & 10.71 & $1.65 \mathrm{E}+05$ & $5.98 \mathrm{E}+05$ \\
\hline $\mathrm{Al}^{+3}$ & 0.32 & $5.78 \mathrm{E}+03$ & $2.10 \mathrm{E}+04$ \\
\hline $\mathrm{Fe}^{43}($ lotal Fe) & $7.85 \mathrm{E}-02$ & $2.94 \mathrm{E}+03$ & $1.07 \mathrm{E}+04$ \\
\hline$C^{+3} \therefore \ldots$ & $\therefore \ldots \ldots$ of & $\therefore 0$ & $\because \div 0$ \\
\hline $\mathrm{Bi}^{+3}$ & $5.74 \mathrm{E}-02$ & $8.04 \mathrm{E}+03$ & $2.91 \mathrm{E}+04$ \\
\hline $\mathrm{La}^{+3}$ & 0 & 0 & 0 \\
\hline $\mathrm{Ce}^{+3}$ & 0 & 0) & 0 \\
\hline $\mathrm{Zr}\left(\right.$ as $\left.\mathrm{ZrO}(\mathrm{OH})_{2}\right)$ & 0 & 0 & 0 \\
\hline $\mathrm{Pb}^{42}$ & 0 & 0 & 0 \\
\hline $\mathrm{Ni}^{+2}$ & $2.21 \mathrm{E}-02$ & $8.68 \mathrm{E}+02$ & $3.15 \mathrm{E}+03$ \\
\hline $\mathrm{Sr}^{+2}$ & 0 & 0 & 0 \\
\hline $\mathrm{Mn}^{*}$ & 0 & 0 & 0 \\
\hline $\mathrm{Ca}^{42}$ & 0 & 0 & 0 \\
\hline $\mathrm{K}^{+1}$ & $2.22 \mathrm{E}-03$ & 58.24 & $2.11 \mathrm{E}+02$ \\
\hline $\mathrm{OH}^{-1}$ & 1.28 & $1.46 \mathrm{E}+0.4$ & $5.29 \mathrm{E}+04$ \\
\hline $\mathrm{NO}^{-1}$ & 7.39 & $3.07 E+05$ & $1.11 E+06$ \\
\hline $\mathrm{NO}_{2}{ }^{-1}$ & 0.23 & $7.07 \mathrm{E}+03$ & $2.56 \mathrm{E}+04$ \\
\hline $\mathrm{CO}^{\cdot 2}$ & 0.35 & $1.40 \mathrm{E}+04$ & $5.08 \mathrm{E}+04$ \\
\hline $\mathrm{PO}^{-3}$ & 0.19 & $1.20 \mathrm{E}+04$ & $4.35 \mathrm{E}+04$ \\
\hline $\mathrm{SO}^{-2}$ & 0.56 & $3.64 \mathrm{E}+04$ & $1.32 E+05$ \\
\hline $\mathrm{Si}\left(\right.$ as $\left.\mathrm{SiO}_{3}{ }^{-2}\right)$ & 0.15 & $2.91 \mathrm{E}+03$ & $1.05 E+04$ \\
\hline $\mathrm{F}^{-1}$ & 0.49 & $6.21 E+03$ & $2.25 \mathrm{E}+04$ \\
\hline $\mathrm{Cl}^{-1}$ & $1.39 \mathrm{E}-02$ & $3.30 \mathrm{E}+02$ & $1.20 \mathrm{E}+03$ \\
\hline $\mathrm{C}_{6} \mathrm{H}_{5} \mathrm{O}_{7} \cdot 3$ & 0 & 0 & 0 \\
\hline EDTA & 0 & 0 & 0 \\
\hline HEDTA $^{-3}$ & 0 & 0 & 0 \\
\hline NTA $^{\cdot 3}$ & 0 & 0 & 0 \\
\hline glycolate & 0 & 0 & 0 \\
\hline acelate ${ }^{-1}$ & $2.95 \mathrm{E}-02$ & $1.16 \mathrm{E}+03$ & $4.22 \mathrm{E}+03$ \\
\hline oxalate & 0 & 0 & 0 \\
\hline DBP & 0 & 0 & 0 \\
\hline $\mathrm{NPH}$ & 0 & 0 & 0 \\
\hline $\mathrm{CCl}_{1}$ & 0 & 0) & 0 \\
\hline hexone & 0 & 0 & 0 \\
\hline $\mathrm{Fe}(\mathrm{CN})_{6}{ }^{4}$ & $1.67 \mathrm{E}-02$ & $4.06 \mathrm{E}+04(\mathrm{~g}-\mathrm{mol})$ & \\
\hline 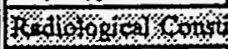 & Kus $/ \% / \% /$ & \% $/ \% / \%$ & \%/ $/$ \% \\
\hline Pu & & 4.97E- $03(\mu \mathrm{Ci} / \mathrm{g})$ & $0.30(\mathrm{~kg})$ \\
\hline $\mathrm{U}$ & $2.09 \mathrm{E}-02(\mathrm{M})$ & $3.33 E+03(\mu \mathrm{g} / \mathrm{g})$ & $1.21 \mathrm{E}+04(\mathrm{~kg})$ \\
\hline Cs & $0.33(\mathrm{Ci} / \mathrm{L})$ & $2.24 \mathrm{E}+02(\mu \mathrm{CJ} / \mathrm{g})$ & $8.13 E+05(G)$ \\
\hline Sr & $1.15 \mathrm{E}-02(\mathrm{Ci} / \mathrm{L})$ & $7.67(\mu \mathrm{Ci} / \mathrm{g})$ & $2.78 \mathrm{E}+04(\mathrm{Ci})$ \\
\hline
\end{tabular}

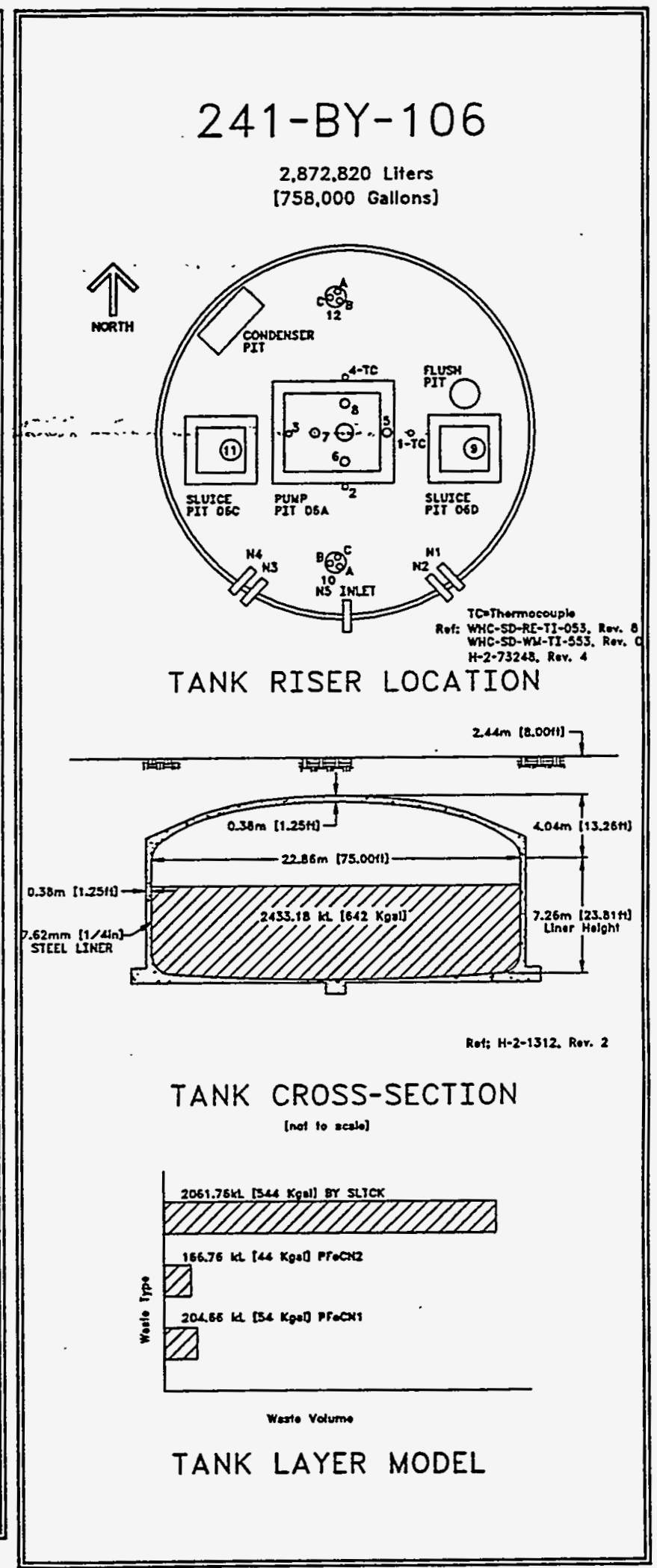

- Composite inventory exchudes supersatant, dintomacoous earth, and cemen

Unkoouns in tank inventory are assigned by Tank Layering Model (ILM) 


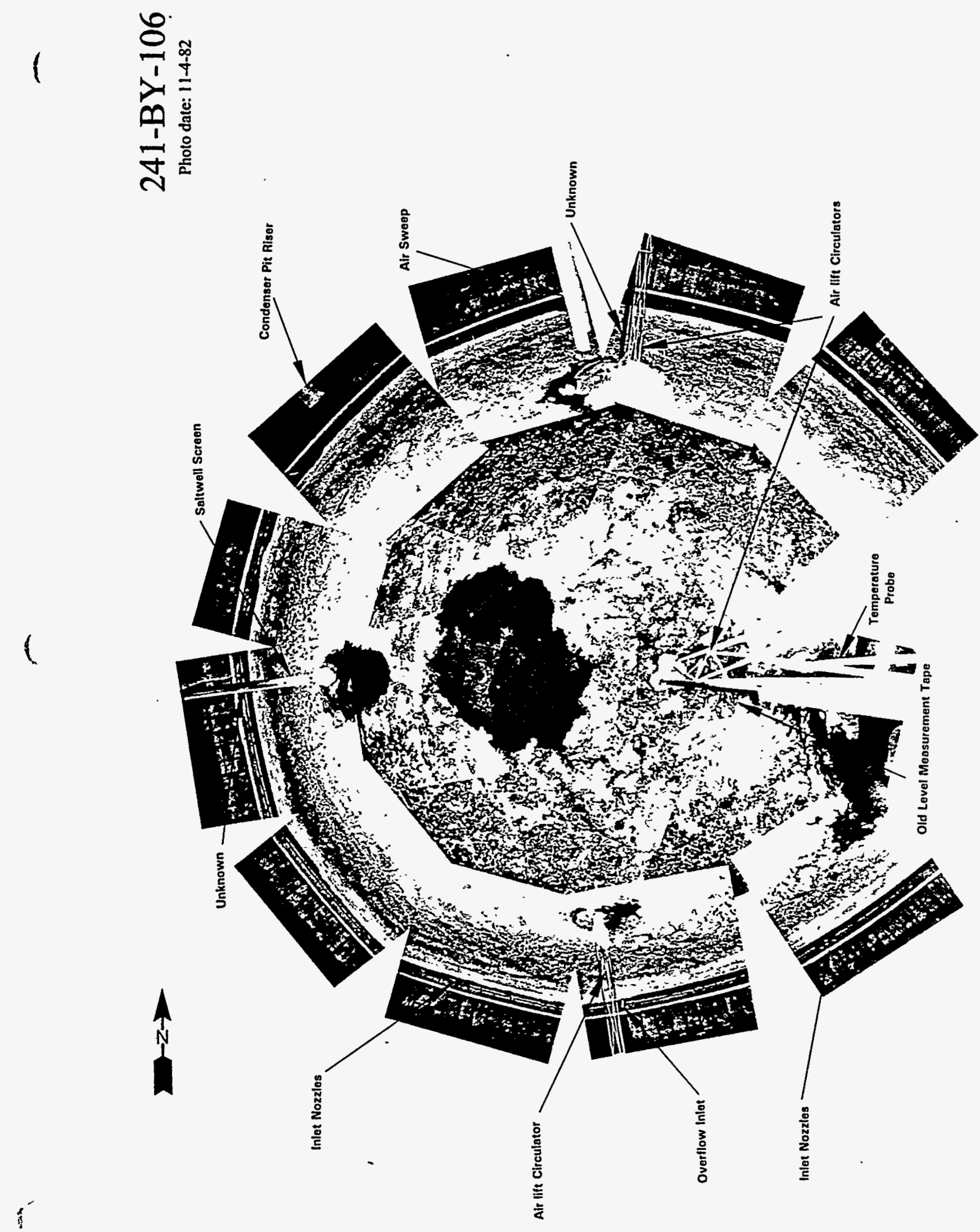


WHC-SD-WM-ER-349, ReV. 0

\subsection{Tank 241-BY-107}

\subsubsection{1-BY-107 Tank History}

\subsubsection{Waste History Tank 241-BY-107}

Tank 241-BY-107 was filled with first-cycle waste from September 1950 to March 1951. The tank integrity was questioned in 1974. A liquid observation well was installed in.the tank in 1975. The tank was removed from service in the first quarter of 1976 and was saltwelI pumped in the third quarter of 1976. The tank was primary stabilized in the first quarter of 1978. Saltwell pumping was completed in June 1979 and the tank was declared interim stabilized in July 1979. Intrusion prevention. was.. completed.. in . December $1982 . .$. The tank was declared an

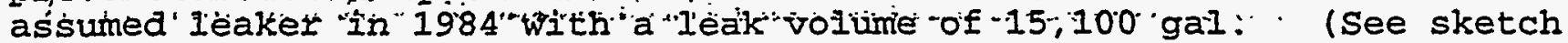
ES-TKS-E45 for a graphical representation of the Tank 241-BY-107 level history.)

\subsubsection{Temperature History 241-BY-107}

The single thermocouple tree in Tank 241-BY-107 has 15 thermocouple probes to record temperature data. The mean temperature for the first daily recorded readings was $35^{\circ} \mathrm{F}$. A sum of the squares regression Iine fit for the first 10 thermocouples shows a slight temperature increase in with a large amount of variability. Regression analysis shows that, for thermocouples 11 through 14 , there is a moderate a mount of variability, and no overall change in temperature. Not enough data points exist to do an accurate regression or variability analysis for thermocouple 15. Annual temperature undulations are apparent after January 1992. The median temperature is $77.9^{\circ} \mathrm{F}$ with a minimum of $30.1^{\circ} \mathrm{F}$ and a maximum of $120.2 \%$. Refer to the supporting document for a more thorough review of the temperature data (Brevick 1994).

\subsubsection{Integrity of Tank 241-BY-107}

Tank 241-BY-107 is categorized as an assumed leaker and is interim stabilized with intrusion prevention completed. The Tank 241-BY-107 surface level is monitored quarterly with a manual tape through riser 4 . A Eigure that graphically represents the surface level measurements from January 1991 to the present can be found in the supporting documents (Brevick 1994). The surface level for the past 3 years has remained steady with readings ranging between 104 and 103 in.

The Tank 241-BY-107 liquid observation well for is located in riser 7. The tank is monitored weekly with a neutron probe and on request with a gamma probe to determine interstitial liquid levels. The maximum deviations from the established baseline are a 0.3 -ft increase or a $0.4-$ ft decrease. Sketch ES-TKS-E45 has a graphical representation of the liquid observation well data.

Six drywells are identified for Tank 241-BY-107. Graphical representations of the drywell data for each active drywell from January

1990 to the present can be found in the supporting document (Brevick

$$
-271-
$$


WHC-SD-WM-ER-349, Rev. 0

1994). Each graph includes the peak $\mathrm{c} / \mathrm{s}$ (some wells have multiple peaks), the depth at which the peak occurred, and the date of the reading. Occurrence reports were written in 1979 and 1980 due to increased activity in the drywells resulting from contamination migration in the soil. The migration was attributed to snow melt, nearby water bibs, and condensate from a steam cleaner entering the soil.

\section{$6.7 .2^{\circ} \quad$ Current Status of Tank 241-BY-107}

Tank 241-BY-107 entered service in December 1950 and currentIy stores 266,000 gal of waste. The waste is comprised of 149,000 gal of saltcake and 117,000 gal of sludge with no supernatant or pumpable liquid remaining. The tank is. identified.on the Ferrocyanide watch List as of January '1991; is passively ventilated; 'and"is-categorized as an assumed leaker with interim stabilization and intrusion prevention completed. Tank 241-BY-107 is equipped to cascade to Tank 241-BY-108 and is first in the three-tank cascade series. The following plan view and tank cross section depict the approximate waste level and riser configuration. Tank 241-BY-107 has a total of 17 risers and five are available for use: two $12-i n$. risers nos. 5 and 8 , and three 18-in. risers nos. 9B, 10A, and 12B (reference drawing H-2-73249 Rev. 2).

\subsubsection{Inventory estimate 241-BY-107}

The following tank layer volume approximation was derived from the Los Alamos National Laboratories Waste Status and Transaction Record Summary (Agnew 1994). The estimated inventory of Tank 241-BY-107 is also presented.

\subsubsection{In-Tank Photograph 241-BY-107}

The Tank 241-BY-107 photo shows a light yellow rough saltcake surface. There are depressions in the surface where equipment currently extends into the saltcake or where equipment has been removed. The waste measures approximately 7.5 ft deep.

$6.7 .3 \quad$ Synopsis Tank 241-BY-107

(To be completed.) 
$-\varepsilon<z-$

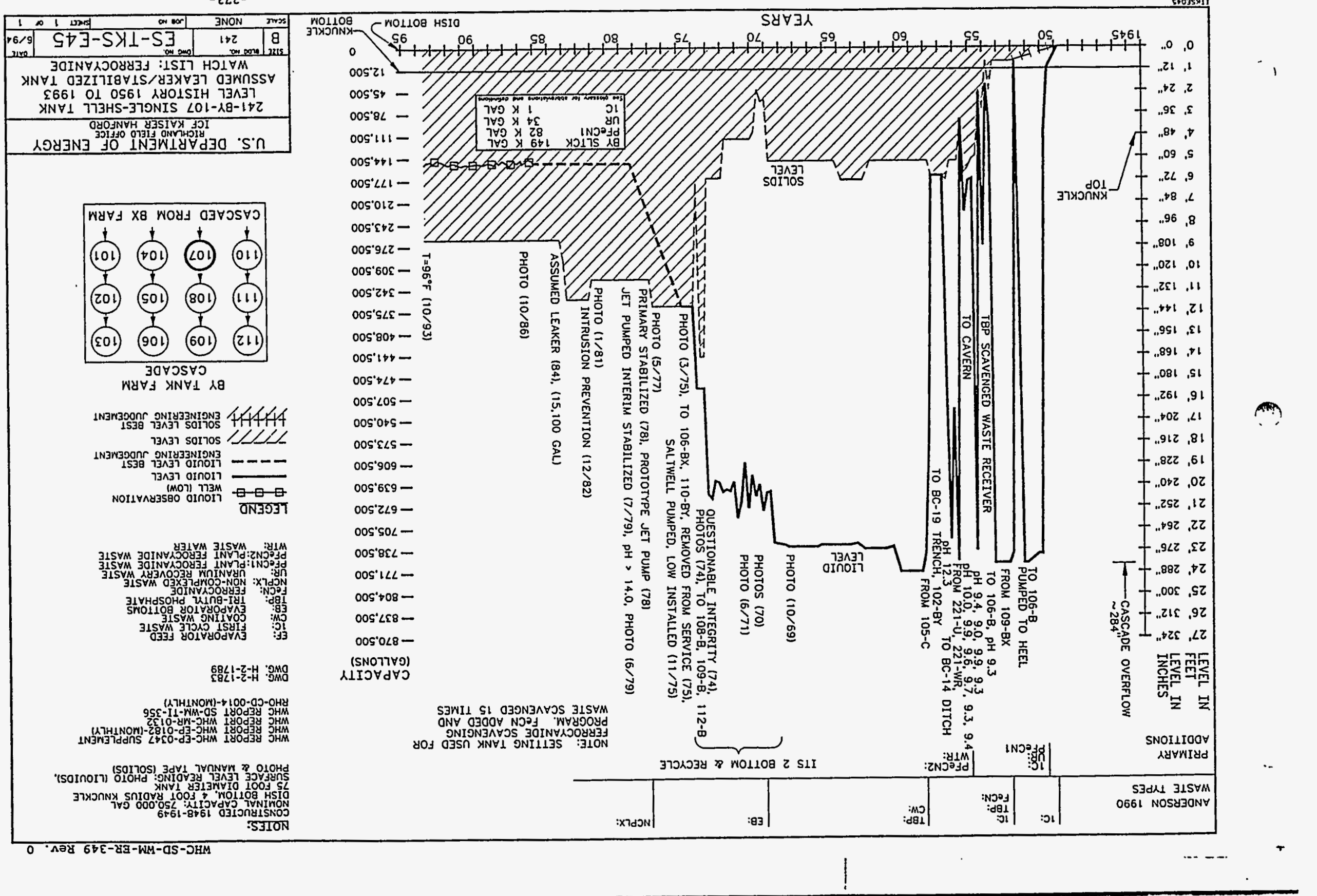


WHC-SD-WM-ER-349, Rev. 0

\begin{tabular}{|c|c|c|c|}
\hline \multicolumn{4}{|c|}{ Single-Shell Tank 241-BY-107 } \\
\hline \multicolumn{4}{|c|}{ Solids Composite Inventory Estimate } \\
\hline \multicolumn{4}{|c|}{ 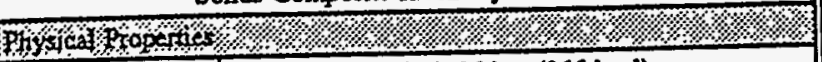 } \\
\hline Total Solid Waste & \multicolumn{3}{|c|}{$1.52 \mathrm{E}+06 \mathrm{~kg}(266 \mathrm{kgal})$} \\
\hline Heas load & \multicolumn{3}{|c|}{$1.38 \mathrm{~kW}(4.70 \mathrm{E}+03 \mathrm{BTU} / \mathrm{hr})$} \\
\hline Bulk Density & \multicolumn{3}{|c|}{$1.51(\mathrm{~g} / \infty)$} \\
\hline Void Fraction & \multicolumn{3}{|c|}{0.64} \\
\hline Water wr\% & \multicolumn{3}{|c|}{33.10} \\
\hline TOC wt\% C (wet) & \multicolumn{3}{|c|}{0.24} \\
\hline \multicolumn{4}{|c|}{ 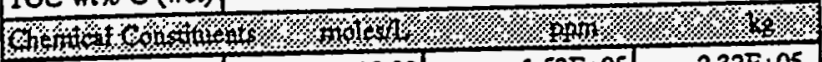 } \\
\hline $\mathrm{Na}^{4+1}$ & 10.00 & $1.53 \mathrm{E}+05$ & $2.32 \mathrm{E}+05$ \\
\hline $\mathrm{Al}^{+3}$ & 0.21 & $3.80 E+03$ & $5.77 \mathrm{E}+03$ \\
\hline $\mathrm{Fe}^{63}($ lotal Fe $)$ & 0.24 & $8.74 \mathrm{E}+03$ & $1.33 \mathrm{E}+04$ \\
\hline $\mathrm{Cr}^{3+\cdots} \cdot \cdots \cdot$ & $\therefore \cdot 5.49 \mathrm{E}-05$ & $\because \cdots+\cdots, 1.89$ & $\cdots \cdots 2.87$ \\
\hline $\mathrm{Bi}^{+3}$ & 0.11 & $1.51 \mathrm{E}+04$ & $2.29 \mathrm{E}+04$ \\
\hline $\mathrm{La}^{43}$ & 0 & o & 0 \\
\hline $\mathrm{Ce}^{+3}$ & 0 & 0 & 0 \\
\hline $\mathrm{Zr}\left(\mathrm{as} \mathrm{ZrO}(\mathrm{OH})_{2}\right)$ & $1.10 \mathrm{E}-04$ & 6.64 & 10.08 \\
\hline $\mathrm{Pb}^{+2}$ & 0 & 0 & 0 \\
\hline $\mathrm{Ni}^{+2}$ & 4.17E-02 & $1.62 \mathrm{E}+03$ & $2.46 \mathrm{E}+03$ \\
\hline$\widehat{S r^{+2}}$ & 0 & 0 & 0 \\
\hline $\mathrm{Mn}^{+4}$ & of & 0 & 0 \\
\hline $\mathrm{Ca}^{+2}$ & 0 & 0 & 0 \\
\hline $\mathrm{K}^{+1}$ & 1.47E-03 & 38.13 & 57.86 \\
\hline $\mathrm{OH}^{2}$ & 1.33 & $1.50 \mathrm{E}+04$ & $2.27 \mathrm{E}+04$ \\
\hline $\mathrm{NO}^{-1}$ & 5.49 & $2.26 \mathrm{E}+05$ & $3.43 E+05$ \\
\hline $\mathrm{NO}_{2-2}^{-1}$ & 0.15 & $4.64 \mathrm{E}+03$ & $7.04 \mathrm{E}+03$ \\
\hline $\mathrm{CO}^{-2}$ & 0.25 & $9.87 \mathrm{E}+03$ & $1.50 \mathrm{E}+04$ \\
\hline $\mathrm{PO}^{-3}$ & 0.43 & $2.68 \mathrm{E}+04$ & 4.07E+04 \\
\hline $\mathrm{SO}^{\cdot 2}$ & 0.94 & $5.97 \mathrm{E}+04$ & $9.06 \mathrm{E}+04$ \\
\hline $\mathrm{Si}\left(\right.$ as $\left.\mathrm{SiO}_{3}^{-2}\right)$ & 0.29 & $5.45 \mathrm{E}+03$ & $8.28 \mathrm{E}+03$ \\
\hline $\mathrm{F}^{-1}$ & 0.36 & $4.48 \mathrm{E}+03$ & $6.79 \mathrm{E}+03$ \\
\hline $\mathrm{Cl}^{-1}$ & 9.85E-03 & $2.31 \mathrm{E}+02$ & $3.51 \mathrm{E}+02$ \\
\hline $\mathrm{C}_{6} \mathrm{H}_{5} \mathrm{O}_{7}{ }^{3}$ & 0 & 0 & 0 \\
\hline EDTA & of & of & 0 \\
\hline HEDTA ${ }^{.3}$ & 0) & of & 0 \\
\hline $\mathrm{NTA}^{-3}$ & of & of & 0 \\
\hline glycolate & 0 & 0 & 0 \\
\hline acetate & $1.95 \mathrm{E}-02$ & $7.62 \mathrm{E}+02$ & $1.16 \mathrm{E}+03$ \\
\hline oxalate ${ }^{-2}$ & 0 & 0 & 0 \\
\hline DBP & of & of & 0 \\
\hline $\mathrm{NPH}$ & of & 0) & 0 \\
\hline $\mathrm{CCl}_{4}$ & 0 & 0 & 0 \\
\hline hexone & 0 & $\begin{array}{r} \\
\end{array}$ & 0 \\
\hline $\mathrm{Fe}(\mathrm{CN})_{6}{ }^{4}$ & \begin{tabular}{|r|}
$4.17 \mathrm{E}-02$ \\
\end{tabular} & $4.19 \mathrm{E}+04(\mathrm{~g}-\mathrm{mol})$ & \\
\hline \multicolumn{4}{|c|}{$\mathrm{Fe}(\mathrm{CN})_{6}$} \\
\hline $\mathrm{Pu}$ & & 1.56E-02 $(\mu \mathrm{Ci} / \mathrm{g})$ & $0.39(\mathrm{~kg})$ \\
\hline $\mathrm{U}$ & $1.92 \mathrm{E}-02(\mathrm{M})$ & $3.03 \mathrm{E}+03(\mathrm{\mu g} / \mathrm{g})$ & $4.60 \mathrm{E}+03(\mathrm{~kg})$ \\
\hline Cs & $0.24(\mathrm{Ci} / \mathrm{L})$ & $1.59 \mathrm{E}+02(\mu \mathrm{Ci} / \mathrm{g})$ & $2.42 E+05(\mathrm{Ci})$ \\
\hline Sr & $3.59 \mathrm{E}-02(\mathrm{Ci} / \mathrm{L})$ & $23.82(\mathrm{\mu Ci} / \mathrm{g})$ & $3.62 \mathrm{E}+04(\mathrm{Ci})$ \\
\hline
\end{tabular}

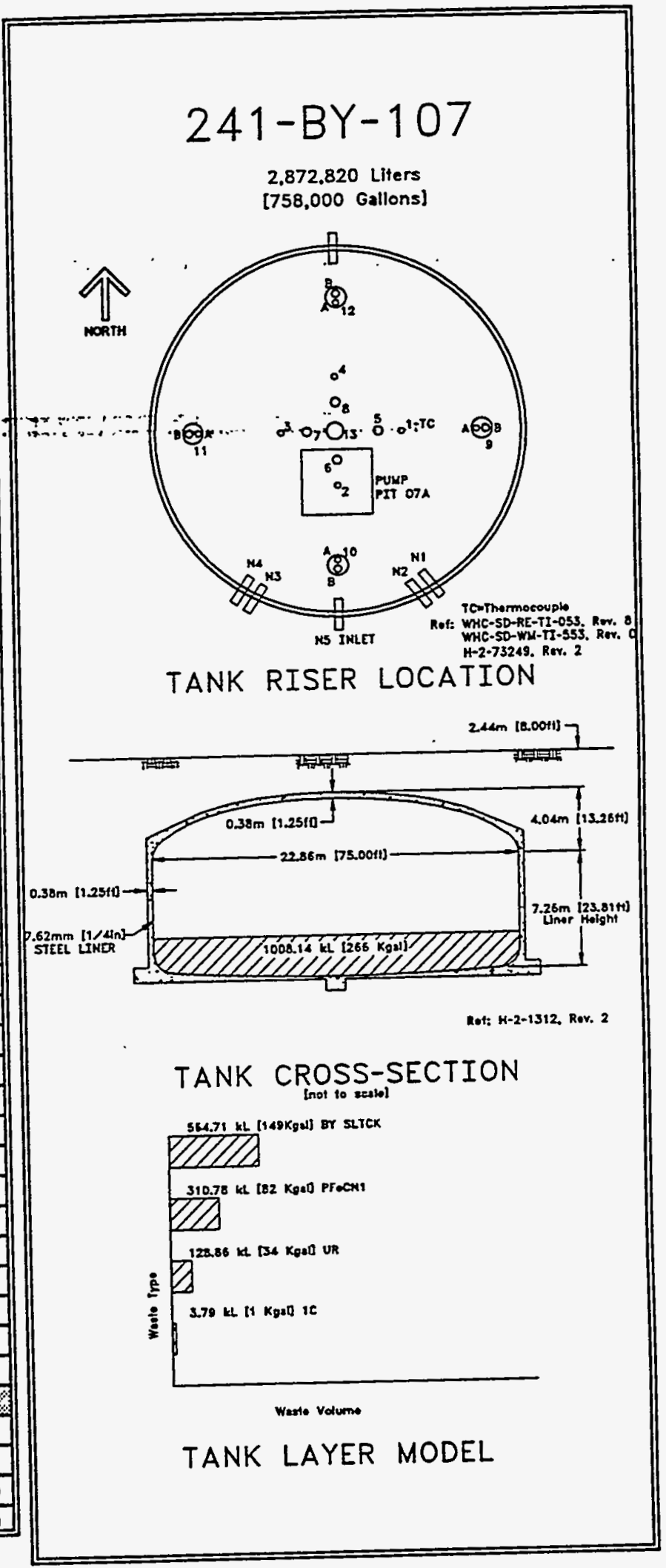




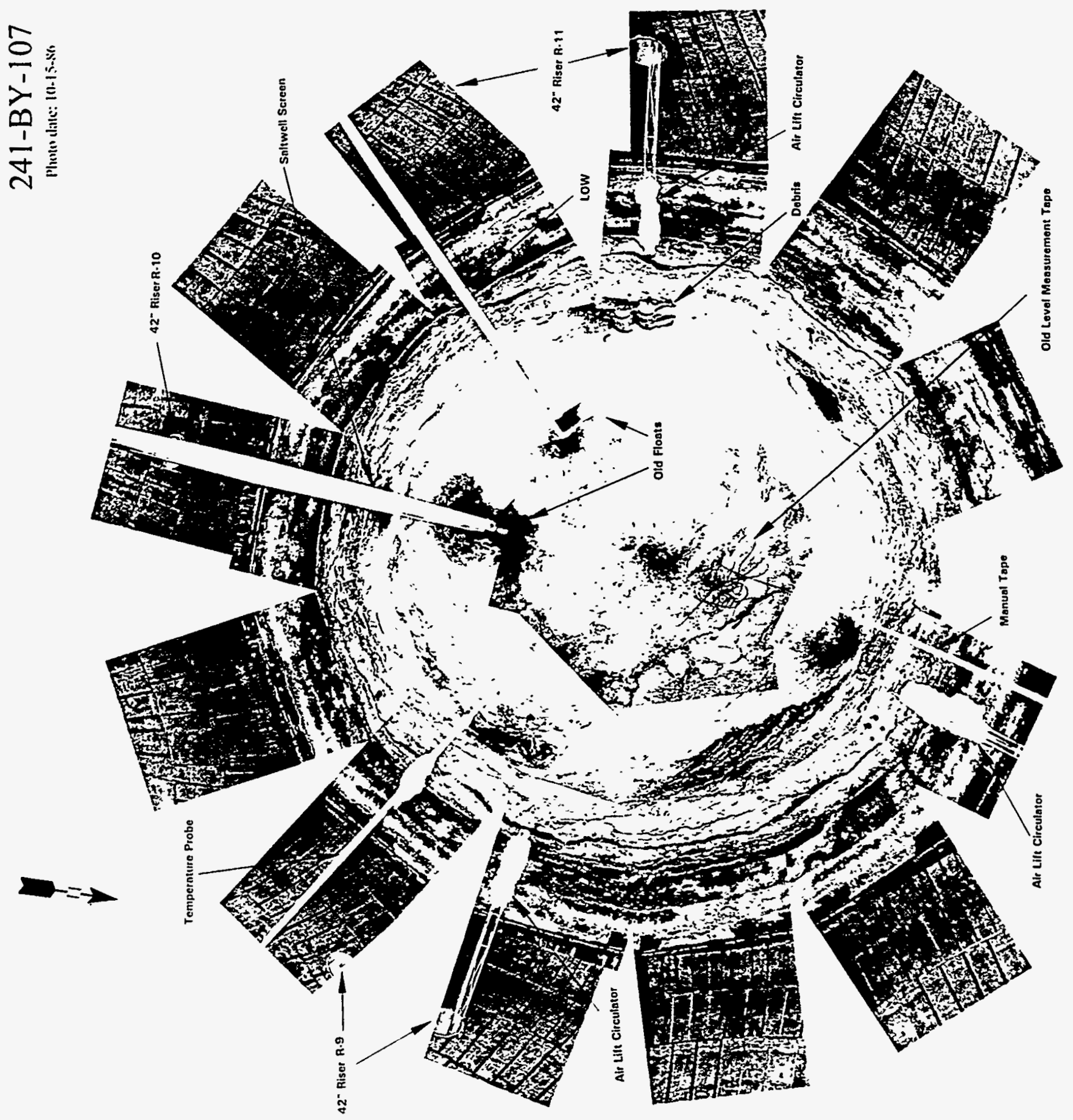




\subsubsection{1-BY-108 Tank History}

\subsubsection{Waste History Tank 241-BY-108}

Tank 241-BY-108 was filled with first-cycle waste from the Tank 241-BY-107 cascade between March 1951. and the second quarter of 1953 . The tank was declared an assumed. leaker in 1972 with a leak volume greater than 5,000 gal. Saltwell pumping started in the first quarter of 1977. The tank was primary stabilized and the pump was removed in 1978. Partial isolation was completed in December 1982. A saltwell pump was installed in January 1984 and the tank was declared interim stabilized. in February. 198. ,..... (See, sketch.ES-TKS-E46. for a graphical

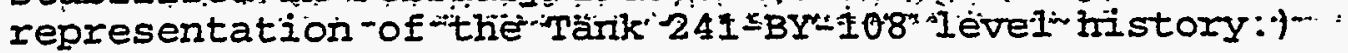

\subsubsection{Temperature History 241-BY-108}

The single thermocouple tree in Tank 241-BY-108 has 13 thermocouple probes to record temperature data. The mean temperature for the first daily recorded readings was $42^{\circ} \mathrm{F}$. A sum of the squares regression line fit for the first 10 thermocouples shows no overall temperature change and a moderate amount of variability. The median temperature is $84^{\circ} \mathrm{F}$ with a minimum of $50^{\circ} \mathrm{F}$ and a maximum of $154^{\circ} \mathrm{F}$. Refer to the supporting document for a more thorough review of the temperature data Brevick 1994).

\subsubsection{Integrity of Tank 241-BY-108}

Tank 241-BY-108 is categorized as an assumed leaker and is interim stabilized with intrusion prevention completed. The Tank 241-BY-108 surface level is monitored quarterly with a manual tape through riser 4 . A figure that graphically represents the surface level measurements from January 1991 to the present can be found in the supporting documents (Brevick 1994). The surface-level for the past 3 years has remained steady and the readings ranging between 88.5 and 86 in.

An occurrence report was issued in January 1980 due to a 2,600-gal liquid intrusion caused by rapid snowmelt into the tank through the pits.

Tank 241-BY-108 does not have a liquid observation well. Six drywells are identified for Tank 241-BY-108. Graphical representations of the data for each active drywell from January 1990. to the present can be found in the supporting document (Brevick 1994). Each graph includes the peak c/s (some wells have multiple peaks), the depth at which the peak occurred, and the date of the reading.

\subsubsection{Current Status of Tank 241-BY-108}

Tank 241-BY-108 entered service in April 1951 and currently stores $228,000 \mathrm{gal}$ of waste. The waste is comprised of 63,000 gal of saltcake and 165,000 gal of sludge with no supernatant or pumpable liguid 
remaining. The tank is identified on the Ferrocyanide watch list and is passively ventilated, and is categorized as an assumed leaker with interim stabilization and intrusion prevention completed. Tank 241-BY108 is equipped to cascade to Tank 241-BY-109 and is second in the three-tank cascade series. The following plan view and tank cross section depict the approximate waste level and riser configuration. Tank 241-BY-108 has 17 risers and five are available for use: three 4in. risers (nos.1, 2, and 5) and two 12-in. risers (nos.9B and 12A).

\subsubsection{Inventory estimate 241-BY-108}

The following tank layer volume approximation was derived from the Los Alamos National Laboratories Waste Status and Transaction Record Summary. (Agnew...19.94. .....The. estimated inventory, of. Tank. 241-BY-108 is also presented:"

\subsubsection{In-Tank Photograph 241-BY-108}

The Tank 241-BY-108 photo shows a white to light rose saltcake surface. At the top center of the photo, an air lift circulator, a temperature probe, and a manual tape are descending into a depression filled with liquid. The waste measures approximately 6.5 ft deep.

6.8.3 Synopsis Tank 241-BY-108

(To be completed.) 


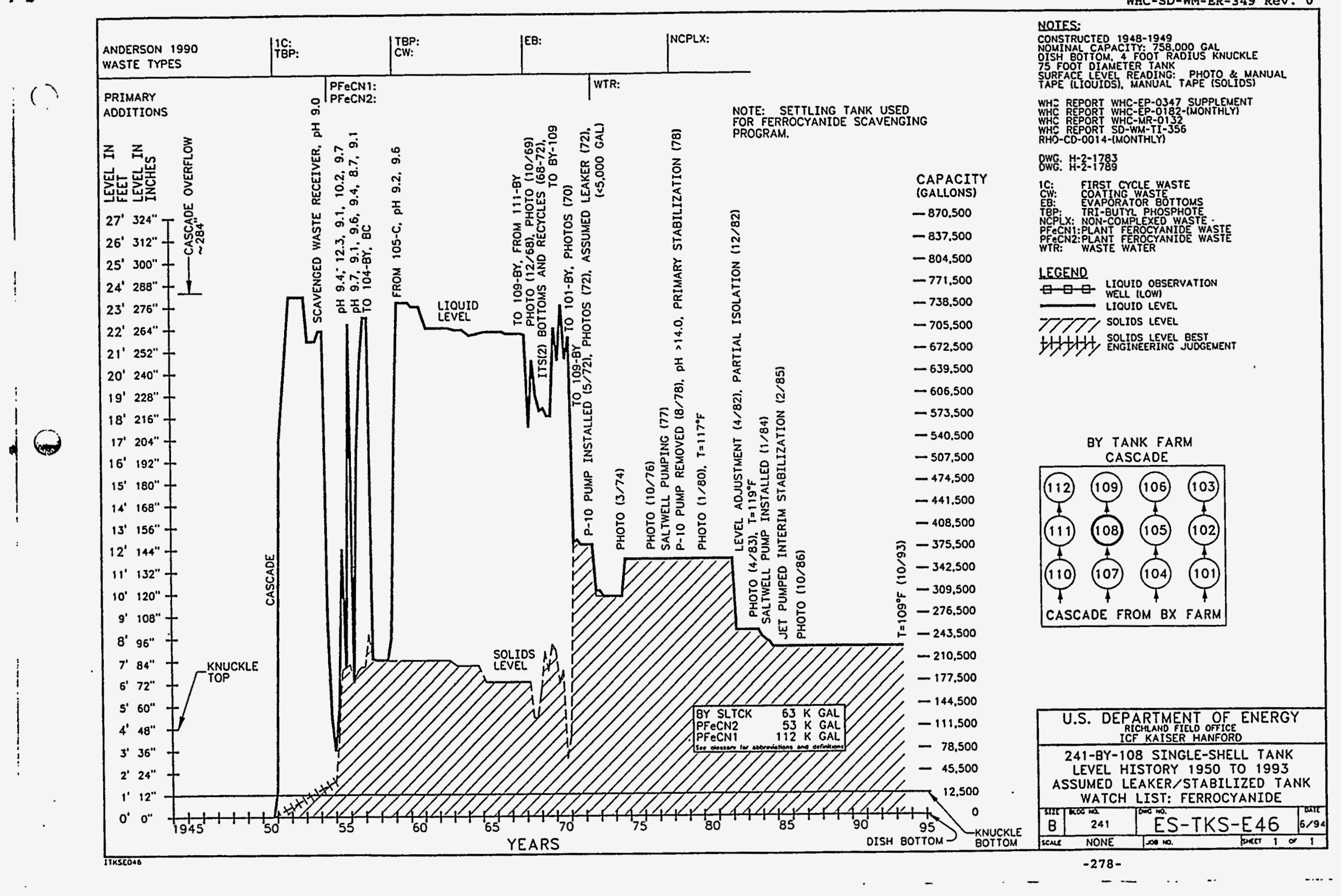




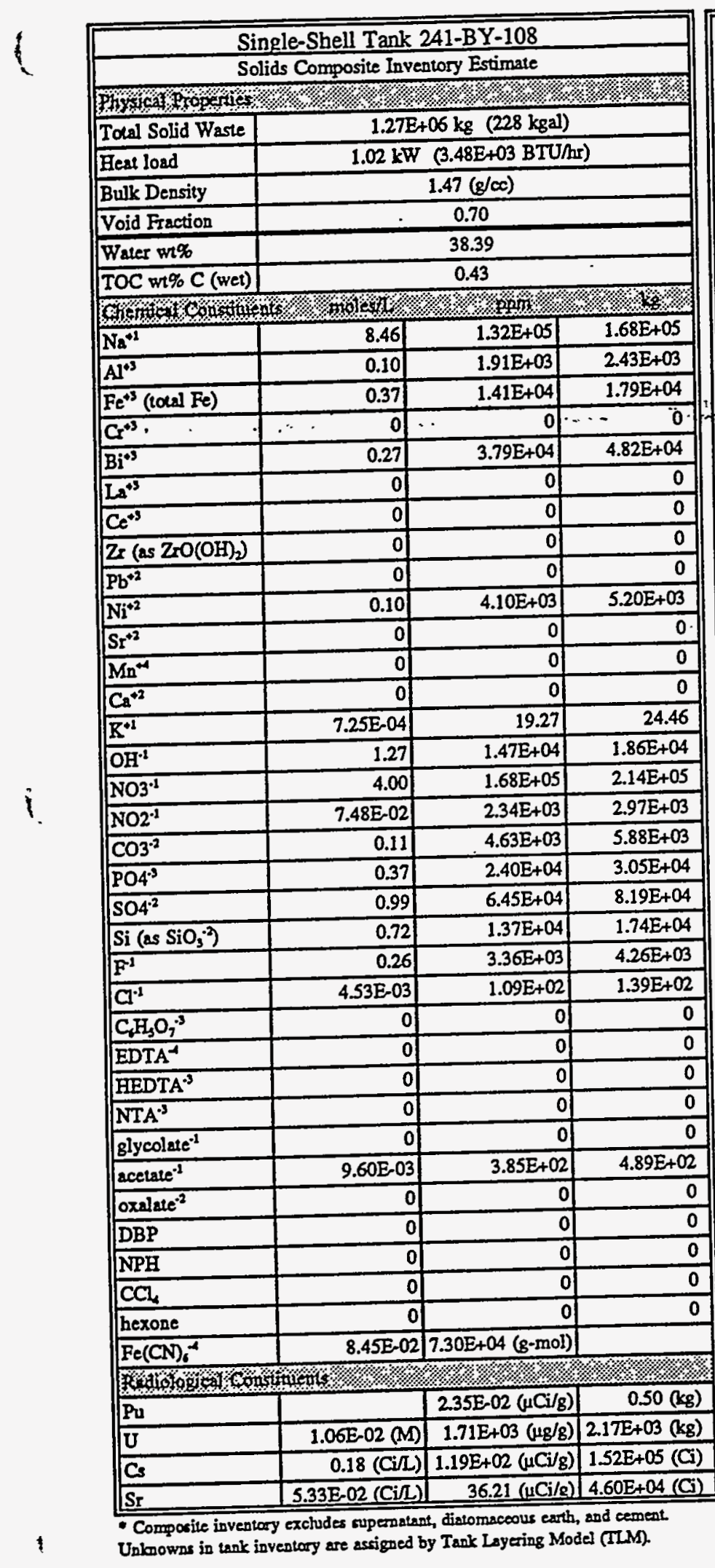

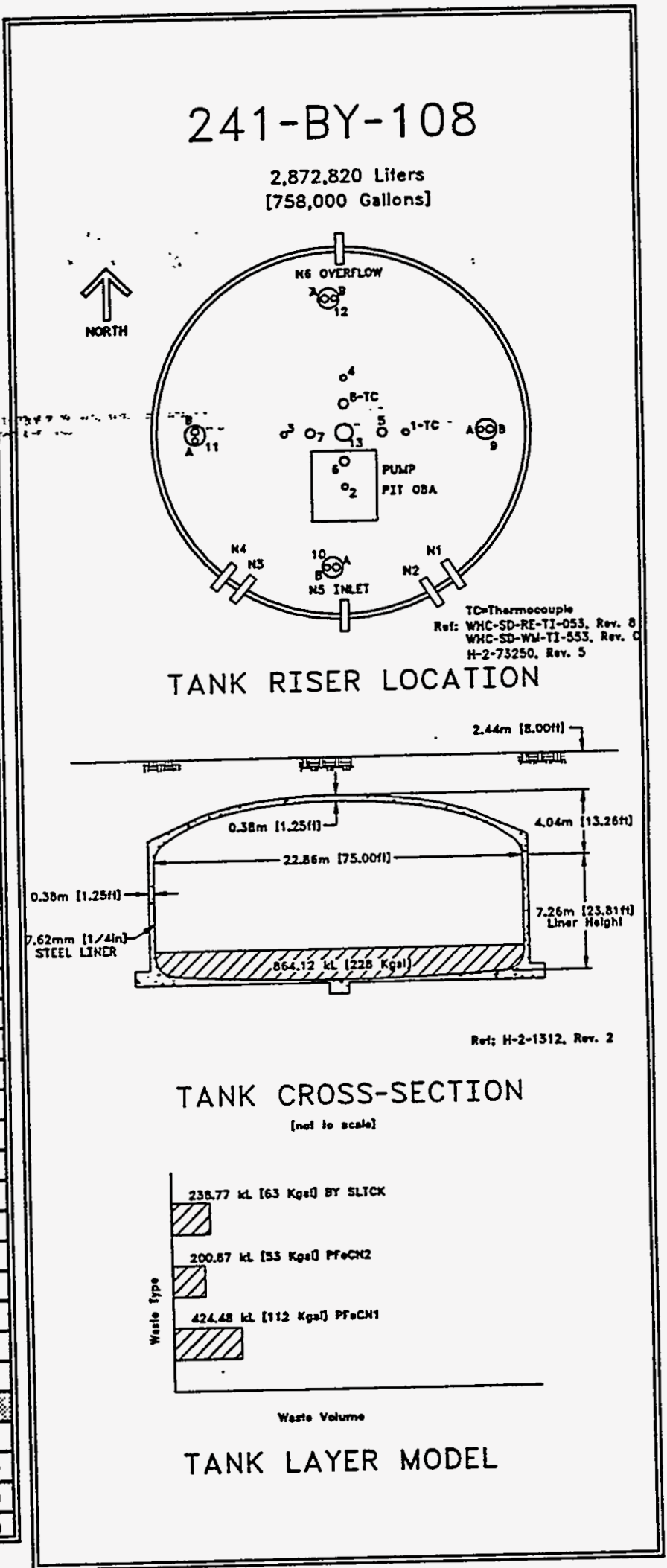




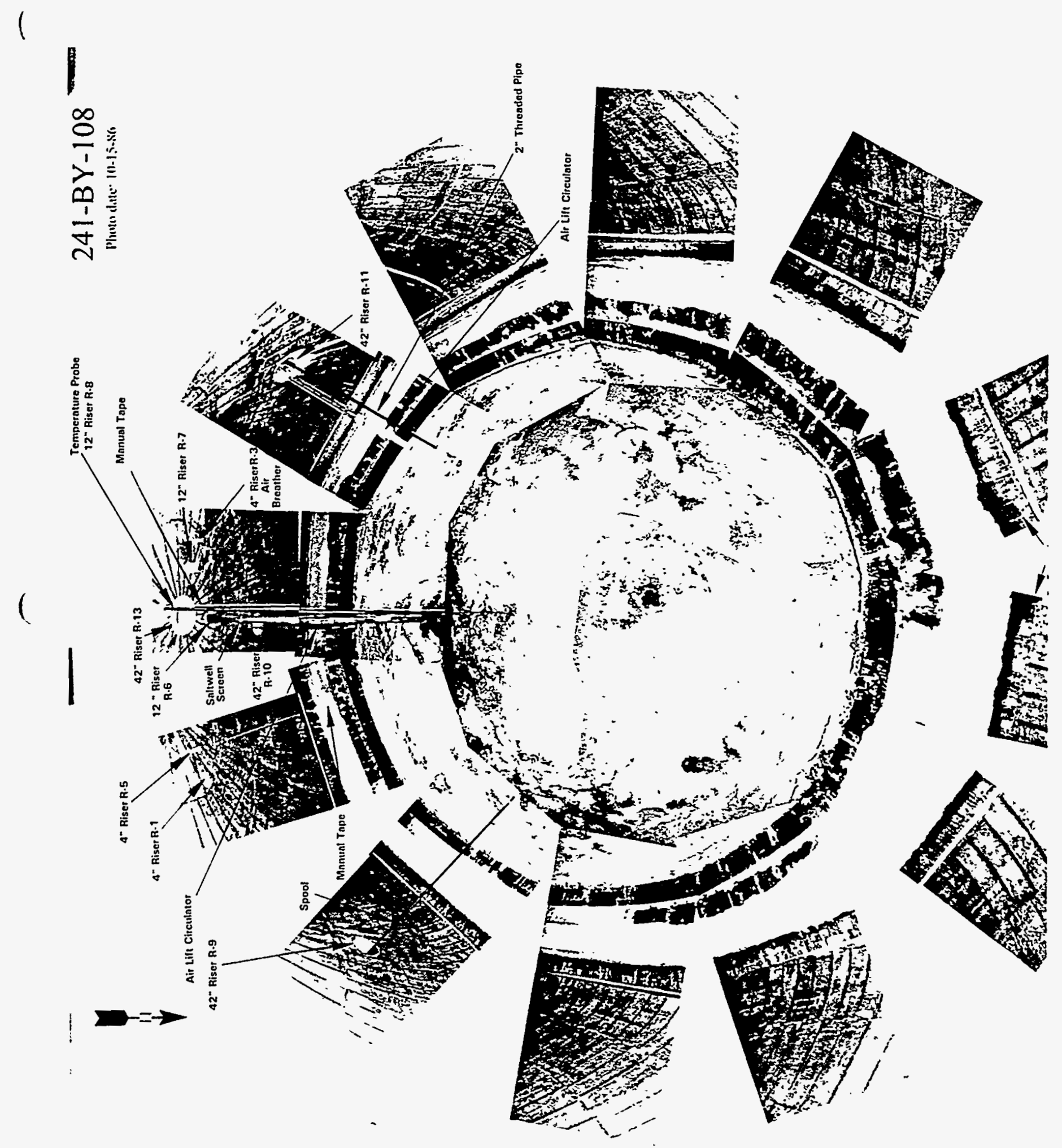




\subsubsection{1-BY-109 Tank History \\ 6.9.1.1 Waste History Tank 241-BY-109}

Tank 241-BY-109 began operation on January 8, 1953 by receiving tributyl phosphate wastes from Tank 241-B-103.. The tank.was deactivated on August 9, -1979 and a solids..level adjustment was made. Another solids level adjustment was made in 1984 and the tank was partially interim isolated in June 1985: The liquid was jet pumped on June 16, 1991 and a solids level adjustment was made. The draw-down from pumping is noticeable in the liquids, solids, and liquid observation well waste levels..... (See. Sketch. ES-TKS-E47...for. a.graphical.. representation of the

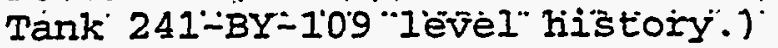

\subsubsection{Temperature History 241-BY-109}

The single thermocouple tree in Tank 241-BY-109 had 12 thermocouple probes to record temperature data. The mean temperature for the first data recorded was $98^{\circ} \mathrm{F}$. A sum of the squares regression line fit for thermocouples 1 through 8 and 10 through 12 over the short time period shows a temperature decrease with a moderate amount of variability. A regression analysis on thermocouple 9 would prove inconclusive due to lack of data. The median temperature is $66^{\circ} \mathrm{F}$ with a minimum of $51^{\circ} \mathrm{F}$ and a maximum of $138^{\circ} \mathrm{F}$. Tank 241-BY-109 currently has no thermocouple tree within the tank. Refer to the supporting document for a more thorough review of the temperature data (Brevick 1994).

\subsubsection{Integrity of Tank 241-BY-109}

Tank 241-BY-109 is partially interim isolated and is considered a sound tank that is awaiting interim stabilization. The Tank 241-BY-109 surface level is monitored daily with a Food Instrument corporation gauge through riser 4. A figure that graphically represents the surface level measurements from January 1991 to the present can be found in the supporting documents (Brevick 1994). The waste level decreases in the midale of 1991 which corresponds with the salt well pumping efforts that began in June 1991. Since the conclusion of salt well pumping, the surface level has remained steady with the readings fluctuating between 140.8 and 137.1 in. The graph depicts erratic data points during the second, third, and fourth quarters of 1993. The erratic data were attributed to a mechanical malfunction in the automatic operation of the Food Instrument Corporation gauge: When the unexpected readings were observed, the liquid observation well data and drywell data were checked to confirm the integrity of the tank.

The Tank 241-BY-109 liquid observation well is located in riser 12B. The tank is monitored weekly with a neutron probe and on request basis with a gamma probe to determine interstitial liquid levels. The maximum deviations from the established baseline are a 0.3 -ft increase and a $0.4-\mathrm{ft}$ decrease. Sketch ES-TKS-E47 contains a graphical representation of the liquid observation well data. 
WHC-SD-WM-ER-349, Rev. 0

Six drywelis are identified for tank 241-BY-109. The supporting document contains graphical representations of the drywell data for the active drywells from January 1990 to the present (Brevick 1994). Each graph includes the peak c/s (some wells have multiple peaks), the depth at which the peak occurred, and the date of the reading.

An off-normal occurrence 10-day report was written on July $3,1991$. Drywells around Tank 241-BY-103 and -108 showed an increase in radiation levels while waste was being transferred from the tanks 241-BY-102, and -109 to the double-contained receiver Tank 244-BX. It was determined that the drywells were detecting the waste in the transfer lines. Flushing of the transfer lines verified that they were not leaking because radiation levels decreased.

\subsubsection{Current Status of Tank 241-BY-109}

Tank 241-BY-109 entered service in 1950 and currently stores 423,000 gal of non-complexed waste. the waste is comprised of 387,000 gal of saltcake, 36,000 gal of unknown waste, and no supernatant with 57,000 gal of pumpable interstitial liquid remaining. The tank is identified as a low-heat load tank, is passively ventilated, and is categorized as sound with partial isolation completed. Tank 241-BY-109 is third in the three-tank cascade series. The following plan view and cross section depict the approximate waste level and riser configuration. Tank 241-BY-109 has 19 risers and 12-in. risers nos. 9A, $10 B$, and $12 C$ are readily available for use.

\subsubsection{Inventory estimate 241-BY-109}

The following tank layer volume approximation was derived from the Los Alamos National Laboratories Waste Status and Transaction Record Summary (Agnew 1994). The estimated inventory of Tank 241-BY-109 is also presented.

\subsubsection{In-Tank Photograph 241-BY-109. .}

The Tank 241-BY-109 photo shows a liquid surface over a submerged solids layer. The only apparatus in the tank is a saltwell screen; no Food Instrument corporation gauge is visible. The liquid shown in the tank photo had a medium brown to black color. The waste measures approximately 12.5 ft deep. Because the solids are submerged, it is impossible to make a distinction between the two solids layers. The photo does not indicate the current status of the tank because it was taken in October 1986 and the tank was saltwell pumped in June 1991.

\subsubsection{Synopsis Tank 241-BY-109}

(To be completed.) 
$0 \rightarrow$ ․

뭉

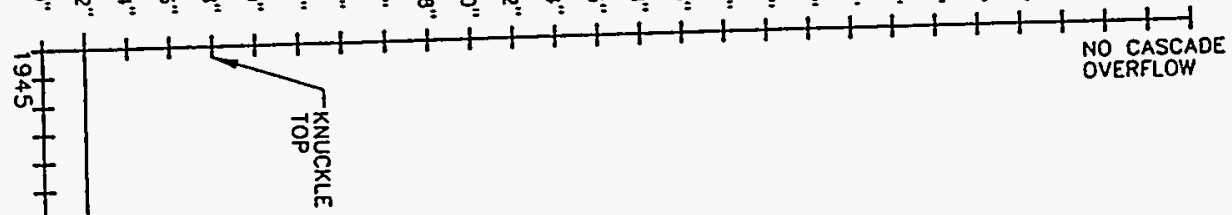

if

HOMOGENATED - SUPERNATANT HOLDER FOR 200 EAST

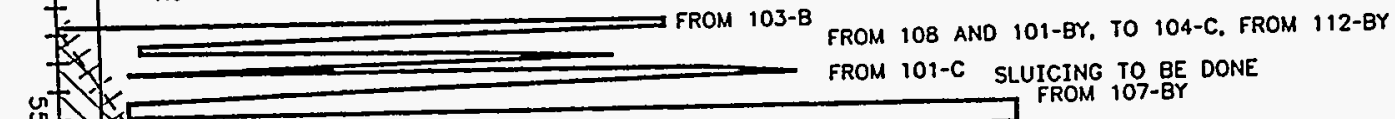

FROM 108 AND 101-BT, TO TOA-C. FRON
FROM 101-C SLUICING TO BE DONE
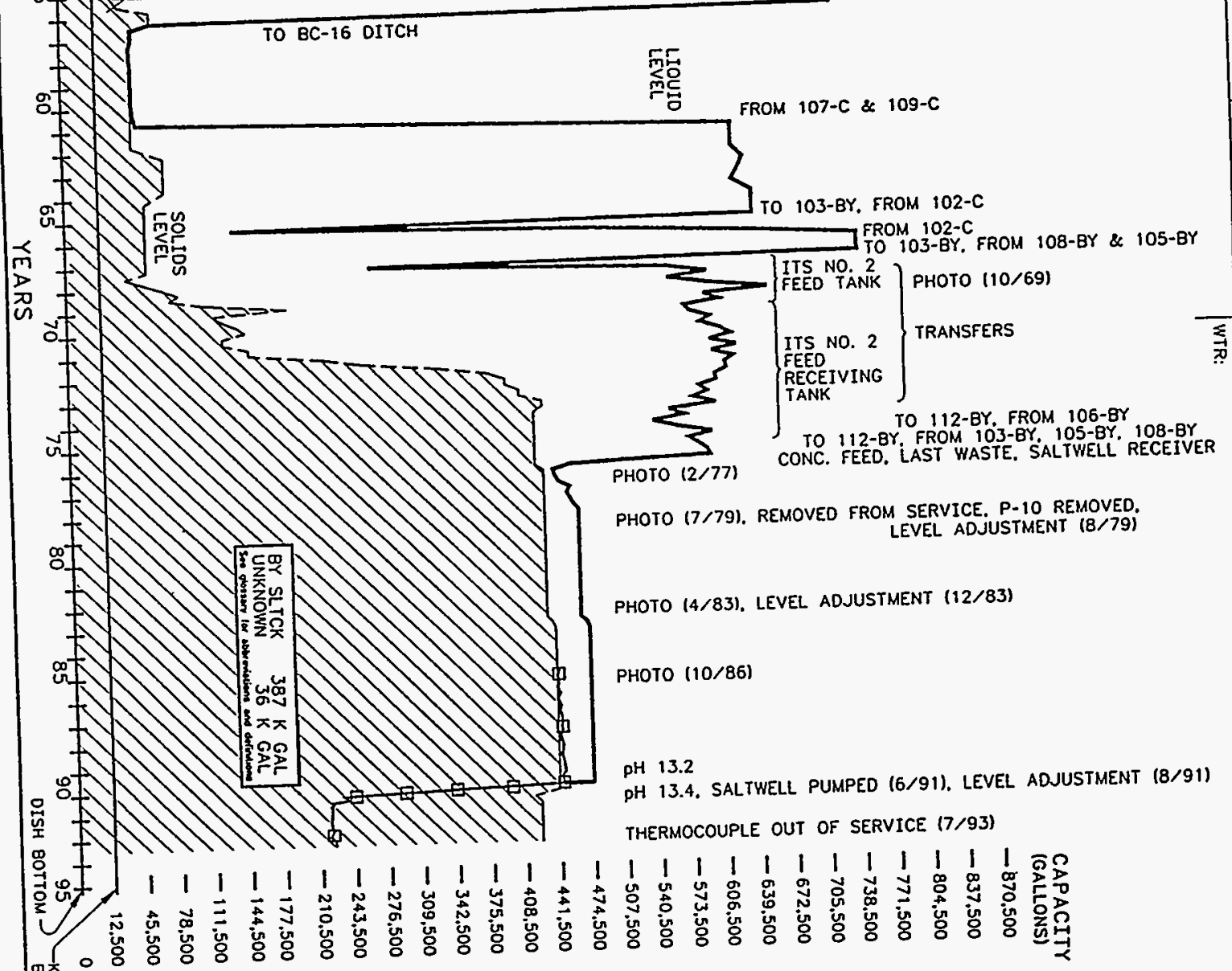

赵

궁동
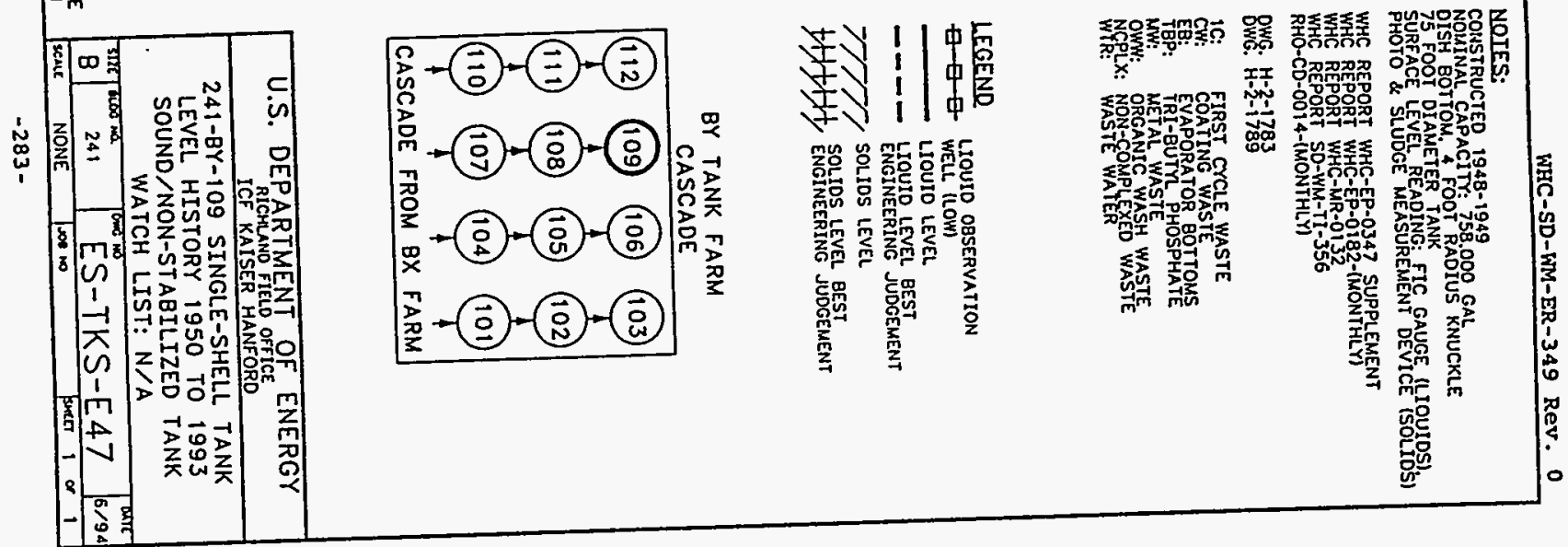


\begin{tabular}{|c|c|c|c|}
\hline \multicolumn{4}{|c|}{ Single-Shell Tank 241-BY-109 } \\
\hline \multicolumn{4}{|c|}{ Solids Composite Inventory Estimate } \\
\hline \multicolumn{4}{|c|}{ 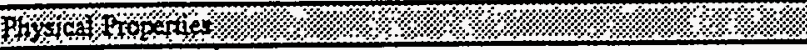 } \\
\hline Total Solid Waste & \multicolumn{3}{|c|}{$2.43 \mathrm{E}+06 \mathrm{~kg}(423 \mathrm{kgal})$} \\
\hline Heat load & \multicolumn{3}{|c|}{$2.89 \mathrm{~kW}(9.85 \mathrm{E}+03 \mathrm{BTU} / \mathrm{hr})$} \\
\hline Bulk Density & \multicolumn{3}{|c|}{$1.51(\mathrm{~g} / \infty)$} \\
\hline Void Fraction & \multicolumn{3}{|c|}{0.65} \\
\hline Water wt\% & \multicolumn{3}{|c|}{34.70} \\
\hline TOC wt\% C (wet) & \multicolumn{3}{|c|}{0.05} \\
\hline \multicolumn{4}{|c|}{ 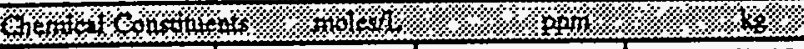 } \\
\hline $\mathrm{Na}+1$ & 11.36 & $1.72 \mathrm{E}+05$ & 4.18E+05 \\
\hline $\mathrm{Al}^{+3}$ & 0.35 & $6.15 \mathrm{E}+03$ & $1.49 \mathrm{E}+04$ \\
\hline $\mathrm{Fe}^{+3}($ total $\mathrm{Fe})$ & of & 0 & 0 \\
\hline $\mathrm{Cr}^{+3}$ & -0 & $\because$ & 0. \\
\hline$B i^{+3}$ & 0 & 요 & 0 \\
\hline $\mathrm{La}^{43}$ & of & 0] & 0 \\
\hline $\mathrm{Ce}^{+3}$ & of & of & 0 \\
\hline $\mathrm{Zx}$ (as $\left.\mathrm{ZrO}(\mathrm{OH})_{2}\right)$ & 의 & 0 & 0 \\
\hline $\mathrm{Pb}^{42}$ & 0 & 0 & 0 \\
\hline $\mathrm{Ni}^{+3}$ & 0 & 0 & 0 \\
\hline $\mathrm{Sr}^{+2}$ & 0 & 0 & 0 \\
\hline $\mathrm{Mn}^{* 4}$ & of & 0 & 0 \\
\hline $\mathrm{Ca}^{42}$ & 0 & 0 & 0 \\
\hline $\mathrm{K}^{+1}$ & $2.40 \mathrm{E}-03$ & 61.96 & $1.50 \mathrm{E}+02$ \\
\hline $\mathrm{OH}^{\cdot 1}$ & 1.43 & $1.60 \mathrm{E}+04$ & $3.88 \mathrm{E}+04$ \\
\hline $\mathrm{NO}^{-2}$ & 7.60 & 3.11E+05 & $7.55 \mathrm{E}+05$ \\
\hline $\mathrm{NO}_{2} \cdot 1$ & 0.25 & $7.52 E+03$ & $1.82 \mathrm{E}+04$ \\
\hline $\mathrm{CO}^{-2}$ & 0.58 & $2.28 \mathrm{E}+04$ & $5.54 \mathrm{E}+04$ \\
\hline $\mathrm{PO4}^{-3}$ & 0.37 & $2.33 \mathrm{E}+04$ & $5.64 \mathrm{E}+04$ \\
\hline $\mathrm{SO}_{4-2}^{-2}$ & 0.41 & $2.63 \mathrm{E}+04$ & $6.37 \mathrm{E}+04$ \\
\hline $\mathrm{Si}$ (as $\mathrm{SiO}_{3}{ }^{-2}$ ) & 0 & 0 & 0 \\
\hline $\mathrm{F}^{-1}$ & 0.50 & $6.30 \mathrm{E}+03$ & $1.53 \mathrm{E}+04$ \\
\hline $\mathrm{Cl}^{-1}$ & $1.50 \mathrm{E}-02$ & $3.51 \mathrm{E}+02$ & $8.51 E+02$ \\
\hline $\mathrm{C}_{4} \mathrm{H}_{3} \mathrm{O}_{7}^{-3}$ & 0 & 아 & 0 \\
\hline EDTA ${ }^{-1}$ & 이 & 0 & 0 \\
\hline HEDTA $^{-3}$ & 요 & 0 & 0 \\
\hline NTA $^{-3}$ & 0 & 0 & 0 \\
\hline glycolate.1 & 0 & 0 & 0 \\
\hline acetate & $3.18 \mathrm{E}-02$ & $1.24 \mathrm{E}+03$ & $3.00 \mathrm{E}+03$ \\
\hline oxalate ${ }^{-2}$ & 0 & 이 & 0 \\
\hline DBP & 0 & 0 & 0 \\
\hline $\mathrm{NPH}$ & 요 & 0 & 0 \\
\hline $\mathrm{CCl}_{4}$ & 0 & 0 & 0 \\
\hline hexone & 0 & 0 & 0 \\
\hline $\mathrm{Fe}(\mathrm{CN})_{6}{ }^{-1}$ & 0 & 0 (g-mol) & \\
\hline \multicolumn{4}{|c|}{ 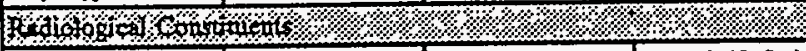 } \\
\hline Pu & & $1.18 \mathrm{E}-02(\mu \mathrm{Ci} / \mathrm{g})$ & $0.48(\mathrm{~kg})$ \\
\hline $\mathbf{U}$ & 8.58E-02 (M) & $1.35 E+04(\mu g / g)$ & $3.27 \mathrm{E}+04(\mathrm{~kg})$ \\
\hline$\overline{C s}$ & $0.34(\mathrm{C} / \mathrm{L})$ & $2.28 \mathrm{E}+02(\mu \mathrm{Ci} / \mathrm{g})$ & $5.52 \mathrm{E}+05(\mathrm{Ci})$ \\
\hline$S$ & $2.76 \mathrm{E}-02(\mathrm{Ci} / \mathrm{L})$ & $18.22(\mu \mathrm{Ci} / \mathrm{g})$ & $4.42 \mathrm{E}+04(\mathrm{Ci})$ \\
\hline
\end{tabular}

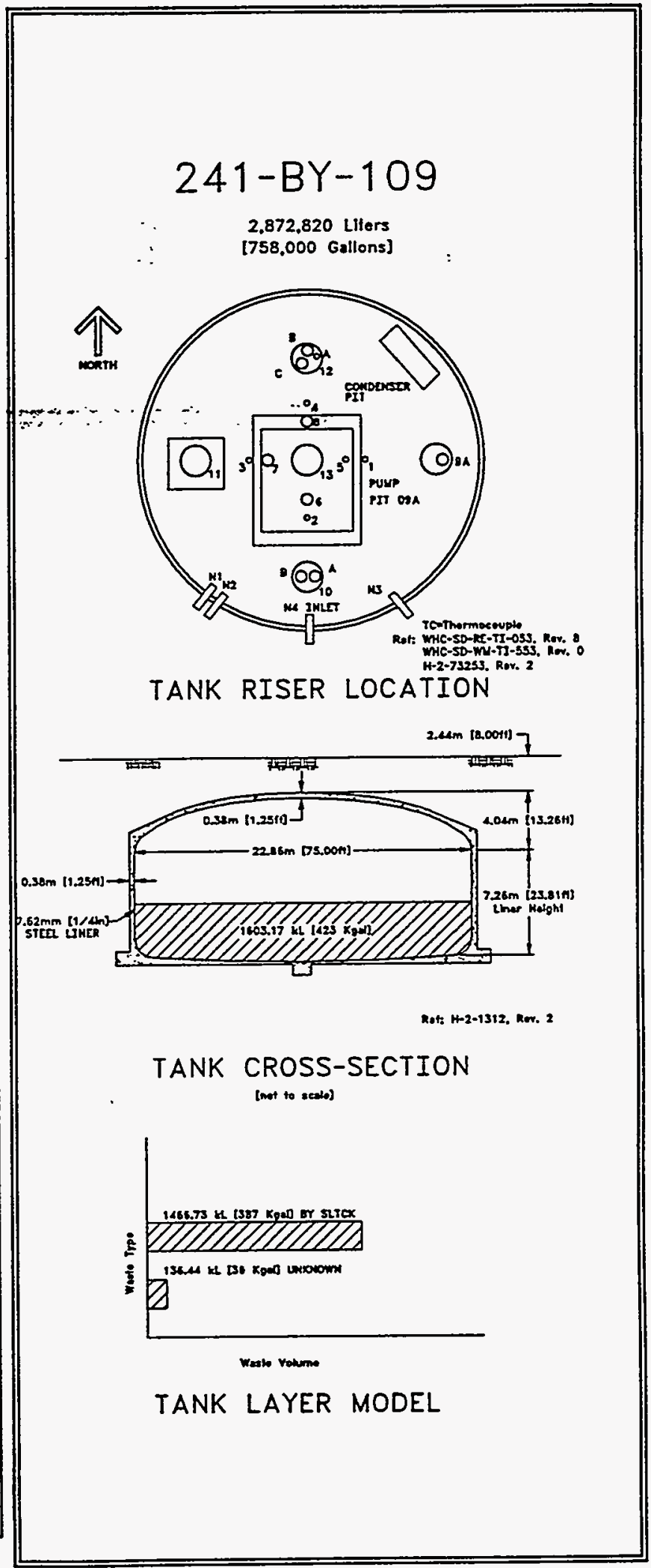

- Composite inventory exchudes supernatant, dialomaccous earth, and cement 
WHC-SD-WM-ER-349 Rev. 0

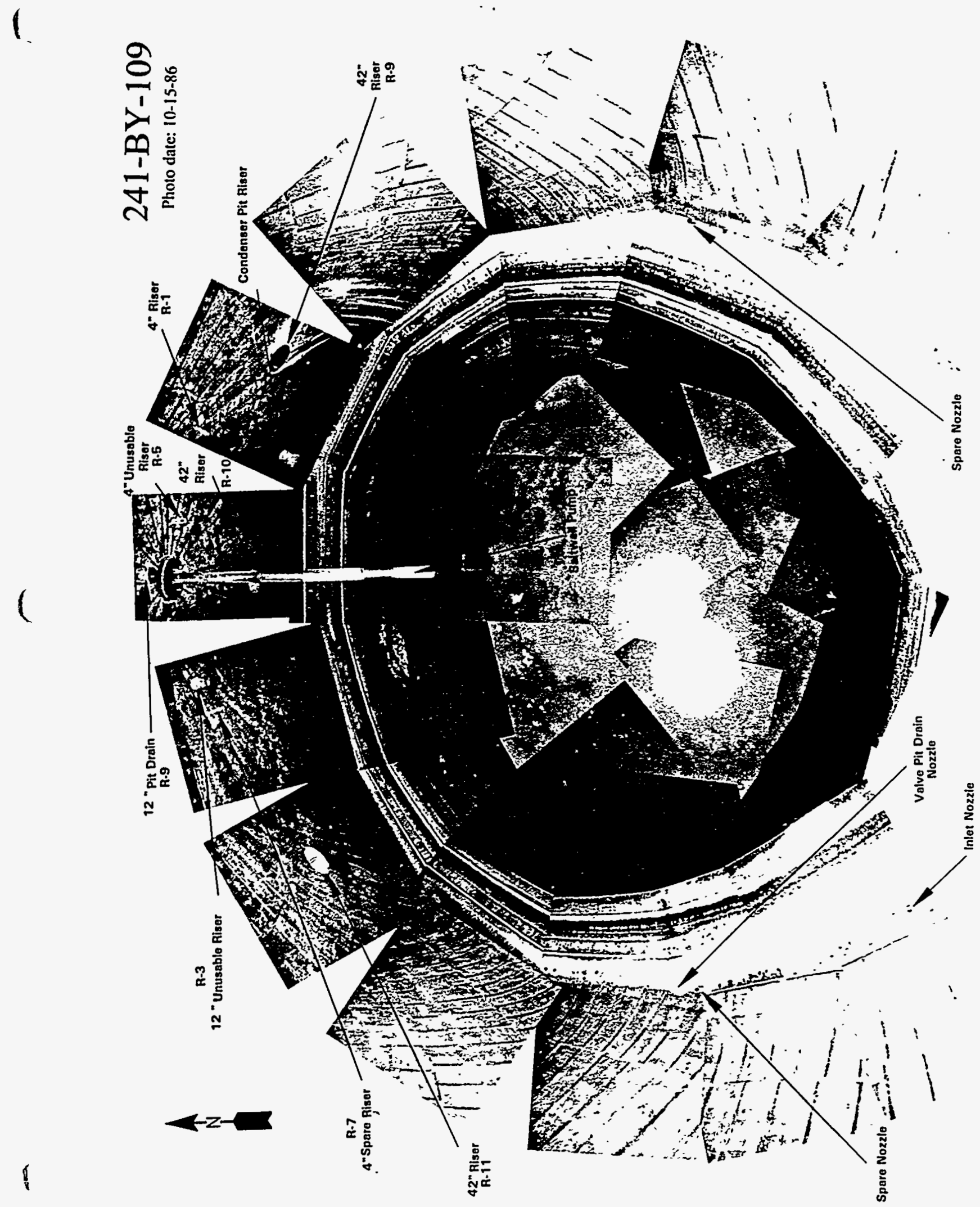


WHC-SD-WM-ER-349, ReV. 0

6.10 Tank 241-BY-110

6.10.1 241-BY-110 Tank History

6.10.1.1 Waste History Tank 241-BY-110

Tank 241-BY-110 was filled with first cycle waste beginning in the fourth quarter of 1951 . A saltwell was installed in 1977 and the tank was declared inactive in 1979. A level adjustment was made in September 1979. Saltwell pumping began in May 1983 and was completed in December 1984. Interim stabilization was completed in January 1985 . Liquid observation well data that are plotted represent the interstitial liquid level. (See sketch ES-TKS-E48 for a graphical representation of the Tank 241-BY-110 level history:

\subsubsection{Temperature History 241-BY-110}

Tank 241-BY-110 has 2 thermocouple trees: one has 14 thermocouple probes and the other has 6 to record temperature data. The mean temperature of the first daily recorded data was $45^{\circ} \mathrm{F}$ for tree 1 and $96^{\circ} F$ for tree 2. A sum of the squares regression line fit of the thermocouples on tree 1 shows a temperature decrease with a moderate amount of variability. The median temperature is $111.8^{\circ} \mathrm{F}$ with a minimum of $48^{\circ} \mathrm{F}$ and a maximum of $204.8^{\circ} \mathrm{F}$. Refer to the supporting document for a more thorough review of the temperature data (Brevick 1994).

\subsubsection{Integrity of Tank 241-BY-110}

Tank 241-BY-110 is categorized as sound, and is interim stabilized with intrusion prevention completed. The in Tank 241-BY-110 surface level is monitored quarterly with a manual tape through riser 4 . A figure that graphically represents the surface level measurements from January 1991 to the present can be found in the supporting documents (Brevick 1994). The surface level plot indicates that most readings range in the 90- to 100-in. level, while four are near the baseline value of $151.75 \mathrm{in.}$ The low readings do not exceed the decrease criteria and are attributed to the uneven surface of the saltcake.

The Tank 241-BY-110 Iiquid observation well is located in riser 3 . The tank is monitored weekly with a neutron probe and on request basis with a gamma probe to determine interstitial liquid levels. The maximum deviations from the established baseline value a $0.3-f t$ increase and a 0.4 -ft decrease. Sketch ES-TKS-E48 has a graphical representation of the Iiquid observation well data.

\subsubsection{Current status of Tank 241-BY-110}

Tank 241-BY-110 entered service in 1951 and currently stores 398,000 gal of waste. The waste is comprised of 208,000 gal of saltcake and 190,000 gal of sludge with no supernatant or pumpable liquid remaining. The tank is identified on the Ferrocyanide watch Iist since January 1991, is passively ventilated, and is categorized as sound with interim stabilization and intrusion prevention completed. Tank 241-BY- 
WHC-SD-WM-ER-349, ReV. 0

110 is equipped to cascade to Tank 241-BY-111 and is first in the threetank cascade series. The following plan view and cross section depict the approximate waste level and riser configuration. Tank 241-BY-110 has 16 risers and 18-in. riser no.10B is available for use.

\subsubsection{Inventory estimate 241-BY-110}

The following tank layer volume approximation was derived from the Los Alamos National Laboratories Waste Status and Transaction Record Summary (Agnew 1994). The estimated inventory of Tank 241-BY-110 is also presented.

\subsubsection{In-Tank Photograph 241-BY-110}

The 'Tank 241-BY -110 photo shows"an"irregular"saltcake"crust that is void of any liquid. The solids range in color from white to medium gray. The photo may be relatively representative of the current tank status because it was taken in July 1987 and the tank has seen no activity since that time. The saltwell screen, liquid observation well, and temperature probe appear to be totally imbedded in the salt cake. The waste measures approximately $12 \mathrm{ft}$ deep.

6.10 .3 Synopsis Tank 241-BY-110

(To be completed.) 


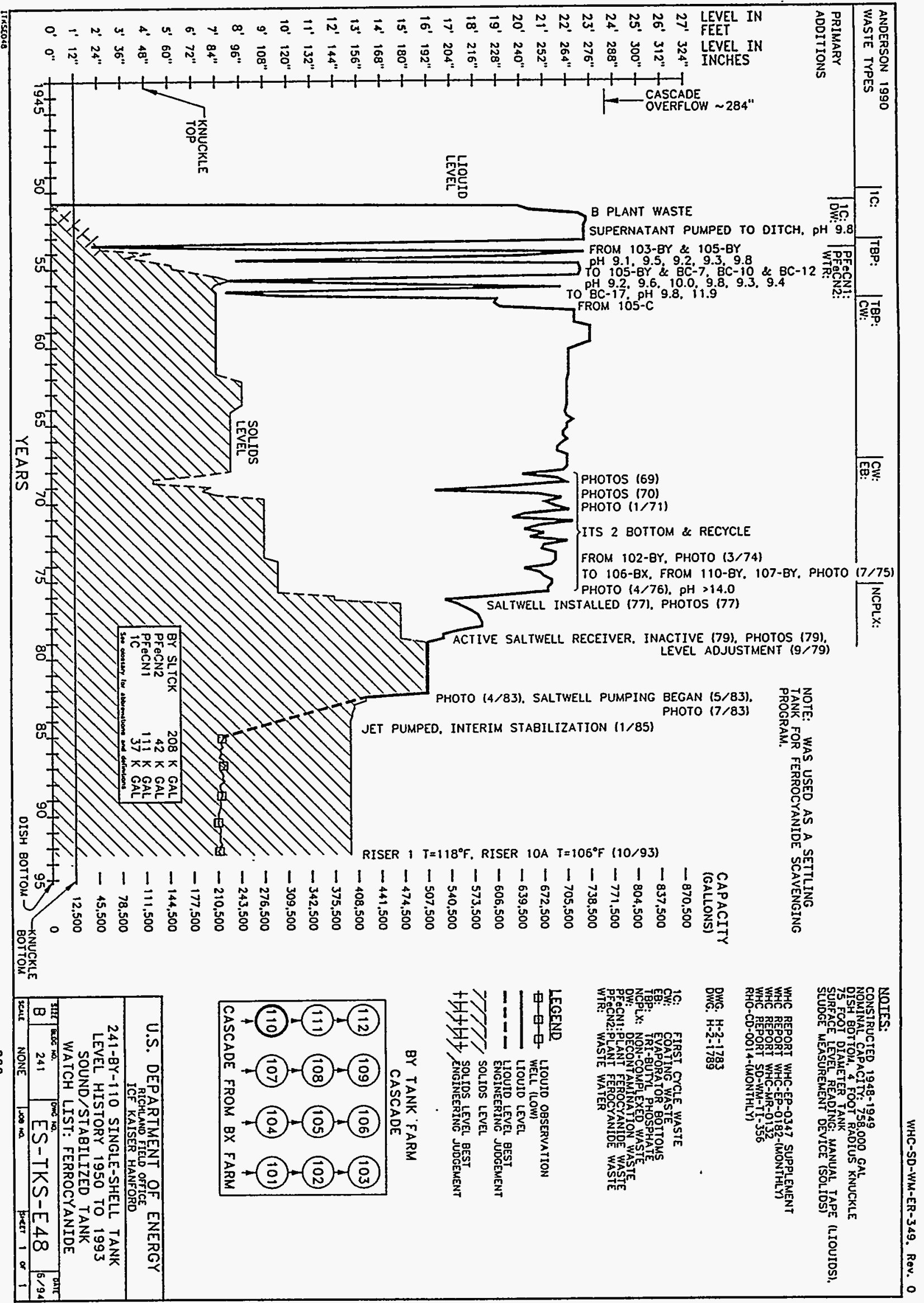


1

\begin{tabular}{|c|c|c|c|}
\hline \multicolumn{4}{|c|}{ Single-Shell Tank 241-BY-110 } \\
\hline \multicolumn{4}{|c|}{ Solids Composite Inventory Estimate } \\
\hline \multicolumn{4}{|c|}{ 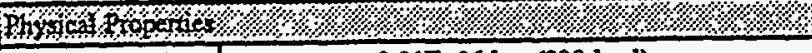 } \\
\hline Total Solid Waste & \multicolumn{3}{|c|}{$2.21 \mathrm{E}+06 \mathrm{~kg}(398 \mathrm{kgal})$} \\
\hline Heal load & \multicolumn{3}{|c|}{$1.95 \mathrm{~kW}(6.66 \mathrm{E}+03 \mathrm{BTU} / \mathrm{hr})$} \\
\hline Bulk Density & \multicolumn{3}{|c|}{$1.47(g / \infty)$} \\
\hline Void Fraction & \multicolumn{3}{|c|}{0.69} \\
\hline Waler wt\% & \multicolumn{3}{|c|}{39.42} \\
\hline TOC wt\% C (wet) & \multicolumn{3}{|c|}{0.26} \\
\hline \multicolumn{4}{|c|}{ W } \\
\hline $\mathrm{Na}^{\mathrm{1}}$ & 9.28 & $1.45 E+05$ & $3.21 E+05$ \\
\hline $\mathrm{Al}^{43}$ & 0.23 & $4.14 \mathrm{E}+03$ & $9.15 \mathrm{E}+03$ \\
\hline $\mathrm{Fe}^{43}(\mathrm{total} \mathrm{Fe})$ & 0.22 & $8.29 \mathrm{E}+03$ & $1.83 \mathrm{E}+04$ \\
\hline $\mathrm{Cr}^{+3} \cdots \cdots \cdots+\cdots$ & $\cdots-1.36 \mathrm{E}: 03$ & $\because 4.1 \cdots 48.06$ & $\therefore=1.06 \mathrm{E}+02$ \\
\hline $\mathrm{Bi}^{+3}$ & 0.15 & $2.14 \mathrm{E}+04$ & $4.73 \mathrm{E}+04$ \\
\hline $\mathrm{La}^{43}$ & 0 & 0 & 0 \\
\hline $\mathrm{Ce}^{+3}$ & 0 & 0 & 0 \\
\hline $\mathrm{Zx}$ (as $\left.\mathrm{ZrO}(\mathrm{OH})_{2}\right)$ & $2.71 \mathrm{E}-03$ & $1.69 \mathrm{E}+02$ & $3.73 \mathrm{E}+02$ \\
\hline $\mathrm{Pb}^{42}$ & 0 & 0 & 0 \\
\hline $\mathrm{Ni}^{+2}$ & $5.42 \mathrm{E}-02$ & $2.17 E+03$ & $4.79 \mathrm{E}+03$ \\
\hline $\mathrm{Sr}^{+2}$ & 0 & 0 & 0 \\
\hline $\mathrm{Mn}^{+\infty}$ & 0 & 이 & 0 \\
\hline $\mathrm{Cs}^{* 2}$ & 0 & 0 & 0 \\
\hline $\mathrm{R}^{+1}$ & $1.37 \mathrm{E}-03$ & 36.51 & 80.77 \\
\hline $\mathrm{OH}^{-1}$ & 1.29 & $1.50 \mathrm{E}+04$ & $3.31 \mathrm{E}+04$ \\
\hline $\mathrm{NO}^{\cdot 1}$ & 5.26 & $2.22 E+05$ & $4.91 E+05$ \\
\hline $\mathrm{NO}_{2}^{-1}$ & 0.15 & $4.75 E+03$ & $1.05 E+04$ \\
\hline $\mathrm{CO}^{-2}$ & 0.21 & $8.78 \mathrm{E}+03$ & $1.94 \mathrm{E}+04$ \\
\hline $\mathrm{PO}^{-3}$ & 0.41 & $2.67 \mathrm{E}+04$ & $5.91 \mathrm{E}+04$ \\
\hline $\mathrm{SO}^{-2}$ & 0.69 & $4.54 \mathrm{E}+04$ & $1.00 \mathrm{E}+05$ \\
\hline $\mathrm{Si}\left(\mathrm{as} \mathrm{SiO}_{3}^{-2}\right)$ & 0.41 & $7.75 \mathrm{E}+03$ & $1.71 E+04$ \\
\hline$F^{1}$ & 0.36 & $4.63 \mathrm{E}+03$ & $1.02 \mathrm{E}+04$ \\
\hline $\mathrm{Cl}^{-2}$ & $8.57 \mathrm{E}-03$ & $2.07 \mathrm{E}+02$ & $4.57 \mathrm{E}+02$ \\
\hline $\mathrm{C}_{6} \mathrm{H}_{5} \mathrm{O}_{7}{ }^{3}$ & 0 & 0 & 0 \\
\hline EDTA $^{-4}$ & 0 & 0 & 0 \\
\hline HEDTA $^{-3}$ & 0 & o & 0 \\
\hline $\mathrm{NTA}^{-3}$ & of & 이 & 0 \\
\hline glycolate & 0 & 0 & 0 \\
\hline acetare ${ }^{-1}$ & $1.82 \mathrm{E}-02$ & $7.30 \mathrm{E}+02$ & $1.62 E+03$ \\
\hline oxalase & 이 & 0 & 0 \\
\hline DBP & 0 & 0 & 0 \\
\hline NPH & 0 & 0 & 0 \\
\hline $\mathrm{CCl}_{4}$ & 0 & 0 & 0 \\
\hline hexone & 0 & 0 & 0 \\
\hline $\mathrm{Fe}(\mathrm{CN})_{6}{ }^{-1}$ & $459 \mathrm{E}-02$ & $6.92 \mathrm{E}+04(\mathrm{~g}-\mathrm{mol})$ & \\
\hline \multicolumn{4}{|c|}{ 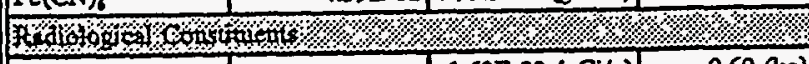 } \\
\hline $\mathrm{Pu}$ & & $1.62 \mathrm{E}-02(\mu \mathrm{Ci} / \mathrm{g})$ & $0.60(\mathrm{~kg})$ \\
\hline $\mathrm{U}$ & 1.45E-02 (M) & $2.35 \mathrm{E}+03(\mathrm{Hg} / \mathrm{g})$ & $5.21 \mathrm{E}+03(\mathrm{~kg})$ \\
\hline Cs & $0.23(\mathrm{Ci} / \mathrm{L})$ & $1.60 \mathrm{E}+02(\mu \mathrm{Ci} / \mathrm{g})$ & $3.54 \mathrm{E}+05(\mathrm{Ci})$ \\
\hline $\mathrm{Sr}$ & $2.90 \mathrm{E}-02(\mathrm{Ci} / \mathrm{L})$ & $19.73(\mu \mathrm{Ci} / \mathrm{g})$ & $4.37 \mathrm{E}+04(\mathrm{Ci})$ \\
\hline
\end{tabular}

- Composite inventory excludes ruperzatanh, distomacoous earth, and cemeat Jubrowns in tank inventory are assigned by Tank Layering Model (TLM).

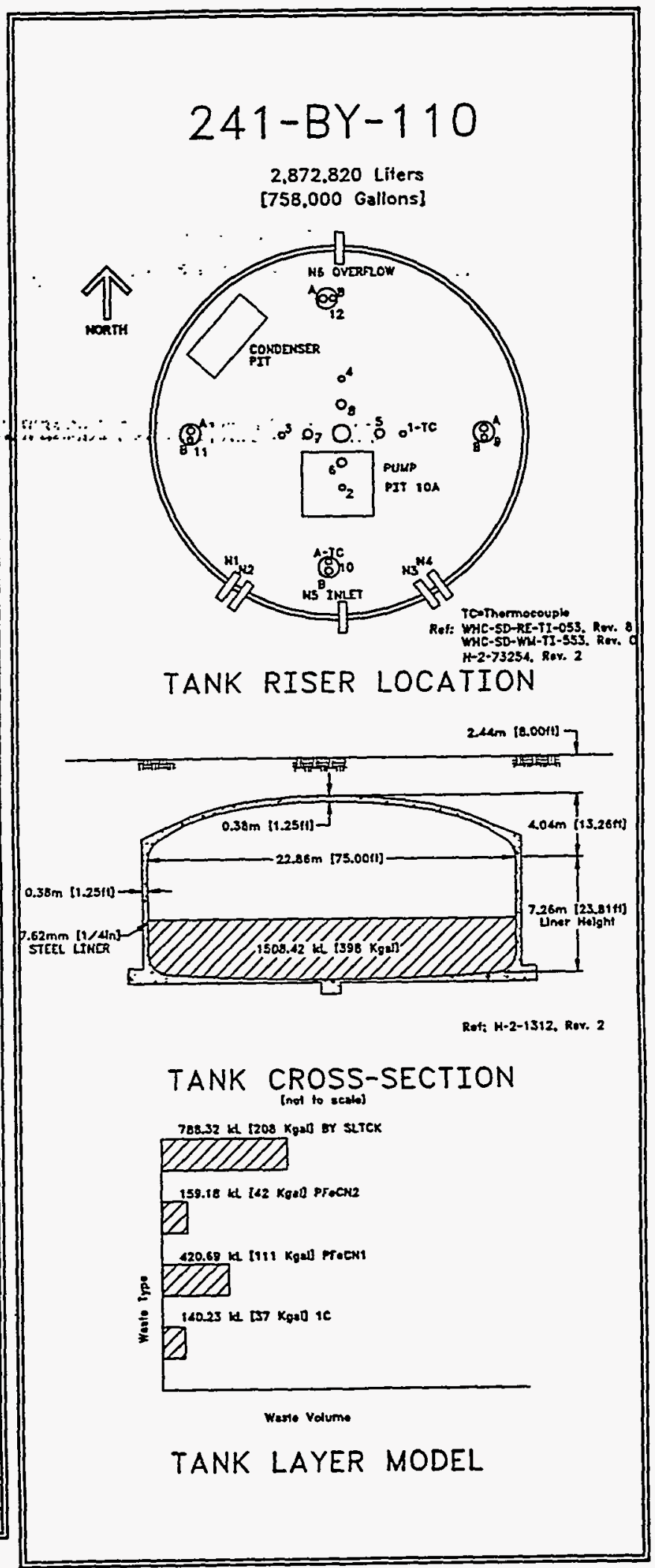

$6 / 94$ 


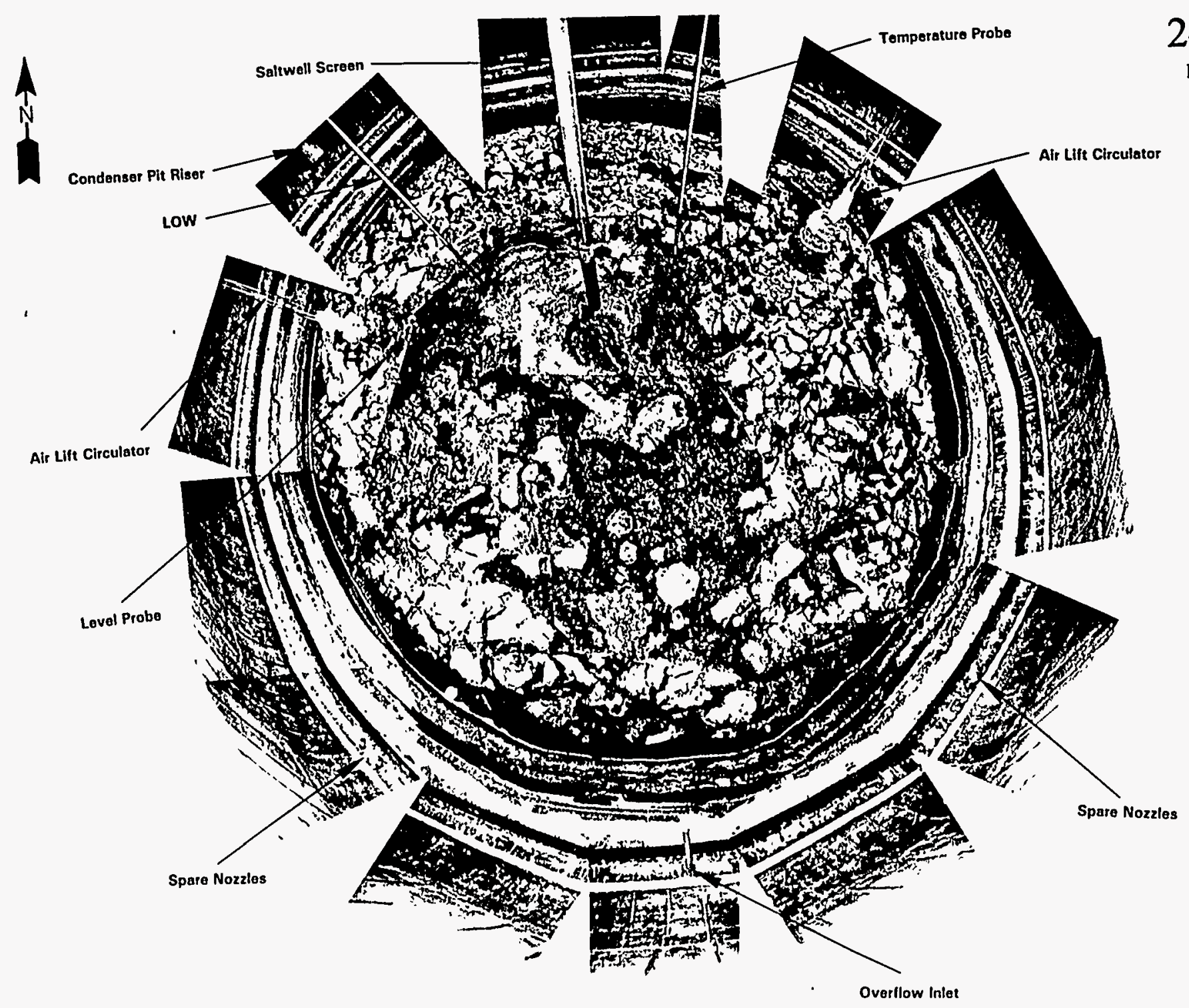

241-BY-110

Photo date: $7-26-84$ 
WHC-SD-WM-ER-349, Rev. 0

6.11 Tank 241-BY-111

6.11.1 241-BY-111 Tank History

6.11.1.1 Waste History Tank 241-BY-111

Tank 241-BY-111 was filled with metal waste in the fourth quarter of 1951. The tank received metal. waste, $U$ plant waste, and high uranium TBP waste until the.first quarter of 1955. A pump was installed in 1975 and the pumping was finished in 1978: Level adjustments were made in June 1980 and in April 1982: After a saltwell pump was installed in September 1983 and the tank was pumped, Tank 241-BY-111 was declared interim stabilized in January 1985. Liquid observation well data was plotted and represents..the interstitial. liquid level. Prior to 1986, an engineering judgement"was'made"based"on the"saltwel'pumping in 1983 and completed pumping in 1985. (See sketch ES-TKS-E49 for a graphically representation of the Tank 241-BY-111 level history.)

\subsubsection{Temperature History 241-BY-111}

Tank 241-BY-111 has 2 thermocouple trees: tree 1 has one thermocouple probe and tree 2 has six thermocouples to record temperature data. The first recorded temperature was $82^{\circ} \mathrm{F}$ for thermocouple tree 1 and $70^{\circ} \mathrm{F}$ for tree 2 . A sum of the squares regression line fit for all the data shows a slight increase in temperature with a small amount of variability. The median temperature is $82^{\circ} \mathrm{F}$ with a minimum of $61^{\circ} \mathrm{F}$ and a maximum of $92^{\circ} \mathrm{F}$. Refer to the supporting document for a more thorough review of the temperature data (Brevick 1994).

\subsubsection{Integrity of Tank 241-BY-111}

Tank 241-BY-111 is categorized as sound, and is interim stabilized with intrusion prevention completed. The Tank 241-BY-111 surface level is monitored quarterly with a manual tape through riser 15. A figure that graphically represents the surface level measurements from January 1991 to the present can be found in the supporting documents (Brevick 1994). The surface level for the past 3 years has remained steady and the readings range from 163.75 to 162.75 in.

The Tank 241-BY-111 liquid observation well is located in riser 1. The tank is monitored weekly with a neutron probe and on request basis with a gamma probe. The maximum deviations from the established baseline is a 0.3-ft increase or a 0.4-ft decrease. Sketch ES-TKS-E49 has a graphical representation of the liquid observation well data.

Four drywells are identified for tank 241-BY-111. Graphical representations of the drywell data for each active drywell from January 1990 to the present can be found in the supporting document (Brevick 1994). Each graph includes the peak $c / s$, the depth at which the peak occurred, and the date of the reading. 
6.11 .2 Current Status of Tank 241-BY-111

Tank 241-BY-111 entered service in 1951 and currently stores $459,000 \mathrm{gal}$ of waste. The waste is comprised of $433,000 \mathrm{gal}$ of saltcake, 26,000 gal of sludge, no supernatant, with no pumpable liquid remaining. The tank is on the Ferrocyanide watch Iist and is passively ventilated. It is categorized as sound, with interim stabilization and intrusion prevention completed. Tank 241-BY-111 is equipped to cascade to Tank 241-BY-112 and is second in the three-tank cascade series. The following plan view and cross section depict the approximate waste level and riser configuration. Tank 241-BY-111 has a total of 19 risers and four are available for use: 4-in. risers nos. 5 and $10 A_{;} 42-i n$. riser no.12; and 12-in. riser no.12A.

\subsubsection{In̈ventory estimate $241=B Y=11 I^{\cdots}$}

The following tank layer volume approximation was derived from the Los Alamos National Laboratories Waste Status and Transaction Record Summary (Agnew 1994). The estimated inventory of Tank 241-BY-111 is also presented.

\subsubsection{In-Tank Photograph 241-BY-111}

The photo of Tank 241-BY-111 shows an uneven saltcake surface varying from white to medium grey. Protruding from the surface are several old discarded level measurement tapes. The airlift circulators are encrusted with solids. The waste measures about 13.5 ft deep.

\subsection{1 .3 Synopsis Tank 241-BY-111}

(To be completed.) 


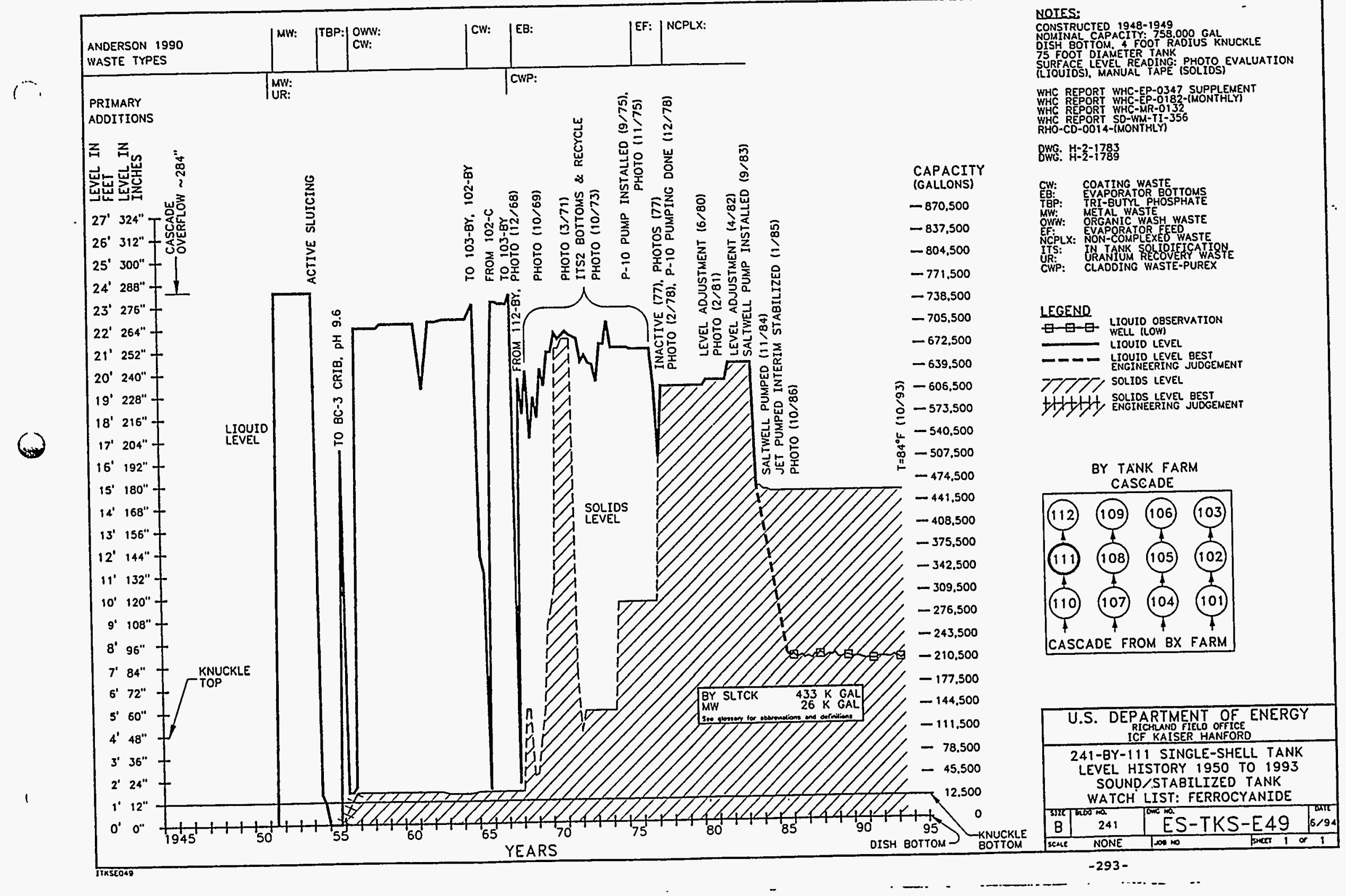




\begin{tabular}{|c|c|c|c|}
\hline \multicolumn{4}{|c|}{ Single-Shell Tank 241-BY-111 } \\
\hline \multicolumn{4}{|c|}{ Solids Composite Inventory Estimate } \\
\hline 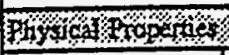 & 28. & $1 \% \% \%$ & $4 \%$ \\
\hline Total Solid Waste & \multicolumn{3}{|c|}{$2.62 \mathrm{E}+06 \mathrm{~kg}(459 \mathrm{kgal})$} \\
\hline Heat load & \multicolumn{3}{|c|}{$3.11 \mathrm{~kW}(1.06 \mathrm{E}+04 \mathrm{BTU} / \mathrm{hr})$} \\
\hline Bulk Density & \multicolumn{3}{|c|}{$1.51(g / \infty)$} \\
\hline Void Fraction & \multicolumn{3}{|c|}{0.67} \\
\hline Water wr\% & \multicolumn{3}{|c|}{34.31} \\
\hline TOC wh\% C (wet) & \multicolumn{3}{|c|}{0.05} \\
\hline \multicolumn{4}{|c|}{ 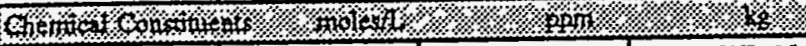 } \\
\hline $\mathrm{Na}^{+1}$ & 11.34 & $1.73 E+05$ & $4.53 \mathrm{E}+05$ \\
\hline $\mathrm{Al}^{43}$ & 0.36 & $6.36 \mathrm{E}+03$ & $1.67 \mathrm{E}+04$ \\
\hline $\mathrm{Fe}^{+3}($ total Fe $)$ & 0 & 0 & 0 \\
\hline $\mathrm{Ca}^{+3}: \mathrm{i}: \mathrm{C}$ & $\because \because 3$ & $\because \quad \because \cdots 0$ & 0 \\
\hline $\mathrm{Bi}^{+3}$ & 0 & 0 & 0 \\
\hline $\mathrm{La}^{43}$ & 0. & 0 & 0 \\
\hline $\mathrm{Ce}^{43}$ & 0) & 이 & 0 \\
\hline $\mathrm{Zx}\left(\operatorname{as~} \mathrm{ZNO}(\mathrm{OH})_{2}\right)$ & 0] & 요 & 0 \\
\hline $\mathrm{Pb}^{+2}$ & 0. & of & 0 \\
\hline $\mathrm{Ni}^{+2}$ & 0] & 0] & 0 \\
\hline$S x^{+2}$ & of & 0 & 0 \\
\hline $\mathrm{Mn}^{*}$ & 0 & 0 & 0 \\
\hline $\mathrm{Ca}^{+2}$ & 0 & 0 & 0 \\
\hline $\mathrm{K}^{+1}$ & $2.48 \mathrm{E}-03$ & 64.13 & $1.68 \mathrm{E}+02$ \\
\hline $\mathrm{OH}^{-1}$ & 1.38 & $1.55 \mathrm{E}+04$ & $4.06 \mathrm{E}+04$ \\
\hline $\mathrm{NO}^{-1}$ & 7.84 & $3.22 \mathrm{E}+05$ & $8.44 E+05$ \\
\hline $\mathrm{NO}^{-2}$ & 0.26 & $7.78 \mathrm{E}+03$ & $2.04 \mathrm{E}+04$ \\
\hline $\mathrm{CO}^{-2}$ & 0.52 & $2.07 \mathrm{E}+04$ & $5.43 E+04$ \\
\hline $\mathrm{PO}^{.3}$ & 0.29 & $1.84 \mathrm{E}+04$ & $4.83 \mathrm{E}+04$ \\
\hline $\mathrm{SO}^{-2}$ & 0.43 & $2.71 E+04$ & $7.10 \mathrm{E}+04$ \\
\hline $\mathrm{Si}\left(\mathrm{as} \mathrm{SiO}_{3}{ }^{2}\right)$ & 0 & 0 & 0 \\
\hline $\mathrm{F}^{-1}$ & 0.52 & $6.52 E+03$ & $1.71 E+04$ \\
\hline $\mathrm{C}^{\cdot 1}$ & $1.55 \mathrm{E}-02$ & $3.63 \mathrm{E}+02$ & $9.52 \mathrm{E}+02$ \\
\hline $\mathrm{C}_{6} \mathrm{H}_{3} \mathrm{O}_{7}{ }^{-3}$ & 0 & 0 & 0 \\
\hline EDTA $^{4}$ & 0 & 0 & 0 \\
\hline HEDTA $^{3}$ & of & 0 & 0 \\
\hline NTA $A^{-3}$ & 욱 & 0 & 0 \\
\hline Blycolate & 0 & 0 & 0 \\
\hline acetate ${ }^{-1}$ & $3.28 \mathrm{E}-02$ & $1.28 \mathrm{E}+03$ & $3.36 \mathrm{E}+03$ \\
\hline oxalate. & 0 & 0 & 0 \\
\hline DBP & 0 & 0 & 0 \\
\hline NPH & 0 & 0 & 0 \\
\hline $\mathrm{CCl}_{4}$ & 의 & 0 & 0 \\
\hline hexone & 0) & 0 & 0 \\
\hline $\mathrm{Fe}(\mathrm{CN})_{6}{ }^{d}$ & 0 & $0(8-\mathrm{mol})$ & \\
\hline \multicolumn{4}{|c|}{ 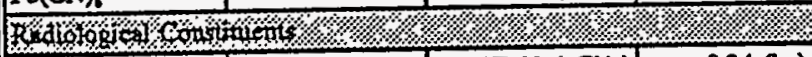 } \\
\hline Pu & & 7.89E-03 $(\mu \mathrm{Ci} / \mathrm{g})$ & $0.34(\mathrm{~kg})$ \\
\hline $\mathrm{U}$ & $6.50 \mathrm{E}-02(\mathrm{M})$ & $1.03 \mathrm{E}+04(\mathrm{ug} / \mathrm{g})$ & $2.69 \mathrm{E}+04(\mathrm{~kg})$ \\
\hline$C_{s}$ & $0.36(\mathrm{Ci} / \mathrm{L})$ & $2.35 \mathrm{E}+02(\mu \mathrm{Ci} / \mathrm{g})$ & $6.17 \mathrm{E}+05(\mathrm{Ci})$ \\
\hline$\underline{S_{r}}$ & $1.84 \mathrm{E}_{0} 02(\mathrm{C} / \mathrm{L})$ & $12.17(\mu \mathrm{Ci} / \mathrm{s})$ & $3.19 E_{+} 04(\mathrm{Ci})$ \\
\hline
\end{tabular}

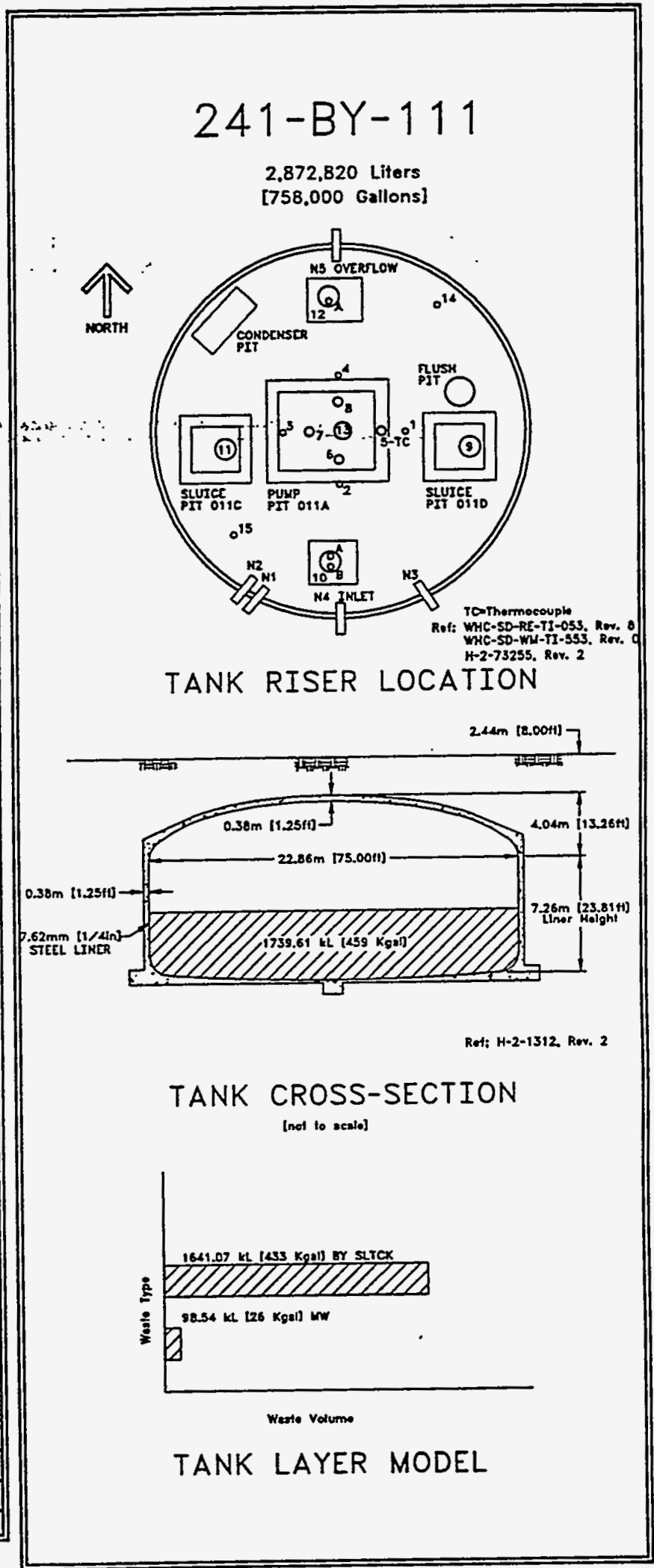

- Compocile inventory exchudes supernatant, diatomaceous earth, and cemeor

Unbnowns in tank invertory are assigned by Tank Layering Model (TLM) 


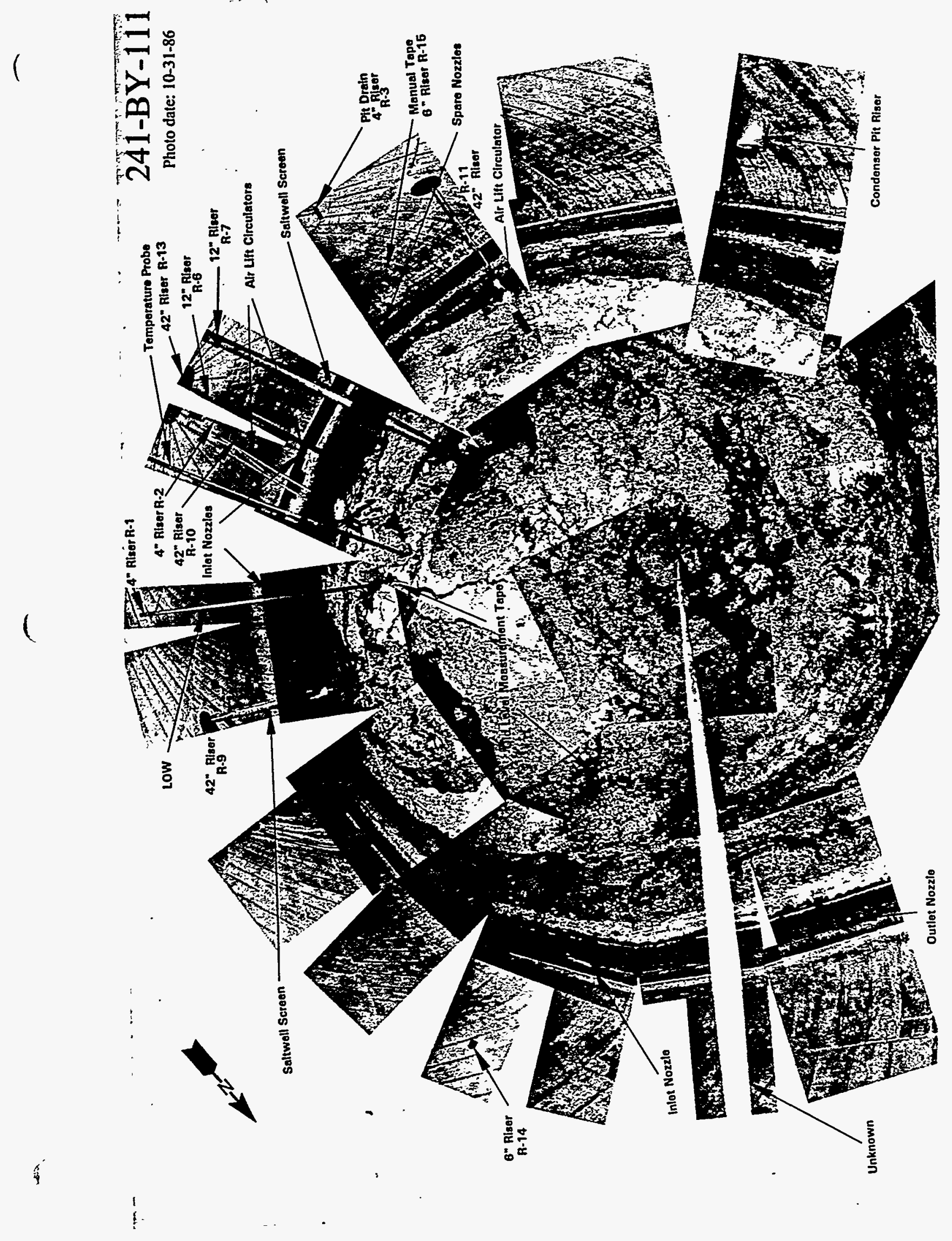


WHC-SD-WM-ER-349, Rev. 0

6.12 Tank 241-BY-112

6.12.1 241-BY-112 Tank History

\subsubsection{Waste History Tank 241-BY-112}

Tank 241-BY-112 was filled with metal waste in the second quarter of 1951. The tank, was removed from service and saltwell pumping was completed in 1976. Primary stabilization was completed in 1978 and the pump was removed in 1979. A level adjustment was made in ApriI 1982. After saltwell pumping was completed, the tank was declared interim stabilized in June 1984. Iiquid observation well data were plotted to represent the interstitial liquid level. Before 1986, an engineering judgement was made: based on pumping : that: was rstarted in september 1983 and was completed in June 1984. (See sketch ES-TKS-E50 for a graphical representation of the Tank 241-BY-112 level history.)

\subsubsection{Temperature History 241-BY-112}

Tank 241-BY-112 has 2 thermocouple trees: tree 1 has one thermocouple probe and tree 2 has six thermocouples to record temperature data. The first recorded temperature was $76.5^{\circ} \mathrm{F}$ for thermocouple tree 1 and $82^{\circ} \mathrm{F}$ for thermocouple tree 2. A sum of the squares regression line fit for all the data shows a slight increase in temperature with a small amount of variability. The median temperature is $82^{\circ} \mathrm{F}$ with a minimum of $63^{\circ} \mathrm{F}$ and a maximum of $90^{\circ} \mathrm{F}$. Refer to the supporting document for a more thorough review of the temperature data (Brevick 1994).

\subsubsection{Integrity of Tank 241-BY-112}

Tank 241-BY-112 is categorized as sound and is interim stabilized with intrusion prevention completed. The Tank 241-BY-112 surface level is monitored quarterly with a manual tape through riser 19. A figure that graphically represents the surface level measurements from January 1991 to the present can be found in the supporting documents (Brevick 1994). The surface level for the past 3 years has remained steady and the readings range from 114.25 to 112.75 in.

The Tank 241-BY-112 liquid observation well for is located in riser 15. The tank is monitored weekly with a neutron probe and on request with a gamma probe. The tank contains a liquid observation well with gamma and neutron probes that are out of compliance with documentation. The monitoring limits are a 0.3 -ft decrease and a 0.4 -ft increase. Sketch ES-TKS-E49 has a graphical representation of the liquid observation well data.

\subsubsection{Current Status of Tank 241-BY-112}

Tank 241-BY-112 entered service in 1951 and currently stores $291,000 \mathrm{gal}$ of waste. The waste is comprised of 274,000 gal of saltcake, 17,000 gal of sludge, with no supernatant or pumpable liquid remaining. This tank is on the Ferrocyanide Watch List as of January 1991, and is passively ventilated. It is categorized as sound, with 
WHC-SD-WM-ER-349, Rev . 0

interim stabilization and intrusion prevention completed. Tank 241-BY112 is the third tank in the three tank cascade series. Following is a plan view and cross section depicting the approximate waste level and riser configuration. Tank $241-B Y-112$ has a total of 21 risers, five of which are readily available four use: three 4 -in. risers No. 2,20 , and 5; one 12-in. riser No. 10A; and one 6-in. riser No. 18.

\section{6,12.2.1 Inventory estimate 241-BY-112}

The following tank layer volume approximation was derived from the Los Alamos National Laboratories Waste Status and Transaction Record Summary (Agnew 1994). The estimated inventory of Tank 241-BY-112 is also presented.

\subsubsection{In-Tank Photograph 241-BY-112}

The Tank 241-BY-112 photo shows a saltcake surface that appears to be clinging several feet up the sides of the tank. The crust is white to grey with tints of yellow. The waste measures approximately $8.5 \mathrm{ft}$ deep. The temperature probe, liquid observation well, Food Instrument Corporation gauge, level probe, center bottom saltwell screen, and the In-Tank Solidification Unit 2 air heater circulator appear to be embedded in saltcake.

\subsubsection{Synopsis Tank 241-BY-112}

(To be completed.) 


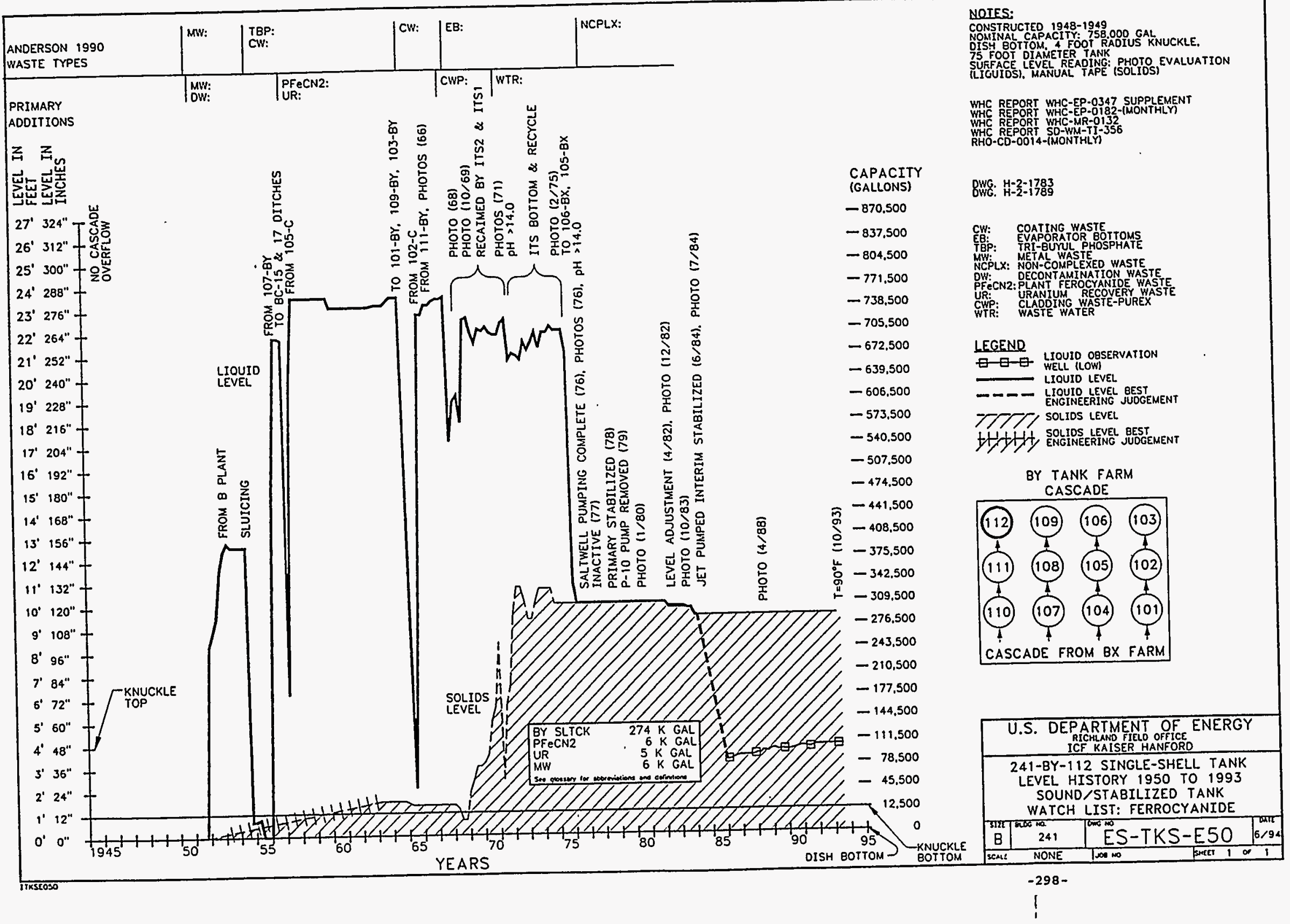




\begin{tabular}{|c|c|c|c|}
\hline \multicolumn{4}{|c|}{ Single-Shell Tank 241-BY-112 } \\
\hline \multicolumn{4}{|c|}{ Solids Composite Inventory Estimate } \\
\hline \multicolumn{4}{|c|}{ 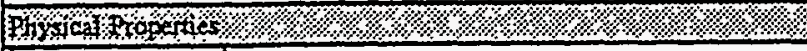 } \\
\hline Total Solid Waste & \multicolumn{3}{|c|}{$1.66 \mathrm{E}+06 \mathrm{~kg}(291 \mathrm{kgal})$} \\
\hline Heat load & \multicolumn{3}{|c|}{$1.92 \mathrm{~kW}(6.55 \mathrm{E}+03 \mathrm{BTU} / \mathrm{hr})$} \\
\hline Bulk Density & \multicolumn{3}{|c|}{$1.50(\mathrm{~g} / \infty)$} \\
\hline Void Fraction & \multicolumn{3}{|c|}{0.67} \\
\hline Water wi\% & \multicolumn{3}{|c|}{33.50} \\
\hline TOC wt\% C (wet) & \multicolumn{3}{|c|}{0.06} \\
\hline \multicolumn{4}{|c|}{ 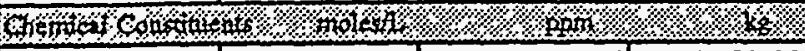 } \\
\hline \begin{tabular}{|l|l|l|l|}
$\mathrm{Na}^{+2}$ & \\
\end{tabular} & 11.24 & $1.72 \mathrm{E}+05$ & $2.85 \mathrm{E}+05$ \\
\hline$\overline{\mathrm{Al}^{+3}}$ & 0.36 & $6.37 \mathrm{E}+03$ & $1.06 \mathrm{E}+04$ \\
\hline $\mathrm{Fe}^{43}$ (total Fe) & $2.09 \mathrm{E}-02$ & $7.77 E+02$ & $1.29 \mathrm{E}+03$ \\
\hline $\mathrm{Cr}^{+3}$ & & $0 \quad 0$ & 0 \\
\hline $\mathrm{Bi}^{+3}$ & 8.38E-03 & $1.16 \mathrm{E}+03$ & $1.93 \mathrm{E}+03$ \\
\hline $\mathrm{La}^{+3}$ & 0 & 0 & 0 \\
\hline $\mathrm{Ce}^{+3}$ & 0 & 0 & 0 \\
\hline $\mathrm{Zr}\left(\operatorname{asc} \mathrm{ZrO}(\mathrm{OH})_{2}\right)$ & 0 & 0 & 0 \\
\hline $\mathrm{Pb}^{+2}$ & 0 & 0 & 0 \\
\hline $\mathrm{Ni}^{2+2}$ & $3.22 \mathrm{E}-03$ & $1.26 \mathrm{E}+02$ & $2.08 \mathrm{E}+02$ \\
\hline$\widehat{\mathrm{Sr}^{+2}}$ & 0 & 0 & 0 \\
\hline $\mathrm{Mn}^{+4}$ & 0 & 0 & 0 \\
\hline $\mathrm{Ca}^{+2}$ & 의 & 0 & 0 \\
\hline$\overline{\mathrm{R}^{+1}}$ & 2.47E-03 & .64 .20 & $1.06 E+02$ \\
\hline $\mathrm{OH}^{-1}$ & 1.33 & $1.50 \mathrm{E}+04$ & $2.49 E+04$ \\
\hline $\mathrm{NO}^{.1}$ & 7.88 & $3.25 \mathrm{E}+05$ & $5.38 \mathrm{E}+05$ \\
\hline $\mathrm{NO}^{-1}$ & 0.25 & $7.79 \mathrm{E}+03$ & $1.29 \mathrm{E}+04$ \\
\hline $\mathrm{CO}^{-2}$ & 0.44 & $.1 .75 \mathrm{E}+04$ & $2.90 \mathrm{E}+04$ \\
\hline $\mathrm{PO}^{.3}$ & 0.23 & $1.43 \mathrm{E}+04$ & $2.37 \mathrm{E}+04$ \\
\hline $\mathrm{SO}_{4}^{\cdot 2}$ & 0.49 & $3.16 \mathrm{E}+04$ & $5.23 \mathrm{E}+04$ \\
\hline $\mathrm{Si}$ (as $\mathrm{SiO}_{3}^{-2}$ ) & $2.26 \mathrm{E}-02$ & $4.21 E+02$ & $6.98 \mathrm{E}+02$ \\
\hline $\mathrm{F}^{-1}$ & 0.52 & $6.56 \mathrm{E}+03$ & $1.09 E+04$ \\
\hline $\mathrm{Cl}^{-1}$ & $1.55 \mathrm{E}-02$ & $3.66 \mathrm{E}+02$ & $6.06 \mathrm{E}+02$ \\
\hline $\mathrm{C}_{6} \mathrm{H}_{5} \mathrm{O}_{7}{ }^{-3}$ & 0 & 0 & 0 \\
\hline $\mathrm{EDTA}^{-1}$ & of & 요 & 0 \\
\hline HEDTA ${ }^{-3}$ & 0 & 0) & 0 \\
\hline $\mathrm{NTA}^{-3}$ & 0 & 요 & 0 \\
\hline glycolate-1 & 0 & 0 & 0 \\
\hline acetate ${ }^{-1}$ & $3.27 \mathrm{E}-02$ & $1.28 \mathrm{E}+03$ & $2.13 E+03$ \\
\hline oxalate ${ }^{-2}$ & 0 & 0 & 0 \\
\hline $\mathrm{DBP}$ & 0 & 0 & 0 \\
\hline NPH & 아 & 0 & 0 \\
\hline $\mathrm{CCl}_{4}$ & 아 & 0 & 0 \\
\hline hexone & 0 & 0 & 0 \\
\hline $\mathrm{Fe}(\mathrm{CN})_{6}^{-1}$ & 1.61E-03 & $1.77 \mathrm{E}+03(\mathrm{~g} \cdot \mathrm{mol})$ & \\
\hline 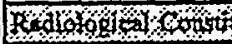 & \%/ & \% $/$ / & ঋ/\% \% \\
\hline Pu & & $4.42 \mathrm{E}-03(\mu \mathrm{Ci} / \mathrm{g})$ & $0.12(\mathrm{~kg})$ \\
\hline $\mathrm{U}$ & $3.85 \mathrm{E}-02(\mathrm{M})$ & $6.09 \mathrm{E}+03(\mu \mathrm{g} / \mathrm{g})$ & $1.01 \mathrm{E}+04(\mathrm{~kg})$ \\
\hline Cs & $0.36(\mathrm{Ci} / \mathrm{L})$ & $2.37 \mathrm{E}+02(\mu \mathrm{Ci} / \mathrm{g})$ & $3.93 \mathrm{E}+05(\mathrm{Ci})$ \\
\hline $\mathrm{si}_{\mathrm{r}}$ & $1.03 \mathrm{E}-02(\mathrm{Ci} / \mathrm{L})$ & $6.83(\mathrm{uCi} / \mathrm{g})$ & $1.13 \mathrm{E}+04(\mathrm{Ci})$ \\
\hline
\end{tabular}

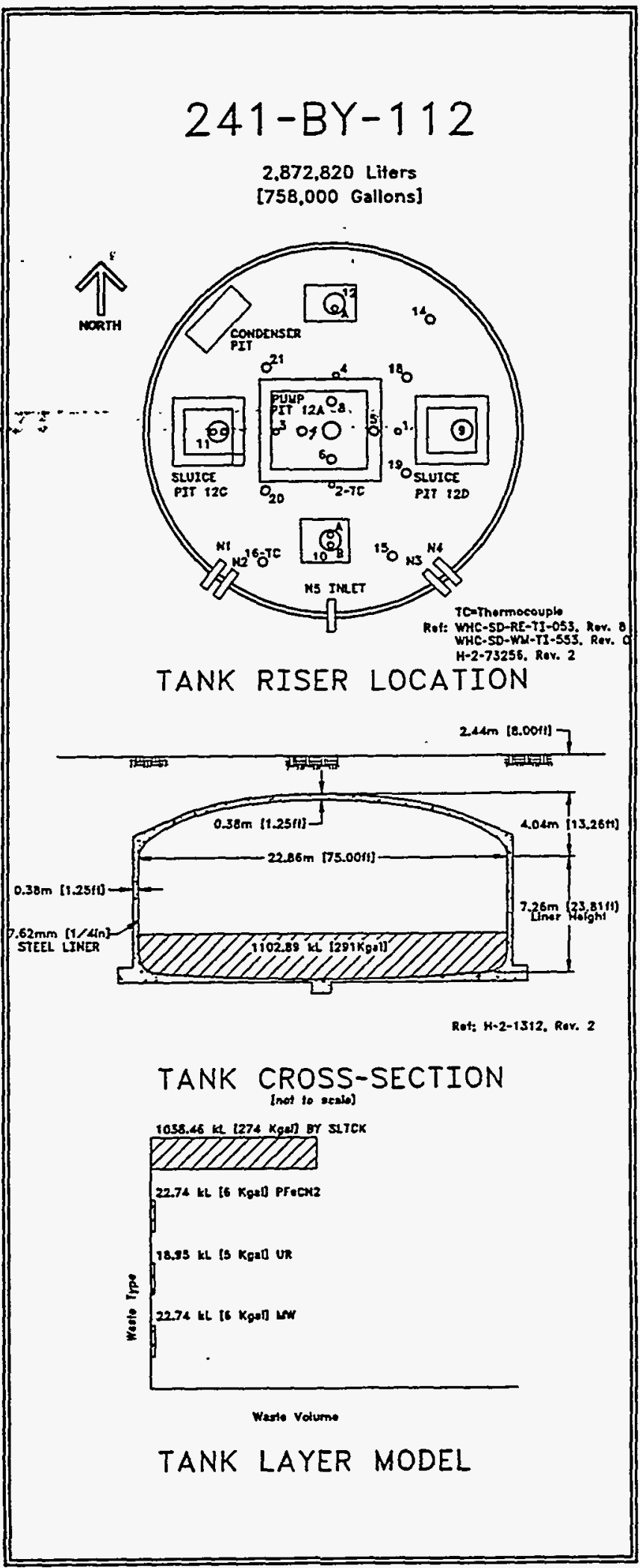


WHC-SD-WM-ER-349 Rev. 0
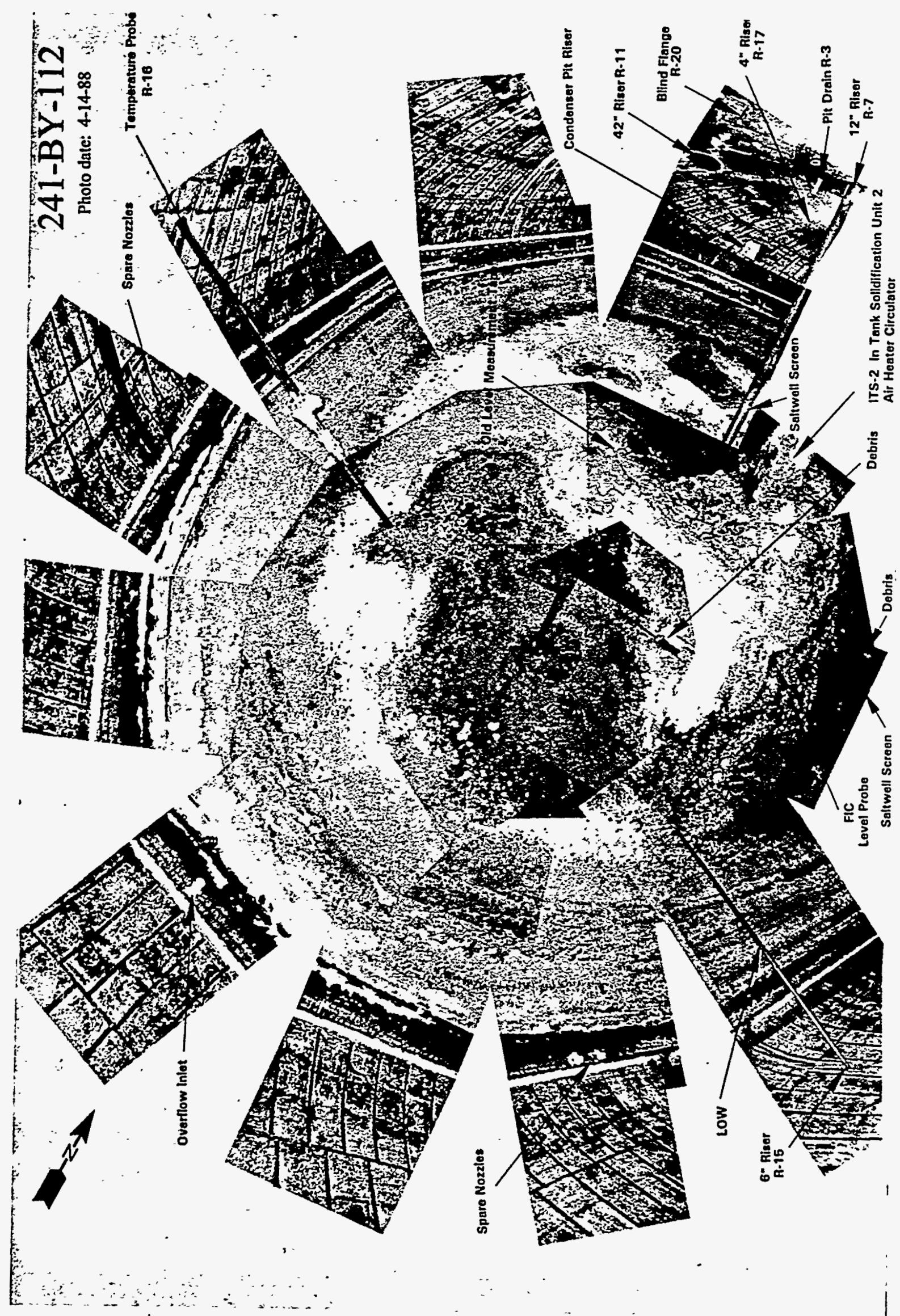
7.0 C Tank Farm

7.0.1 C Tank Farm History

The 241-C Tank Farm was constructed between 1943 and 1944 and is located north of 7 th Avenue and west of Canton Avenue in the 200-East Area. The C Tank Farm contains twelve 100 series; 530,000 gal; 75-ft diameter tanks and four 200-series; 55,000 gal, 20-ft diameter singleshell tanks. Built as one of the first generation tank farms, the $C$ Tank Farm was designed for non-boiling waste with a maximum fluid temperature of $220^{\circ} \mathrm{F}$. The cascade overflow lines connect three tanks together. Because the tanks are in a three by four arrangement, there are four groups of cascading tanks. A cascade group consists of three tanks. . In . a step, configuration : ... The ..cascade overflow. height is approximately" 188" in." from the tank bottom. Tie lines between the smallex 55,000-gal tanks were at the same elevation which allowed them to overflow and equalize tank volumes.

A 1993 color aerial photograph of the C Tank Farm shows tank orientation of the 100 series and 200 series tanks, a diversion box, and a north arrow. The arrows between tanks represent the cascade overflow lines and the flow direction. 


\section{Tank Farm}

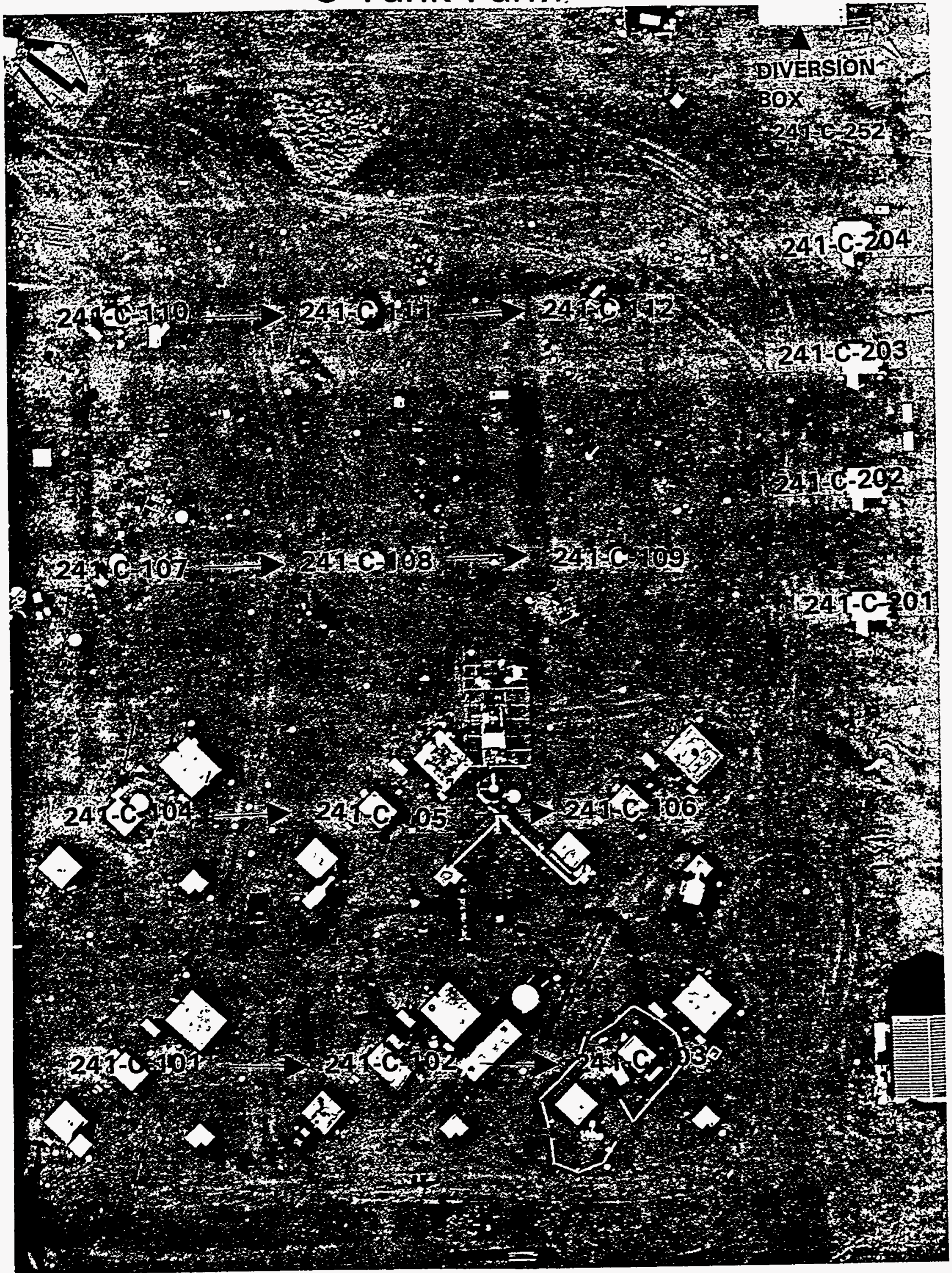




\subsubsection{C Tank Farm Waste History}

Tanks 241-C-101 through -106 received metal waste and Tanks 241-C107 through -112 received first-cycle waste and $B$ Plant decontamination waste. Tanks 241-C-201 through -204 were used to settle waste while the supernatant was sent to a crib. The $C$ Tank Farm tanks also received PUREX Plant fission product waste from 241-C-106 which still has a large amount of strontium. The strontium waste has caused a high-heat load in 241-C-106 which requires water additions for cooling. Currently, a project is underway to allow waste sluicing from Tank 241-C-106. Tank 241-C-105 no longer requires water additions for cooling purposes. Tanks 24I-C-105 and 241-C-106 are connected to an exhauster which provides some cooling.

Slüicing för uranium recovery in the $c$ Tank Farmbegan in 1952 and was completed by 1955. Tanks 241-C-101 through -106 and 241-C-201 through C-204 were sluiced for uranium recovery. Tank 241-C-104 was used as a tank-to-tank sluicing receiver in 1954, and the tank waste was sent later to the $244-C R$ process vault.

Tanks 241-C-108, -109, -111, and -112 were used as primary settling tanks for the "in-farm scavenged" uranium. The waste that was scavanged originated in the various 200-East Area tanks.

\subsubsection{C Tank Farm Temperature History}

All tanks within the C Tank Farm contain at least one thermocouple tree. Tanks 241-C-106, 241-C-109, and 241-C-112 contain two thermocouple trees. Tanks $241-C-105$ and $241-C-106$ are present and former High-Heat Load Watch List tanks and tanks 241-C-108, -109, -111, and -112 are present and former Ferrocyanide watch Iist tanks. Therefore, they all have a weekly temperature reading requirement. Tank 241-C-103 has been on the Organic Salts Watch List since January 1991 monitored weekly. The remaining tanks have monthly or semiannual reading requirements.

Only Tank 241-C-106 is on the High-Heat Load Watch List for critical monitor of temperature data. Periodic water additions have been required to the tank to maintain evaporative cooling and to prevent overheating and resultant unacceptable structural damage from exceeding structural temperature limits. The tank is scheduled for partial waste retrieval in 1997 when cooling water additions will be discontinued.

\subsubsection{C Tank Farm Integrity}

All twelve 530,000-gal tanks and four 55,000-gal tanks in the $C$ Tank Farm are out of service. As of July 1993, nine are categorized as sound (Tanks 241-C-102,-103, -104, -105, -106, -107, -108, -109, -112) and seven are categorized as assumed leakers (Tanks 241-C-101, -110, $111,-201,-202,-203,-204$ ).

The C Tank Farm has 70 leak detection wells that were drilled from 1944 to 1982. Ten drywells are not tank-specific and currently do 
not have readings greater than the $50 \mathrm{c} / \mathrm{s}$ background radiation. The drywells are monitored weekly, bi-weekly, monthly, yearly, or on request with scintillation probes. The following action criteria are for increasing activity: if the normal readings are less than $200 \mathrm{c} / \mathrm{s}$, the readings must double and exceed $200 \mathrm{c} / \mathrm{s}$; if the normal readings are greater than $200 \mathrm{c} / \mathrm{s}$, the readings must double.

The following illustration of the B Tank Farm layout includes information on the drywell peaks, tank integrity, and tank isolation. The drywell information is based on summarized data from 1990 and data prior to 1986 .

\subsubsection{Current Status of C Tank Farm}

Six tanks in the C'Tank"Farm are identified. on 'a watch-list: Tanks 241-C-103, -106, -108, -109, -111, and -112 were added to a list officially in January 1991. Tank 241-C-103 is on the Organic Salts Watch List and Tank 241-C-106 is on the High Heat Load Watch List. Tanks 241-C-108, -109, -111, and -112 are on the Ferrocyanide watch List, and have been declared unreviewed safety questions because their explosion potential exceeds previously reported safety analysis consequences. Tank 241-C-105 was removed from the High-Heat Load Watch Iist recently and is monitored on a weekly basis. The total volume of waste in the $C$ Tank Farm is 2,144,000 gal: 169,000 gal of supernatant; 5,000 gal saltslurry; $292,000 \mathrm{gal}$ of unknown solids; and $1,678,000 \mathrm{gal}$ of sludge. 


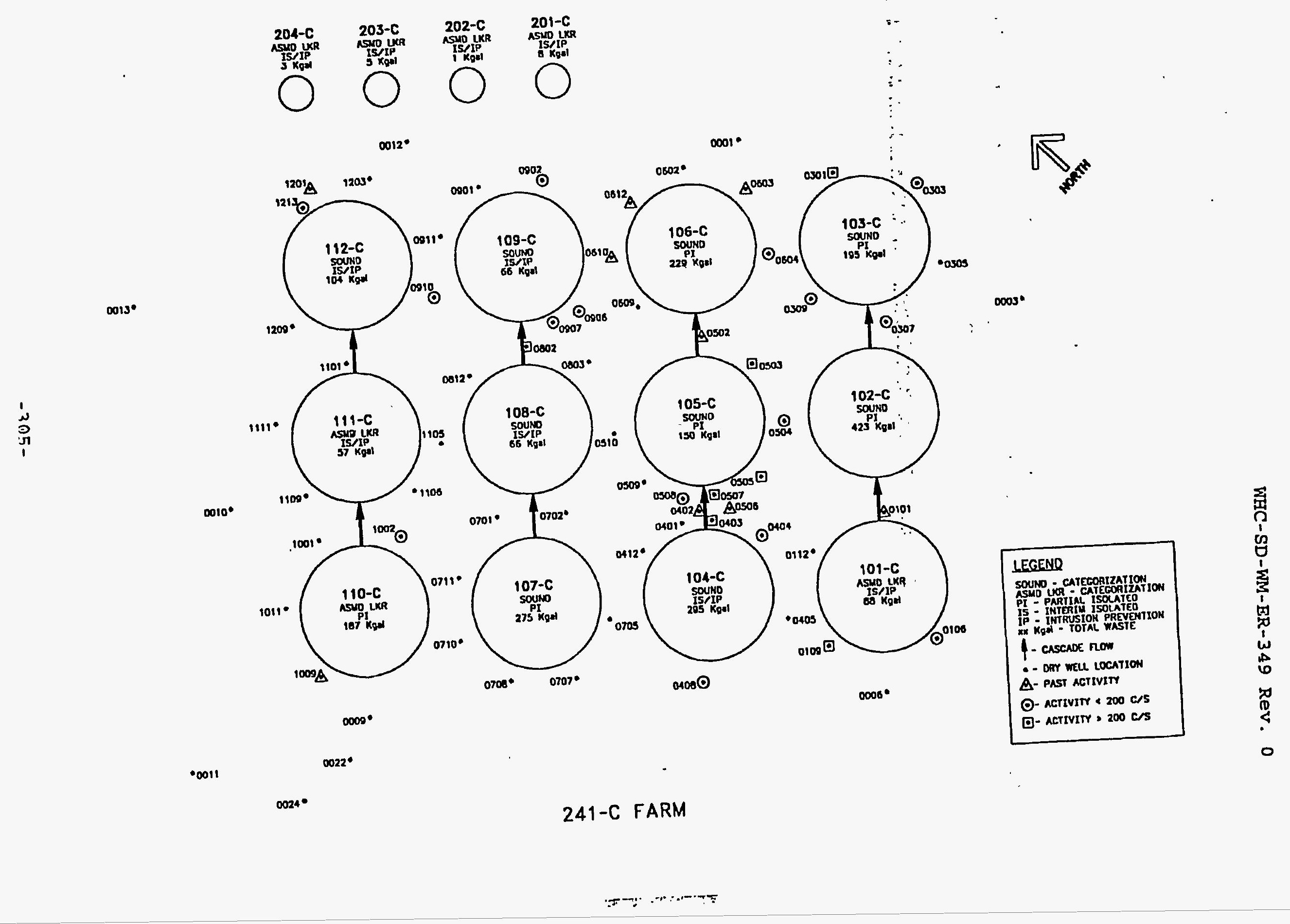


7.1 Tank 241-C-101

7.1.1 241-C-101 Tank History

7.1.1.1 Waste History Tank 241-C-101

Tank 241-C-101 received metal waste in March 1946 and was full by May 1946. The tank was cascading during 1946 and 1953. The tank was noted as.a possible. leaker in the third quarter of 197.0 and as a suspect leaker in 1973. The tank was removed from service in the first quarter of 1976. A saltwell pump was installed in 1976 and pumping was completed in 1979. Primary stabilization was completed in 1978. The tank was declared an assumed leaker in 1980 with a leak volume of 20,000 gal. A level. adjustment_was made in April.19.82 and intrusion prevention was completed "in" December "1982".... Interim "stabiłization" was completed administratively and a level adjustment was made in November 1983. (See sketch ES-TKS-E51 for a graphical representation of the Tank 241-C-101 level history.)

\subsubsection{Temperature History 241-C-101}

The single thermocouple tree in Tank 241-C-101 has 11 thermocouple probes to record temperature data. The mean temperature of the first recorded data from this thermocouple tree was $93^{\circ} \mathrm{F}$. A sum of the squares regression line fit shows a slight decrease in temperature. with little variability in the data. The median temperature is $86^{\circ} \mathrm{F}$ with a minimum of $75.2^{\circ} \mathrm{F}$ and a maximum of $97^{\circ} \mathrm{F}$. Refer to the supporting documents for a more thorough review of the temperature data (Brevick 1994).

\subsubsection{Integrity of Tank $241-C-101$}

Tank 241-C-101 is categorized as an assumed leaker and is interim stabilized with intrusion prevention completed. The Tank 241-C-101 surface level is monitored quarterly with a manual tape. A figure that graphically represents the surface level measurements from January 1991 to the present can be found in the supporting documents (Brevick 1994). The surface level plot includes an inaccurate read of 64.5 -in, which is attributed to input error of the field data sheets into the Surveillance Analysis Computer System. Another inaccurate reading of $15.75-$ in, has been superseded by an apparent "rerun".

Disregarding these two data points, the surface level has remained steady ranging between 25 and 26.25 in.

Four drywells are identified for tank 241-C-101. Graphical representations of the active drywells from January 1990 to the present can be found in the supporting documents (Brevick 1994) .

7.1.2 Current Status of Tank 241-C-101

Tank 241-C-101 entered service in March 1946 and currently stores $88,000 \mathrm{gal}$ of waste. The waste is comprised of 15,000 gal of unknown waste; 73,000 gal of sludge; no supernatant, with no pumpable liquid remaining. The tank is a low heat load tank, and is passively 
WHC-SD-WM-ER-349, Rev. 0

ventilated. It is categorized as an assumed leaker, with interim stabilization and intrusion prevention completed. Tank 241-C-101 is equipped to cascade to Tank 241-C-102 and is first in the three-tank cascade series. The following plan view and cross section depict of the approximate waste level and riser configuration. Tank 241-C-101 has 9 risers and two are available for use: one 4-in. riser (no.1) and one 12-in. riser (no.7).

\subsubsection{Inventory estimate 241-C-101}

The following tank layer volume approximation was derived from the Los Alamos National Laboratories Waste Status and Transaction Record Summary (Agnew 1994). The estimated inventory of Tank 241-C-101 is also presented..

\subsubsection{In-Tank Photograph 241-C-101}

The Tank 241-C-101 photo shows a black and white sludge surface with no visible liquid. The tank contains approximately $88,000 \mathrm{gal}$ of sludge which is approximately 2 ft deep.

7.1 .3 Synopsis Tank 241-C-101

(To be completed.) 
WHC-SD-WM-ER-349 ReV, 0

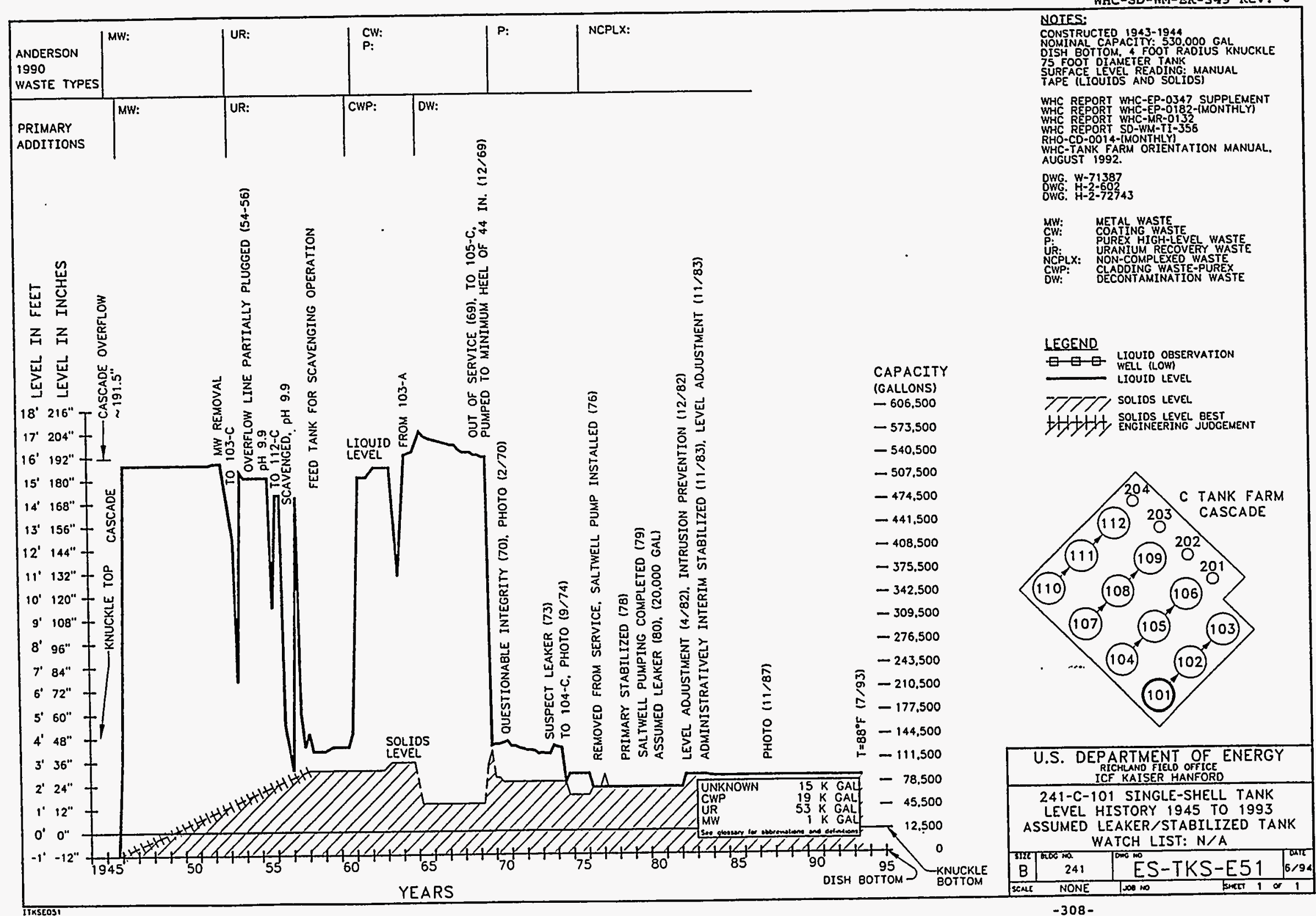




\begin{tabular}{|c|c|c|c|}
\hline \multicolumn{4}{|c|}{ Single-Shell Tank 241-C-101 } \\
\hline \multicolumn{4}{|c|}{ Solids Composite Inventory Estimate } \\
\hline Physolshopatho & & \%/\% \% & \% \% \%/ \\
\hline Total Solid Waste & \multicolumn{3}{|c|}{$5.39 \mathrm{E}+05 \mathrm{~kg}(88 \mathrm{kgal})$} \\
\hline Heat load & \multicolumn{3}{|c|}{$0.16 \mathrm{~kW}(5.49 \mathrm{E}+02 \mathrm{BTU} / \mathrm{hr})$} \\
\hline Bulk Density & \multicolumn{3}{|c|}{$1.62(g / \infty)$} \\
\hline Void Fraction & \multicolumn{3}{|c|}{0.38} \\
\hline Water wt\% & \multicolumn{3}{|c|}{28.74} \\
\hline TOC wr\% C (wet) & \multicolumn{3}{|c|}{0.00} \\
\hline \multicolumn{4}{|l|}{ 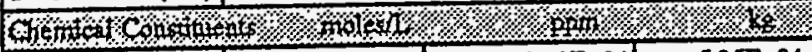 } \\
\hline \begin{tabular}{|l|l}
$\mathrm{Na}^{+1}$ \\
\end{tabular} & 6.99 & $9.93 \mathrm{E}+04$ & $5.35 \mathrm{E}+04$ \\
\hline $\mathrm{Al}^{43}$ & 2.24 & $3.73 E+04$ & 2.01E+04 \\
\hline $\mathrm{Fe}^{+3}(\operatorname{total} \mathrm{Fe})$ & 0.36 & $1.25 \mathrm{E}+04$ & $6.72 \mathrm{E}+03$ \\
\hline $\mathrm{Cr}^{+3}$ & of & $\therefore \quad 0$ & 0 \\
\hline $\mathrm{Bi}^{+3}$ & of & 0 & 0 \\
\hline $\mathrm{Le}^{+3}$ & 0. & 아 & 0 \\
\hline $\mathrm{Ce}^{43}$ & of & of & 0 \\
\hline $\mathrm{Zx}\left(\mathrm{as} \mathrm{ZrO}(\mathrm{OH})_{2}\right)$ & 아 & 요 & 0 \\
\hline $\mathrm{Pb}^{+2}$ & of & 이 & 0 \\
\hline $\mathrm{Ni}^{+2}$ & 이 & 0. & 0 \\
\hline $\mathrm{Sr}^{+2}$ & of & of & 0 \\
\hline $\mathrm{Mn}^{+4}$ & of & of & 0 \\
\hline $\mathrm{Ca}^{42}$ & of & 0 & 0 \\
\hline $\mathrm{K}^{+1}$ & 0 & o & 0 \\
\hline $\mathrm{OH}^{-1}$ & 7.96 & $8.36 \mathrm{E} \div 04$ & $4.51 \mathrm{E}+04$ \\
\hline $\mathrm{NO}^{-1}$ & 0.60 & $2.30 \mathrm{E}+04$ & $1.24 \mathrm{E}+04$ \\
\hline $\mathrm{NO}^{-1}$ & $7.14 \mathrm{E}-02$ & $2.03 E+03$ & $1.09 \mathrm{E}+03$ \\
\hline $\mathrm{CO}^{-2}$ & 0.11 & $4.06 \mathrm{E}+03$ & $2.19 \mathrm{E}+03$ \\
\hline $\mathrm{PO}^{-3}$ & 1.00 & $5.85 \mathrm{E}+04$ & $3.15 \mathrm{E}+04$ \\
\hline $\mathrm{SO}^{-2}$ & 1.56 & $9.24 E+04$ & $4.99 E+04$ \\
\hline $\mathrm{Si}\left(\right.$ as $\mathrm{SiO}_{3}{ }^{-2}$ ) & 0 & 0 & 0 \\
\hline $\mathrm{F}^{-1}$ & 0 & 0 & 0 \\
\hline $\mathrm{C}^{-1}$ & $3.12 \mathrm{E}-03$ & 68.18 & 36.77 \\
\hline $\mathrm{C}_{6} \mathrm{H}_{5} \mathrm{O}_{7}{ }^{-3}$ & 0 & 0 & 0 \\
\hline EDTA $^{-1}$ & 0 & 0 & 0 \\
\hline HEDTA $^{-3}$ & 0 & 0 & 0 \\
\hline $\mathrm{NTA}^{-3}$ & 0 & 요 & 0 \\
\hline glycolate ${ }^{-1}$ & 의 & 의 & 0 \\
\hline acetate ${ }^{-1}$ & 0 & 0 & 0 \\
\hline oxalare ${ }^{-2}$ & 0 & 0 & 0 \\
\hline $\mathrm{DBP}$ & 요 & 0 & 0 \\
\hline NPH & 0 & 0 & 0 \\
\hline $\mathrm{CCl}_{4}$ & of & of & 0 \\
\hline hexone & 이 & 0 & 0 \\
\hline $\mathrm{Fc}(\mathrm{CN})_{6}{ }^{2}$ & 0 & $0(\mathrm{~g}-\mathrm{mol})$ & \\
\hline \multicolumn{4}{|c|}{ 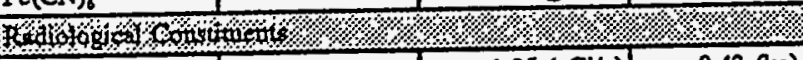 } \\
\hline $\mathrm{Pu}$ & & $1.05(\mu \mathrm{Ci} / \mathrm{g})$ & $9.43(\mathrm{~kg})$ \\
\hline $\mathrm{U}$ & $2.82 \mathrm{E}-02(\mathrm{M})$ & $4.15 \mathrm{E}+03(\mathrm{ug} / \mathrm{g})$ & $2.24 \mathrm{E}+03(\mathrm{~kg})$ \\
\hline Cs & $1.05 \mathrm{E}-03(\mathrm{Ci} / \mathrm{L})$ & $0.65(1 \mathrm{CI} / \mathrm{g})$ & $3.51 E+02(\mathrm{Ci})$ \\
\hline $\mathbf{S r}$ & $7.09 \mathrm{E}-02(\mathrm{Ci} \Omega)$ & $43.78(\mu \mathrm{Ci} / \mathrm{g})$ & $2.36 \mathrm{E}+04(\mathrm{Ci})$ \\
\hline
\end{tabular}

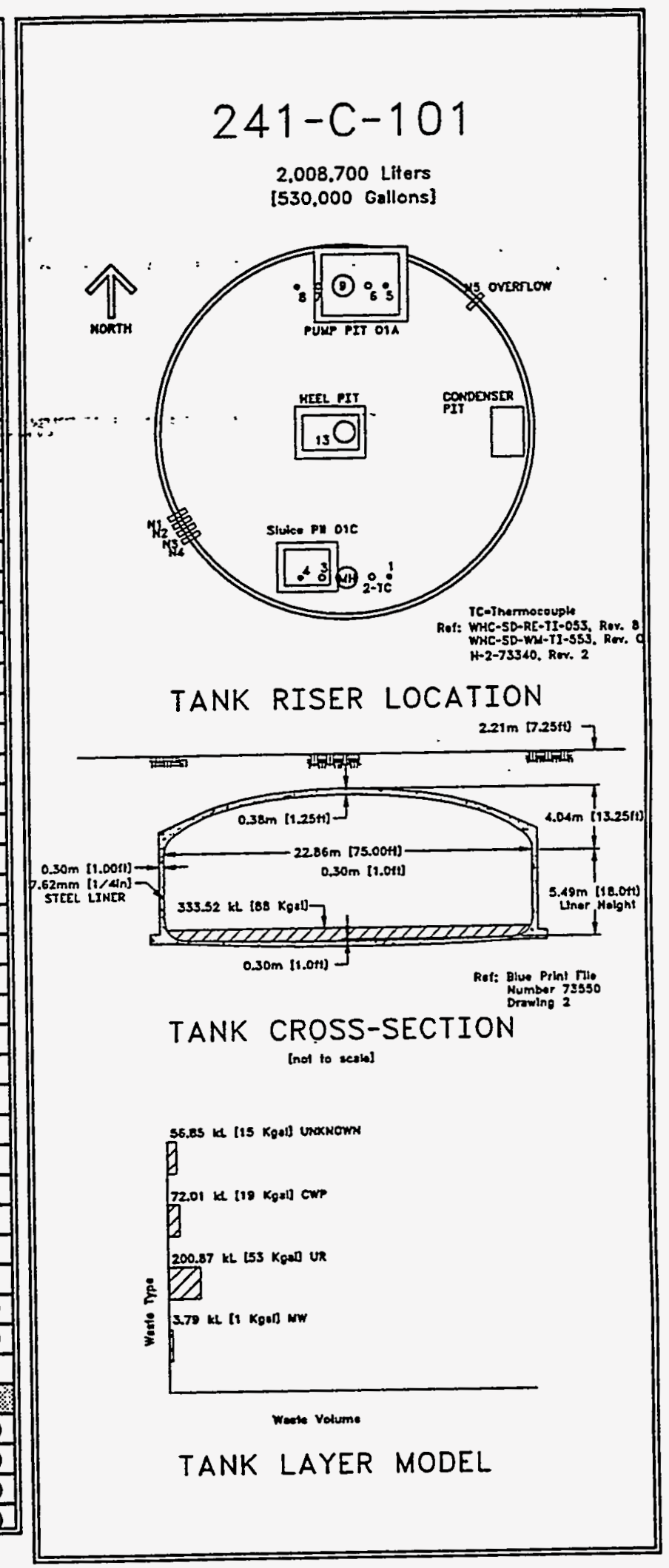

$6 / 94$ 
WHC-SD-WM-ER-349 Rev. 0

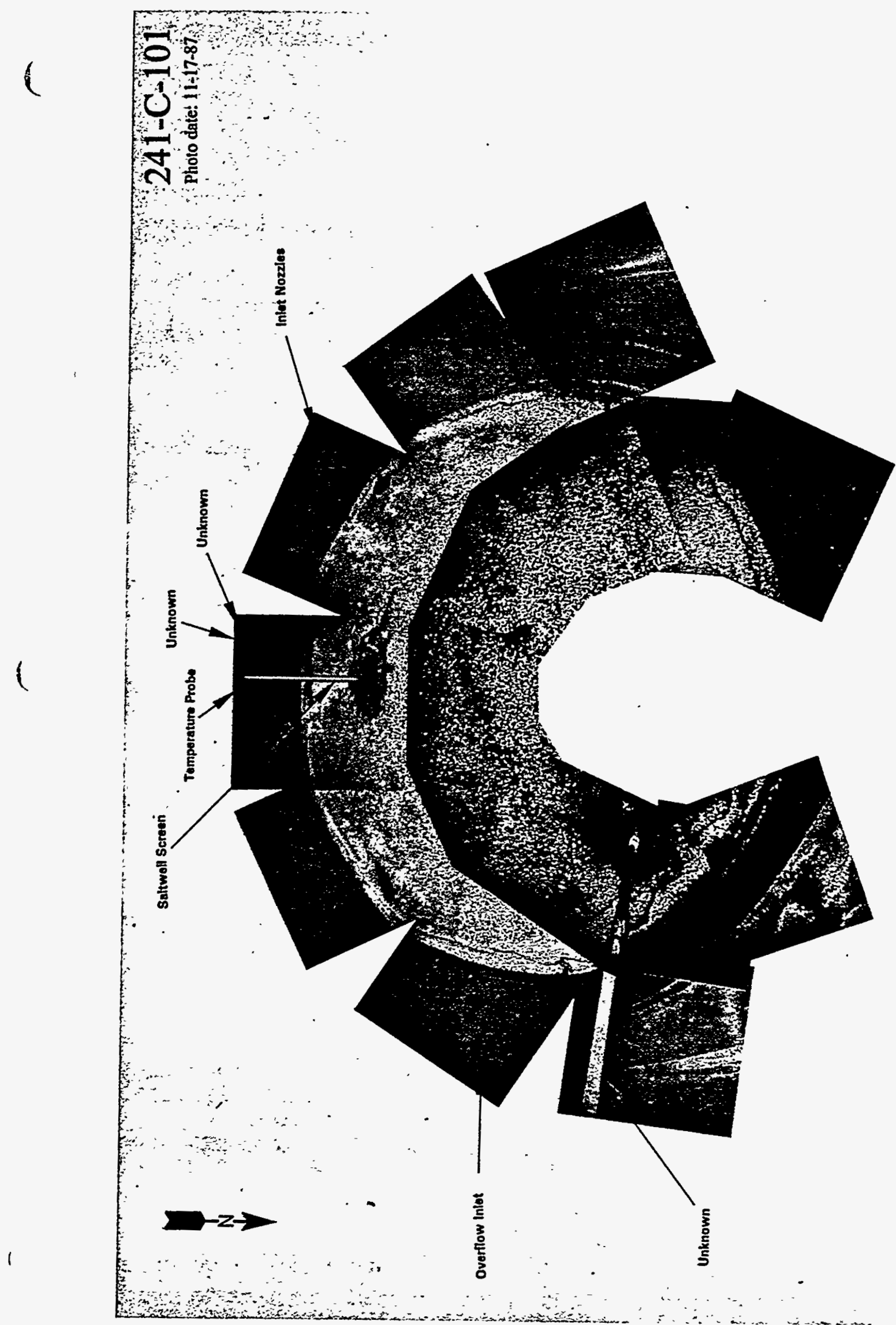




\subsection{Tank 241-C-102}

7.2.1 241-C-102 Tank History

7.2.1.1 Waste History Tank 241-C-102

Tank 241-C-102 was filled in May 1946 from the Tank 241-C-101 cascade overflow. The tank was removed from-service during the first quarter of 1976. A salt well pump was installed in 197.7 and pumping was completed in 1978. The tank was declared inactive in the first quarter of 1978. A level adjustment was made in April 1982 and the tank was partialiy isolated in December 1982. In November 1991, the tank was saltwell-pumped again. (See sketch ES-TKS-E52 for a graphical representation of the Tank 241-C-102...level. history ..). .

\subsubsection{Temperature History 241-C-102}

The single thermocouple tree in Tank 241-C-102 has 11 thermocouple probes to record temperature data. Because there is only one data point, a regression and variability assessment is not possible. The median temperature is $94^{\circ} \mathrm{F}$ with a minimum of $85^{\circ} \mathrm{F}$ and a maximum of $96^{\circ} \mathrm{F}$. Refer to the supporting documents for a more thorough review of the temperature data (Brevick 1994).

\subsubsection{Integrity of Tank 241-C-102}

Tank 241-C-102 is categorized as sound and is partially isolated. The Tank 241-C-102 surface level is monitored with a Food Instrument Corporation gauge through riser 2. The gauge is set in the intrusion mode for a 1 -in. increase. Data are not available for a surface level plot due to the Food Instrument Corporation gauge setting.

Tank 241-C-102 has no liquid observation well or drywells.

\subsubsection{Current Status of Tank 241-C-102}

Tank 241-C-102 entered service in May 1946 and currently stores 423,000 gal of waste comprised of 78,000 gal of unknown waste; 165,000 gal of sludge; no supernatant, with 19,000 gal of pumpable liquid remaining. The tank is identified as a non-watch list low-heat load tank, is passively ventilated, and is categorized as sound with partial isolation completed. Tank 241-C-102 is equipped to cascade to Tank 241C-103 and is second in the three-tank cascade series. The following plan view and cross-section depict the approximate waste level and riser configuration. Tank 241-C-102 has 10 risers and $12-i n$. riser no.3 is available for use.

\subsubsection{Inventory estimate $241-\mathrm{C}-102$}

The following tank layer volume approximation was derived from the Los Alamos National Laboratories waste Status and Transaction Record Summary (Agnew 1994). The estimated inventory of Tank 241-C-102 is also presented. 
WHC-SD-WM-ER-349, Rev. 0

7.2.2.2 In-Tank Photograph 241-C-102

The Tank 241-C-102 photo shows a black sludge with small pockets of liquid. The tank contains approximately 423,000 gal of waste which is approximately $12.5 \mathrm{ft}$ deep. A level adjustment was made as a result of the photo.

7.2.3 Synopsis Tank 241-C-102

(To be completed.) 


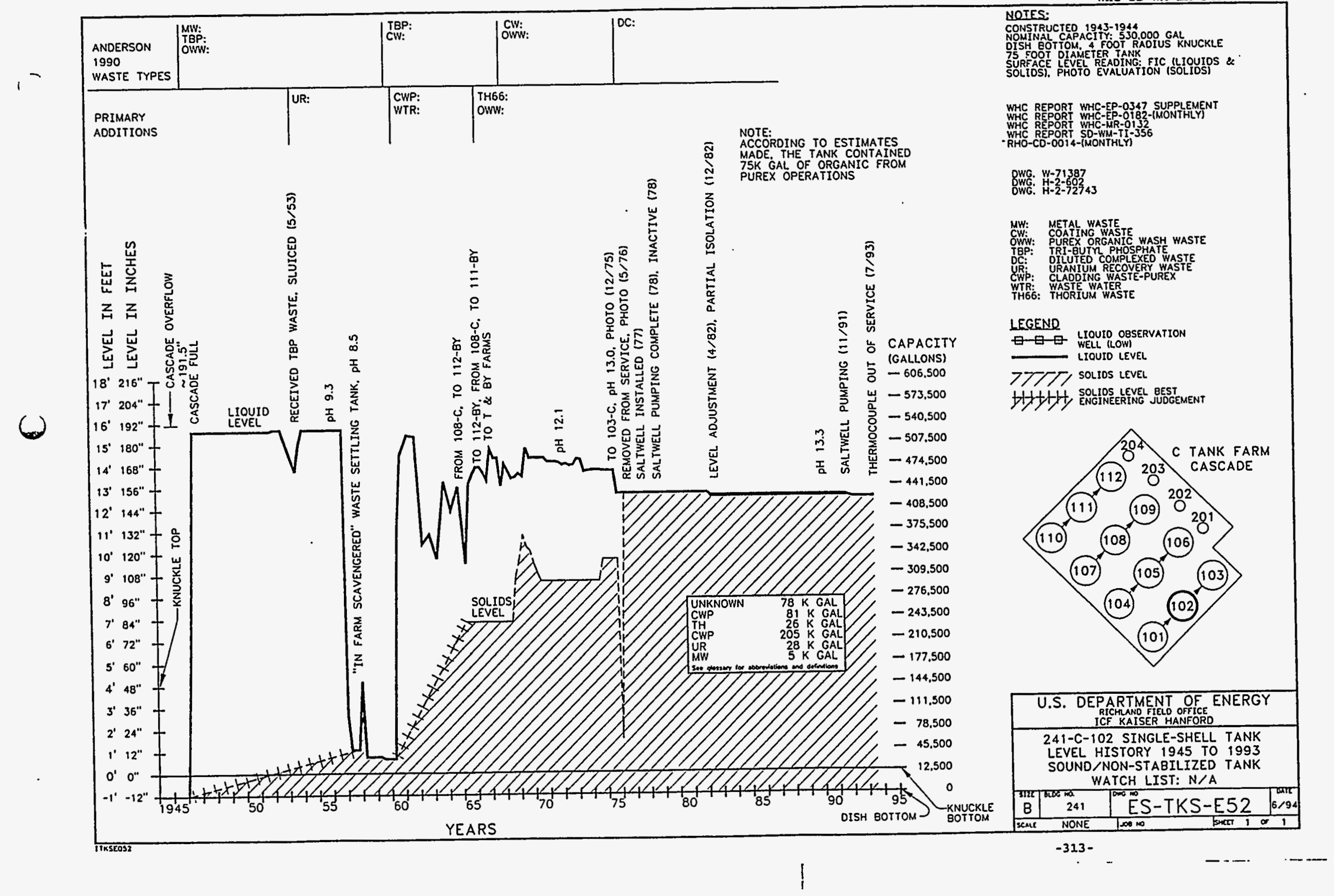




\begin{tabular}{|c|c|c|c|}
\hline \multicolumn{4}{|c|}{ Single-Shell Tank 241-C-102 } \\
\hline \multicolumn{4}{|c|}{ Solids Composite Inventory Estimate } \\
\hline 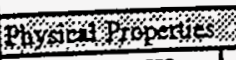 & \% \% \% & $\% \% \% \%$ & \%\%\% \\
\hline Total Solid Waste & $2.48 \mathrm{E} t$ & $E+06 \mathrm{~kg}$ (423 kgal) & \\
\hline Heal load & \multicolumn{3}{|c|}{$0.12 \mathrm{~kW}(4.17 \mathrm{E}+02 \mathrm{BTU} / \mathrm{hr})$} \\
\hline Bulk Density & \multicolumn{3}{|c|}{$1.55(\mathrm{~g} / \mathrm{cc})$} \\
\hline Void Fraction & \multicolumn{3}{|c|}{0.62} \\
\hline Water wis & \multicolumn{3}{|c|}{52.84} \\
\hline TOC wig C (wet) & \multicolumn{3}{|c|}{0.00} \\
\hline \multicolumn{4}{|c|}{ TOC wio C (wen) } \\
\hline \begin{tabular}{|l|l|}
$\mathrm{Na}^{+3}$ \\
\end{tabular} & 1.96 & $2.91 \mathrm{E}+04$ & $7.20 \mathrm{E}+04$ \\
\hline $\mathrm{Al}^{+3}$ & 4.78 & $8.34 \mathrm{E}+04$ & $2.07 \mathrm{E}+05$ \\
\hline $\mathrm{Fe}^{+3}(\mathrm{total} \mathrm{Fe})$ & $6.62 \mathrm{E}-02$ & $2.39 E+03$ & $5.92 \mathrm{E}+03$ \\
\hline $\mathrm{Cr}^{+3}, \vdots$ & $\therefore$. of & \begin{tabular}{l|l}
0 & 0 \\
\end{tabular} & $\because \because \quad 0$ \\
\hline $\mathrm{Bi}^{+3}$ & of & 0 & 0 \\
\hline $\mathrm{LA}^{43}$ & 0 & of & 0 \\
\hline $\mathrm{Ce}^{+3}$ & of & 0 & 0 \\
\hline $\mathrm{Zx}$ (as $\left.2 \mathrm{OO}(\mathrm{OH})_{2}\right)$ & 0.33 & $1.97 \mathrm{E}+04$ & $4.88 \mathrm{E}+04$ \\
\hline $\mathrm{Pb}^{+2}$ & 0 & 0 & 0 \\
\hline $\mathrm{Ni}^{+2}$ & of & 0 & 0 \\
\hline $\mathrm{Sr}^{\circ 2}$ & 0 & 0 & 0 \\
\hline $\mathrm{Mn}$ & of & of & 0 \\
\hline $\mathrm{Ca}^{42}$ & 0 & 0 & 0 \\
\hline $\mathrm{K}^{+1}$ & $5.56 \mathrm{E}-0.4$ & 14.04 & 34.78 \\
\hline $\mathrm{OH}^{-1}$ & 16.05 & $1.76 \mathrm{E}+05$ & $4.37 \mathrm{E}+05$ \\
\hline $\mathrm{NO}^{-1}$ & 0.48 & $1.94 \mathrm{E}+04$ & $4.81 \mathrm{E}+04$ \\
\hline $\mathrm{NO}^{-\mathrm{I}}$ & 0.18 & $5.48 \mathrm{E}+03$ & $1.36 \mathrm{E}+04$ \\
\hline $\cos ^{\cdot 2}$ & $4.09 \mathrm{E}-02$ & $1.59 \mathrm{E}+03$ & $3.93 E+03$ \\
\hline $\mathrm{PO}^{\cdot 3}$ & 0.23 & $1.39 \mathrm{E}+04$ & $3.44 \mathrm{E}+04$ \\
\hline $504^{-2}$ & 0.18 & $1.09 \mathrm{E}+04$ & $2.69 \mathrm{E}+04$ \\
\hline $\mathrm{Si}$ (as $\left.\mathrm{SiO}_{3}{ }^{2}\right)$ & 2.04E-02 & $3.71 \mathrm{E}+02$ & $9.19 \mathrm{E}+02$ \\
\hline $\mathrm{F}^{1}$ & 3.09E-02 & $3.80 \mathrm{E}+02$ & $9.41 E+02$ \\
\hline $\mathrm{Cl}^{-1}$ & 3.42E-04 & 7.84 & 19.42 \\
\hline $\mathrm{C}_{6} \mathrm{H}_{3} \mathrm{O}_{7}^{-3}$ & 0 & 0 & 0 \\
\hline EDTA $^{-1}$ & of & 0 & 0 \\
\hline HEDTA ${ }^{-3}$ & 의 & 0 & 0 \\
\hline $\mathrm{NTA}^{-3}$ & of & 0 & 0 \\
\hline Blycolate ${ }^{-1}$ & 0 & 0 & 0 \\
\hline acetate ${ }^{-1}$ & of & 0 & 0 \\
\hline oxalate & 0 & 0 & 0 \\
\hline DBP & 0 & 0 & 0 \\
\hline $\mathrm{NPH}$ & 0 & 0 & 0 \\
\hline $\mathrm{CCl}_{6}$ & of & of & 0 \\
\hline hexone & 의 & 0 & 0 \\
\hline $\mathrm{Fe}(\mathrm{CN})_{6}^{-1}$ & 0 & $0(\mathrm{~g}-\mathrm{mol})$ & \\
\hline \multicolumn{4}{|c|}{$\mathrm{Fe}(\mathrm{CN})_{6}$} \\
\hline $\mathrm{Pu}$ & & $2.21(\mu \mathrm{Ci} / \mathrm{g})$ & $91.05(\mathrm{~kg})$ \\
\hline $\mathrm{U}$ & $1.11 \mathrm{E}-02 \mathrm{M})$ & $1.70 \mathrm{E}+03(\mu \mathrm{g} / \mathrm{g})$ & $4.22 \mathrm{E}+03(\mathrm{~kg})$ \\
\hline Th & 1.77E-04 (M) & $27.26(\mu \mathrm{g} / \mathrm{g})$ & $67.50(\mathrm{~kg})$ \\
\hline Cs & $1.49 \mathrm{E}-04(\mathrm{Ci} / \mathrm{L})$ & $9.63 \mathrm{E}-02(\mu \mathrm{Ci} / \mathrm{g})$ & $2.38 \mathrm{E}+02(\mathrm{Ci})$ \\
\hline St & $1.12 \mathrm{E}-02(\mathrm{C} / \mathrm{L}) \mathrm{L}$ & $7.25(\mu \mathrm{Ci} / \Omega)$ & $1.80 \mathrm{E}+04(\mathrm{Ci})$ \\
\hline
\end{tabular}

: Composite inventory exchudes supenatant, diatomaccours earth, and cemeol

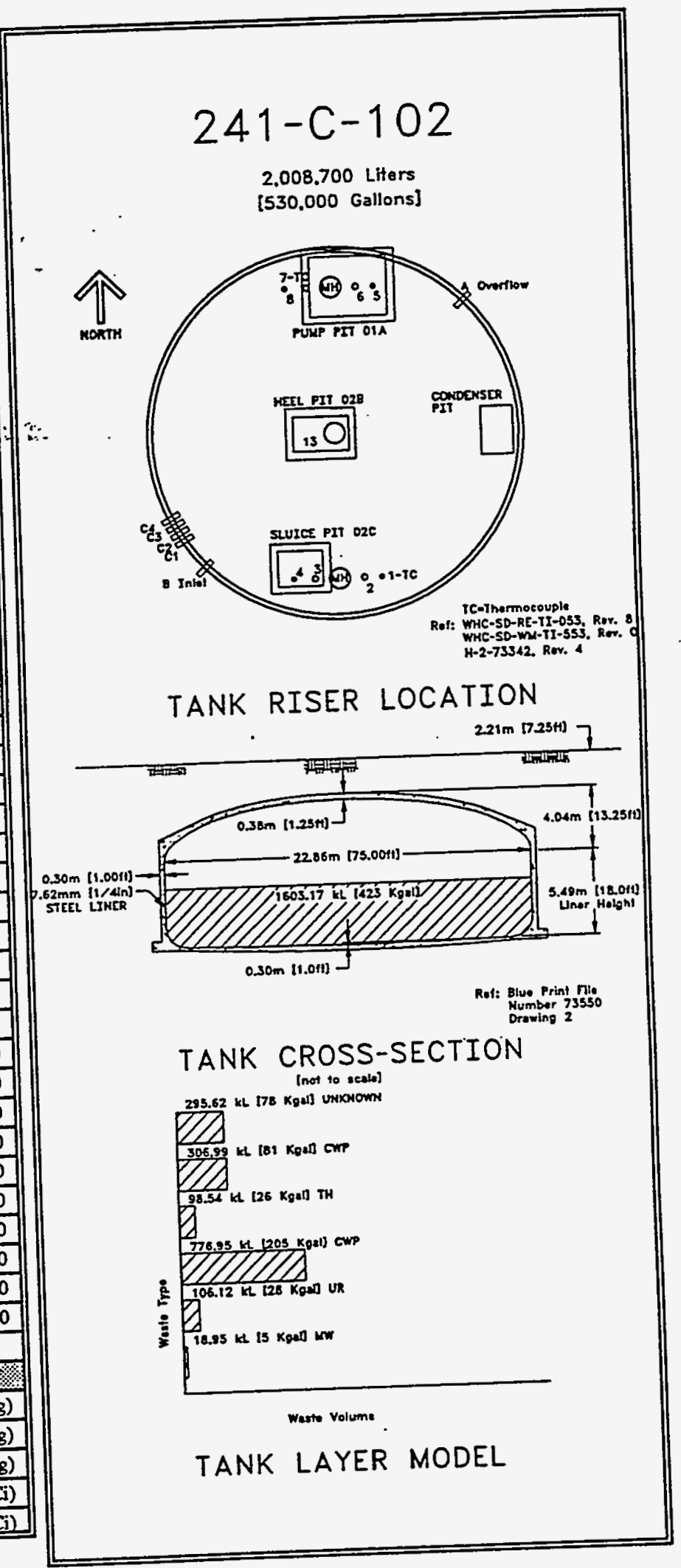

$6 / 94$ 
WHC-SD-WM-ER-349 Rev. 0

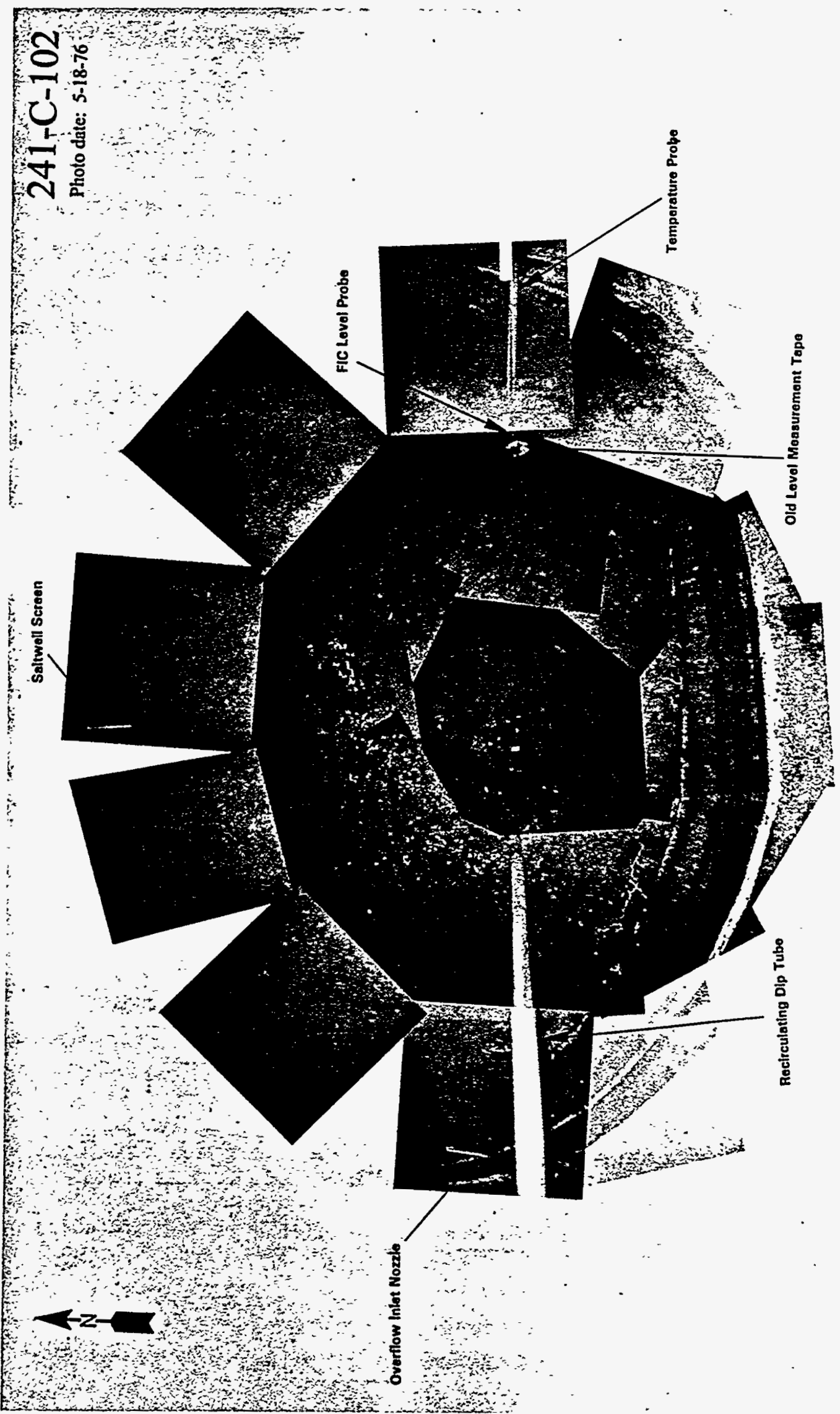


7.3.1 241-C-103 Tank History

7.3.1.1 Waste History Tank 241-C-103

Tank 241-C-103 received metal waste from the Tank 241-C-102 cascade in August 1946 until the fourth quarter of 1952 .

Partial isolation was completed' in December.1982. A 'Ievel adjustment was made in October 1990. The tank is classified as a nonstabilized tank. (See sketch ES-TKS-E53 for a graphical representation of the Tank 241-C-103 level history.)

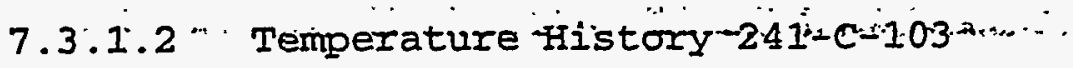

The single thermocouple tree in Tank 241-C-103 has five thermocouple probes to record temperature data. The mean temperature of the first data recorded for thermocouples $I$ through 4 was $120^{\circ} \mathrm{F}$. A sum of the squares regression line fit shows a slight decrease in temperature with. Iittle variability. Not enough data points are available for thermocouple 5 to do an accurate regression or variability analysis. The median temperature is $116^{\circ} \mathrm{F}$ with a minimum of $95^{\circ} \mathrm{F}$ and a maximum of $140^{\circ} \mathrm{F}$. Refer to the supporting documents for a more thorough review of the temperature data (Brevick 1994).

\subsubsection{Integrity of Tank 241-C-103}

Tank 241-C-103 is categorized as sound and is partially isolated. The Tank 241-C-103 surface level is monitored through riser 8 . Graphical representations of the surface level measurements from January 1991 to the present can be found in the supporting documents (Brevick 1994). The surface level plot indicates a decreasing trend over the past three years with the readings ranging from 67 to 66.3 in. (average 66.4 in.) during the first quarter of 1991 and steadily decreasing to a range of 66.2 to 65.9 in. (average 66 in.) during the Iast half of 1993.

An unusual occurrence report was issued in october 1988 due to a decreasing trend of surface level measurements. The liquid loss was attributed to natural breathing of the tank. An off-normal occurrence report was issued in November 1990 due to a decreasing trend in the surface level. The loss of liquid was attributed to evaporation.

Five drywells are identified for tank 241-C-103. Graphical representations of the active drywells from January 1990 to the present can be found in the supporting documents (Brevick 1994).

\subsubsection{Current Status of Tank 241-C-103}

Tank 241-C-103 entered service in August 1946 and currently stores $195,000 \mathrm{gal}$ of waste. The waste is comprised of 133,000 gal of supernatant; 3,000 gal of unknown waste; 59,000 gal of sludge; no saltcake with $133,000 \mathrm{gal}$ of pumpable liquid remaining. The tank has 
WHC-SD-WM-ER-349, Rev. 0

been on the Organic Salts Watch List tank since January 1991, is passively ventilated, and is categorized as sound, with partial isolation completed. Tank $241-\mathrm{C}-103$ is third in the three-tank cascade series. The following plan view and tank cross section depict the approximate waste level and riser configuration. Tank 241-C-103 has 10 risers and 12-in. riser no. 7 is available for use.

\subsubsection{Inventory estimate 241-C-103}

The following tank layer volume approximation was derived from the Los Alamos National Laboratories Waste Status and Transaction Record Sumnary (Agnew 1994). The estimated inventory of Tank 241-C-103 is also presented.

\section{3 .2 .2 In-Tank-Photograph-241-C=103....}

The Tank 241-C-103 photo shows a dark brown liquid surface with no visible sludge. The waste is approximately $5.5 \mathrm{ft}$ deep. The two unknown objects on the left side of the photo are probabiy pieces of equipment that were cut off and allowed to fall back into the tank. The recorded waste level was adjusted as a result of the photo.

7.3.3 Synopsis Tank 241-C-103

(To be completed.) 


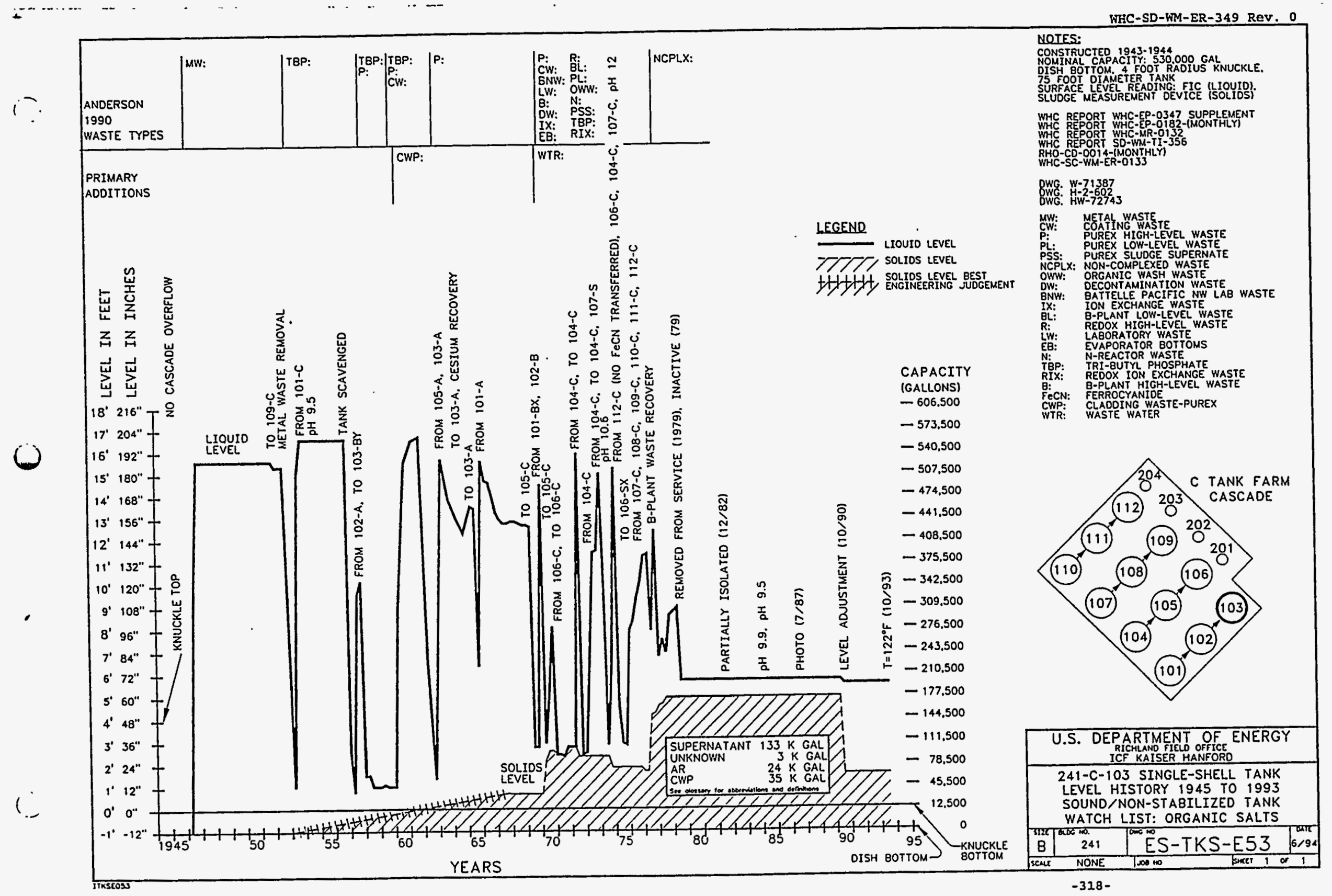




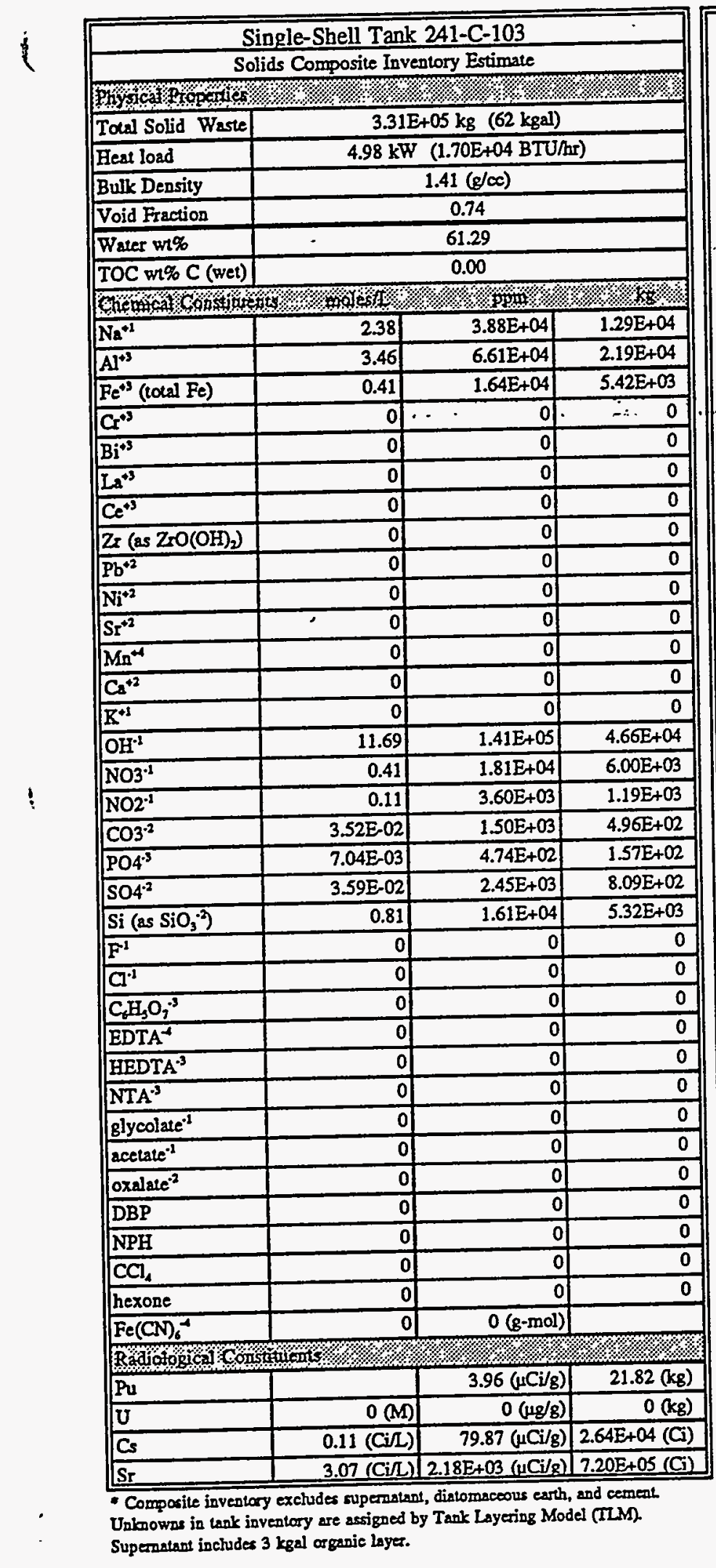

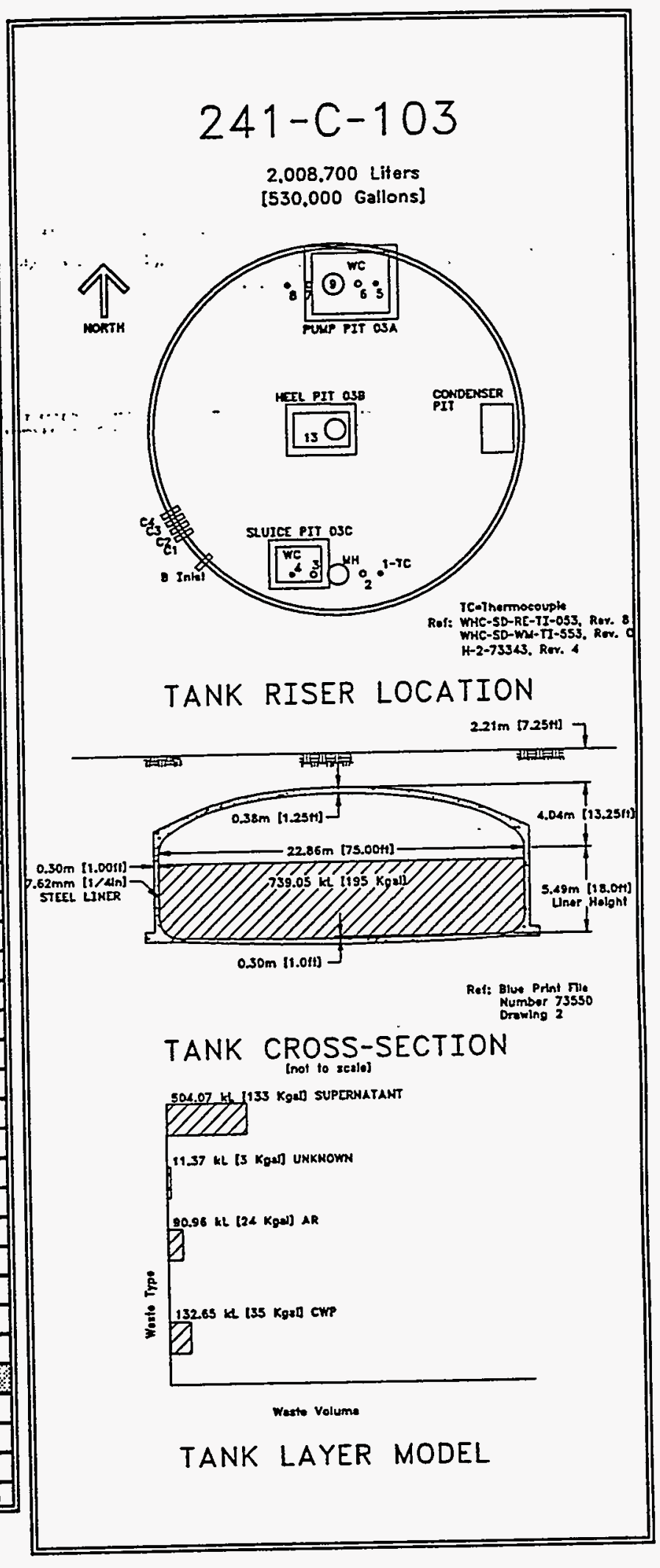


WHC-SD-WM-ER-349 Rev. 0

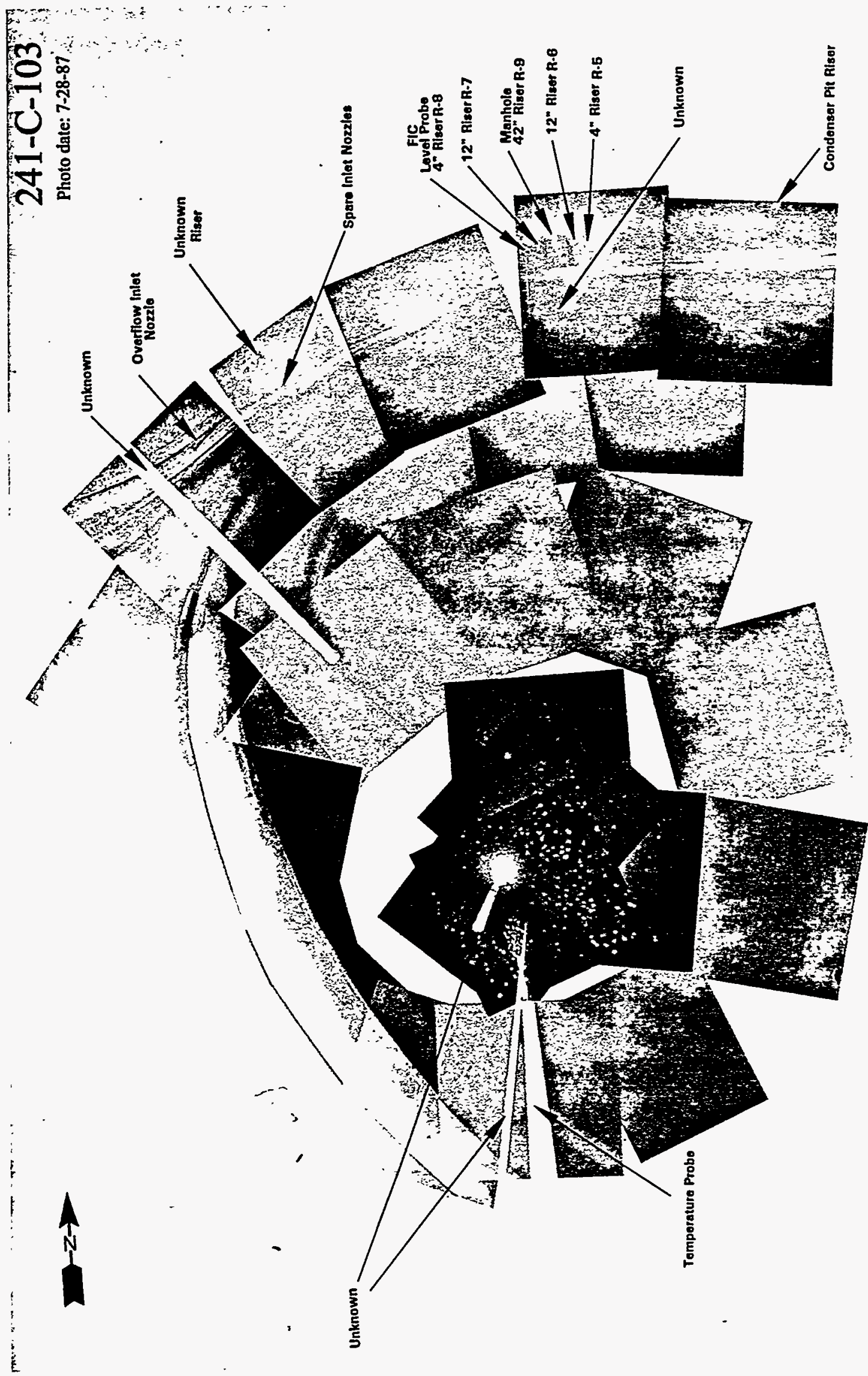


WHC-SD-WM-ER-349, ReV. O

\subsection{Tank 241-C-104}

\subsubsection{1-C-104 Tank History \\ 7.4.1.1 Waste History Tank 241-C-104}

Tank 241-C-104 began to fill with metal waste in October 1946. The tank was declared inactive in March $1980 .$. Partial isolation was completed in December 1982. Level-adjustments were made in July 1982 and April 1983. The tank was declared interim stabilized in September 1989 after salt well pumping was completed. A level adjustment was made in September 1989. Intrusion prevention was completed in February 1991. (See sketch ES-TKS-E54 for a graphical representation of the Tank 241-C104 level. history. H........

\subsubsection{Temperature History 241-C-104}

The single thermocouple tree in Tank 241-C-104 has 12 thermocouple probes. The mean temperature of the data on the first daily recorded readings was $81.4^{\circ} \mathrm{F}$. Because there is a maximum of three data points for one thermocouple, a sum of the squares regression line fit for any thermocouple does not give accurate information; however, little variability exists in the data. The median temperature is $80^{\circ} \mathrm{F}$ with a minimum of $72^{\circ} \mathrm{F}$ and a maximum of $92^{\circ} \mathrm{F}$. Refer to the supporting documents for a more thorough review of the temperature data (Brevick 1994).

\subsubsection{Integrity of Tank 241-C-104}

Tank 241-C-104 is categorized as sound and is interim stabilized with intrusion prevention completed. The Tank 241-C-104 surface level is monitored with a Food Instrument Corporation gauge through riser 8 .

A graphical representation of the surface level measurements from January 1991 to the present can be found in the supporting documents (Brevick, 1994). The surface level graph indicates fluctuating data in a decreasing trend with the readings ranging between 90.2 and 87.1 in.

Seven drywells are identified for tank 241-C-104. Graphical representations of the active drywells from January 1990 to the present can be found in the supporting documents (Brevick, 1994).

\subsubsection{Current status of Tank 241-C-104}

Tank 241-C-104 entered service in October 1946 and currently stores $295,000 \mathrm{gal}$ of waste. The waste is comprised of 63,000 gal of unknown waste; 232,000 gal of sludge with 5,000 gal of pumpable liquid remaining. The tank is identified as a low-heat load tank, is actively ventilated, and is categorized as sound with interim stabilization and intrusion prevention completed. Tank $241-C-104$ is equipped to cascade to Tank 241-C-105 and is first in the three-tank cascade series. The following plan view and tank cross section depict the approximate waste level and riser configuration. Tank 241-C-104 has 12 risers and 12-in. riser no.3 is available for use. 
7.4.2.1 Inventory estimate 241-C-104

The following tank layer volume approximation was derived from the Los Alamos National Laboratories Waste Status and Transaction Record Summary (Agnew 1994). The estimated inventory of Tank 241-C-104 is also presented. :

7.4.2.2 In-Tank Photograph 241-C-104

The Tank 241-C-104 photo shows a dry, dark brown sludge surface. The waste is approximately 295,000 gal or about 8.5 ft deep.

7.4.3 Synopsis Tank 241-C-104

(To be cömpleted.) 


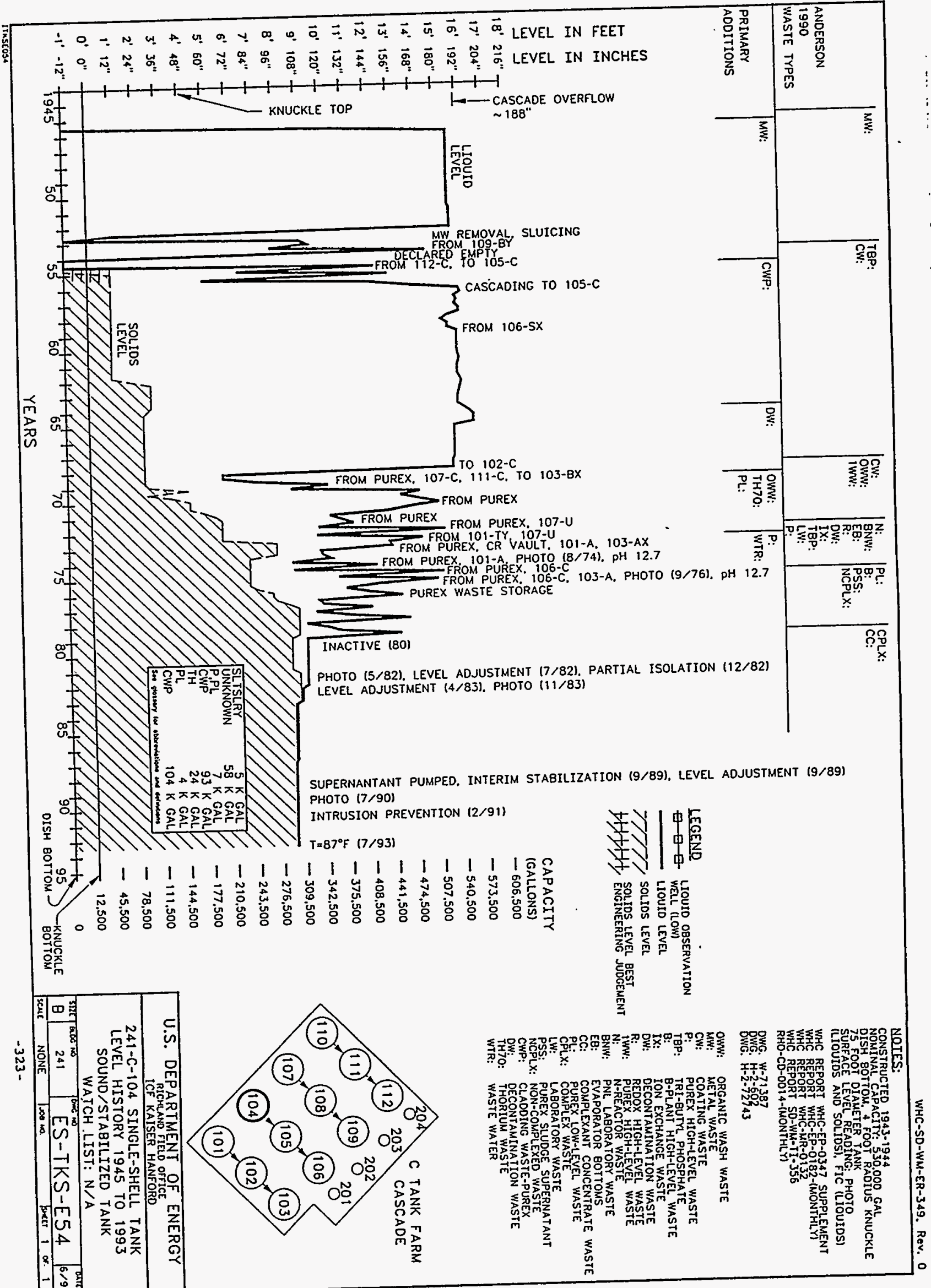


WHC-SD-WM-ER-349, Rev. 0

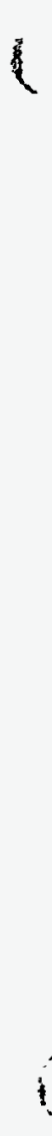

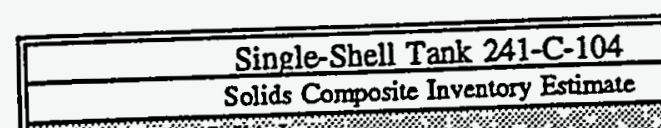

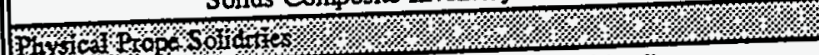
Tousl Solids Waste $1.68 \mathrm{E}+06 \mathrm{~kg}(295 \mathrm{kgal})$

\begin{tabular}{l|l}
\hline Heat load & $10.03 \mathrm{~kW}(3.42 \mathrm{E}+04 \mathrm{BTU} / \mathrm{hr})$ \\
\hline
\end{tabular}

Hear load

Bulk Densily

Waler wt\%

TOC wt\% C (wet)

G.

$\mathrm{Na}^{+1}$

\begin{tabular}{|c|c|c|c|}
\hline $\mathrm{Na}_{2}$ & 5 & & $1.07 E+05$ \\
\hline $\mathrm{Al}^{+3}$ & 3.56 & $6.39 \mathrm{E}+04$ & $\frac{1.07 E+0 s}{1.33 E+0}$ \\
\hline $\mathrm{Fe}^{+3}(\mathrm{lotsl} \mathrm{Fe})$ & 0.21 & $7.91 \mathrm{E}+03$ & $1.33 \mathrm{E}+0$ \\
\hline
\end{tabular}

$\mathrm{Cr}^{+3}$

$\mathrm{Bi}^{+3}$

$\mathrm{La}^{\mathrm{s}}$

$\mathrm{Zr}$ (as $\mathrm{ZrO}(\mathrm{OH})_{2}$

$\mathrm{Pb}^{+2}$

$\frac{\mathrm{Pi}}{\mathrm{Ni}^{+2}}$

\begin{tabular}{|l|r}
\hline $\mathrm{Ni}^{+2}$ & 0 \\
\hline $\mathrm{Mn}^{+4}$ & 0 \\
\hline $\mathrm{C}^{4+2}$ & 0
\end{tabular}

$\mathrm{Ca}^{42}$

$\mathrm{K}$

$\mathrm{K}^{+1}$

$\mathrm{NO}^{2}$

$\mathrm{NO} 2$

$\mathrm{PO}^{\prime 3}$

$\mathrm{SO}^{-2}$

$\mathrm{Si}\left(\right.$ as $\left.\mathrm{SiO}_{3}{ }^{-2}\right)$

$\mathrm{F}^{-1}$

Cl

$\mathrm{C}_{6} \mathrm{H}_{3} \mathrm{O}_{7}^{-3}$

EDTA

HEDTA ${ }^{3}$

NTA $^{-3}$

glycolate ${ }^{-3}$

acelste

oxalate ${ }^{-2}$

DBP

NPH

$\mathrm{CCl}_{4}$

hexone

$\mathrm{Fe}(\mathrm{CN})_{6}{ }^{4}$

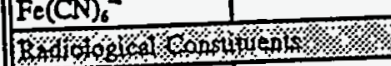

\begin{tabular}{|l|r|r|r|}
\hline $\mathrm{Pu}$ & & $2.45(\mu \mathrm{Ci} / \mathrm{g})$ & $68.45(\mathrm{~kg})$ \\
\hline $\mathrm{U}$ & $0 \mathrm{M})$ & $0(\mu \mathrm{g} / \mathrm{g})$ & $0(\mathrm{~kg})$ \\
\hline $\mathrm{Th}$ & $2.33 \mathrm{E}-04(\mathrm{M})$ & $36.80(\mu \mathrm{g} / \mathrm{g})$ & $61.80(\mathrm{~kg})$ \\
\hline $\mathrm{Cs}$ & $5.91 \mathrm{E}-02(\mathrm{Ci} / \mathrm{L})$ & $39.30(\mu \mathrm{Ci} / \mathrm{g})$ & $6.60 \mathrm{E}+04(\mathrm{Ci})$ \\
\hline $\mathrm{Sr}$ & $1.29(\mathrm{Ci} / \mathrm{L})$ & $8.59 \mathrm{E}+02(\mu \mathrm{Ci} / \mathrm{g})$ & $1.44 \mathrm{E}+06(\mathrm{Ci})$ \\
\hline
\end{tabular}

\begin{tabular}{|l|l}
\hline $\mathrm{Sr}$ & $1.29(\mathrm{Ci} / \mathrm{L}) / 8.59 \mathrm{E}+02(\mu \mathrm{Cl} / \mathrm{g}) / 1.44 \mathrm{E}+06$ \\
\hline
\end{tabular}

- Comporite inventory excludes supernatant, dialomaceour earha, aod cemp).

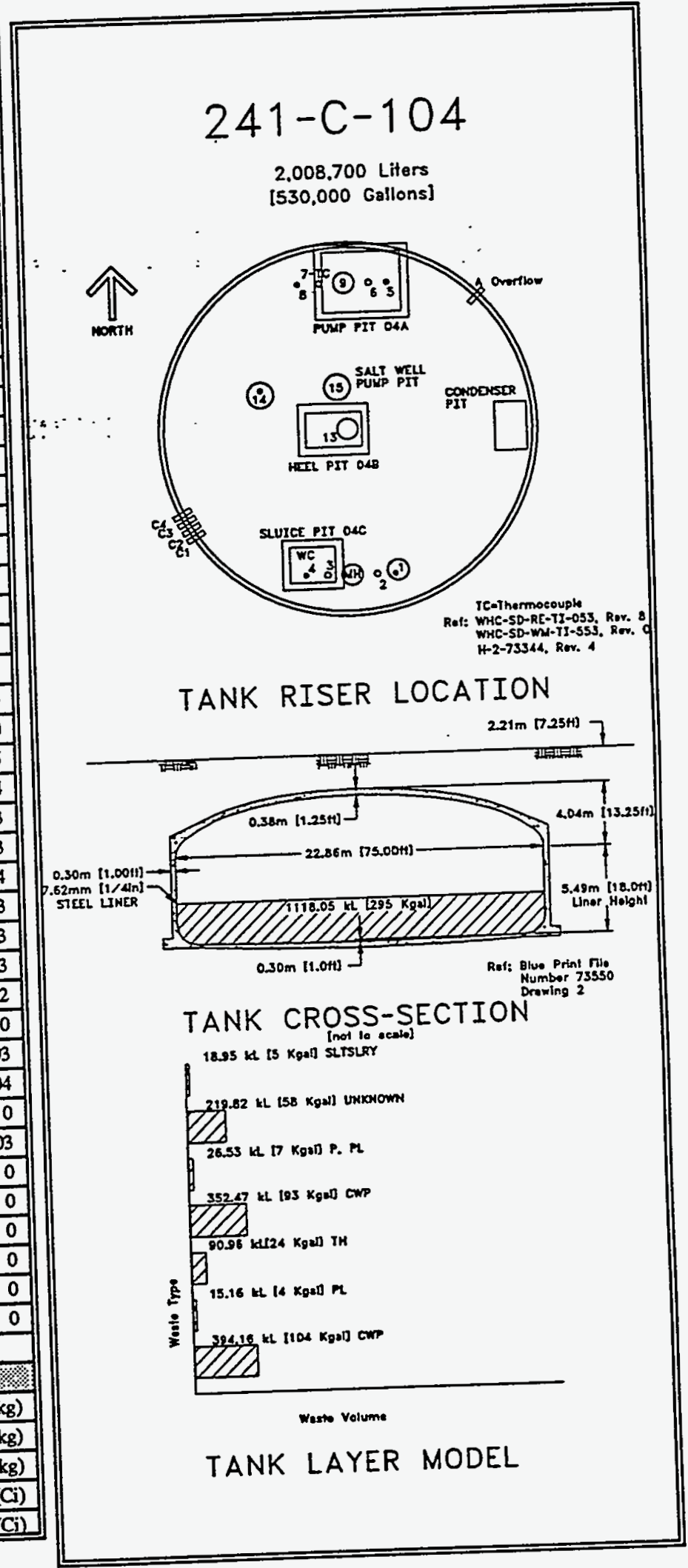

$6 / 94$ 
WHC-SD-WM-ER-349 Rev. 0
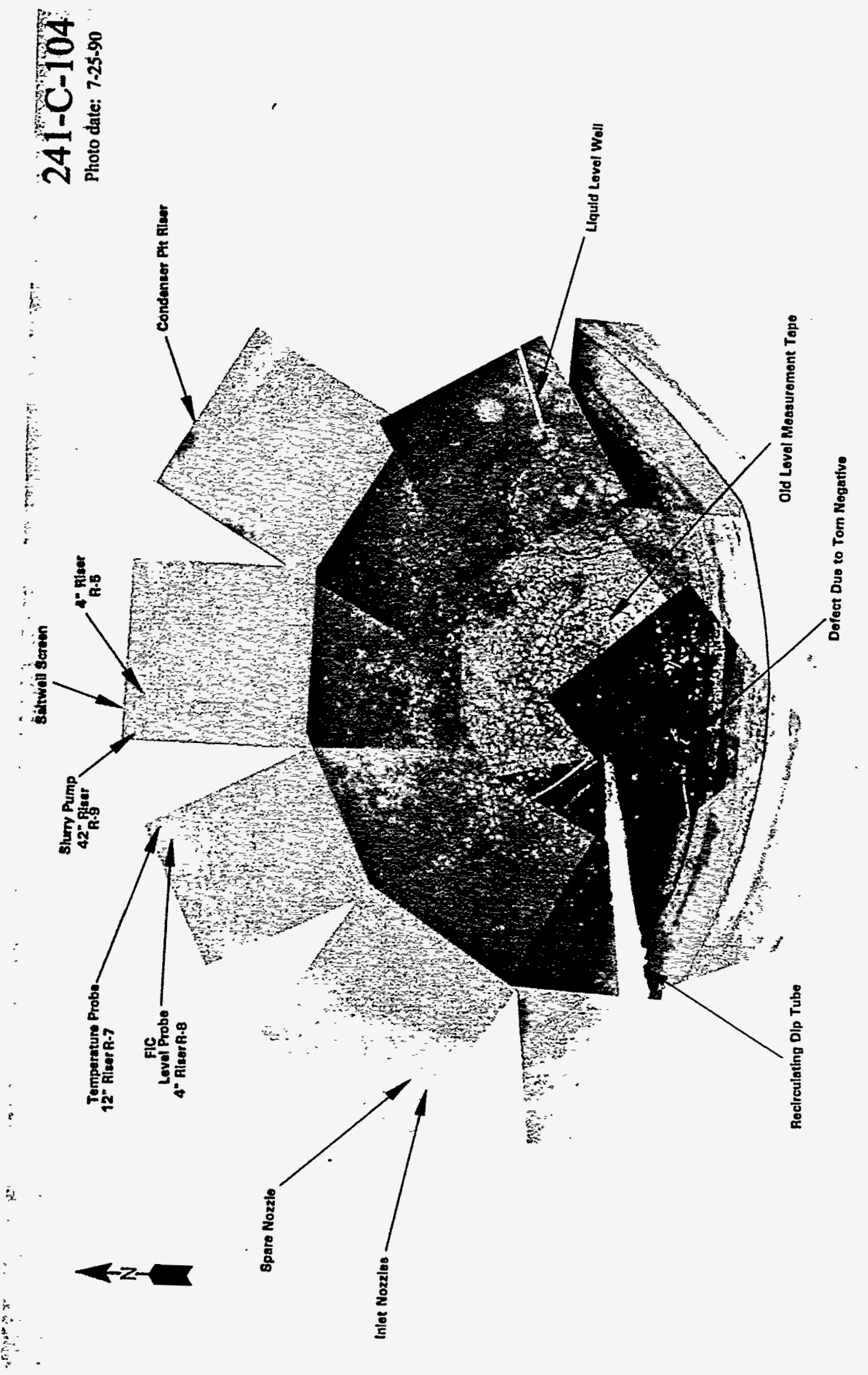
WHC-SD-WM-ER-349, Rev. 0

7.5 Tank 241-C-105

7.5.1 241-C-105 Tank History

7.5.1.1 Waste History Tank 241-C-105

Tank 241-C-105 received metal waste via the 241-C-104 cascade line Exom February 1947 until November 1953. . The tank became inactive when all single-shell tanks were declared inactive in November 1980 . 'Level adjustments were made in May 1979 and May 1983, and partial isolation was completed in August 1983. - A level adjustment was made in May 1985 and water additions for evaporative cooling were stopped in January 1988. The tank is non-stabilized. (See sketch ES-TKS-E55 for a graphical representation. of the Tank .41-C-105. level history.)

\subsubsection{Temperature History 241-C-105}

The single thermocouple tree in Tank 241-C-105 has seven thermocouple probes to record temperature data. The mean temperature of the first data recorded for thermocouples 1 through 4 was $78^{\circ} \mathrm{F}$. A sum of the squares regression line fit for the first five thermocouples shows a slight temperature increase with a moderate amount of variability. There are not enough points for an accurate regression or variability analysis on thermocouples 6 and 7 . The median temperature is $93^{\circ} \mathrm{F}$ with a minimum of $65^{\circ} \mathrm{F}$ and a maximum of $138^{\circ} \mathrm{F}$. Prior to 1984 and from mid-1985 to 1987, temperature was controlled by adding water. Refer to the supporting documents for a more thorough review of the temperature data (Brevick 1994).

\subsubsection{Integrity of Tank 241-C-105}

Tank 241-C-105 is categorized as sound and is partially isolated. The Tank 241-C-105 surface level is monitored with a Food Instrument corporation gauge through riser 8. A graphical representation of the surface level measurements from January 1991 to the present can be found in the supporting documents (Brevick, 1994). The surface level plot during the addition of cooling water indicates a decreasing trend with the readings ranging from 48.9 to $48.6 \mathrm{in.}$ (average 48.7 in.) during the first quarter of 1991 and steadily decreasing to 48.3 to $47.8-i n$. (average $48.1 \mathrm{in.)}$ during the second quarter of 1993 . Since the cooling water addition stopped, the surface level has ranged from 47.5 to 46.4 in. (average 46.9-in.).

Nine drywells are identified for tank 241-C-105. Graphical representations of the active drywells from January 1990 to the present can be found in the supporting documents (Brevick, 1994).

\subsubsection{Current Status of Tank 241-C-105}

Tank 241-C-105 entered service in February 1946 and currently stores 150,000 gal of waste. The waste is comprised of 54,000 gal of unknown waste; $96,000 \mathrm{gal}$ of sludge; no supernatant or saltcake with 4,000 gal of pumpable liquid remaining. The tank is identified as a 
low-heat load tank, is actively ventilated, and is categorized as sound with partial isolation completed. Tank 241-C-105 is equipped to cascade to Tank 241-C-106 and is first in the three-tank cascade series. The following plan view and tank cross section depict the approximate waste level and riser configuration. Tank 241-C-105 has 12 risers and $12-$ in. risers nos. 3 and no.7 are available for use.

7.5.2.1 Inventory estimate $241-\mathrm{C}-105$

The following tank layer volume approximation was derived from the Ios Alamos National Laboratories Waste Status and Transaction Record Summary (Agnew 1994). The estimated inventory of Tank 241-C-105 is also presented.

7.5.2.2 In-Tank Photograph 241- $\dot{\mathrm{C}}-105$

The Tank 241-C-105 photo shows a black supernatant surface and a sludge ring around the edge of the tank. There are approximately 3,000 gal of waste which measures almost $4.5 \mathrm{ft}$ deep. The haziness in the photo may be due to the film quality. The tank has had the supernatant pumped since the photo was taken.

7.5.3 Synopsis Tank 241-C-105

(To be completed.) 


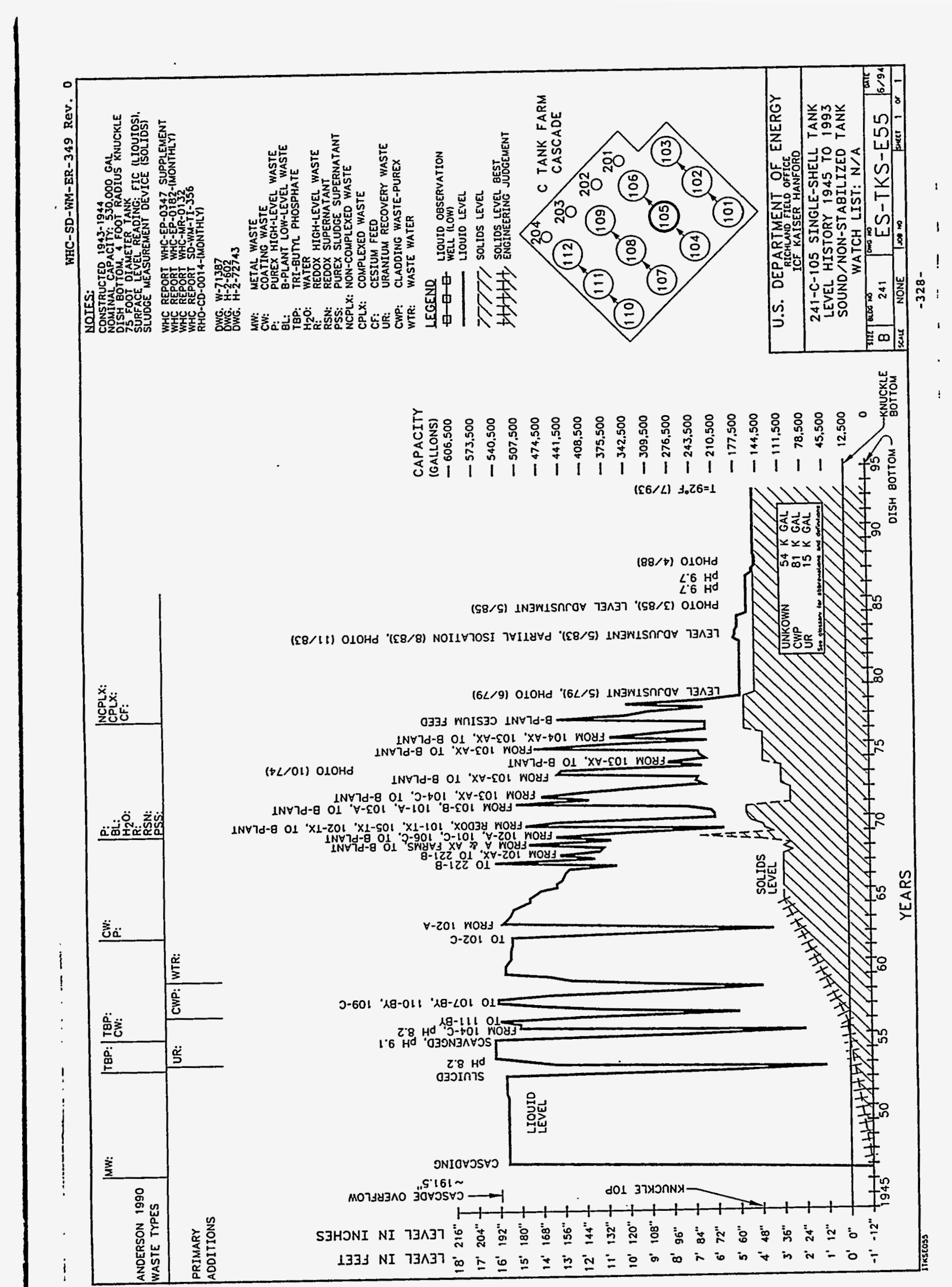


WHC-SD-WM-ER-349, Rev. 0

\begin{tabular}{|c|c|c|c|}
\hline \multicolumn{4}{|c|}{ Single-Shell Tank 241-C-105 } \\
\hline \multicolumn{4}{|c|}{ Solids Composite Inventory Estimale } \\
\hline \multicolumn{4}{|c|}{ 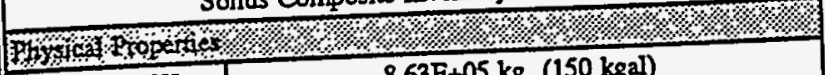 } \\
\hline Total Solid Waste & \multicolumn{3}{|c|}{$8.63 \mathrm{E}+05 \mathrm{~kg}(150 \mathrm{kgal})$} \\
\hline Heat load & \multicolumn{3}{|c|}{$4.31 \mathrm{E}-02 \mathrm{~kW}(1.47 \mathrm{E}+02 \mathrm{BTU} / \mathrm{hr})$} \\
\hline Bulk Density & \multicolumn{3}{|c|}{$1.52(g / c)$} \\
\hline Void Fraction & \multicolumn{3}{|c|}{0.64} \\
\hline Water wt\% & \multicolumn{3}{|c|}{51.49} \\
\hline TOC wt\% C (wet) & \multicolumn{3}{|c|}{0.00} \\
\hline \multicolumn{4}{|c|}{ TOC wt\% C (wet) } \\
\hline $\mathrm{Na}^{* 1}$ & 2.38 & $3.60 \mathrm{E}+04$ & $3.11 E+04$ \\
\hline $\mathrm{Al}^{+3}$ & 4.81 & $8.54 \mathrm{E}+04$ & $7.37 \mathrm{E}+04$ \\
\hline $\mathrm{Fe}^{\mathrm{C}^{33}}(\operatorname{cotal} \mathrm{Fe})$ & 6.00E-02 & $2.20 \mathrm{E}+03$ & $1.90 \mathrm{E}+03$ \\
\hline$C_{2}^{43}: a_{1}$ & $\therefore \quad 0$ & $\therefore 0$ & $\begin{array}{l} \\
\end{array}$ \\
\hline $\mathrm{Bi}^{+3}$ & of & 0 & 0 \\
\hline $\mathrm{La}^{+3}$ & of & 0 & 0 \\
\hline $\mathrm{Ce}^{43}$ & 0 & 0) & 0 \\
\hline $\mathrm{Zx}$ (as $\left.\mathrm{ZrO}(\mathrm{OH})_{2}\right)$ & 0 & 0 & 0 \\
\hline $\mathrm{Pb}^{+2}$ & 0 & 0 & 0 \\
\hline $\mathrm{Ni}^{+2}$ & 의 & 0 & 0 \\
\hline $\mathrm{Sr}^{42}$ & of & 0 & 0 \\
\hline $\mathrm{Mn}^{+\infty}$ & 요 & 0 & 0 \\
\hline $\mathrm{Ca}^{42}$ & 아 & 0 & 0 \\
\hline $\mathrm{K}^{+1}$ & 0 & 0 & 0 \\
\hline $\mathrm{OB}^{-2}$ & 14.90 & $1.67 \mathrm{E}+05$ & $1.44 \mathrm{E}+05$ \\
\hline $\mathrm{NO3}^{-1}$ & 0.45 & $1.83 E+04$ & $1.58 \mathrm{E}+04$ \\
\hline $\mathrm{NO}^{-1}$ & 0.37 & $1.12 \mathrm{E}+04$ & $9.64 \mathrm{E}+03$ \\
\hline $\mathrm{CO}^{.2}$ & $1.38 \mathrm{E}-02$ & $5.43 \mathrm{E}+02$ & $4.69 \mathrm{E}+02$ \\
\hline PO4.5 & 0.16 & $1.00 \mathrm{E}+04$ & $8.63 \mathrm{E}+03$ \\
\hline $\mathrm{SO}^{-2}$ & 0.26 & $1.63 \mathrm{E}+04$ & $1.41 \mathrm{E}+04$ \\
\hline $\mathrm{Si}\left(\mathrm{as} \mathrm{SiO}_{3}{ }^{-2}\right)$ & 0.13 & $2.46 E+03$ & $2.13 \mathrm{E}+03$ \\
\hline $\mathrm{F}^{-1}$ & 0 & 0 & 0 \\
\hline$\frac{\mathrm{C}^{-1}}{\mathrm{CH}}$ & 5.17E-04 & 12.05 & 10.41 \\
\hline$\frac{\mathrm{C}_{8} \mathrm{H}_{3} \mathrm{O}_{7}^{-3}}{\mathrm{EDTA}^{4}}$ & $\begin{array}{r}0 \\
0\end{array}$ & 0 & 0 \\
\hline $\begin{array}{l}\text { EDTA }^{-4} \\
\text { HEDTA }\end{array}$ & 0 & 이 & 0 \\
\hline $\mathrm{NTA}^{-3}$ & $\frac{0}{0}$ & 0 & 0 \\
\hline glycolute & 0 & 0 & 0 \\
\hline acetate ${ }^{-1}$ & \begin{tabular}{l|l}
0 & \\
0 &
\end{tabular} & 0 & 0 \\
\hline oxalate & 0 & of & 0 \\
\hline DBP & 0) & 0) & 0 \\
\hline NPH & 0 & 0 & 0 \\
\hline $\mathrm{CCl}_{4}$ & 0 & 0 & $\frac{0}{0}$ \\
\hline hexone & 인 & $\begin{array}{r}0 \\
0 \\
\end{array}$ & $\frac{0}{0}$ \\
\hline $\mathrm{Fe}(\mathrm{CN})_{6}^{-1}$ & 0 & 0 & 1) \\
\hline $\begin{array}{l}\mathrm{Pu} \text { olofor } \\
\mathrm{Pu}\end{array}$ & 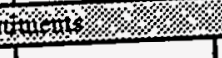 & $\% / \% / \%$ & \% \\
\hline \begin{tabular}{|l}
$\mathrm{Pu}$ \\
$\mathrm{U}$
\end{tabular} & & $1.44(\mu \mathrm{Ci} / \mathrm{g})$ & 3) $20.74\left(\mathrm{~kg}_{\mathrm{g}}\right)$ \\
\hline \begin{tabular}{|l|}
$\mathrm{U}$ \\
$\mathrm{Cs}$ \\
\end{tabular} & $3.26 \mathrm{E}-03(\mathrm{M})$ & $5.10 \mathrm{E}+02(1 \mathrm{~g} / \mathrm{g})$ & 3) $\frac{20.74(\mathrm{~kg})}{3)}$ \\
\hline \begin{tabular}{|l|} 
Cs \\
Sr \\
\end{tabular} & \begin{tabular}{|l|}
$1.69 \mathrm{E}-04(\mathrm{CiL})$ \\
$1.12 \mathrm{E}-02(\mathrm{Ci} / \mathrm{L})$ \\
\end{tabular} & $0.11(\mu \mathrm{Ci} / \mathrm{g})$ & g) $95.95(\mathrm{Ci})$ \\
\hline & $1.12 \mathrm{E}-02(\mathrm{Ci} / \mathrm{L})$ & $7.34(\mathrm{\mu Ci} / \mathrm{g})$ & 2) $6.33 \mathrm{E}+03(\mathrm{Ci})$ \\
\hline
\end{tabular}

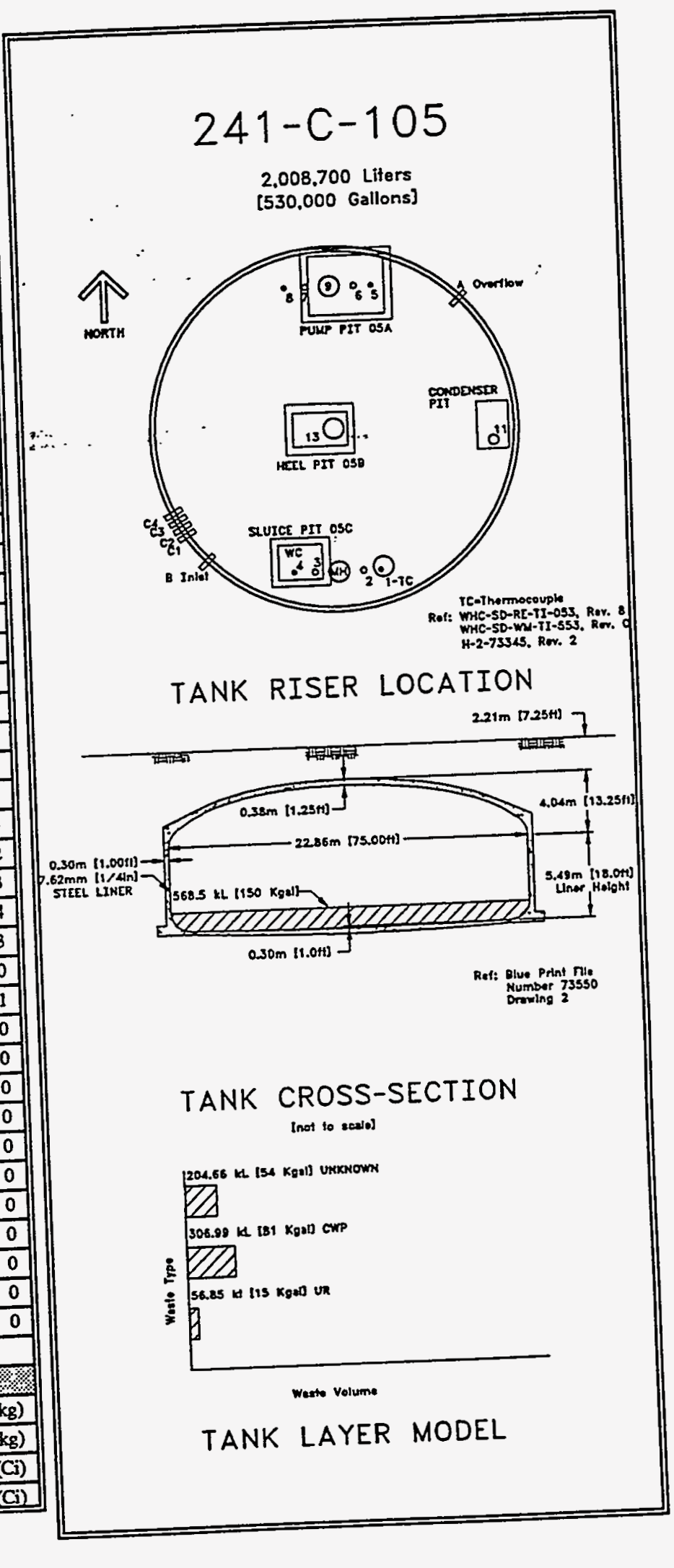




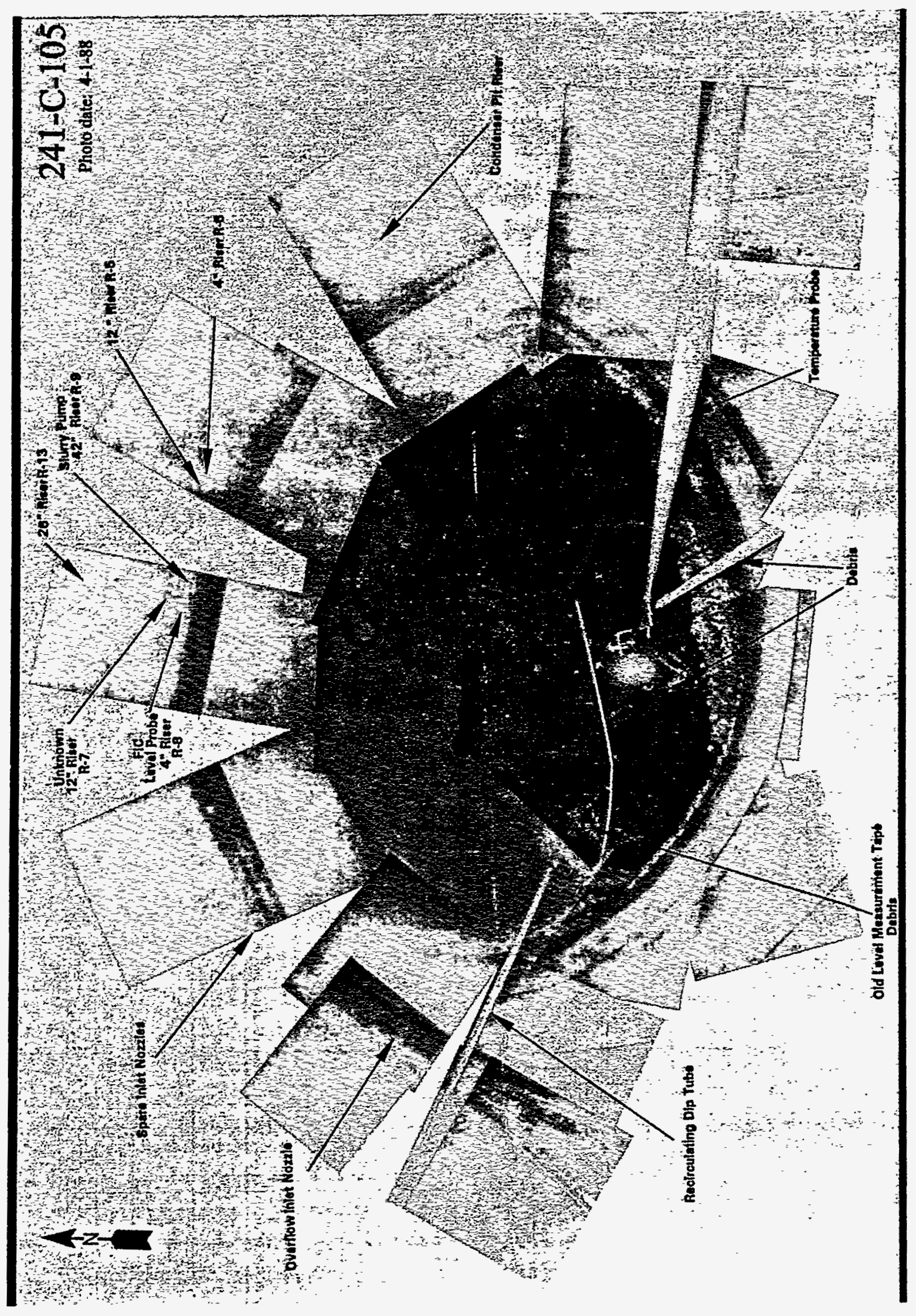




\subsection{Tank 241-C-106}

\section{6 .1 \\ 241-C-106 Tank History \\ 7.6.1.1 Waste History Tank 241-C-106}

Tank 241-C-106 was filled with metal waste from Tank 241-C-105 cascade in 1947. The tank was declared inactive in 1979. A level adjustment was made in April 1984. The tank was partially isolated in August 1983. Various level changes in the 1980 s can be explained by the water additions required to keep the tank temperature at a manageable level. The tank is considered nonstabilized. (See sketch ES-TKS-E56 for a graphical representation of the Tank 241-C-106 level history.)

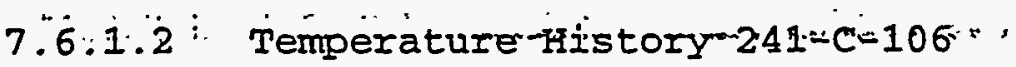

Tank 241-C-106 has two thermocouple trees: tree 1 has seven thermocouple probes and tree 2 has twelve thermocouple probes. The mean temperature of the first daily recorded readings was $103^{\circ} \mathrm{F}$ for tree 1 , and $108^{\circ} \mathrm{F}$ for tree 2 . A sum of the squares regression line fit shows a slight increase in temperature readings for tree 1 with moderate to large variability in the data. For tree 2, a sum of the squares regression line fit shows a temperature decline with a small amount of variability in the data. The median temperature in the tank is $100^{\circ} \mathrm{F}$ with a minimum of $47^{\circ} \mathrm{F}$ and a maximum of $199^{\circ} \mathrm{F}$. Refer to the supporting documents for a more thorough review of the temperature data (Brevick 1994).

\subsubsection{Integrity of Tank 241-C-106}

Tank 241-C-106 is categorized as sound and is partially isolated. The Tank 241-C-105 surface level is monitored with a Food Instrument corporation gauge through riser 1 . The figure graphically representing the surface level measurements from January 1991 to the present can be found in the Supporting Documents (Brevick 1994). The surface level graph has fluctuated throughout the past 3 years with the readings ranging from 78.9 to 74.25 in.

An occurrence report was issued in November 1990 because of a slow surface level increase to the 2 -in increase limit. The increase was preceeded by the exhauster failure and the Food Instrument corporation gauge failure.

Six drywells are identified for tank 241-C-106. Graphical representations of the active drywells from January 1990 to the present can be found in the supporting documents (Brevick, 1994).

\subsubsection{Current Status of Tank 241-C-106}

Tank 241-C-106 entered service in June 1947 and currently stores 229,000 gal of non-complexed waste. The waste is comprised of 32,000 gal of supernatant; 52,000 gal of unknown waste; 145,000 gal of sludge; no saltcake with 42,000 gal of pumpable liquid remaining. The tank was 
placed on the High-Heat Load Watch List in January 1991 and is actively ventilated. It is categorized as sound with partial isolation completed. Tank 241-C-106 is third in the three-tank cascade series. The following plan view and tank cross section depict the approximate waste level and riser configuration. Tank 241-C-106 has 15 risers and 12-in. risers nos. 3 and 7 are available for use.

\subsubsection{Inventory estimate 241-C-106}

The following tank layer volume approximation was derived from the Los Alamos National Laboratories Waste Status and Transaction Record Summary (Agnew 1994). The estimated inventory of Tank 241-C-106 is also presented.

\subsection{2:2 In-Tank Photograph 24I-C-106}

The Tank 241-C-106 photo shows a rust brown supernatant surface and possible sludge appearing through to the left and right of the distributor jet. The waste measures approximately 6 ft deep. The old float to the right is from a flex and float pump.

7.6.3 Synopsis Tank 241-C-106

(To be completed.) 


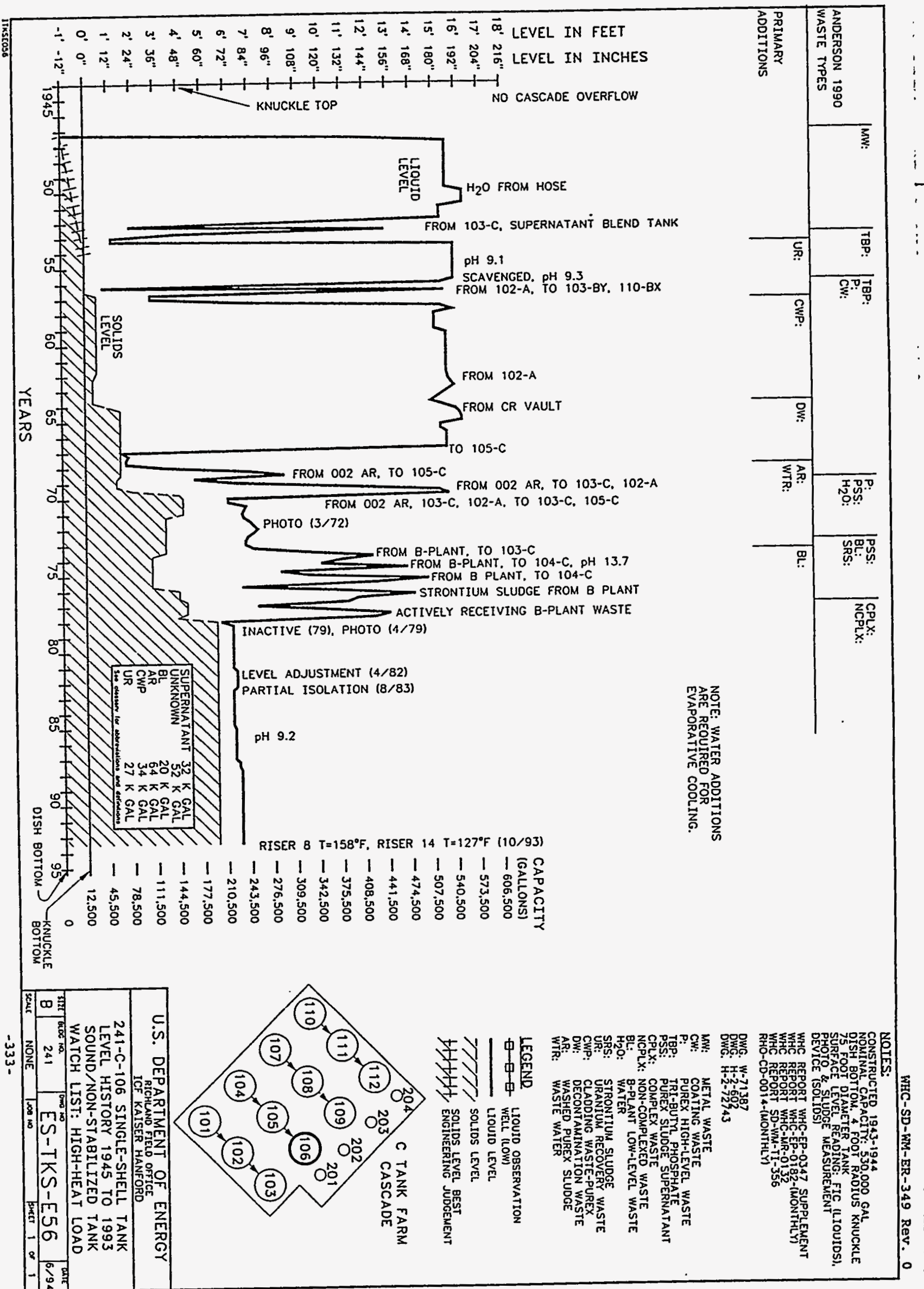


WHC-SD-WM-ER-349, Rev. 0

\begin{tabular}{|c|c|c|c|}
\hline \multicolumn{4}{|c|}{ Single-Shell Tank 241-C-106 } \\
\hline \multicolumn{4}{|c|}{ Solids Composite Inventory Estimate } \\
\hline \multicolumn{4}{|c|}{ 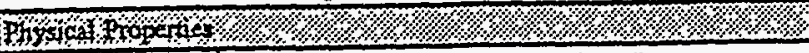 } \\
\hline Total Solid Waste & \multicolumn{3}{|c|}{$1.05 \mathrm{E}+06 \mathrm{~kg}(197 \mathrm{kgal})$} \\
\hline Heat load & \multicolumn{3}{|c|}{$35.05 \mathrm{~kW}(1.20 \mathrm{E}+05 \mathrm{BTU} / \mathrm{hr})$} \\
\hline Bulk Density & \multicolumn{3}{|c|}{$1.40(\mathrm{~g} / \mathrm{cc})$} \\
\hline Void Fraction & \multicolumn{3}{|c|}{0.72} \\
\hline Water wt\% & \multicolumn{3}{|c|}{52.73} \\
\hline TOC wt\% C (wet) & \multicolumn{3}{|c|}{0.07} \\
\hline \multicolumn{4}{|c|}{ 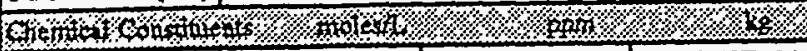 } \\
\hline $\mathrm{Na}^{+2}$ & 5.50 & $9.02 \mathrm{E}+04$ & $9.43 \mathrm{E}+04$ \\
\hline $\mathrm{Al}^{+3}$ & 1.33 & $2.55 \mathrm{E}+04$ & $2.67 \mathrm{E}+04$ \\
\hline $\mathrm{Fe}^{+3}$ (tolal $\left.\mathrm{Fe}\right)$ & 1.02 & $4.05 \mathrm{E}+04$ & $4.24 \mathrm{E}+04$ \\
\hline $\mathrm{Cr}^{+3}$ & 3.45E-08 & $1.28 \mathrm{E}-03$ & $\because \cdots 1.34 \mathrm{E} 03$ \\
\hline $\mathrm{Bi}^{+3}$ & 0 & 0 & $\begin{array}{r}0 \\
\end{array}$ \\
\hline $\mathrm{La}^{43}$ & 여 & of & 0 \\
\hline $\mathrm{Ce}^{+3}$ & of & of & 0 \\
\hline $\mathrm{Zr}$ (as $\left.\mathrm{ZrO}(\mathrm{OH})_{2}\right)$ & 0 & 0 & 0 \\
\hline $\mathrm{Pb}^{+3}$ & 0 & 0 & 0 \\
\hline $\mathrm{Ni}^{+2}$ & $4.76 \mathrm{E}-02$ & $1.99 \mathrm{E}+03$ & $2.08 E+03$ \\
\hline $\mathrm{Sr}^{\circ 2}$ & 0 & 0 & 0 \\
\hline $\mathrm{Mn}^{+4}$ & of & 0 & 0 \\
\hline $\mathrm{Ca}^{42}$ & 0 & 0) & 0 \\
\hline $\mathrm{R}^{+1}$ & 0 & 0 & 0 \\
\hline $\mathrm{OH}^{13}$ & 7.32 & $8.87 \mathrm{E}+04$ & $9.28 \mathrm{E}+04$ \\
\hline $\mathrm{NO}^{-1}$ & 0.67 & $2.94 \mathrm{E}+04$ & $3.07 \mathrm{E}+04$ \\
\hline $\mathrm{NO}^{-1}$ & $9.67 \mathrm{E}-02$ & $3.17 \mathrm{E}+03$ & $3.32 \mathrm{E}+03$ \\
\hline $\mathrm{CO}^{.2}$ & 0.11 & $4.50 \mathrm{E}+03$ & $4.71 \mathrm{E}+03$ \\
\hline $\mathrm{PO}^{.3}$ & 0.23 & $1.55 \mathrm{E}+04$ & $1.62 E+04$ \\
\hline $\mathrm{SO}^{-2}$ & 0.41 & $2.84 \mathrm{E}+04$ & $2.97 \mathrm{E}+04$ \\
\hline $\mathrm{Si}$ (as $\mathrm{SiO}_{3}^{-2}$ ) & 1.42 & $2.85 \mathrm{E}+04$ & $2.98 \mathrm{E}+04$ \\
\hline $\bar{F}^{-1}$ & of & 0 & 0 \\
\hline$a^{-1}$ & $7.09 \mathrm{E}-04$ & 17.91 & 18.73 \\
\hline $\mathrm{C}_{6} \mathrm{H}_{5} \mathrm{O}_{7}{ }^{3}$ & $2.59 \mathrm{E}-03$ & $3.48 \mathrm{E}+02$ & $3.64 E+02$ \\
\hline EDTA ${ }^{-1}$ & 0 & 0 & 0 \\
\hline HEDTA $^{-3}$ & 0 & of & 0 \\
\hline NTA $^{3}$ & 0 & 0 & 0 \\
\hline Blycolare $e^{-1}$ & $3.45 \mathrm{E}-02$ & $1.84 \mathrm{E}+03$ & $1.93 \mathrm{E}+03$ \\
\hline acelare & 0 & 0 & 0 \\
\hline oxalate & 요 & 의 & 0 \\
\hline DBP & 0 & of & 0 \\
\hline NPE & 0) & 0) & 0 \\
\hline $\mathrm{CCl}_{4}$ & a) & of & $\underline{0}$ \\
\hline hexone & of & 0 & 0 \\
\hline $\mathrm{Fe}(\mathrm{CN})_{6}^{-1}$ & 0] & $0(\mathrm{~g}-\mathrm{mol})$ & \\
\hline \multicolumn{4}{|c|}{ 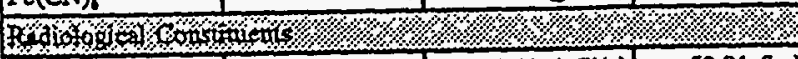 } \\
\hline Pu & & $3.03\left(1 \mathrm{C} \mathrm{Ci}_{\mathrm{B}}\right)$ & $52.81(\mathrm{~kg})$ \\
\hline $\mathrm{U}$ & $1.08 \mathrm{E}-02(\mathrm{M})$ & $1.84 \mathrm{E}+03(\mu \mathrm{g} / \mathrm{g})$ & $1.93 \mathrm{E}+03(\mathrm{~kg})$ \\
\hline Cs & $0.13(\mathrm{C} / 2)$ & $91.12(\mu \mathrm{Ci} / \mathrm{B})$ & $9.53 \mathrm{E}+04(\mathrm{Ci})$ \\
\hline $\mathrm{Sr}$ & $6.88(\mathrm{Ci} / \mathrm{L})$ & $4.91 \mathrm{E}+03(1 \mathrm{Ci} / \mathrm{g})$ & $5.13 \mathrm{E}+06(\mathrm{C})$ \\
\hline
\end{tabular}

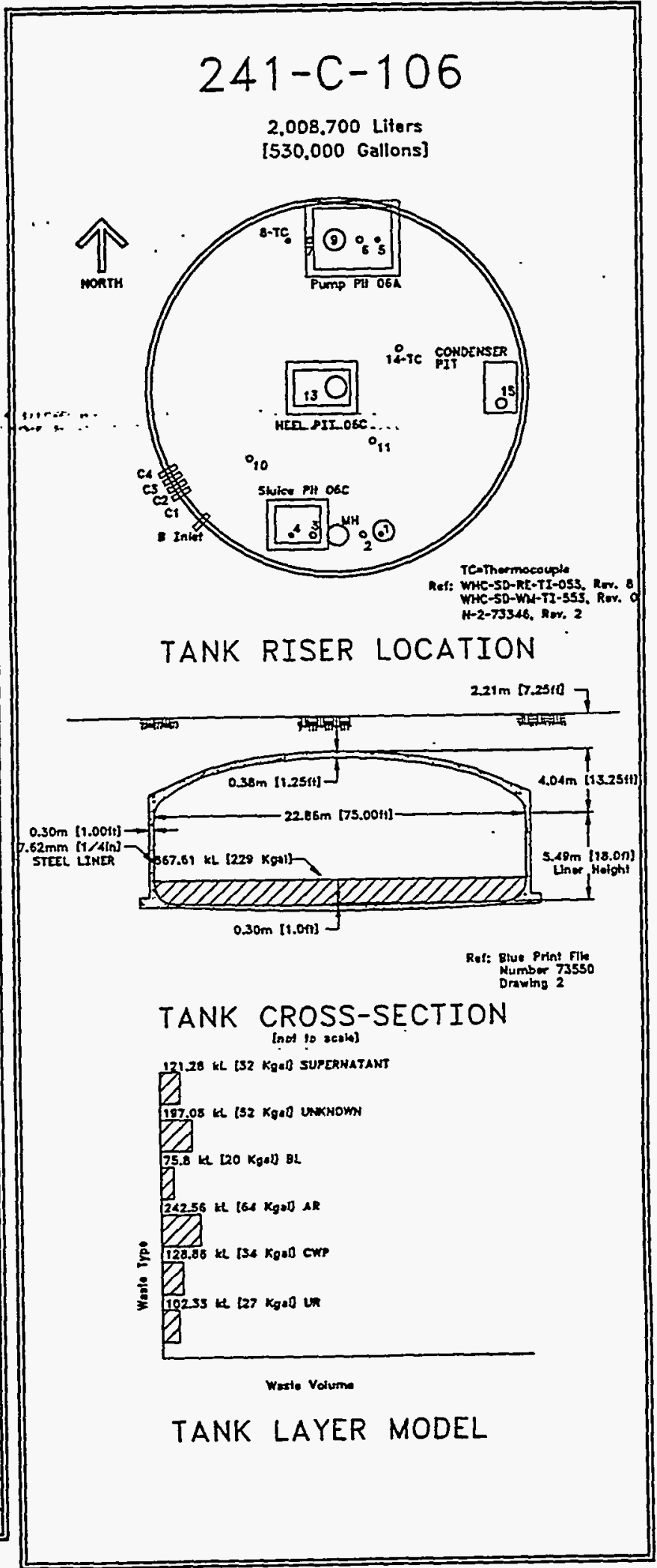

- Comporite investory excluder supernatant, diatomaceous earth, and cemeon 
WHC-SD-WM-ER-349 ReV. 0
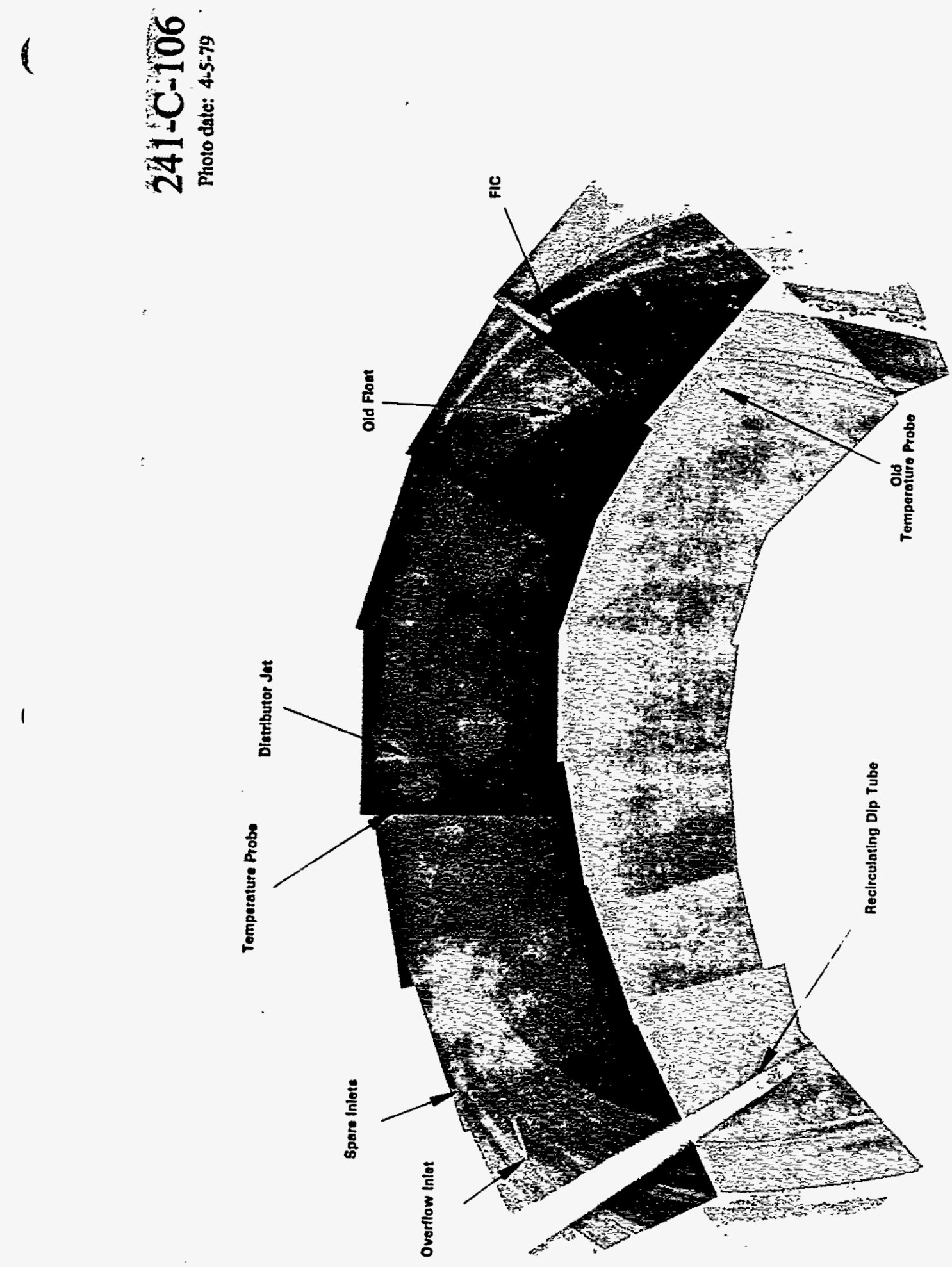
WHC-SD-WM-ER-349, Rev. 0

7.7 Tank 241-C-107

\section{$7.7 .1241-C-107$ Tank History}

7.7.1.1 Waste History Tank 241-C-107

Tank 241-C-107 was filled with first-cycle waste from April 1946 to September 1947. The tank was declared inactive in 1978 and a level adjustment was made in 1979. . Partial.isolation was completed in December 1982. Ievel adjustments were made in July 1978 and January 1992. The tank is awaiting stabilization. (See sketch ES-TKS-E57 for a graphical representation of the Tank 241-C-107 level history.)

7.7.1.2. Temperature History. 241-C-107.

The single thermocouple tree in Tank 241-C-107 has seven thermocouple probes. The mean temperature of the first recorded data for thermocouples 1 through 6 was $142^{\circ} \mathrm{F}$. A sum of the squares regression line fit for these probes shows a slight decrease in temperature with a moderate amount of variability in the data. There is not enough information on probe 7 to achieve an accurate regression or variability analysis. The median temperature is $118^{\circ} \mathrm{F}$ with a minimum of $100^{\circ} \mathrm{F}$ and a maximum of $168^{\circ} \mathrm{F}$. Refer to the supporting documents for a more thorough review of the temperature data (Brevick 1994).

\subsubsection{Integrity of Tank 241-C-107}

Tank 241-C-107 is categorized as sound and is partially isolated. The Tank 241-C-107 surface level is monitored with a Food Instrument Corporation gauge through riser 8. A graphical representation of the surface level measurements from January 1991 to the present can be found in the supporting documents (Brevick, 1994). The Food Instrument Corporation gauge is out of service and the surface level monitoring is out of compliance as of June 1993.

Seven drywells are identified for tank 241-C-107: Graphical representations of the active drywells from January 1990 to the present can be found in the supporting documents (Brevick, 1994).

An occurrence report was issued in August 1992 due to radiation increase in Drywell 30-07-11. The increase was due to radioactive waste contained within the 110-C saltwell transfer line. Flushing the line returned the drywell readings to pre-event levels.

7.7.2 Current status of Tank 241-C-107

Tank 241-C-107 entered service in April 1946 and currently stores $275,000 \mathrm{gal}$ of dilute complex waste. The waste is comprised of 21,000 gal of unknown waste; 254,000 gal of sludge; no supernatant of saltcake, with $20,000 \mathrm{gal}$ of pumpable liquid remaining. The tank is identified as a low-heat load tank, is passively ventilated, and is categorized as sound with partial isolation completed. Tank 241-C-107 is equipped to cascade to Tank 241-C-108 and is first in the three-tank cascade series. 
The following plan view and tank cross section depict the approximate waste level and riser configuration. Tank 241-C-107 has 9 risers and 12-in. risers nos. 2, 3, and 7 are available for use.

7.7.2.1 Inventory estimate 241-C-107

The following tank layer volume approximation was derived from the Ios Alamos National Laboratories Waste Status and Transaction Record Summary (Agnew 1994). The estimated inventory of Tank 241-C-107 is also presented.

7.7.2.2 In-Tank Photograph 241-C-107

No. Photograph. is. currently available for Tank .241-C-107.

7.7.3 Synopsis Tank 241-C-107

(To be completed.) 
$-8 \varepsilon \varepsilon-$

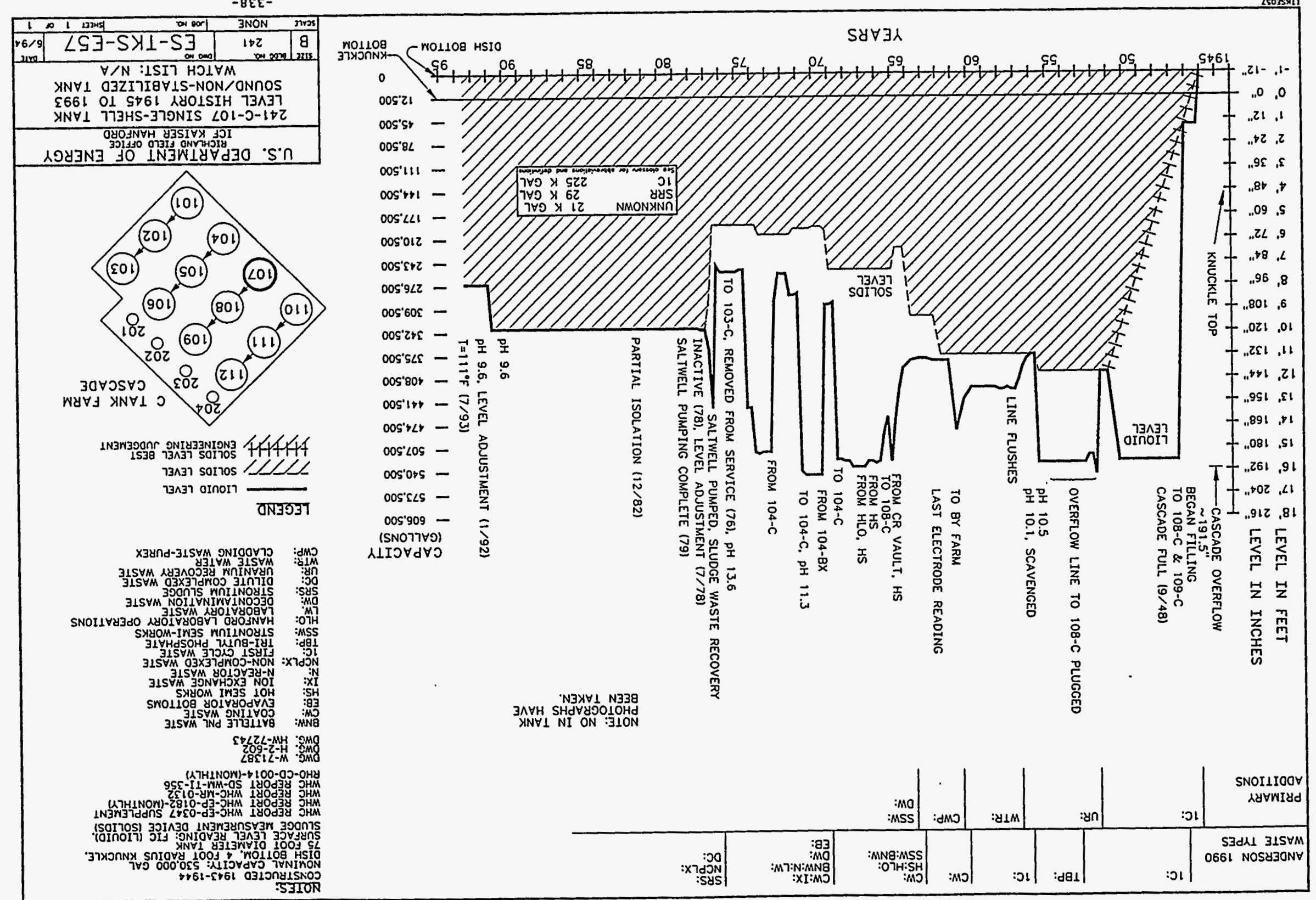




\begin{tabular}{|c|c|c|c|}
\hline \multicolumn{4}{|c|}{ Single-Shell Tank 241-C-107 } \\
\hline \multicolumn{4}{|c|}{ Solids Composite Inventory Estimate } \\
\hline 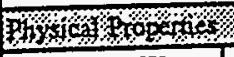 & \%\% \% \% & $\% \% \% \%$ & \\
\hline Total Solid Waste & \multicolumn{3}{|c|}{$1.38 \mathrm{E}+06 \mathrm{~kg}(275 \mathrm{kgal})$} \\
\hline Heat load & \multicolumn{3}{|c|}{$5.59 \mathrm{~kW}(1.91 \mathrm{E}+04 \mathrm{BTU} / \mathrm{hr})$} \\
\hline Bulk Density & \multicolumn{3}{|c|}{$1.33(\mathrm{~g} / \infty)$} \\
\hline Void Fraction & \multicolumn{3}{|c|}{0.62} \\
\hline \begin{tabular}{|l|} 
Water wis \\
\end{tabular} & \multicolumn{3}{|c|}{68.54} \\
\hline TOC wt\% C (wet) & \multicolumn{3}{|c|}{0.46} \\
\hline \multicolumn{4}{|c|}{ Ged } \\
\hline $\mathrm{Na}^{+1}$ & 5.84 & $1.01 E+05$ & $1.40 \mathrm{E}+05$ \\
\hline $\mathrm{Al}^{+3}$ & 0.27 & $5.45 \mathrm{E}+03$ & $7.54 \mathrm{E}+03$ \\
\hline $\mathrm{Fe}^{43}($ total Fe $)$ & 0.28 & $1.19 \mathrm{E}+04$ & $1.64 \mathrm{E}+04$ \\
\hline $\mathrm{Cr}^{+3}$ & $1.31 \mathrm{E}-02$ & 5.11E+02. & $\cdots 7.07 \mathrm{E}+02$ \\
\hline $\mathrm{Bi}^{+3}$ & 9.14E-02 & $1.44 \mathrm{E}+04$ & $1.99 \mathrm{E}+04$ \\
\hline $\mathrm{La}^{43}$ & 0 & 0 & 0 \\
\hline $\mathrm{Ce}^{43}$ & 0 & 0 & 0 \\
\hline $\mathrm{Zr}$ (as $\mathrm{ZrO}\left(\mathrm{OH}_{2}\right)$ & 2.61E-02 & $1.79 \mathrm{E}+03$ & $2.48 \mathrm{E}+03$ \\
\hline $\mathrm{Pb}^{+2}$ & 0 & o & 0 \\
\hline $\mathrm{Ni}^{+2}$ & 0 & 0 & 0 \\
\hline $\mathrm{Sr}^{42}$ & 0 & 0 & 0 \\
\hline $\mathrm{Mn}$ & 0 & 0 & 0 \\
\hline $\mathrm{Ca}^{+2}$ & 0 & 0 & 0 \\
\hline $\mathrm{R}^{+1}$ & 0 & 0 & 0 \\
\hline $\mathrm{OH}^{\cdot 2}$ & 1.65 & $2.11 \mathrm{E}+04$ & $2.92 \mathrm{E}+04$ \\
\hline $\mathrm{NO}^{-1}$ & 0.15 & $7.02 \mathrm{E}+03$ & $9.71 E+03$ \\
\hline $\mathrm{NO}^{-1}$ & $9.64 \mathrm{E}-02$ & $3.34 \mathrm{E}+03$ & $4.62 E+03$ \\
\hline $\mathrm{CO}^{-2}$ & 2.37E-02 & $1.07 \mathrm{E}+03$ & $1.48 \mathrm{E}+03$ \\
\hline $\mathrm{PO}^{-3}$ & 1.58 & $1.13 E+05$ & $1.57 \mathrm{E}+05$ \\
\hline $504^{-2}$ & $4.29 \mathrm{E}-02$ & $3.10 \mathrm{E}+03$ & $4.29 \mathrm{E}+03$ \\
\hline $\mathrm{Si}$ (as $\mathrm{SiO}_{3}{ }^{-2}$ ) & 0.42 & $8.81 \mathrm{E}+03$ & $1.22 \mathrm{E}+04$ \\
\hline $\mathrm{F}^{-1}$ & 0.13 & $1.81 E+03$ & $2.50 \mathrm{E}+03$ \\
\hline$a^{-1}$ & 0 & o & 0 \\
\hline $\mathrm{C}_{6} \mathrm{H}_{5} \mathrm{O}_{7}^{-3}$ & 0 & 0 & 0 \\
\hline $\mathrm{EDTA}^{4}$ & $1.42 \mathrm{E}-02$ & $3.08 \mathrm{E}+03$ & $4.27 \mathrm{E}+03$ \\
\hline HEDTA $^{-3}$ & 2.84E-02 & $5.87 \mathrm{E}+03$ & $8.12 \mathrm{E}+03$ \\
\hline NTA $^{3}$ & 0 & 0 & 0 \\
\hline glycolate & $2.84 \mathrm{E}-02$ & $1.61 E+03$ & $2.22 \mathrm{E}+03$ \\
\hline acetate ${ }^{-1}$ & o & 0 & 0 \\
\hline oxalate $e^{-2}$ & of & 0 & 0 \\
\hline DBP & 0 & 요 & 0 \\
\hline NPH & of & 요 & 0 \\
\hline $\mathrm{CCl}_{4}$ & 0 & 요 & 0 \\
\hline hexone & 0 & 0 & 0 \\
\hline $\mathrm{Fe}(\mathrm{CN})_{6}{ }^{-1}$ & 01 & $0(\mathrm{~g}-\mathrm{mol})$ & \\
\hline \begin{tabular}{|l}
$\mathrm{Pu}$ \\
$\mathrm{U}$ \\
\end{tabular} & & $0.30(\mu \mathrm{Ci} / \mathrm{g})$ & $6.96(\mathrm{~kg})$ \\
\hline \begin{tabular}{|l|}
$\mathrm{U}$ \\
\end{tabular} & \begin{tabular}{r|}
$0(M)$ \\
$3.11 E-02(C i / L)$ \\
\end{tabular} & $0(1 \mu / 8)$ & $0(\mathrm{~kg})$ \\
\hline $\begin{array}{l}\text { Cs } \\
\mathrm{Sr} \\
\end{array}$ & \begin{tabular}{|r|}
$3.11 \mathrm{E}-02(\mathrm{Ci} / \mathrm{L})$ \\
$0.77(\mathrm{Ci} / \mathrm{L})$ \\
\end{tabular} & $23.42(\mu \mathrm{CJ} / \mathrm{g})$ & $3.24 \mathrm{E}+04(\mathrm{Ci})$ \\
\hline - $C_{0}$ & $0.77(\mathrm{Ci} / \mathrm{L})$ & 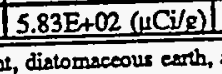 & $8.06 \mathrm{E}_{+} 05(\mathrm{Ci})$ \\
\hline
\end{tabular}

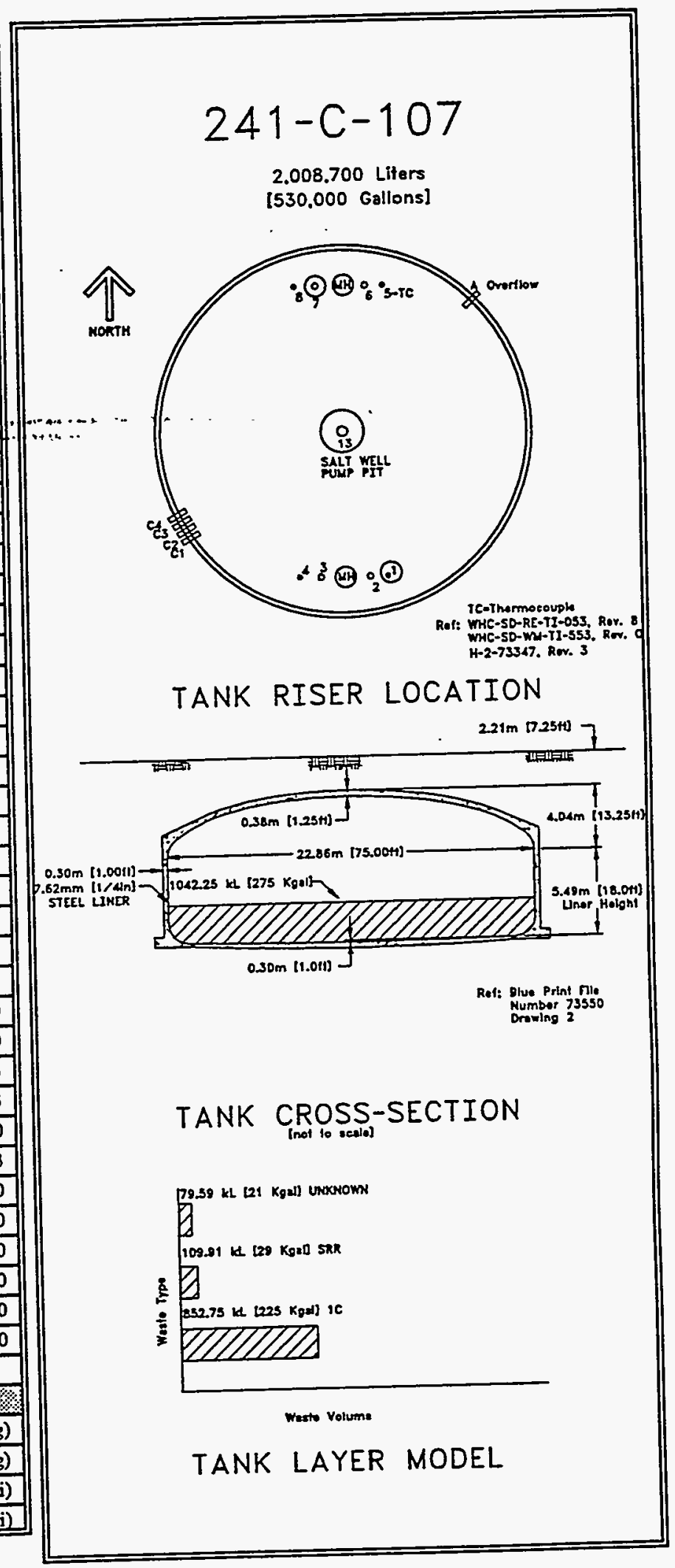


WHC-SD-WM-ER-349, Rev. 0 No Photograph is currently available for Tank 241-C-107. $*$ 
WHC-SD-WM-ER-349, Rev. 0

7.8 Tank 241-C-108

7.8.1 241-C-108 Tank History

7.8.1.1 Waste History Tank 241-C-108

Tank 241-C-108 was filled with Tank 241-C-107 cascade overflow and first-cycle waste from september 1947 to March 1948 and again in 1952 . The tank was removed from service: in the first quarter of 1976. Saltwell pumping began in 1976 and was completed in 1978. The tank was declared inactive in late 1977. Intrusion prevention was complete by December 1982. A level adjustment was made in February 1984 and interim stabilization was completed administratively in March 1984. (See sketch ES-TKS-E58. for previous.. figures. and,ax.graphical. representation of the Tank 24I-C-108" 'évè "history.j'

\subsubsection{Temperature History 241-C-108}

The single thermocouple tree in Tank 241-C-108 has 16 thermocouple probes to record temperature data. The mean temperature of the first recorded data for thermocouples 1 through 11 was $81^{\circ} \mathrm{F}$. A sum of the squares regression line fit over the first 12 probes shows a slight temperature decrease with a small amount of variability. There are not enough points for an accurate regression analysis on thermocouples 13 to 16. The median temperature is $74^{\circ} \mathrm{F}$ with a minimum of $63^{\circ} \mathrm{F}$ and a maximum of $91^{\circ} \mathrm{F}$. Refer to the supporting documents for a more thorough review of the temperature data (Brevick 1994).

\subsubsection{Integrity of Tank 241-C-108}

Tank 241-C-108 is categorized as sound and is interim stabilized with intrusion prevention completed. The surface level in Tank 241-C-108 is monitored quarterly with a manual tape through riser 1. Liquid waste volume is determined by a manual tape surface level gauge, and solid waste volume is determined by.. a sludge level measurement device. A graphical representation of the surface level measurements from January 1991 to the present can be found in the supporting documents (Brevick, 1994). The surface level graph shows fluctuation with the readings ranging from 13.25 to 20 in.

An occurrence report was issued in 1974 due to increasing activity in dry well 30-08-02. The activity was attributed to lateral movement of existing contamination.

Three drywells are identified for tank 241-C-108. A graphical representation of the arywell data for the active drywell from January 1990 to the present can be found in the supporting documents (Brevick, 1994).

\subsubsection{Current Status of Tank 241-C-108}

Tank 241-C-108 entered service in september 1947 and currently stores 66,000 gal of non-complex waste. The waste is comprised entirely 
of sludge with no of pumpable liquid remaining. The tank has been on the Ferrocyanide Watch List since January 1991 and is passively ventilated. It is categorized as sound with interim stabilization and intrusion prevention completed. Tank $241-C-108$ is equipped to cascade to Tank 241-C-109 and is second in the three-tank cascade series. The following plan view and tank cross section depict the approximate waste level and riser configuration. Tank 241-C-108 has 9 risers and four ...re available for use: one 4-in. riser (no.8) and three 12-in. risers (nos.3, 6, and 7).

\subsubsection{Inventory estimate 241-C-108}

The following tank layer volume approximation was derived from the Los Alamós. Nationalu: Laboratories" -Waste."Status" and. Transaction Record Summary (Agnew 1994). The estimated inventory of Tank 241-C-108 is also presented.

7.8.2.2 In-Tank Photograph 241-C-108

No information is currently available.

7.8.3 Synopsis Tank 241-C-108

(To be completed.) 


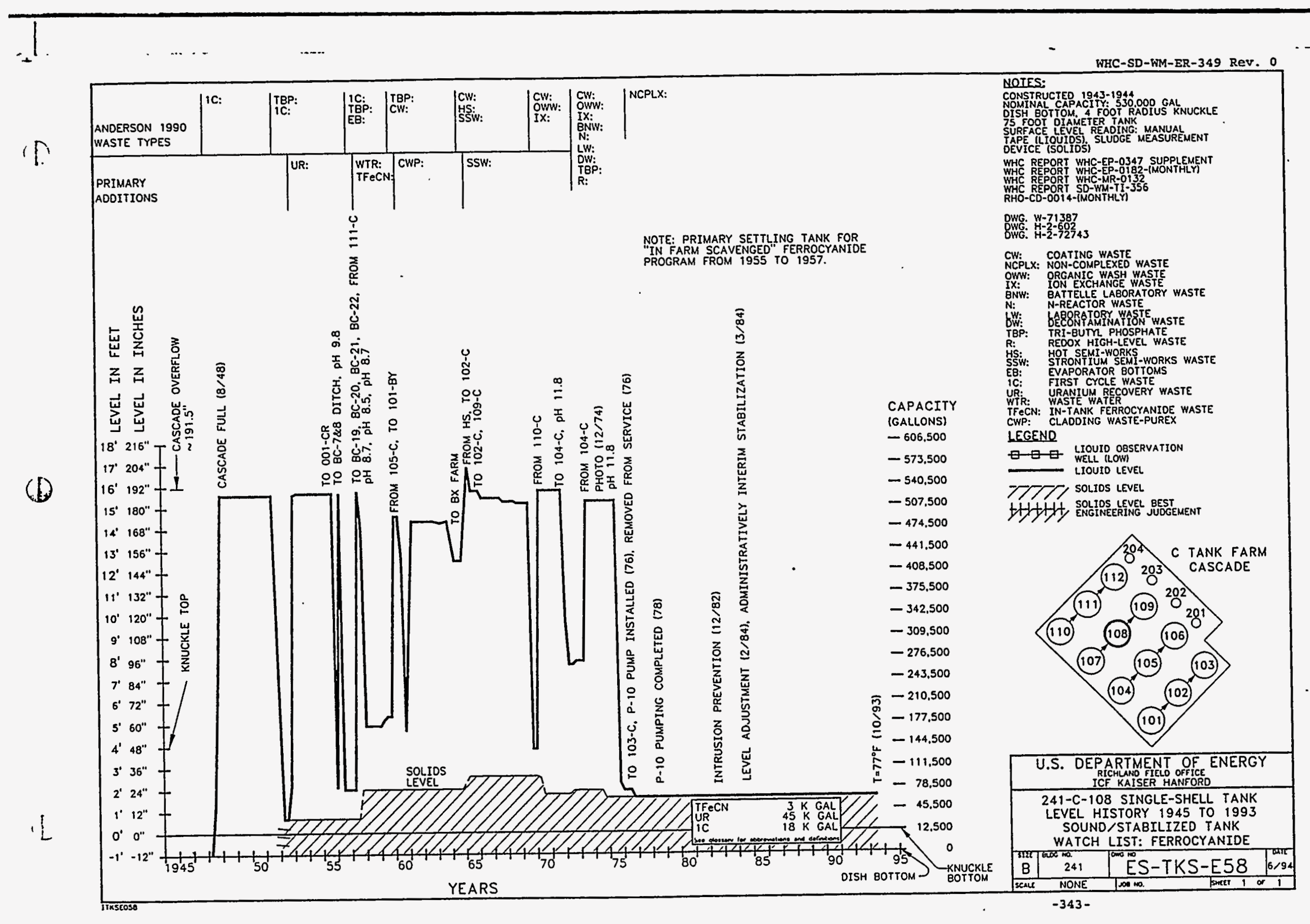




\begin{tabular}{|c|c|c|c|}
\hline \multicolumn{4}{|c|}{ Single-Shell Tank 241-C-108 } \\
\hline \multicolumn{4}{|c|}{ Solids Composite Inventory Estimate } \\
\hline 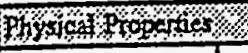 & \%/. & \% & \\
\hline Totsl Solid Warte & \multicolumn{3}{|c|}{$3.91 \mathrm{E}+05 \mathrm{~kg}(66 \mathrm{kgal})$} \\
\hline \begin{tabular}{|l|l|} 
Heat losd \\
\end{tabular} & \multicolumn{3}{|c|}{$0.23 \mathrm{~kW}(7.82 \mathrm{E}+02 \mathrm{BTU} / \mathrm{hr})$} \\
\hline Bulk Density & \multicolumn{3}{|c|}{$1.57(g / \propto)$} \\
\hline Void Fraction & \multicolumn{3}{|c|}{0.35} \\
\hline Water wr\% & \multicolumn{3}{|c|}{29.69} \\
\hline TOC wh\% C (wet) & \multicolumn{3}{|c|}{$\begin{array}{|ll|}0.09 & \cdot \\
\end{array}$} \\
\hline \multicolumn{4}{|c|}{ 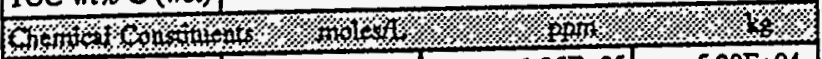 } \\
\hline \begin{tabular}{|l|}
$\mathrm{Na}^{+1}$ \\
\end{tabular} & 9.21 & $1.35 \mathrm{E}+05$ & $5.29 \mathrm{E}+04$ \\
\hline $\mathrm{Al}^{+3}$ & $8.18 \mathrm{E}-02$ & $1.41 E+03$ & $5.51 E+02$ \\
\hline $\mathrm{Fe}^{43}$ (cotal Fe) & 0.49 & $1.73 \mathrm{E}+04$ & $6.77 \mathrm{E}+03$ \\
\hline $\mathrm{Cr}^{3}$ & $3.98 \mathrm{E}-03$ & $13^{2} \cdots 1.32 \mathrm{EFAO2}$ & $\therefore 2 \ldots .151 .32$ \\
\hline $\mathrm{Bi}^{+3}$ & $2.79 \mathrm{E}-02$ & $3.72 \mathrm{E}+03$ & $1.45 E+03$ \\
\hline $\mathrm{La}^{\mathbf{3}}$ & - & o & 0 \\
\hline $\mathrm{Ce}^{+3}$ & of & of & 0 \\
\hline $\mathrm{Zx}$ (as $\left.\mathrm{ZrO}(\mathrm{OH})_{2}\right)$ & 7.96E-03 & $4.64 \mathrm{E}+02$ & $1.81 \mathrm{E}+02$ \\
\hline $\mathrm{Pb}^{42}$ & of & 0 & 0 \\
\hline $\mathrm{Ni}^{+2}$ & 3.25E-02 & $1.22 \mathrm{E}+03$ & $4.26 \mathrm{E}+02$ \\
\hline$S r^{42}$ & 0 & 0 & 0 \\
\hline $\mathrm{Mn}^{+4}$ & 0. & of & 0 \\
\hline $\mathrm{Ca}^{42}$ & of & 0 & 0 \\
\hline $\mathrm{K}^{\circ 1}$ & 0 & 0 & 0 \\
\hline $\mathrm{OH}^{\cdot 1}$ & 1.78 & $1.93 \mathrm{E}+04$ & $7.54 \mathrm{E}+03$ \\
\hline $\mathrm{NO}^{-1}$ & 0.64 & $2.53 \mathrm{E}+04$ & $9.88 \mathrm{E}+03$ \\
\hline $\mathrm{NO2}^{-1}$ & $3.70 \mathrm{E}-02$ & $1.09 \mathrm{E}+03$ & $4.26 \mathrm{E}+02$ \\
\hline $\mathrm{CO}^{-2}$ & 9.38E-02 & $3.59 \mathrm{E}+03$ & $1.41 E+03$ \\
\hline $\mathrm{PO}^{-3}$ & 1.58 & $9.58 \mathrm{E}+04$ & $3.75 \mathrm{E}+04$ \\
\hline $\mathrm{SO}^{2}$ & 1.77 & $1.09 \mathrm{E}+05$ & $4.26 \mathrm{E}+04$ \\
\hline $\mathrm{Si}\left(\right.$ as $\left.\mathrm{SiO}_{3}^{-2}\right)$ & $7.56 \mathrm{E}-02$ & $1.36 \mathrm{E}+03$ & $5.31 \mathrm{E}+02$ \\
\hline $\mathrm{F}^{-1}$ & $3.85 \mathrm{E}-02$ & 4.67E+02 & $1.83 E+02$ \\
\hline $\mathrm{Cl}^{-1}$ & $3.53 \mathrm{E}-03$ & 79.81 & 31.22 \\
\hline $\mathrm{C}_{6} \mathrm{H}_{3} \mathrm{O}_{7}^{-3}$ & o & o & 0 \\
\hline EDTA $^{-1}$ & 0 & 0 & 0 \\
\hline HEDTA ${ }^{-3}$ & of & 0 & 0 \\
\hline $\mathrm{NTA}^{.3}$ & 0 & 0 & 0 \\
\hline glycolute & of & 아 & 0 \\
\hline acetate ${ }^{-1}$ & of & 0 & 0 \\
\hline oxalste & of & 0 & 0 \\
\hline DBP & 0 & 0 & 0 \\
\hline NPH & 0 & of & 0 \\
\hline $\mathrm{CCl}_{2}$ & 0 & of & 0 \\
\hline hexone & 0 & o & 0 \\
\hline $\mathrm{Fe}(\mathrm{CN})_{6}{ }^{4}$ & $1.62 \mathrm{E}-02$ & $4.05 \mathrm{E}+03(8-\mathrm{mol})$ & \\
\hline \multicolumn{4}{|c|}{ 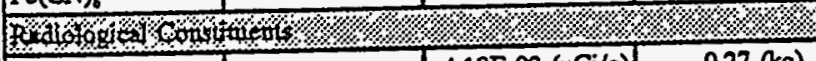 } \\
\hline \begin{tabular}{|l|l}
$\mathbf{P u}$ \\
\end{tabular} & & $4.18 \mathrm{E}-02(\mu \mathrm{Ci} / \mathrm{g})$ & $0.27(\mathrm{~kg})$ \\
\hline $\mathrm{U}$ & 2.22E-02 (M) & $3.38 \mathrm{E}+03(\mu \mathrm{g} / \mathrm{g})$ & $1.32 \mathrm{E}+03(\mathrm{~kg})$ \\
\hline Cs & $8.26 \mathrm{E}-02(\mathrm{Ci} / \mathrm{L})$ & $52.73(\mathrm{uCi} / \mathrm{g})$ & $2.06 \mathrm{E}+04(\mathrm{Ci})$ \\
\hline$S_{r}$ & $7.86 \mathrm{E}-02(\mathrm{Ci} / \mathrm{L})$ & $50.22(\mu \mathrm{Ci} / \mathrm{g})$ & $1.96 \mathrm{E}+04(\mathrm{Ci})$ \\
\hline
\end{tabular}

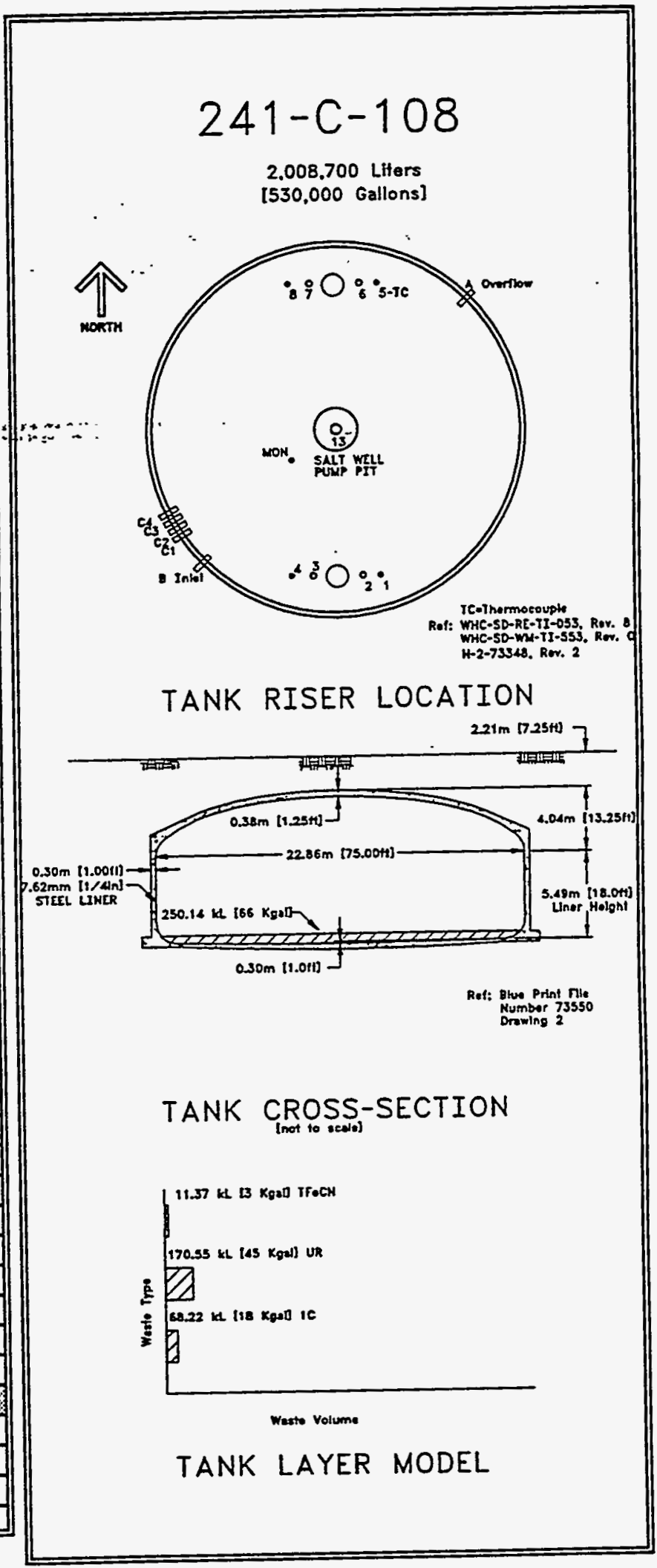


WHC-SD-WM-ER-349, ReV . 0

No Photograph is currently available for Tank 241-C-108. 
7.9.1 241-C-109 Tank History

7.9.1.1 Waste History Tank 241-C-109

From April 1948 to September 1948 and again in 1953, Tank 241-C-109 was filled via the Tank 241-C-108 cascade line with Eirst-cycle waste that remained in the tank until the third quarter of 1952. In 1976, the tank was removed form service and a pump was installed. The tank was inactive in 1978 and pumping was completed in 1979. Intrusion prevention was completed in December 1982 and interim stabilization and a level adjustment were completed in November 1983. (See sketch ES-TKSE59 for a-graphical-representation of the fank-241-C-1.09-Ievel history.)

\subsubsection{Temperature History 241-C-109}

Tank 241-C-109 has two thermocouple trees: tree 1 has twelve thermocouple probes and tree 2 has eleven thermocouple probes. The mean temperature of the first daily recorded readings was $72.5^{\circ} \mathrm{F}$ for tree 1 , and $85.5^{\circ} \mathrm{F}$ for tree 2 . A sum of the squares regression line fit over both trees shows virtually no overali temperature change with little variability in data. The median temperature is $76^{\circ} \mathrm{F}$ with a minimum of $63^{\circ} \mathrm{F}$ and a maximum of $88^{\circ} \mathrm{F}$. Refer to the supporting documents for a more thorough review of the temperature data (Brevick 1994).

\subsubsection{Integrity of Tank 241-C-109}

Tank 241-C-109 is categorized as sound and is interim stabilized with intrusion prevention completed. The Tank 241-C-109 surface level is monitored quarterly with a manual tape through riser 1. A graphical representation of the surface level measurements from January 1991 to the present can be found in the supporting documents (Brevick, 1994). The surface level for the past 3 years remained steady with the readings ranging from 18 to 18.5 in.

Six drywells are identified for tank 241-C-109. A graphical representation of the active drywelis from January 1990 to the present can be found in the supporting documents (Brevick, 1994).

An occurrence report was issued in January 1982 due to increasing activity in drywell 30-09-06. The activity was attributed to the migration of existing radionuclides in the soil in the vicinity of tank C-108.

\subsubsection{Current Status of Tank 241-C-109}

Tank 241-C-109 entered service in April 1948 and currently stores 66,000 gal of waste. The waste is comprised of 4,000 gal of supernatant; 3,000 gal of unknown waste; 59,000 gal of sludge with no saltcake or pumpable liquid remaining. The tank has been identified on the Ferrocyanide Watch list since January 1991, is passively ventilated, and is categorized as sound with interim stabilization and intrusion 
prevention completed. Tank 241-C-109 is third in the three-tank cascade series. The following plan view and tank cross-section depict the approximate waste level and riser configuration. Tank 241-C-109 has 9 risers and five are available for use: one 4-in. riser (no.5) and four 12-in. risers (nos. 2, 3, 6, and 7).

\subsubsection{Inventory estimate 241-C-109}

The following tank layer volume approximation was derived from the Los Alamos National Laboratories Waste Status and Transaction Record Summary (Agnew 1994). The estimated inventory of Tank 241-C-109 is also presented.

-7.9.2.2 In-Tank ‥Photograph. 241-C-109.........

The Tank 241-C-109 photo shows brown supernatant with patches of black sludge. The waste measures slightly more than 2 ft deep. No equipment is visible in the photo but the edge of the tank can be seen on the bottom edge of the photo. Most of the supernatant has been pumped out since the photo was taken.

7.9.3 Synopsis Tank 241-C-109

(To be completed.) 


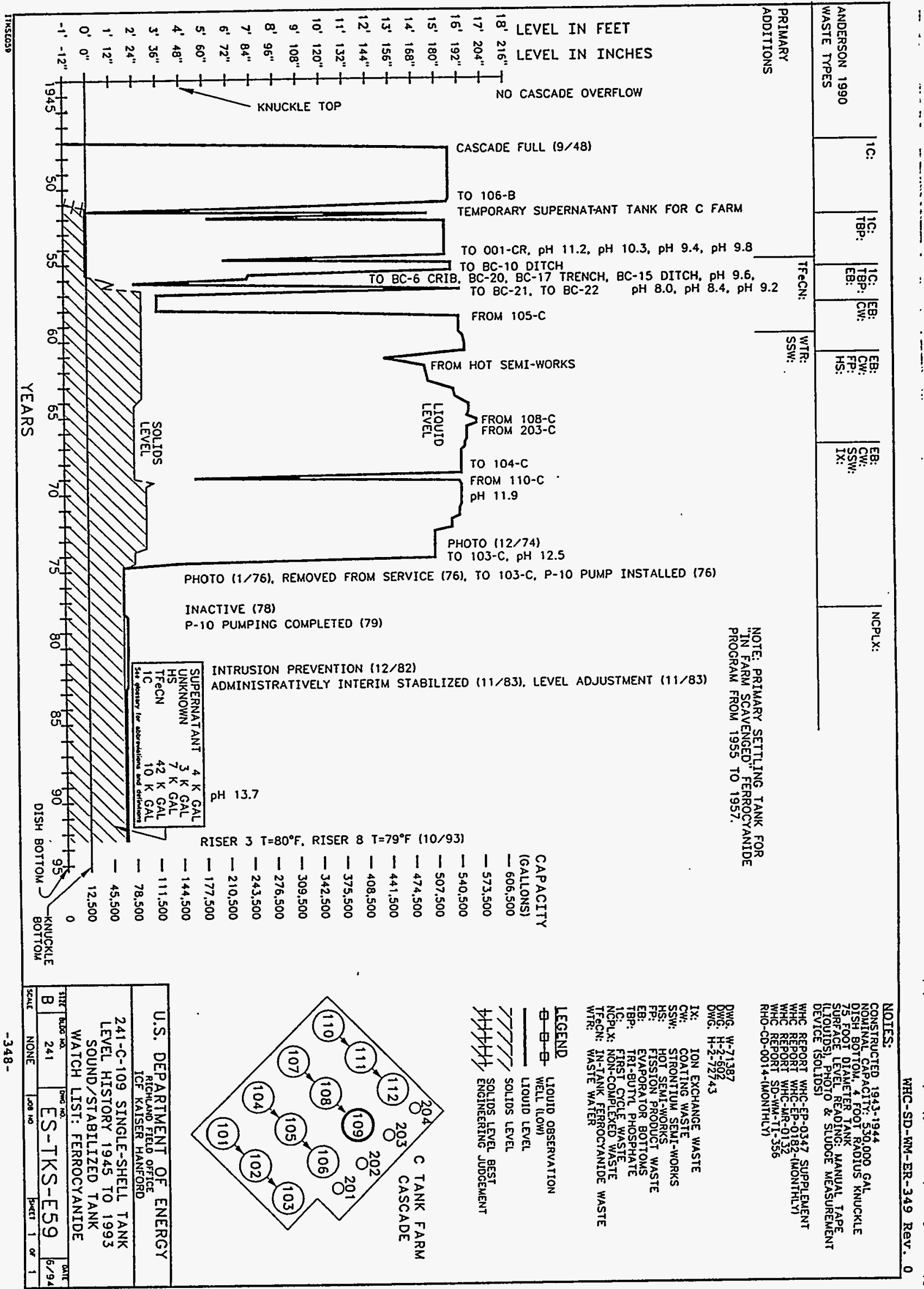


WHC-SD-WM-ER-349, ReV. 0

\begin{tabular}{|c|c|c|c|}
\hline \multicolumn{4}{|c|}{ Single-Shell Tank 241-C-109 } \\
\hline \multicolumn{4}{|c|}{ Solids Composite Inventory Estimate } \\
\hline \multicolumn{4}{|c|}{ 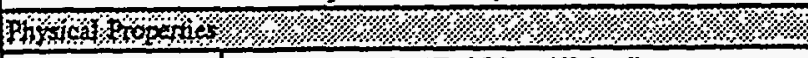 } \\
\hline Total Solid Waste & \multicolumn{3}{|c|}{$3.11 \mathrm{E}+05 \mathrm{~kg}(62 \mathrm{kgal})$} \\
\hline \begin{tabular}{|l|} 
Heat load \\
\end{tabular} & \multicolumn{3}{|c|}{$6.79 \mathrm{~kW}(2.32 \mathrm{E}+04 \mathrm{BTU} / \mathrm{hr})$} \\
\hline Bulk Density & \multicolumn{3}{|c|}{$1.32(g / \infty)$} \\
\hline Void Fraction & \multicolumn{3}{|c|}{0.91} \\
\hline Water wt\% & \multicolumn{3}{|c|}{80.44} \\
\hline TOC wi\% C (wet) & \multicolumn{3}{|c|}{1.66} \\
\hline \multicolumn{4}{|c|}{ Ghowhos ostiont } \\
\hline $\mathrm{Na}^{+1}$ & 3.94 & $6.85 \mathrm{E}+04$ & $2.13 E+04$ \\
\hline $\mathrm{Al}^{3+3}$ & $4.84 \mathrm{E}-02$ & $9.85 \mathrm{E}+02$ & $3.06 \mathrm{E}+02$ \\
\hline $\mathrm{Fec}^{\mathrm{t3}} \cdot($ total $\mathrm{Fe})$ & 0.46 & $1.96 \mathrm{E}+04$ & $6.08 \mathrm{E}+03$ \\
\hline $\mathrm{Cr}^{33}$ & 2.35E-03 & $92: 44$ & $\cdots \cdots 28.73$ \\
\hline $\mathrm{Bi}^{+3}$ & $1.65 \mathrm{E}-02$ & $2.60 \mathrm{E}+03$ & $8.08 \mathrm{E}+02$ \\
\hline $\mathrm{La}^{43}$ & of & 0 & 0 \\
\hline $\mathrm{Ce}^{+3}$ & 0 & 0 & 0 \\
\hline $\mathrm{Zr}$ (as $\left.\mathrm{Z} \mathrm{O}(\mathrm{OH})_{2}\right)$ & 4.71E-03 & $3.24 \mathrm{E}+02$ & $1.01 \mathrm{E}+02$ \\
\hline $\mathrm{Pb}^{+2}$ & 0.19 & $3.00 \mathrm{E}+04$ & $9.33 \mathrm{E}+03$ \\
\hline $\mathrm{Ni}^{+2}$ & 0.52 & $2.30 \mathrm{E}+04$ & $7.14 \mathrm{E}+03$ \\
\hline $\mathrm{Sr}^{+2}$ & of & 0 & 0 \\
\hline $\mathrm{Mn}^{4+}$ & 0 & 이 & 0 \\
\hline $\mathrm{Ca}^{+2}$ & o & 0 & 0 \\
\hline $\mathrm{R}^{+2}$ & $7.83 \mathrm{E}-03$ & $2.31 \mathrm{E}+02$ & 71.88 \\
\hline $\mathrm{OH}^{-1}$ & 1.68 & $2.16 \mathrm{E}+04$ & $6.72 E+03$ \\
\hline $\mathrm{NO}^{-1}$ & 1.89 & $8.85 \mathrm{E}+04$ & $2.75 \mathrm{E}+04$ \\
\hline $\mathrm{NO}^{-1}$ & 0.14 & $4.85 E+03$ & $1.51 \mathrm{E}+03$ \\
\hline $\mathrm{CO}^{-2}$ & $1.00 \mathrm{E}-02$ & $4.55 E+02$ & $1.41 \mathrm{E}+02$ \\
\hline $\mathrm{PO}^{-3}$ & 0.38 & $2.72 E+04$ & $8.45 \mathrm{E}+03$ \\
\hline $\mathrm{SO}_{4}^{-2}$ & $2.26 \mathrm{E}-02$ & $1.64 \mathrm{E}+03$ & $5.10 \mathrm{E}+02$ \\
\hline $\mathrm{Si}\left(\right.$ as $\left.\mathrm{SiO}_{3}{ }^{-2}\right)$ & 4.47E-02 & $9.49 \mathrm{E}+02$ & $2.95 E+02$ \\
\hline $\mathrm{F}^{-1}$ & $2.28 \mathrm{E}-02$ & $3.27 \mathrm{E}+02$ & $1.02 E+02$ \\
\hline $\mathrm{Cl}^{12}$ & 0 & 0 & 0 \\
\hline $\mathrm{C}_{6} \mathrm{H}_{3} \mathrm{O}_{7}^{-5}$ & 0 & 0] & 0 \\
\hline EDTA $^{4}$ & 0 & of & 0 \\
\hline $\mathrm{HEDTA}^{-3}$ & 0] & of & 0 \\
\hline $\mathrm{NTA}^{-3}$ & of & of & 0 \\
\hline glycolate & 0 & 0 & 0 \\
\hline acetare $^{-1}$ & 0.13 & $6.00 \mathrm{E}+03$ & $1.86 E+03$ \\
\hline oxalate & 0 & 0 & 0 \\
\hline DBP & 0 & 0 & 0 \\
\hline $\mathrm{NPH}$ & 0 & 0 & 0 \\
\hline $\mathrm{CCl}_{4}$ & a & 0 & 0 \\
\hline hexone & 0 & $\begin{array}{r}0 \\
\end{array}$ & 0 \\
\hline $\mathrm{Fe}(\mathrm{CN})_{6}^{2}$ & 0.26 & $6.08 \mathrm{E}+04(\mathrm{~g}-\mathrm{mol})$ & \\
\hline \multicolumn{4}{|c|}{ 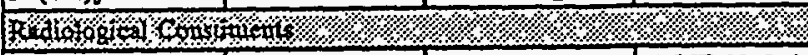 } \\
\hline \begin{tabular}{|l|}
$\mathrm{Pu}$ \\
\end{tabular} & & $7.24 \mathrm{E}-03(\mu \mathrm{Ci} / \mathrm{g})$ & $3.75 \mathrm{E}-02(\mathrm{~kg})$ \\
\hline $\mathrm{U}$ & $0(\mathrm{M})$ & $0(\mu \mathrm{g} / \mathrm{g})$ & $0(\mathrm{~kg})$ \\
\hline Cs & $1.30(\mathrm{Ci} / \mathrm{L})$ & $9.79 \mathrm{E}+02(\mu \mathrm{Ci} / \mathrm{g})$ & $3.04 \mathrm{E}+05(\mathrm{Ci})$ \\
\hline Sr & $3.39(\mathrm{C} / \mathrm{L})$ & $2.56 \mathrm{E}+03(\mu \mathrm{Ci} / \mathrm{g})$ & $7.95 \mathrm{E}+05(\mathrm{Ci})$ \\
\hline
\end{tabular}

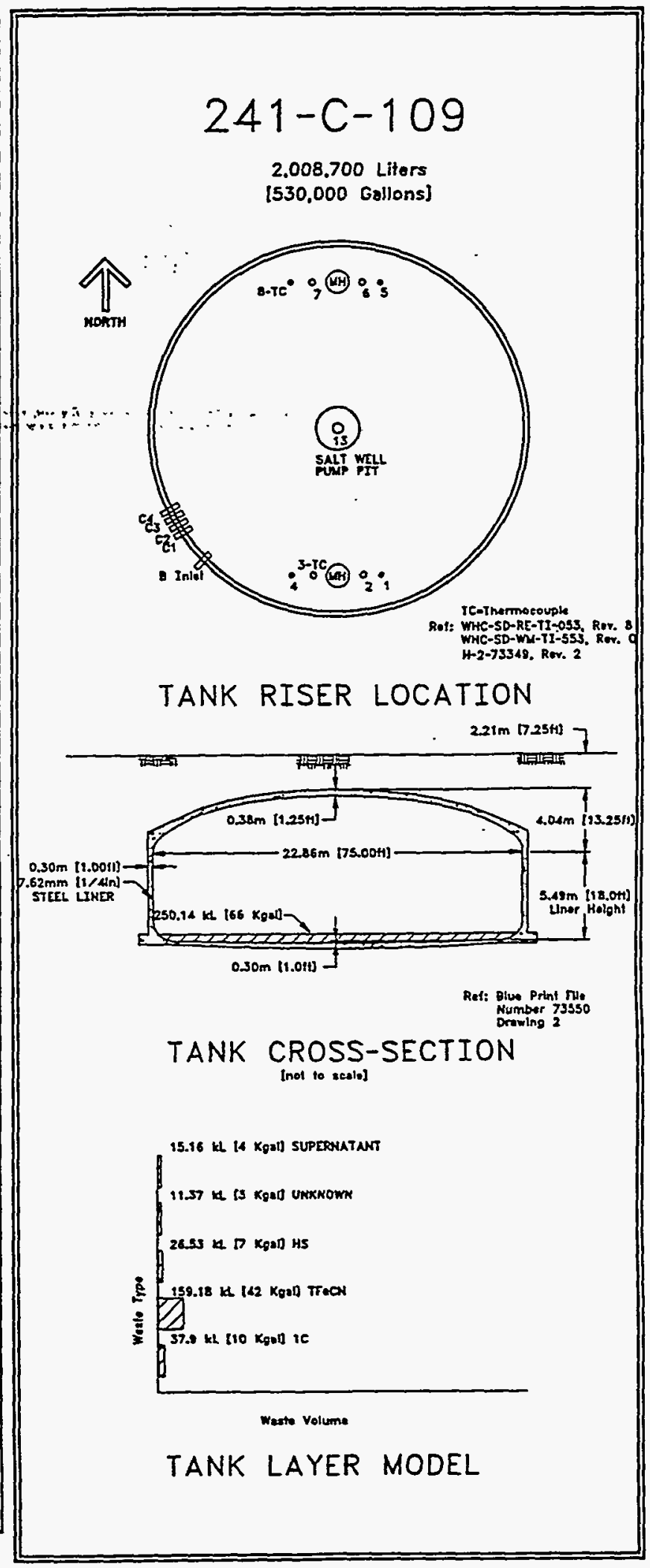

$-349-$

$6 / 94$ 


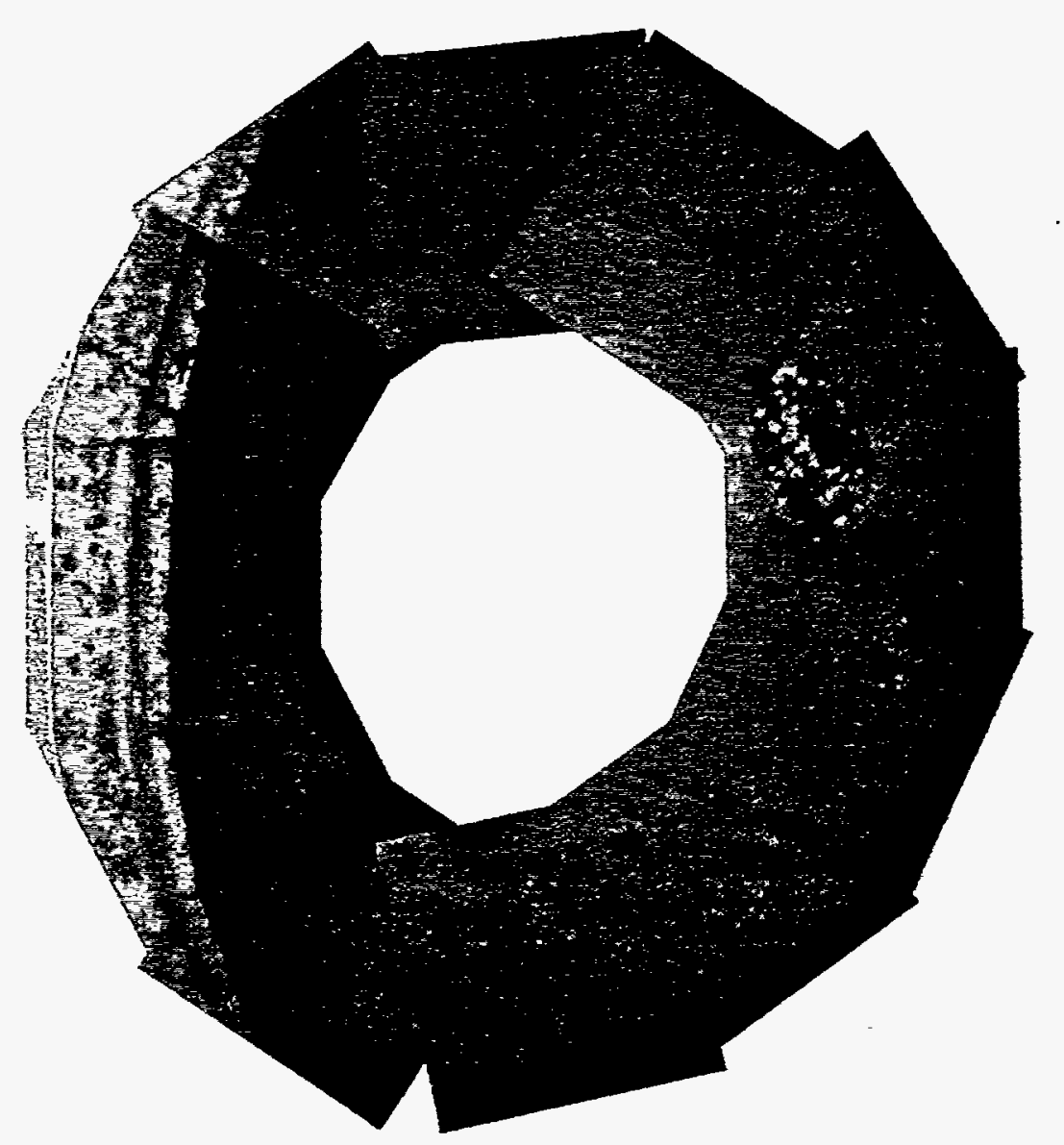


7.10.1 241-C-110 Tank History

7.10.1.1 Waste History Tank 241-C-110

Tank 241-C-110 was filled with first-cycle waste from May 1964 to April 1967. The tank was removed from service in 1976 and saltwell pumping began. The tank was inactive in 1978 and primary stabilization was completed in September 1979. Partial isolation was completed in December 1982. The tank was declared an assumed leaker in 1984 with a leak volume of $2,000 \mathrm{gal}$. Level adjustments were made in December 1984 and May 1985. (See sketch ES-TKS-E60 for a graphical representation of the Tank 241-C-1,10. Ievel history) ... . . .

\subsubsection{Temperature History 241-C-110}

The single thermocouple tree in Tank 241-C-110 has eleven thermocouple probes to record temperature data. The mean temperature of the first recorded data for thermocouples 6 through 11 was $69^{\circ} \mathrm{F}$. A sum of the squares regression line fit of the available data shows a slight temperature decrease with little variability in data. The median temperature is $68^{\circ} \mathrm{F}$ with a minimum of $61^{\circ} \mathrm{F}$ and a maximum of $71^{\circ} \mathrm{F}$. Refer to the supporting documents (Brevick 1994) for a more thorough review of the temperature data.

\subsubsection{Integrity of Tank 241-C-110}

Tank 241-C-110 is categorized as an assumed leaker and is partially isolated. The Tank 241-C-110 surface level is monitored daily with a manual tape. A graphical representation of the surface level measurements from January 1991 to the present can be found in the supporting documents (Brevick, 1994). The surface level graph indicates a decrease during the fourth quarter of 1991 which corresponds to the saltwell pumping effort conducted at that time. The current baseline value was established in JuIY 1993 and, since that time, the surface level has remained steady with the readings ranging from 64.75 to 65.25 in.

Four drywells are identified for tank 241-C-101. Graphical representation of the data for the active drywell from January 1990 to the present can be found in the supporting documents (Brevick, 1994).

\subsubsection{Current Status of Tank 241-C-110}

Tank 241-C-110 entered service in May 1946 and currently stores $187,000 \mathrm{gal}$ of waste. The waste is comprised of 187,000 gal of sludge with 5,000 gal of pumpable liquid remaining. The tank is identified as a low-heat load tank, is passively ventilated, and is categorized as an assumed leaker with partial isolation completed. Tank 241-C-110 is equipped to cascade to 241-C-111 and is first in the three-tank cascade series. The following plan view and tank cross section depict the approximate waste level and riser configuration. Tank 241-C-110 has 9

$$
-351-
$$


WHC-SD-WM-ER-349, Rev. 0

risers and four are available for use: one 4-in. riser (no.5) and three 12-in. risers (nos.2, 6, and 7).

\subsubsection{Inventory estimate 241-C-110}

The following tank layer volume approximation was derived from the Los Alamos National Laboratories Waste Status and Transaction Record Summary (Agnew 1994). The estimated inventory of Tank 241-C-110 is also presented.

\subsubsection{In-Tank Photograph 241-C-110}

The Tank 241-C-110 photo shows a rust-red sludge surface with pools of supernatant... The sludge...is approximately. 6..ft.deep. or about 187,000 gai. The black tubing in the pile of debris on the IefE side of the photo may be a rubber garden hose. The remaining debris is old level measurement tapes. The tank has been saltwell pumped as a result of the photo being taken.

$7.10 .3 \quad$ Synopsis Tank 241-C-110

(To be completed.) 


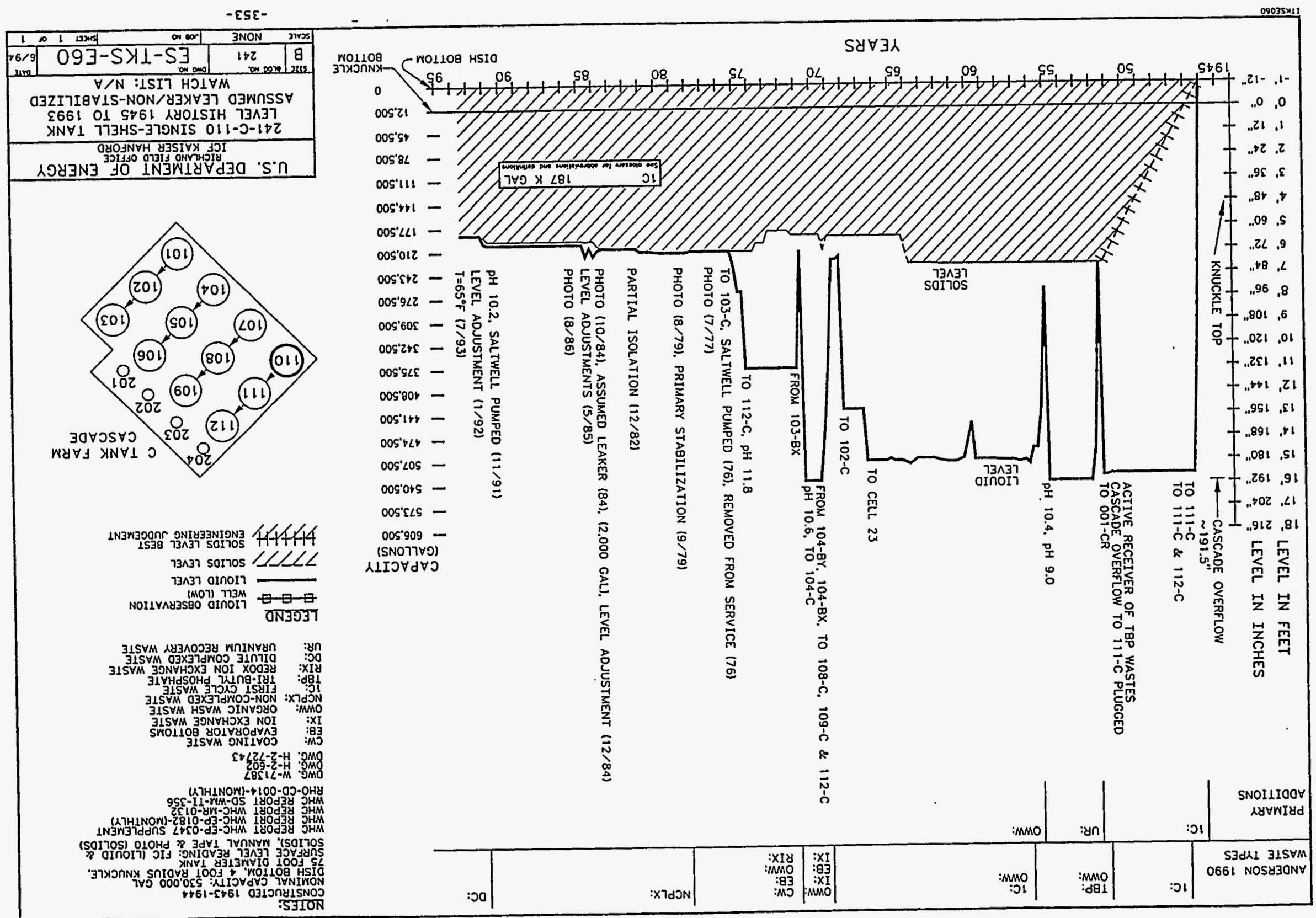




\begin{tabular}{|c|c|c|c|}
\hline \multicolumn{4}{|c|}{ Single-Shell Tank 241-C-110 } \\
\hline \multicolumn{4}{|c|}{ Solids Composite Inventory Estimate } \\
\hline \multicolumn{4}{|c|}{ 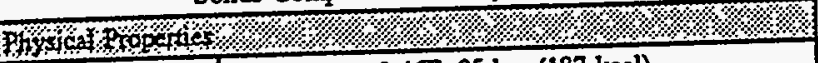 } \\
\hline Total Solid Waste & \multicolumn{3}{|c|}{$9.46 \mathrm{E}+05 \mathrm{~kg}(187 \mathrm{kgal})$} \\
\hline Heat load & \multicolumn{3}{|c|}{ 4.77E-02 kW (1.63E+02 BTU/hr) } \\
\hline Bulk Density & \multicolumn{3}{|c|}{$1.34(g / \infty)$} \\
\hline Void Fraction & \multicolumn{3}{|c|}{0.58} \\
\hline Water wt\% & \multicolumn{3}{|c|}{68.44} \\
\hline TOC wt\% C (wet) & \multicolumn{3}{|c|}{0.00} \\
\hline \multicolumn{4}{|c|}{ 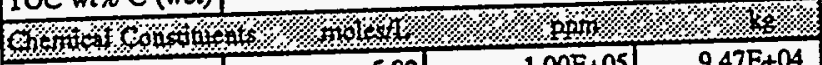 } \\
\hline $\mathrm{Na}^{+1}$ & 5.82 & $1.00 \mathrm{E}+05$ & $9.47 \mathrm{E}+04$ \\
\hline $\mathrm{Al}^{+3}$ & 0.30 & $6.06 \mathrm{E}+03$ & $5.73 \mathrm{E}+03$ \\
\hline $\mathrm{Fe}^{+3}$ (total $\left.\mathrm{Fe}\right)$ & $\begin{array}{r}0.22 \\
\end{array}$ & $9.15 \mathrm{E}+03$ & $8.66 \mathrm{E}+03$ \\
\hline $\mathrm{Cr}^{+3} \cdot$ & 1.46E:02: & $5: 68 \mathrm{E}+02$ & $-5.37 \mathrm{E}+02$ \\
\hline $\mathrm{Bi}^{+3}$ & 0.10 & $1.60 \mathrm{E}+04$ & $1.51 \mathrm{E}+04$ \\
\hline $\mathrm{La}^{48}$ & 인 & 0 & 0 \\
\hline $\mathrm{Ce}^{+3}$ & $\therefore \quad 0$ & 0 & 0 \\
\hline $\mathrm{Zx}\left(\right.$ as $\left.\mathrm{ZrO}(\mathrm{OH})_{2}\right)$ & $2.92 \mathrm{E}-02$ & $1.99 \mathrm{E}+03$ & $1.89 \mathrm{E}+03$ \\
\hline $\mathrm{Pb}^{+2}$ & 0 & 0 & 0 \\
\hline $\mathrm{Ni}^{+2}$ & 0 & 0 & 0 \\
\hline $\mathrm{Sr}^{+2}$ & 0 & 0 & 0 \\
\hline $\mathrm{Mn}^{+4}$ & of & 0 & 0 \\
\hline $\mathrm{Ca}^{+2}$ & 0 & 0 & 0 \\
\hline $\mathrm{K}^{41}$ & 0 & 0 & 0 \\
\hline $\mathrm{OH}^{-1}$ & 1.55 & $1.97 E+04$ & $1.87 \mathrm{E}+04$ \\
\hline $\mathrm{NO3}^{-1}$ & 0.10 & $4.86 \mathrm{E}+03$ & $4.59 \mathrm{E}+03$ \\
\hline $\mathrm{NO}^{\prime 2}$ & 0.11 & $3.71 \mathrm{E}+03$ & $3.51 E+03$ \\
\hline $\mathrm{CO}^{2.2}$ & 0 & 0 & 0 \\
\hline $\mathrm{PO}^{\cdot 3}$ & 1.77 & $1.26 \varepsilon+05$ & $1.19 E+05$ \\
\hline $\mathrm{SO}^{-2}$ & $3.72 \mathrm{E}-02$ & $2.67 \mathrm{E}+03$ & $2.53 E+03$ \\
\hline $\mathrm{Si}\left(\mathrm{as} \mathrm{SiO}_{3}{ }^{-2}\right)$ & 0.28 & $5.83 \mathrm{E}+03$ & $5.51 E+03$ \\
\hline $\mathrm{F}^{-1}$ & 0.14 & $2.01 \mathrm{E}+03$ & $1.90 \mathrm{E}+03$ \\
\hline $\mathrm{C}^{-1}$ & 0 & 0 & 0 \\
\hline $\mathrm{C}_{6} \mathrm{H}_{5} \mathrm{O}_{7}{ }^{-3}$ & 요 & 0 & 0 \\
\hline EDTA $^{-1}$ & 0 & 0 & 0 \\
\hline HEDTA ${ }^{-3}$ & 0 & 0 & 0 \\
\hline $\mathrm{NTA}^{3}$ & 0 & 0 & 0 \\
\hline glycolate ${ }^{-1}$ & of & 0 & 0 \\
\hline acetate ${ }^{-1}$ & 0 & 0 & 0 \\
\hline oxalate ${ }^{-2}$ & 0 & 0 & 0 \\
\hline $\mathrm{DBP}$ & 0 & 0 & 0 \\
\hline NPH & 0 & 어 & 0 \\
\hline $\mathrm{CCl}_{4}$ & 0 & 0 & 0 \\
\hline hexone & 0 & 0 & 0 \\
\hline $\mathrm{Fe}(\mathrm{CN})_{6}^{-{ }^{-}}$ & $\begin{array}{r}0 \\
\end{array}$ & $0(\mathrm{~g}-\mathrm{mol})$ & \\
\hline \multicolumn{4}{|c|}{$\mathrm{Fe}(\mathrm{CN})_{6}^{-}$} \\
\hline $\mathrm{Pu}$ & & $4.45 \mathrm{E}-02(\mu \mathrm{Ci} / \mathrm{g})$ & $0.70(\mathrm{~kg})$ \\
\hline $\mathrm{U}$ & $\mathrm{O}(\mathrm{M})$ & $0(\mu / g)$ & $0(\mathrm{~kg})$ \\
\hline Cs & $8.65 \mathrm{E}-04(\mathrm{Ci} / \mathrm{L})$ & $0.65(\mu C i / g)$ & $6.12 \mathrm{E}+02(\mathrm{Ci})$ \\
\hline$S_{\mathbf{s}}$ & $9.40 \mathrm{E}-03(\mathrm{Ci} / \mathrm{L})$ & $7.03(\mu \mathrm{Ci} / \mathrm{g})$ & $6.65 \mathrm{E}+03(\mathrm{Cj})$ \\
\hline
\end{tabular}

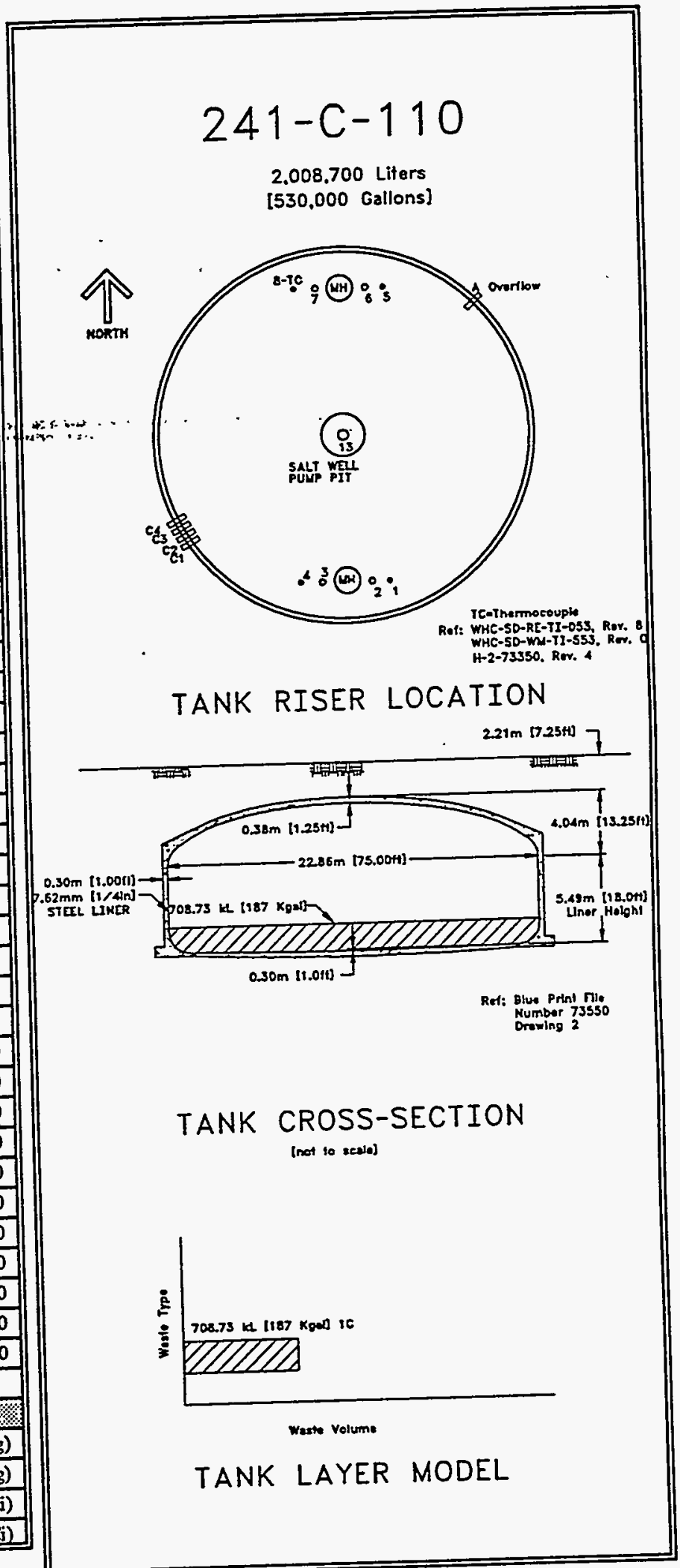




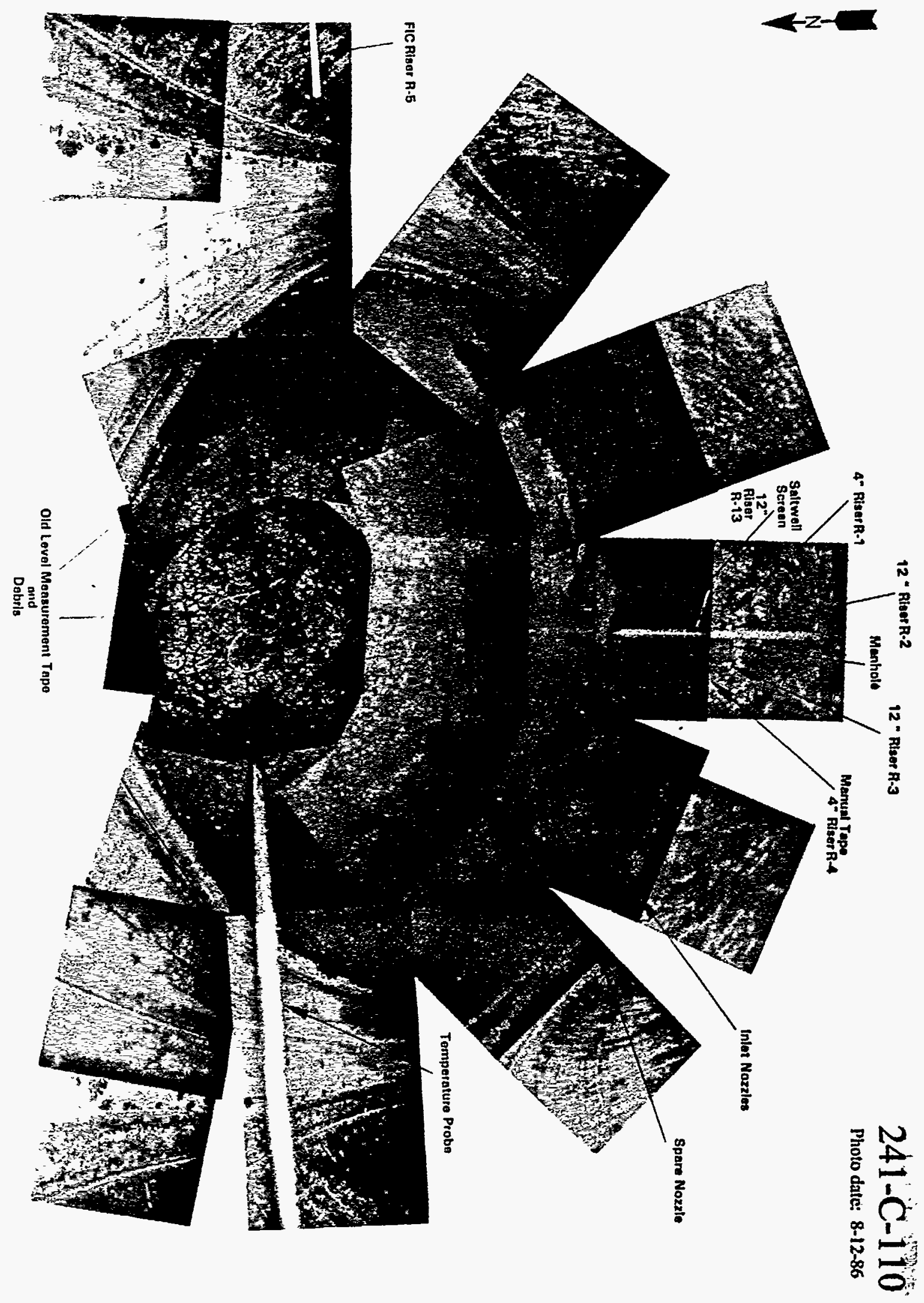


WHC-SD-WM-ER-349, Rev. 0

7.11 Tank 241-C-111

7.11.1 241-C-111 Tank History

7.11.1.1 Waste History Tank 241-C-111

Tank 241-C-111 began to receive first-cycle waste in August 1946 and was filled and cascaded to Tank 241-C-1.1.2 from November 1946 until April 1947. The tank was a suspect leaker and was removed from service in 1975. The tank became inactive in 1978. The tank was declared an assumed leaker in 1968 with a leak volume of 5,500 gal. Saltwell pumping began in 1976 and was completed in 1978. A level adjustment was made in April 1982 and intrusion prevention was completed in December 1982.; Interim stabinization .was complete in March: 1984.: (See sketch ES-TKS-E61 for a graphical representation of the Tank 241-C-111 level history.)

\subsubsection{Temperature History 241-C-111}

The single thermocouple tree in Tank 241-C-111 has 12 thermocouple probes to record temperature data. The mean temperature of the. first daily recorded readings was $82^{\circ} \mathrm{F}$. A sum of the squares regression line fit for all the data shows a slight decrease in temperature with a moderate amount of variability. The tank has an annual temperature undulation that is more evident after JuIY 1991. The median temperature is $73^{\circ} \mathrm{F}$ with a minimum of $59^{\circ} \mathrm{F}$ and a maximum of $85^{\circ} \mathrm{F}$. Refer to the supporting documents for a more thorough review of the temperature data (Brevick 1994).

\subsection{1:3 Integrity of Tank 241-C-111}

Tank 241-C-111 is categorized as an assumed leaker and is interim stabilized with intrusion prevention completed. The Tank 241-C-111 surface level is monitored quarterly with a manual tape through riser 8 . A graphical representation of the- surface level measurements from January 1991 to the present can be found in the supporting documents (Brevick, 1994). The surface level has remained steady for the past 3 years with the readings ranging from 16.5 to 15.25 in.

Five drywells are identified for tank 241-C-111, none of which are considered active.

\subsubsection{Current Status of Tank 241-C-111}

Tank 241-C-111 entered service in August 1946 and currently stores 57,000 gal of waste. The waste is comprised entirely of sludge with no of pumpable liquid remaining. The tank has been identified on the Ferrocyanide Watch List, since January 1991, is passively ventilated, and is categorized as an assumed leaker with interim stabilization and intrusion prevention completed. Tank $241-C-111$ is equipped to cascade to Tank 241-C-112 and is second in the three-tank cascade series. The following plan view and tank cross section depict the approximate waste level and riser configuration. Tank 241-C-111 has 9 risers and three 
WHC-SD-WM-ER-349, Rev. 0

are available for use: one 4-in. riser (no.4) and two 12-in. risers (nos.2 and 6).

\subsubsection{Inventory estimate 241-C-111}

The following tank layer volume approximation was derived from the Ios Alamos National Laboratories Waste Status and Transaction Record Summary (Agnew 1994). The estimated inventory of Tank 241-C-111 is also presented.

\subsubsection{In-Tank Photograph 241-C-111}

The Tank 241-C-111 photo shows a dark Iiquid surface. The tank has been sal twel1 pumped: since" the photo was taken and the new. solids level is approximately 2 ft deep.

\subsubsection{Synopsis Tank 241-C-111}

(To be completed.) 


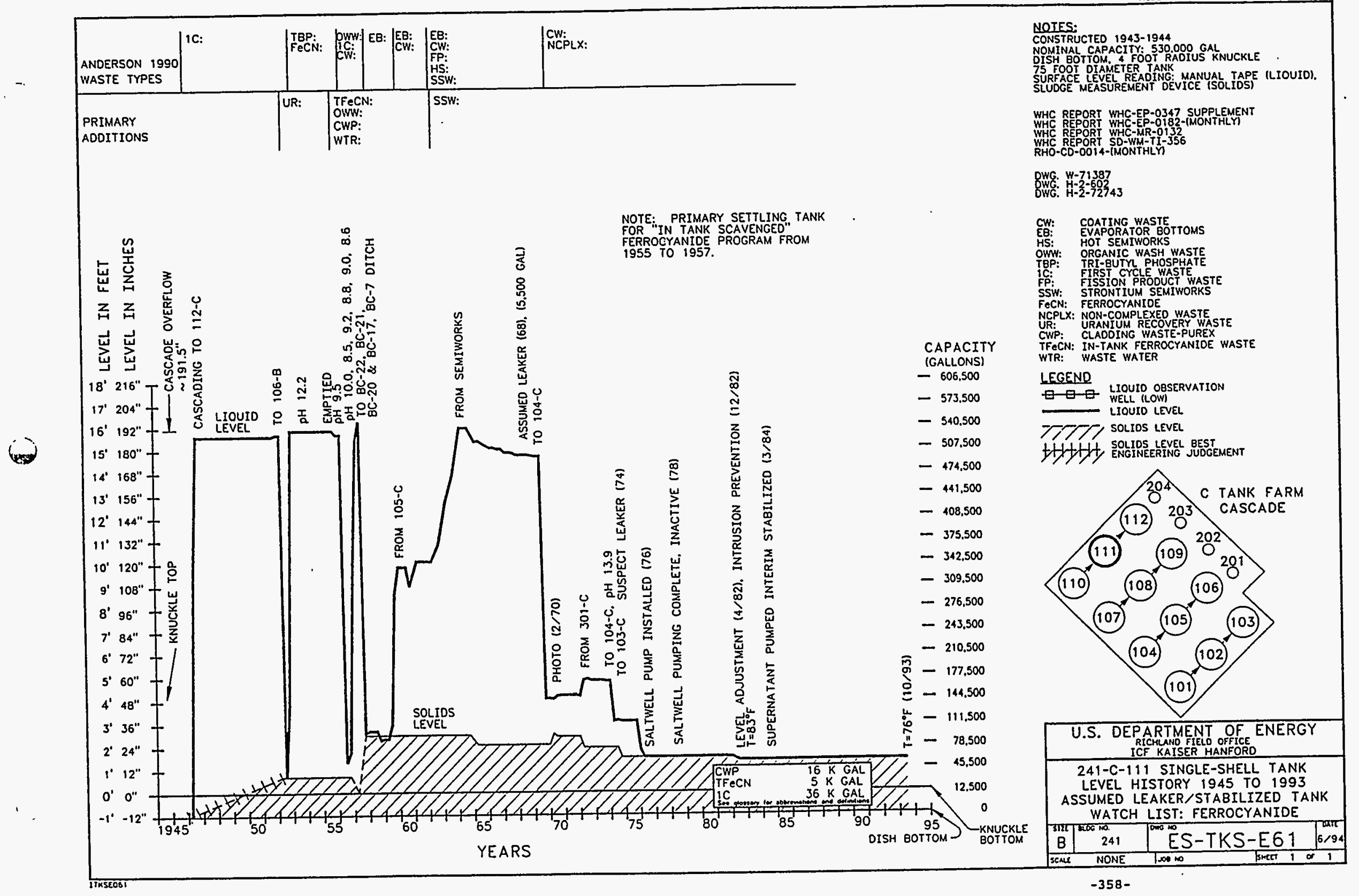




\begin{tabular}{|c|c|c|c|}
\hline \multicolumn{4}{|c|}{ Single-Shell Tank 241-C-111 } \\
\hline \multicolumn{4}{|c|}{ Solids Composite Inventory Estimale } \\
\hline 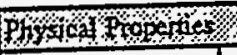 & $\% \% / \%$ & \%: \% \% & \\
\hline Total Solid Waste & \multicolumn{3}{|c|}{$2.96 \mathrm{E}+05 \mathrm{~kg}(57 \mathrm{kgal})$} \\
\hline \begin{tabular}{|l|} 
Heat load \\
\end{tabular} & \multicolumn{3}{|c|}{$0.17 \mathrm{~kW}(5.72 \mathrm{E}+02 \mathrm{BTU} / \mathrm{hr})$} \\
\hline Bulk Density & \multicolumn{3}{|c|}{$1.37(g / \infty)$} \\
\hline Void Fraction & \multicolumn{3}{|c|}{0.65} \\
\hline Water wr\% & \multicolumn{3}{|c|}{66.49} \\
\hline TOC w:\% C (wet) & \multicolumn{3}{|c|}{0.18} \\
\hline \multicolumn{4}{|c|}{ 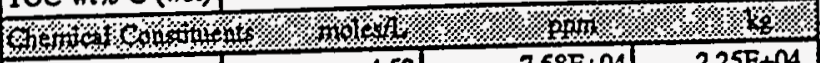 } \\
\hline \begin{tabular}{|l|l|}
$\mathrm{Na}^{41}$ & \\
\end{tabular} & 4.53 & $7.58 \mathrm{E}+04$ & $2.25 E+04$ \\
\hline $\mathrm{Al}^{+3}$ & 1.61 & $3.15 E+04$ & $9.35 \mathrm{E}+03$ \\
\hline $\mathrm{Fe}^{43}$ (total Fe) & 0.17 & $6.89 \mathrm{E}+03$ & $2.04 \mathrm{E}+03$ \\
\hline $\mathrm{Cr}^{43}$ & 9.22E:03 & sai. $=3.49 \mathrm{E}+02+2$ & $1.03 E+02$ \\
\hline $\mathrm{Bi}^{+3}$ & 6.45E-02 & $9.82 \mathrm{E}+03$ & $2.91 \mathrm{E}+03$ \\
\hline $\mathrm{Ls}^{43}$ & 0 & 0 & 0 \\
\hline $\mathrm{Ce}^{43}$ & 0 & 0 & 0 \\
\hline $\mathrm{Zx}$ (as $\left.\mathrm{ZrO}(\mathrm{OH})_{2}\right)$ & $1.84 \mathrm{E}-02$ & $1.22 \mathrm{E}+03$ & $3.63 \mathrm{E}+02$ \\
\hline $\mathrm{Pb}^{+2}$ & 0 & of & 0 \\
\hline $\mathrm{Ni}^{+2}$ & $6.27 \mathrm{E}-02$ & $2.68 \mathrm{E}+03$ & $7.94 \mathrm{E}+02$ \\
\hline$\overline{S I^{42}}$ & 0 & 0 & 0 \\
\hline $\mathrm{Mn}^{-4}$ & of & 0 & 0 \\
\hline $\mathrm{Ca}^{-2}$ & of & 0 & 0 \\
\hline $\mathrm{B}^{+1}$ & 0 & o & 0 \\
\hline $\mathrm{OH}^{.1}$ & 5.42 & $6.70 \mathrm{E}+04$ & $1.99 \mathrm{E}+04$ \\
\hline $\mathrm{NO}^{-1}$ & 0.39 & $1.75 E+04$ & $5.18 \mathrm{E}+03$ \\
\hline $\mathrm{NO}^{-1}$ & 0.24 & $8.04 E+03$ & $2.38 \mathrm{E}+03$ \\
\hline $\mathrm{CO}^{-2}$ & of & 우 & 0 \\
\hline $\mathrm{PO}^{-3}$ & 1.13 & $7.81 \mathrm{E}+04$ & $2.31 E+04$ \\
\hline $504^{-2}$ & $2.43 \mathrm{E}-02$ & $1.70 \mathrm{E}+03$ & $5.04 E+02$ \\
\hline $\mathrm{Si}\left(\right.$ as $\left.\mathrm{SiO}_{3}^{-2}\right)$ & 0.24 & $5.00 \mathrm{E}+03$ & $1.48 \mathrm{E}+03$ \\
\hline $\mathrm{F}^{-1}$ & 8.92E-02 & $1.23 \mathrm{E}+03$ & $3.66 E+02$ \\
\hline $\mathrm{Cl}^{-1}$ & 0 & o & 0 \\
\hline $\mathrm{C}_{6} \mathrm{H}_{5} \mathrm{O}_{7}{ }^{-3}$ & 0 & 0 & 0 \\
\hline EDTA $^{-1}$ & 0 & of & 0 \\
\hline HEDTA ${ }^{-3}$ & 0 & 0 & 0 \\
\hline $\mathrm{NTA}^{-3}$ & 0 & of & 0 \\
\hline glycolate ${ }^{-1}$ & 0 & 0) & 0 \\
\hline acetale ${ }^{-1}$ & 0 & 0 & 0 \\
\hline oxalate & 0 & 0 & 0 \\
\hline DBP & 0 & 0 & 0 \\
\hline $\mathrm{NPH}$ & of & 0 & 0 \\
\hline $\mathrm{CCL}_{4}$ & 0 & 0) & 0 \\
\hline hexone & 0 & $\begin{array}{r} \\
\end{array}$ & 0 \\
\hline $\mathrm{Fe}(\mathrm{CN})_{6}^{-1}$ & $3.13 \mathrm{E}-02$ & $6.76 \mathrm{E}+03(\mathrm{~g}-\mathrm{mol})$ & \\
\hline \multicolumn{4}{|c|}{ 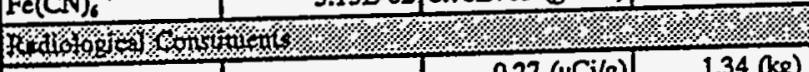 } \\
\hline $\mathrm{Pu}$ & & $0.27(\mu \mathrm{Ci} / g)$ & $1.34(\mathrm{~kg})$ \\
\hline $\mathrm{U}$ & $0(\mathrm{M})$ & $0(\mu g / g)$ & $0(\mathrm{~kg})$ \\
\hline Cs & $0.16(\mathrm{Ci} / \mathrm{L})$ & $1.14 \mathrm{E}+02(\mu \mathrm{Ci} / \mathrm{g})$ & $3.39 \mathrm{E}+04(\mathrm{G})$ \\
\hline$S r$ & $5.93 \mathrm{E}-03(\mathrm{C} / \mathrm{L})$ & $4.32(\mathrm{uCi} / \mathrm{g})$ & $1.28 \mathrm{E}+03(\mathrm{Ci})$ \\
\hline
\end{tabular}

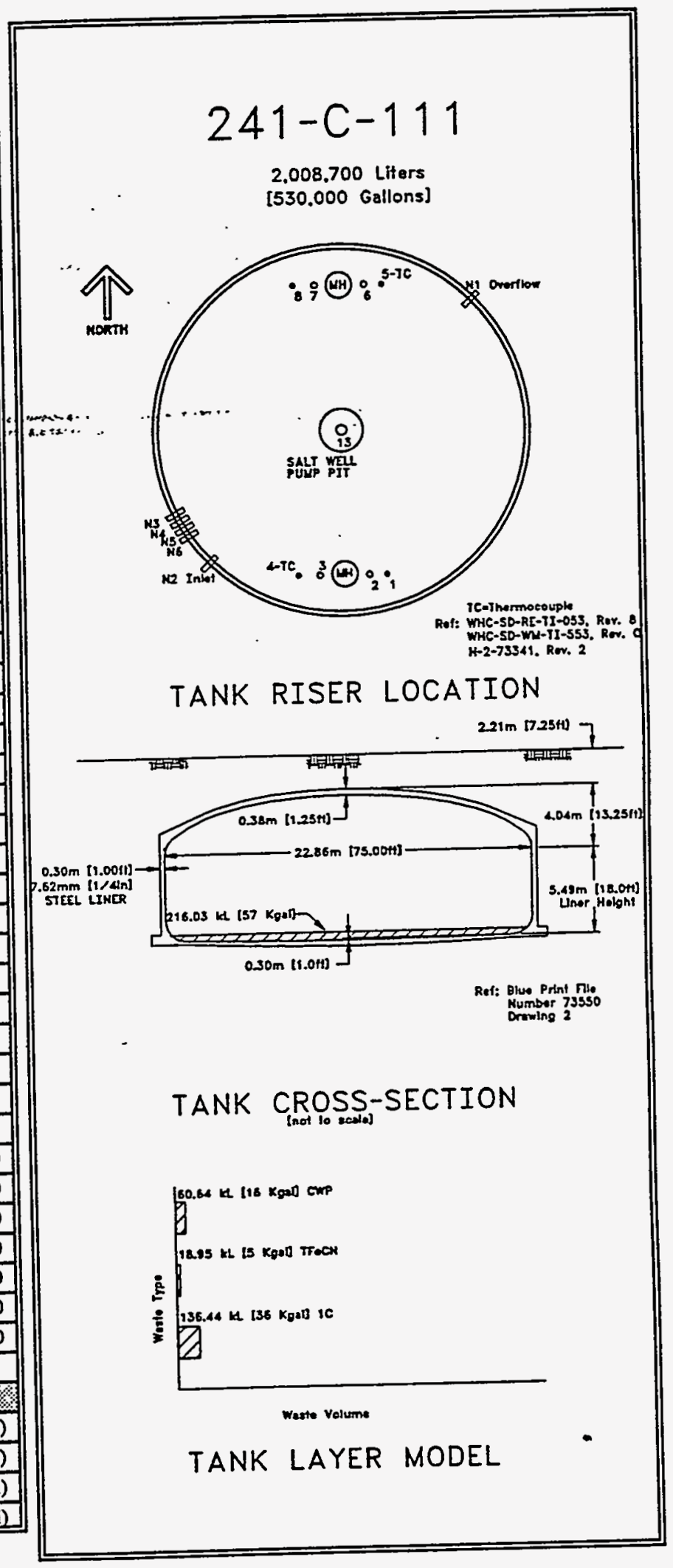


WHC-SD-WM-ER-349 Rev. O

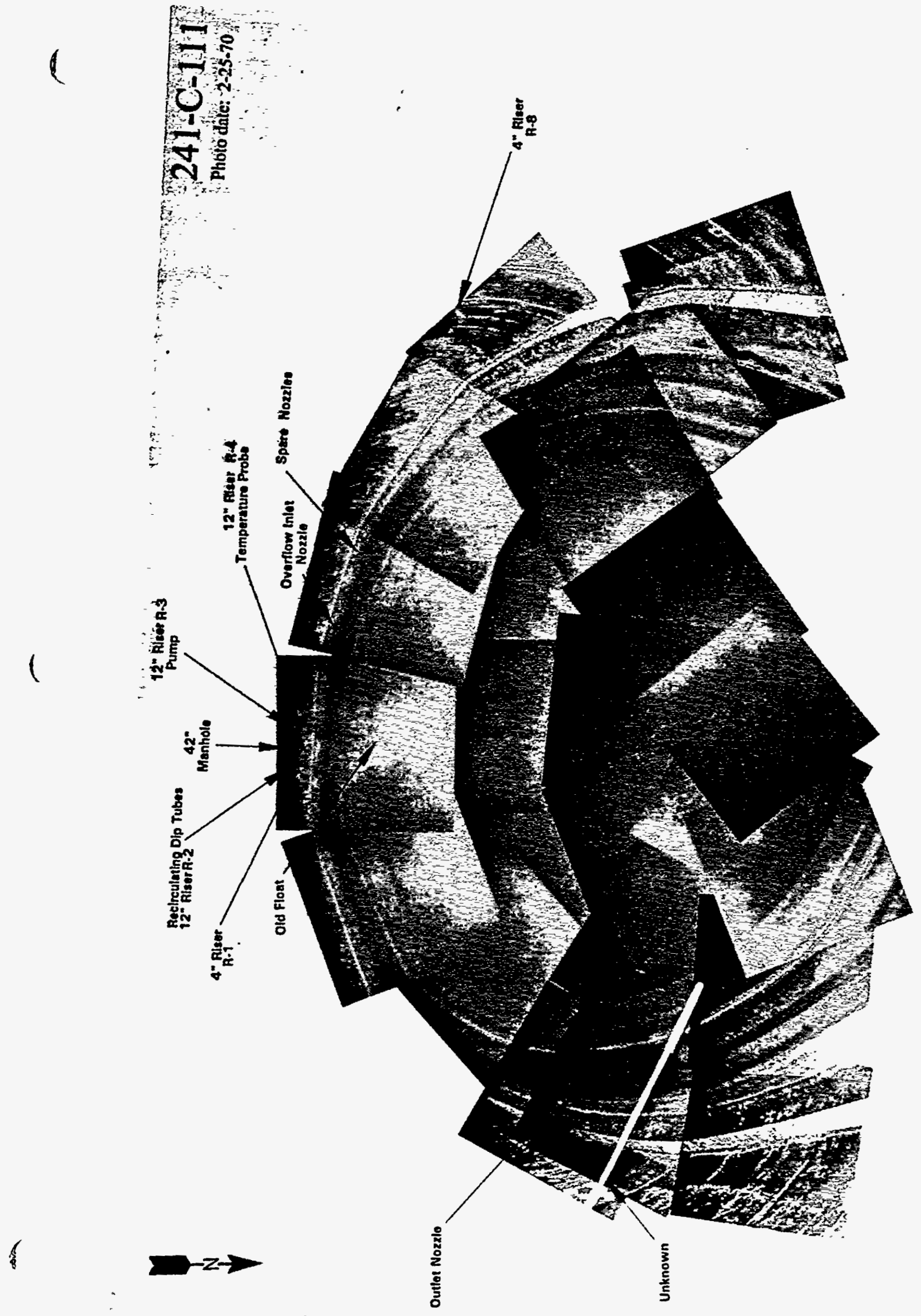


7.12.1 241-C-112 Tank History

\subsubsection{Waste History Tank 241-C-112}

Tank 241-C-112 began to fill with first-cycle waste from the Tank 241-C-111 cascade overflow inlet line in November 1946. In the first quarter of 1976; the tank was removed from service and it was declared inactive in the third quarter of 1977. A saltwell pump was installed in the tank in 1976 and pumping was completed in 1979. Partial isolation was completed in 1982. The tank was declared administratively interim stabilized and a level adjustment was made in september 1990. (See sketch ES-TKS-E62 for.. the .readings...and.a, ...graphical...representation of the Tank 241"C-112"level history,l

\subsection{2 .1 .2 Temperature History 241-C-112}

There are two thermocouple probes in Tank 241-C-112. Tree 1 has 16 thermocouple probes and tree 2 has 11 thermocouple probes. The mean temperature of the first recorded daily readings was $92^{\circ} \mathrm{F}$ for tree 1 , and $86^{\circ} \mathrm{F}$ for tree 2. A sum of the squares regression line fit for the first 11 thermocouples shows a temperature decrease with a large amount of variability in the data. Not enough data for thermocouples 12 through 16 are available to do an accurate regression or variability analysis. For tree 2, a sum of the squares regression line fit for all the data shows a temperature decrease with a moderate amount of variability in the data. Some of the variance from these trees could be due to annual temperature undulations that are more evident after January 1990. The median temperature for both trees is $79^{\circ} \mathrm{F}$ with a minimum of $59^{\circ} \mathrm{F}$ and a maximum of $109^{\circ} \mathrm{F}$. Refer to the supporting documents for a more thorough review of the temperature data (Brevick 1994).

\subsubsection{Integrity of Tank $241-\mathrm{C}-112$}

Tank 241-C-112 is categorized as sound and is interim stabilized with intrusion prevention completed. The Tank 241-C-112 surface level is monitored quarterly with a manual tape. A graphical representation of the surface level measurements from January 1991 to the present can be found in the supporting documents (Brevick, 1994). The surface level has remained steady for the past 3 years with the readings ranging from 32.75 to 34.75 in.

Four drywells are identified for tank 241-C-112. A graphical representation of the data for the active drywell from January 1990 to the present can be found in the supporting documents (Brevick, 1994).

\subsection{2 .2 Current Status of Tank 241-C-112}

Tank 241-C-112 entered service in November 1946 and currently stores 104,000 gal of waste. The waste is comprised of 8,000 gal of unknown waste; 96,000 gal of sludge with 26,000 gal of pumpable liquid remaining. The tank has been identified on the Ferrocyanide Watch Iist 
since January 1991, is passively ventilated, and is categorized as sound with interim stabilization and partial isolation completed. Tank 241-C112 is third in the three-tank cascade series. The following plan view and tank cross section depict the approximate waste level and riser configuration. Tank 241-C-112 has 9 risers and 12-in. risers (nos. 2, 6 , and 7) are available for use.

\subsubsection{Inventory estimate $241-\mathrm{C}-112$}

The following tank layer volume approximation was derived from the Los Alamos National Laboratories Waste Status and Transaction Record Sumnary (Agnew 1994). The estimated inventory of Tank 241-C-112 is also presented.

\subsubsection{In-Tank Photograph 241-C-112}

The Tank 241-C-112 photo shows a dark brown moist sludge surface with no appreciable amounts of supernatant. Approximately 104,000 gal of waste are in the tank which measures about 3 ft deep. The hazy appearance of the photos indicates that a fog or mist may be present.

\section{$7.12 .3 \quad$ Synopsis Tank 241-C-112}

(To be completed.) 


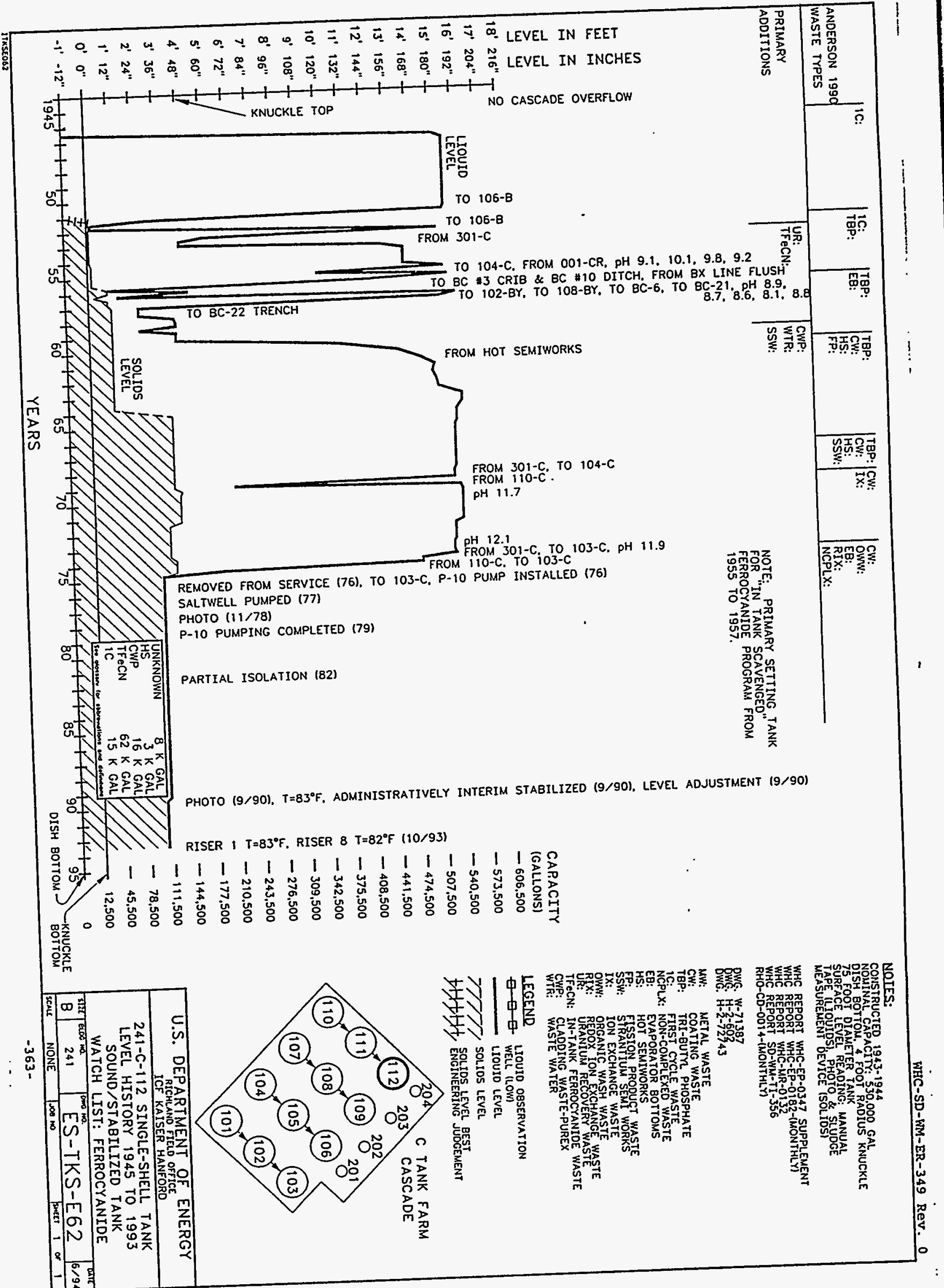


WHC-SD-WM-ER-349, Rev. 0

\begin{tabular}{|c|c|c|c|}
\hline \multicolumn{4}{|c|}{ Single-Shell Tank 241-C-112 } \\
\hline \multicolumn{4}{|c|}{ Solids Composite Inventory Estimate } \\
\hline 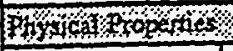 & \%\%\% & $1 \% 8 \% \%$ & $2 . \%$ \\
\hline Toual Solid Waste & \multicolumn{3}{|c|}{$5.27 \mathrm{E}+05 \mathrm{~kg}(104 \mathrm{kgal})$} \\
\hline Heat load & \multicolumn{3}{|c|}{$4.52 \mathrm{~kW}(1.54 \mathrm{E}+04 \mathrm{BTU} / \mathrm{hr})$} \\
\hline Bulk Density & \multicolumn{3}{|c|}{$1.34(g / \infty)$} \\
\hline Void Fraction & \multicolumn{3}{|c|}{.0 .88} \\
\hline Water wr\% & \multicolumn{3}{|c|}{79.08} \\
\hline TOC wr\% C (wet) & \multicolumn{3}{|c|}{1.40} \\
\hline \multicolumn{4}{|c|}{ 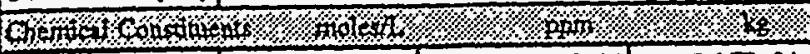 } \\
\hline \begin{tabular}{|l|l|}
$\mathrm{Na}^{* 1}$ & \\
\end{tabular} & 3.48 & $5.97 \mathrm{E}+04$ & $3.15 \mathrm{E}+04$ \\
\hline $\mathrm{Al}^{+3}$ & 0.93 & $1.88 \mathrm{E}+04$ & $9.92 \mathrm{E}+03$ \\
\hline $\mathrm{Fe}^{\mathrm{s}}($ cotal Fe $)$. & 0.32 & $1.32 E+04$ & $6,93 \mathrm{E}+03$ \\
\hline $\mathrm{Cr}^{+3}$ & 2.11E-03 & 81.84 & $43.10^{\circ}$ \\
\hline $\mathrm{Bi}^{i^{3}}$ & $1.47 \mathrm{E}-02$ & $2.30 \mathrm{E}+03$ & $1.21 E+03$ \\
\hline $2 a^{+3}$ & of & 0 & 0 \\
\hline $\mathrm{Ce}^{+3}$ & 0 & 0 & 0 \\
\hline $\mathrm{Zr}\left(\mathrm{as} \mathrm{ZrO}(\mathrm{OH})_{2}\right)$ & $4.21 \mathrm{E}-03$ & $2.87 \mathrm{E}+02$ & $1.51 \mathrm{E}+02$ \\
\hline $\mathrm{Pb}^{+2}$ & $4.90 \mathrm{E}-02$ & $7.59 \mathrm{E}+03$ & $4.00 \mathrm{E}+03$ \\
\hline $\mathrm{Ni}^{+2}$ & 0.48 & $2.11 \mathrm{E}+04$ & $1.11 E+04$ \\
\hline $\mathrm{Sr}^{+2}$ & 0 & 0 & 0 \\
\hline $\mathrm{Mn}^{+4}$ & of & 0] & 0 \\
\hline $\mathrm{Ca}^{+3}$ & 0 & 0 & 0 \\
\hline $\mathrm{K}^{+1}$ & $2.00 \mathrm{E}-03$ & 58.50 & 30.80 \\
\hline $\mathrm{OH}^{-1}$ & 3.64 & 4.63E+04 & $2.44 E+04$ \\
\hline $\mathrm{NO}^{-1}$ & 1.67 & $7.72 \mathrm{E}+04$ & 4.07E+04 \\
\hline $\mathrm{NO}^{-1}$ & 0.16 & $5.41 \mathrm{E}+03$ & $2.85 E+03$ \\
\hline $\mathrm{COB}^{-2}$ & $2.57 \mathrm{E}-03$ & $1.15 E+02$ & 60.61 \\
\hline $\mathrm{PO}^{-3}$ & 0.34 & $2.43 \mathrm{E}+04$ & $1.28 \mathrm{E}+04$ \\
\hline $\mathrm{SO4}^{-2}$ & $1.44 \mathrm{E}-02$ & $1.04 \mathrm{E}+03$ & $5.46 E+02$ \\
\hline $\mathrm{Si}\left(\mathrm{as} \mathrm{SiO}_{3}^{-2}\right)$ & $4.00 \mathrm{E}-02$ & $8.40 \mathrm{E}+02$ & $4.42 \mathrm{E}+02$ \\
\hline$F^{-1}$ & $2.04 \mathrm{E}-02$ & $2.89 \mathrm{E}+02$ & $1.52 \mathrm{E}+02$ \\
\hline$a^{-1}$ & of & 0 & 0 \\
\hline $\mathrm{C}_{6} \mathrm{H}_{5} \mathrm{O}_{7}{ }^{3}$ & 의 & 0 & 0 \\
\hline EDTA $^{-1}$ & ㅇ) & 0 & 0 \\
\hline HEDTA $^{-3}$ & of & 0 & 0 \\
\hline $\mathrm{NTA}^{-3}$ & 요 & of & 0 \\
\hline glycolate & 0 & 0 & 0 \\
\hline acelste ${ }^{-1}$ & $3.44 \mathrm{E}-02$ & $1.52 \mathrm{E}+03$ & $7.99 \mathrm{E}+02$ \\
\hline 0xalate & 0 & of & 0 \\
\hline DBP & 0) & 아 & 0 \\
\hline NPE & 0 & 0 & 0 \\
\hline $\mathrm{CO}_{2}$ & 0 & of & 0 \\
\hline hexone & 0 & o & 0 \\
\hline $\mathrm{Fe}(\mathrm{CN})_{6}{ }^{-1}$ & 0.24 & $9.46 \mathrm{E}+04(\mathrm{~g}-\mathrm{mol})$ & \\
\hline \multicolumn{4}{|c|}{ 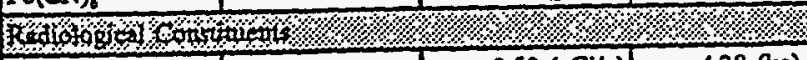 } \\
\hline $\mathrm{Pu}$ & & $0.50(\mu \mathrm{C} / \mathrm{g})$ & $4.38(\mathrm{~kg})$ \\
\hline $\mathrm{U}$ & $0(M)$ & $0(\mu \mathrm{g} / \mathrm{g})$ & $0(\mathrm{~kg})$ \\
\hline Cs & $1.20(\mathrm{Ci})$ & $8.99 \mathrm{E}+02(\mu \mathrm{Ci} / \mathrm{g})$ & $4.73 \mathrm{E}+05(\mathrm{Ci})$ \\
\hline $\mathrm{Sr}$ & $0.87(\mathrm{C} / 2)$ & $6.48 \mathrm{E}+02(\mu \mathrm{C} / \mathrm{g})$ & $3.41 \mathrm{E}+05(\mathrm{Ci})$ \\
\hline
\end{tabular}

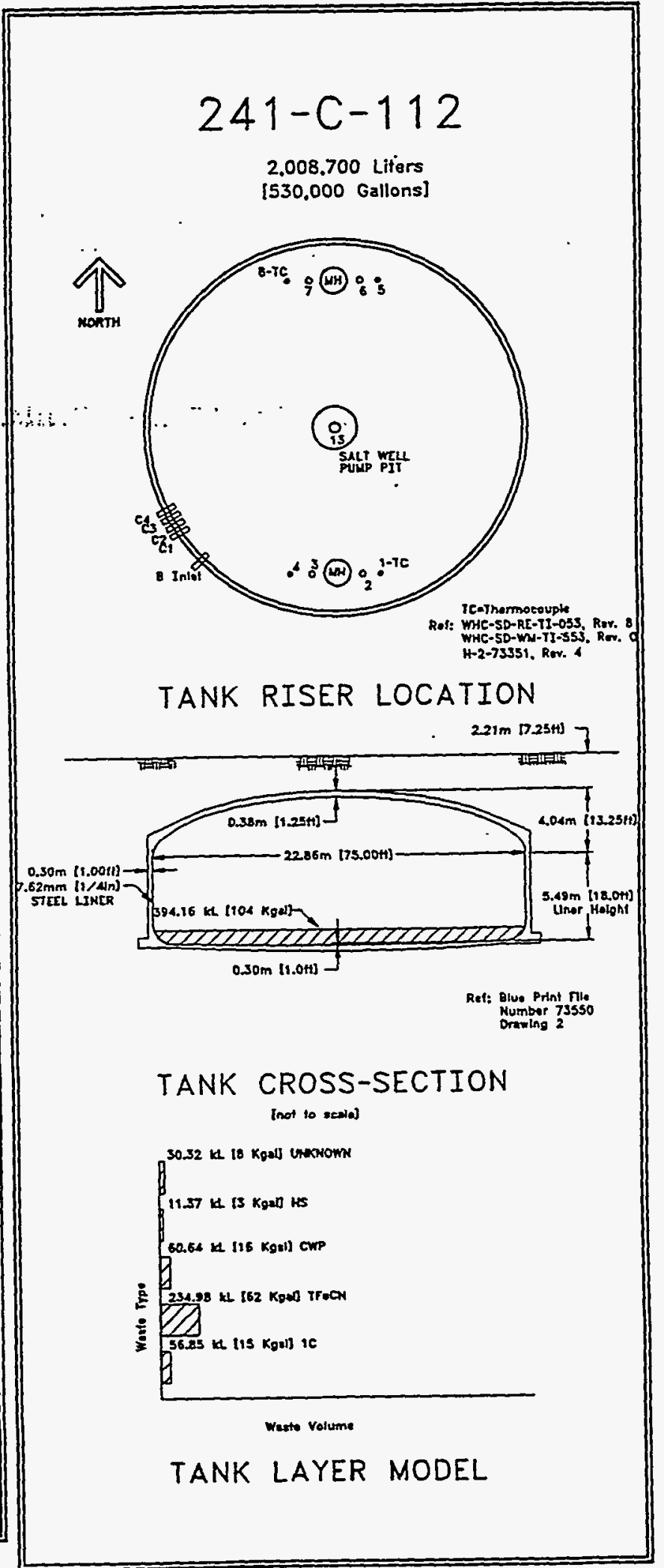


WHC-SD-WM-ER-349 ReV. 0

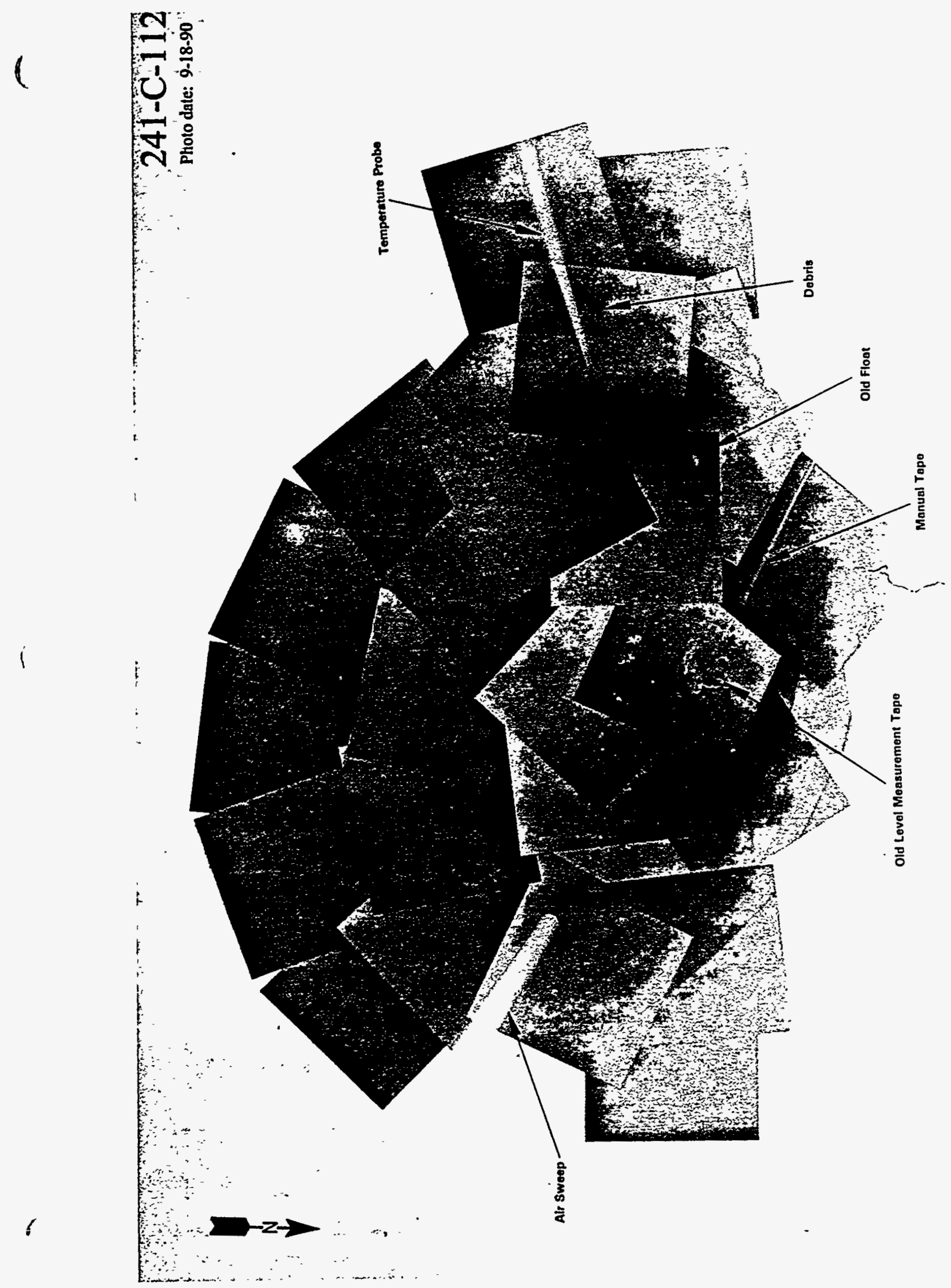


7.13 Tank 241-C-201

7.13.1 241-C-201 Tank History

\subsubsection{Waste History Tank 241-C-201}

Tank 241-C-201 began to operate in 1947 by receiving metal waste and was filled March through November. Tank 241-C-201 was removed from service in the first quarter of. 1976 and was not intended for reuse. The tank was actively restricted in the first quarter of 1977 and was declared inactive in the last quarter of 1977. Interim stabilization was completed in March 1982. Level adjustments were made in March 1982, April 1982, and April 1990. Intrusion prevention was completed in December 1982 . . .Tank. 241-C-201 was...consider.ed. an assumed leaker in 1988 with a leak volüme of-550 "gal-" (See-sketch-ES-TKS-E62-for a graphical representation of the Tank 241-C-201 level history.)

\subsubsection{Temperature History 241-C-201}

The single thermocouple tree in Tank 241-C-201 has 11 thermocouple probes to record temperature data. The mean temperature of the first daily readings was $64.5^{\circ} \mathrm{F}$. A sum of the squares regression Iine fit for all the thermocouples shows a slight decrease in temperature with little variability in the data. The median temperature is $63^{\circ} \mathrm{F}$ with a minimum of $59^{\circ} \mathrm{F}$ and a maximum of $69^{\circ} \mathrm{F}$. Refer to the supporting documents for a more thorough review of the temperature data (Brevick 1994).

\subsubsection{Integrity of Tank 241-C-201}

Tank 241-C-201 is categorized as an assumed leaker and is interim stabilized with intrusion prevention completed. The Tank 241-C-201 surface level is monitored quarterly with a manual tape through riser 5 . A graphical representation of the surface level measurements from January 1991 to the present can be found in the supporting documents (Brevick, 1994). The surface level has remained steady for the past 3 years with the readings ranging from 11 to $13.25 \mathrm{in}$. wells.

Tank 241-C-201 does not have any drywells or liquid observation

\subsubsection{Current Status of Tank 241-C-201}

Tank 241-C-201 entered service in 1953 and currently stores 2,000 gal of waste. The waste is comprised entirely of sludge with no of pumpable liquid remaining. The tank is identified as a low-heat load tank, and is passively ventilated, and is categorized as an assumed leaker with interim stabilization and intrusion prevention completed. Tank 241-C-201 is not in a cascade series but is hooked to a diversion box. The following plan view and tank cross section depict the approximate waste level and riser configuration. Tank 241-C-201 has 10 risers and 12-in. riser no.7 is available for use. 


\subsubsection{Inventory estimate 241-C-201}

The following tank layer volume approximation that follows was derived from the Los Alamos National Laboratories Waste status and Transaction Record Summary (Agnew 1994). The estimated inventory of Tank 241-C-201 is also presented.

\subsubsection{In-Tank Photograph 241-C-201}

The Tank 241-C-201 photo shows a black and yellow sludge surface with no liquid. Approximately 2,000 gal of waste are in the tank which measures about 1 ft deep. The white spot on the left edge of four of the photos is part of the camera system and is not part of the tank. The debris may: be: an rold thermocoupd:ew... The unknown: risers. do not show on any the drawings; therefore, it is impossible to determine their size and purpose. The tank was level adjusted as a result of the photo.

7.13.3 Synopsis Tank 241-C-201

(To be completed.) 
$-89 \varepsilon-$

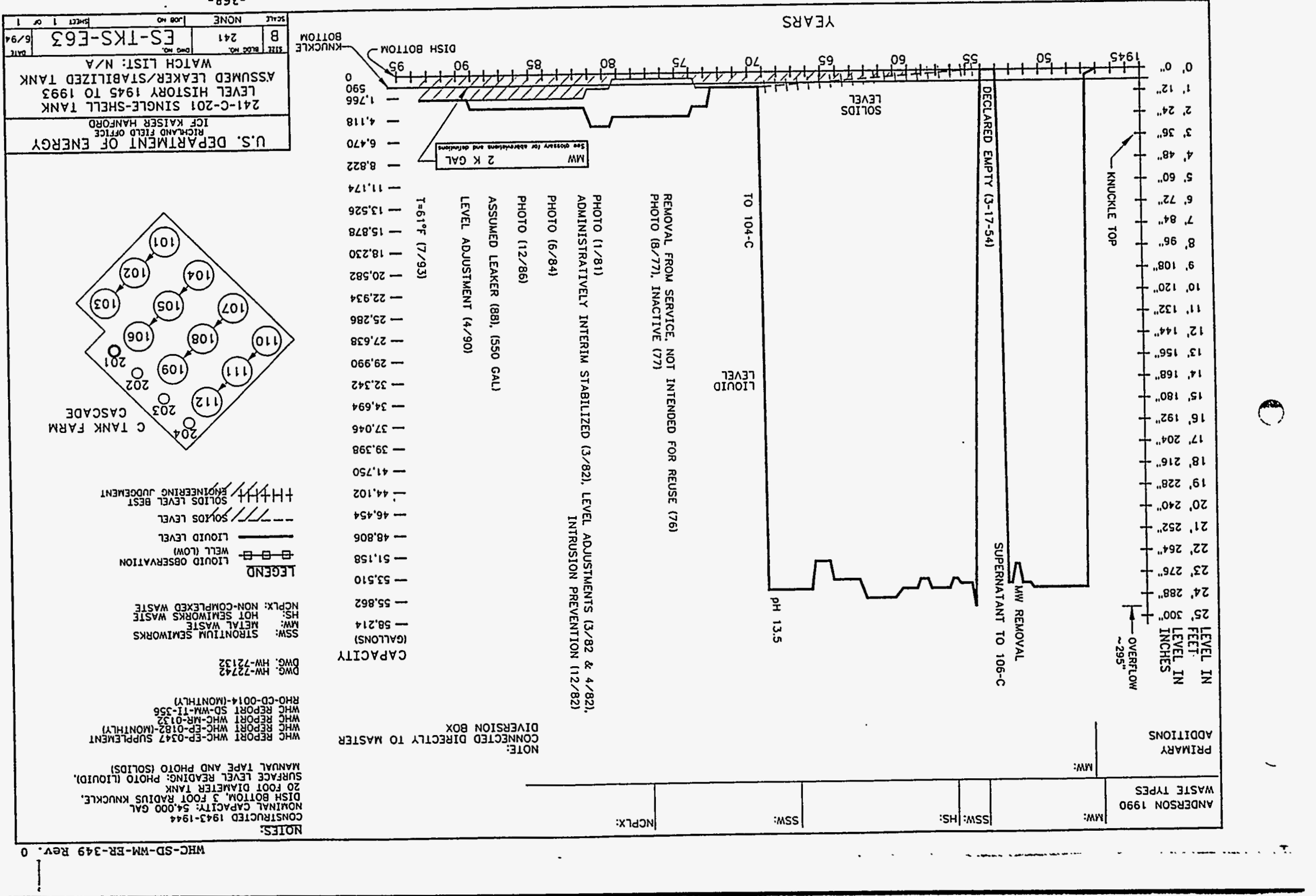


WHC-SD-WM-ER-349, Rev. 0

\begin{tabular}{|c|c|c|c|}
\hline \multicolumn{4}{|c|}{ Single-Shell Tank 241-C-201 } \\
\hline \multicolumn{4}{|c|}{ Solids Composite Inventory Estimate } \\
\hline \multicolumn{4}{|c|}{ 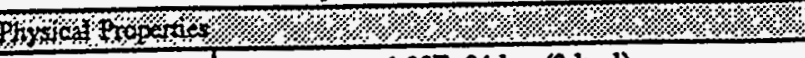 } \\
\hline Tolal Solid Waste & \multicolumn{3}{|c|}{$1.28 \mathrm{E}+04 \mathrm{~kg}(2 \mathrm{kgal})$} \\
\hline Heat load & \multicolumn{3}{|c|}{$1.67 \mathrm{E}-02 \times W(5.68 \mathrm{E}+01 \mathrm{BTU} / \mathrm{hr})$} \\
\hline Bulk Density & \multicolumn{3}{|c|}{$1.70(\mathrm{~g} / \propto)$} \\
\hline Void Fraction & \multicolumn{3}{|c|}{0.20} \\
\hline Water wr\% & \multicolumn{3}{|c|}{47.24} \\
\hline TOC wr\% C (wet) & \multicolumn{3}{|c|}{0.00} \\
\hline \multicolumn{4}{|c|}{ Whongas 6 on } \\
\hline $\mathrm{Na}^{\mathbf{* 1}}$ & 11.98 & $1.62 \mathrm{E}+05$ & $2.08 \mathrm{E}+03$ \\
\hline $\mathrm{Al}^{+3}$ & 요 & 0 & 0 \\
\hline $\mathrm{Fe}^{+3}(\operatorname{total} \mathrm{Fe})$ & 0 & $\cdot 0$ & 0 \\
\hline $\mathrm{Cr}^{+3}:$ & 0): & 0 & 0 \\
\hline$\overline{\mathrm{Bi}^{+3}}$ & 0 & 요 & 0 \\
\hline $\mathrm{La}^{+3}$ & 0] & of & 0 \\
\hline $\mathrm{Ce}^{+3}$ & of & 요 & 0 \\
\hline $\mathrm{Zr}\left(\operatorname{ass} \mathrm{Z} \mathrm{O}(\mathrm{OH})_{2}\right)$ & 0 & 0 & 0 \\
\hline $\mathrm{Pb}^{+2}$ & of & 0) & 0 \\
\hline $\mathrm{Ni}^{4+2}$ & of & 0 & 0 \\
\hline $\mathrm{Sr}^{+2}$ & 0 & 0 & 0 \\
\hline $\mathrm{Mn}^{+4}$ & 이 & 0 & 0 \\
\hline $\mathrm{Ca}^{+2}$ & 의 & 아 & 0 \\
\hline $\mathrm{K}^{+1}$ & 0 & o & 0 \\
\hline $\mathrm{OH}^{-1}$ & 3.06 & $3.07 \mathrm{E}+04$ & $3.94 \mathrm{E}+02$ \\
\hline $\mathrm{NO}^{-1}$ & $2.04 \mathrm{E}-02$ & $7.46 \mathrm{E}+02$ & 9.57 \\
\hline $\mathrm{NO}^{-1}$ & 0 & 0 & 0 \\
\hline $\mathrm{CO}^{2 \cdot}$ & 2.35 & $8.33 E+04$ & 1.07E+03 \\
\hline $\mathrm{PO}^{-3}$ & 2.87 & $1.61 \mathrm{E}+05$ & $2.07 \mathrm{E}+03$ \\
\hline $\mathrm{SO}^{-2}$ & $4.28 \mathrm{E}-02$ & $2.43 \mathrm{E}+03$ & 31.13 \\
\hline $\mathrm{Si}$ (as $\mathrm{SiO}_{3}{ }^{-2}$ ) & 0 & 0 & 0 \\
\hline$F^{-1}$ & 0 & 0 & 0 \\
\hline $\mathrm{Cl}^{-1}$ & 0 & 아 & 0 \\
\hline $\mathrm{C}_{6} \mathrm{H}_{5} \mathrm{O}_{7}{ }^{3}$ & 0 & of & 0 \\
\hline $\mathrm{EDTA}^{-4}$ & 0 & of & 0 \\
\hline HEDTA ${ }^{-3}$ & of & 0 & 0 \\
\hline $\mathrm{NTA}^{-3}$ & 0 & 요 & 0 \\
\hline glycolase & 0 & 0 & 0 \\
\hline acelate & of & 0 & 0 \\
\hline oxalate ${ }^{-2}$ & 아 & of & 0 \\
\hline DBP & of & of & 0 \\
\hline $\mathrm{NPH}$ & of & 0) & 0 \\
\hline $\mathrm{CCl}_{4}$ & of & of & 0 \\
\hline hexone & 0 & 0 & 0 \\
\hline $\mathrm{Fe}(\mathrm{CN})_{8}^{-1}$ & 0 & $0(\mathrm{~g}-\mathrm{mol})$ & \\
\hline 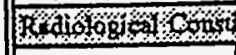 & ong $/ 2 / \%$ & ক/. & \% \\
\hline Pu & & $0.12(\mu \mathrm{Ci} / g)$ & $2.65 \mathrm{E}-02(\mathrm{~kg})$ \\
\hline $\mathrm{U}$ & $0.75(\mathrm{M})$ & $1.06 \mathrm{E}+05(118 / 8)$ & $1.36 \mathrm{E}+03(\mathrm{~kg})$ \\
\hline Cs & $3.13 \mathrm{E}-03(\mathrm{Ci} / \mathrm{L})$ & $1.85(\mu \mathrm{Ci} / \mathrm{g})$ & $23.73(\mathrm{Ci})$ \\
\hline$S r$ & $0.32(\mathrm{Ci} / \mathrm{L})$ & $1.91 \mathrm{E}+02(\mu \mathrm{C} / \mathrm{g})$ & $2.45 \mathrm{E}+03$ (Ci) \\
\hline
\end{tabular}

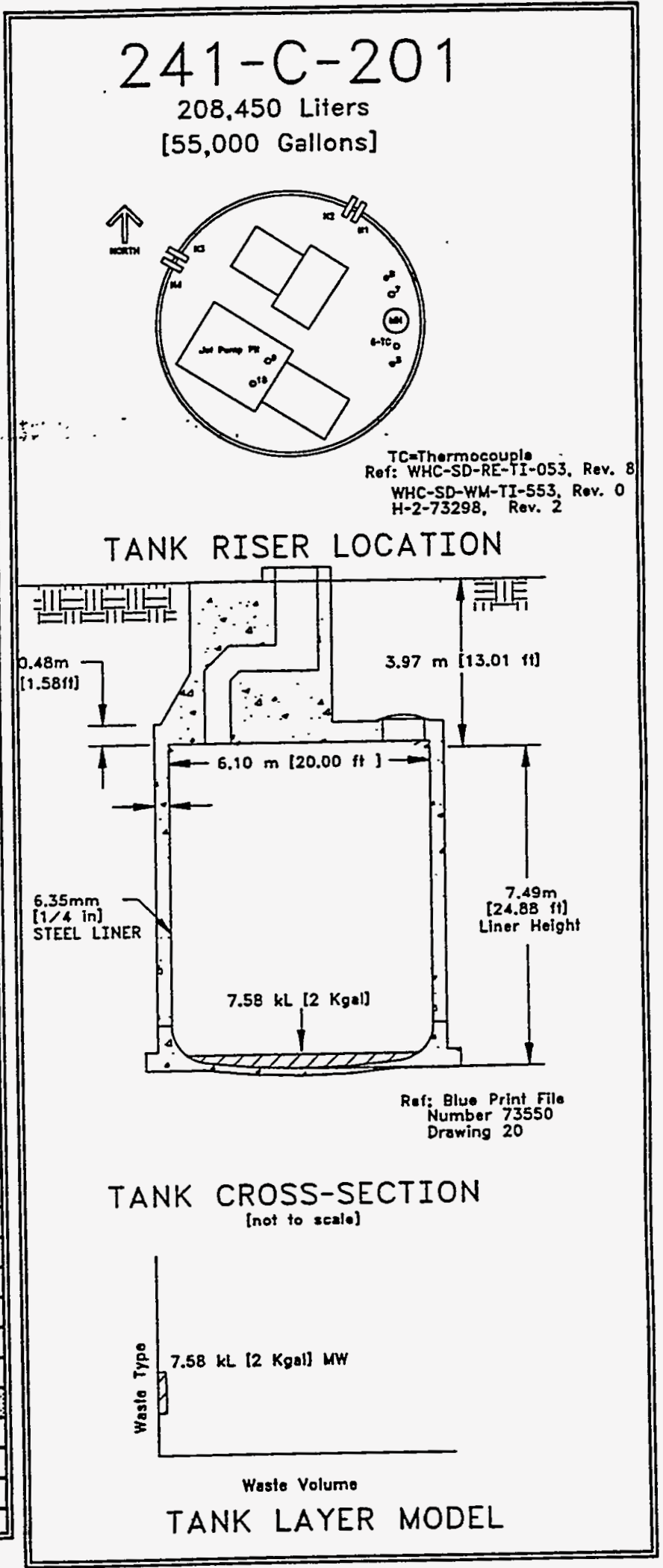

- Composite inventory exchdes supersatant, diatomacoous carth, and cement

Unkowows in tank inventory are assigned by Tark Layecing Model (TLM) 


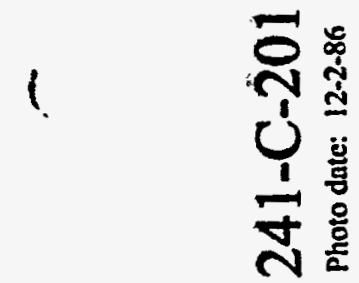

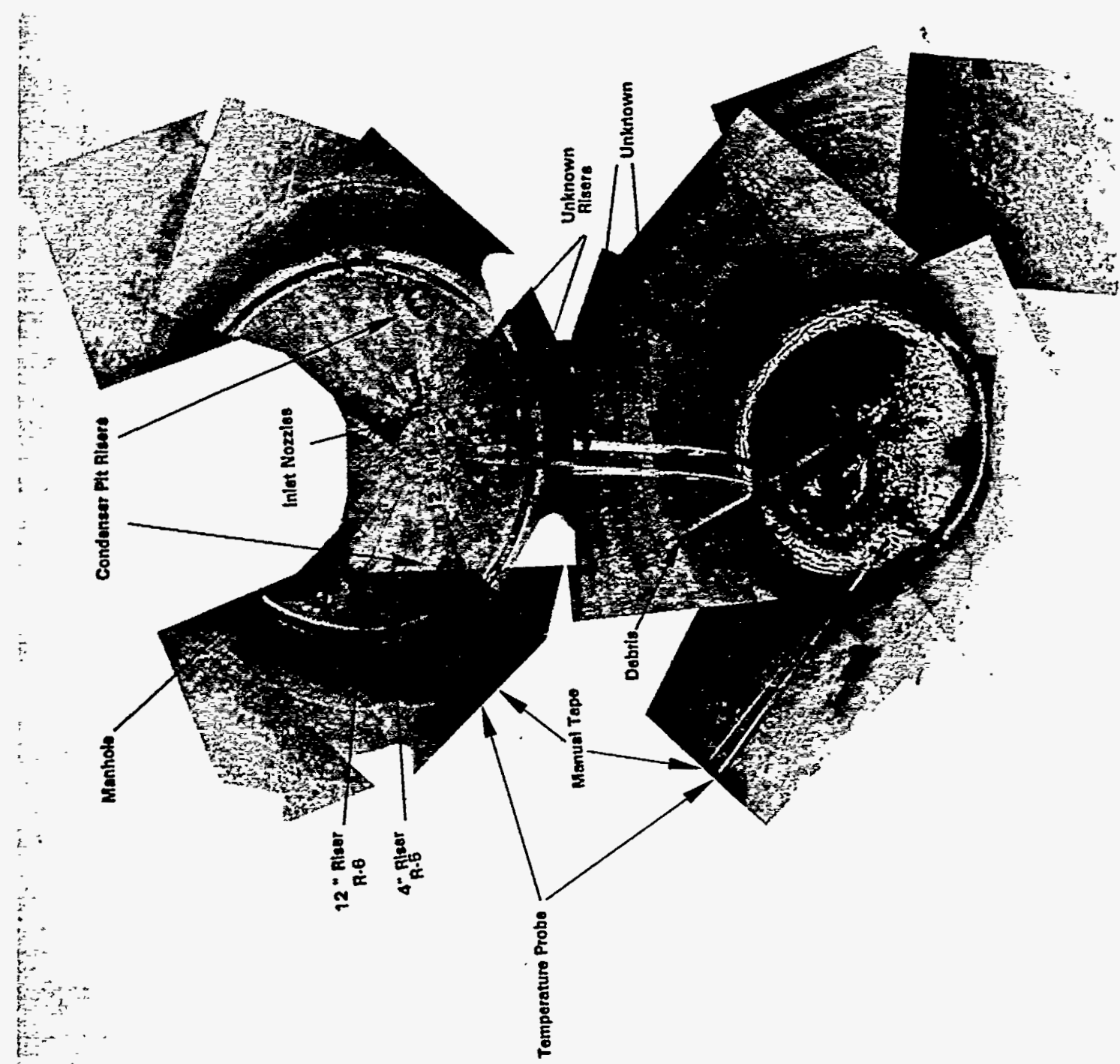

1 
7.14.1 241-C-202 Tank History

7.14.1.1 Waste History Tank 241-C-202

Tank 241-C-202 began to fill with metal waste during March and November of 1947. Tank 241-C-202 was removed from service in the Eirst quarter of 1976 and was not intended for reuse. The tank was actively restricted in the first quarter of 1977 and was declared inactive in the third quarter of 1977. Tank 241-C-202 was interim stabilized in August 1981. Intrusion prevention was completed in December 1982. The tank was declared an assumed leaker in 1988 with a leak volume of $450 \mathrm{gal}$. (See sketch ES-TKS-E64. Forwa.graphigal:-representation of: the Tank 241-C202 Ievel history.)

\subsubsection{Temperature History 241-C-202}

The single thermocouple tree in Tank 241-C-202 has 11 thermocouple probes. The mean temperature of the first daily recorded readings was $58^{\circ} \mathrm{F}$. A sum of the squares regression line fit for the data shows a slight increase in temperature with a small amount of variability. The median temperature is $61^{\circ} \mathrm{F}$ with a minimum of $56^{\circ} \mathrm{F}$ and a maximum of $68^{\circ} \mathrm{F}$. Refer to the supporting documents for a more thorough review of the temperature data (Brevick 1994).

\subsubsection{Integrity of Tank 241-C-202}

Tank 241-C-202 is categorized as an assumed leaker and is interim stabilized with intrusion prevention completed. The Tank 241-C-202 surface level is monitored quarterly with a manual tape through riser 5 . A graphical representation of the surface level measurements from January 1991 to the present can be found in the supporting documents (Brevick, 1994). The surface level has remained steady for the past 3 years with the readings ranging from 7.25 to $8.5 \mathrm{in}$. welis.

Tank 241-C-202 does not have any drywells or liquid observation

\subsubsection{Current Status of Tank 241-C-202}

Tank 241-C-202 entered service in 1947 and currently stores 1,000 gal of waste comprised entirely of sludge with no pumpable liquid remaining. The tank is identified as a low-heat load tank, is passively ventilated, and is considered empty, and is categorized as an assumed leaker with interim stabilization and intrusion prevention completed. Tank 241-C-202 is not in a cascade series but is connected to a diversion box. The following plan view and tank cross section depict the approximate waste level and riser configuration. Tank 241-C-202 has 10 risers and 12 -in. riser no.7 is available for use. 
7.14.2.1 Inventory estimate 241-C-202

The following tank layer volume approximation was derived from the Los Alamos National Laboratories Waste Status and Transaction Record Summary (Agnew 1994). The estimated inventory of Tank 241-C-202 is also presented.

\section{.7.14.2.2 In-Tank Photograph 241-C-202}

The Tank 241-C-202 photo shows approximately 1,000 gal of yellow sludge which is about 1 ft deep. The debris may be an old thermocouple.

7.14.3 Synopsis Tank 241-C-202

(To be completed.) 


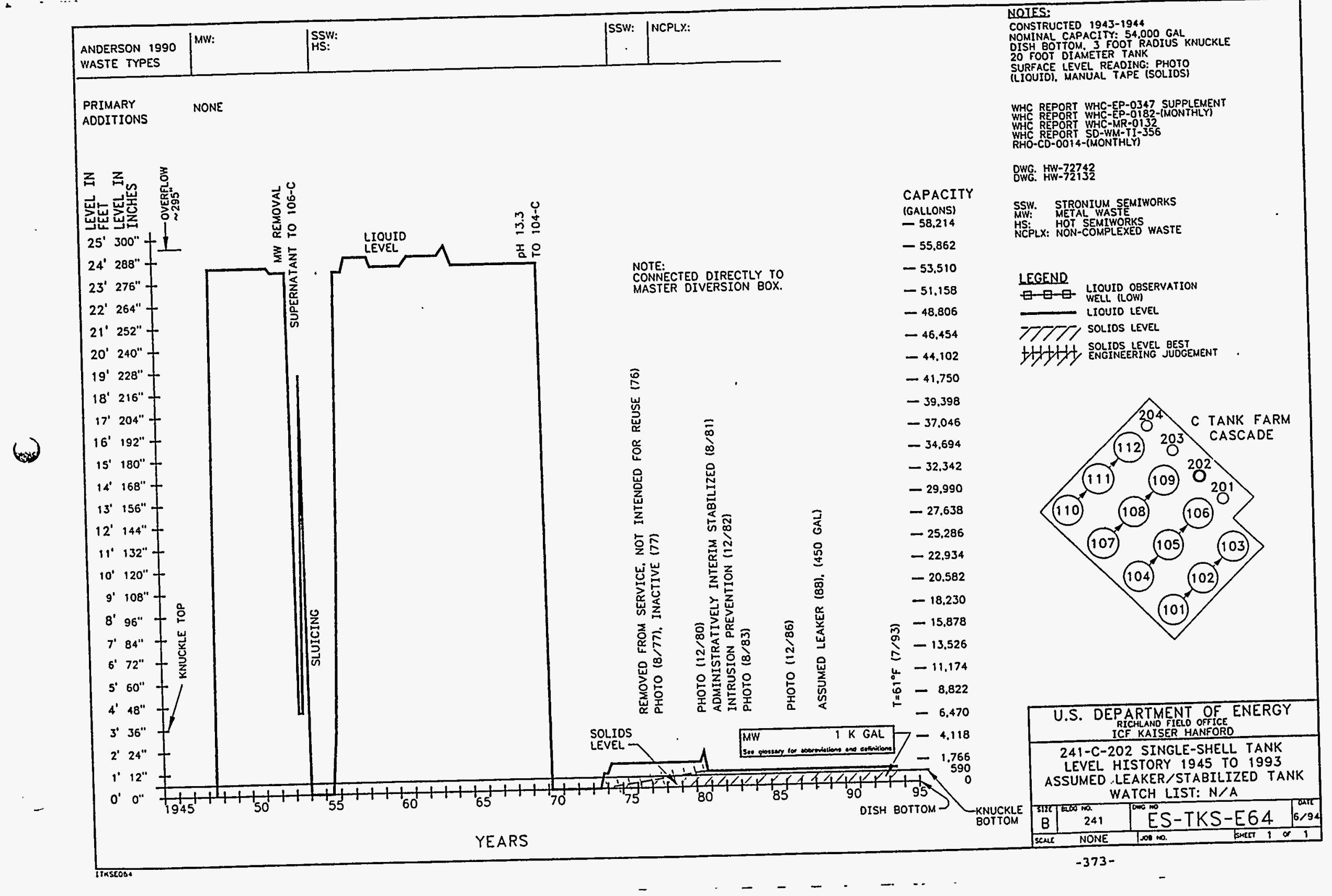




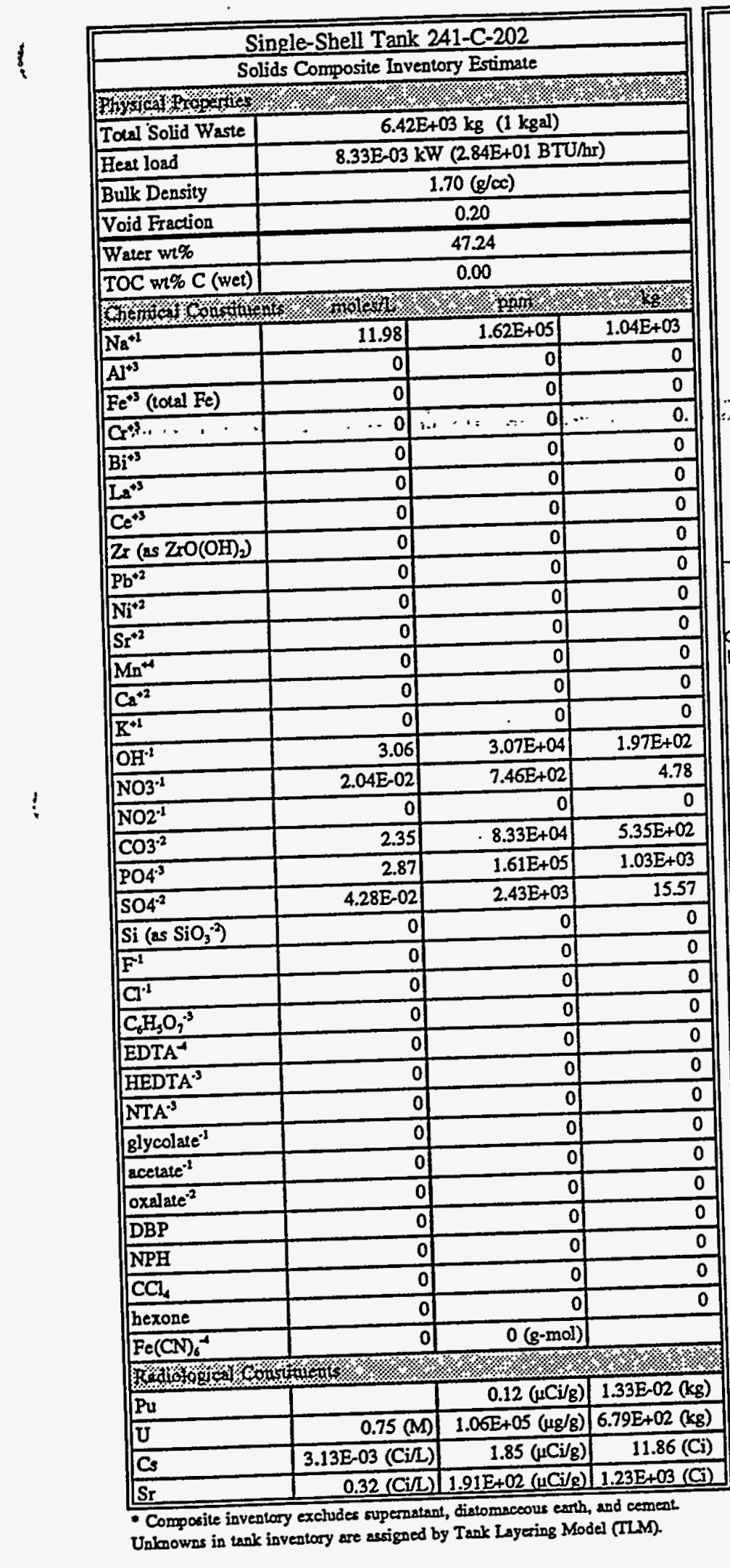

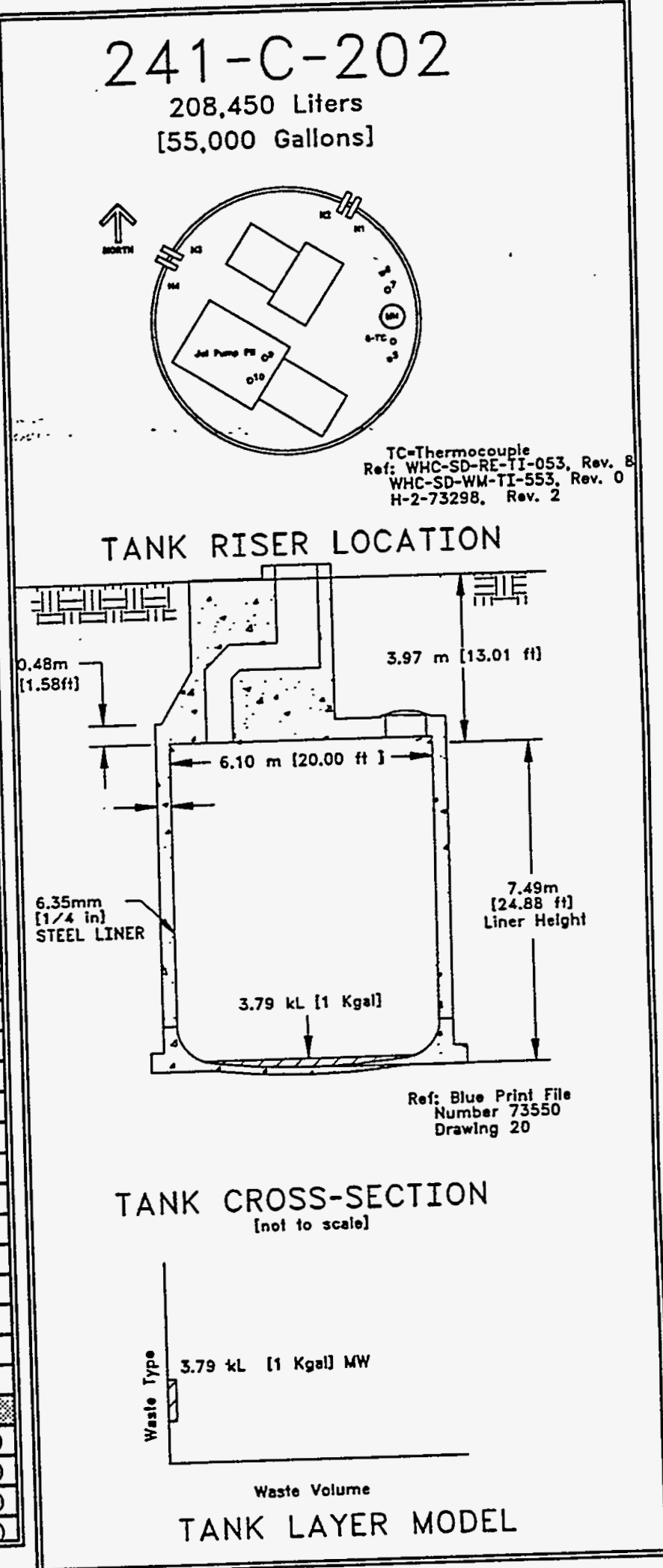




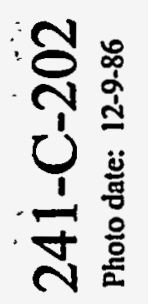

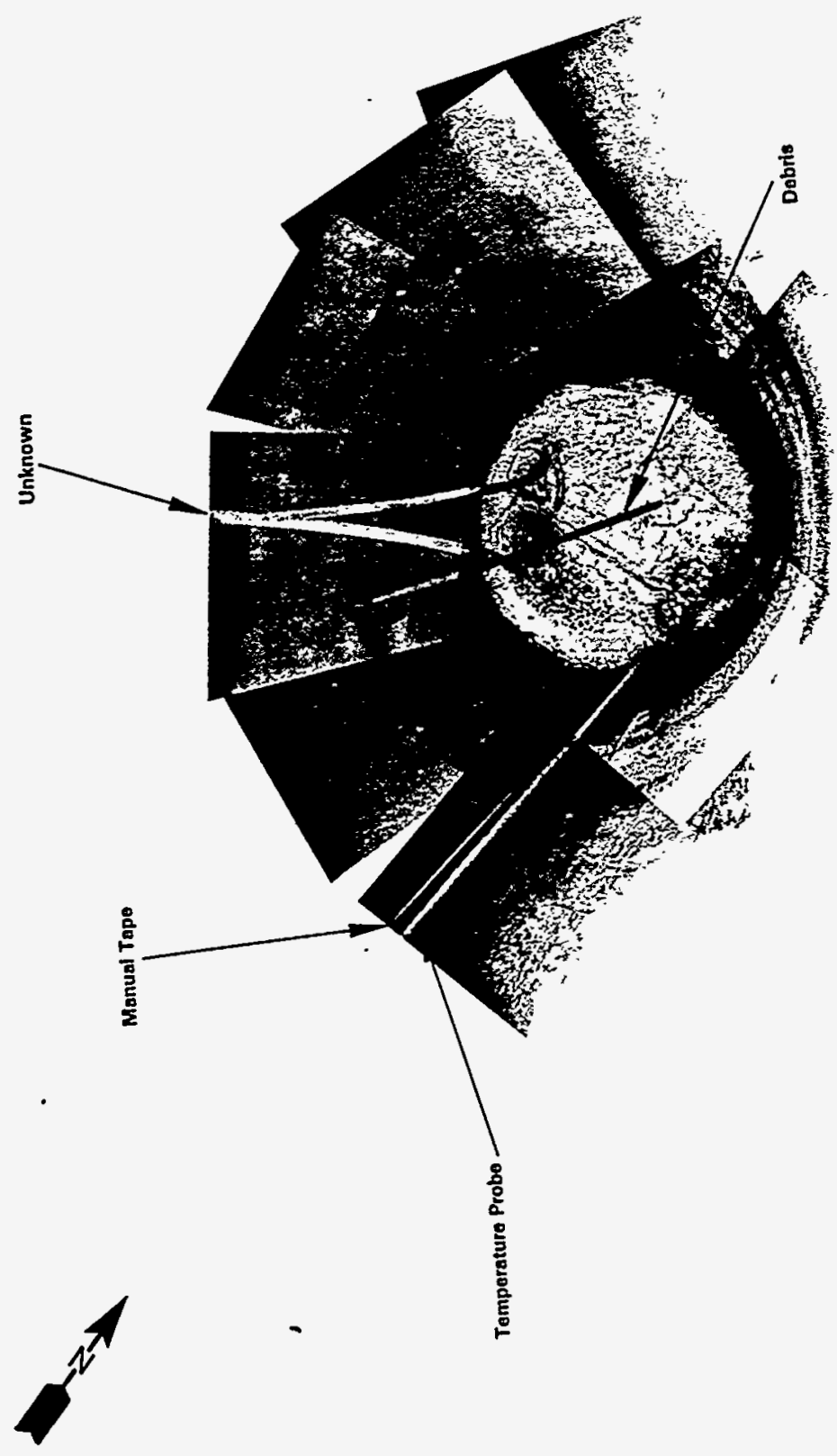


WHC-SD-WM-ER-349, Rev. 0

7.15 Tank 241-C-203

7.15.1 241-C-203 Tank History

7.15.1.1 Waste History Tank 241-C-203

Tank 241-C-203 began to operate in 1947 by receiving metal waste and was filled during March and November. In the first quarter of 1976 , Tank 241-C-203 was removed from service and was not intended for reuse. The tank was declared inactive in the fourth quarter of 1977 . Interim stabilization was completed in March 1982 . Intrusion prevention was in place in December 1982. Tank 241-C-203 was declared an assumed leaker in 1984 with a leak volume of 400 gal. In December 1986, a cracked sludge surface. with no visible liquids was observed. (See sketch EsTKS-E65 for"a-graphicaz-representation-of-the-"Tank" 241-E-203 level history.)

\subsubsection{Temperature History 241-C-203}

The single thermocouple tree in Tank 241-C-203 has 11 thermocouple probes. The mean temperature of the first daily recorded readings was $51^{\circ} \mathrm{F}$. A sum of the squares regression line fit for the applicable data shows a temperature increase with a small amount of variability. The median temperature is $58^{\circ} \mathrm{F}$ with a minimum of $50^{\circ} \mathrm{F}$ and a maximum of $67^{\circ} \mathrm{F}$. Refer to the supporting documents for a more thorough review of the temperature data (Brevick 1994).

\subsubsection{Integrity of Tank 241-C-203}

Tank 241-C-203 is categorized as an assumed leaker and is interim stabilized with intrusion prevention completed. The Tank 241-C-203 surface level is monitored quarterly with a manual tape through riser 5 . A figure that graphically represents the surface level measurements from January 1991 to the present can be found in the supporting documents (Brevick, 1994). The surface level has remained steady for the past 3 years with the readings ranging from 21.5 to $19.5 \mathrm{in}$. wells.

Tank 241-C-203 does not have any drywells or liquid observation

\subsubsection{Current Status of Tank 241-C-203}

Tank 241-C-203 entered service in 1947 and currently stores 5,000 gal of waste comprised entirely of sludge with no pumpable liquid remaining. The tank is identified as a low-heat load tank, is passively ventilated, and is categorized as an assumed leaker with interim stabilization and intrusion prevention completed. Tank 241-C-203 is not in a cascade series. The following plan view and tank cross section depict the approximate waste level and riser configuration. Tank 241-C203 has 10 risers and 12-in. riser no.7 is available for use. 
WHC-SD-WM-ER-349, ReV. 0

\subsubsection{Inventory estimate 241-C-203}

The following tank layer volume approximation was derived from the Los Alamos National Laboratories Waste Status and Transaction Record Summary (Agnew 1994). The estimated inventory of Tank 241-C-203 is also presented.

\subsubsection{In-Tank Photograph 241-C-203} $\cdots$

The Tank 241-C-203 photo shows approximately 5,000 gal of black and yellow sludge which measures about $2.5 \mathrm{ft}$ deep. The debris may be an old thermocouple. The risers do not appear on any drawings; therefore, their size and purpose is unknown.

$7.15 .3^{\cdots}$ Sÿnopsis Tañk $241=c=203 \cdots$

(To be completed.) 


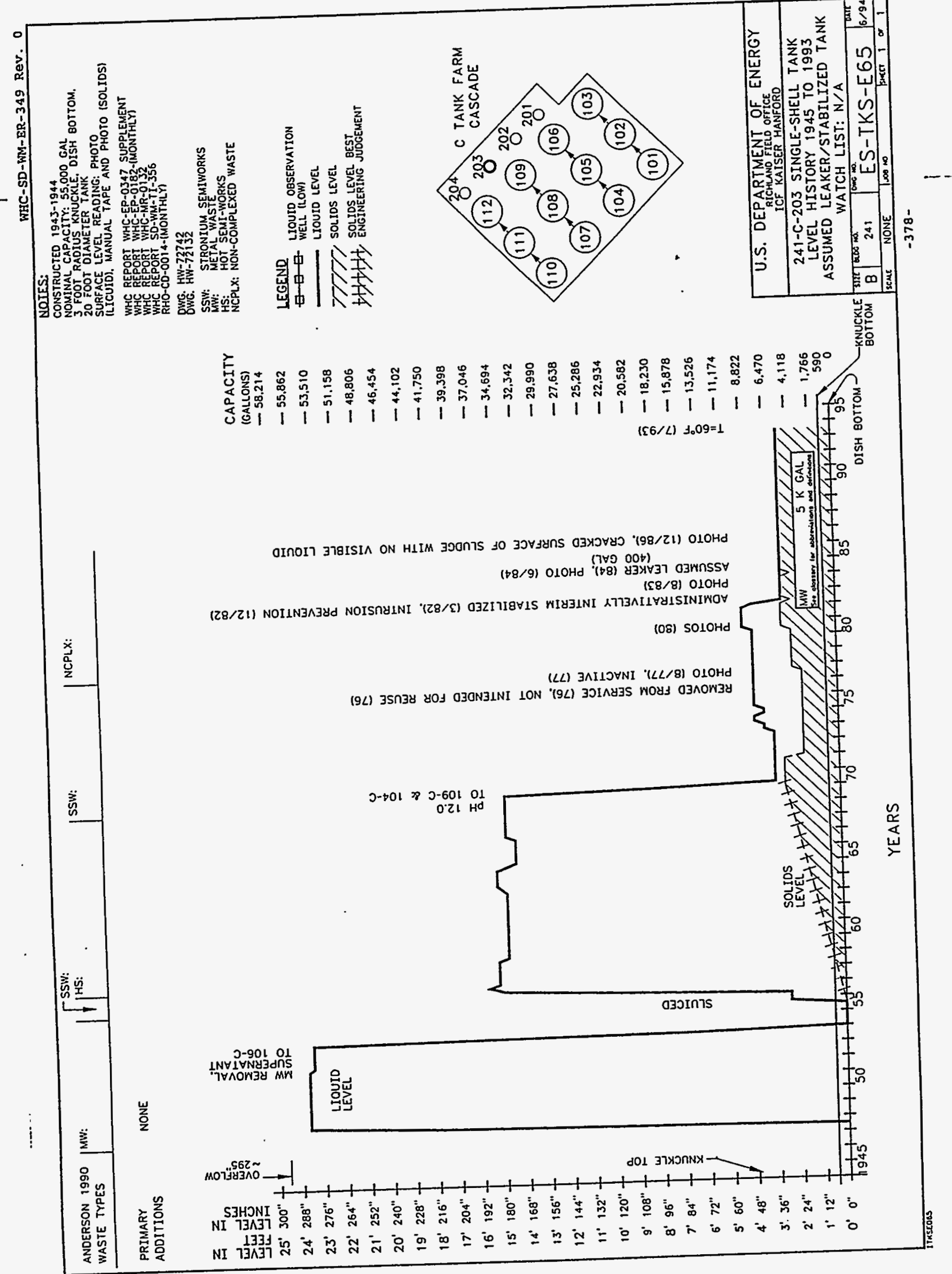




\begin{tabular}{|c|c|c|c|}
\hline \multicolumn{4}{|c|}{ Single-Shell Tank 241-C-203 } \\
\hline \multicolumn{4}{|c|}{ Solids Composite Inventory Estimate } \\
\hline \multicolumn{4}{|c|}{ 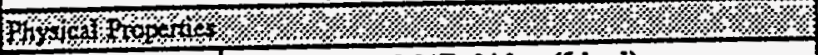 } \\
\hline Tolal Solid Waste & \multicolumn{3}{|c|}{$3.21 \mathrm{E}+04 \mathrm{~kg}(5 \mathrm{kgal})$} \\
\hline Heat load & \multicolumn{3}{|c|}{$4.16 \mathrm{E}-02 \mathrm{~kW}(1.42 \mathrm{E}+02 \mathrm{BTU} / \mathrm{hr})$} \\
\hline Bulk Density & \multicolumn{3}{|c|}{$1.70(\mathrm{~g} / \mathrm{c})$} \\
\hline Void Fraction & \multicolumn{3}{|c|}{0.20} \\
\hline Water wh\% & \multicolumn{3}{|c|}{47.24} \\
\hline TOC w $\%$ C (wet) & \multicolumn{3}{|c|}{0.00} \\
\hline \multicolumn{4}{|c|}{ 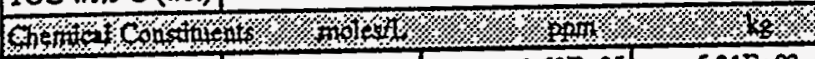 } \\
\hline \begin{tabular}{l|l}
$\mathrm{Na}^{+1}$ & \\
\end{tabular} & 11.98 & $1.62 \mathrm{E}+05$ & $5.21 \mathrm{E}+03$ \\
\hline $\mathrm{Al}^{+3}$ & 0 & 0 & 0 \\
\hline $\mathrm{Fe}^{43}(\operatorname{total} \mathrm{Fe})$ & 0 & o. & 0 \\
\hline $\mathrm{Cr}^{43}$ & - & 0:: & 0 \\
\hline $\mathrm{Bi}^{+3}$ & of & of & 0 \\
\hline $\mathrm{La}^{\mathrm{a}}$ & of & 0] & 0 \\
\hline $\mathrm{Ce}^{43}$ & 0 & of & 0 \\
\hline $\mathrm{Zr}\left(\mathrm{as} \mathrm{ZrO}\left(\mathrm{OH}_{2}\right)_{2}\right.$ & 句 & of & 0 \\
\hline $\mathrm{Pb}^{+2}$ & 0 & 0 & 0 \\
\hline $\mathrm{Ni}^{+2}$ & 0 & of & 0 \\
\hline $\mathrm{Sr}^{42}$ & of & 0] & 0 \\
\hline $\mathrm{Mn}^{+4}$ & 요 & of & 0 \\
\hline $\mathrm{Ca}^{42}$ & of & of & 0 \\
\hline $\mathrm{K}^{+1}$ & 0 & 0 & 0 \\
\hline $\mathrm{OH}^{\cdot 2}$ & 3.06 & $3.07 \mathrm{E}+04$ & $9.84 \mathrm{E}+02$ \\
\hline $\mathrm{NO3}^{-1}$ & $2.04 \mathrm{E}-02$ & $7.46 \mathrm{E}+02$ & 23.92 \\
\hline $\mathrm{NO}^{\cdot 1}$ & o & 0 & 0 \\
\hline $\mathrm{CO}^{2}$ & 2.35 & $8.33 E+04$ & $2.67 \mathrm{E}+03$ \\
\hline $\mathrm{PO}^{-3}$ & 2.87 & $1.61 \mathrm{E}+05$ & $5.17 \mathrm{E}+03$ \\
\hline $\mathrm{SO}^{-2}$ & $4.28 \mathrm{E}-02$ & $2.43 \mathrm{E}+03$ & 77.83 \\
\hline $\mathrm{Si}\left(\right.$ as $\left.\mathrm{SiO}_{3}^{-2}\right)$ & of & of & 0 \\
\hline $\mathrm{F}^{-1}$ & of & 0 & 0 \\
\hline $\mathrm{C}^{-1}$ & o) & 0 & 0 \\
\hline $\mathrm{C}_{6} \mathrm{H}_{5} \mathrm{O}_{7}^{-3}$ & of & of & 0 \\
\hline $\mathrm{EDTA}^{4}$ & of & 0 & 0 \\
\hline HEDTA ${ }^{3}$ & of & of & 0 \\
\hline NTA $^{-3}$ & of & 0 & 0 \\
\hline Blycolate-1 & 0 & of & 0 \\
\hline scetate ${ }^{-1}$ & of & of & 0 \\
\hline oxalate & 0 & of & 0 \\
\hline DBP & of & 0 & 0 \\
\hline $\mathrm{NPH}$ & of & 이 & 0 \\
\hline $\mathrm{CCl}_{8}$ & 0 & of & 0 \\
\hline hexone & 0 & 0 & 0 \\
\hline $\mathrm{Fe}(\mathrm{CN})_{6}$ & 0 & $0(\mathrm{~g}-\mathrm{mol})$ & \\
\hline \multicolumn{4}{|c|}{ 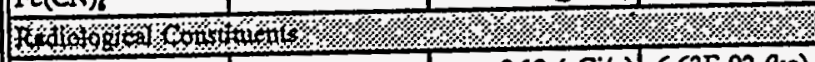 } \\
\hline $\mathrm{Pu}$ & & $0.12(\mu \mathrm{Ci} / \mathrm{B})$ & $6.63 \mathrm{E}-02(\mathrm{~kg})$ \\
\hline $\mathrm{U}$ & $0.75(\mathrm{M})$ & $1.06 \mathrm{E}+05(\mu \mathrm{g} / \mathrm{g})$ & $3.39 \mathrm{E}+03(\mathrm{~kg})$ \\
\hline Cs & $3.13 \mathrm{E}-03(\mathrm{Ci} / \mathrm{L})$ & $1.85(\mu \mathrm{Ci} / g)$ & $59.32(\mathrm{Ci})$ \\
\hline Sr & $0.32(\mathrm{C} / \mathrm{L})$ & $1.91 \mathrm{E}+02(\mu \mathrm{Cl} / \mathrm{g})$ & $6.14 \mathrm{E}+03(\mathrm{G})$ \\
\hline
\end{tabular}

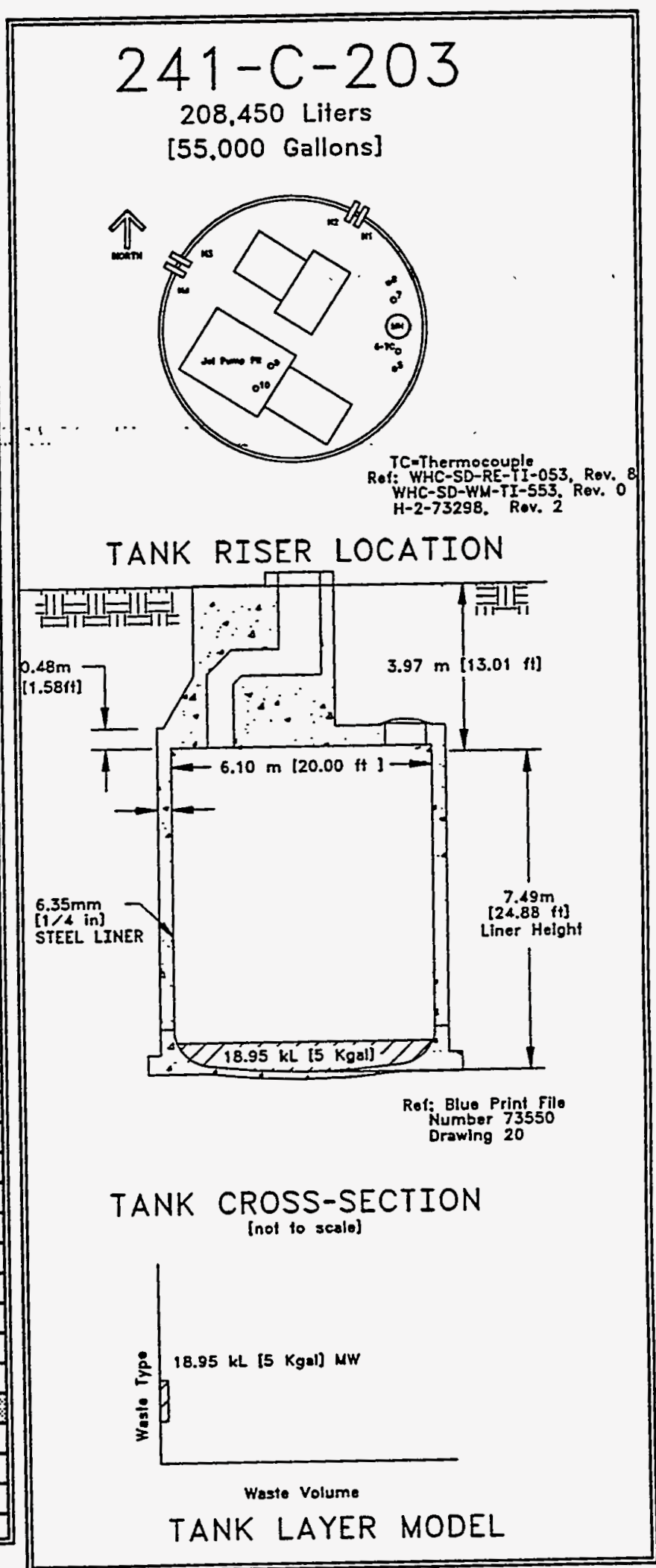




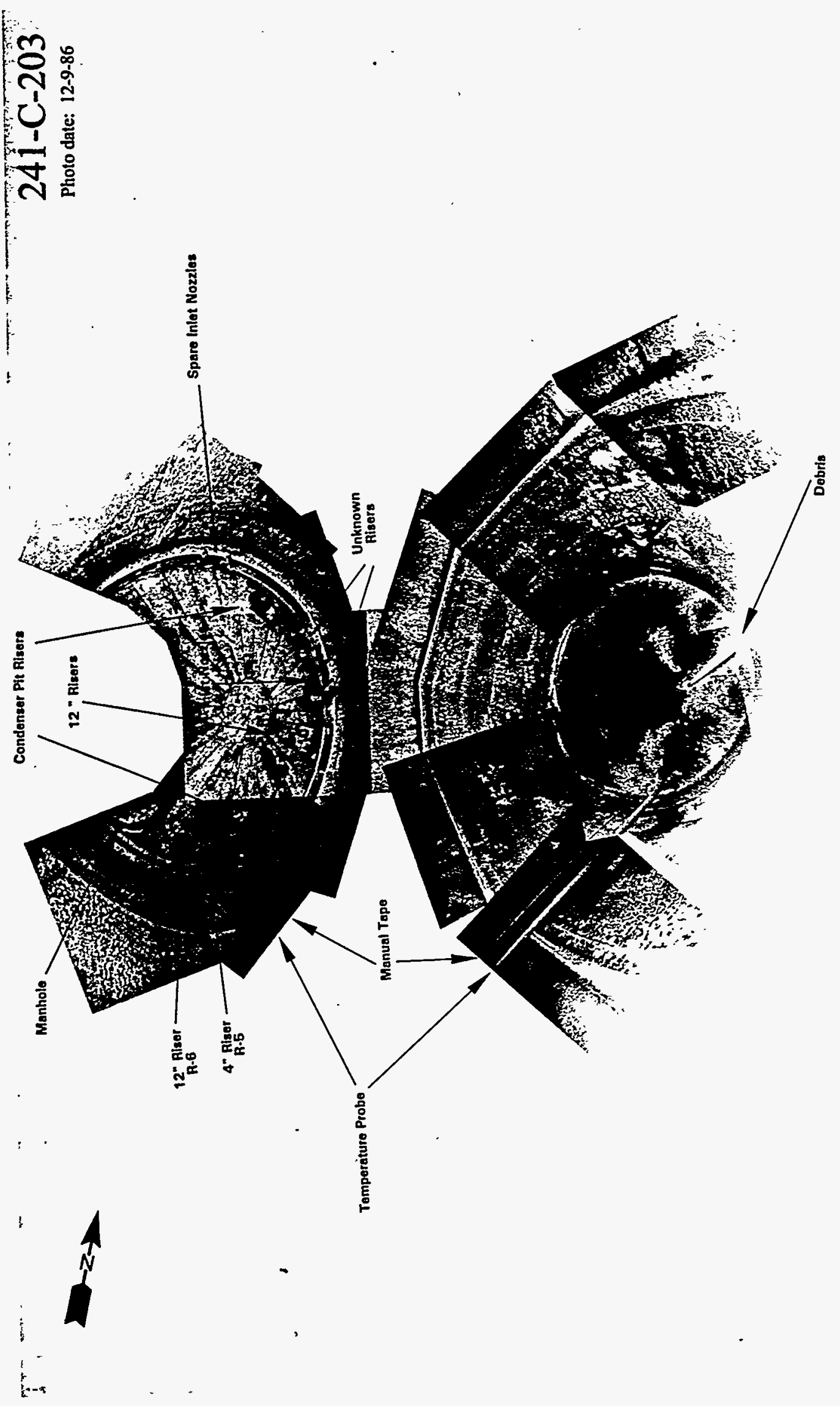


7.16.1 241-C-204 Tank History

7.16.1.1 Waste History Tank 241-C-204

Tank 241-C-204 began to operate in early January 1948 by receiving metal waste, and it was full by the:end of January 1948. Tank 241-C-204 was not intended for reuse by $1976^{\circ}$ and was declared inactive in 1977. A level adjustment was completed in April 1982. Interim stabilization was completed in September 1982. Intrusion prevention was in place in December 1982. Tank 241-C-204 was declared an assumed leaker in 1988 with a leak volume of $350 \mathrm{gal}$. (See sketch ES-TKS-E66 for a graphical representation of , the .Tank ..241-C-204. level. history..) -

\subsubsection{Temperature History 241-C-204}

There is no verification that Tank 241-C-204 ever had a thermocouple tree.

\subsubsection{Integrity of Tank 241-C-204}

Tank 241-C-204 is categorized as an assumed leaker and is interim stabilized with intrusion prevention completed. The Tank 241-C-204 surface level is monitored daily with a manual tape through riser 5 . A graphical representation of the surface level measurements from January 1991 to the present can be found in the supporting documents (Brevick, 1994). The current waste level baseline was established on November 8 , 1993. Since that time, the readings have ranged between 8.25 and 8.75 in., with one unexplained reading of $102 \mathrm{in.}$ wells.

Tank 241-C-204 does not have any drywells or liquid observation

\subsubsection{Current Status of Tank 241-C-204}

Tank 241-C-204 entered service in 1948 and currently stores 3,000 gal of waste comprised entirely of sludge with no pumpable liquid remaining. The tank is identified as a low-heat load tank, is passively ventilated, and is categorized as an assumed leaker with interim stabilization and intrusion prevention completed. Tank 241-C-204 is not in a cascade series but is connected to a diversion box. The following plan view and tank cross section depict the approximate waste level and riser configuration. Tank 241-C-204 has 10 risers and 12-in. riser no.7 is available for use.

\subsubsection{Inventory estimate 241-C-204}

The following tank layer volume approximation was derived from the Ios Alamos National Laboratories Waste Status and Transaction Record Summary (Agnew 1994). The estimated inventory of Tank 241-C-204 is also presented. 


\subsubsection{In-Tank Photograph 241-C-204}

The Tank 241-C-204 photo shows a black and yellow sludge with a small pool of supernatant. There are approximately 3,000 gal of waste which measures about 1.5 ft deep. The unknown risers shown do not appear on any drawings; therefore, it is difficult to determine their size and purpose. The glowing dot at the bottom center of the photo is a reflection of the flash. The debris may be an old thermocouple tree or assembly.

\subsubsection{Synopsis Tank 241-C-204}

(To be completed.) 
$0-N$ a

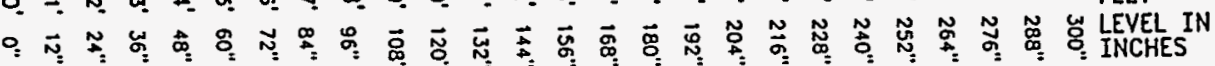

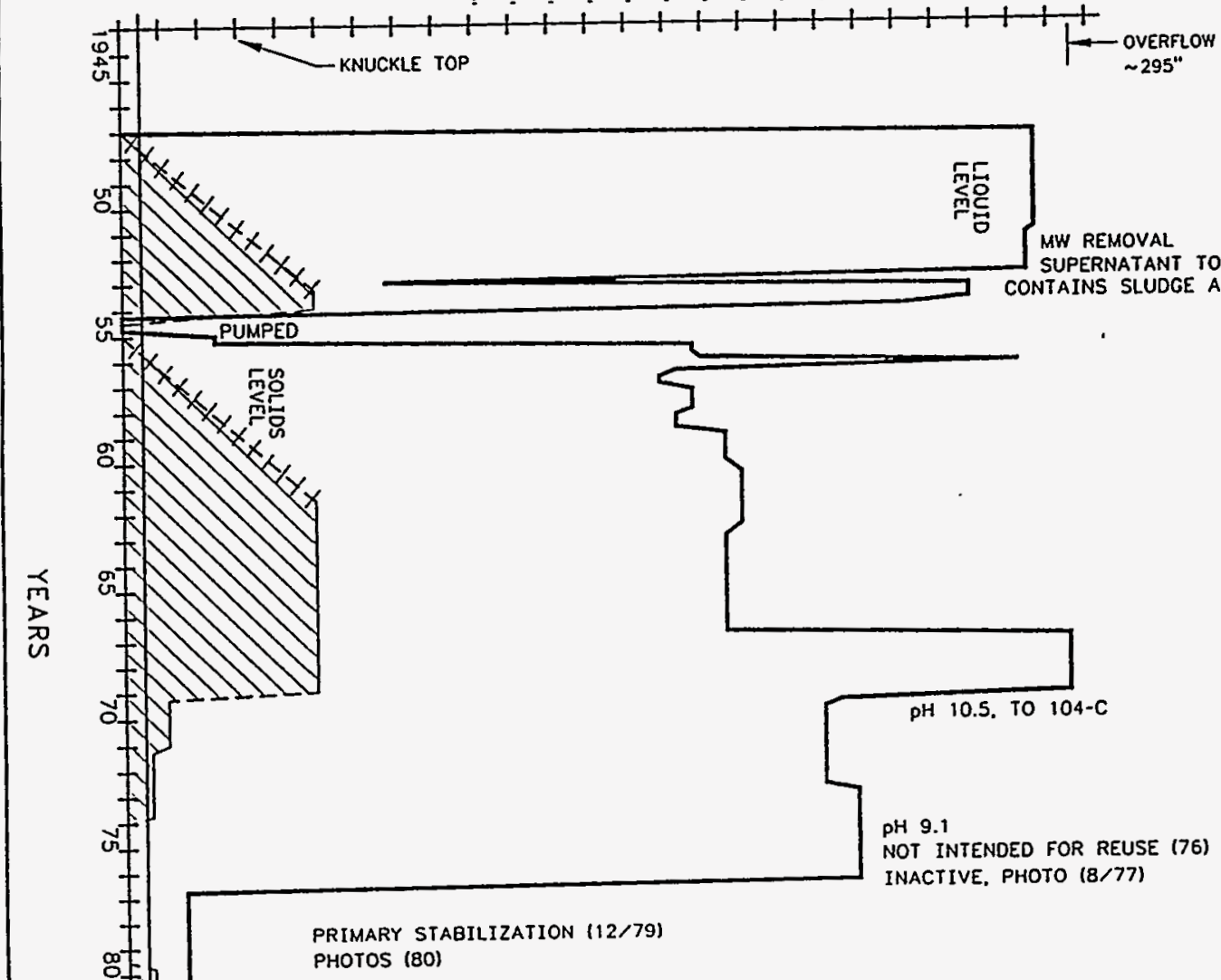

PHOTOS (8O)

F. LEVEL ADJUSTMENT (4/82). ADMINISTRATIVELY INTERIM STABILIZATION $(9 / 82)$, INTRUSION PREVENTION $(12 / 82)$ PHOTO $(8 / 83)$

PHOTO $(12 / 86)$

ASSUMED LEAKER (88), (350 GAL)

of

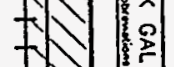

thy

\&A

皮

然

N

THERMOCOUPLES OUT OF SERVICE (7/93)

ơf $1 \begin{array}{lllllllllllllllllllllllll}1 & 1 & 1 & 1 & 1 & 1 & 1 & 1 & 1 & 1 & 1 & 1 & 1 & 1 & 1 & 1 & 1 & 1 & 1 & 1 & 1 & 1 & 1 & 1 & 5\end{array}$

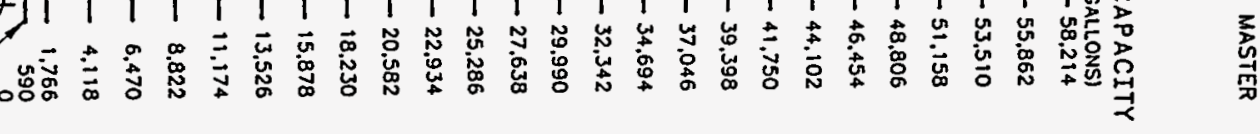
跧 西
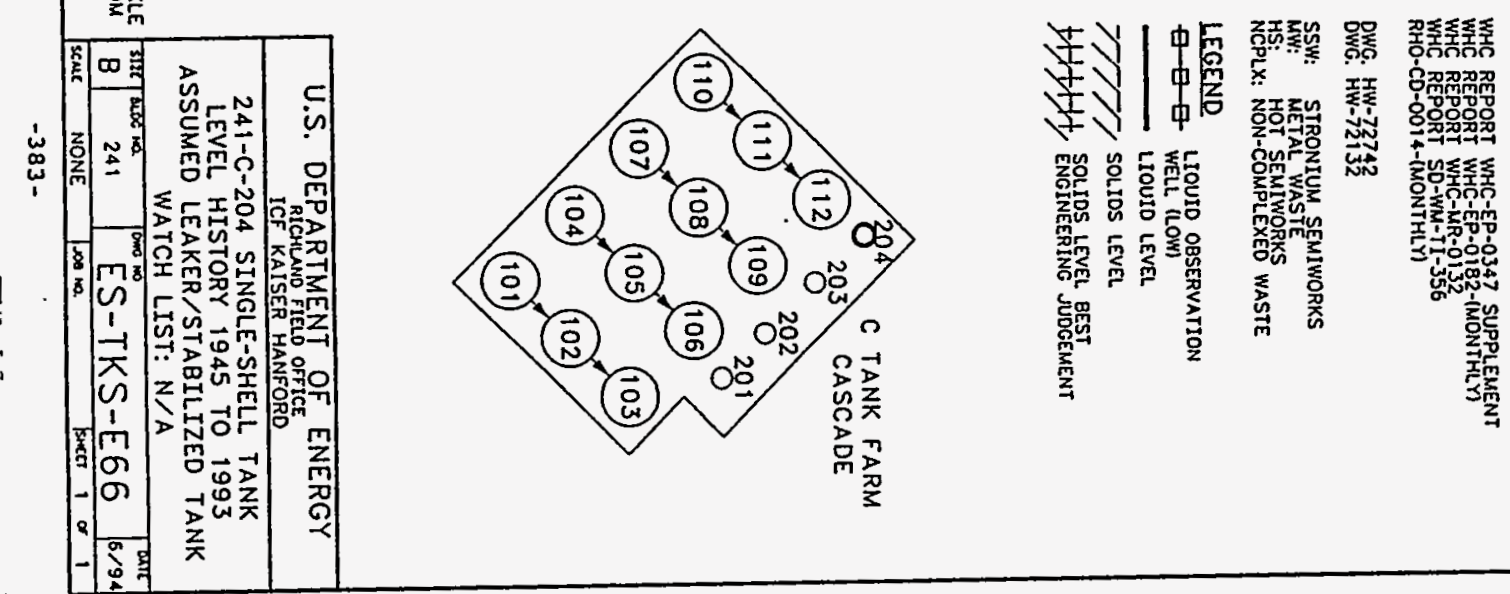
WHC-SD-WM-ER-349, Rev. 0

\begin{tabular}{|c|c|c|c|}
\hline \multicolumn{4}{|c|}{ Single-Shell Tank 241-C-204 } \\
\hline \multicolumn{4}{|c|}{ Solids Composite Inventory Estimate } \\
\hline AHow & $\%$ & \%1\% & 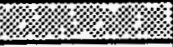 \\
\hline Total Solid Waste & \multicolumn{3}{|c|}{$1.92 \mathrm{E}+04 \mathrm{~kg}(3 \mathrm{kgal})$} \\
\hline \begin{tabular}{|l|l|} 
Heat load \\
\end{tabular} & \multicolumn{3}{|c|}{$2.50 \mathrm{E}-02 \mathrm{~kW}(8.52 \mathrm{E}+01 \mathrm{BTU} / \mathrm{hr})$} \\
\hline Bulk Density & \multicolumn{3}{|c|}{$1.70(g / \infty)$} \\
\hline Void Fraction & \multicolumn{3}{|c|}{0.20} \\
\hline Water wt\% & \multicolumn{3}{|c|}{47.24} \\
\hline TOC wr\% C (wet) & \multicolumn{3}{|c|}{0.00} \\
\hline \multicolumn{4}{|c|}{ 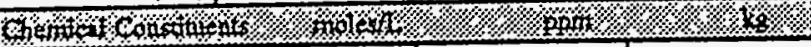 } \\
\hline $\mathrm{Na}^{+1}$ & 11.98 & $1.62 \mathrm{E}+05$ & $3.13 \mathrm{E}+03$ \\
\hline $\mathrm{Al}^{03}$ & 0 & 0 & 0 \\
\hline $\mathrm{Fe}^{+3}($ total Fe $)$ & 0] & 이 & 0 \\
\hline $\mathrm{Cr}^{+3}$ & 0 & 0] & 0. \\
\hline $\mathrm{Bi}^{+3}$ & of & 0 & 0 \\
\hline $\mathrm{La}^{\mathrm{s}^{3}}$ & of & 요 & 0 \\
\hline $\mathrm{Ce}^{+3}$ & 0 & 0 & 0 \\
\hline $\mathrm{Zr}$ (as $\left.\mathrm{ZrO}(\mathrm{OH})_{2}\right)$ & 요 & 0 & 0 \\
\hline $\mathrm{Pb}^{+2}$ & 의 & of & 0 \\
\hline $\mathrm{Ni}^{+2}$ & 0) & 0 & 0 \\
\hline $\mathrm{Sr}^{+2}$ & 요 & of & 0 \\
\hline $\mathrm{Mn}^{-\infty}$ & o & of & 0 \\
\hline $\mathrm{Ca}^{42}$ & 0 & 0] & 0 \\
\hline $\mathrm{R}^{+1}$ & 0 & 0 & 0 \\
\hline $\mathrm{OH}^{\cdot 2}$ & 3.06 & $3.07 \mathrm{E}+04$ & $5.90 \mathrm{E}+02$ \\
\hline $\mathrm{NO}^{-1}$ & 2.04E-02 & $7.46 \mathrm{E}+02$ & 14.35 \\
\hline $\mathrm{NO}^{-1}$ & of & 0 & 0 \\
\hline $\mathrm{CO}^{-2}$ & 2.35 & $8.33 \mathrm{E}+04$ & $1.60 \mathrm{E}+03$ \\
\hline $\mathrm{PO4}^{-3}$ & 2.87 & $1.61 \mathrm{E}+05$ & $3.10 \mathrm{E}+03$ \\
\hline $\mathrm{SO}^{.2}$ & $4.28 \mathrm{E}-02$ & $2.43 \mathrm{E}+03$ & 46.70 \\
\hline $\mathrm{Si}$ (as $\mathrm{SiO}_{3}^{-2}$ ) & 0 & 0 & 0 \\
\hline $\mathrm{F}^{-1}$ & of & 0 & 0 \\
\hline $\mathrm{C}^{-1}$ & of & 0 & 0 \\
\hline $\mathrm{C}_{6} \mathrm{H}_{3} \mathrm{O}_{7}{ }^{3}$ & of & 0 & 0 \\
\hline $\mathrm{EDTA}^{-4}$ & 요 & of & 0 \\
\hline HEDTA ${ }^{3}$ & 요 & of & 0 \\
\hline NTA $^{-3}$ & of & 0) & 0 \\
\hline Blycolate ${ }^{-1}$ & of & 0 & 0 \\
\hline acetate & 0 & of & 0 \\
\hline oxal ate. & of & 0 & 0 \\
\hline DBP & of & 0 & 0 \\
\hline $\mathrm{NPH}$ & 0 & 0 & 0 \\
\hline $\mathrm{CCl}_{4}$ & of & 0 & 0 \\
\hline hexone & 의 & 0 & 0 \\
\hline $\mathrm{Fe}(\mathrm{CN})^{2}$ & 0 & $0(\mathrm{~g}-\mathrm{mol})$ & \\
\hline \multicolumn{4}{|c|}{ 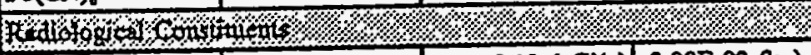 } \\
\hline $\begin{array}{ll}\mathrm{Pu} \\
\end{array}$ & & $0.12(\mu \mathrm{C} / \mathrm{g})$ & $3.98 \mathrm{E}-02(\mathrm{~kg})$ \\
\hline $\bar{U}$ & $0.75(\mathrm{M})$ & $1.06 \mathrm{E}+05(\mu \mathrm{g} / \mathrm{g})$ & $2.04 \mathrm{E}+03(\mathrm{~kg})$ \\
\hline Cs & $3.13 \mathrm{E}-03(\mathrm{Ci} / \mathrm{L})$ & $1.85(\mu \mathrm{Ci} / \mathrm{g})$ & $35.59(\mathrm{Cj})$ \\
\hline St & $0.32(\mathrm{C} / \mathrm{L})$ & $1.91 \mathrm{E}+02(\mu \mathrm{C} / \mathrm{g})$ & $3.68 \mathrm{E}+03(\mathrm{Ci})$ \\
\hline
\end{tabular}

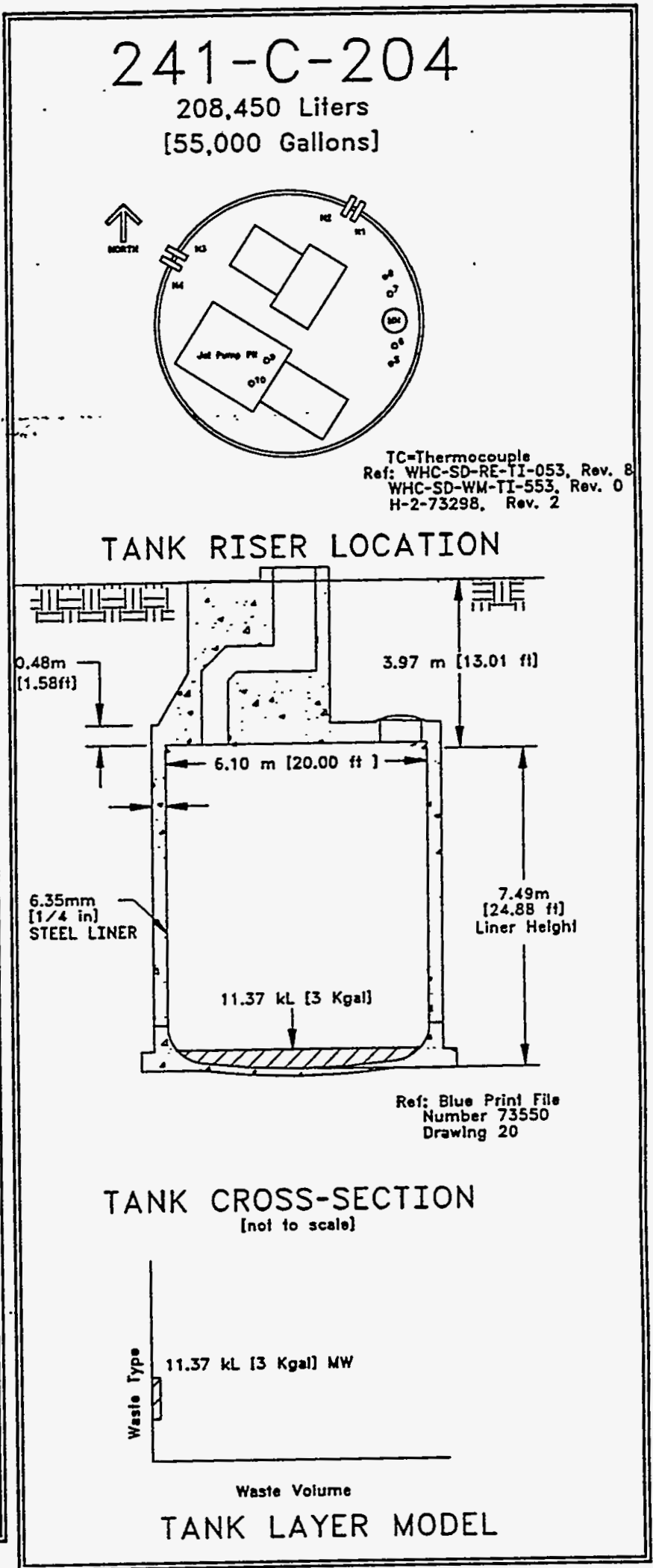




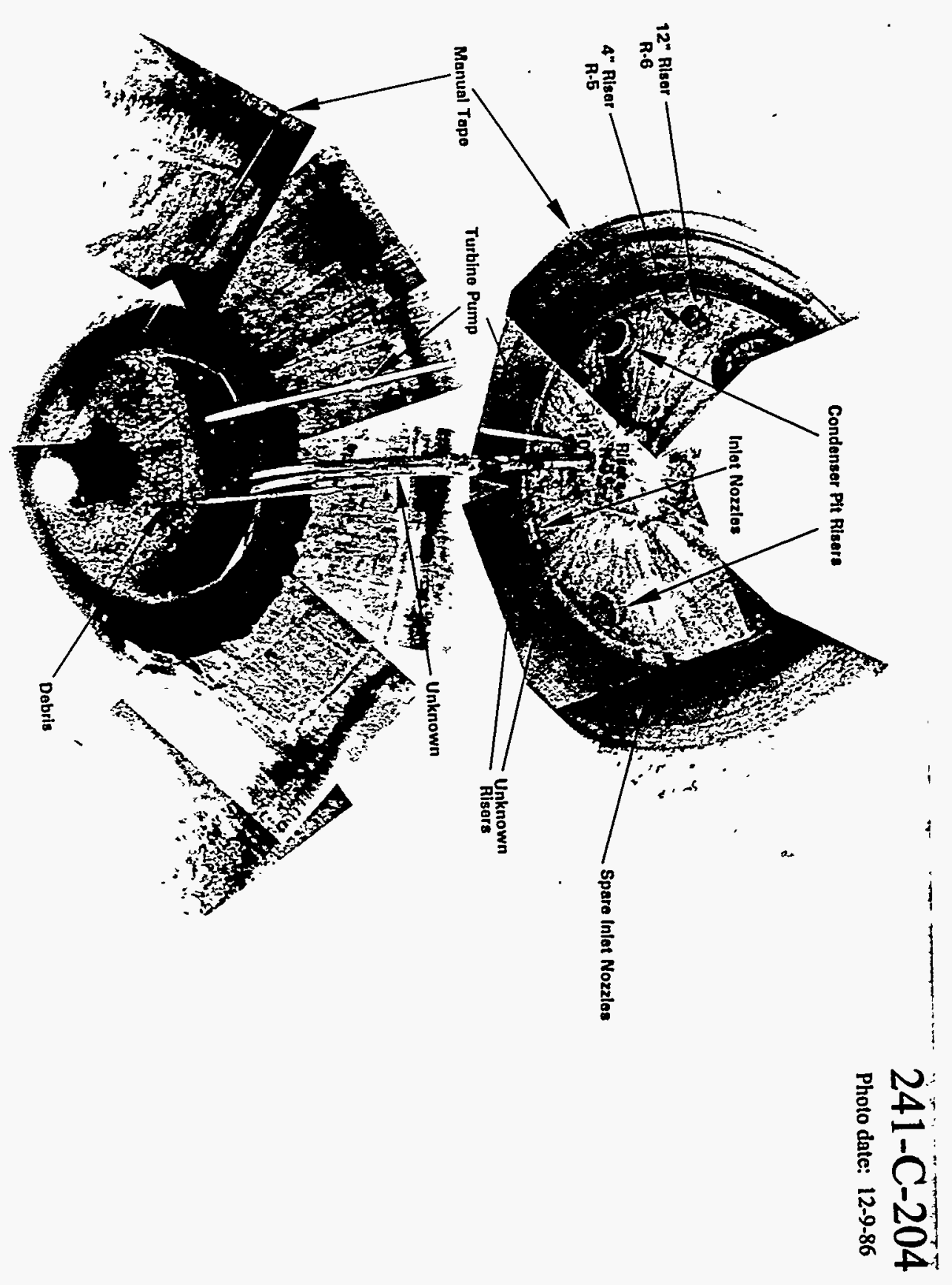


D

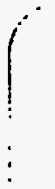

-
$\vdots$
$\vdots$
$\vdots$

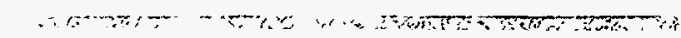

$x-\cdots$ 


\section{GLOSSARY}

\subsection{7}

0.33

1

IAYIN.

IAZIN

$1 C$

1CEB

$1 \mathrm{CS}$

Ist Generation Tank

$222-B$

$222-C$

$222-T$

$222-U$

224

224-F

2312

$242-A$

$242-B$

242-S

242-T

2AYIN
Transaction flag key-monthly volumes derived from semiannual reports.

Transaction flag. key-monthly volumes derived from quarterly reports.

Monthly report.

See Waste Abbreviations.

See Waste Abbreviations.

See Waste Abbreviations.

See Waste Abbreviations.

See Waste Abbreviations.

The original tank design encompassing Tank Farms B, C, T, U (excluding the 200 series tanks), and BX. These tanks have an operating capacity of 530,000 gal, a 75-ft diameter, a 12-in. dish bottom, and a 4-ft knuckle. Also see Type II tanks.

See Facilities.

See Facilities.

See Facilities.

See Facilities.

See Waste Abbreviations.

See Waste Abbreviations.

See Waste Abbreviations.

See Facilities.

See Facilities.

See Facilities.

See Facilities.

See Waste Abbreviations. 
2AZIN

$2 C$

2nd Generation Tank

2SYIN

3

3AWIN

3rd Generation Tank

4th Generation Tank

$5-6$

$5-6 \#$

SAWIN

5th Generation Tank

6

GAWIN

A Plant (PUREX)

AI SLTCK

A2 SLTSLRY

Active Tank
See Waste Abbreviations.

See Waste Abbreviations.

Same as original tank design (1st generation, or type II) except the operating capacity was increased to $758,000 \mathrm{gal}$. Also see Type III tanks.

See Waste Abbreviations.

Quarterly report.

See Waste Abbreviations. . . .

The first generation of the type IV tanks, contains the Sx Tank Farm only. These tanks have a 1,000,000 gal operating capacity, a 75-ft diameter, a 14.875-in. dish bottom, and no knuckle. Also see Type IV tanks.

The second generation of the type IV tanks, contains the A Tank Farm only. These tanks are the same as the 3 rd generation except they have a flat bottom. Also see Type IV tanks.

See Waste Abbreviations.

Cells 5 and 6 from B-Plant.

See Waste Abbreviations.

The third generation of the type IV tanks, contains the AX Tank Farm only. These tanks are the same as the 4 th generation with the addition of grid drain slots beneath the steel liner bottom.

Semiannual report.

See Waste Abbreviations.

See Facilities.

See IAANL Defined Waste List.

See LANL Defined Waste List.

A tank that contains more than 33,000 gal of waste and/or is still involved in waste management operations. 
Active Drywel1

$A D D$

ADJ

AGE, AGING

Aging Waste

Airlift Circulator

Annulus

$A R$ Vault

AR

Assumed Leaker

Assumed Re-leaker

Assumed Leaking Tank

\section{B SLTCK}

B

B Plant (222-B)
Drywell in which radiation readings of greater than 50 counts/second are detected. To be considered active, the readings must be consistent as to depth and radiation level for repeated readings.

Add primary waste from process.

Adjustment. to waste amount-see CORR.

Waste Abbreviation.

High-level, first-cycle solvent extraction waste. from the PUREX Plant (NCAW).

The airlift circulators are installed in tanks used to age wastes. The circulators promote mixing of the supernate and prevent agglomeration of radionuclides. By maintaining motion within the body of liquid, the circulators minimize superheat buildup and, consequently, minimize bumping.

A vessel space in the form of a ring; the space between concentric walls.

A structure containing tanks and chemical processing equipment that is used for waste processing or storage operations.

See IANI Defined Waste List.

A waste storage tank for which surveillance data, in the past, has indicated a loss of liquid attributed to a breach of integrity.

A designation that exists after a tank has been declared an "assumed leaker" and then the surveillance data indicate a new loss of liquid attributed to a breach of integrity.

In 1984, the criteria designations of "suspect leaker," "questionable integrity," "confirmed leaker, " "declared leaker,"

"borderline," and "dormant" were merged into one category now reported as "assumed leaker."

See LANL Defined Waste List.

See Waste Abbreviations.

See Facilities. 
Background Radiation

Baseline

BFSH

BL

$\mathrm{BLEB}$

BLIX

BLIXB

BNW

BNW

BPDCC

BPDCS

BPDCV

BPFPS

BPLCS

BPLDC

BPLDN

Bumping, Tank Bump

BVCLN

BY SITCK

C Plant $(222-C)$

C PLANT
Radioactivity from naturally occurring sources; primarily radiation from cosmogenic and naturally occurring radionuclides.

A reference; for example, a specified liquid level or radiation level against which new information is compared.

See Waste Abbreviations.

See Waste Abbreviations.

See Waste Abbreviations.

See Waste Abbreviations.

See Waste Abbreviations.

Battelle Northwest Laboratory.

See Waste Abbreviations.

See Waste Abbreviations.

See Waste Abbreviations.

See Waste Abbreviations.

See Waste Abbreviations.

See Waste Abbreviations.

See Waste Abbreviations.

See Waste Abbreviations.

A tank bump occurs when solids overheat in the lower portion of the tank. The hot solids rapidly transfer heat to the liquid, some of which quickly vaporizes. The sudden pressurization caused by vapor generation is called a "bump".

See Waste Abbreviations.

See LANL Defined Waste List.

See Facilities.

See SSW. 
Caisson

Calcine

CARB

CAS

Cascade

CASS

Catch Tanks

CAW

$\mathrm{CC}$

CCGL

CCGR

CCPL

CCPLX

CCW
An underground structure used to store highlevel waste; typical designs include corrugated metal or concrete cylinders, 55gal drums welded end-to-end, and vertical steel pipes below grade.

To heat a substance to a high temperature, but below its melting point, causing loss of volatile constituents such as moisture; refers also to the material produced by this process.

See Waste Abbreviations.

Cascade-see SET and END. This process filled three tanks with one pump using overflow siphoning. Normal use was with a sequence of tarks such as 101, 102, 103, or 110, 111, 112 .

Eleven of the single-shell tank farms (all except the AX Tank Farm) were equipped with overflow lines between tanks. The tanks were connected in series and were placed at different elevations creating a downhill gradient for liquids to flow from one tank to another.

Acronym for Computer Automated Surveillance System.

Small capacity single-shell tanks associated with diversion boxes and diverter stations. The tanks are designed to receive any transfer line cleanout, spills or. leakage from the boxes, or leakage from the adjacent pipe encasement.

Current acid waste; this is PUREX acid HLW.

See Waste Abbreviations.

See Waste Abbreviations.

See Waste Abbreviations.

See Waste Abbreviations.

See Waste Abbreviations.

Concentrated customer waste. 
CDF

CE

CELI 23

CEM

CF

CON

COND

Condensate

Conductivity Probe

Confirmed or

Storage Declared Leaker

COOL

CORR

CP

CPLX

CR Vault

Crib
Composition data file or transaction flag key-unit volume assumed to make stream active.

See Waste Abbreviations.

Waste from cell 23 at B-Plant. Cell 23 contained an evaporator.

See Waste Abbreviations.

See Waste Abbreviations.

Seer Waste:-Abbrevitations:

Condensate-see EVAP, EB.

Iiquid formed from cooling vapors.

A device that completes an electrical circuit when contacted by a conductive material.

The designation of any underground waste tank where the data are considered sufficient to support a conclusion with 95 percent confidence that the tank has leaked.

Change in waste volume due to cooling. See CORR.

Correction to waste amount-see ADJ, LEAK, COOL.

See Waste Abbreviations.

See Waste Abbreviations.

Facility located adjacent to C Farm, used for scavenging campaign following uranium

recovery. Ferrocyanide was added to tank supernatants in $C R$ Vault and the slurry was returned to C-Farm.

A linear excavation approximately $15 \mathrm{ft}$ in depth, with a perforated pipe in the bottom. The ditch is backfilled with broken rock or other loose material and then covered by soil and by a liquid impermeable membrane; the pipe is then used to distribute intermediate level liquid wastes along the crib. 
Crust

CSFD

CSR

CST

CSWLE

CSWLW

CTW

$\mathrm{CW}$

CWP

CWP / ZR

CWP2

CWR

$\operatorname{cx} 70$

D

DBP

DC

DCS

$D E$

DE

DeIiquescent

Desiccant

Diatomaceous Earth
A hard surface layer that has formed on top of the liquid in many waste tanks that contain concentrated solutions.

See Waste Abbreviations.

See Waste Abbreviations.

See Waste Abbreviations.

See Waste Abbreviations.

See Waste Abbreviations.

Caustic waste for makèp.

See Waste Abbreviations

See Waste Abbreviations.

See Waste Abbreviations.

See LANL Defined Waste List.

See Waste Abbreviations.

See Waste Abbreviations.

Transaction Flag Key-Amount by difference.

Dibutyl phosphate.

See Waste Abbreviations.

Acroynm for dilute. caustic solutions

Acronym for diatomaceous earth that was added to Tanks 241-BX-102, -SX-113, -TX-106, and U-104 from 1970 to 1972 .

See IANL Defined Waste Iist.

A solid that is capable of absorbing moisture from the air and becoming a liquid.

A drying agent such as diatomaceous earth.

Diatomite, a light friable siliceous material, derived chiefly from diatom (algae) remains that is added to selected underground waste storage tanks to absorb and, thereby, immobilize residual liquids. (i.e help to stabilize the tank). 
DBP

DIL

DILFD

Ditch

Diversion Box

DN/PT

DN/PD

DN

Double-Shell Tank

Double-Shell slurry

Double-Shell slurry (DSSF)

-...

Drywell

Drywell (in-tank)

DSS

DSSF
Dibutyl phosphate.

Dilution

Dilute feed

A Iinearly oriented excavation often used for the temporary diversion or disposal of process waste streams:

A below grade concrete enclosure containing the remotely maintained jumpers and spare nozzles for the routing of waste solution to storage tank faxmsiz:......

See Waste Abbreviations.

See Waste Abbreviations.

See Waste Abbreviations.

The newer underground waste storage tanks consisting of a concrete shell and two concentric carbon steel liners with an annular space between the liners.

Waste that exceeds the sodium aluminate saturation boundary in the evaporator without exceeding receiver tank composition limits. For reporting purposes, DSS is considered a solid.

Waste concentrated just before reaching Feed the sodium aluminate saturation boundary in the evaporator.without. exceeding-receiver - . tank composition Iimits. This form is not as concentrated as DSS.

A steel casing, generally 6 inches in diameter drilled into the ground to various depths, and used to insert monitoring instruments for measuring the presence of radioactivity or moisture content.

A sealed casing within a tank that is attached to a riser. It is used to insert experimental equipment, such as neutron or acoustical probes, to determine the level of arainable interstitial liquor.

See Waste Abbreviations.

See Waste Abbreviations. 
DUMM

DUMMY

DW

DWBIX

$\mathbf{E}$

EB

EDTA: .

EF

EFD

END

Environs

EV

EVAP

EVAPF

Evaporator Feed

Evaporator-Crystallizer
See Waste Abbreviations.

See Waste Abbreviations.

See Waste Abbreviations.

See Waste Abbreviations.

Transaction flag key-waste transferred

through evaporator.

See Waste Abbreviations.

Ethylenediaminetetraacetic.acia...

See Waste Abbreviations.

See Waste Abbreviations.

Disconnect Cascaded Tanks, see CAS, Set.

Surrounding area, vicinity.

Evaporation.

See Waste Abbreviations.

See Waste Abbreviations.

Any waste liquid that can be concentrated to form saltcake; e.g., low heat waste, dilute interstitial liquor, aged waste, and other radioactive waste solutions.

\section{2-A and 242-S waste concentration}

facilities that operate at a reduced pressure (vacuum) and are capable of producing a slurry containing about 30 volume percent solids at a specific gravity of greater than 1.6 .

EVS

Partial neutralization in the 242-S Evaporator.

EVT

HEDTA destruction in the $242-B$ or 242-T Evaporators.

FD

See Waste Abbreviations.

FECN
Ferrocyanide wastes created during a scavenging campaign in 1953-57. See SCAV, POO, TOO. 
WHC-SD-WM-ER-349, Rev . 0

Ferrocyanide

FIC

FLSH

FP

FP

GA

Gamma Ray

GAS

GM Instrument

GROUP

Gunite

$\mathrm{H}_{2} \mathrm{O}$

HDRI
An ion composed of iron and cyanide with the chemical formula of $\mathrm{Fe}(\mathrm{CN})^{-4}{ }_{6}$.

A Food Instrument corporation automatic liquid level gauge based on a conductivity probe. At Hanford, they are electrically connected to a computer for data transmission, analysis, and reporting. Local readings may also be obtained from a dial.

Waste contained 10 percent of the original fission product activity and 2 percent of the products. By-product cake solution was mixed with product waste and neutralized with 50 percent caustic. The waste contained a mixture of suspended solids, hydroxides, carbonate and phosphate, scavenger metals, chromium, iron, sodium, and silicofluoride.

See Waste Abbreviations.

Fission Product Waste. Waste produced at B Plant and Hot Semiworks in campaigns for Cs and $\mathrm{Sr}$ recovery during the 1960s. Cs was removed from PUREX supernatant and $\mathrm{Sr}$ was removed from PUREX sludge; both were removed from acidic waste.

See Waste Abbreviations.

Gain to tank.

Electromagnetic radiation sometimes emitted by the nuclei_of..radioactive substances.... during decay, similar in nature to $\mathrm{x}$-rays.

Slurry growth as a result of gas generation.

Instrument for detecting low-level beta and gamma radiation using a Geiger-Mueller tube.

A group of tanks where ITS averaged the supernatant phases-see ITS.

A building material consisting of a mixture of cement, sand, and water that is sprayed onto a mold.

Water.

See Waste Abbreviations. 
HEAT

HEDTA

Heel

Hexone

High-Level Waste

Historical Information

HLO

HILO

HLW

HOT-SEMI

HS

HS

HWVP

I\&S

Inactive Tank

INST
A tank correction, see CORR, COOL.

N hydroxy-ethylenediaminetriacetic acia.

The amount remaining in a vessel or container after most of the contents have been removed.

Methyl isobutyl ketone, an organic solvent used in the REDOX solvent extraction process. Also known as Isobutyl methyl ketone, Methyl isobutyl ketone, 4-Methyl 2-pentanone, MIBK.

Waste from the fuel reprocessing operations in separations..plants...

All information obtained from material referenced in published documentation and unpublished sources. Unpublished sources include electronically retrieved data (i.e. temperatures, liquid observation well, sampling, and surface level) and photographs.

See Waste Abbreviations.

Hanford Laboratory Operations.

See Waste Abbreviations.

See HS, SSW.

See Waste Abbreviations.

Hot Semi-Works. A pilot facility that had a variety of operations. C Plant.

Dilute, non-complexed waste from the vitrification plant.

Tank isolated and stabilized.

A tank that has been removed from liquidprocessing service, has been pumped to less than 33,000 gal of waste, and is waiting to be, or is in the process of being, stabilized and interim isolated. Includes all tanks not in active or active-restricted categories. otherwise inactive contingency spares that would be used if an active tank failed are also included.

Change in tank level due to change in instrumentation. 
Interim Isolated

Interim Stabilized

Interstitial Liquor

Interstitial

Intrusion Mode

FIC setting

Intrusion Prevention

ISO

ITS

IWW

IX

Jet Pump

Knuckle
An administrative designation reflecting the completion of the physical effort required to minimize the addition of liquids into an inactive storage tank, process vault, sump, catch tank, or diversion box.

A tank which contains less than 50,000 gallons of drainable interstitial liquid and has less than 5,000 gallons of supernatant Iiquid. If the tank was jet pumped to achieve interim stabilization, then the jet pump flow must also have been at or below 0.05 gallons per minute before interim stabilization is wompleted.... . .

The liquid that fills the interstices or the void volume in the solid material in a waste tank.

The volume within a solid matrix made up of the crevices, cracks, and void spaces.

The FIC probe is positioned a short distance above the waste surface. If the surface level of the waste in the tank increases, thereby touching the probe tip, a positive indication is received.

This is an administrative designation reflecting the completion of the physical effort required to minimize the addition of liquid into an inactive storage tank, process vault, catch tank, sump, or diversion box.

Tank is interim-isolated.

The In-Tank Solidification Program was a program used to reduce waste volume directly by evaporating the wastes from inside certain tanks in the BX and BY Farms. The process used both hot air (ITS-1) and an electric heater (ITS-2).

See Waste Abbreviations.

See Waste Abbreviations.

A modified commercially available low capacity jet pump used as a salt well pump.

Point where the side wall and the bottom curved surface of a tank meet. 
L222S

I3A4A

LaF

Lateral

Leak Detection Pit

IEAKK

LETF

Level Adjustment

Level History

Liquid Observation WeIl (LOW)

Liquid Level Best Engineering Judgement Line

LO

LUNC

$L W$
See Waste Abbreviations.

See Waste Abbreviations.

See Waste Abbreviations.

Forizontal arywell under A Farm and certain SX Farm waste storage tanks.

Collection point for any leakage from AX Farm tanks. The pits are equipped with radiation and liquid detection instruments.

Tank leak volume, see CORR.

Isiquid effluent treatment facility from NReactor.

Any update in the waste inventory (or tank level) in a tank. The adjustments usually result from surveillance observations or historical investigations.

A diagram that shows the history of the waste level and waste level changes in a tank. The diagram also includes other related data.

Iiquid observation wells are used to monitor the interstitial liquid levei (IIL) in single-shell waste storage tanks. Three probes are used to monitor changes in the IIL: acoustic, gamma, and neutron. Each method can indicate intrusions or leakage by increases or decreases in the ILL.

During the initial fill of certain single-shell tanks, only the liquid level was reported. To adjust for the big increase in level height, which occurred when solids were added to the record, a sloped line was used to reflect solids volume between the initial fill and the time the solids data was recorded.

- Loss from tank.

See Waste Abbreviations.

See Waste Abbreviations. 
Metal Waste (MW)

Molarity:...:

Mole

MW

MWF

$\mathrm{N}$

NCAW

NCPI

NCPLEX

NCPLX

NCRW

Neutralized PUREX Acid

Neutron Probe

NFAW
Waste from the extraction containing all the uranium, approximately 90 percent of the original fission product activity, and approximately 1 percent of the product. This waste was brought just to the neutral point with 50 percent caustic and then treated with an excess of sodium carbonate. This procedure yielded almost completely soluble waste at a minimum total volume. The exact composition of the carbonate compounds was not known but was assumed to be an uranium phosphate carbonate mixture.

Number: of gram molecular.weights(moles) per liter of solution.

The amount of a substance with weight equal to the molecular weight in grams.

See Waste Abbreviations.

See Waste Abbreviations.

See Waste Abbreviations.

See Waste Abbreviations.

See Waste Abbreviations.

See Waste Abbreviations.

See Waste Abbreviations.

See Waste Abbreviations.

The original plant in 1956 neutralized Waste all the high-ievel waste and sent it to the 241-A Tank Farm. As fission product recovery started, a portion of the waste was treated for strontium recovery and then neutralized. As of 1967, all of the high-level waste left PUREX as an acid solution for treatment at $B$ Plant.

Probe equipped with a neutron source and detector. They are used in dry well monitoring to determine the moisture content of the soil as one means for detecting leaks in underground waste storage tanks or pipelines.

See Waste Abbreviations. 
NHAW

NIT

Noise At The Bottom of Well--Drywell Probe

Non-Complexed (NCPLX)

NPF

NRAW

NRP82

NRPO4

NRSO 4

NTA

Nuclear reactor

Open Hole Salt Well

Organic Wash Waste(OWW)

Out-of-Service-Tank

OWW

P

P1:

P2 :
See Waste Abbreviations.

$\mathrm{HNO}_{3} / \mathrm{KMNO}_{4}$ solution added during evaporator operation.

Erroneous reading caused by probe coming contact with foreign objects at the bottom of a well.

General waste term applied to all Hanford Site liquors not identified as complexed (containing organics).

Normal, para.fin hyarocarbon.

See Waste Abbreviations.

See Waste Abbreviations.

See Waste Abbreviations.

See Waste Abbreviations.

Nitrilotriacetic acid.

A device for creating a controlled nuclear chain reaction using atomic fuel, as for the production of energy.

A well in which a pump is inserted in solid waste. Frequently used to remove the liquid from tanks containing less than 2 feet of sludge.

The solvent used in. PUREX. was treated before reuse by washing with potassium permanganate and sodium carbonate, followed by dilute nitric acid and then a sodium carbonate wash.

A tank that does not meet the definition of an in-service tank. Before september 1988, these tanks were defined as inactive. (Note: all single-shell tanks (SSTs) are out of service.\}

See Waste Abbreviations.

See Waste Abbreviations.

See IAANL Defined Waste List.

See LANL Defined Waste List. 


\author{
PADFG \\ PADWG \\ Partially Interim \\ Isolated
}

PAS

PASF

PAW

PD

PDBNG

PDBSU

PDBTG

PDCSS

PDL87

PDL89

PDNSG

PDS87

PDS89

PDSLG

PDSUP

PFECN

PFeCN1:

PFeCN2 :

PFMMS

PFP (z-Plant)

PFP
See Waste Abbreviations.

See Waste Abbreviations.

The administrative designation reflecting the completion of the physical effort required for Interim Isolation except for the isolation of risers and piping that will be required for jet pumping or for other methods of stabilization.

See Waste Abbreviations.

See. Waste. Abbreviations...... . .

See Waste Abbreviations.

See Waste Abbreviations.

See Waste Abbreviations.

See Waste Abbreviations.

See Waste Abbreviations.

See Waste Abbreviations.

See Waste Abbreviations.

See Waste Abbreviation.

See Waste Abbreviations.

See Waste Abbreviations.

See Waste Abbreviations.

See Waste Abbreviations.

See Waste Abbreviations.

See Waste Abbreviations.

See LANL Defined Waste List.

See LANL Defined Waste Iist.

See Waste Abbreviations.

See facilities.

Plutonium finishing plant waste (see Z, 224, PRF). 
WHC-SD-WM-ER-349, Rev. O

PFPGR

PFPNT

PFPPT

PFPSI

$\mathrm{pH}$

Pile

PI

PML89

PMS89

PN

PNE

POO-P\#\#

Portland Cement

PRF

Primary Addition

Primary Stabilization
See Waste Abbreviations.

See Waste Abbreviations.

See Waste Abbreviations.

See Waste Abbreviations.

A measure of the hydrogen ion concentration in a solution.

An early term used to describe a nuclear reactor.

See Waiste Abbrieviations.

See Waste Abbreviations.

See Waste Abbreviations.

See Waste Abbreviations.

See Waste Abbreviations.

In-Plant scavenging with FeCN-see SCAV, TOOT\#\#.

A hydraulic cement made by finely pulverizing the clinker produced by calcining to

incipient fusion a mixture of clay and

limestone or similar materials.

Plutonium Reclaimation Facility-Type of waste generated in Z-Plant for "finishing wastes". Solvent based extraction process using $\mathrm{CCl}_{4} / \mathrm{TBP}$.

An addition of waste from a specific plant or process vault. These additions come from the "waste Status and Transaction Record

Summary", WHC-SD-WM-TI-614\&-615 Rev. 0 DRAFT.

The condition of an inactive waste storage tank after all liquid above the solids, other than isolated surface pockets, has been removed. Isolated surface pockets of liquid are those not pumpable by conventional techniques. 
Probe

PSL

PSS

PSSF

Psychrometry

PT

PUREX

PX865

PXBAW

PXBSG

PXFTF

PXIOW

PXMET

PXMSC

PXINAW

Questionable Integrity

$\mathbf{R}$

R SLTCK:

RI:

R2 :
A device used to get information about the environment. In this report, an instrument package designed to be inserted in drywells, risers, or ports to measure waste characteristics.

See Waste Abbreviations.

See Waste Abbreviations.

See Waste Abbreviations.

Determination of humidity or dew point from wet..and dry. bulb.temperatures with the difference in the "two-used"as"a"measure of aryness in the atmosphere.

See Waste Abbreviations.

See Facilities.

See Waste Abbreviations.

See Waste Abbreviations.

See Waste Abbreviations.

See Waste Abbreviations.

See Waste Abbreviations.

See Waste Abbreviations.

See Waste Abbreviations.

See Waste Abbreviations.

Any tank that has a small decrease in liquid level or a radiation increase in an associated dry well, for which the data are insufficient to support a conclusion with 95 percent confidence that the tank is sound.

See Waste Abbreviations.

See IAANL Defined Waste List.

See LANL Defined Waste list.

See LANL Defined Waste List. 
WHC-SD-WM-ER-349, Rev. 0

Radiation Zone

Radiation

Readily available

Risers

REC

REDOX

Removed From Service (Tanks)

Rerun Drywell Data

RESD

RIX

RMC

RSN

RSS

RTX

$S$

S-Plant (REDOX)

S1 SLTCK:

S2 SLTSLRY:

Salt Cake

Salt Well
An area containing radioactive materials in quantities significant enough to require control of personnel entry to the area.

Particles and electromagnetic energy emitted by nuclear transformations that are capable of producing ions when interacting with matter.

Risers located above grade which do not have apparatus attached to or contained in them.

Receive waste from another tank-see XFER.

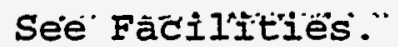

Any tank that is a confirmed leaker or is not intended for reuse.

Surveillance data which supersedes "suspect data".

See Waste Abbreviations.

See Waste Abbreviations.

Remote Mechanical C-Iine -Process used in zPlant.

See Waste Abbreviations.

See Waste Abbreviations.

See Waste Abbreviations.

Transaction Flag Key-Partial neutralization (PNF).

See Facilities.

See LANL Defined Waste List.

See IANL Defined Waste List.

Crystallized nitrate and other salts deposited in waste tanks, usually after active measures are taken to remove moisture.

A hole drilled or sluiced into a salt cake and lined with a cylindrical screen to permit drainage and jet pumping of interstitial liquors. 
SCAV

Scavenged

Scintillation Monitor

Self-Evaporation

SET

SIX

SL

SL3SY

sludge

Slugs

sluicing, or sluiced

slurry

Sound Tank

SPRG
Scavenging campaign with FECN on TBP, 195257. See TOO-T\#\#, POO-P\#\#.

Waste which has been treated with ferrocyanide to remove cesium from the supernatant by precipitating it into the sludge.

A radiation detection instrument based on the principle that light pulses are produced in some materials when they are exposed to radiation.

Highnlerel -I.iquid, radioactive waste whose constituent radionuclides contribute sufficient decay heat to cause the solution to boil and/or self-concentrate.

A waste material in which moisture is being lost as the moisture changes to a vapor and diffuses into the atmosphere.

Connect cascaded tanks together-see CAS and END.

See Waste Abbreviations.

See Waste Abbreviations.

See Waste Abbreviations.

Primarily insoluble metal hydroxides and oxides precipitated from neutralized waste.

An early term for uranium fuel. elements which. had been machined or extruded into short cylinders which were then clad or encased in corrosion-resistant metals.

To dissolve or suspend in solution by action of a high pressure water stream in order to pump solids from tanks.

Insoluble material suspended in water or aqueous solution.

The classification of a waste storage tank for which surveillance data indicates there has been no loss of liquid attributed to a breach of integrity.

Sparge-transfer of water or volume 
SRR

SRS

SRS

SSW

STAB

Stabilization

Static Tank

Strontium Semi-Works

SU

Supernatant

(supernatant Iiquid)

Surveillance

Suspect Data

SV

SW RCR

SWLIQ

SWLQW

$T-P l a n t(222-T)$

TI SITCK:
See Waste Abbreviations.

See Waste Abbreviations.

See Waste Abbreviations.

See Waste Abbreviations.

Tank stabilized by removal of liquid. Both floating suction and salt-well jet pumps used to remove liquid.

The removal, or immobilization, as completely as possible,... of the liquid contained in a radioactive 'waste'storage tank' by'salt well pumping, open hole salt well pumping, diatomaceous earth addition, etc.

A tank with no significant change in liquid level or involvement in transfer operations during a stated period of time.

Called C-Plant or Hot Semi-Works, was a pilot plant for both Redox and Purex, then reconfigured for strontium recovery.

See Waste Abbreviations.

In waste storage tanks, the liquid quantity defined by the difference between the measured liquid level and the measured average solias level in a tank.

Regular or systematic watch kept over someone or something.

Surveillance data which does not fall within the expected range and is superseded by "reruns."

Transaction Flag Key-Amount by difference in solids.

Salt-well Receiver.

See Waste Abbreviations.

See Waste Abbreviation.

See Facilities.

See LANL, Defined Waste Iist. 


$$
\text { WHC-SD-WM-ER-349, Rev. } 0
$$

T2 SLTCK:

Tank Farm

TBP

TBP

TCO

Terminal Iiquor

TFeCN

TH

Thermocouple Tree

Thermocouple, Thermocouple probe

ThermowelI

THI

Thorium
See IANL Defined Waste Iist.

An area containing a number of storage tanks; i.e., a chemical tank farm for storage of chemicals used in a plant, or underground waste tank storage of radioactive waste.

Tributyl phosphate, a solvent used in the PUREX solvent extraction process.

See Waste Abbreviations.

See Waste Abbreviations.

The liquid product from the evaporationcrystallization process which, upon further concentration, forms an unacceptable solid for storage in single-shell tanks. Terminal liquor is characterized by a caustic concentration of approximately $5.5 \mathrm{M}$ (the caustic molarity will be lower if the aluminum salt saturation is reached first).

See Waste Abbreviations.

See Waste Abbreviations.

A group of thermocouples assembled in a pipe and inserted into a waste tank for measuring temperatures at regular (normally 2 feet) vertical intervals.

A probe for measuring temperature, consisting of two dissimilar metal wires joined at one end (hot junction) with the free ends joined to a measuring instrument. Electrical potential changes due to temperature changes at the hot end are measured and calibrated to read out as temperature.

A well in a waste tank which contains thermocouples.

See Waste Abbreviations.

A chemical element which is also a fertile material. By fertile is meant that when subjected to radiation in a nuclear reactor it will be converted, in this case, to ${ }^{233}$ uranium, a potential fuel. 
$T K$

TI

TOO-T\#\#

TRLAL

TPLAN

TPLAS

TR

Trench

trFlag

Tributyl Phosphate (TBP)

Type I Tank

Type II Tank

Type III Tank

Type IV Tank

Type V Tank

$U-P l a n t(222-U)$

U1U2
Tank. TK-17-2, however, was an early designation for B-Plant.

See Waste Abbreviations.

In-Tank scavenging with FECN, see SCAV, P\#\#.

See Waste Abbreviations.

See Waste Abbreviations.

See Waste Abbreviations.

Traisseritirom tank." $\because$.

A deep furrow in the ground. At Hanford they are used for the disposal of solid waste.

Transaction Flag Keys-used by W-Trac-see CDF, $D, E, S, S V, 1,3,6,0.17,0.33$.

A chemical compound, also an organic solvent used in the PUREX solvent extraction process.

These are the 200 series $B, C, T$, and U Farm tanks. They have an operating capacity of 55,000 gal, a 20-ft diameter, a 6-in. dish bottom, and a 3-ft knuckle. There is no generation associated with type I tanks.

These are the original, 1st generation, tank designs, encompassing $B, C, T, U$ (excluding the 200 series tanks), and BX Tank Farms. Also see 1st Generation Tank.

These are the 2nd Generation tank designs, encompasing BY, S, TX, and TY Tank Farms. Also see 2 nd Generation Tank.

These include $3 \mathrm{rd}, 4 \mathrm{th}$, and 5 th generation tank designs, encompasing SX, A, and AX Tank Farms respectively. Also see 3 rd Generation Tank, 4th Generation Tank, and 5th Gneration Tank.

These are the first double shell tank designs, encompasing $A Y, A Z$, and SY Tank Farms.

See Facilities.

See Waste Abbreviations. 
WHC-SD-WM-ER-349, Rev. 0

UNKN

UNKNOWIN :

UR

UR:

Watch Iist Tank

WATER

WTR

WVP

XFER

z

Z-Plant

Z-PLANT

ZAW

ZHIGH

ZLAB

ZLOW

ZPRFL

ZPRFS

ZRM
Unknown waste origin sink.

See IANI Defined Waste List.

Uranium recovery operation in 222-U, 1952-57. Created TBP (primary waste) and FECN

(scavenging wastes). See TFeCN, PFeCN, POO, TOO, FeCN.

See LANL Defined Waste List.

An underground storage tank containing waste that requires special safety precautions because it. may haxe.a. serious.potential for release of high-level"radioactive waste because of uncontrolled increases in temperature or pressure. Special restrictions have been placed on these tanks by "Safety Measures for Waste Tanks at Hanford Nuclear Reservation, "Section 3137 of the National Defense Authorization Act for Fiscal Year 1991, November 5, 1990, Public Law 101-501 (also known as the Wyden Amendment).

Flush water from various sources.

Water.

Waste volume projections

Transfer of waste out of tank.

See Waste Abbreviations

See Facilities

PFP. Plutonium Finishing Plant.

See Waste Abbreviations.

See Waste Abbreviations.

See Waste Abbreviations.

See Waste Abbreviations.

See Waste Abbreviations.

See Waste Abbreviations.

See Waste Abbreviations. 


$$
\text { WHC-SD-WM-ER-349, ReV. } 0
$$

8.1 Waste Abbreviations

\section{WASTE ABBREVIATIONS}

1AYIN

1AZIN

IC

$1 \mathrm{CEB}$

$1 C S$

224

224-F

$231 z$

2AYIN

2AZIN

$2 \mathrm{C}$

2SYIN

3AWIN

$5-6$

5AWIN

6AWIN

AGE, AGING

B

B860N

BFSH

BL

BLEB

BLIX
Concentrated complex waste from 101 AY inventory

Pre 2-81 101Az inventory

First cycle waste

Ist cycle evaporator bottoms

lst cycle scavenging waste.

224-U waste

224-U waste. LaF Pu finishing plant

Dilute, phosphate waste from 2312

laboratories

Pre 2-81 102AY inventory

Pre 2-81 concentrated complex waste from 102AZ inventory

Second cycle waste

Pre 2-81 102SY inventory

Pre 2-81 103AW inventory

B-Plant tank 5,6 waste

Pre 2-81 105Aw inventory

Concentrated phosphate waste in 106 AW inventory

Aging waste

B-Plant high- level waste

Dilute, non-complexed waste from B Plant cell drainage

B-Plant flush waste water

B-Plant low-level waste

B-Plant low-level evaporator bottoms

B-Plant low level ion exchange 


$$
\text { WHC-SD-WM-ER-349, Rev. } 0
$$

BLIXB

BNW

BPDCC

BPDCS

BPDCV

BPFPS :

BPLCS

BPLDC

BPLDN

BVCLN

$C A R B$

CC

CCGL

CCGR

CCPI

CCPIX

CE

CEM

CF

CON

CP
B-Plant low level ion exchange bottoms

Battelle Northwest Laboratory waste

Dilute, complexed waste from B Plant cesium processing

Dilute, complexed waste from B Plant strontium processing

Dilute, complexed waste from B Plant vessel clean-out

B. Plant.high Tru.solids, from retrieved PFP solids

Dilute, non-complexed waste from B Plant strontium processing

Dilute, complexed waste from B Plant cesium processing

Dilute, non-complexed waste from B Plant cesium processing

Dilute, non-complexed waste from B Plant vessel clean-out

PUREX organic wash waste

Complexant concentrate waste

B-Plant high Tru solids from retrieved complexed concentrate

Dilute, non-complexed waste from retrieved complexed concentrate

Complexant concentrate

Complexant concentrate-see CPLX

Evaporator concentrate

Concrete-see CON

Cesium feed

Concrete-see CEM

Concentrated phosphate waste from in Reactor decontamination 
WHC-SD-WM-ER-349, ReV . 0

\begin{tabular}{|c|c|}
\hline CPLX & Complex waste \\
\hline CSFD & Cesium feed \\
\hline CSR & Waste sent to B-Plant for cesium recovery \\
\hline CST & Caustic solution \\
\hline CSWLE & Complexed salt well liquid east area \\
\hline CSWLIW & Complexed salt well Iiquid west area \\
\hline$C W$ & Coating waste \\
\hline CWP / ZR & Coating waste (PUREX), Zirconium cladding \\
\hline CWP & Coating waste (PUREX) \\
\hline CWR & Coating waste (REDOX) \\
\hline $\mathrm{CX70}$ & $\begin{array}{l}\text { Dilute, complexed mixture hot-semiworks Tru } \\
\text { solids }\end{array}$ \\
\hline DC & Dilute complexed waste \\
\hline$D N / P D$ & DN with P Tru solids \\
\hline DN & Dilute non-complexed waste \\
\hline $\mathrm{DN} / \mathrm{PT}$ & DN with PFP Tru solids \\
\hline DSS & Double-shell slurry \\
\hline DSSF & Double-shell slurry feed \\
\hline DUMM & Dummy waste \\
\hline DUMMY & Dummy waste \\
\hline DW & Decontamination waste \\
\hline DWBIX & $\begin{array}{l}\text { Decontamination waste and B-Plant.ion } \\
\text { exchange }\end{array}$ \\
\hline EB & Evaporator bottoms \\
\hline EF & Evaporator Eeed \\
\hline EFD & Evaporator feed dilute \\
\hline EVAP & Evaporator feed (post 1976) \\
\hline
\end{tabular}


EVAPF

FD

FLSH

FP

FDRL

HLO

HLW

HS

IWW

IX

L222S

L $3 A 4 A$

LaF

LUNC

LW

MW

MWF

N

NCAW

NCPLEX

NCPLX

NCPL

NCRW

NFAW
Dilute, non-complexed waste from evaporator pad flush

Feed dilute

Flush water

Fission product waste

Hanford defense residual 1iquor

Hanford laboratory operations waste

High, lewel waste-generic for all Hanford tank wastes

Hot semiworks waste

PUREX \#1 acid concentrator waste

Ion exchange waste

2225 laboratory, dilute non-complexed waste

Dilute non-complexed laboratory wastes from $300 \& 400$ areas

Lanthanum fluoride waste generated in PFP

Dilute, non-complexed waste from UNC fuels fabrication

Laboratory waste

Metal waste. ..... .

Metal waste feed

N-Reactor waste

Neutralized current acid waste, primary HLW stream from PUREX process

Non-complexed waste-see NCPLX

Non-complexed waste-see NCPLEX

Non-Complexed waste

Neutralized cladding removal waste-same as CWP.

Aging waste from PUREX/PFM high level waste 
WHC-SD-WM-ER-349, Rev. 0

NHAW

NRAW

NRP82

NRPO4

NRSO4

OWW

$P \cdots$

PADFG

PADWG

PAS

PASF

PAW

PD

PDBNG

PDBSU

PDBTG

PDCSS

PDL87

PDL89

PDNSG

PDS87

PDS89
Aging waste from PUREX/PFM processing of NPR fuel

Aging waste from PUREX/PFM residue acid waste

Dilute, non-complexed waste from FY82 100-N area waste transfer

Dilute, phosphate.waste from $100 \mathrm{~N}$ area

Dilute, non-complexed waste from 100N area

Organic wash waste

PUREX wás'te

Purex ammonia destruction waste, from fuels grade fuel

Purex ammonia destruction waste, from weapons grade fuel

Purex acidified sludge

Purex ammonia scrubber feed

Purex acidified waste

Purex decladding waste

Decladding sludge (non-Tru) from B Plant processing

Dilute, non-complexed waste from B Plant decladding. waste

B Plant aging waste solids from Purex decladding waste

Dilute non-complexed Purex decladding waste, FY1986 only

Purex decladding supernatant, 1987

Purex decladding supernatant, non-Tru, spent metathesis removed

Non-Tru decladding sludge from Purex

Purex decladding sludge

Purex decladding sludge after FY89 
WHC-SD-WM-ER-349, Rev. 0

PDSLG

PDSUP

PFeCN

PFMMS

PFPGR

PFPNT

PFPPT

PFPSL

PI

PML89

PMS89

PN

PNF

PSL

PSS

PSSF

PT

PX86S

PXBAW

PXBSG

PXFTF

PXIOW
Purex decladding sludge sol Purex

Dilute, non-complexed waste, Purex decladding waste

Ferrocyanide sludge produced by in-plant scavenging of waste from uranium recovery

Dilute, non-complexed waste from shear/leach processing of NPR Euel

Dilute, non-complexed waste from retrieved PFP solids

Non-tru sludge from the PFP sol $\mathrm{z}$ Plant

Dilute, non-complexed waste from the PFP (with TRUEX)

High-tru sludge from the PFP sol $\mathrm{z}$ Plant

PUREX low-level waste

Purex spent metathesis liquid after FY89

Purex spent metathesis solids after FY89

Purex neutralized cladding waste

Partial neutralized waste

Purex sludge sluiced during recovery of strontium

PUREX sludge supernatant

Purex sludge supernatant feed

Tru solids from $200 \mathrm{~W}$

Dilute, non-complexed waste from Purex miscellaneous streams(NPR fuel) FY86

$B$ Plant aging waste supernatant from retrieved aging waste

B Plant aging waste solids from retrieved aging waste

Dilute, non-complexed waste from Purex miscellaneous streams (FFTF)

Purex low level waste 
PXIET

PXMSC

PXINAW

R

RESD

RIX

RSN $\cdots$

RSS

RTX

SIX

SL

SI3SY

SRR

SRS

SRS

SSW

SU

SWLIQ

SWLQW

TBP

TCO

TFECN

TH
Purex dilute, non-complexed decladding: spent metathesis

Dilute, non-complexed waste from Purex miscellaneous streams (NPR fuel)

Aging waste from Purex high level waste REDOX waste

Residual evaporator liquor

REDOX ion exchange waste

REDOX.supernatant

Redox sludge supernatant

Redox ion exchange

PUREX ion exchange waste

sludge

Double shell slurry from end of FY80, 1035Y inventory

Waste sent to B-Plant for strontium recovery Strontium sludge

Strontium recovery supernatant

strontium semiworks waste

Supernatant

Dilute, non-complexed waste from east area single shell tanks

Dilute, non-complexed waste from west area single shell tanks

Tri-Butyl Phosphate

Dilute non-complexed waste from terminal cleanout

Ferrocyanide sludge produced by in-tank or in-farm scavenging

Thoria HIW or cladding waste 
WHC-SD-WM-ER-349, Rev. 0

\begin{tabular}{|c|c|}
\hline THL & Thoria low level waste \\
\hline$T L$ & Terminal 1iquor \\
\hline TPLAI & Dilute, non-complexed waste from $T$ Plant \\
\hline TPLAN & Dilute, non-complexed waste from $T$ Plant \\
\hline "TPLAS & Sludge from $T$ Plant operations \\
\hline U1U2 & $\begin{array}{l}\text { Dilute, non-complexed waste from } \mathrm{U} 1 / \mathrm{U} 2 \\
\text { groundwater pumping }\end{array}$ \\
\hline $\mathbf{z}$ & $Z=P \cdot \operatorname{lant} t_{1}$ waste \\
\hline ZAW & $\begin{array}{l}\text { Purex waste stream from zirconium cladded } \\
\text { fuel }\end{array}$ \\
\hline ZHIGH & $\begin{array}{l}\text { Dilute, non-complexed waste from the PFP } \\
\text { (without Truex) }\end{array}$ \\
\hline $\mathrm{ZLAB}$ & $\begin{array}{l}\text { Dilute, non-complexed waste from the PFP } \\
\text { laboratories }\end{array}$ \\
\hline ZLOW & $\begin{array}{l}\text { Dilute, non-complexed waste from Pre-FY85 z } \\
\text { Plant operations }\end{array}$ \\
\hline ZPRFI & $\begin{array}{l}\text { Dilute, non-complexed waste from PRF } \\
\text { processing }\end{array}$ \\
\hline ZPRFS & PFP Tru solids from PRF processing \\
\hline ZRMCL & $\begin{array}{l}\text { Dilute, non-complexed waste from PFP RMC } \\
\text { processing }\end{array}$ \\
\hline ZRMCS & PFP Tru solids from PFP RMC processing \\
\hline
\end{tabular}


8.2 IANL Defined Wastes

IANT DEFINED WASTE IIST

A1 SLTCK

A2 SLTSLRY

$A R$

B SLTCK

BY SLTCK

CWP2

$\mathrm{DE}$

PI

P2

PFeCN1

PFeCN2

R SITCK

R1

R2

S1 SLTCK

S2 SLTSLRY

T1 SLTCK

T2 SLTCK
Saltcake waste generated from the 242-A evaporator-crystallizer from 1977 until 1980.

Salt slurry waste generated from the 242-A evaporator-crystalizer from 1981 until 1994.

"Washed" PUREX sludge fromthe AR vault.

Saltcake waste generated from the 242-B evaporator from -1951"until 1*1955:"

Saltcake waste generated from in-tank solidification units 1 and 2 between 1965 and 1974 .

Cladding waste-PUREX 2

Diatomaceous earth.

PUREX high-level waste generated between 1955 and 1962 .

PUREX high-level waste generated between 1963 and 1967.

Ferrocyanide sludge generated from in-plant scavenging of waste from uranium recovery.

Same as PFeCN1, except used $0.0025 \mathrm{M}$ ferrocyanide.

Salt cake waste from the REDOX concentrator. REDOX waste generated between 1952 and 1957 . REDOX waste generated between 1958 and 1966.

Saltcake waste generated from the 242-S evaporator/crystallizer from 1973 until 1976.

Salt slurry waste generated from the 242-S evaporator-crystaliizer from 1977 until 1980.

Saltcake waste generated from the 242-T evaporator from 1951 until 1955.

Saltcake waste generated from the 242-T evaporator from 1965 until 1955. 
WHC-SD-WM-ER-349, Rev. 0

UNKNOWN

UR
Unkown waste type.

Uranium recovery waste (also known as tributyl phosphate (TBP) waste). 
WHC-SD-WM-ER-349, REV. 0

8.3 Facilities

FACIIITIES

A Plant (PUREX)

B Plant $(222-B)$

C plant $(222-\mathrm{C}): \cdots \cdot$

$S$ Plant (REDOX)

T Plant $(222-\mathrm{T})$

U Plant $(222-U)$

PFP (Z Plant)

$242-\mathrm{A}$

$242-B$

$242-5$

$242-T$
The facility at Hanford which contains the latest solvent extraction process for recovery of both plutonium and uranium.

On of the three original bismuth-phosphate processing facilities. Later converted to a waste fractionation plant.

Initialiya piłot plant-for Redox, later a pilot plant for Purex and B-Plant waste partitioning.

The facility at Hanford which contains the original extraction process for recovery of both plutonium and uranium.

One of the three original bismuth-phosphate processing facilities. Later converted to a decontamination facility.

One of the three original bismuth-phosphate processing facilities. Later converted to a uranium recovery plant.

Plutonium Finishing Plant. The final operations for production of plutonium products are carried out in this facility.

A forced circulation vacuum evaporation system.

An evaporator that operates at atmospheric pressure. Also referred to as an open air type evaporator.

A forced circulation vacuum evaporation system.

An evaporator that operates at atmospheric pressure. Also referred to as an open air type evaporator. 


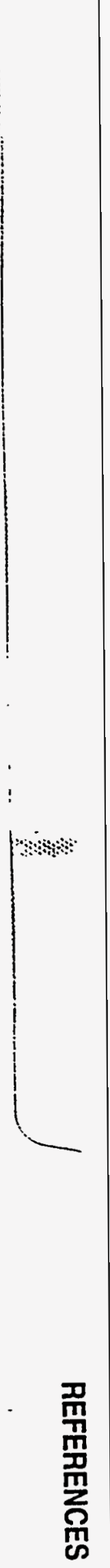


WHC-SD-WM-ER-349, Rev. 0

Agnew, S.F., February 1994, Waste Status and Transaction Record Summary for the Northeast Quadrant, WHC-SD-WM-TI-615, REV. 0, Westinghouse Hanford Company, Richland, Washington.

Agnew, S.F., February 1994, Waste Status and Transaction Record Summary for the Southwest Quadrant, WHC-SD-WM-TI-614, REV. 0, Westinghouse Hanford Company, Richland, Washington.

Agnew, S.F., February 1994, Estimated Chemical and Radiochemical Inventories spreadsheet: NE Quadrant, $A, A X, B, B X, B Y, C$ Farms, WHCSD-WM-TI-628, REV. 0, Westinghouse Hanford Company, Richland, Washington::

Agnew, S.F., February 1994, Estimated Chemical and Radiochemical Inventories Spreadsheet: SW Quadrant, $S, S X, U$ Farms, WHC-SD-WM-TI631, REV. 0, Westinghouse Hanford Company, Richland, Washington.

Agnew, S.F. March 1994, Tank Layer Model (TLM) Spreadsheet: NE Quadrant, $A, A X, B, B X, B Y, C$ Farms, WHC-SD-WM-TI-627, REV. 0 , Westinghouse Hanford Company, Richland, Washington.

Agnew, S.F. March 1994, Tank Layer Model (TLM) Spreadsheet: SW Quadrant, $S, S X, U$ Farms, WHC-SD-WM-TI-630, REV. 0, Westinghouse Hanford Company, Richland, Washington.

Agnew, S.F. April 1994, Hanford Defined Wastes: Chemical and Radionuclide Compositions, WHC-SD-WM-TI-629, REV. 0, Westinghouse Hanford Company, Richland, Washington.

Allen, G.K., March 1976, Estimated Inventory of Chemicals Added to Underground waste Tanks, 1944 through 1975, ARH-CD-610B, Atlantic Richfield Hanford Company, Richland, Washington.

Alstad, A.T., September 19, 1991, Riser Configuration Document for Single-Shell Waste Tanks, WHC-SD-RE-TI-053, Rev. 8, Westinghouse Hanford Company, Richland, Washington.

Anderson, J.D., January, 1972- December 1972, Waste Status Summary Chemical Processing Division, ARH-2456, Atlantic Richfield Hanford Company, Richland, Washington.

Anderson, J.D., January, 1973- December 1973, Waste Status Summary Chemical Processing Division, ARH-2794, Atlantic Richfield Hanford Company, Richland, Washington.

Anderson, J.D., January, 1974- December 1974, Waste Status Summary Operations Division, ARH-CD-133, Atlantic Richfield Hanford Company, Richland, Washington.

Anderson, J.D., January, 1974- December 1974, Waste Status Summary Chemical Processing Division, ARH-CD-133, Atlantic Richfield Hanford 
WHC-SD-WM-ER-349, Rev. 0

Company, Richland, Washington.

Anderson, J.D., January, 1975- December 1975, Waste Status Summary Production and Waste Management Division, ARH-CD-336, Atlantic Richfield Hanford Company, Richland, Washington.

Anderson, J.D., January, 1976- September 1976, Waste Status Summary Production and Waste Management Division, ARH-CD-702, Atlantic Richfield Hanford Company, Richland, Washington.

Anderson, J.D., October, 1976- May 1977, Waste Status Summary Production and Waste Management Division, ARH-CD-822, Atlantic Richfield Hanford Company, Richland, Washington.

Arderson, J.D., June 1990\%" History of the 200"Areas Tank Farms, WHC-MR-0132, Westinghouse Hanford Company, Richland, Washington.

ARHCO, June, 1969, SX Tank Farm Air Cooling Safety Analysis, ARH-1291, Atlantic Richfield Hanford Company, Richland, Washington.

ARHCO, July, 1972 through December, Chemical Processing Division Waste Status Summary, Quarterly Reports, ARH-2456 C and D, Atlantic

Richfield Hanford Company, Richland, Washington.

ARHCO, January, 1973 through December 1973, Chemical Processing Division Waste Status Summary, Quarterly Reports, ARH-2694 A, B, C, and D, Atlantic Richfield Hanford Company, Richland, Washington.

ARHCO, January, 1973 through September 1975, Operations Division Waste Status Summary, Quarterly Reports, ARH-CD-133 A, B, C, and D, Atlantic Richfield Hanford Company, Richland, Washington.

ARCHO, September, 1976, Production and Waste Management Division Waste Status summary, Monthly Reports ARH-CD-702, Atlantic Richfield Hanford Company, Richland, Washington.

ARCHO, October, 1976 through June 1977, Production and Waste Management Division Waste Status Summary, Monthly Report, ARH-CD-822, Atlantic Richfield Hanford Company, Richland, Washington.

Babad, H., D. M. Camaioni, M. A. Lilga, W. D. Samuels, and D. M. Strachan, February 1993, Tank Waste Chemistry- A New Understanding of Waste Aging, WHC-SA-1694-FP, Westinghouse Hanford Company, Richland, Washington.

Borsheim, G.L., and B. C. Simpson, October 1991. An Assessment of the Inventories of the Ferrocyanide Watchlist Tanks, WHC-SD-WM-ER-133 Rev. 0 , Westinghouse Hanford Company, Richland, Washington.

Borsheim, G.I., August 2, 1989, Single-Shell Tank Isolation Safety Analysis Report, SD-WM-SAR-006-Rev 2, Westinghouse Hanford Company, Richland, Washington. 
WHC-SD-WM-ER-349, Rev. 0

Borshiem, G. I. and N. W. Kirch, March 1991, Summary of Single-shell

Tank Waste Stability, WHC-EP-0347, Westinghouse Hanford Company,

Richland, Washington.

Boyles, V.C., June 1981, Safety Analysis Report: Stabilization of Single-Shell Waste Storage Tanks by Saltwell Jet Pumping, RHO-SD-WM-SAR-034, Rev.0, Rockwell Hanfora Operations, Richland, Washington.

Brevick, C.H., I. A. Gaddis, and W. W. Pickett, July, 1994, Supporting Document for North East Quadrant Historical Tank Content Estimate Report for A-Tank Farm, WHC-SD-WM-ER-308, Rev.0, ICF Kaiser Hanford Company, Richland, Washington.

Brevick, С:H:, L.: A: Gaddis; and W. W: Pickëtt, Jüly, 1994; supporting Document for North East Quadrant Historical Tank Content Estimate Report for AX-Tank Farm, WHC-SD-WM-ER-309, Rev.0, ICF Kaiser Hanford Company, Richland, Washington.

Brevick, C.H., I. A. Gaddis, and W. W. Pickett, JuIy, 1994, Supporting Document for North East Quadrant Historical Tank Content Estimate Report for B-Tank Farm, WHC-SD-WM-ER-310, Rev.0, ICF Kaiser Hanford Company, Richland, Washington.

Brevick, C.H., I. A. Gaddis, and W. W. Pickett, July, 1994, Supporting Document for North East Quadrant Historical Tank Content Estimate Report for BX-Tank Farm, WHC-SD-WM-ER-311, Rev.0, ICF Kaiser Hanford Company, Richland, Washington.

Brevick, C.H., I. A. Gaddis, and W. W. Pickett, July, 1994, Supporting Document for North East Quadrant Historical Tank Content Estimate Report for BY-Tank Farm, WHC-SD-WM-ER-312, Rev.0, ICF Kaiser Hanford Company, Richland, Washington.

Brevick, C.H., I. A. Gaddis, and W. W. Pickett, July, 1994, Supporting Document for North East Quadrant Historical Tank Content Estimate Report for C-Tank Farm, WHC-SD-WM-ER-313, Rev.0, ICF Kaiser Hanford Company, Richland, Washington.

Brevick, C.H., L. A. Gaddis, and W. W. Pickett, August, 1994, Supporting Document for South West Quadrant Historical Tark Content Estimate Report for S-Tank Farm, WHC-SD-WM-ER-313, Rev.0, ICF Kaiser Hanford Company, Richland, Washington.

Brevick, C.H., I. A. Gaddis, and W. W. Pickett, August, 1994, Supporting Document for South West Quadrant Historical Tank Content Estimate Report for SX-Tank Farm, WHC-SD-WM-ER-313, Rev.0, ICF Kaiser Hanford Company, Richland, Washington.

Brevick, C.H., I. A. Gadais, and W. W. Pickett, August, 1994, Supporting Document for South West Quadrant Historical Tank Content Estimate Report for U-Tank Farm, WHC-SD-WM-ER-313, Rev.0, ICF Kaiser Hanford Company, Richland, Washington. 
WHC-SD-WM-ER-349, Rev. 0

Brown, W.G., April 26.1993, Hazard Identification and Evaluation for Non-Stabilized Single Shell Tanks, SD-WM-SAR-022, Rev. 0, Westinghouse Hanford Company, Richland, Washington.

Bussell, J.H., February 3, 1992, Engineering Evaluation of Thermocouples in FeCN Watchlist Tanks, WHC-SD-WM-ER-134, Rev O-A, Westinghouse Hanford Company, Richland, washington.

Carpenter, G.K., April, 1953 - June 1953, Waste Status Summary Separations Section, HW-28043 etc., General Electric Company, Richland, Washington.

Carpenter, G.K., September, 1953 - May 1954, Waste Status Summary -

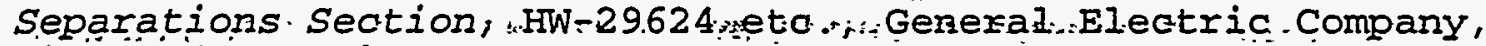
Richland, Washington.

Carter, George J., April, 1986- September 1986, Waste Status Summary, RHO-RE-SR-14, Rockwel I Hanford Operations, Richland, Washington.

Cooley, C.R., and G.L. Richardson, July 17, 1963, Hot Semiworks Strontium-90 Recovery Program, HW-72666, General Electric Company, Richland, Washington.

ERDA, December, 1975, Waste Management Operations, ERDA-1538, Energy Research and Development Administration, Richland, Washington.

Escobar, Glenn A., October, 1986- January 1987, Waste Status Summary, RHO-RE-SR-14, Rockwell Hanford Operations, Richland, Washington.

Farley, W.G., May 20, 1992, Safety Assessment for Thermocouple Tree System Installation and Operation in Nonleaking Ferrocyanide Tanks, WHC-SD-WM-SAD-014, Rev. 1, Westinghouse Hanford Company, Richland, Washington.

GE Co., July 10, 1951, REDOX Technical Manual, HW-18700-Del, General Electric Company, Richland, Washing.ton... .

Gerber, M.S., September, 1992, Legend and Legacy: Fifty Years of Defense Production at the Hanford Site, WHC-MR-0293, Rev 2, Westinghouse Hanford Company, Richland, Washington

Gerber, M.S., November, 1993, A Brief History of the Purex and $\mathrm{UO}_{3}$ Facilities, WHC-MR-0437, Westinghouse Hanford Company, Richland, Washington.

Gerber, M.S., September,1993, Multiple Missions: The 300 Area in Hanford Site History, WHC-MR-0440, Westinghouse Hanford Company, Richland, Washington.

Hanlon, B.M., November, 1989- December, 1990, Tank Farm Surveillance and Waste Status Summary Report, WHC-EP-0182, Westinghouse Hanford Company, Richland, Washington.

Hanlon, B.M., January, 1991- December, 1991, Tank Farm Surveillance 
WHC-SD-WM-ER-349, ReV. 0

and Waste Status Summary Report, WHC-EP-0182, Westinghouse Hanford Company, Richland, Washington.

Hanlon, B.M., January, 1992- December, 1992, Tank Farm Surveillance and Waste Status Summary Report, WHC-EP-0182, Westinghouse Hanford Company, Richland, Washington.

Hanlon, B.M., July, 1993, Tank Farm Surveillance and Waste status Summary Report for July 1993, WHC-EP-0182-64, Westinghouse Hanford Company, Richland, Washington.

Hanlon, B.M., January, 1993-October, 1993, Tank Farm Surveillance and Waste Status Summary Report, WHC-EP-0182, Westinghouse Hanford

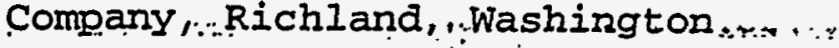

Hatch, P., December 18, 1969, Limitations for use of Underground Waste Tanks, ARH-951, Atlantic Richfield Hanford Company, Richland, Washington.

HEW, January 11, 1944, CVI, "Specifications for Construction of Composite storage Tanks BIdg. No. 241, "Project 9536, CVI 73550, Hanford Engineer Works, Richland, Washington.

Jenkins, C., M. Danielson, B. Rarig, R. Campbell, T. Ambalam, C. Kenoyer, and I. Hall, February, 1993, Engineering Evaluation of Alternatives Managing the Assumed Leak from SST 241-T-101, EEA-93-1, Kaiser Engineers Hanford, Richland, Washington.

Jungfleisch, F. M., March 1984, Preliminary Estimation of the Waste Inventories in Hanford Tanks through 1980, SD-WM-TI-057, Rev.0, Rockwell Hanford operations, Richland, Washington.

KEH, February 1993, EEP Managing the Assumed Leak From SST, KEEA-93-1, Kaiser Engineers Hanford, Richland, Washington.

Kirkman, M.J., G. I. Ritter, and P. W. Smith, March 6, 1969, B-Plant Production Schedule and In-Tank Solidification Alternatives, ARH-900, Atlantic Richfield Hanford Company, Richland, Washington.

Kreig, S.A., W.W. Jenkins; K.J. Leist, K. G. Squires, and J. F. Thompson, June 1990, Single-Shell Tank Waste Retrieval Study, WHC-EP-0352, UC-721, Westinghouse Hanford Company, Richland, Washington.

Lentz, J.E., April 1959- December 1959, Waste Status Summary Chemical Processing Department, HW-58579 etc., General Electric Company, Richland, Washington.

Lentz, J.E., January 1960- December 1960, Waste Status Summary Chemical Processing Department, HW-63896 etc., General Electric Company, Richland, Washington.

Liverman, J.I., December 1975, Final Environmental Statement, Waste 
WHC-SD-WM-ER-349, Rev. 0

Management Operations Volume 1 and 2, ERDA-1538, Energy Research and Development Administration, Richland, Washington.

Lucas, G.E., June 1989, Waste Types in Hanford Single-Shell Tanks, WHC-SD-ER-TI-001, Rev. 0, Westinghouse Hanford Company, Richland, Washington.

McBride, J.P., July, 1953, Waste Status Summary - Separations Section, HW-29054, General Electric Company, Richland, Washington.

McCann, D.C., July, 1981- October 1981, Waste Status Summary, RHO-CD14, Rockwell Hanford Operations, Richland, Washington.

McCann,.. D.C.., October...1981-. December 1982,... Waste. Status. Summary, RHORE-SR-14, Rockweli Hañfôrd Operations, Richland, Wäshington.

MCCann, D.C., January, 1983- December 1983, Waste Status Summary, RHORE-SR-14, Rockwell Hanford Operations, Richland, Washington.

MCCann, D.C., January, 1984- February 1985, Waste Status Summary, RHORE-SR-14, Rockwell Hanford Operations, Richland, Washington.

Morganthaler, A.C., February, 1952 - March 1953, Waste Status Summary - Separations Section, HW-27897 etc., General Electric Company, Richland, Washington.

Mudd, O.C., January, 1979- December 1979, Waste Status Summary, RHOCD-14, Rockwell Hanford Operations, Richland, Washington.

Mudd, O.C., January, 1980- December 1980, Waste Status Summary, RHOCD-14, Rockwell Hanford Operations, Richland, Washington.

Mudd, O.C., January, 1981- June 1981, Waste Status Summary, RHO-CD-14, Rockwell Hanford Operations, Richland, Washington.

Mulvey, C.A., June, 1977- December 1977; waste Status Summary, RHO-CD14, Rockwell Fanford Operations, Richland, Washington.

Mulvey, C.A., January, 1978- December 1978, Waste Status Summary, RHOCD-14, Rockwell Hanford Operations, Richland, washington.

Peterson, D.E., June, 1954- May 1955, Waste Status Summary Separations Section, HW-32389 etc., General Electric Company, Richland, Washington.

Peterson, D.E., June, 1955- May 1956, Waste Status Summary Separations Section, HW-38000 etc., General Electric Company, Richland, Washington.

Peterson, D.E., September, 1956- December 1956, Waste Status Summary Chemical Processing Department, HW-45738 etc.. General Electric

Company, Richland, Washington. 
WHC-SD-WM-ER-349, Rev. 0

Peterson, D.E., June, 1956-August 1956, Waste Status Summary Separations Section, HW-43895 etc., General Electric Company. Richland, Washington.

Pines, A.G., January 4, 1991, 244-AR Vault Safety Analysis Report, SDWM-SAR 018 Rev. 0, Westinghouse Hanford Company, Richland, Washington.

Prosk, W., and D.A. Smith, January 1986, Tank Isolation Safety Analysis Report, SD-WM-SAR-006 Rev. 1, Rockwell Hanford Operations, Richland, Washington.

RHO, June 1977 through October 1981, Waste Status Summary, Monthly Reports RHO-CD-14, Rockwell Hanford Operations, Richland, Washington.

RHO, November 1981 "throügh June 1987; Waste Status Summary; Monthly Reports RHO-RE-SR-014, Rockwell Hanford Operations, Richland, Washingtor.

Roberts, R.E., January, 1957- December 1957, Waste Status Summary Chemical Processing Department, HW-48144 etc., General Electric Company, Richland, Washington.

Roberts, R.E., January, 1958- October 1958, Waste Status Summary Chemical Processing Department, HW-54916 etc., General Electric Company, Richland, Washington.

Roberts, R.E., January, 1961- December 1961, Waste Status Summary Chemical Processing Department, HW-71610 etc., General Electric Company, Richland, Washington.

Roberts, R.E., January, 1962- December 1962, Waste Status Summary Chemical Processing Department, HW-74647 etc., General Electric Company, Richland, Washington.

Roberts, R.E., January, 1963- December 1963, Waste Status Summary Chemical Processing Department, $H W-78279$ etc., General Electric Company, Richland, Washington.

Roberts, R.E., January, 1964- December 1964, Waste Status Summary Chemical Processing Department, $\mathrm{HW}-83308$ etc., General Electric Company, Richland, Washington.

Roberts, R.E., January, 1965- December 1965, Waste Status Summary Chemical Processing Department, HW-83906 etc., General Electric Company, Richland, Washington.

Roberts, R.E., October, 1966- December 1966, Waste Status Summary Chemical Processing Division, IsO-674, Isochem Inc., Richland, Washington.

Roberts, R.E., January, 1966- September 1966, Waste Status Summary Chemical Processing Department, HW-83906 etc., General Electric Company, Richland, Washington. 
WHC-SD-WM-ER-349, ReV. 0

Rodenhizer, D.G., September 30, 1987, Hanford Waste Tank Sluicing History, SD-WM-TI-302, Westinghouse Hanford Company, Richland, washington.

Rutherford, M.J., August 31, 1948, Additional Waste storage Facilities 200-East Area, Specification No. HW 3783, General Electric Company, Richland, Washington.

Scaief, C.C. III, October 19, 1993, TMACS I/O Termination Point Listing, WHC-8D-WM-TI-594, Rev. 0, Westinghouse Hanford Company, Richland, Washington.

Smith, D.A., August 1986, SAR, Hazard Identification and Evaluation for NonStabilizedising Ie-She1I:TankS.:SD-WM-SAR-022 Rev. 0, Rockwell Hanford Operations, Richland, Washington.

Stahl, S.M., November 22, 1993, Hanford Site Tank Farm Facilities Interim Safety Basis, Volume 1 and 2, WHC-SD-WM-ISB-001, Westinghouse Hanford Company, Richland, Washington.

Stong, F.S., September 29, 19860, Drywell Van In-Tank Liquid Observation Well Surveillance Data Interpretation, RHO-SD-WM-TI-237, Rockwell Hanford Operations, Richland, Washington.

ThanMai, T. T., April 27, 1993, Thermocouple status Single-Shell and Double-Shell Waste Tanks, WHC-SD-WM-TI-553, Rev. 0, Westinghouse Hanford Company, Richland, Washington.

Thress, M A., November 1958- February 1959, waste Status Summary Chemical Processing Department, HW-58579 etc., General Electric Company, Richland, Washington.

Thurman, Jack M., June, 1987 through December 1987, Tank Farm Surveillance and Waste Status Summary Report, Monthly Reports WHC-SP 0038, Westinghouse Hanford Company, Richland, Washington..

Thurman, Jack M., December, 1987 through June 1993, Tank Farm Surveillance and Waste Status Summary Report, Monthly Reports WHC-EP-0182-55, Westinghouse Hanford Company, Richland, Washington.

Thurman, Jack M., February, 1987- June 1987, Waste Status Summary, RHO-RE-SR-14, Rockwell Hanford Operations, Richland, Washington.

Thurman, Jack M., July, 1987- March, 1988, Waste status Summary, WHCSP-0038, Westinghouse Hanford Company, Richland, Washington.

Thurman, Jack M., April, 1988-December, 1988, Tank Farm Surveillance and Waste Status Summary Report, WHC-EP-0182, Westinghouse Hanford Company, Richland, Washington.

Thurman, Jack M., January, 1989- October, 1989, Tank Farm Surveillance and Waste Status Summary Report, WHC-EP-0182, Westinghouse Hanford Company, Richland, Washington. 
WHC-SD-WM-ER-349, Rev. 0

U.S.DOE, December 1987, EIS, Disposal of Hanford Defense High Level, Transuranic, and Tank Wastes, DOE/EIS-0113 Volume 1-5, Department of Energy, Richland, Washington.

Uebelacker, D.I., October, 1968- December 1968, Waste Status Summary Chemical Processing Division, ARH-1061, Atlantic Richfield Hanford Company, Richland, Washington.

Uebelacker, D.I., January, 1969- December 1969, Waste Status Summary Chemical Processing Division, ARH-1200, Atlantic Richfield Hanford Company, Richland, Washington.

Uebelacker, D.I., January, 1970- December 1970, Waste Status Summary Chemical. Processing Division, ARHi-1666, Atlantic Richfield Hanford Company, Richland, Wäshington.

Vail, Terry S., January, 1985- March 1986, Waste Status Summary, RHoRE-SR-14, Rockwell Hanford Operations, Richland, Washington.

Wagoner, J.D., March 18, 1993, Wyden Request, Document No. $9301156 \mathrm{~B}$ R3, U.S. Department of Energy, Richland, washington.

Waite, J.I., April 1991, Tank Wastes Discharged Directly to the Soil at the Hanford Site, WHC-MR-227, Westinghouse Hanford Company,

Richland, Washington.

Welty, R. K., September 1988, Waste Storage Tank Status and Leak Detection Criteria, WHC-SD-WM-TI-356, Westinghouse Hanford Company, Vol. 1 and 2, Richland, Washington.

Welty, R.K. and Norma J. Vermeulen, September 12, 1989 with ECNs through November 08, 1993, Waste Storage Tank Status and Leak Detection Criteria, WHC-SD-WM-TI-357, Rev. 1K, Westinghouse Hanford Company, Richland, Washington.

WHC, September, 1991, Failure to Continuously Man Control Room During Transfer Per Procedure, Occurrence Report RL--WHC--Tank

Farm-1991-1019, Westinghouse Hanford Company, Richland, Washington.

WHC, July, 1991, High Radiation Readings in 241-BY Drywells, Occurrence Report RI--WHC-Tank Farm-1991-1022, Westinghouse Hanford Company, Richland, Washington.

WHC, August 1993, Hanford Site Tank Farm Facilities Interim Safety Basis, WHC-SD-WM-ISB-001 Rev. 1, Volume 1 and Volume 2., Westinghouse Hanford Company,

WHC, March, 1993, Hanford Watchlist Tank Surveillance Trends, Letter to the Honorable Ron Wyden, Westinghouse Hanford Company, Richland, Washington.

WHC, July, 1993, Unauthorized Water Usage at 241-BY Tank Farm Results in Exceeding Raw Water Operational Iimit, Occurrence Report 
WHC-SD-WM-ER-349, KeV. 0

RI--WHC-Tank Farm-1993-0050, Westinghouse Hanford Company, Richland, Washington.

Winters, W.I., I. Jensen, L.M. Jasaki, R.L. Weiss, J.F. Keller, A.J. Schmidt, and M.G. Woodruff, May 1989, Waste Characterization Plan for the Hanford Site Single-Shell Tanks, WHC-EP-0210, Westinghouse Hanford Company, Richland, Washington. 